\title{
An Archaeological Survey of Twin Buttes Reservoir, Tom Green County, Texas
}

\author{
Raymond P. Mauldin \\ Center for Archeological Research, University of Texas at San Antonio \\ David L. Nickels
}

Follow this and additional works at: https://scholarworks.sfasu.edu/ita

Part of the American Material Culture Commons, Archaeological Anthropology Commons, Environmental Studies Commons, Other American Studies Commons, Other Arts and Humanities Commons, Other History of Art, Architecture, and Archaeology Commons, and the United States History Commons

Tell us how this article helped you.

This Article is brought to you for free and open access by the Center for Regional Heritage Research at SFA ScholarWorks. It has been accepted for inclusion in Index of Texas Archaeology: Open Access Gray Literature from the Lone Star State by an authorized editor of SFA ScholarWorks. For more information, please contact cdsscholarworks@sfasu.edu. 


\section{An Archaeological Survey of Twin Buttes Reservoir, Tom Green County, Texas \\ Creative Commons License \\ (c) () () (9)}

This work is licensed under a Creative Commons Attribution-NonCommercial 4.0 International License 


\section{An-Aredacelogical Stuvey of}

\section{Twin Buttes Reservoir \\ Fon-Green County, Texas}

\section{Volume I}

Raymond P. Mauldin

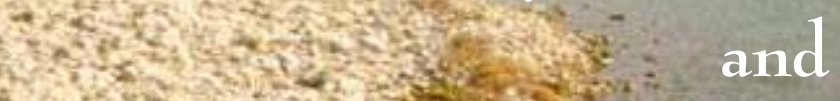

- 3. David L. Nickels

with Contributions by

C. Britt Bousman, Wulf Gose, Ruth Mathews, Preston McWhorter, Kristi Miller, Clemente Murguia, Lee Nordt, Tanya Norris, Katie Plum, Rick Robinson, and Preston Stone

Center for Archaeological Research The University of Texas at San Antonio Archaeological Survey Report, No. 300 2001
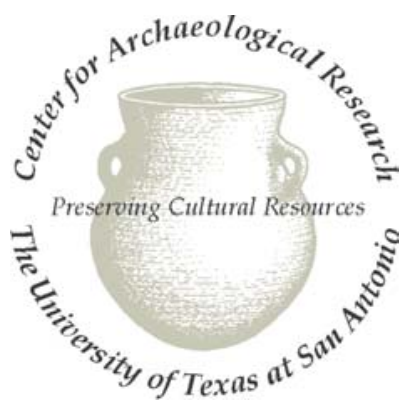


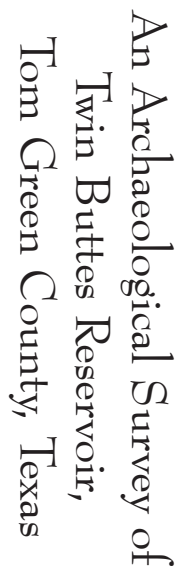

$\frac{5}{3}$

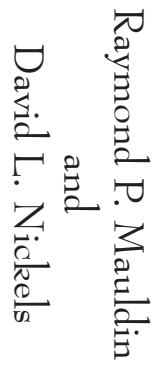

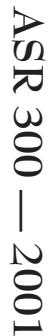




\title{
An Archaeological Survey of Twin Buttes Reservoir, Tom Green County, Texas
}

\author{
Volume I
}

\section{Raymond P. Mauldin and David L. Nickels}

\author{
Robert J. Hard and C. Britt Bousman
}

Principal Investigators

Ccopyright 2001

Center for Archaeological Research

The University of Texas at San Antonio

Archaeological Survey Report, No. 300 
The following information is provided in accordance with the General Rules of Practice and Procedure, Chapter 41.11 (Investigative Reports), Texas Antiquities Committee:

1. Type of investigation: Class III archaeological survey

2. Project name: Twin Buttes Archaeological Survey

3. County: Tom Green

4. Principal investigator(s): Robert J. Hard and C. Britt Bousman

5. Name and location of sponsoring agency: Bureau of Reclamation, Oklahoma City Field Office, 4149 Highline Blvd., Suite 200, Oklahoma City, OK 73108

6. Texas Antiquities Permit No.: N/A

7. Published by the Center for Archaeological Research, The University of Texas at San Antonio, 6900 N. Loop 1604 W., San Antonio, Texas 78249-0658, 2001

A list of publications offered by the Center for Archaeological Research is available. Call (210) 458-4378; write to the Center for Archaeological Research, The University of Texas at San Antonio, 6900 N. Loop 1604 W., San Antonio, Texas 78249-0658; e-mail to car@lonestar.utsa.edu; or visit CAR's web site at http://car.utsa.edu. 


\begin{abstract}
From December of 1998 through November of 1999, the Center for Archaeological Research (CAR), at The University of Texas at San Antonio (UTSA) conducted a Class III archaeological survey of 10,195 acres (4125 ha) within Twin Buttes Reservoir, a flood control and irrigation facility near the city of San Angelo in westcentral Tom Green County, Texas. The 100 percent pedestrian survey, conducted for the Department of the Interior, Bureau of Reclamation (BOR), was primarily a Section 110, of the National Historic Preservation Act (NHPA), effort. The survey was conducted in conjunction with repair of existing seepage at Twin Buttes Dam. The repair, conducted under the Safety of Dams program, involved the construction of several borrow pits. Since the Safety of Dams repair required BOR to inventory several areas of the reservoir lands under Section 106 of the NHPA, it was decided to expand the Section 106 work, and do the entire Section 110 survey of the reservoir.

CAR recorded 178 new archaeological sites, and revisited 21 previously recorded sites, within the reservoir. On these 199 sites, 19 historic components were identified, reflecting primarily farming and ranching activities. The prehistoric sites reflect occupation from the early Paleoindian period through the Late Prehistoric period. While recommendations regarding the eligibility of sites to the National Register of Historic Places (NRHP) were not required by the survey, based on the survey results CAR recommends that 13 of the 19 historic components have moderate or high research potential. Within the prehistoric data set, 48 sites have high research potential, 33 have moderate research potential, and 111 sites have limited research value.
\end{abstract}




\title{
An Archaeological Survey of Twin Buttes Reservoir Tom Green County, Texas
}

\author{
Volume I: \\ Chapter 1: Introduction \\ Chapter 2: Project Overview \\ Chapter 3: Project Environment \\ Chapter 4: Geoarchaeology \\ Chapter 5: Cultural Chronology and Previous Archaeology \\ Chapter 6: Methods
}

Chapter 7: Prehistoric Data; Research Perspective, Analytical Issues, and Project Goals

Chapter 8: Survey Results and Prehistoric Data Analysis

Chapter 9: Archaeological Record Investigations

Chapter 10: Historic Sites; Background and Research Design

Chapter 11: Historic Sites; Survey Results and Analysis

Chapter 12: Summary and Recommendations

\section{Volume II:}

Appendix A: Prehistoric Site Descriptions and Summary

\section{Volume III:}

Appendix B: Shovel and Auger Data

Appendix C: Excavation Summary

Appendix D: Surface Observation Data

Appendix E: Biface Data

Appendix F: Unique Items Data

Appendix G: Isolated Finds Data

Appendix H: Radiocarbon Data

Appendix I: Soil-Stratigraphic Descriptions

Appendix J: Paleomagnetic and Magnetic Soil Susceptibility Results

Appendix K: Project Forms

Appendix L: Previous Land Ownership 


\section{An Archaeological Survey of Twin Buttes Reservoir}

\section{Contents Volume I}

Abstract

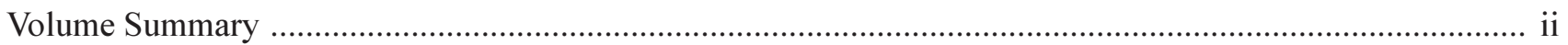

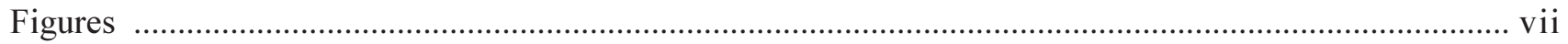

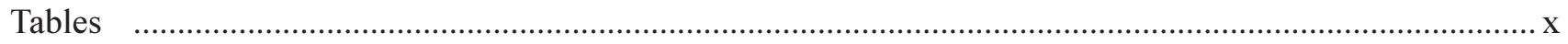

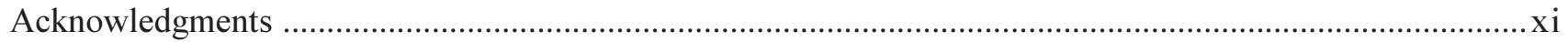

Chapter 1: Introduction

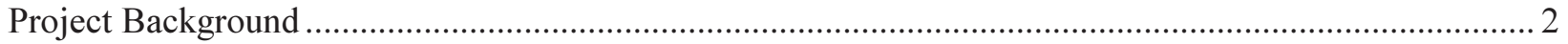

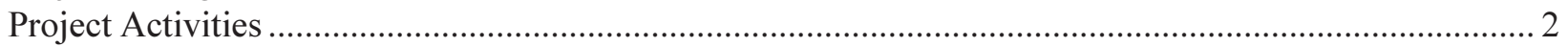

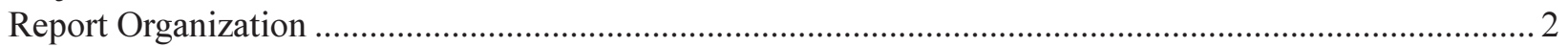

Chapter 2: An Overview of the Twin Buttes Archaeological Project

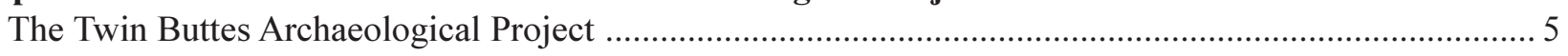

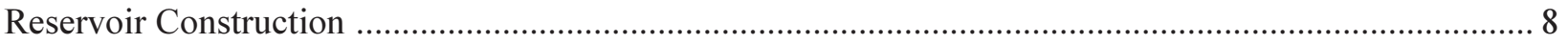

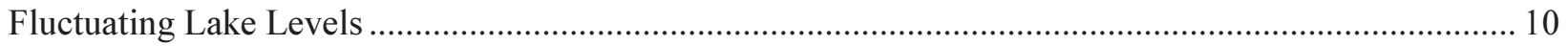

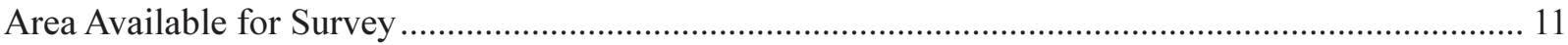

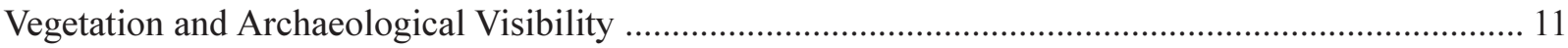

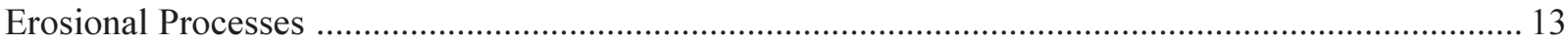

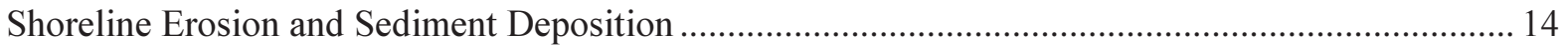

Near Shore and Offshore Erosional/Depositional Changes .............................................................. 19

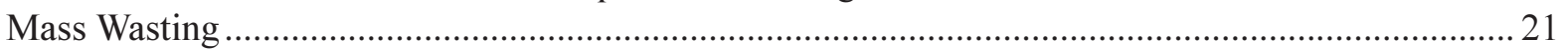

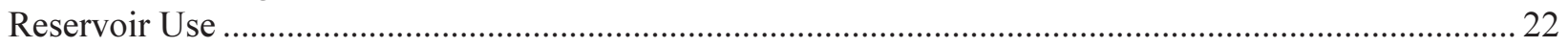

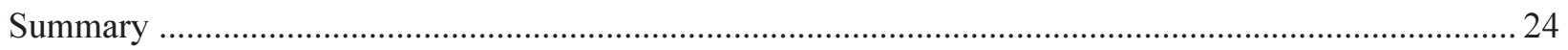

Chapter 3: The Project Environment

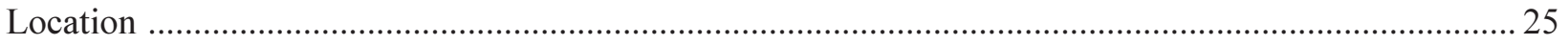

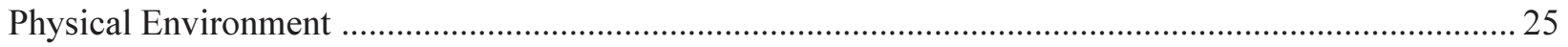

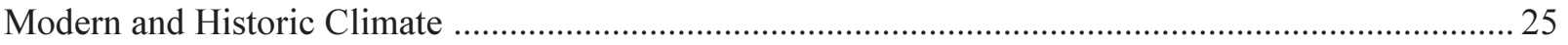

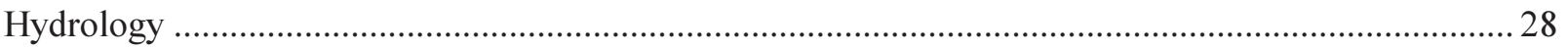

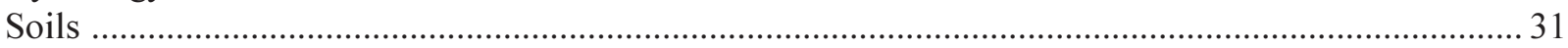

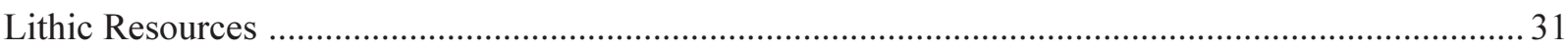

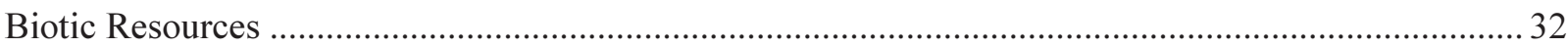

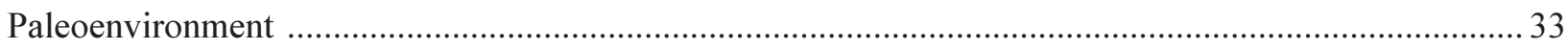

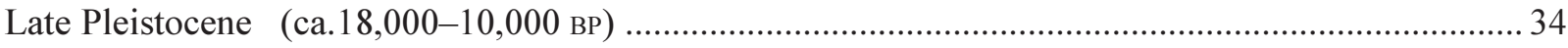

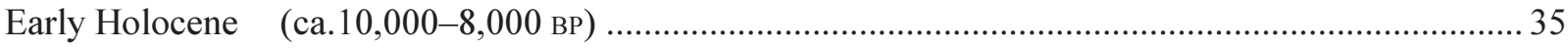

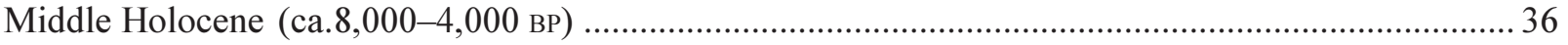

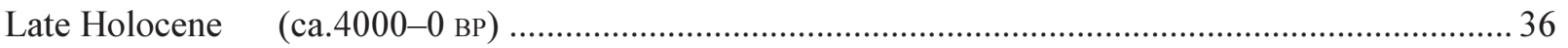

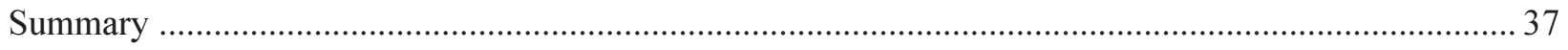

Chapter 4: Geoarchaeology of the Twin Buttes Project Area

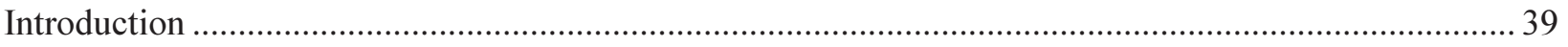

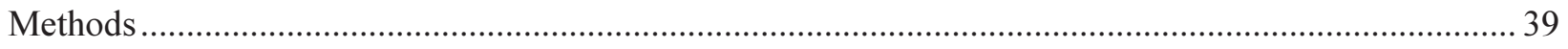

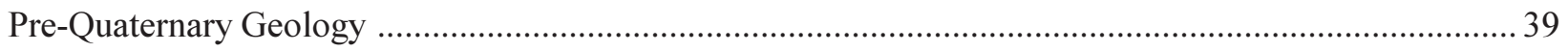

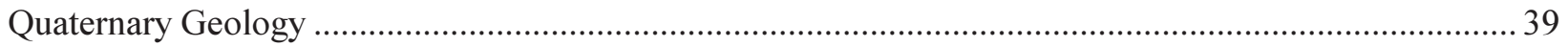

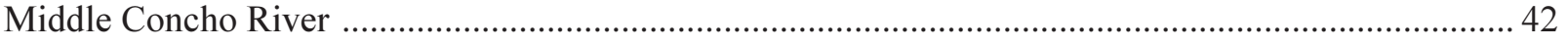

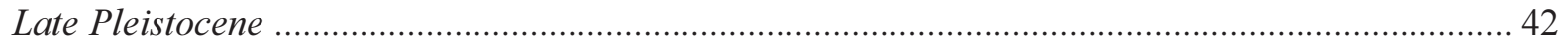

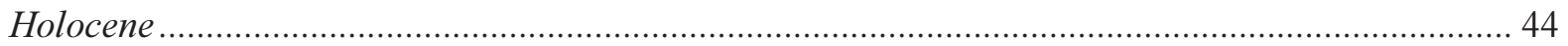

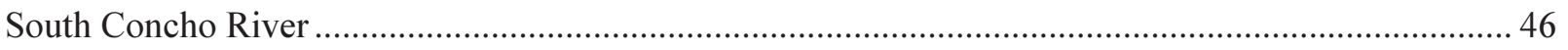




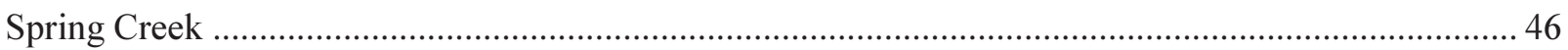

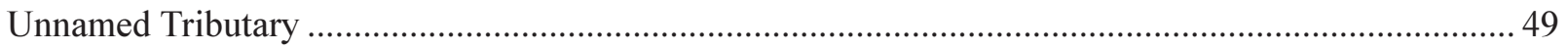

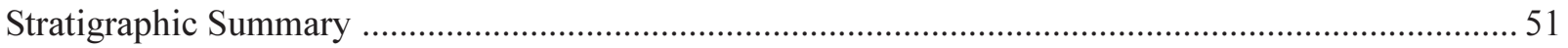

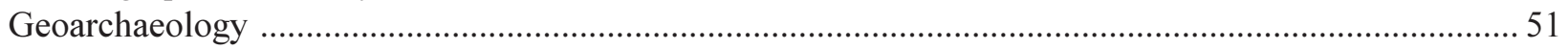

Site 41TG378

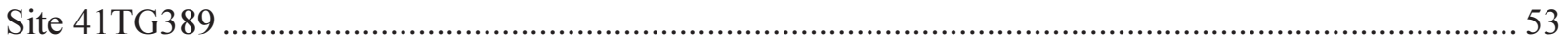

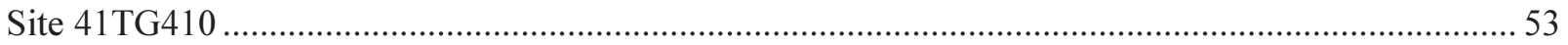

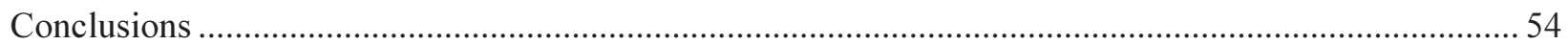

\section{Chapter 5: Cultural Chronology and Previous Archaeological Research}

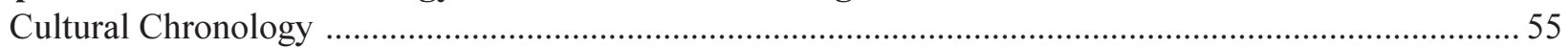

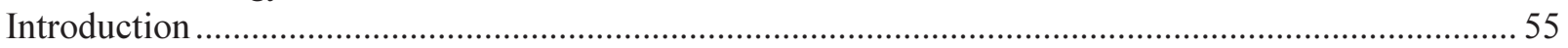

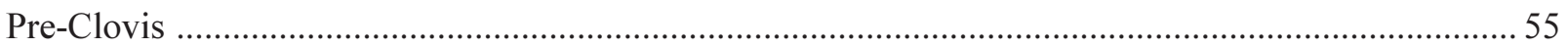

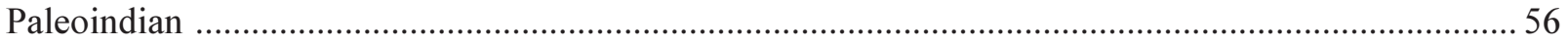

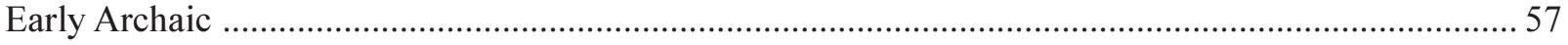

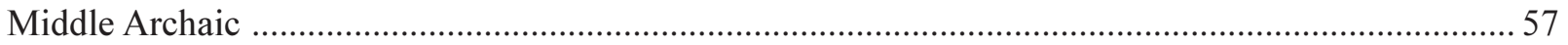

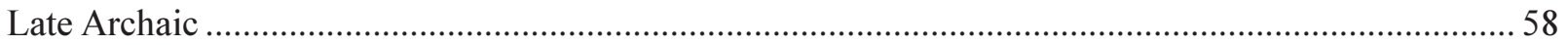

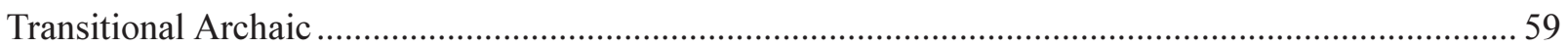

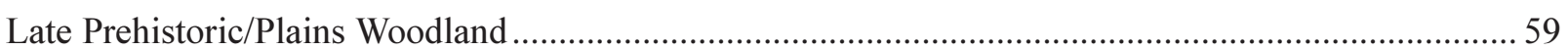

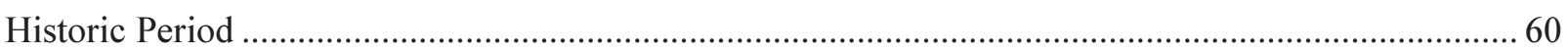

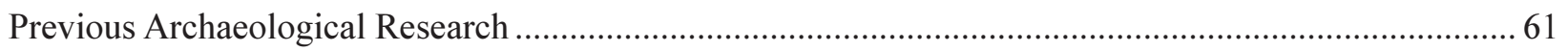

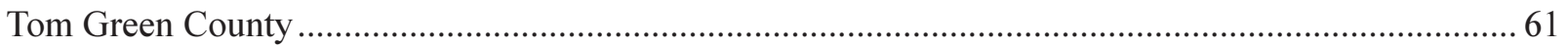

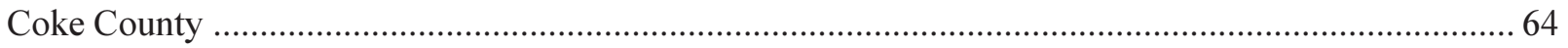

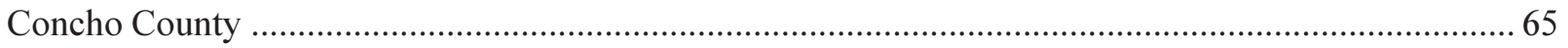

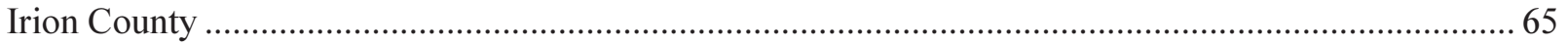

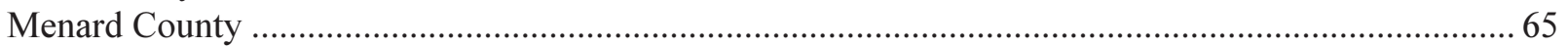

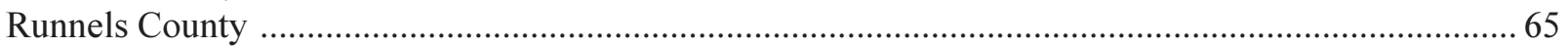

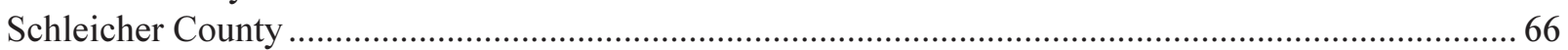

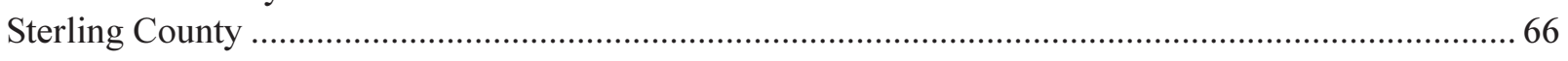

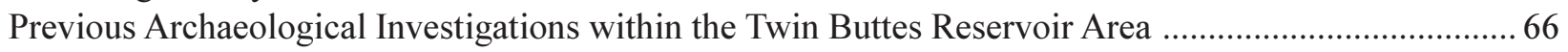

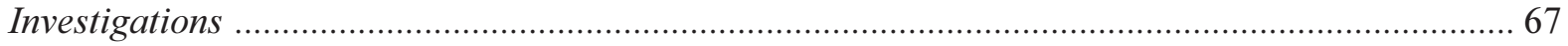

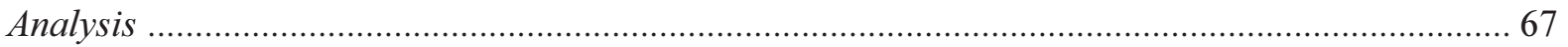

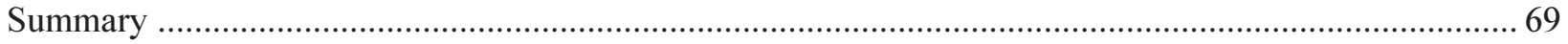

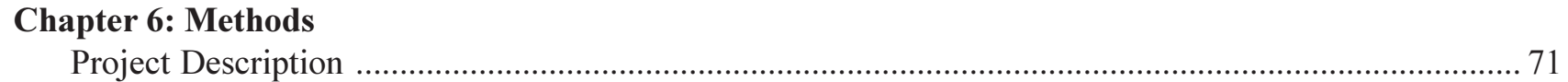

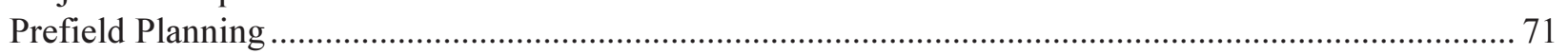

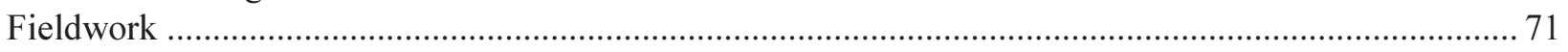

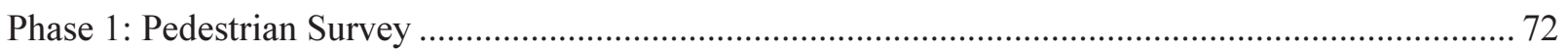

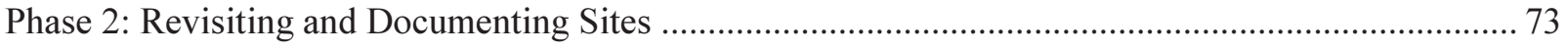

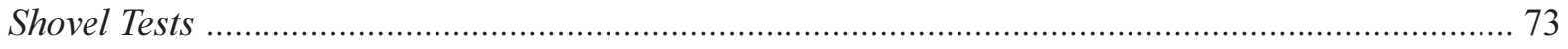

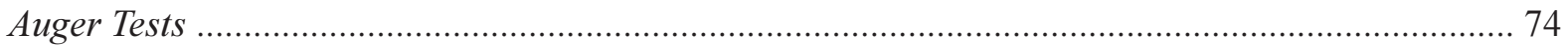

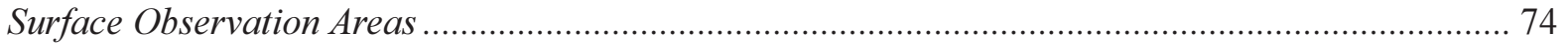

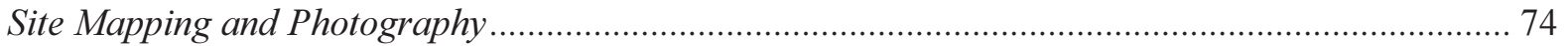

Phase 3: Excavation and Geomorphic Documentation ........................................................................ 74

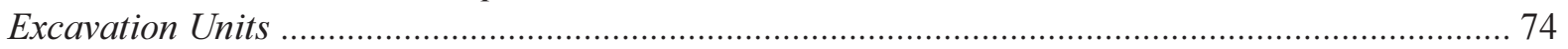

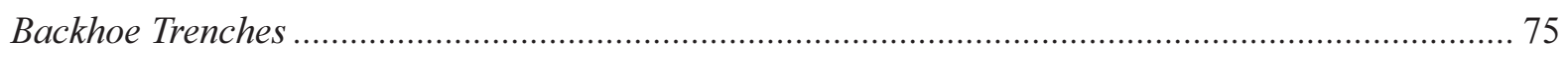

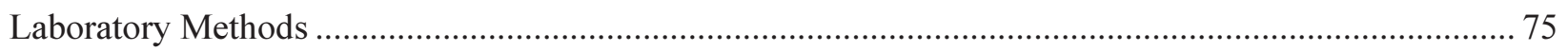

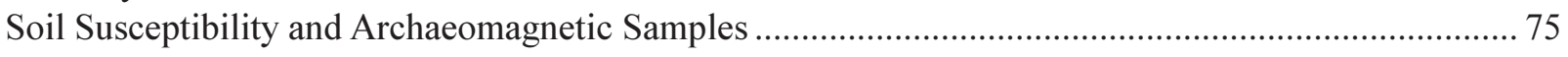

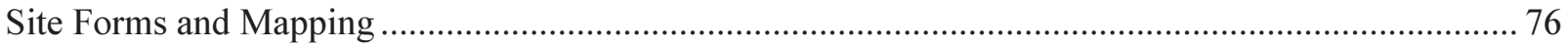

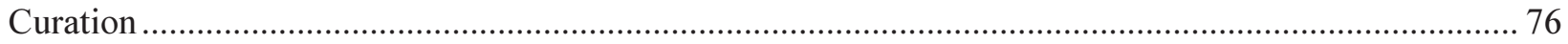


Chapter 7: Prehistoric Data: Research Perspective, Analytical Issues, and Project Goals

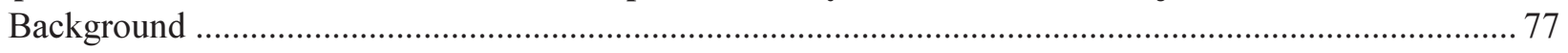

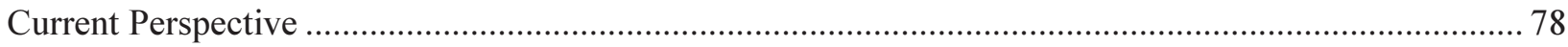

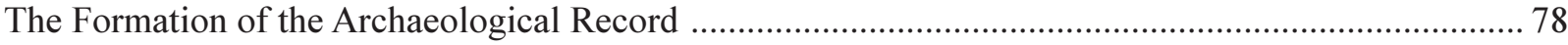

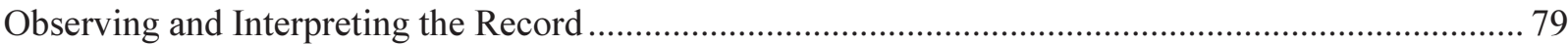

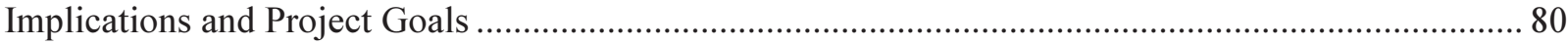

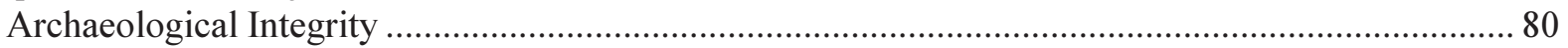

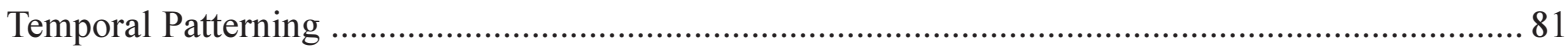

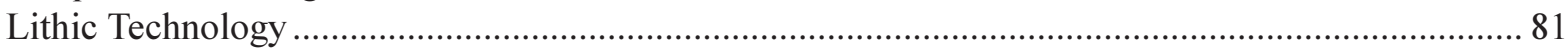

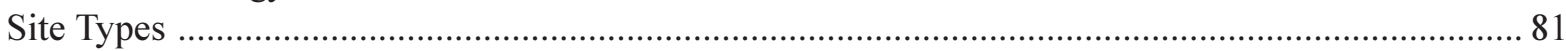

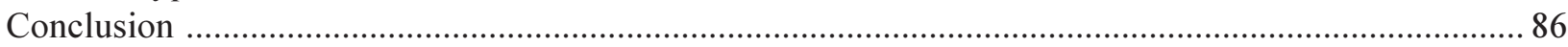

Chapter 8: Survey Results and Prehistoric Data Analysis

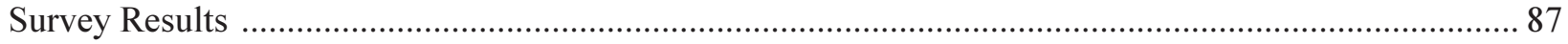

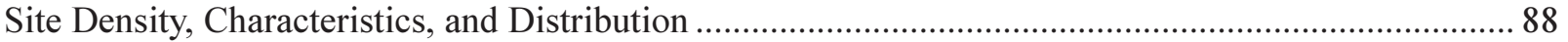

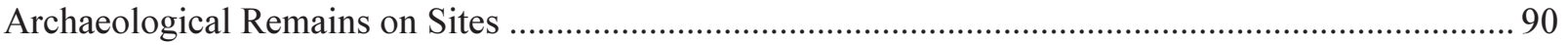

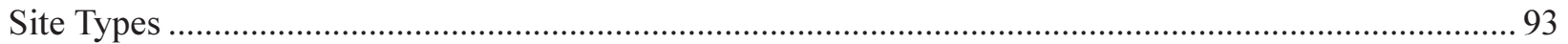

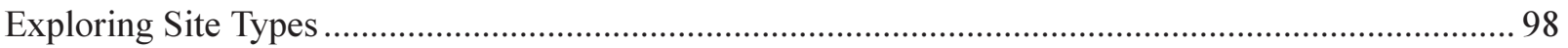

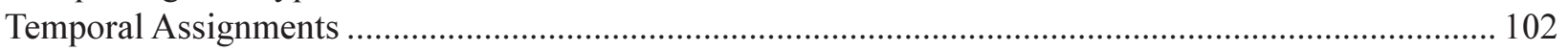

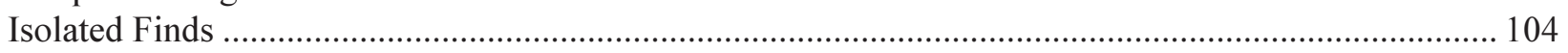

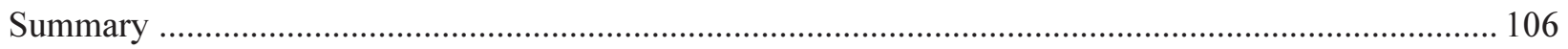

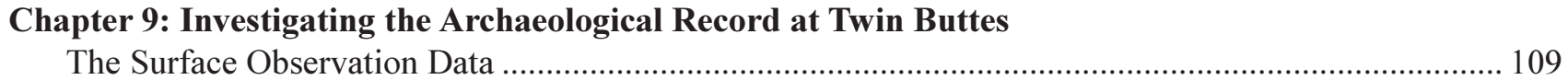

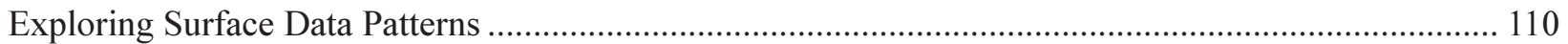

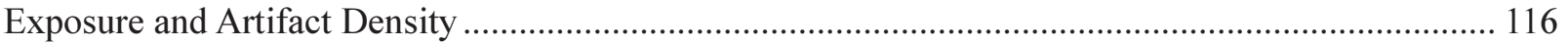

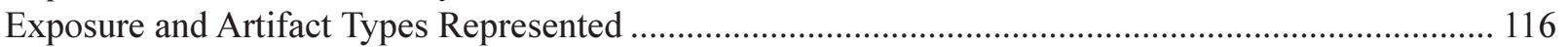

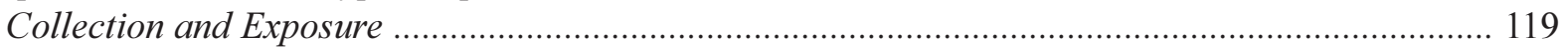

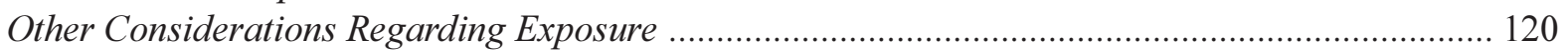

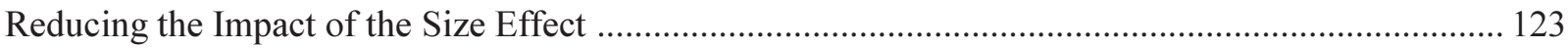

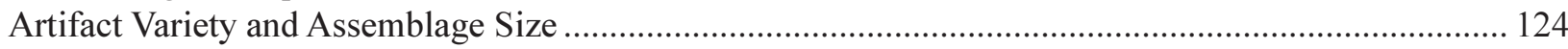

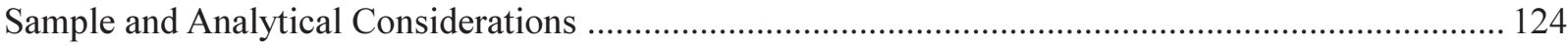

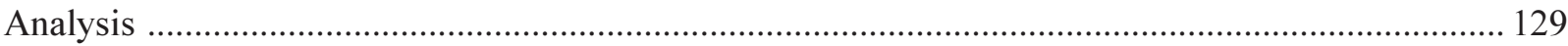

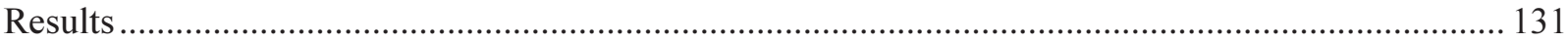

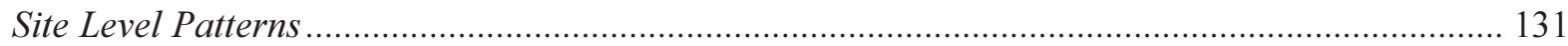

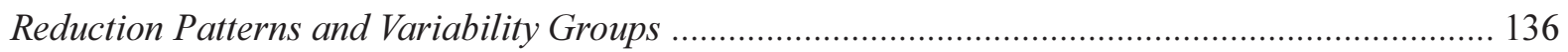

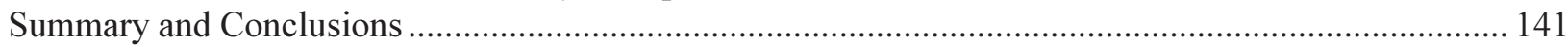

Chapter 10: Background and Research Design for Historic Sites

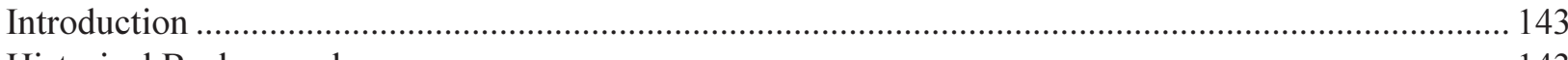

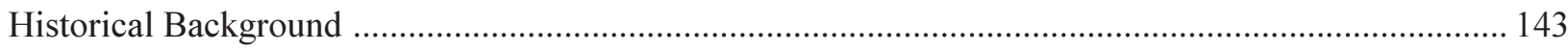

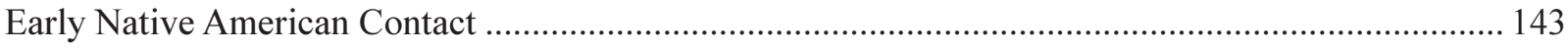

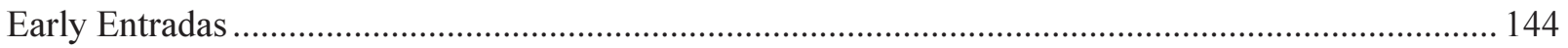

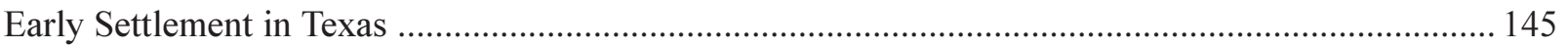

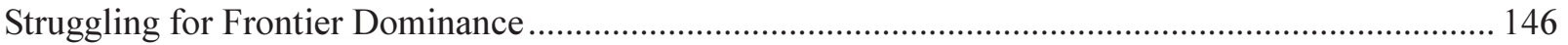

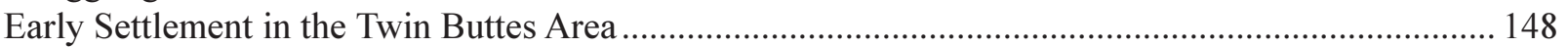

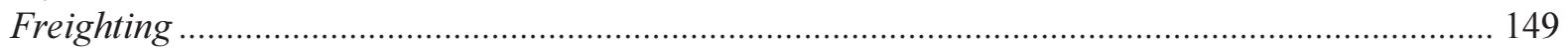

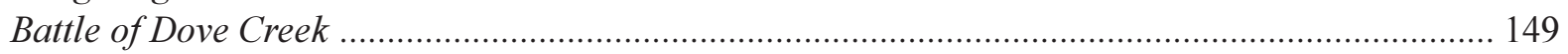

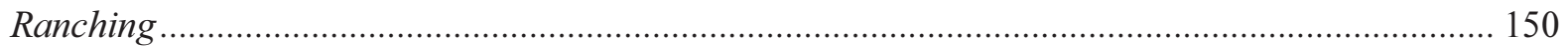

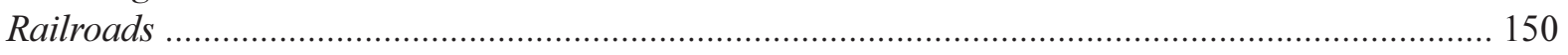

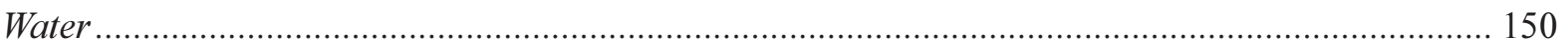




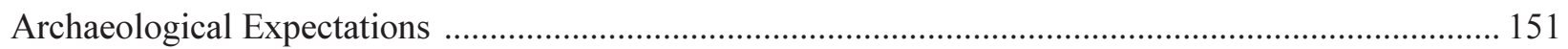

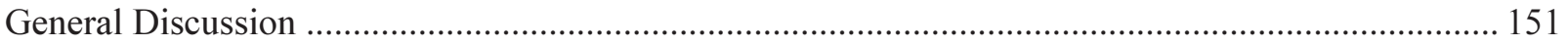

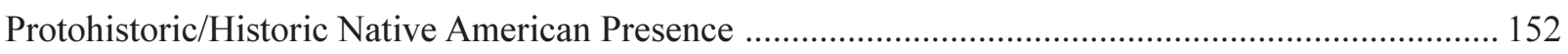

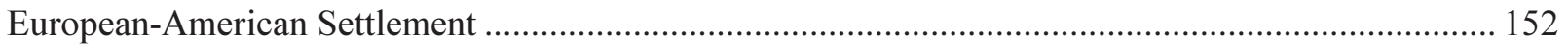

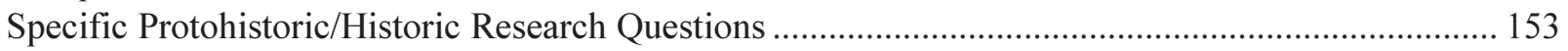

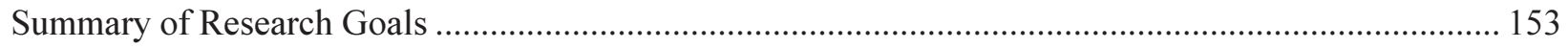

Chapter 11: Historic Sites Survey Results and Analysis
Introduction

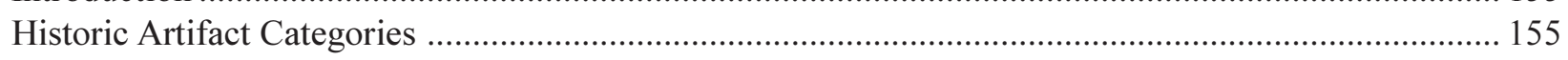

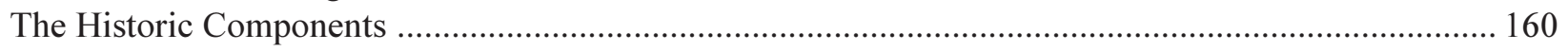

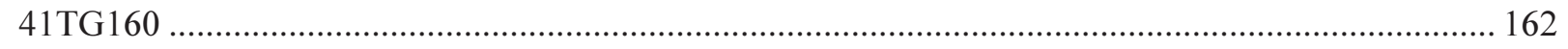

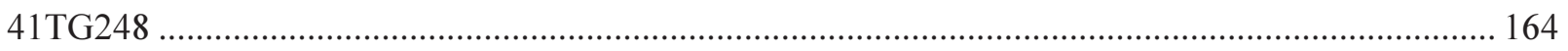

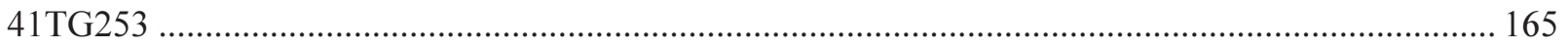

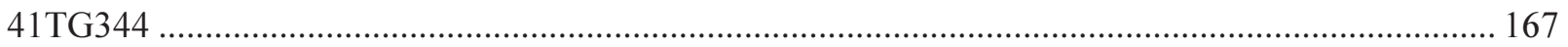

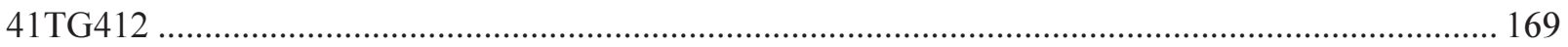

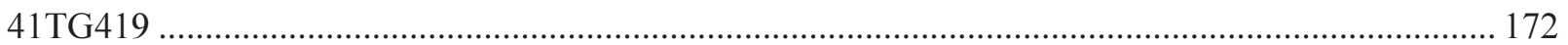

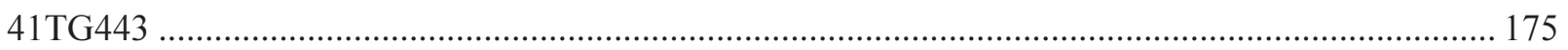

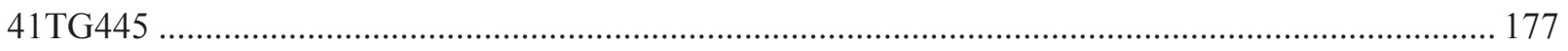

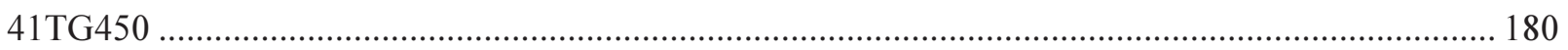

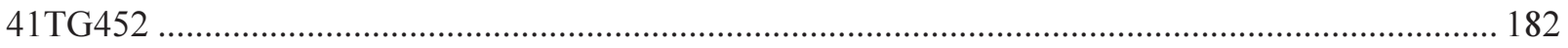

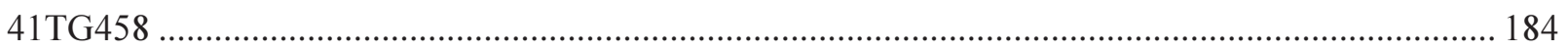

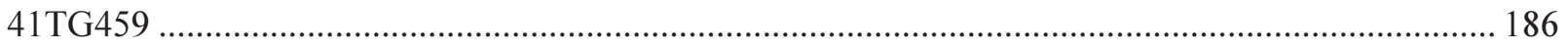

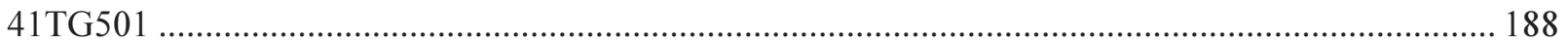

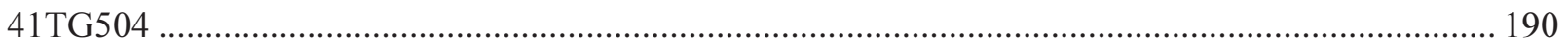

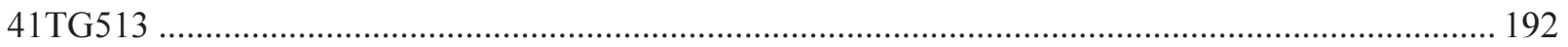

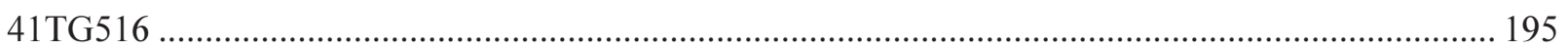

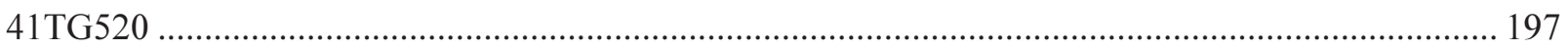

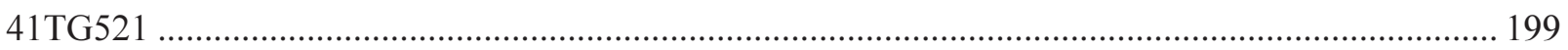

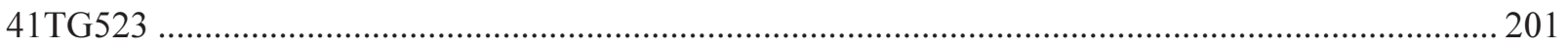

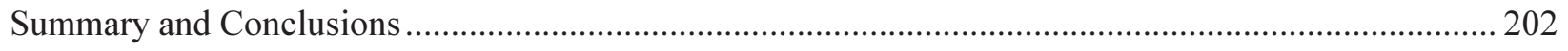

Chapter 12: Summary and Recommendations

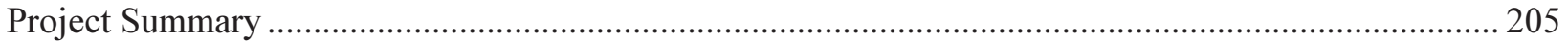

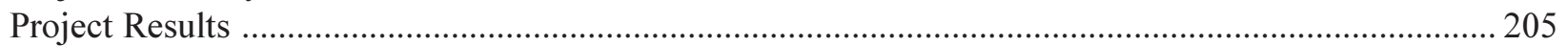

Recommendations and Management Considerations .......................................................................... 205

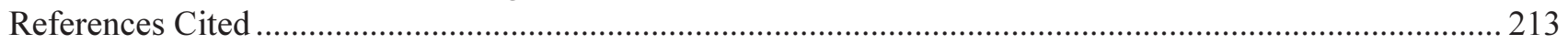




\section{Figures}

Figure 1-1. General location of the Twin Buttes Archaeological Project. .................................................... 1

Figure 2-1. Project area with major drainages and landmarks identified................................................. 6

Figure 2-2. The distribution of archaeological sites at Twin Buttes Reservoir. ............................................. 7

Figure 2-3. Enlargement of a USGS 1:10,000 color infrared aerial photo with borrow pits identified.............8

Figure 2-4. Small borrow pit exposed at low water levels. ................................................................... 9

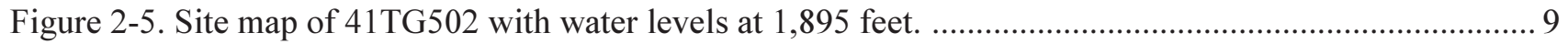

Figure 2-6. Twin Buttes Reservoir water storage levels (1963-1998) ....................................................... 10

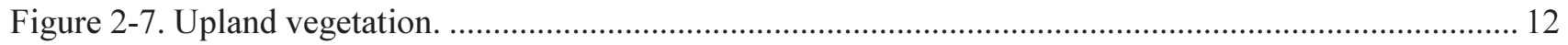

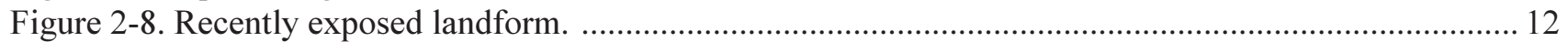

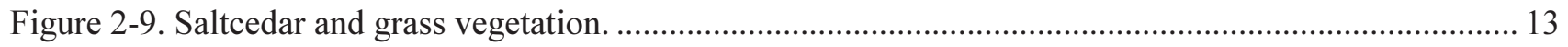

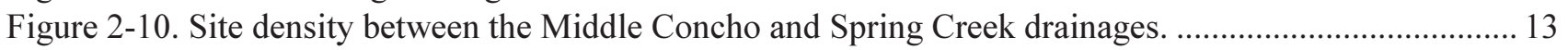

Figure 2-11. Enlargement of a USGS 1:10,000 color infrared aerial photo. ............................................... 15

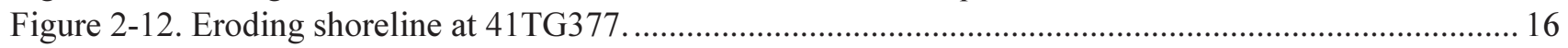

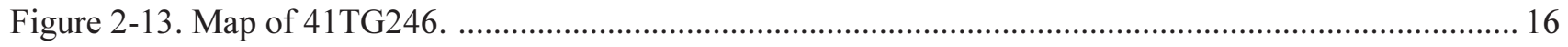

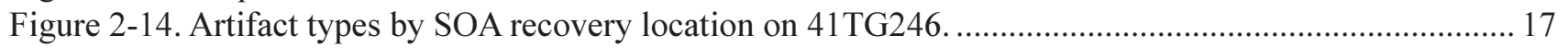

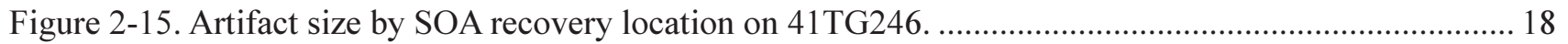

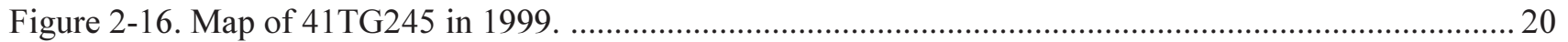

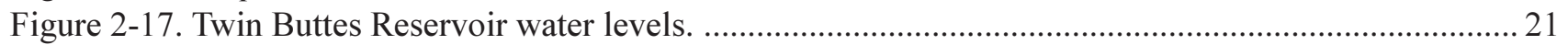

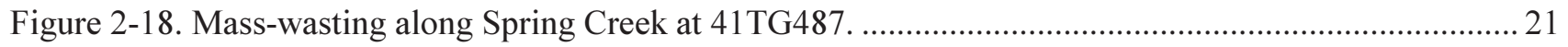

Figure 2-19. Private collection of points and other bifaces from Twin Buttes and surrounding area.............. 23

Figure 2-20. Cattle damage along Spring Creek shoreline. ...................................................................... 23

Figure 3-1. Natural Regions of Texas with the Twin Buttes Project area identified.....................................26

Figure 3-2. Natural Regions of Tom Green and surrounding counties. ...................................................... 27

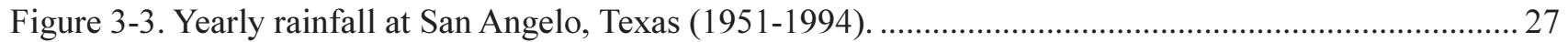

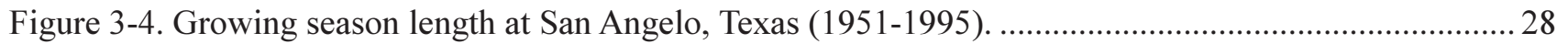

Figure 3-5. Palmer Drought Severity Index, Climate Division 6 (1900-1990). .......................................... 29

Figure 3-6. Average monthly streamflow of the South Concho (1930-1990). ............................................. 30

Figure 3-7. Yearly deviations from median streamflow, South Concho River (1931-1970)......................... 31

Figure 3-8. Vegetation complexes in Tom Green and surrounding counties............................................... 33

Figure 3-9. Paleontological and archaeological sites discussed in the text.................................................. 34

Figure 3-10. Poaceae pollen percentages for Boriack and Patschke Bogs. .................................................... 35

Figure 3-11. Regional climatic indicators for Central Texas................................................................... 38

Figure 4-1. Geological formations in the vicinity of the Twin Buttes project area....................................... 40

Figure 4-2. Schematic geologic cross section in the vicinity of the project area. ......................................... 41

Figure 4-3. Topographic map along the Middle Concho River. ............................................................... 43

Figure 4-4. Alluvial stratigraphic cross section based on exposures from BHT-2, BHT-3, and BHT-4. ........ 44

Figure 4-5. Alluvial stratigraphic cross section based on exposures from CB2a, CB2b, and CB2c.............. 44

Figure 4-6. Alluvial stratigraphic cross section based on exposures from BHT-1, CB1a, and CB1b. ............ 45

Figure 4-7. Alluvial stratigraphic cross section based on exposures from CB3 and TU1 at site 41TG389..... 45

Figure 4-8. Topographic map along the South Concho River. ..................................................................... 47

Figure 4-9. Alluvial stratigraphic cross-section based on exposures from CB6 and CB7. ........................... 47

Figure 4-10. Topographic map along Spring Creek. ............................................................................... 48

Figure 4-11. Alluvial stratigraphic cross-section based on exposures from BHT-8, BHT-10, and CB5 ........ 48

Figure 4-12. Topographic map along the Unnamed Tributary. .............................................................. 50

Figure 4-13. Alluvial stratigraphic cross-section based on exposures from BHT-5, BHT-6, and BHT-7. ....... 50

Figure 4-14. Schematic geologic cross-section in the area of site 41TG378. .................................................5 53

Figure 5-1. Project area with surrounding counties and major rivers identified. .......................................... 62 


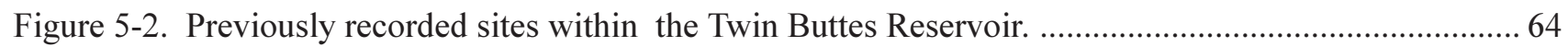

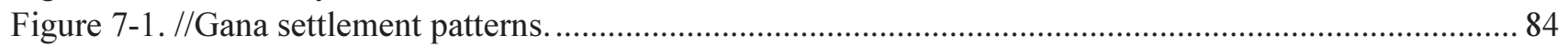

Figure 7-2. Expected relationships between number of artifacts, artifact types, and task variety. .................. 86

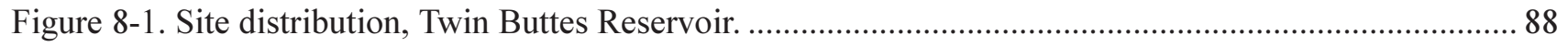

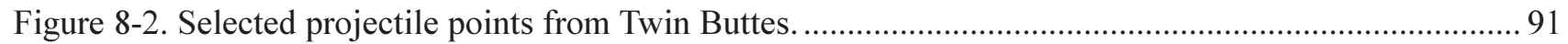

Figure 8-3. Selected chipped stone tools from Twin Buttes. ................................................................... 92

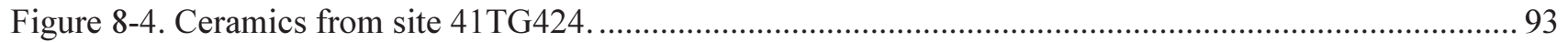

Figure 8-5. Examples of ground stone recovered from Twin Buttes............................................................. 94

Figure 8-6. Burned and fire-cracked limestone features. ...................................................................... 95

Figure 8-7. Examples of mortar holes recorded at Twin Buttes. ................................................................ 96

Figure 8-8. Box plot of site area by assemblage size groups. ....................................................................... 99

Figure 8-9. Box plot of distance to water $(\mathrm{km})$ by assemblage size groups. ............................................ 101

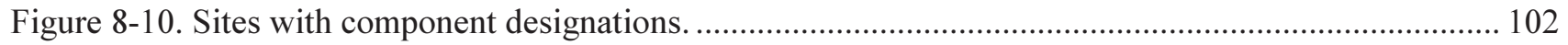

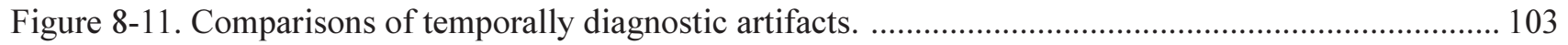

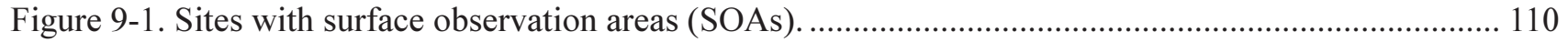

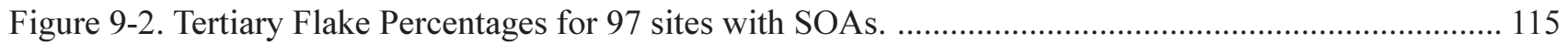

Figure 9-3. Exposure and mean artifact length by class. ....................................................................... 117

Figure 9-4. Percentage of artifacts by size groups on unexposed and exposed surfaces. ............................. 118

Figure 9-5. Percentage of non-flake artifacts by length for unexposed and exposed surfaces. ..................... 119

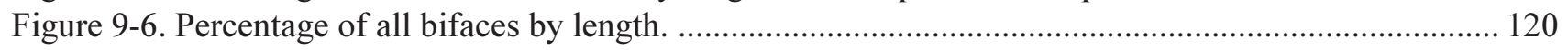

Figure 9-7. Percentage of bifaces without cortex by length for unexposed and exposed surfaces. ................ 120

Figure 9-8. Percentage of cores with cortex, tested cobbles, and other tools. ............................................ 121

Figure 9-9. Differential sampling fractions from a single population...................................................... 122

Figure 9-10. SOA boundaries on 41TG362, a site with two different activity areas noted on survey........... 125

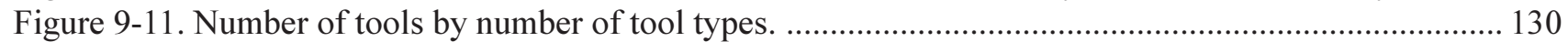

Figure 9-12. Log of number of tools by number of tool types with least squares line................................. 130

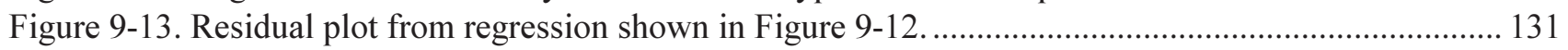

Figure 9-14. Studentized residuals for sites without features or FCR .................................................. 137

Figure 9-15. Studentized residuals for sites with features or FCR ......................................................... 137

Figure 9-16. Box plot of distance to water for low and high variety groups. .............................................. 138

Figure 9-17. Box plot of distance to water for subset of low and high variety groups. .............................. 138

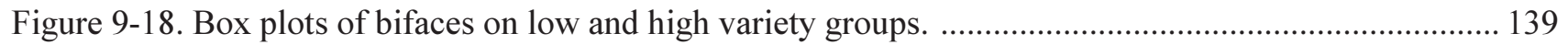

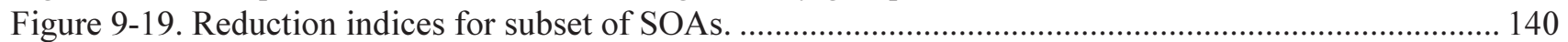

Figure 11-1. Historic site locations within the Twin Buttes Reservoir survey area. ................................... 160

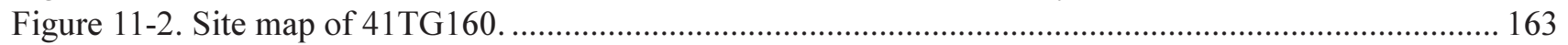

Figure 11-3. Photograph of Gardner's Dam (41TG248) across the South Concho River............................. 164

Figure 11-4. Photograph of White's Dam (41TG253) across Spring Creek. ................................................. 165

Figure 11-5. Writing and impressions on concrete ditch wall just below White's Dam. ............................. 166

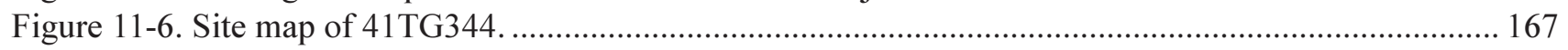

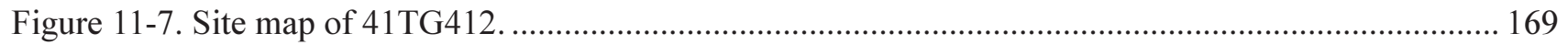

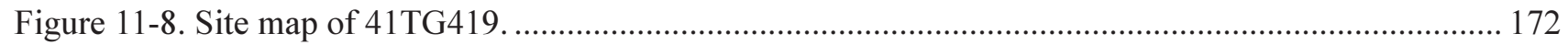

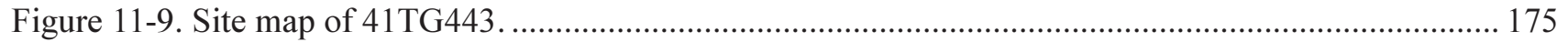

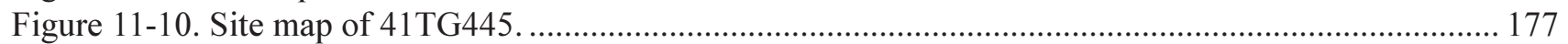

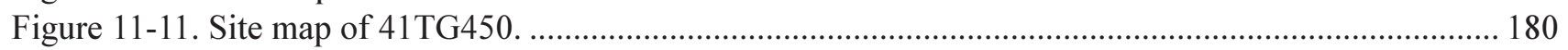

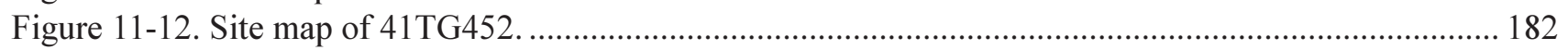

Figure 11-13. Photograph of piers from a pier and beam structure at 41TG452. .................................... 183

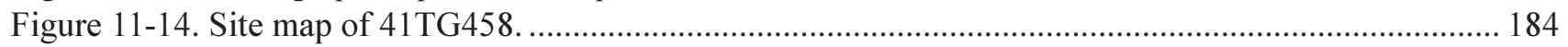

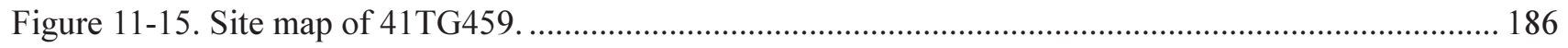

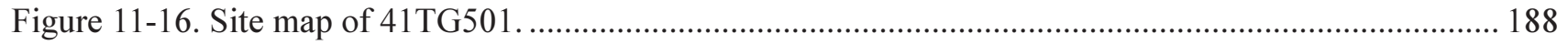




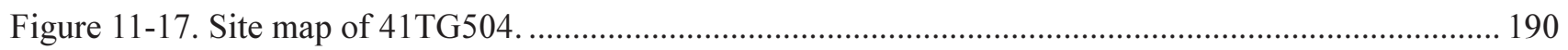

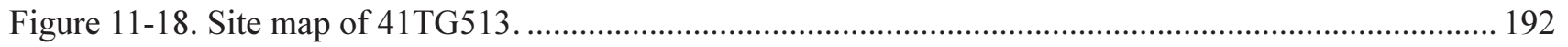

Figure 11-19. Photograph of sandstone structure of unknown age (41TG513). ......................................... 193

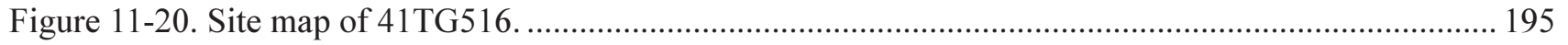

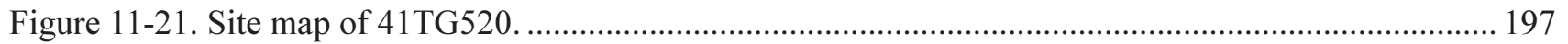

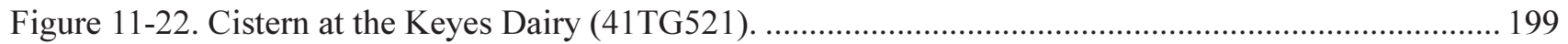

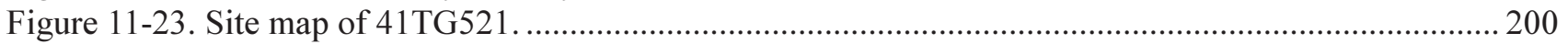

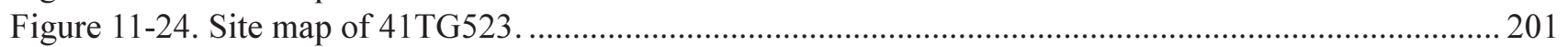

Figure 12-1. Vertical Distribution of Shovel Test Results from 41TG472 .............................................. 206

Figure 12-2. Photographs of site 41TG502 (November, 1999; January, 2000). ........................................ 211 


\section{Tables}

Table 2-1. Exposure and Inundation of Twin Buttes Reservoir for Selected Elevations (1971-1998)............. 11

Table 5-1. Site Types and Attributes in Twin Buttes, Knickerbocker, and Pecan Station Quadrangles ............. 68

Table 6-1. Size Definitions for Prehistoric Archaeological Occurrences ...................................................... 73

Table 7-1. Temporal Periods, BP Date Ranges, and Selected Diagnostic Artifact Types ............................... 82

Table 8-1. Selected Characteristics of 190 Prehistoric Sites at Twin Buttes ................................................. 89

Table 8-2. Selected Attributes of site types identified on the Twin Buttes Project ...................................... 97

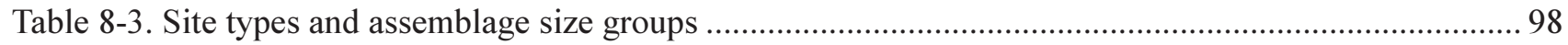

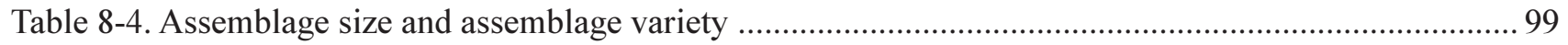

Table 8-5. Assemblage size groups and presence/absence of hearths ....................................................... 100

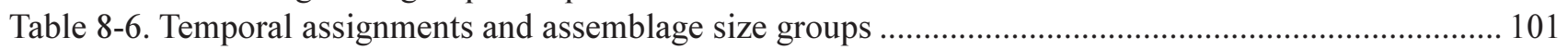

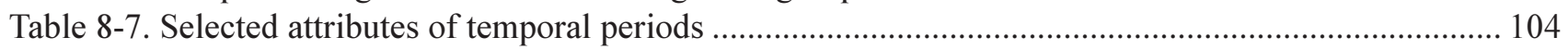

Table 8-8. Isolated finds by major artifact type for the Twin Buttes Survey ................................................ 105

Table 8-9. Site and Isolated Find non-flake data by Artifact Type for Twin Buttes .................................... 106

Table 9-1. Surface Observation Data from Twin Buttes Reservoir ............................................................ 111

Table 9-2: Observed Frequencies of Artifact Types by Exposure ........................................................... 117

Table 9-3. Observed Frequencies of Artifact Types by Exposure for items greater than $2 \mathrm{~cm} \ldots \ldots \ldots \ldots \ldots \ldots \ldots . . \ldots \ldots$

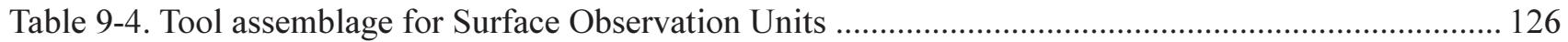

Table 9-5. Regression results and site level data for surface observation areas ........................................... 132

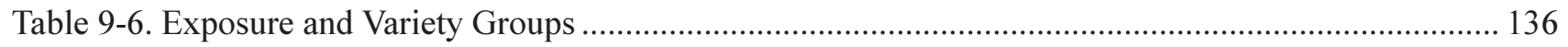

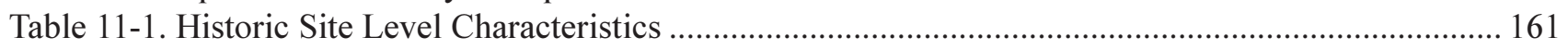

Table 11-2. Artifacts inferring occupation period at 41TG412 ….......................................................... 171

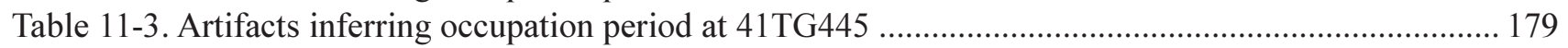

Table 11-4. Years of manufacture or distribution of bottles documented at 41TG459 …........................... 187

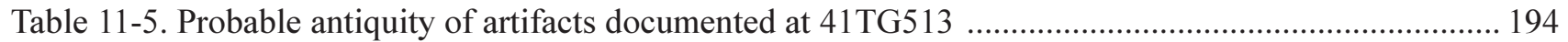

Table 11-6. Surmised development in the Twin Buttes Reservoir survey area .......................................... 203

Table 12-1. Recommended Research Potential for Historic Sites/Components ......................................... 207

Table 12-2. Prehistoric Sites/Components With High Research Potential .................................................... 208

Table 12-3. Prehistoric Sites/Components With Moderate Research Potential ........................................... 209

Table 12-4. Archaeological Sites With Limited Research Potential ............................................................ 210 


\section{Acknowledgments}

Dr. Robert J. Hard and Dr. C. Britt Bousman of CAR served as co-principal investigators on the project. Daily field operations were directed by project archaeologist Dr. Raymond Mauldin, with the assistance of David Nickels. Mr. Nickels, along with Anthony Lyle, served as crew chiefs on the project. CAR crew members who worked on the survey included Frederick Almarez, Kirk French, Lance Lamb, Brian Langner, Ruth Mathews, Preston McWhorter, and Kristi Miller. Laboratory analysis was performed by David Nickels, Connie Gibson, Ruth Mathews, Bruce Moses, Gloria Murguia, Clemente Murguia, Rick Robinson, Preston McWhorter, Kristi Miller, and Richard Young. Dr. Lee Nordt and Mr. Corey Crawford of Baylor University conducted the geomorphic work described in Chapter 4. Dr. Steven A. Tomka helped with the identification of diagnostic artifacts and Ms. Tanya Norris, Katie Plum, and Preston Stone of Angelo State University provided help with archival research on the historic material. Maryanne King and Johanna Hunziker edited this report.

The authors would like to thank Mr. Hector Garcia and Mr. Robert Blasing, of the Bureau of Reclamation, Department of the Interior, for their assistance throughout the project. Special thanks to Jack Woodrow, Violet Winfield, and all the folks from the Concho Valley Archaeological Society for making our stay in San Angelo so pleasant and to the late Mr. B. J. Corbell, owner of Spring Creek Ranch, for his generosity and genuine interest in our archaeological survey. 



\section{Chapter 1: Introduction}

\section{David Nickels and Raymond Mauldin}

In November 1998, the Center for Archaeological Research (CAR) of The University of Texas at San Antonio (UTSA) contracted with the United States Department of the Interior, Bureau of Reclamation to conduct a Class III archaeological survey of just over 10,000 acres (4047 ha) of mostly undisturbed land at
Twin Buttes Reservoir, a flood control and irrigation facility near the city of San Angelo in west-central Tom Green County, Texas (Figure 1-1). The purpose of this project was to identify and map archaeological sites on Bureau of Reclamation lands in the reservoir area.

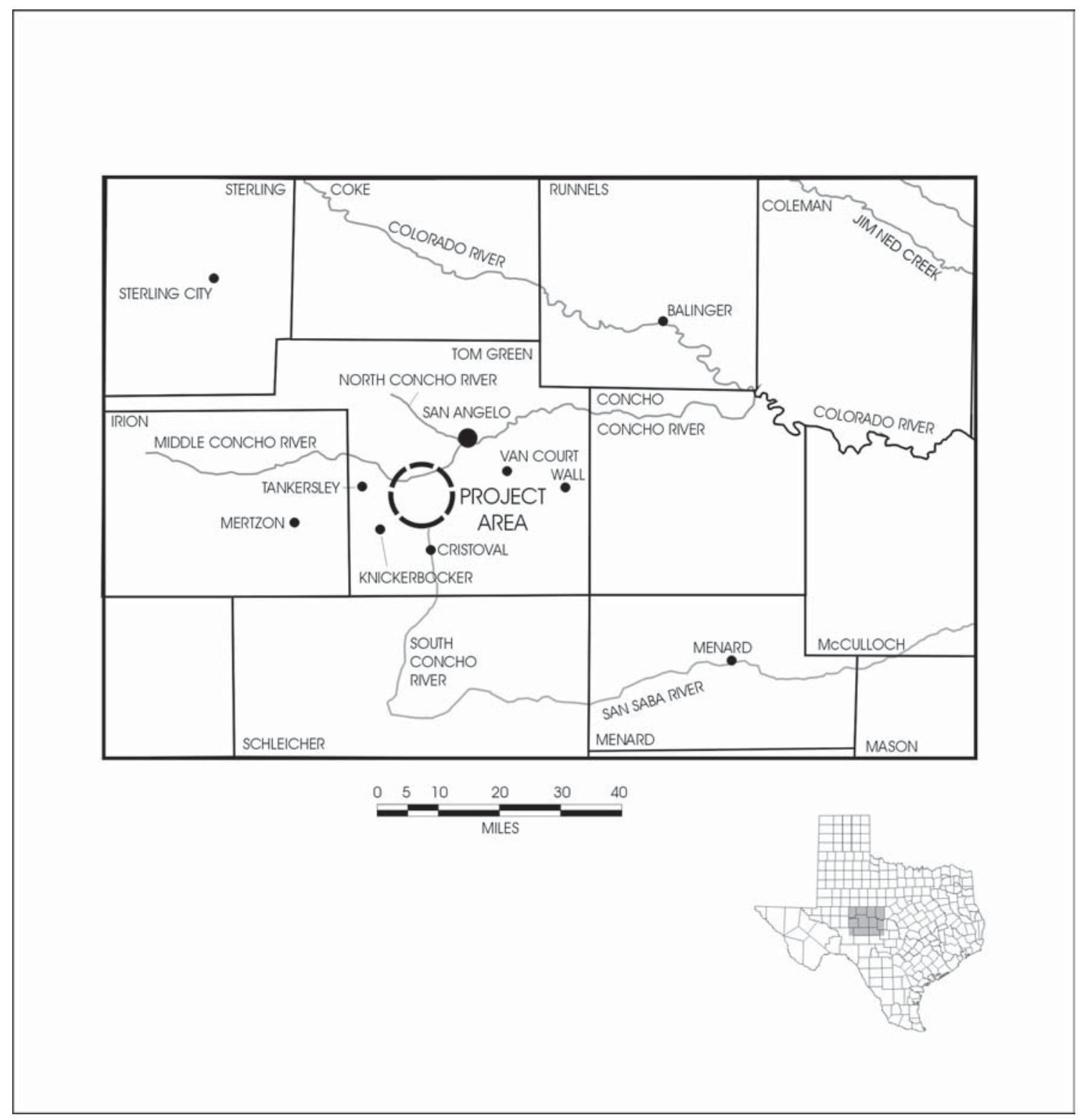

Figure 1-1. General location of the Twin Buttes Archaeological Project. 


\section{Project Background}

The Department of the Interior, Bureau of Reclamation was the agency charged with oversight management of archaeological compliance related activities during the duration of the project. The Twin Buttes survey was undertaken to meet requirements under sections 106 and 110 of the National Historic Preservation Act (NHPA). Under Sections 106 and 110 of the NHPA, the protection of cultural resources is related to their eligibility for inclusion in the National Register of Historic Properties (NRHP), which is in turn, dependent on their NRHP significance as defined in 36 CFR 60. The National Historic Preservation Act Amendments of 1992 clarified Section 110 and directed federal agencies to establish preservation programs corresponding to their activities and effects on historic properties. Under Section 110, federal agencies may evaluate the significance of cultural resources not currently threatened to assist with the development of preservation planning. The federal regulatory process is described in detail in 36 CFR 800.

The present survey, which was primarily a Section 110 effort, was conducted in conjunction with repair of existing seepage at Twin Buttes Dam. The repair, conducted under the Safety of Dams program, involved the excavation of several borrow pits. Since the Safety of Dams repair required the Bureau of Reclamation to inventory several areas of the reservoir lands under Section 106 of the NHPA, it was decided to expand the Section 106 work, and do the entire 110 survey of the reservoir. That is, the Safety of Dams project triggered the decision to start the total inventory within Twin Buttes Reservoir. The current project, then, provided an opportunity to generate information on all cultural resources within Twin Buttes Reservoir, as well as explore the effects of the operation of the dam on those resources.

\section{Project Activities}

The Twin Buttes archaeological project involved a 100 percent pedestrian survey of 10,195 acres (4125 ha). The survey identified a total of 178 new sites, and 21 previously recorded sites were revisited. In conjunction with the survey, CAR also conducted a limited surface collection strategy focused on temporally diagnostic artifacts, field analysis of 21,769 artifacts on 97 selected sites, 1,058 shovel tests and 57 auger tests on 187 sites, 48 shovel tests off-site, five 1 x 1 meter hand-excavated units on four sites, and 10 backhoe trenches. The backhoe trenches were excavated in conjunction with a geomorphic study, designed to accompany the archaeological work, conducted by Dr. Lee C. Nordt and Dr. C. Britt Bousman. The archaeological survey project relied heavily on hand-held Trimble ${ }^{\circledR}$ global positioning system (GPS) receivers to accurately locate both site and isolate information. These data were used in conjunction with ArchView ${ }^{\circledR}$ Geographical Information Systems (GIS) software. Most of the field work was accomplished by 3 to 5-person crews who were in the field from December of 1998 through April of 1999. An additional field visit by a smaller crew was made in November of 1999 . In addition to recording data on the 199 archaeological sites, the project recorded a total of 393 isolated finds. The artifacts, records, and other materials recovered or generated during the fieldwork and subsequent laboratory analysis are curated at the CAR-UTSA Laboratory.

\section{Report Organization}

The format and organization of this report is somewhat different than commonly seen in survey reports from the state. Typically, survey reports are composed of a series of introductory chapters focused on background. These are followed by a section on research design, a section on methodology, a section on results, and a section on significance. The results chapter is typically the heart of the document, consisting of detailed descriptions of prehistoric and historic sites found during the survey. While the current report contains these elements, the order of presentation and the emphasis is somewhat different.

This report is divided into three volumes. Volume 1 contains a total of 12 chapters, including this introductory chapter. An overview of the project is presented in Chapter 2, while environmental background for the project area is discussed in Chapter 3. Chapter 4 provides a discussion of the geomorphology of the project area. Chapter 5 synthesizes previous archaeological research in the Twin Buttes region. 
Chapter 6 presents field and laboratory methodology employed during the project. This discussion is presented before, rather than after, the research designs for the prehistoric and historic materials, even though the methodology was influenced by the prehistoric and historic research designs. This format allows Chapter 7, which outlines the research issues, to be followed by the eighth and ninth chapters that explore the prehistoric data in detail. Neither of these chapters provide a site by site discussion of the results, but rather focus on summary level data for both sites and isolates. The grouping of these three chapters, all of which focus on the prehistoric data, is designed to facilitate the presentation of the arguments. Chapters 10 and 11 discuss historic research issues and results, and are somewhat analogous to the Chapter 7 through 9 discussion for the prehistoric data. A project summary, along with some general management and research suggestions for the Twin Buttes area, is presented in Chapter 12.

Volumes 2 and 3 of this report present supporting data for the project. In all, twelve different appendices are provided. The appendices include detailed site descriptions in Volume 2 (Appendix A), and in Volume 3; shovel test data (Appendix B), excavation summaries (Appendix C), surface artifact observation data (Appendix D), metric data on bifaces collected and observed on the project (Appendix E), unique items collected (Appendix F), data on isolated finds including maps of their distribution (Appendix G), radiocarbon data sheets (Appendix $\mathrm{H}$ ), backhoe trench profile descriptions (Appendix I), data on paleomagnetic and soil susceptibility (Appendix J), examples of all project forms (Appendix K), and information on previous land ownership (Appendix L). In addition to these project and site specific data sets, Texas archaeological site forms were prepared or updated for all 199 sites observed or previously recorded in the project area. These are available at the Texas Archeological Research Laboratory in Austin. 



\section{Chapter 2: An Overview of the Twin Buttes Archaeological Project}

\section{Raymond Mauldin and David Nickels}

As noted in the previous chapter, the Twin Buttes Archaeological Project was conducted by the Center for Archaeological Research at the request of the Bureau of Reclamation, United States Department of the Interior. The project was primarily a survey of the Twin Buttes Reservoir in Tom Green County of west-central Texas. Several projects had been conducted in the Reservoir, including an early reconnaissance by Willis (1958; Green 1959) who recorded five archaeological sites, and small surveys of selected portions of the reservoir by Creel (1978), Barger (1980), Etchieson (1985), and Hageman (1993). However, the current project was the first systematic survey of Twin Buttes Reservoir.

Twin Buttes Dam, an 8.1 mile (13.04 km) long earthen filled wall, was constructed between May 3, 1960 and February 13, 1963 (USBR 1999; USGS 1999a). Impounding of water began in December of 1963. Since the completion of Twin Buttes Dam, water reservoir levels have fluctuated in response to the variable and unpredictable rainfall in this portion of the state. While a maximum water content of 205,200 acre-feet was achieved on May 12, 1975, only during a few periods has the pool capacity reached the 186,000 acre-feet conservation capacity for which the reservoir was designed. Nevertheless, the reservoir has served as an important source of water for the city of San Angelo, and provided recreational opportunities for the people of Tom Green and surrounding counties (Handbook of Texas Online 1999a; USBR 1999; USGS 1999a; Weidenfeld and Flores 1976).

The construction of the reservoir in the early 1960s, the fluctuating lake levels since that time, and the history of use of the reservoir over the last 36 years created several problems which, while potentially present on other surveys, were exacerbated on the Twin Buttes project. This chapter presents an introduction to the Twin Buttes archaeological project, with emphasis on aspects of those problems that impact the description and analysis of the survey results presented in subsequent chapters.

\section{The Twin Buttes Archaeological Project}

Before considering the various processes that impact both our observations of the archaeological record and the characteristics of that record at Twin Buttes Reservoir, it is necessary to briefly summarize several aspects of the survey area and the project. As details on the project area are presented in subsequent chapters, our goal here is simply to provide a context for discussing the impacts associated with dam construction and use.

Figure 2-1 presents the overall project area. The axis of the dam runs roughly northwest to southeast. Most of the lands within the project boundary on the western side of the dam have, at some point since construction, been inundated by water collected in the reservoir. Two separate reservoir pools, identified as the Main Pool and the South Pool, are present. The pools are connected by a 3.22 mile $(5.18 \mathrm{~km})$ equalization canal and are frequently maintained at different water levels. When water levels are above roughly 1,927 feet $(587 \mathrm{~m})$ in the Main Pool, the two pools join to form a single lake (USBR 1999; USGS 1999a).

Three primary drainages, the South Concho, Spring Creek, and the Middle Concho, cut through the project area. A secondary, unnamed tributary of the Middle Concho is located to the north. During our survey, the South Reservoir Pool (Figure 2-1) was maintained at an elevation of just under 1,927 feet (587 meters), while water in the Main Pool hovered at about 1,900 feet (579 meters). The South Concho flows into the South Pool, while the Main Pool is fed by both Spring Creek and the Middle Concho, as well as by water from the equalization channel. At the time of the survey, only Spring Creek and the South Concho had 


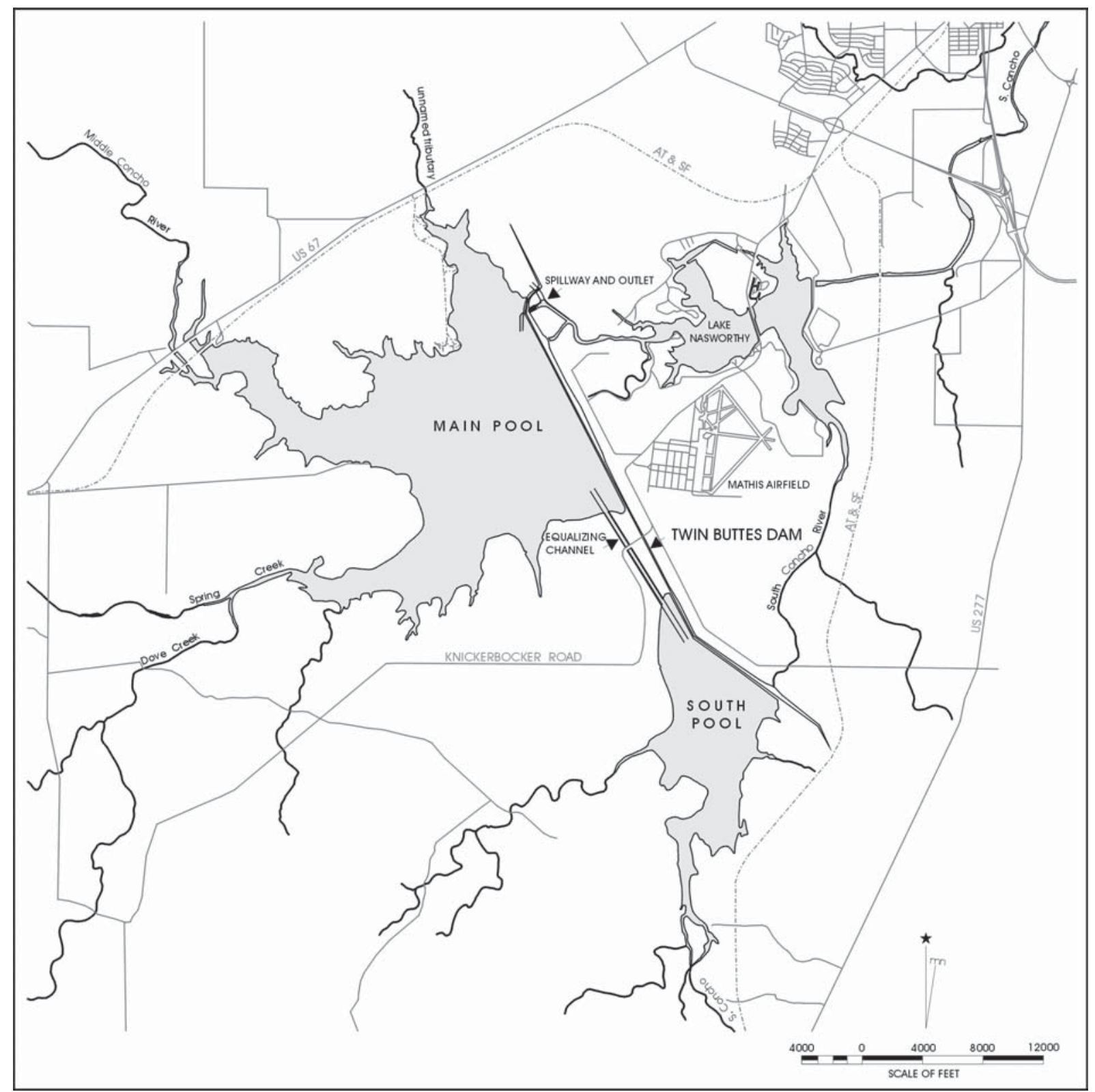

Figure 2-1. Project area with major drainages and landmarks identified (adapted from Etchieson 1985).

significant water flowing; the Middle Concho was essentially dry. Water in the Middle Concho reflected the elevation of the Main Reservoir Pool rather than representing any actual inflow to Twin Buttes Reservoir. Below the dam, water is released from the Main Pool into the Middle Concho, and eventually flows into Lake Nasworthy (Figure 2-1) located to the northeast (USBR 1999; USGS 1999a).

The project area, consisting of the land managed by the Bureau of Reclamation, is approximately 12,790 acres (5176 ha). Of this area, roughly 316 acres (130.7 ha) were unavailable for survey, consisting of the dam itself or areas in which land ownership was disputed. At the time of this survey, water levels in the reservoir pools and in the three rivers excluded roughly 2,295 acres (928.9 ha). The actual area surveyed was approximately 10,195 acres (4125.5 ha).

Figure 2-2 presents the distribution of the 199 sites recorded or revisited during the project. New sites are identified in red, while previously recorded sites are 
This page has been

redacted because it

contains restricted

information. 


\section{Reservoir Construction}

Although details on construction are not available, building Twin Buttes Dam, an earth filled structure 8.1 miles in length, resulted in significant modifications of the landscape. It appears that much of the dam was built using earth borrowed, at least in part, from the reservoir pool area. While several quarries existed prior to dam borrowing activities (Etchieson 1985:910), impacts from building the dam, a structure that has a volume of 21,442,000 cubic feet (USBR 1999), must have been substantial. This volume of earth is equivalent to roughly 102 trenches with dimensions of 100 by 100 feet, all excavated to a depth of 21 feet.

Figure 2-3 is an enlargement of a 1:10,000 scale USGS color infrared aerial photo of a section of the main pool taken on February 5, 1996. The water level in the figure was at an elevation of 1,910 feet $(582 \mathrm{~m})$. Portions of two large borrow areas are clearly visible in the photo.
Figure 2-4 is a photograph of another borrow area exposed at low water levels during the CAR survey. While the number, size, and location of these borrow pits are unknown, a substantial amount of material was certainly removed from the conservation pool area to construct the dam.

At least some of these construction activities impacted archaeological sites. This can be seen in Figure 2-5, a map of 41TG502. This site was recorded during our November visit to Twin Buttes when water levels were at 1,895 feet $(577.6 \mathrm{~m})$ in the main pool. Note the 1,900 foot contour, located to the north of the site, as well as the essentially square corner of the water level in this same area. A consideration of the figure will demonstrate that as the water level is at 1,895 feet, the landform identified by the 1,900 foot contour no longer exists. Given the shape of the land at the shoreline, it is probable that a large borrow area is present at this location. Similar contour changes have been initiated along the unnamed tributary leading into the Middle Concho (Figure 2-1).

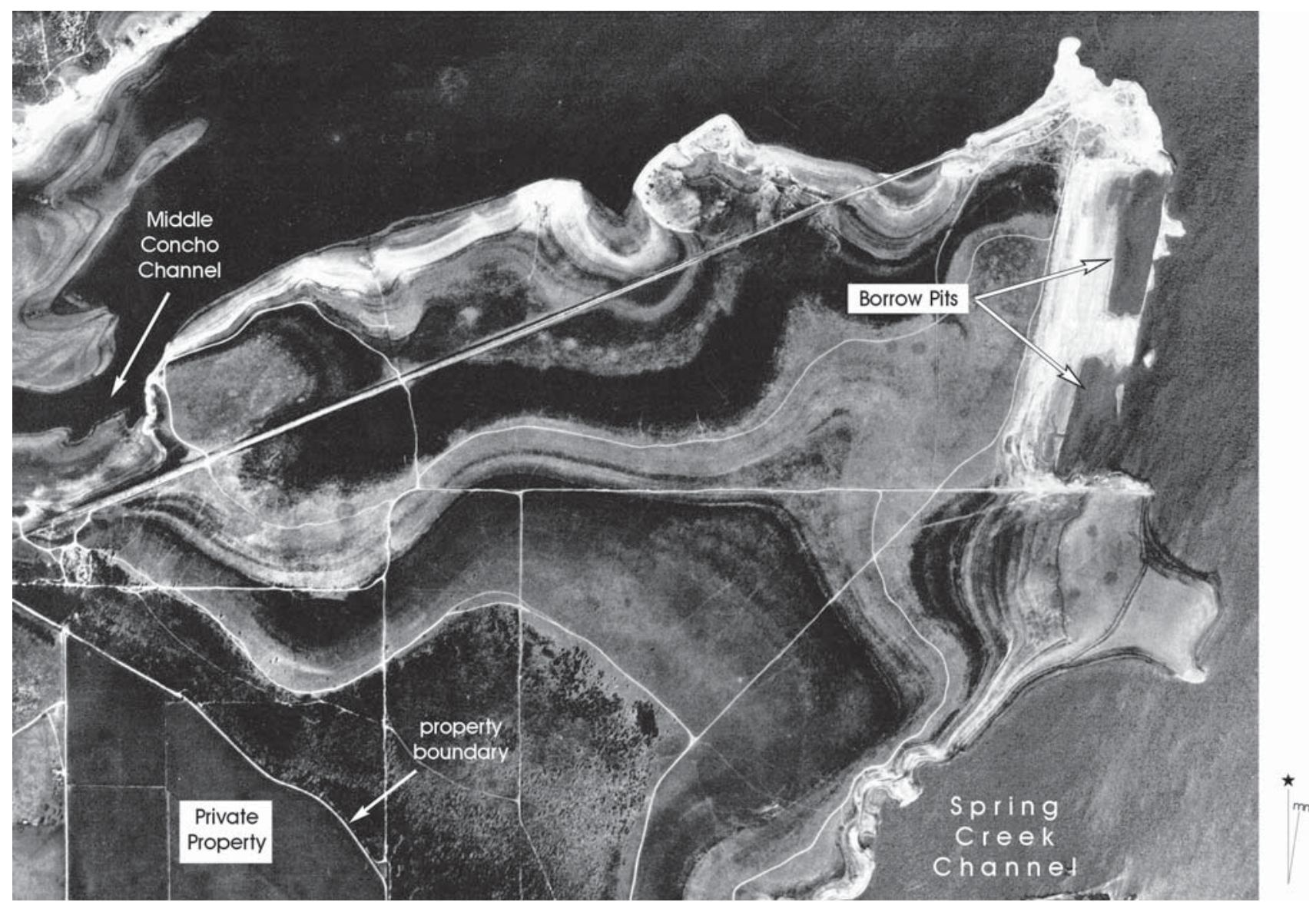

Figure 2-3. Enlargement of a USGS 1:10,000 color infrared aerial photo with borrow pits identified. 


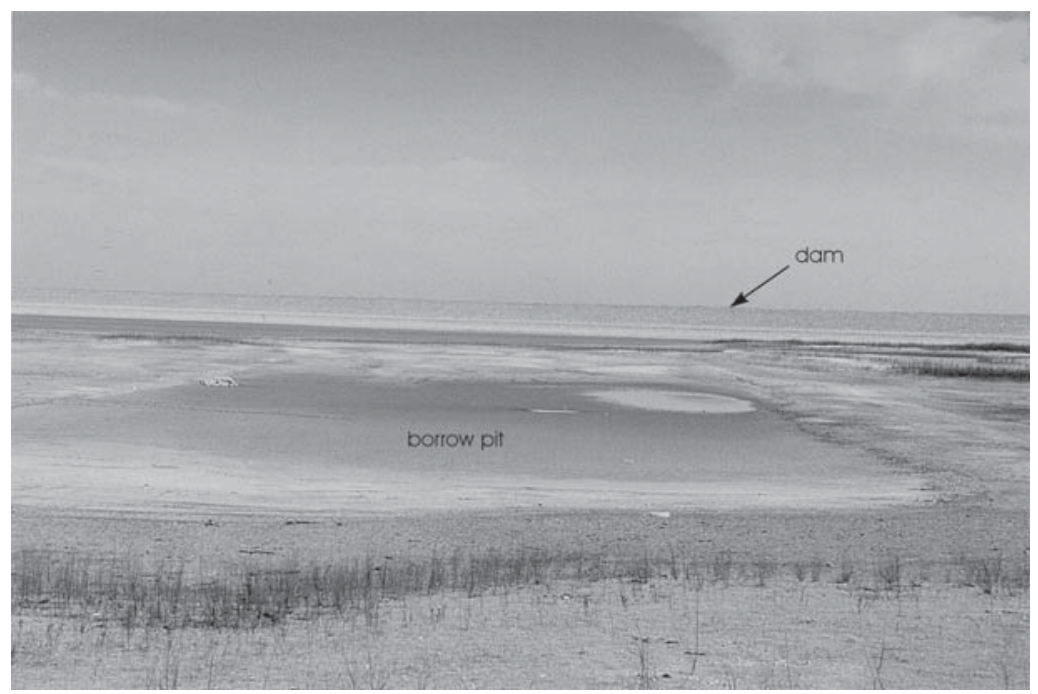

Figure 2-4. Small borrow pit exposed at low water levels.

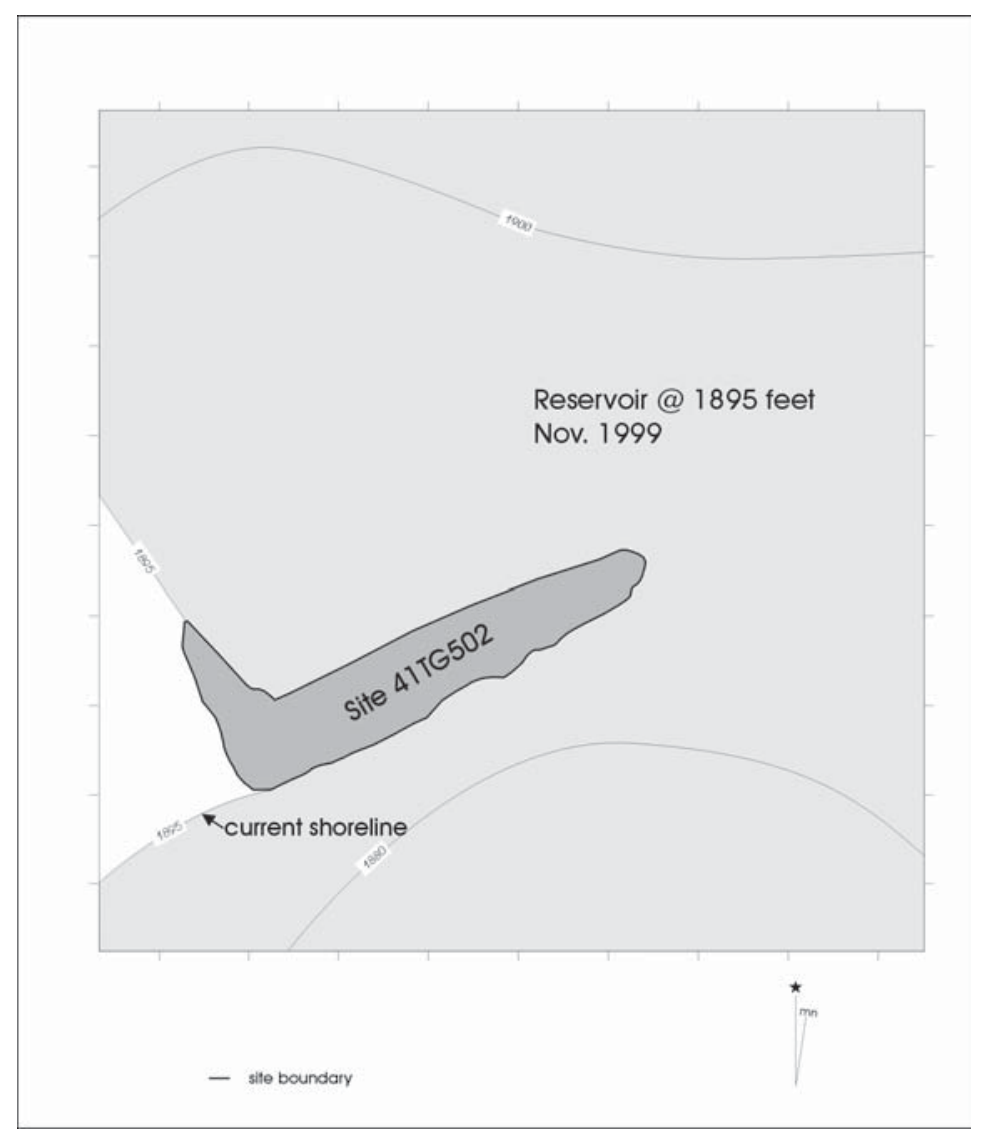

Figure 2-5. Site map of 41TG502 with water levels at 1,895 feet. Note: The landform represented by the 1,900 foot contour, taken from the USGS 1:24,000 Knickerbocker Quadrangle, no longer exists. 


\section{Fluctuating Lake Levels}

Since December of 1963, water levels in the reservoir have fluctuated as a result of varying rainfall and water use requirements. The maximum capacity of the reservoir is 186,000 acre-feet, which translates to a conservation pool with an equivalent elevation of 1,940 feet $(591.3 \mathrm{~m})$. The Bureau of Reclamation has maintained detailed data on conservation pool capacity in acre-feet for the Main Pool since 1963, and have actual pool elevation data for more recent years (USBR 1999; USGS 1999b). The coexistence of these two data sets for the more recent period allows us to use acrefeet data as an estimate of reservoir elevation since the early 1960s. However, as several different volumes of water are associated with the same elevation, only an estimate of pool elevation is possible.

Figure 2-6 presents a summary of the acre-feet levels for the reservoir from January 1963 through January 1998 (USBR 1999; USGS 1999b). These data demonstrate that fluctuations are common. Prior to August of 1971, the reservoir pool was consistently below 23,500 acre-feet, a capacity that roughly translates into a pool elevation of 1,900 feet. From August 1971 through August 1983, the reservoir was well above the 50,000 acre-feet level, and it was during this period that the maximum water content of 205,200 acre-feet, resulting in a lake elevation of just over 1,942 feet $(591.9 \mathrm{~m})$, was recorded on May 12, 1975. Between late-1977 and the mid-1980s, lake levels were declining. A low capacity of 16,560 acre-feet, which correlates with an elevation of between 1,900 and 1,895 feet, was recorded in September 1985. Figure 2-6 clearly demonstrates that throughout the late-1980s and into the $1990 \mathrm{~s}$, water levels have continued to fluctuate dramatically.

Table 2-1 summarizes the history of exposure and inundation for four different contour intervals, 1,900 feet $(579 \mathrm{~m}), 1,910$ feet $(582.2 \mathrm{~m}), 1,920$ feet $(585.2 \mathrm{~m})$, and 1,940 feet $(591.3 \mathrm{~m})$ from January 1971 through January 1998. Elevation data are extrapolated from acre-feet observations (USGS 1999b). These data demonstrate that during this 27 year period, lands below 1,940 feet within the reservoir pool area have been under water at two different times for a total period of 9.5 months. Conversely, those areas at 1,900 feet have spent just over 25 of these 27 years under water, and land located at 1,920 feet have spent over 18 years under water.

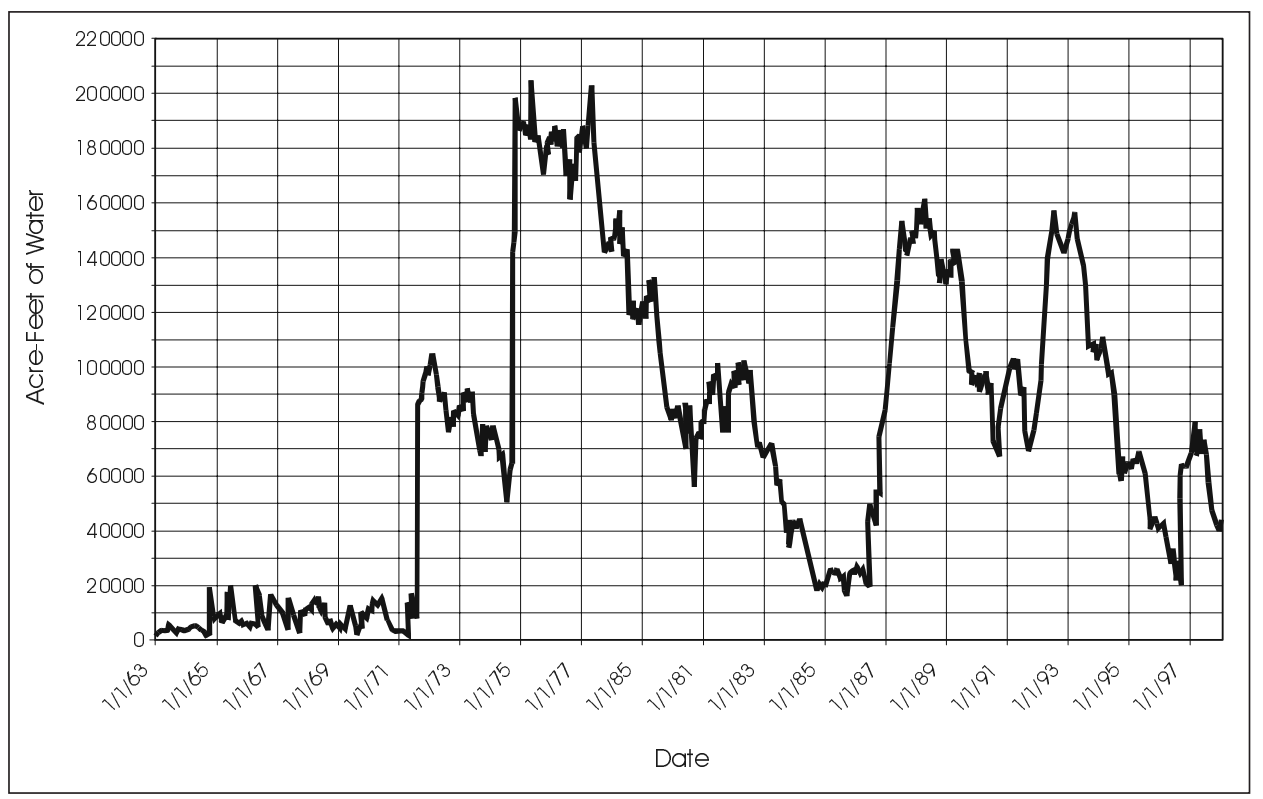

Figure 2-6. Twin Buttes Reservoir water storage levels (1963-1998). 
Table 2-1. Exposure and Inundation of Twin Buttes Reservoir for Selected Elevations (1971-1998)

\begin{tabular}{|cccc|}
\hline $\begin{array}{c}\text { Elevation } \\
\text { (Ft.) }\end{array}$ & $\begin{array}{c}\text { Inundation } \\
\text { (\# of Months) }\end{array}$ & $\begin{array}{c}\text { Exposure } \\
\text { (\# of months) }\end{array}$ & $\begin{array}{c}\text { Inundation/Exposure } \\
\text { Events }\end{array}$ \\
\hline 1900 & 303 & 21 & 5 \\
1910 & 282 & 42 & 4 \\
1920 & 224 & 100 & 8 \\
1940 & 9.5 & 314.5 & 2 \\
\hline
\end{tabular}

Just as critical for discussing impacts to archaeological sites is the history of inundation and exposure. For example, the 1,920 foot contour has minimally been exposed and inundated eight different times during this 27 year period (Table 2-1). These fluctuating levels have a number of impacts on the landscape and the archaeological record. These impacts include both direct effects related to erosion and deposition, as well as indirect effects such as determining the location for modern camping, artifact collecting activities, cattle grazing, and off-road vehicle use. While some of these impacts are considered below, the most immediate impact on the current survey was that the extant shoreline determined what land was, and was not, available for survey.

\section{Area Available for Survey}

Much of the current survey was conducted between December 1998 and April 1999. During most of this period, the main reservoir pool fluctuated around 1,900 feet, while the south pool was maintained at just under 1,927 feet. These water levels (see Figure 2-1) excluded roughly 2,295 acres (928.9 ha) from survey. During our revisit to the project area in November 1999 , the water levels in the main pool had dropped to 1,895 feet. This five foot drop exposed a significant amount of land that had been underwater during December 1998. While we recorded 41TG502 as a result of the receding water, this newly exposed land has not been systematically surveyed, and it is certainly the case that many more sites are present within the reservoir at elevations below 1,900 feet in the main pool, and below 1,927 feet in the south pool. It is also the case that for many sites at the 1,900 foot elevation level in the main pool area and at 1,927 foot elevation in the south pool area, our site boundaries underestimate the total site area as the water level often forms one or more of the mapped boundaries.

More importantly than either the amount of land area excluded from survey or the impact of lake levels on site boundaries is the differential lake coverage between the main and south pools. Reference to Figures 2-1 and 2-2 will demonstrate that a significant portion of the land area associated with the South Concho is under water. In Chapters 8 and 9 of this report, we consider aspects of site distribution and artifact densities with respect both to drainages and distance to water. The results of these comparisons are influenced by the fact that a significant portion of the land along the banks of the South Concho is unavailable for survey. The excluded area likely contains site densities comparable to those from the exposed areas of the South Concho, located both upstream and below the dam. These densities are among the highest on the project (Figure 2-2).

\section{Vegetation and Archaeological Visibility}

The fluctuating reservoir levels also influence visibility of archaeological deposits through alterations in vegetation. During his reconnaissance of the area in 1958 , Willis describes the upland vegetation as "covered with range grass, while in the river channel there is a heavy growth of mesquite, oak and pecan. The adjacent bottom land has a heavy undergrowth of grass and brush." (Willis 1958:1). Areas above the 1,940 foot contour, as well as areas located outside of the conservation pool area, still have a variety of grasses, and mesquite, agarita, prickly pear, and juniper are also frequent (Figure 2-7). However, as demonstrated 


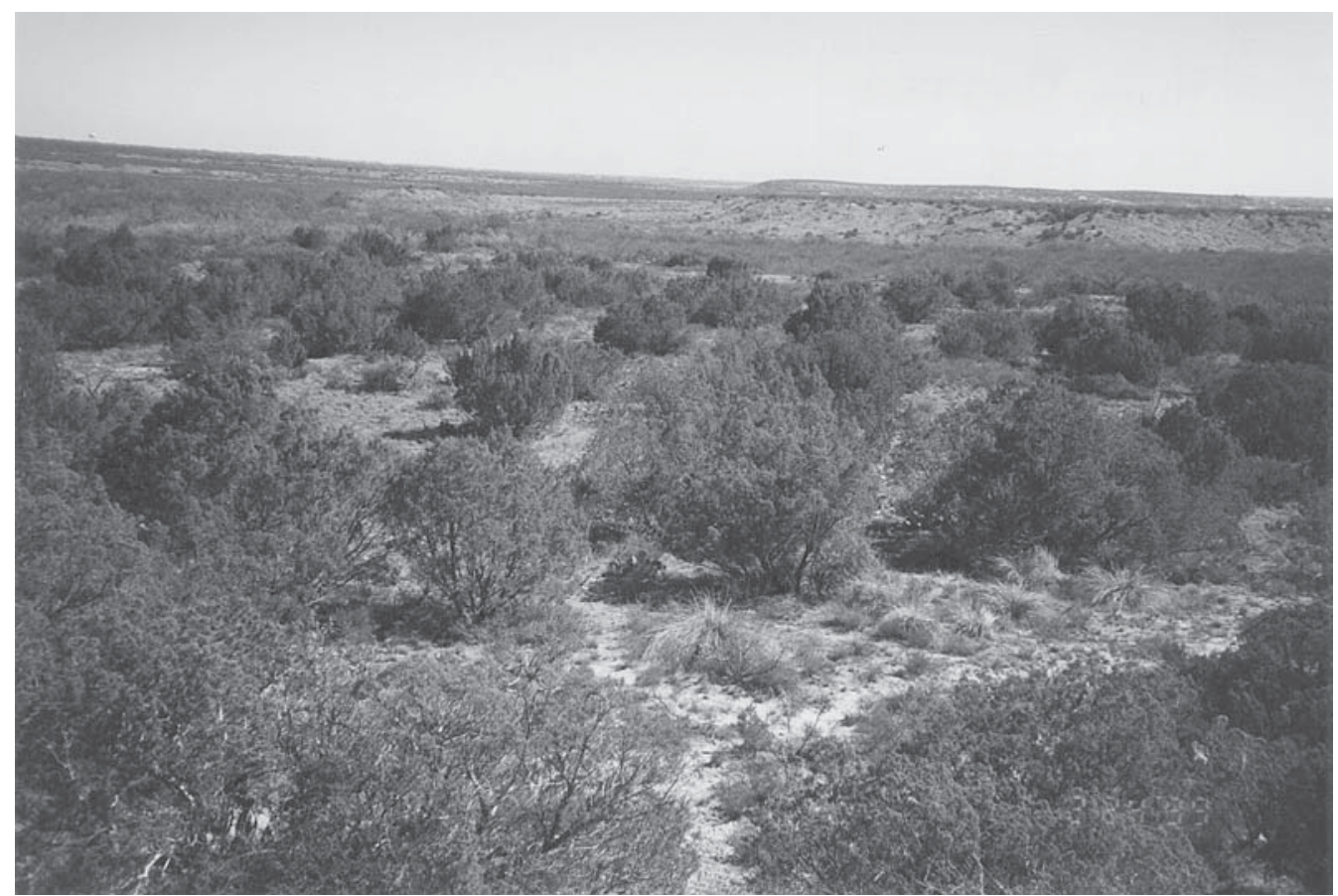

Figure 2-7. Upland vegetation.

in Table 2-1, those areas in the reservoir pool area between 1,900 and 1,940 feet have been inundated and exposed at several points since 1971. Inundation quickly kills the natural vegetation, and when lake waters recede, these areas are frequently bare ground with isolated mesquite stumps (Figure 2-8). Within a short period of time, these areas are invaded by a series of vegetation communities that ultimately seem to stabilize in dense stands of saltcedar underlain with a thick, short mat of grass (Figure 2-9). In those settings with this saltcedar vegetation complex, ground visibility is minimal.

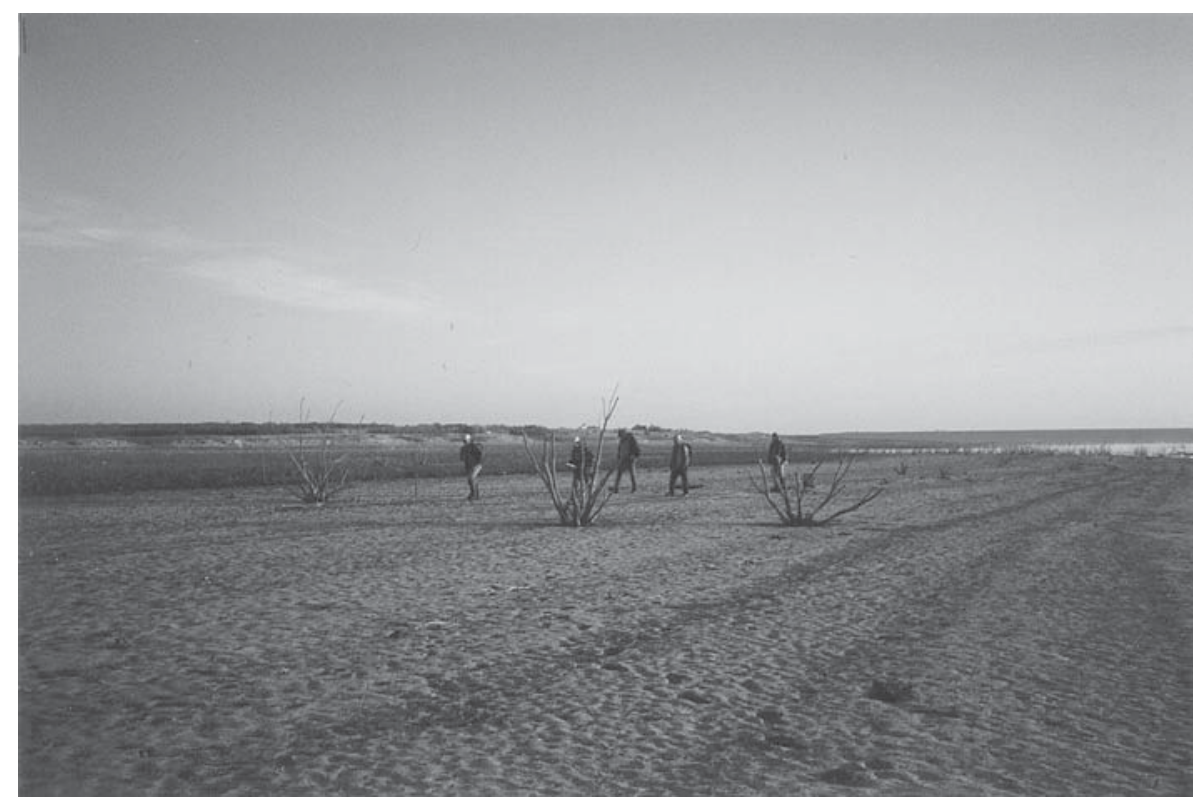

Figure 2-8. Recently exposed landform. 
This page has been

redacted because it

contains restricted

information. 
shoreline erosion and deposition as a result of wave action, near shore and offshore erosion and deposition, and the potential for undercutting or mass wasting of shorelines. These processes are extremely complex, minimally involving interactions between wind intensity and direction, wave energy, water level, the near shore and offshore elevation profiles, the shoreline shape and elevation profile, vegetation, and the geological composition of the shoreline (see Bascom 1980; Conley and Inman 1992; George et al. 1994; Holman and Bowen 1982; Peregrine 1983; Svendsen et al. 1987; Waters 1992:249-280). Even a rudimentary understanding of these processes, involving issues of fluid dynamics, turbulence, and nonlinear relationships, are beyond our ken. Here, we are primarily concerned with documenting the existence of these processes as well as considering their impact on the archaeological record at Twin Buttes.

\section{Shoreline Erosion and Sediment Deposition}

One of the most pervasive and damaging impacts associated with the operation of the reservoir is related to shoreline erosion. Depending on a variety of factors, shoreline erosion can have a substantial impact. For example, long-term studies of coastal and lake settings document that shoreline erosion can be substantial, often resulting in the average annual removal of over 10 feet of beach front a year (Barnes 1998; TGLO 1999). While certainly not analogous to a coastline setting, portions of the Twin Buttes Reservoir are impacted by the same processes. Figure 2-11, an aerial photo taken from the same series as Figure 2-3, clearly demonstrates that multiple shorelines and extensive erosion are associated with wave action in the reservoir. Old shorelines, especially between the 1,910 and 1,930-foot elevation range, are ubiquitous in the main reservoir pool. While winds average between 9 and 12.2 miles per hour (mph) throughout the year at San Angelo, the spring months of March, April, and May have the highest average wind speed with monthly average winds above $11 \mathrm{mph}$. Peak gusts in excess of $70 \mathrm{mph}$ have been recorded for May, June, and November at San Angelo (National Weather Service 1999). Substantial waves, swells, and lake warnings were issued during the current survey period (WinterSpring 1999) as a result of high winds. These winddriven waves have a substantial impact on the shoreline. Figure 2-12, a photo of a section of shoreline along 41TG377, shows the ongoing removal of sediment, and the corresponding deflation and exposure of artifacts, that result from wave action.

In order to demonstrate one of the potential impacts of shoreline erosion on assemblage level data, we use surface observations from site 41TG246. As discussed in detail in Chapter 9, a series of observations, including artifact type (e.g., core, flake, biface), cortex, maximum size, and material type were systematically made on artifacts on a sample of sites from throughout the project area (see Appendix D). In most cases, the sites were selected using two criteria, artifact density and distribution. Once selected, a walkover of the site was conducted to identify areas of high intra-site density. These areas were then systematically scanned, and all artifacts within the arbitrarily defined area were recorded. The location and configuration of the area was recorded with a hand-held GPS unit, allowing the rapid calculation of artifact densities. The goal of the observations was to collect sufficient data to investigate differences both within and between sites, as well as data that could be used to compare different areas of the reservoir.

In the case of the collection area for site 41TG246, the surface observation data also provides information on the impact of shoreline erosion on assemblages. Figure 2-13 documents the site, as well as the location of the surface observation area. The surface observation area (SOA), which encompassed 530 square meters, was centered along an old shoreline and was split into three different observation units during observation. Surface observation unit 1 consisted of a 210 square meter area immediately below the shoreline. Unit 2 was composed of the shoreline itself, an area of 40 square meters, and unit 3 was a 280 square meter area located above the shoreline. A total of 434 items were recorded in the three SOAs on this site. However, even though the three observation units are located next to each other, these artifacts were not distributed evenly across the units. Artifacts are concentrated on the shoreline. Three-hundred and thirty of the 434 artifacts were recovered from the shoreline unit, an overall density of 8.25 items per square meter. In contrast, the observation units above and below the shoreline sample had densities of only 0.204 and 0.224 artifacts per square meter. The concentration of artifacts along the shoreline is probably a result of differential exposure as a function of erosion and deposition. 

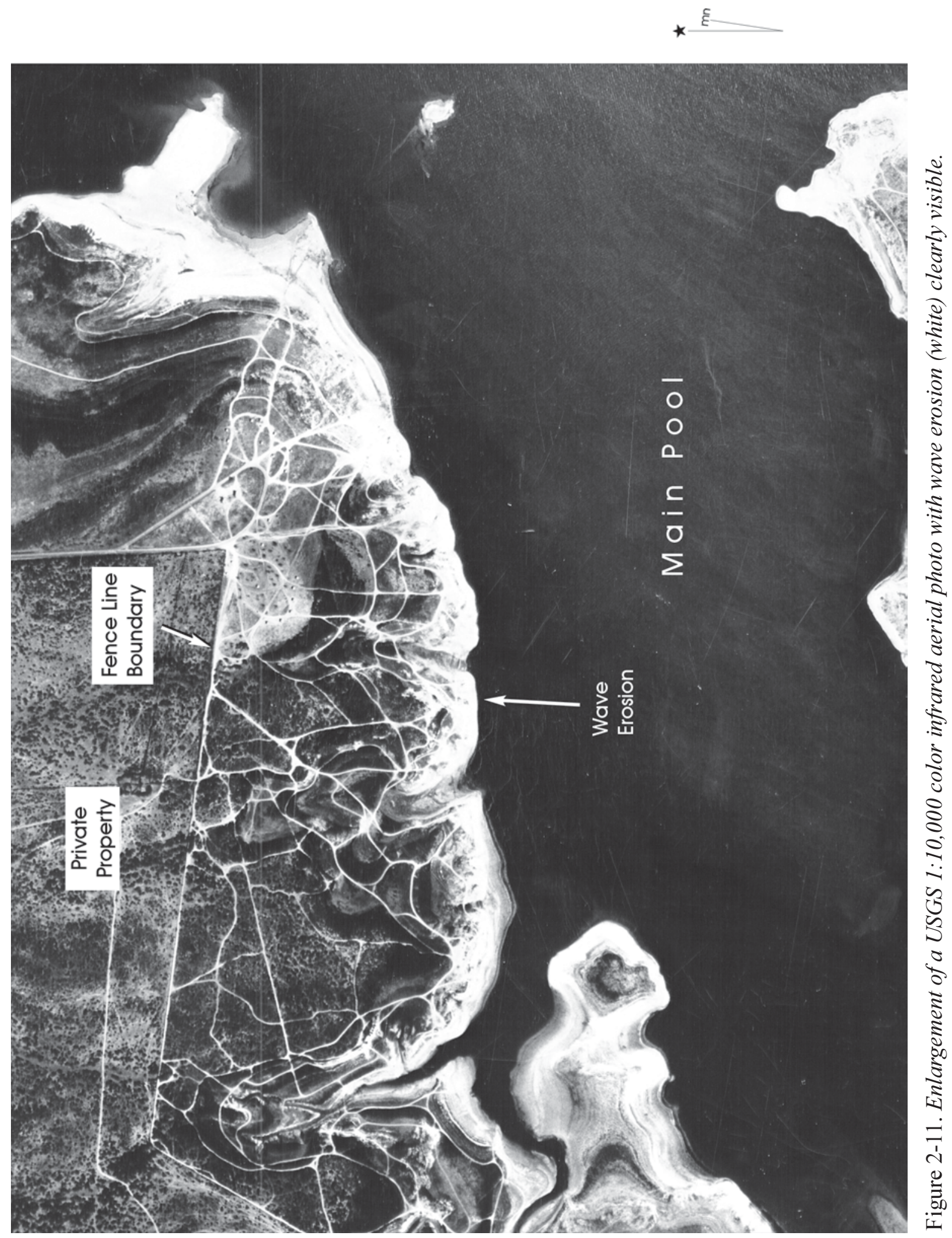


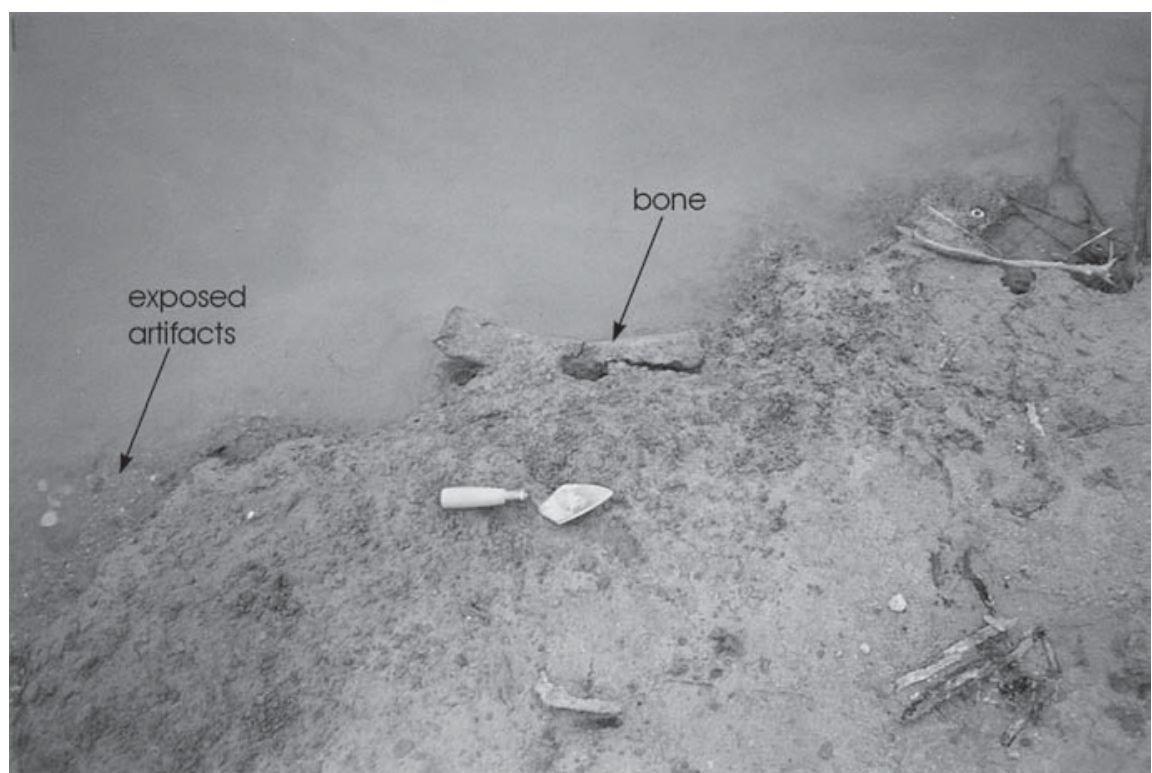

Figure 2-12. Eroding shoreline at $41 T G 377$.

Note: Murky appearance of the water, the exposed artifacts to the left of the frame, and the faunal material just above the trowel at the water's edge.

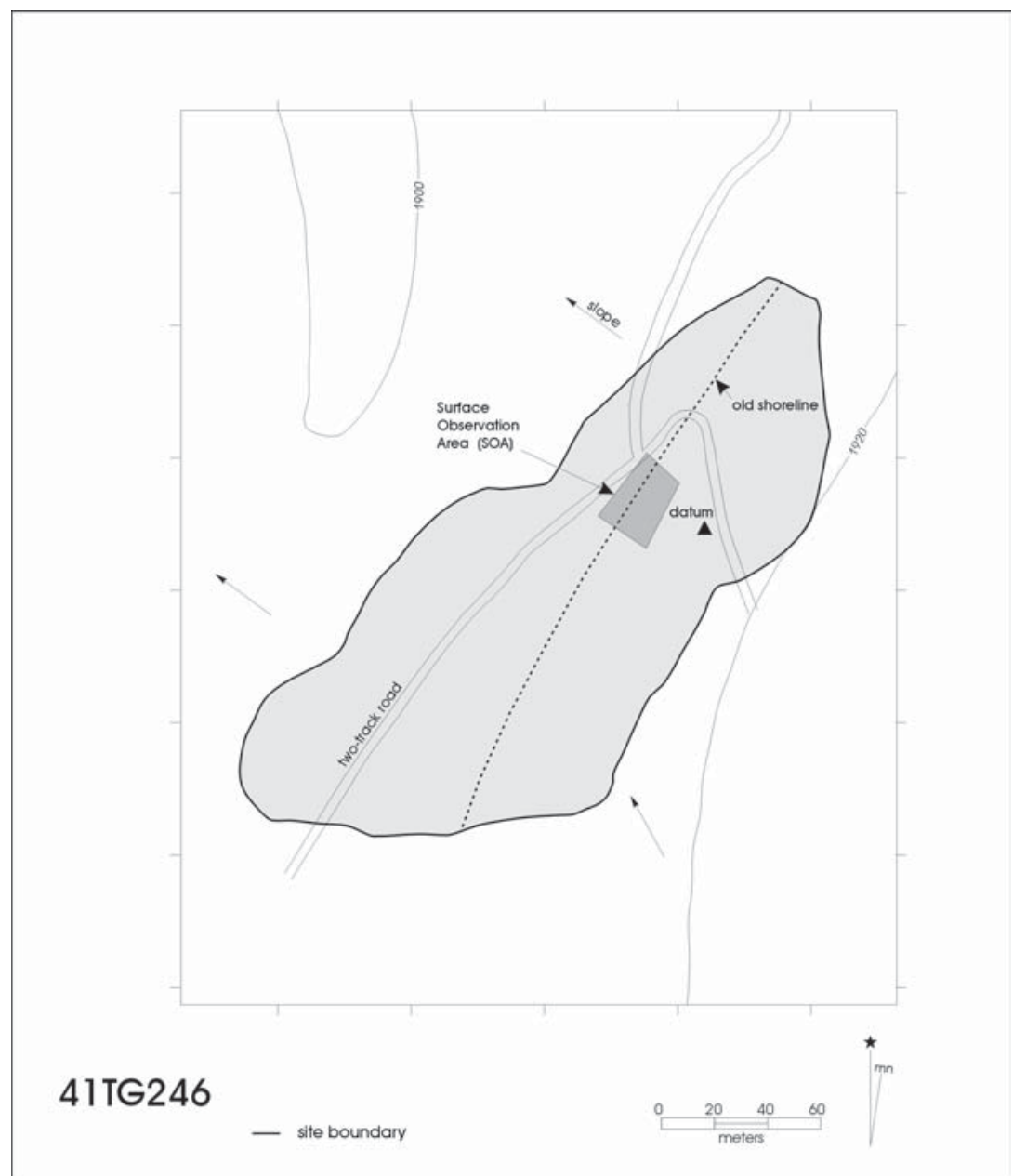

Figure 2-13. Map of 41TG246.

Note: Old shoreline and the location of the surface observation area. 
Figure 2-14 presents a percentage breakdown of major artifact types by observation unit for 41TG246. Differences between the shoreline unit and the units above and below the shoreline are apparent. The shoreline is dominated by tertiary flakes $(n=248 ; 75.15$ percent) with low percentages of cores $(n=3 ; 0.91$ percent) and formal tools such as bifaces and unifaces $(n=6 ; 1.82$ percent). In contrast, the areas above and below the shoreline have assemblage compositions that are quite similar to each other, and quite different from the shoreline assemblage. The combined samples from above and below the shoreline have an assemblage with only 37.5 percent tertiary flakes $(n=39)$, but with core percentages of 25 percent $(n=26)$ and formal tool percentages of 10.6 percent $(n=11)$. Attributes such as the percentage of tertiary flakes, cores, and formal tools are often used to infer reduction activities (e.g., Collins 1975) and certainly play a role in the assignment of sites to different types (e.g., base camps, lithic procurement sites). Differences of this magnitude, which are statistically significant when the frequencies of the six artifact groups are contrasted to the three observation units $\left(X^{2}=116.105 ; \mathrm{df}=10\right.$; $\mathrm{p}<.0001$ ), could certainly be inferred to reflect different behaviors. However, these differences are not the result of behavior; they are simply the result of geomorphic processes that condition surface artifact size.

The relationship between artifact size and the observation units, which is explored in detail in Chapter 9, can be seen in Figure 2-15. The figure considers maximum artifact length in $1 \mathrm{~cm}$ increments by observation unit. The mode in the top histogram falls between 4 and $5 \mathrm{~cm}$, and the majority of artifacts from above the shoreline are greater than $5 \mathrm{~cm}$ in length. Note also the lack of artifacts smaller than $1 \mathrm{~cm}$, as well as the low number of artifacts in the 1 to 2 and 2 to 3 size ranges. The shoreline histogram (middle) has a very different distribution. The mode is from 2 to $3 \mathrm{~cm}$, and few artifacts are above $5 \mathrm{~cm}$ in length. The size distribution of artifacts collected from below the shoreline (bottom histogram) closely resembles the above shoreline histogram. The mode in the bottom histogram is between 4 and $5 \mathrm{~cm}$. While this histogram has a secondary peak at 1 to $2 \mathrm{~cm}$, this may simply reflect a problem with the field definition of where the old shoreline actually began. Combining the top and bottom data sets produces a mean artifact size of $5.20 \mathrm{~cm}$ $(n=104)$. This contrasts to a mean size of $2.74 \mathrm{~cm}$ for the 330 artifacts on the shoreline. Artifacts on the shoreline are, on average, $2.46 \mathrm{~cm}$ smaller than artifacts above and below the shoreline.

The impact of wave erosion on sediments at the shoreline and the deposition of sediments above and below the shoreline may account for different artifact sizes, and indirectly, different artifact types. First, it may be the case that small artifacts are differentially covered 


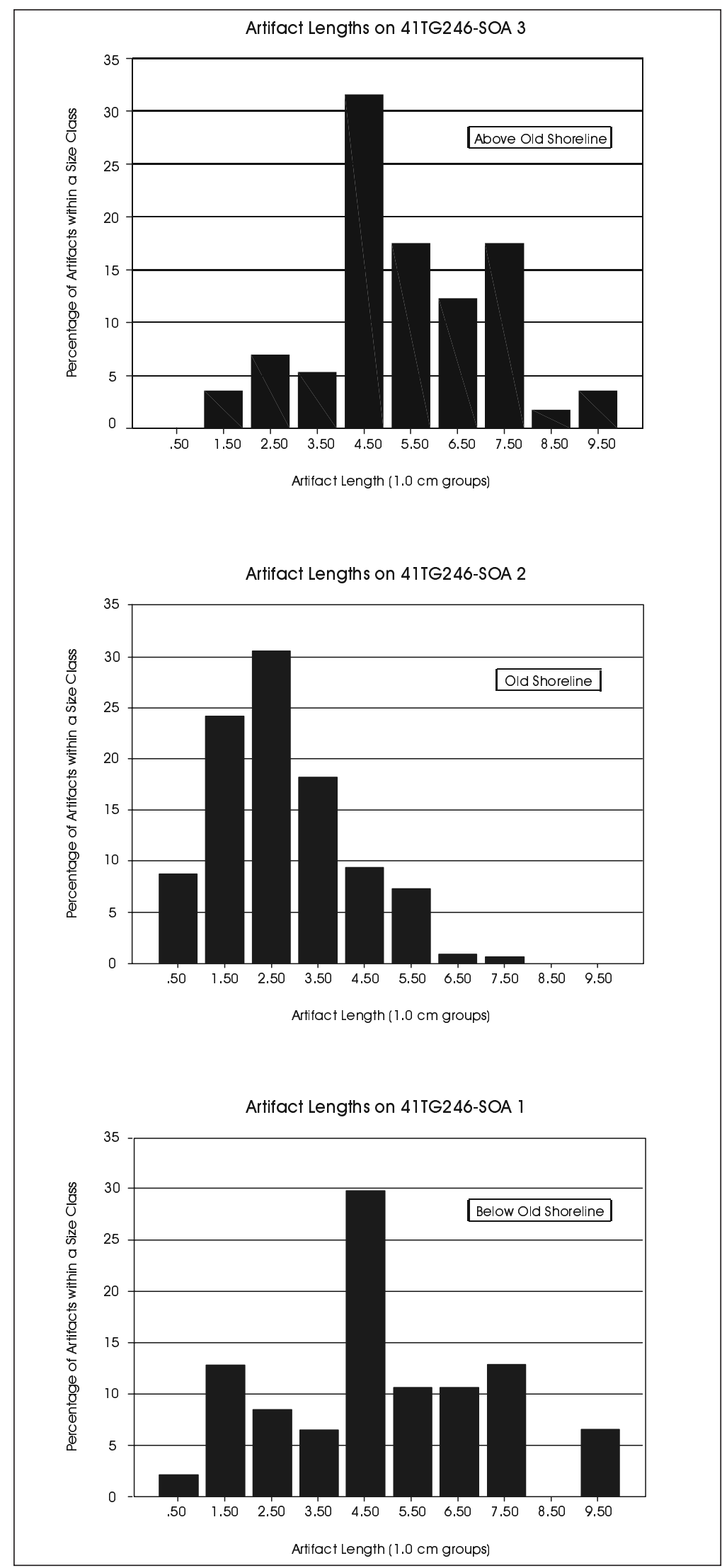

Figure 2-15. Artifact size by SOA recovery location on $41 T G 246$. 
by sediments deposited below and above the shoreline. The sediments below the shoreline are possibly the result of the erosion of the shoreline itself, while sediments above the shoreline may be associated with previous depositional events. Recall that this area, at an elevation of approximately 1,910 feet, has been inundated and exposed at several points since the construction of the Reservoir. Several different erosional and depositional events have probably impacted this location. The deposition of only a few centimeters of sediment would be more than sufficient to cover tertiary flakes, resulting in the skewed surface size distribution in Figure 2-15. Tertiary flakes, which dominate the assemblage from the shoreline unit, are small, with a mean flake length of $2.67 \mathrm{~cm}$ for the SOA $(n=287)$. Cores $(n=29)$ and formal tools $(n=17)$ are much larger, with average lengths of these artifacts for the SOA of $6.71 \mathrm{~cm}$ and $5.38 \mathrm{~cm}$, respectively. It may also be the case that at least some of the small tertiary flakes have been removed from areas below and above the shoreline, and concentrated in the shoreline unit. Without excavation data, the relative contributions of these two potential processes can not be ascertained. However, both are probably in operation at this location, and combine to form both the skewed size distribution in Figure 2-15 and the different assemblage level data in Figure 2-14.

The example of the impact of shoreline erosion on assemblage characteristics for site 41TG246 is certainly not unique. In fact, the history of inundation and exposure documented previously suggests that most assemblages located at elevations below 1,942 feet within the conservation pool area have been subjected to similar processes, though to varying degrees depending upon their particular elevation.

\section{Near Shore and Offshore Erosional/ Depositional Changes}

The erosional/depositional impacts of wave action that produced the assemblage patterns for $41 \mathrm{TG} 246$ discussed above is not confined to the shoreline. Depending on wave energy, subsurface profile, and subsurface composition, a complex pattern of erosion, deposition, and reworking of subsurface sediments can occur (see Waters 1992:249-290). In the case of Twin Buttes, such near shore impacts are probably especially relevant within a few meters of a given shoreline. Farther offshore, deposition is probably occurring in the reservoir bottom. Unlike the previous section where spacial data were available to consider the impact of the process on the archaeological record, no such data exist with regard to the processes associated with near and offshore erosion. While a variety of sandbar-like features are present in the currently exposed land surface, and while lake sediment was observed in several backhoe trenches, no data on the specific impacts of these processes on the archaeological record are available. However, differences in survey between sites described by Etchieson (1985) and revisited by CAR in 1999 , coupled with data on reservoir fluctuations during the intervening time, are intriguing. One such case is $41 \mathrm{TG} 245$.

Etchieson recorded the site in late May of $1985 . \mathrm{He}$ describes 41TG245 as consisting " ...of a thin scatter of lithic debitage which is composed mainly of primary flakes with smaller amounts of secondary debris" (Etchieson 1985:9). Etchieson noted that worked items, burned rock, and features were not present at the site. An examination of the site form from 1985 for $41 \mathrm{TG} 245$ shows the site as an oval shaped scatter measuring roughly 100 meters east-west by 50 meters north-south. CAR archaeologists revisited this site in 1999. Figure 2-16 presents our map of 41TG245. The site dimensions have now increased to over 200 meters east-west, and almost 400 meters north-south. We identified 17 fire-cracked rock hearths in a dense cluster. A single surface observation area of 590 square meters produced observations on 169 artifacts. These assemblage data are quite different than those described by Etchieson, and include a variety of artifact types not noted for the site in 1985. The assemblage is dominated by tertiary flakes ( 56.8 percent). The primary and secondary flakes that Etchieson noted were dominant in 1985 comprise only 14.2 percent and 12.4 percent of the 1999 assemblage. In addition, cores make up 13.6 percent of the surface observation sample, and both unifaces and utilized flakes are present in the SOA. Outside the SOA sample, CAR noted the presence of bifaces and retouched flakes, and estimated that scattered fire-cracked rock not associated with the 17 hearths may exceed 1,000 pieces. 
A number of scenarios can be imagined that may account for these differences in the site size and the assemblage character of 41TG245 seen in 1985 and 1999. Most scenarios would involve differences in recording procedure and site definition between the two archaeological teams. While our site criteria and recording procedures may certainly be different from Etchieson (1985), and while this may account for some of the differences in site size, it is unlikely that Etchieson simply failed to record the 17 hearths and scattered fire-cracked rock, especially when he explicitly notes that no features are present. It is more likely that the 17 features, along with the tertiary flakes, utilized flakes, cores, bifaces, retouched items, and scattered fire-cracked rock observed on the surface in 1999, simply were not visible 14 years earlier.

Figure 2-17 presents main pool water levels from May 21, 1985, the date of Etchieson's original recording of 41TG245, to January 1, 1998. The acre-feet values which are potentially associated with the 1,920 foot contour, the central elevation of 41TG245, are identified by the band across the figure. Water records for 1998-1999 are not shown, but throughout this period the reservoir was consistently below the 1,915 foot level. Examination of the figure will demonstrate that after the initial recording, the surface at $41 \mathrm{TG} 245$ was subjected to a complex pattern of exposure and inundation. The site was well above the water level from May 1985 until October 1986. The surface was then well below the water level for over 40 months. During September 1990 and again in the months of August and September 1991, water levels fluctuated near the 1,920 foot elevation of the site. Inundated for the next 2.5 years, the site is again close to the water line for a ten month period between August 1994 and June 1995. From June 1995 to October of the following year, the site area is above the water line, and between October 1996 and July 1997, the shoreline is again fluctuating near 41TG245. Since that point, the site has been above the water level. Fluctuations at or near the 1,920 foot contour certainly exposed the site to both shoreline and near shore erosional processes. Depending on a number of variables, this could have resulted in the removal of sediment and the exposure of both the hearths and additional material which CAR documented in 1999.

It may also be the case that some of these features are modern, being created by campers and fishermen during the 5.5 years of site exposure between 1985 and 1999. As discussed subsequently, many hearths that are clearly modern were observed on the project. While this is possible, we were conservative in assigning any feature to the prehistoric category, and therefore feel that it is unlikely that all 17

Figure 2-16. Map of 41TG245 in 1999. 


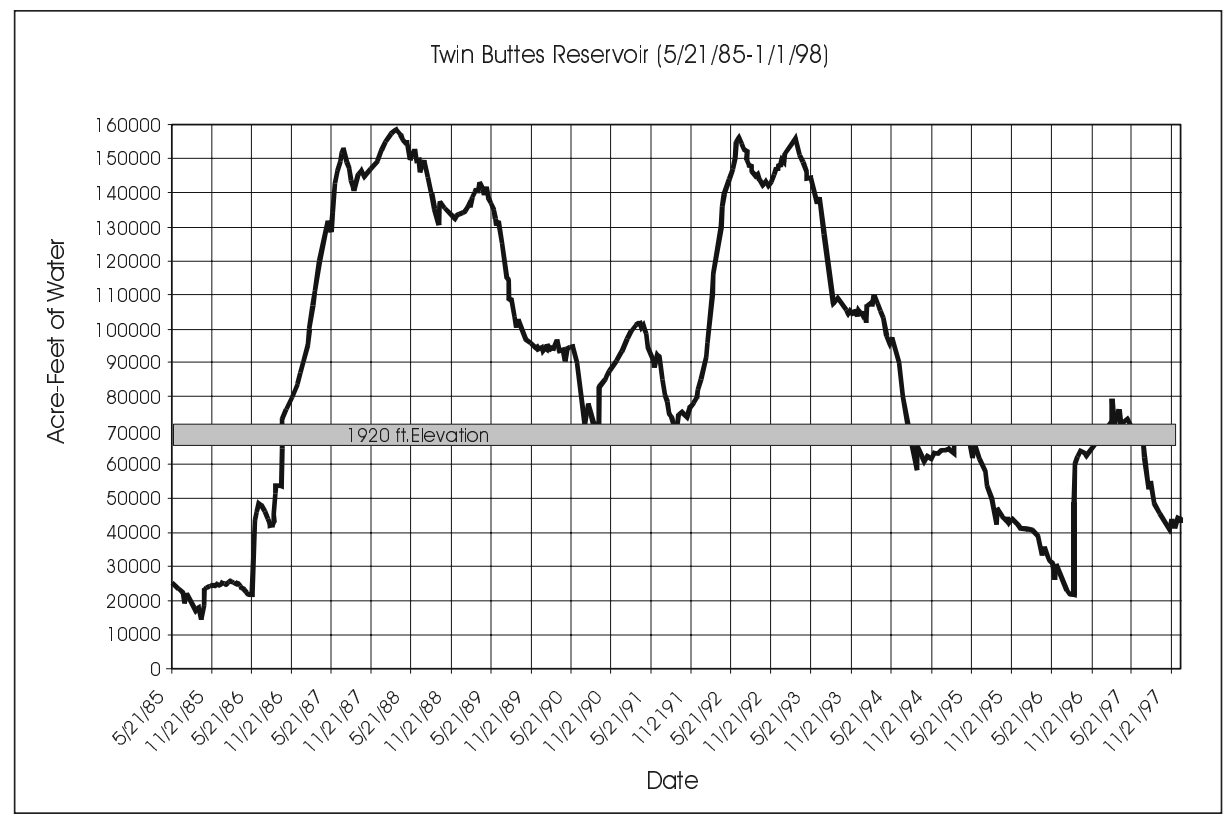

Figure 2-17. Twin Buttes Reservoir water levels in acre-feet (5/21/85-1/1/98), with 1,920 foot elevation range identified.

features, along with the over 1,000 pieces of scattered fire-cracked rock, are modern. In addition, the suggestion that the features may be modern cannot account for the differences in artifacts or the changes in site size observed between 1985 and 1999. The most probable scenario is that the differences seen at 41TG245 are the result of shoreline and near shore erosion, and the resulting greater exposure of previously buried material. In this regard, Etchieson also noted that site 41TG246, used in the previous section to discuss shoreline erosion and located just to the north of 41TG245, lacked features (Etchieson 1985:10). Our revisit noted nine fire-cracked rock features at $41 \mathrm{TG} 246$.

\section{Mass Wasting}

This final erosional variable is perhaps the most dramatic, though it is probably the least common on the current project. The basic process involves the undercutting of bluffs by prolonged wave action or running water. This results in the eventual creation of an overhang, which then collapses (Waters 1992:254-255). Several cases of this phenomena have been observed along the current drainage shorelines at Twin Buttes, and most of these cases are probably the result of pre-reservoir erosion associated with the original drainages. Figure 2-18 presents an example of one such case at $41 \mathrm{TG} 487$, a site located along

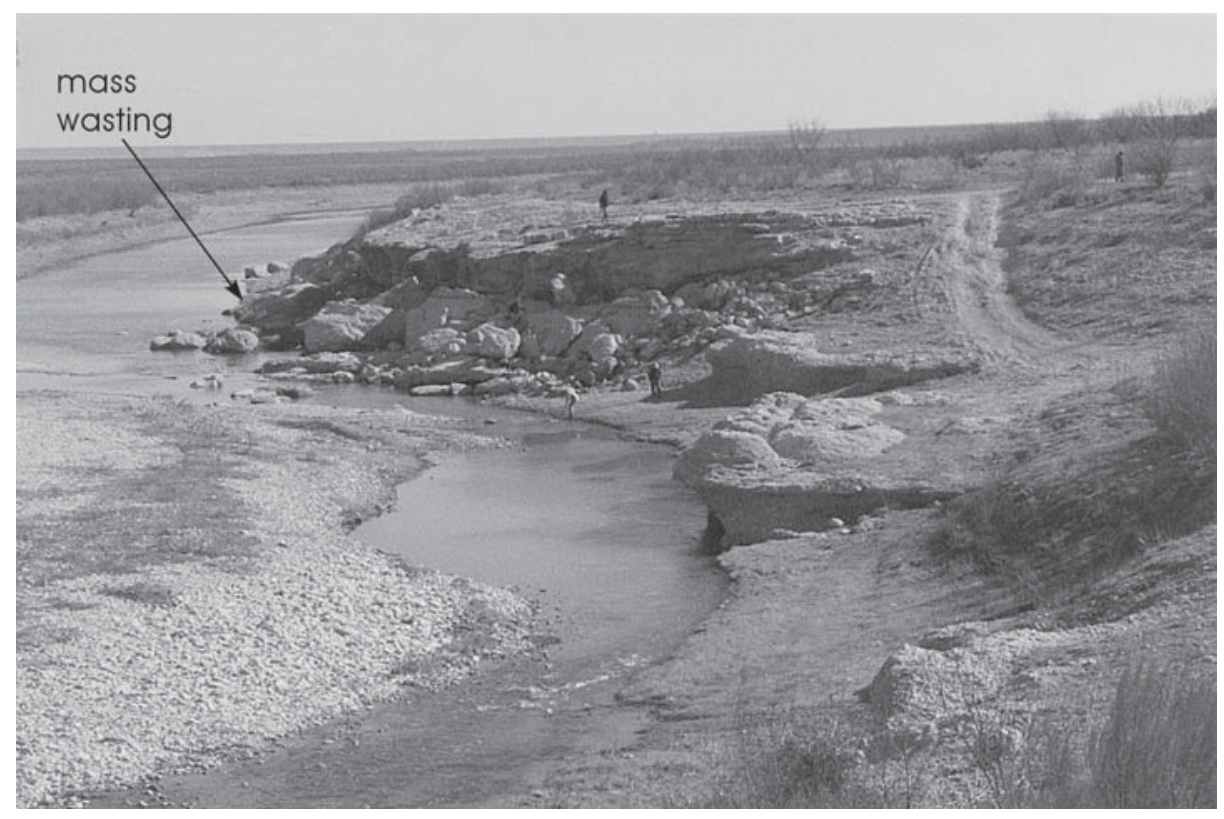

Figure 2-18. Mass-wasting along Spring Creek at $41 T G 487$. 
Spring Creek. Visible in the photograph are a series of large limestone blocks collapsed into the creek. Smaller cracks in the conglomerate, and section of tilted conglomerate, are common on top of this, as well as several other bluffs along the major drainages. Should water levels increase and be maintained for sufficient periods, it is likely that additional sections will eventually cleave off into the channel. Similar cases are probably present at a variety of sites, including 41TG110, 41TG464, and 41TG405.

\section{Reservoir Use}

The existence of a large body of water surrounded by vegetation that often forms dense cover in an area characterized as semi-arid guarantees the reservoir a high frequency of use by the residents of Tom Green and surrounding counties. When this situation is combined with the fact that access to the reservoir is essentially unrestricted and frequently un-monitored, a wide variety of activities are conducted within the Twin Buttes boundary. These activities include, but certainly are not limited to, fishing, hunting, weekend camping, graduation parties, artifact collecting, four-wheel drive practice, dirt bike races, modern flint-knapping, cattle and sheep grazing, and the disposal of unwanted items ranging in size from bottle caps to living room couches, camper shells, and washing machines. While all of these activities have various impacts upon the archaeological database, one of the most significant is certainly artifact collecting.

As noted in the previous section, shoreline erosion is common in the region, and the changing and eroding shorelines both expose previously buried archaeological material and serve to concentrate camping and fishing activities in the same general area. During the survey, we frequently observed individuals fishing, camping, and walking along shorelines that had recently been exposed. Collecting of artifacts in the context of these activities certainly occurs. Figure 2-19 is an example of one such collection that we were able to document. Much of this material was collected from areas along the Middle Concho drainage, and several specimens could be assigned to site 41TG427. Clearly, many other collections exist. Discussions with local residents suggest that collecting behavior ranges from items picked up on casual visits, to the systematic scouring of newly exposed shorelines for artifacts. Many individuals are unaware that such behavior violates Federal law. We will suggest in Chapter 9 that collecting behavior has significantly depleted portions of the archaeological record of bifaces which tend to be diagnostic, and it is not surprising that on the current survey, only 91 bifaces were collected. A significant percentage of those 91 bifaces were too fragmentary for temporal placement (see Appendix F). This collecting behavior directly impacts the interpretive potential of the database, as temporally sensitive projectile points are the primary means by which sites are assigned to temporal periods.

Other activities conducted at the reservoir also complicate interpretations. For example, hundreds of hearths are present on the current project. We recorded in excess of 500 fire-cracked rock features as prehistoric, but ignored many other features which had clear indications of recent use (e.g., large amounts of wood charcoal, modern trash). While we are generally confident in our assignment, in several cases hearths that we recorded as prehistoric may be modern, and hearths that we chose to regard as modern may be prehistoric. These problems are related to the fact that when land surfaces are exposed, camping and fishing activities, which frequently involve the construction of a hearth, are concentrated along the shoreline. Inundate these surfaces, and sediments can be deposited around the features, making them appear to have some antiquity. Combine this with turbation of the sediments through both plant and animal activities, and an association of modern features and prehistoric artifacts can occur. Conversely, there are certainly cases of prehistoric hearths that have not been recorded, simply as a function of the deposition of modern trash in the vicinity of the features.

Finally, a series of behaviors conducted at the reservoir exacerbate the rate of erosion. These certainly include off-road traffic and cattle grazing activities, both of which damage vegetation and sediment structure. Figure 2-11, presented previously, demonstrates the impact of vehicular traffic. The fence line shown in the upper portion of the photo divides private land from reservoir property. White areas in the photograph are exposed limestone. While this degree of traffic is not typical, many areas of the reservoir receive substantial use. 


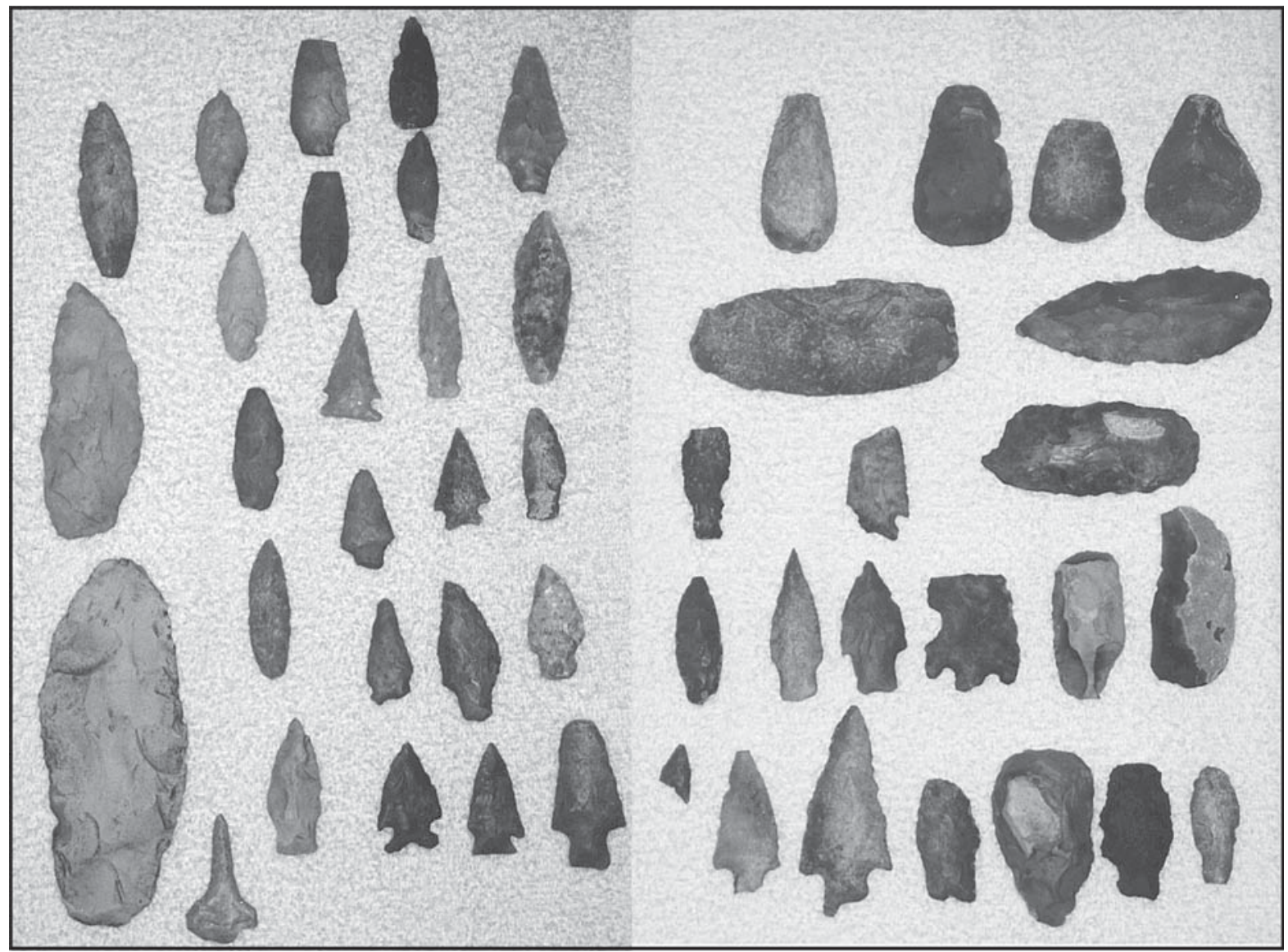

Figure 2-19. Private collection of points and other bifaces from Twin Buttes and surrounding area.

Figure 2-20 demonstrates an additional impact associated with cattle grazing. Cattle are frequently observed close to the shoreline, probably as a result of both the availability of water and the growth of new forage in these exposed areas. As evidenced in the photograph, the concentration of cattle in these fragile areas results in significant destabilization of the sediments, and certainly accelerates the erosion of deposits.

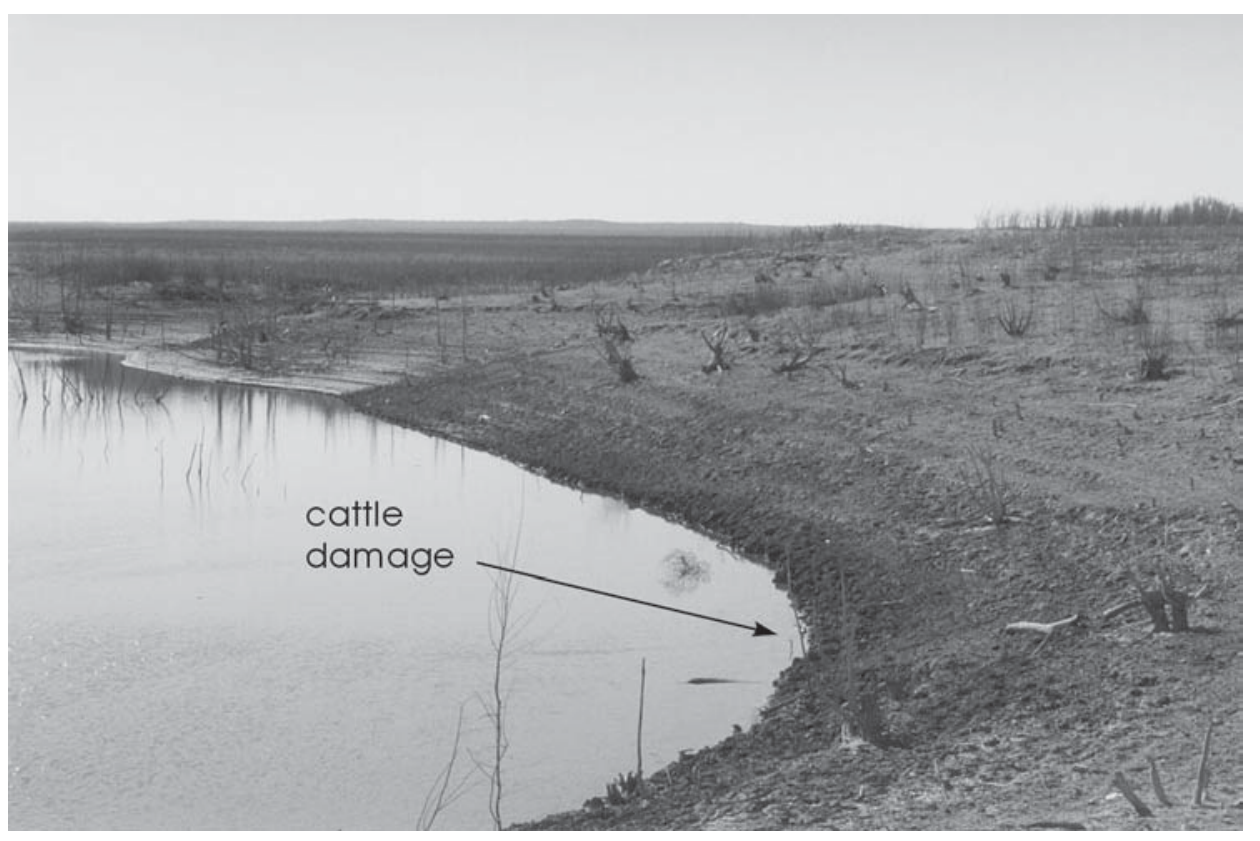

Figure 2-20. Cattle damage along Spring Creek shoreline. 


\section{Summary}

The various processes discussed in this chapter impact the visibility, integrity, and character of the archaeological record. While, to varying degrees, all archaeological projects are impacted by similar processes, the degree of influence of these processes in the case of the Twin Buttes Archaeological Project is exacerbated by the construction and use of the reservoir itself. The processes that potentially impact archaeological material on any given location are extremely complex. A given location can serve as a shoreline, be subject to either erosion and/or deposition, be transformed into a submerged shoreline by an increase in the water levels of the reservoir, and be impacted by different erosional and depositional process. The location could then be transformed into an offshore area where deposition may occur. The location may be subsequently exposed, with the sediments subject to eolian erosion. Complicate this picture by introducing cattle on some surfaces, modern camping, and artifact collecting behavior. Finally, repeat this process several times, varying the length of exposure and inundation. The level of complexity may be close to that which is thus structuring the archaeological record at Twin Buttes. 


\section{Chapter 3: The Project Environment}

\section{David Nickels and Raymond Mauldin}

In this chapter, we provide an overview of the project environment. Included are discussions of the modern physical environment of the study area and regional paleoenvironmental patterns.

\section{Location}

The project is located within the borders of Twin Buttes Reservoir, Tom Green County, in west-central Texas. The 989,000-acre county is comprised primarily of ranch land, with about 195,000 acres used for farming, 14,000 of which are irrigated (Weidenfeld and Flores 1976:1). Twin Buttes Reservoir is named after two prominent features, towering nearly 200 feet above the relatively flat or gently sloping surrounding terrain. The lower slope of the eastern butte lies within the northern portion of the reservoir property and the Concho River watershed. As noted in the previous chapter, the earthen filled Twin Buttes dam was constructed in the early 1960s across three major drainages in the region, the Middle Concho, the South Concho, and Spring Creek. The reservoir retains runoff from 2,813 square miles of the Edwards Plateau and surrounding plains (USGS 1999a).

\section{Physical Environment}

This section summarizes the modern and historic climate, hydrology, soils, lithic resource distribution, and flora and faunal resources of the project area as well as some aspects of these resources in surrounding counties. The physical environment is the biotic and abiotic landscape on which historic occupations, discussed in subsequent chapters, operated. In addition, several aspects of the modern physical environment, such as broad scale patterns in soils and lithic resources, can be applied to much of the prehistoric sequence. While modern climate and hydrological data are not directly applicable to most of the prehistoric sequence in the project area, the discussion provides a baseline for considering paleoenvironmental changes that are discussed at the end of this chapter.

The Twin Buttes Reservoir project area lies within the southwestern portion of Tom Green County, at the southern edge of the Rolling Plains (Osage Plains), an undulating plain with sometimes steeply eroded canyons (Fenneman 1931:54). Bordering the project area on the south and west is the Edwards Plateau in Central Texas "Hill Country," so named for its rugged, stream-eroded topography (Figure 3-1, 3-2). The Rolling Plains, with its silty clay loams and stony clays in the valleys overlying Permian-age silt and sandstone beds, covers about 80 percent of Tom Green County, gradually changing into fine sandy loams on the eroded slopes of the Edwards Plateau (Figure 3-1, 3-2). Geologically, the area provides abundant outcrops of limestone and gravels from the Edwards limestone and San Angelo conglomerate formations. Physiographically, the region falls in the Northwest Margin of the Edwards Plateau Section of the Great Plains province (Fenneman 1931). Elevation in Tom Green county ranges from 1,717 feet in the north to 2,480 feet in the south.

\section{Modern and Historic Climate}

The modern climate of the San Angelo area is classified as semi-arid though humidity, often in excess of 40 percent, is high for such a characterization. Large fluctuations in temperature occur throughout the year, with average daily maximum temperatures ranging from $97.5^{\circ} \mathrm{F}$ during August to around $59^{\circ} \mathrm{F}$ in January, and average daily minimums ranging from a July high of $72.7^{\circ} \mathrm{F}$ down to $34.3^{\circ} \mathrm{F}$ in January (Weidenfeld and Flores 1976:56-57). The average precipitation over the last 30 years was 20.45 inches (National Weather Service 1999) though significant fluctuations are common. Figure 3-3 demonstrates these fluctuations in yearly precipitation from 1951 through 1994 


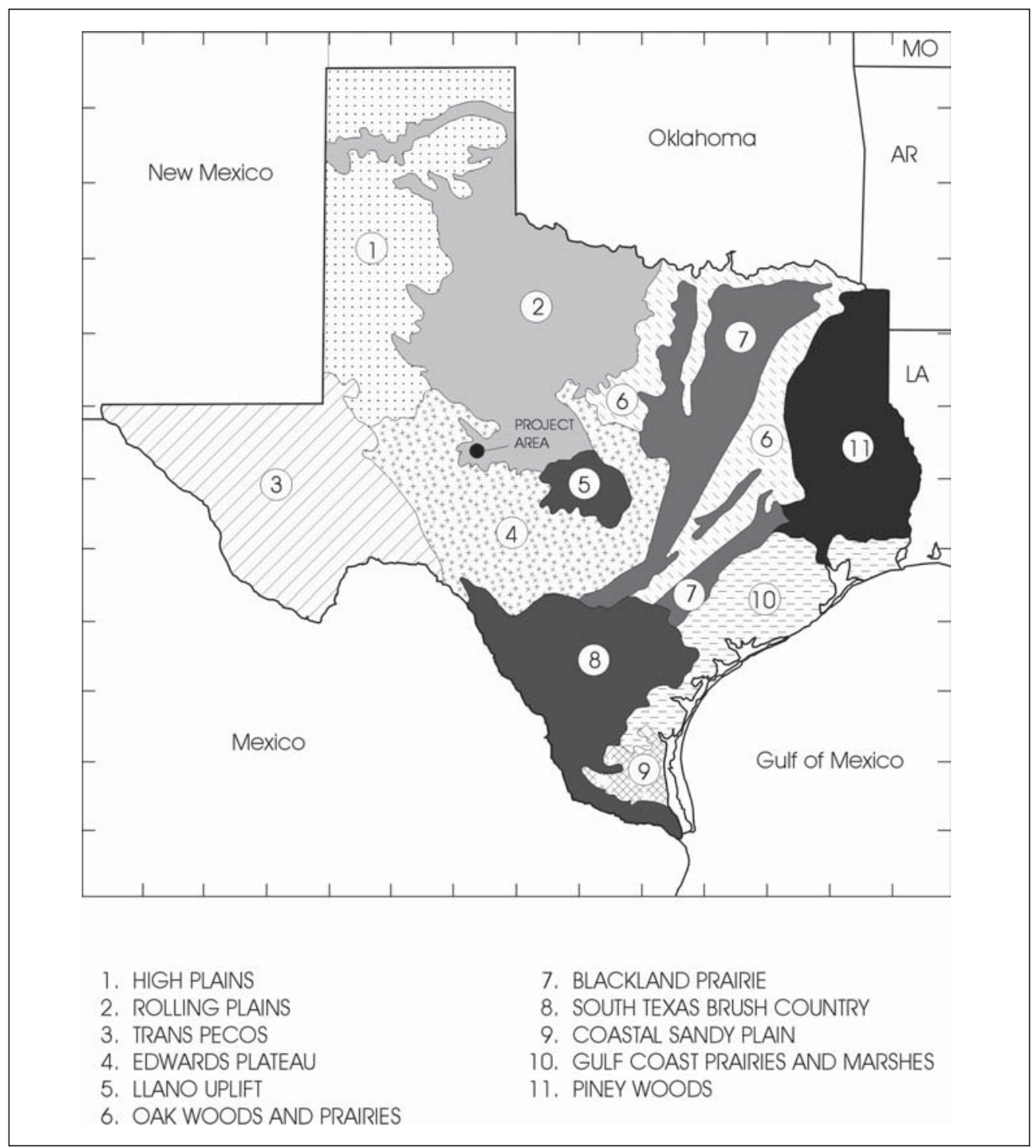

Figure 3-1. Natural Regions of Texas with the Twin Buttes Project area identified.

(NCDC 1999a). The driest year during this period was 1956 with only 7.25 inches of precipitation, while the wettest year was 1987 with just over 38 inches. Monthly precipitation patterns are bimodal with peak rainfall occurring in the months of May (mean=2.95 inches) and September (mean=2.57 inches). Over 64 percent of the yearly precipitation occurs between May and October, with the driest period being late fall, winter, and the early spring months of November through February.

Although the growing season averages around 232 days a year (Handbook of Texas Online 1999a; Weidenfeld and Flores 1976:55), data in Figure 3-4 indicate that the number of days per year between freezing temperatures fluctuated significantly between 1951 and 1995. During two of those 45 years the growing season was under 200 days, while growing seasons in excess of 260 days occurred in four of those years (NCDC 1999b).

The combination of variable rainfall and temperature patterns results in frequent droughts as well as periods of abundant moisture. Figure 3-5 documents this pattern of instability as measured by the Palmer Drought Severity Index (PDSI) for Climate Division 6 in Texas from 1900 through 1990 (NCDC 1999c). Division 6, which includes Tom Green County, covers a large area of west Texas. Roughly, Division 6 stretches from the Pecos River on the west to the 


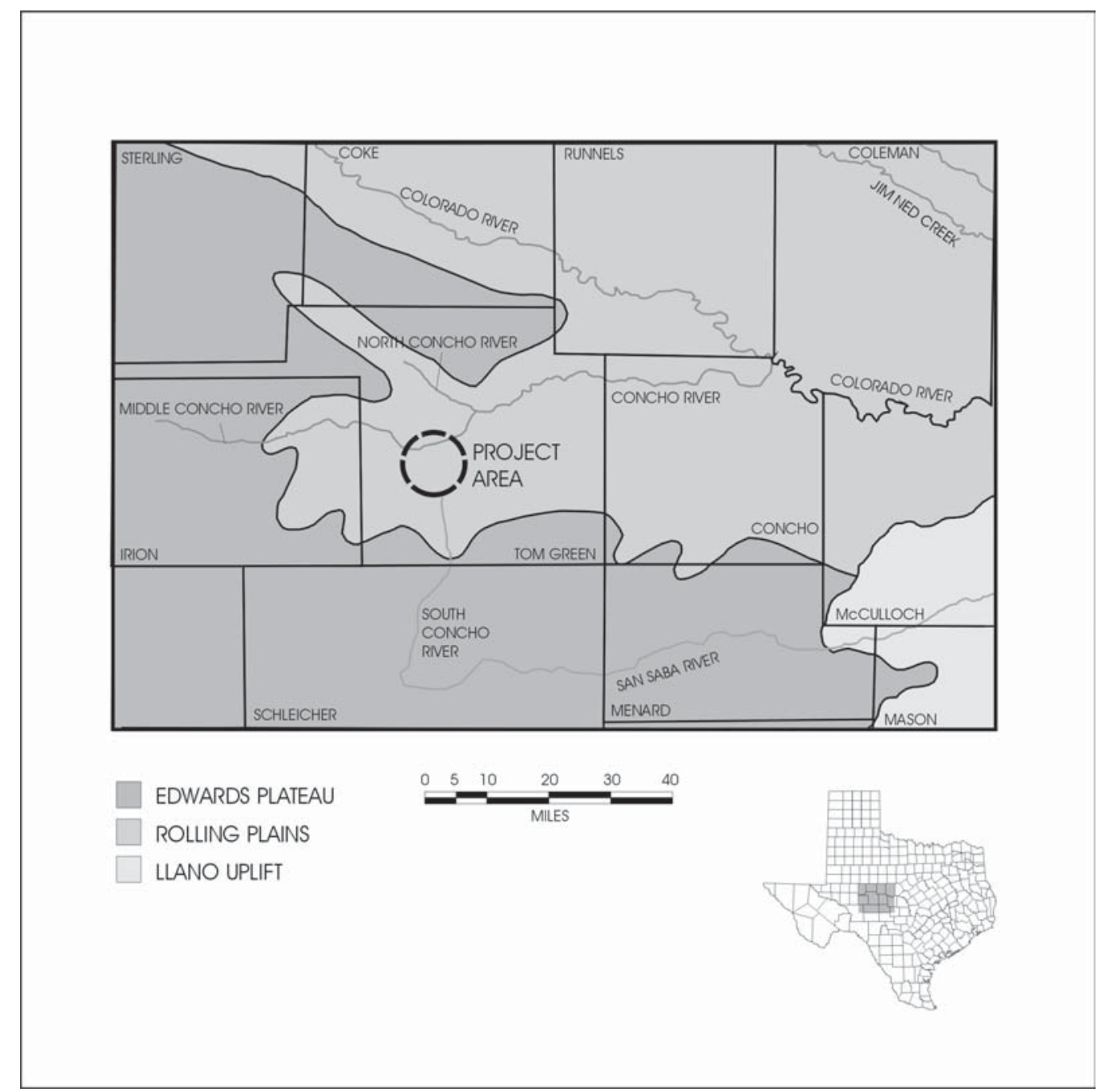

Figure 3-2. Natural Regions of Tom Green and surrounding counties.

Colorado River on the east, and from Coke County in the north to the Rio Grande and Kinney County in the south. The PDSI was developed by Palmer (1965) to provide a standardized measure of monthly deviations from normal weather conditions that could be compared across regions. It is calculated using temperature and precipitation data in combination with information on the available water content in the soil (Alley 1984; Karl 1983). The index varies from a value of over 4.0 (extremely wet) to less than a -4.0 (extremely dry), with normal conditions ranging between 0.49 and -0.49 . Values greater than 2.0 or less than 2.0 are common indicators of moderately wet or dry periods. During the 90 years shown in Figure 3-5, 26 percent $(n=281)$ of the months were above 2.0 , indicating abundant moisture, and 25 percent $(\mathrm{n}=272)$ were less than -2.0 , indicating drought.

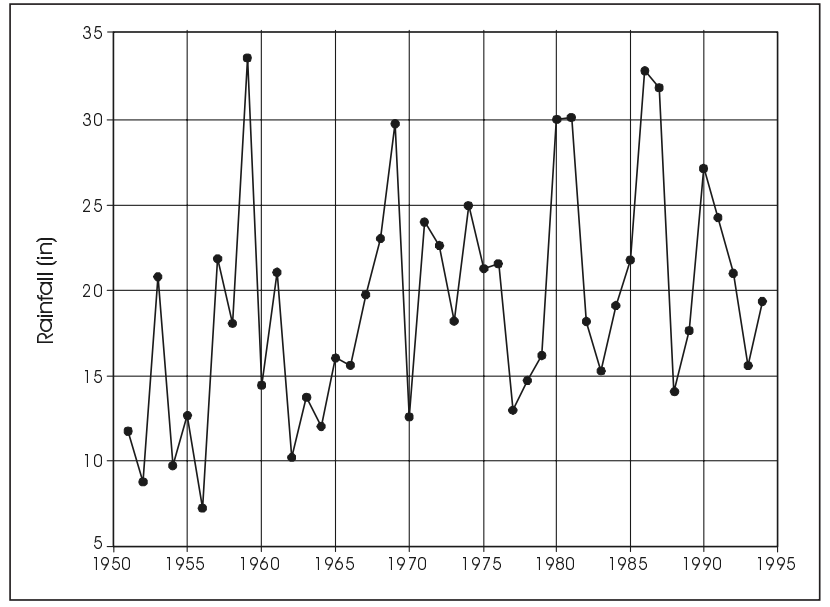

Figure 3-3. Yearly rainfall at San Angelo, Texas (1951-1994). 


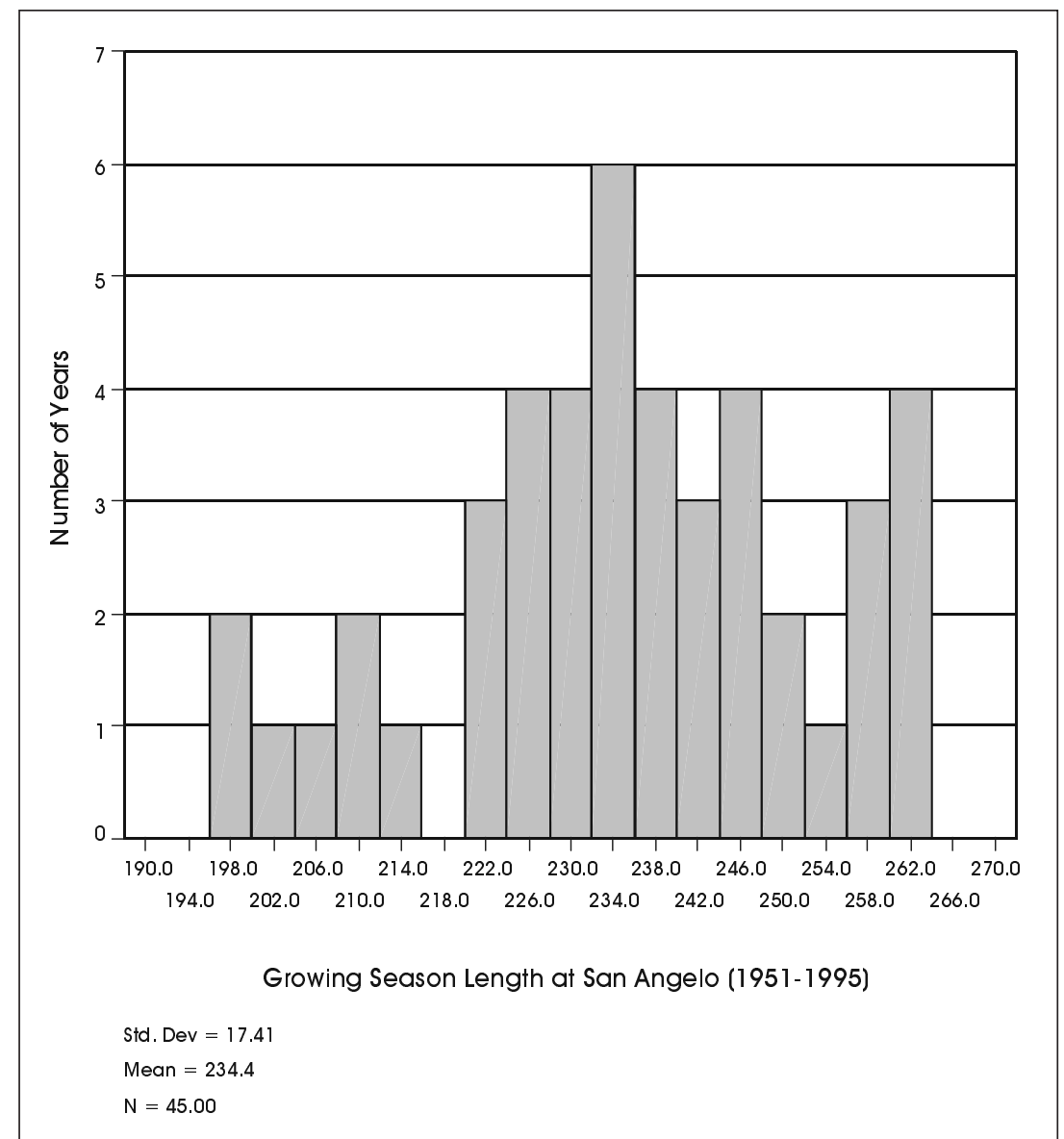

Figure 3-4. Growing season length at San Angelo, Texas (1951-1995).

More critical than the actual number of months above or below the arbitrary PDSI levels of 2.0 and -2.0 is the pattern of consecutive months that are at or near these critical values. Consecutive months at or near these values indicate protracted wet or dry conditions. From 1900 to 1990 there are only two periods where moderately wet conditions, indicated by PDSI values close to or exceeding 2.0, occur for more than 24 consecutive months (Figure 3-5). The first, in the early 1930 s, consists of 28 consecutive months of abundant rainfall, and the second, in the late $1950 \mathrm{~s}$, consists of 38 consecutive months. In contrast, there are four intervals of consecutive months of drought. These occurred between 1909 and 1912 (37 months), 1916 and 1918 (32 months), 1933 and 1935 (30 months), and from 1950 to 1957 (77 months). These prolonged droughts would have a severe impact on local flora and fauna and would be devastating for agricultural and ranching activities (e.g., Holden 1928).

\section{Hydrology}

The PDSI values discussed above are based on regional scale patterns in rainfall, temperature, and soils. Not considered in the determination of periods of drought and abundant moisture is the local hydrology. A variety of major drainages and springs are present in the project region. Three major drainages that make up the Concho River watershed converge within Tom Green County; the North Concho, Middle Concho, and South Concho join near San Angelo to form the Concho, which ultimately empties into the Colorado River to the northeast. A few of the major tributaries flowing into the rivers include Spring, Dove, Burks, Pecan, and Kickapoo creeks (Handbook of Texas Online 1999a). Four of these drainages, the South Concho, the Middle Concho, Dove Creek, and Spring Creek all flow into Twin Buttes Reservoir. 


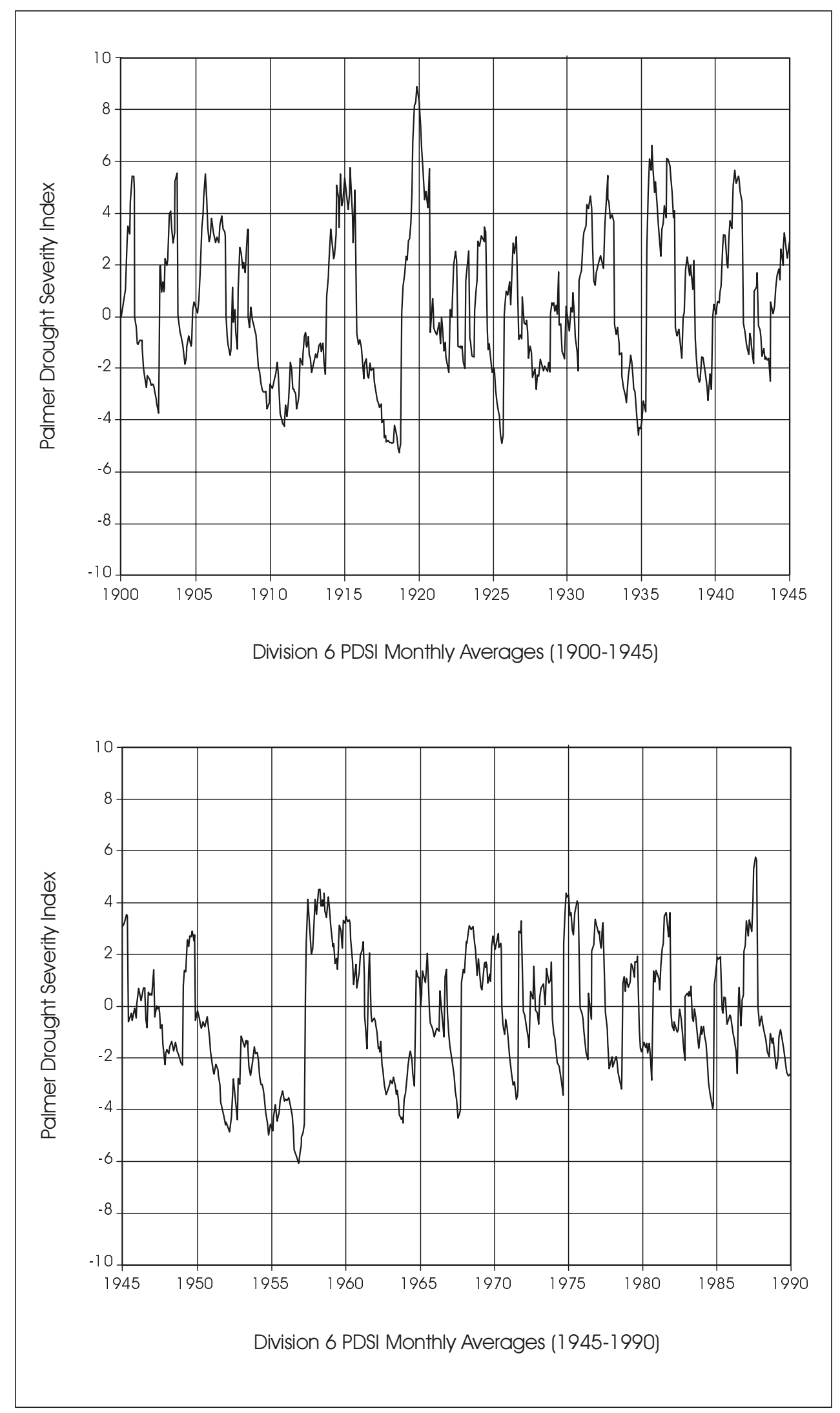

Figure 3-5. Palmer Drought Severity Index, Climate Division 6 (1900-1990). 
Streamflow data, recorded as cubic feet per second (cfs), are available for the South Concho at Christoval from the early 1930s (USGS 1999c). Figure 3-6 uses data from 1930 to 1990 to consider monthly flow patterns in the South Concho. Three peak periods are present; May, July, and the months of September and October. The May and September-October peaks correspond to the bimodal rainfall peaks noted previously. The July peak is probably related to regional runoff. Low monthly streamflow is characteristic of the winter and early spring. While informative at a general scale, these monthly averages do not reflect the extreme variability in the daily flow rates. An examination of the daily records suggest that peak flows during a given month are characterized by short periods, on the scale of 2 to 6 days, when water levels surge and then drop off rapidly. Nevertheless, only two of over 22,200 daily observations between 1930 and 1990 recorded no water flowing in the South Concho at Christoval (USGS 1999c).

Figure 3-7 summarizes aspects of the South Concho streamflow data at a yearly scale from 1931 through 1970. The figure presents deviations from the median streamflow, represented by the 0 line on the y axis.

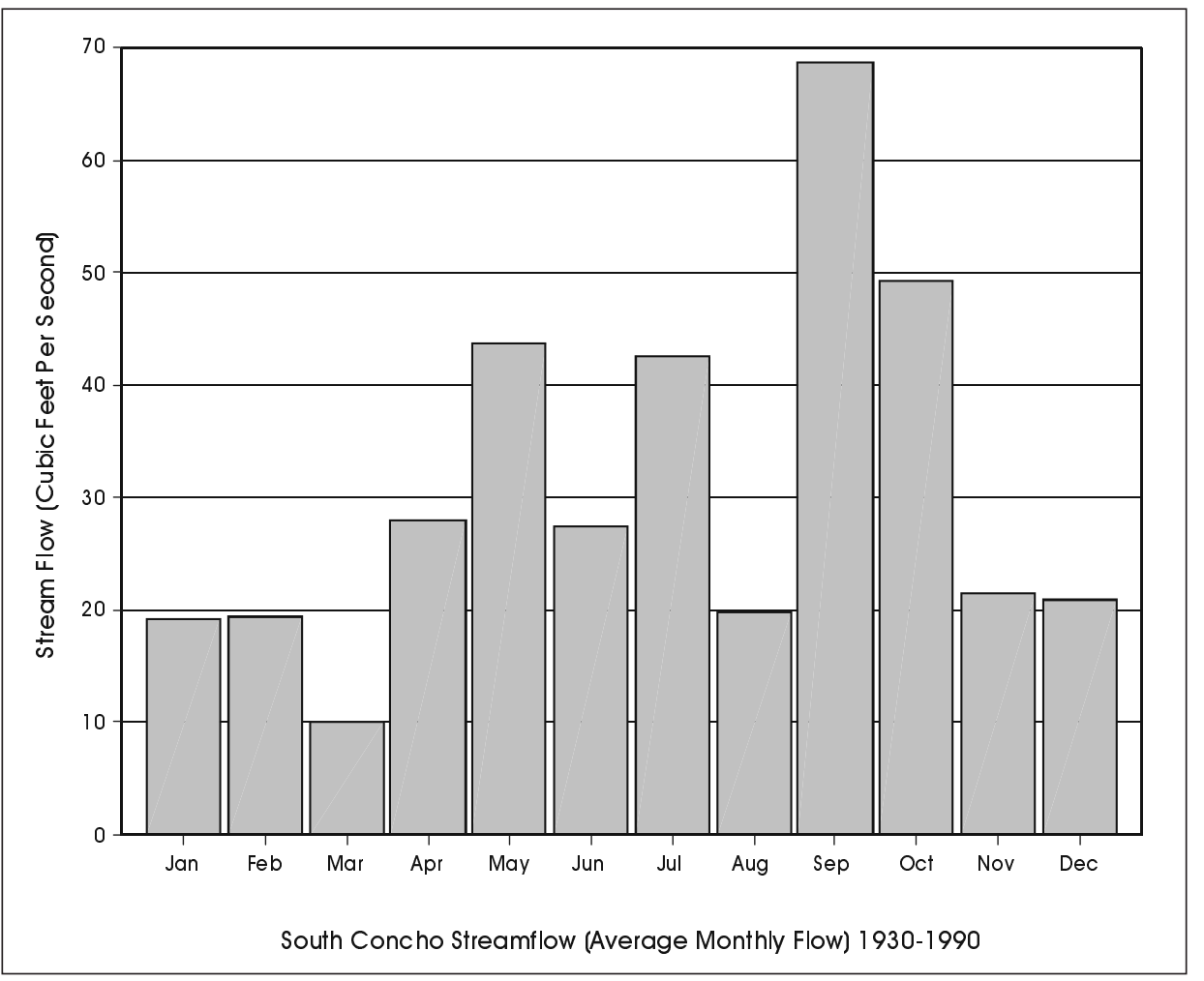

Figure 3-6. Average monthly streamflow of the South Concho (1930-1990).
Points above and below 0 reflect deviations from the median value of $16.9 \mathrm{cfs}$. Drought periods identified by the PDSI data summarized above, such as between 1933 and 1935, as well as between 1950 and 1957, are clearly evident in the figure, as are periods of abundant rainfall identified in the PDSI plot for the early 1930s and late 1950s. However, also apparent in the figure are high streamflows in the late 1930s and low streamflows in the mid to late 1960s.

Streamflow data are available for Spring Creek stretching back to 1959 (USGS 1999d), Dove Creek back to 1960 (USGS 1999e), and for two locations on the Middle Concho (USGS 1999f). In the cases of Dove and Spring creeks, data suggest that these drainages have flow characteristics similar to the South Concho pattern described above, although both drainages contain a lower volume of water. Data are available for the Middle Concho at a recording station located within the Twin Buttes Survey area from 1930 through 1961, and from a recording station at Tankersley from 1961 through 1995 (USGS 1999f). Unlike the South Concho, the Middle Concho at both the Twin Buttes station and at the Tankersley station has an extremely low water volume dating back to the 1930 s. For example, in 1960 no water flow was present for 218 days, or 60 percent, of the year at the Twin Buttes station, and the most frequently recorded value for the average daily flow since 1930 is $0 \mathrm{cfs}$. While a high volume of water is present in the Middle Concho near the headwaters (Jack Woodrow, personal communication 1998), it appears that sometime before 1930 much of the Middle Concho flow disappears into the aquifer at a location above Tankersley. No water was flowing in the Middle Concho during this project. 
The surface water provided by rivers and creeks is supplemented in the area by springs. Among the many springs that have attracted people to the region for millennia are Good Springs (also known as Seven, Headwater, or Spring Creek Springs) located near the Mertzon community in Irion County, Dove Creek Springs southeast of Mertzon, Government (also known as Main Springs), in nearby Schleicher County, Mill Spring south of Christoval, Lipan Spring southeast of Wall, and Kickapoo Spring south of Vancourt (Brune 1975:46-47, 68, 71-72). While long-term data on spring discharge rates are not available, Brune (1975) notes several examples of

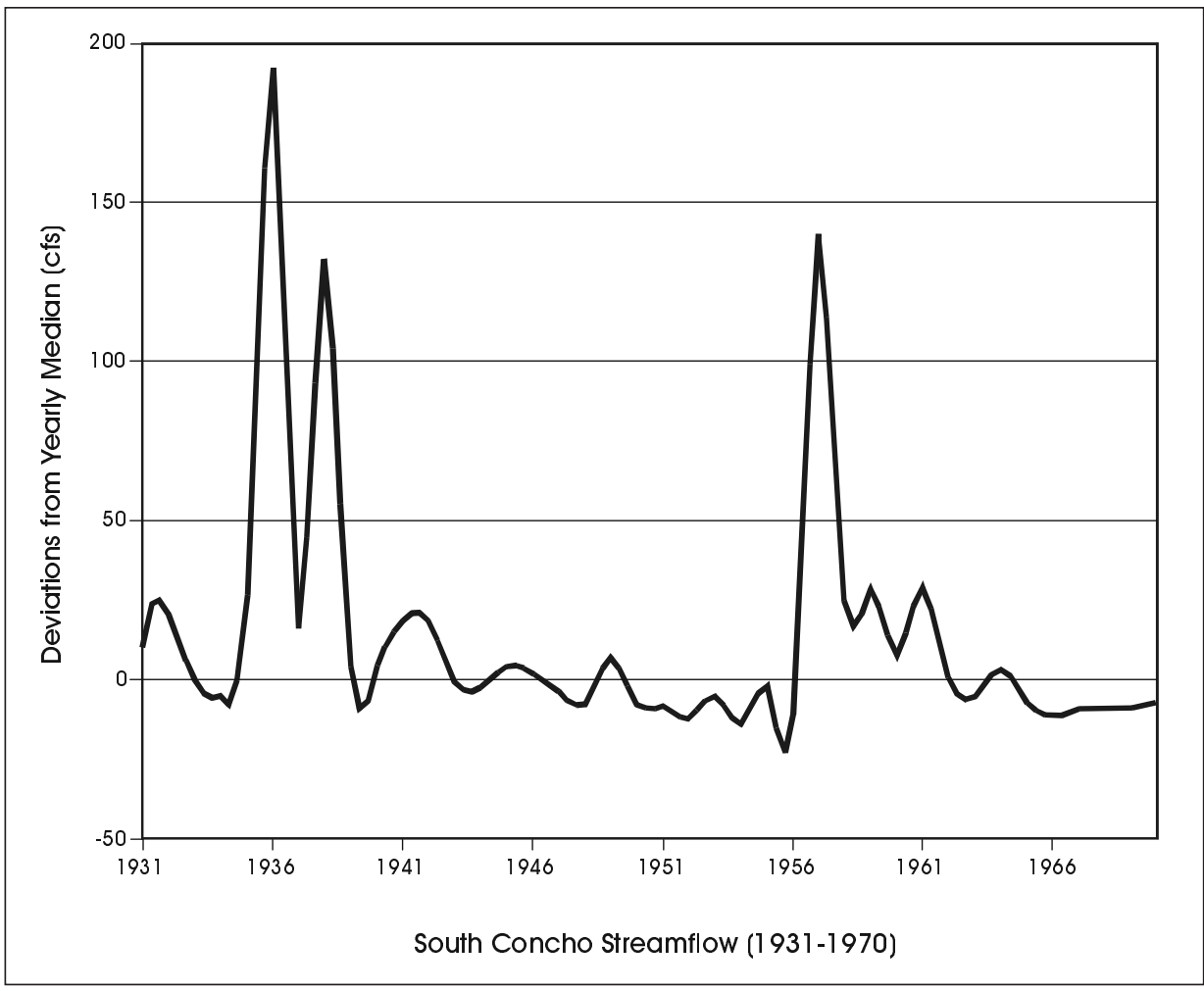

Figure 3-7. Yearly deviations from median streamflow, South Concho River (1931-1970). historically documented springs in Irion, Schleicher, and Tom Green counties, which no longer flow, probably as a result of a lowered water table.

\section{Soils}

The soil survey for Tom Green County (Weidenfeld and Flores 1976) shows that the soils in the upland components overlooking the Middle Concho, South Concho and Spring Creek in the Twin Buttes Reservoir project are the Kimbrough-Mereta-Angelo association, which are clay loam, calcareous soils underlain by indurated caliche on gently sloping outwash plains. Because of their superposition on the sloping landscape they are often less than 20 inches deep. Angelo association soils occur on the smooth outwash plains nearer the confluence of the Middle Concho and Spring Creek, and in the lower reaches of the western side of the South Concho above the dam. The Angelo soils are primarily a clay loam with a calcareous substratum subject to high degrees of shrinking and swelling, causing vertical cracking in severe droughts.
Typically the texture is a clay loam in the upper 6 inches, grading to a reddish-brown clay to 22 inches, followed by 30 inches of pink silty clay loam, smoothly transitioning to a reddish-yellow clay loam. Within the immediate floodplain of each of the drainages is Rioconcho-Spur associated soils. They are also a clay loam that is usually a grayish-brown in the upper 36 inches grading to a light-brown clay loam commonly 80 inches below the surface. Because of their location along rivers and creeks other intrusive soils may occur in irregular deposits (Weidenfeld and Flores 1976).

\section{Lithic Resources}

A detailed discussion of the geomorphology and aspects of the geologic history of the study area can be found in Chapter 4. Here, we summarize details of the landscape with emphasis on the distribution of lithic resources. The geomorphic surfaces in the project area consist of floodplains, fluviatile terraces, slopes, and ridge crests (Barnes 1974). The greater 
portion of the project area is made up of recent Holocene and Pleistocene caliche and gravel deposits (Qc) or Late Pleistocene fluviatile terrace deposits (Qt). The caliche and gravel deposits cover the broad expanse between the Middle Concho and Spring Creek, and run along the north edge of the Middle Concho above Highway 67. Normally these deposits are topographically above fluviatile terrace deposits and it therefore seems probable that the reservoir has inundated terrace deposits along the lower streambeds. Except for a strip adjacent to Burks Creek, the area west of the South Concho is a Late Pleistocene fluviatile terrace $(\mathrm{Qc})$ that contains lithic material in the form of chert pebbles and cobbles, quartzite, igneous and metamorphic rocks. More recent, Holocene and Pleistocene deposits in the form of Quaternary undivided intimately associated alluviums (Qau) were deposited along the eastern edge of the South Concho, and a finger extends parallel to the Middle Concho in the upper elevations. Some Cretaceous age chert and limestone could be dissected into small areas within the alluvium. In the northern portion of the project area on a broad finger ridge between two unnamed tributaries of the Middle Concho, the caliche and gravel deposits (Qc) are present above Quaternary (Qao) deposits of boulder, cobbles and pebbles of Cretaceous age limestone and chert. The oldest lithic deposits occur in the extreme northeastern portion of the project area, below the eastern Twin Butte and an unnamed north-south tributary of the Middle Concho. They are Lower Cretaceous Antlers Sand (Ka) and Middle Cretaceous (Permian) Blaine $(\mathrm{Pb})$ formations. Antlers Sand consists of sandstone, siltstone, conglomerate, white and pink quartz, quartzite, and black chert. Artifacts observed during the archaeological survey indicate that the cherts were being heavily exploited, along with minimal quantities of quartz.

\section{Biotic Resources}

The study area is located at an ecotone between the Rolling Plains and the Edwards Plateau (see Figure 3-1, 3-2). Summaries of modern flora and fauna can be found in Eckhardt (1975), Maxwell (1979), and Creel (1978, 1990; see also Lintz et al. 1993a; Quigg and Peck 1995). At a general level, the western Edwards Plateau is primarily a live oak-mesquite savannah while the Rolling Plains is a mesquite savannah. However, the interplay of soils, moisture, and temperature results in a mosaic of vegetation types as can be seen in Figure 3-8. The eastern portion of the region displayed in Figure 3-8 is dominated by live oak, ash juniper, and mesquite. The western portion of the region is dominated by more shrub and brush vegetation, with mesquite, lotebush, and juniper being the dominant plant types. Within Tom Green County, Eckhardt (1975) identified several different vegetation communities, including mesquite-tobosamixed grass prairie, mesquite-mixed grassland, juniper savannah, oak savannah, and riparian vegetation.

Maxwell (1979) summaries specific plant types for each of the vegetation communities described at a general level by Eckhardt (1975). Mesquite-tobosamixed grass prairie and the mesquite-mixed grasslands are primarily confined to the uplands of the region, dominating flat mesa tops, though it is also present in the Lipan Flat and some lowland settings of the Rolling Plains (Maxwell 1979)

Juniper savannah is characteristic of shallower, stony soils and is frequently present on hillsides and slopes of the region. The lower, undulating hills of the region are dominated by live oak savannah, and Maxwell (1979:24) reports large stands of this vegetation community at the headwaters of Spring and Dove creeks, as well at the headwaters of the South Concho. The riparian vegetation community, confined to the deeper soils along stream banks, includes dense stands of pecan (Carya illinioensis), elm (Ulmas americana), black willow (Salix nigra), and hackberry (Celtis sp.).

Quigg and Peck (1995; See also Lintz et al. 1993a) note that 317 species of birds, 35 species of fish, 36 species of snakes, 18 species of mussels, and a variety of small reptiles are likely to be present in the area. Lintz et al. (1993b), working at O. H. Ivie Reservoir to the northeast of the current project, list 47 species of mammals native to the region, including whitetail deer (Odocoileus virginianus) and pronghorn (Antilocapra americana). Historically, bison (Bison bison) were present in the region into the late nineteenth century, and it appears that at various points over the last several hundred years, these herds were substantial (see Creel 1990; Creel et al. 1990). 


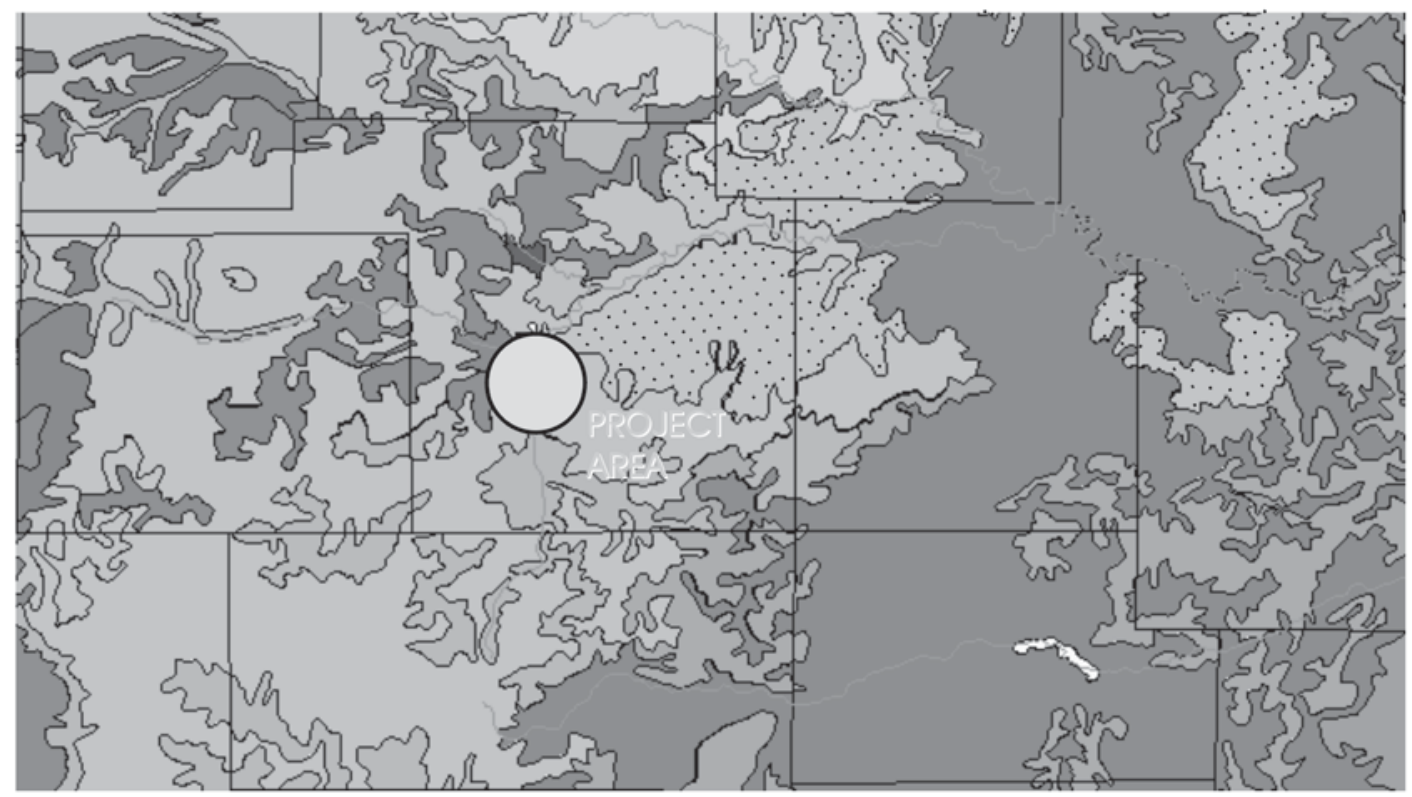

live oak-mesuite-ashe juniper park

live oak-ash juniper park

$\because$ crops and/or urban

mesquite-lotebush brush

mesquite-lotebush shrub

mesquite-juniper shrub

mesquite-juniper-live oak brush

mesquite-hackberry brush/woods

live oak-mesquite park

mesquite-juniper brush
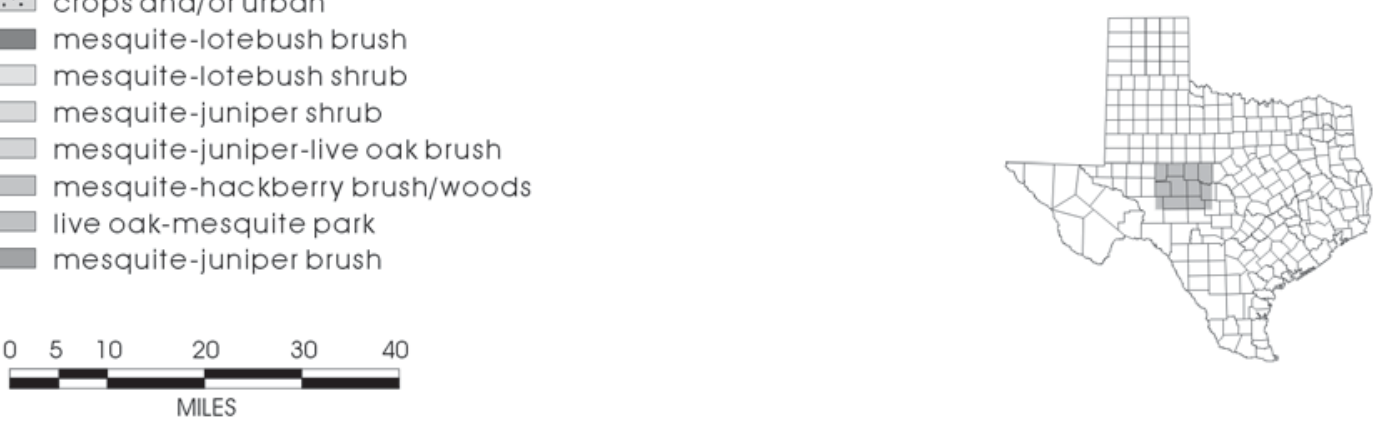

Figure 3-8. Vegetation complexes in Tom Green and surrounding counties.

\section{Paleoenvironment}

The changing scope and depth of paleoenvironmental studies provides broadly applicable schemes on climatic and vegetation shifts that have occurred over the past 18,000 years in Texas. Recent research, particularly during the past decade, has contributed immensely toward understanding the Paleoenvironment of the state (e.g., Bousman 1998; Brown 1998; Caran 1998; Frederick 1998; Fredlund et al. 1998; Kibler 1998; Ricklis and Cox 1998). These studies continue to refine and complicate the larger context of Late Quaternary climatic change. Unfortunately, the paleoclimate of Texas contains significant gaps primarily due to the scarcity of deep, finely stratified, and well-dated deposits (Stahle and Cleaveland 1995:51), as well as uneven history of work across the state. Nowhere are these gaps more apparent than in the immediate study area. Consequently, this section relies on information taken from a variety of studies located primarily to the east and south of the current project, along with data from the Southern Plains. 
Below, we use a number of different data sets, including pollen, phytolith, geomorphic, oxygen-isotope, and faunal data, in an attempt to document aspects of the paleoenvironment from the close of the Pleistocene until the modern era (Figure 3-9). Each of these data sets monitor climate and vegetation changes at varying spacial and temporal scales. In addition, each data set has specific problems associated with preservation, sampling, chronological control, and interpretation. A detailed review of the problems and prospects associated with each specific data set is beyond the scope of this chapter, and several excellent discussions are available (e.g., Bousman 1998; Collins 1995; Hall and Valastro 1995; Johnson and Goode 1994).

\section{Late Pleistocene (са. 18,000-10,000 вР)}

In Central Texas, pollen spectra from Boriack Bog (Figure 3-9) suggest a shift from grasslands before 16,500 вр (вР; years before 1950) to woodlands before 12,500 $\mathrm{BP}$ in a moist and cool climate (Bousman 1994:79). The same spectra reveal a decline in spruce (probably cold-adapted) pollen by 15,000 BP, indicating a trend toward a warmer climate. Bousman's

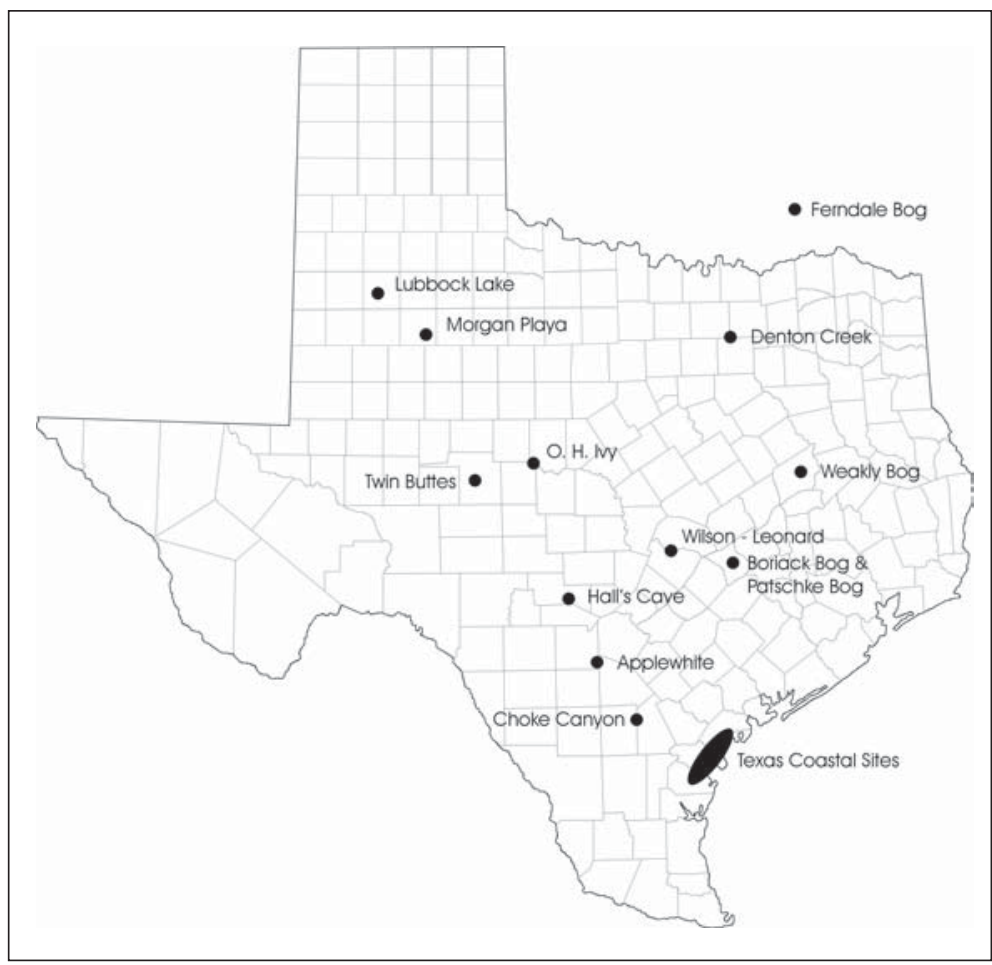

Figure 3-9. Paleontological and archaeological sites discussed in the text.
(1992) oxygen-isotope evidence from South Texas complements the bog pollen data and suggests early warming by $15,000 \mathrm{BP}$.

Toomey et al. (1993) argue that from Hall's Cave in the Edwards Plateau in Central Texas (Figure 3-9), summer temperatures in the Late Pleistocene were $6{ }^{\circ} \mathrm{C}$ cooler than present averages, and that by 13,000 BP (or 12,500 BP [Toomey and Stafford 1994]) the wetter interval became warm and more arid. Between 12,500 and $11,800 \mathrm{BP}$, the Boriack Bog data indicate that a drier episode stimulated a brief shift to grasslands, collaborated by oxygen-isotope ratios showing a cooler setting in South Texas (Bousman 1992; 1994:80). The Hall's Cave record indicates a wetter interval around 11,000 вр (Toomey and Stafford 1994).

Recently, Camper (1991) has reanalyzed Patschke Bog, a Central Texas bog near Boriack Bog (Bousman $1994,1998)$ that was originally investigated by Potzger and Tharp (1943, 1947). The samples presented by Camper appear to represent a continuous, and relatively well-dated sequence stretching back to 17,000 BP. However, as Bousman (1998:207-208) notes, the Patschke data have significant frequencies of local marsh taxa, such as alder (Alnus) and Cyperaceae, which make the identification of regional changes difficult. In an attempt to clarify the pattern of regional change indicated at Patschke Bog, we reviewed the raw pollen grain counts from Patschke Bog (Camper 1991). While Bousman (1998) is correct in noting the high level of marsh taxa throughout the deposits, it appears that Camper's grain counts, unavailable to Bousman in 1998, are extremely high. Average counts are just over 370 grains per level, and none of the 51 separate levels has a count lower than 270 . It is therefore possible to eliminate the marsh taxa pollen for Patschke Bog, an exercise that results in an average sample size of just over 215 grains per level with more than 50 percent of the levels having sample sizes above 200. Only in three cases do the revised counts drop below a sample of 100 grains, and in each of these low sample cases, the 
overall pattern revealed by the low sample levels is supported by adjacent levels with higher frequencies.

While a complete examination of the potential of these data are beyond the scope of the present chapter, Figure 3-10 lists the revised percentages for grass (Poaceae) taxa for Patschke Bog, as well as the grass percentages for Boriack Bog with major contaminants removed (Bousman 1998). An examination of the figure shows good correlation with Bousman's (1998) summary, especially in light of the fact that the dating of the sediment core analyzed from Boriack Bog (Core 1) is based on four radiocarbon dates from an adjacent core (Bousman, personal communication 1999). The Patschke Core 4 samples are supported by four

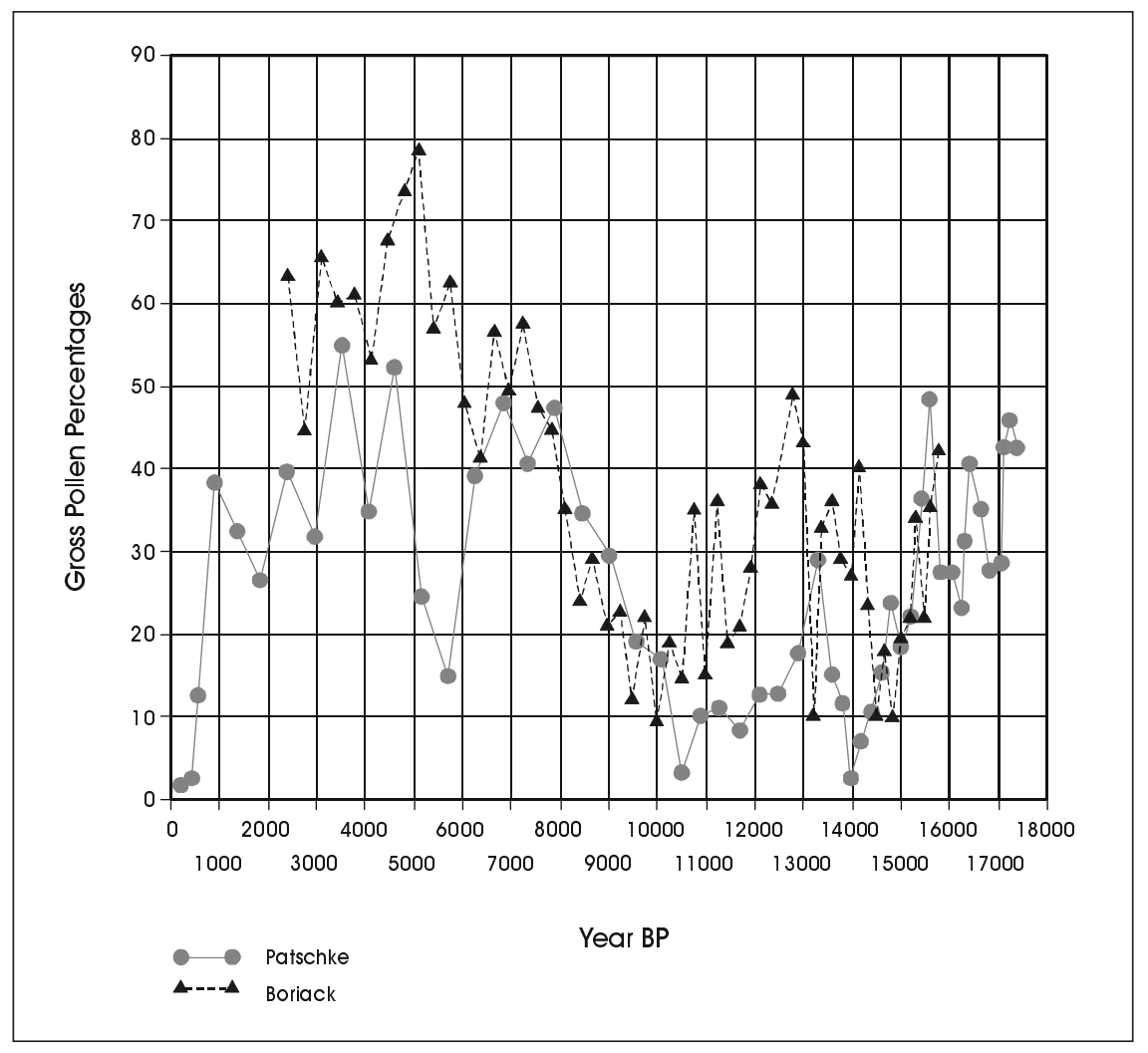

Figure 3-10. Poaceae pollen percentages for Boriack and Patschke Bogs. radiocarbon dates from that core, and by additional dates from Core 2 located less than 2 yards away from Core 4 (Camper 1991:31).

The Patschke pollen sequence (Figure 3-10) suggests that between roughly $17,000 \mathrm{BP}$ and $15,500 \mathrm{BP}$, a cool grassland environment may be present. After 15,500 $\mathrm{BP}$, a rapid decline is indicated which reaches a low at roughly $14,000 \mathrm{BP}$. While there is a brief spike in grass percentages around 13,200 BP, low grass frequencies are present until roughly 10,500 BP. Though not shown in Figure 3-10, pollen from cold adapted arboreal species such as spruce (Picea) are not present in the Patschke sequence after about $8000 \mathrm{BP}$, and are not frequent after the late Pleistocene.

\section{Early Holocene (ca. 10,000-8000 вР)}

Pollen samples from the Llano Estacado and the dry caves of the trans-Pecos region prompted Bryant and Shafer (1977:15-19) to suggest a gradual warming and drying trend throughout the Holocene (after about

10,000 BP). Others, including Aten (1979) and Gunn and Mahula (1977), use data from Oklahoma and eastern Texas to propose a more variable change from the colder, wetter Pleistocene to the modern climate.

Innovative research in opal phytolith analysis from archaeological sites on the Coastal Plain of South Texas (Robinson 1979) also showed that, at least since the Early Holocene, climatic change has been highly variable (Figure 3-9). Climatic fluctuations in the Holocene are also suggested by Bousman (1998), again based on the Boriack and Weakly Bog data from Central Texas (Figure 3-9). Toward the PleistoceneHolocene boundary at about 10,000 BP, arboreal species in the Boriack Bog spectra show a return of woodlands by $9500 \mathrm{BP}$, followed by their decline and a reestablished predominance of open vegetation communities. Woodlands, reestablished by 8750 BP, were replaced by grasslands by 7500 BP (Bousman 1994:80). The gradual warming trend is supported by the consistent increase in grass pollen at Patschke 
(Figure 3-10). Robinson (1979:109) associated his oldest phytolith sample, although poorly dated, with a Late Paleoindian or Pre-Archaic period and suggested an age of about $8000 \mathrm{BP}$. The predominance of tall grass species, white oak phytoliths, a generally high frequency of other tree species (unidentifiable), and the generally small size of the grass phytoliths indicated a wet environment. In East Texas, fossil pollen counts from Ferndale Bog in southeastern Oklahoma (Figure 3-9) indicate grasslands were predominant in that area around 11,000-8000 BP (Bryant and Holloway 1985). Closer to the Twin Buttes area, analysis of opaline phytoliths recovered from Zone A in Morgan Playa (Figure 3-9) on the Rolling Plains of northwest Texas (Garza County) indicate a higher than expected percentage of $\mathrm{C} 3$ grasses, with $\mathrm{C} 4$ tall grasses present, suggesting a wetter $(\mathrm{ca} .10 \mathrm{~cm}$ of rainfall) environment than today. Zone A represents an approximated period between the Early Holocene and 7900 Bр (Fredlund et al. 1998).

\section{Middle Holocene (ca. 8000-4000 вР)}

The continuous decline of the woodlands in the Early Holocene was briefly checked around $6000 \mathrm{BP}$, but resumed its slide until 5000 BP when arboreal pollen slowly increased with the appearance of a wetter climate (Bousman 1994:80). This mid-Holocene arid period indicated at Boriack Bog agrees with data presented by Nordt et al. (1994) from the Applewhite project near San Antonio (Figure 3-9), where a dry period for roughly the same time frame (6000 to 4800 BP) is indicated. Humphrey and Ferring (1994) discovered the same arid episode in north-central Texas, but with greater duration (6500 to $4000 \mathrm{BP}$ ), agreeing with the revised interpretation from Hall's Cave for an arid episode between 7000 and 2500 BP (Toomey and Stafford 1994). Johnson and Goode (1994) report a later occurrence between 5000 and 2500 BP (calibrated). The opal phytolith records from the WilsonLeonard site (Figure 3-9) in Central Texas (Fredlund 1994), and two sites on Colette Creek in South Texas (Robinson 1979:111), agree with increasing aridity in the Middle Holocene, indicated by spreading grasslands around $4400 \mathrm{BP}$ and ca. $4500 \mathrm{BP}$, respectively. However, a sample from slightly higher in the Colette Creek strata with roughly the same age argues for a quickly appearing, yet brief, wet episode (Robinson's
[1979:111] Sample 4), followed by a return to an arid climate up to ca. 2750 BP. Grass pollen data from Patschke suggest a grassland setting for the Middle Holocene, but with a marked, brief decline between 6000 and $5000 \mathrm{BP}$, hinting at a wetter interval.

Phytolith analysis of sediments from the Choke Canyon project (Figure 3-9) add to the claim of considerable climatic variability (Robinson 1982:597-610). Between 5300 and 4300 BP, Robinson (1982:598) infers a cool, mesic climatic regime that shifts to a more arid period and then returns to conditions both cooler and wetter than today's by 3250 BP. Fredlund et al. (1998) see significantly more moisture present during the period 5600-7900 BP than today in the form of C4 tall grasses from opaline phytoliths at Morgan Playa, northwest Texas. However between ca. 5600 and 600 BP, Fredlund et al. (1998) have identified an increase in the presence of $\mathrm{C} 4$ short-grasses that are characteristic of a more xeric (ca. $5 \mathrm{~cm}$ of rainfall) and slightly warmer environment than exists in modern times. Fossil pollen counts from Ferndale Bog are again used to infer the Middle Holocene environment of East Texas. Although not supported by fossil pollen, Bryant and Holloway (1985:55) believe that percentages of taxa such as oak, sweetgum, and pine, which adapt to drier conditions, may have increased. As the grasses and weeds decreased, oak, which was present at the end of the late-glacial period, has steadily increased. Percentages of sedge pollen, which thrives in moist environments, also began to increase with the decline of grasses and weeds, peaking at around 6,500 BP, dropping off slightly, and then peaking again a few hundred years ago (Bryant and Holloway 1985:55).

\section{Late Holocene (4000-0 вP)}

There are indicators that climate continued to fluctuate in the Late Holocene. Nordt et al. (1994) suggest a warm and dry episode between 3000 and 1500 BP based on stable carbon ratios from deposits at Applewhite Reservoir. Toomey and Stafford (1994) see a wet period appearing about 2500 BP at Hall's Cave. Their observations agree with those of Robinson (1979:112), suggesting a very wet episode. Ricklis and Cox's (1998) study of oyster-growth patterns on the Texas Gulf coast (Figure 3-9) tentatively implies a shift to a cooler climate 
ca. $3000 \mathrm{BP}$, emerging out of a much warmer Middle Holocene. The Gulf Coast data tend to agree with the Choke Canyon analysis that points to mesic conditions (similar to today's) by 2450 BP (Robinson 1982:598599). Afterward, a shift to more xeric conditions occurred by 1000 BP, but Robinson suggests that they may have been more mesic than modern conditions. The predominance of short grass species agrees with large quantities of bison remains documented in archaeological context at Choke Canyon (Robinson 1982:599). Grass pollen frequencies in the Boriack and Weakly Bog pollen spectra indicate drying episodes at 1600-1500 BP and 500-400 вP (Bousman 1994:80). Data from Patschke suggest a fluctuating but generally dry period early in the Late Holocene, with accelerated mesic conditions after about 1000 BP. Studies of eolian dune sediments west of Big Spring in northwest Texas (Frederick 1998) and near Lubbock in the Panhandle (Holliday 1985), along with eolian deposits in Boren Rockshelter southeast of Lubbock (Kibler 1998), suggest a dry period occurred in the region between 1300 and 800 BP.

Brown (1998) demonstrated that the mean oxygen isotope values $\left({ }^{18} \mathrm{O}\right)$ for fresh water mussel shells from Denton Creek (41DL270) in north-central Texas (Figure 3-9) can be used to make general inferences about past air and water temperatures, rainfall, and evaporation. Higher isotope values occurring in mussel shells from dated contexts suggests a cool and wet climate around $3500 \mathrm{BP}$, a warm, dry climate around $2850 \mathrm{BP}$, then cooling off and becoming wetter between 2500 and $1500 \mathrm{BP}$, and finally a warming trend occurring after 1500 вр (Brown 1998:164). The conclusions reached from Brown's study of fresh water mussels are generally comparable to those of Humphrey and Ferring's (1994) study of soil carbonate stable isotopes. The carbon isotope data from north-central Texas indicates that between 4500 and 2000 BP the climate was moist, but began drying by $2000 \mathrm{BP}$, and for the next 500 years the area was much drier. However, around $1500 \mathrm{BP}$ another shift occurred, and after 1500 BP the climate again returned to wetter conditions. Data from Ferndale Bog suggests oaks and pines, which adapt to drier conditions, peaked around 700 years ago, dropping in quantity slightly to the present, while sedges have increased significantly in the past few hundred years (Bryant and Holloway 1985).

\section{Summary}

A consideration of the previous discussion suggests that the paleoenvironment of Texas is quite varied. While, in part, this variability may reflect problems with comparing different proxy data sets that measure different aspects of climate at varying spatial and temporal scales, as well as problems with the temporal assignment of particular samples or sequences, the variability may be real, especially during certain periods. This point can be seen in Figure 3-11, a summary of climate patterns suggested by four different data sets. The figure includes two faunal data sets as relative indicators of xeric and mesic conditions. The first data set uses Dillehay's (1974) presence/absence data for bison in the central Texas and southern plains area (see also Collins 1995; Creel et al. 1990; Hurt 1980) as well as faunal material from Hall's Cave reported by Collins (1995). In addition, two pollen data sets, the frequency of grass pollen taken from the revised counts at Patschke Bog and the arboreal pollen frequencies taken from the second counts at Boriack Bog with potentially local marsh taxa removed (Bousman 1998). While a variety of other data sets are available, these four are selected because they span much of the 12,000 years of interest and are only reflective of two different data types, pollen and fauna.

At a general level, there is good agreement between these four different data sets, especially for the period before $4000 \mathrm{BP}$. There are also periods throughout the sequence where differences are present. The waning of the Pleistocene clearly marked a transition from a cooler, wetter environment to one that steadily grew warmer and drier. All four data sets indicate that much of the Early Holocene was relatively mesic. The Middle Holocene is generally warm and/or dry, with a brief mesic period suggested sometime between 6000 and 5000 BP. Between about 1500 and 750 years ago, all three available data sets hint at a dryer period, while a more mesic interval is suggested by two of the three applicable data sets for the last 750 to 800 years (see Figure 3-11).

In terms of the particular Twin Buttes area, it is unlikely that these climatic changes have dramatically altered the floral and faunal communities in the past few thousand years. This can be seen most clearly in fauna (see Creel 1990; Creel et al. 1990). The greater 


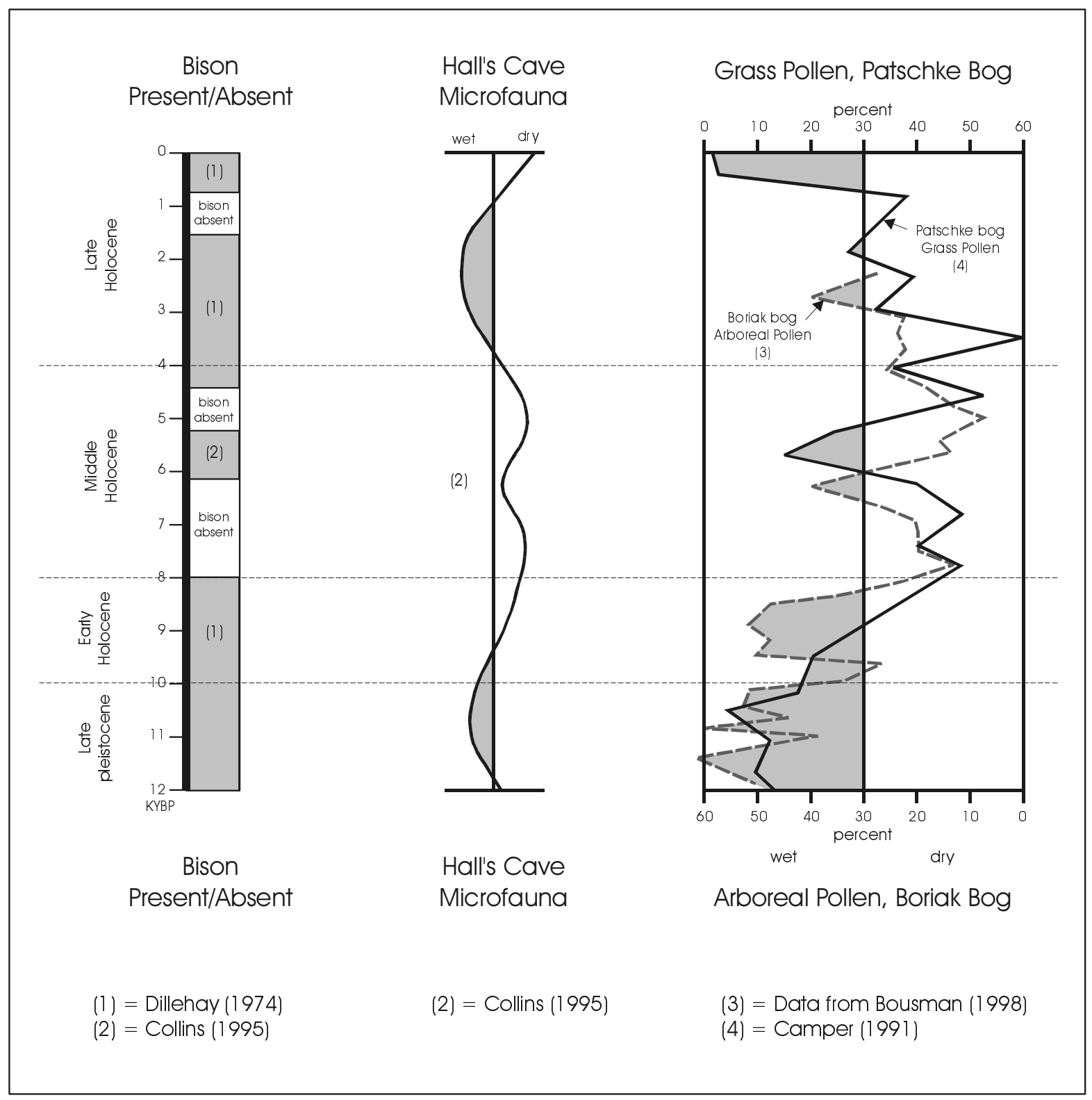

Figure 3-11. Regional climatic indicators for Central Texas.

changes have been induced by recent and historic human intervention through the clearing of wooded areas along the rivers for construction purposes, pumping more water for irrigation, which has lowered water tables, and overgrazing by livestock. The introduction of sheep in the late 1870 s, large openrange cattle herds in the $1860 \mathrm{~s}$, and increasing human populations in the region throughout the latenineteenth and early-twentieth century, have dramatically altered the flora and fauna, and changed water flow patterns. It is likely that prior to these dramatic changes, the streams and springs documented earlier in this chapter flowed with greater abundance during wetter intervals, and may have been unpredictable during the longer dry periods. More mesic intervals seem to correlate with greater abundance of a variety of plants and animals, including high return resources such as bison. To the degree that there is some relationship between the overall productivity of the environment, these mesic intervals, and prehistoric use of the area, relatively higher levels of occupation should be present during much of the Late Pleistocene and Early Holocene, as well as throughout the Late Holocene. Conversely, drier periods, such as between 8000 and $6000 \mathrm{BP}$, should see relatively less intensive use of the project area. 


\title{
Chapter 4: \\ Geoarchaeology of the Twin Buttes Project Area
}

\author{
Lee Nordt and Britt Bousman
}

\section{Introduction}

The purpose of the geoarchaeological investigation was to reconstruct the late Quaternary alluvial history of the major streams in the project area, and to make inferences about prehistoric preservation potentials and site formation processes. The archaeological record is strongly influenced by geological processes of deposition, erosion, and soil formation (Waters 1992).

\section{Methods}

The geoarchaeological investigation was conducted with field reconnaissance, interpretations from the local soil survey (Wiedenfeld and Flores 1976), topographic maps, geological sheets (Barnes 1975, 1992), and soil-stratigraphic descriptions from ten backhoe trenches (BHT) and ten cutbank exposures (CB). Descriptions were written following standards and procedures outlined by the Soil Survey Division Staff (1993) and Folk (1980).

The alluvial chronology was established by eight radiocarbon ages, stratigraphic position, degree of soil development, and time-diagnostic artifacts. Radiocarbon ages were determined by Beta Analytic, Inc., corrected for variations in stable carbon isotopes, and reported in radiocarbon years before present (BP). The potential influence of contamination from reservoir waters during high stages is unclear. Future radiocarbon dating should be conducted, if possible, on charcoal from cultural features or from wood from reliable contexts. This would test the validity of radiocarbon humate dating in these situations. We proceed under the assumption that the humate radiocarbon ages are correct within context of the routine interpretations that can be made by these types of samples, unless otherwise stated.

\section{Pre-Quaternary Geology}

The geological units in the project area range in age from Permian to Holocene (Figure 4-1). Permian deposits are part of the Blaine and San Angelo formations and consist of multicolored, partly calcareous, interbedded shales and sandstones. These formations outcrop in the central and northern part of the project area in the uplands and along deeply dissected low-order tributaries. Cretaceous units make up the remainder of the upland units, which consist of the Antlers Sand and Edwards Limestone. The Antlers contains mainly partly calcareous, multicolored, and cross-bedded sandstones. The Edwards is made up principally of thick, massive, and cherty limestones.

\section{Quaternary Geology}

The Quaternary history of the area is complex and poorly understood. The North, Middle and South Concho rivers, Spring Creek, and several other tributaries converge within the general project area, forming the Concho River to the east of the San Angelo and Twin Buttes Reservoir (Figure 4-1). This combined drainage basin covers mainly Cretaceous limestones, shales, marls, and sandstones. In addition, the North and Middle Concho rivers head on the margin of the southern High Plains eroding into the Ogallala and Blackwater Draw formations (Barnes 1992).

Four broad Quaternary geomorphic areas can be identified in and around the project area: Middle Pleistocene alluvium from the upland Seymor Formation, Middle and Late Pleistocene alluvium within the modern drainage basins, and deeply dissected Holocene alluvium bordering the modern tributary network (Figure 4-1).

The Seymor Formation consists of isolated upland remnants unconformably resting on Permian and 


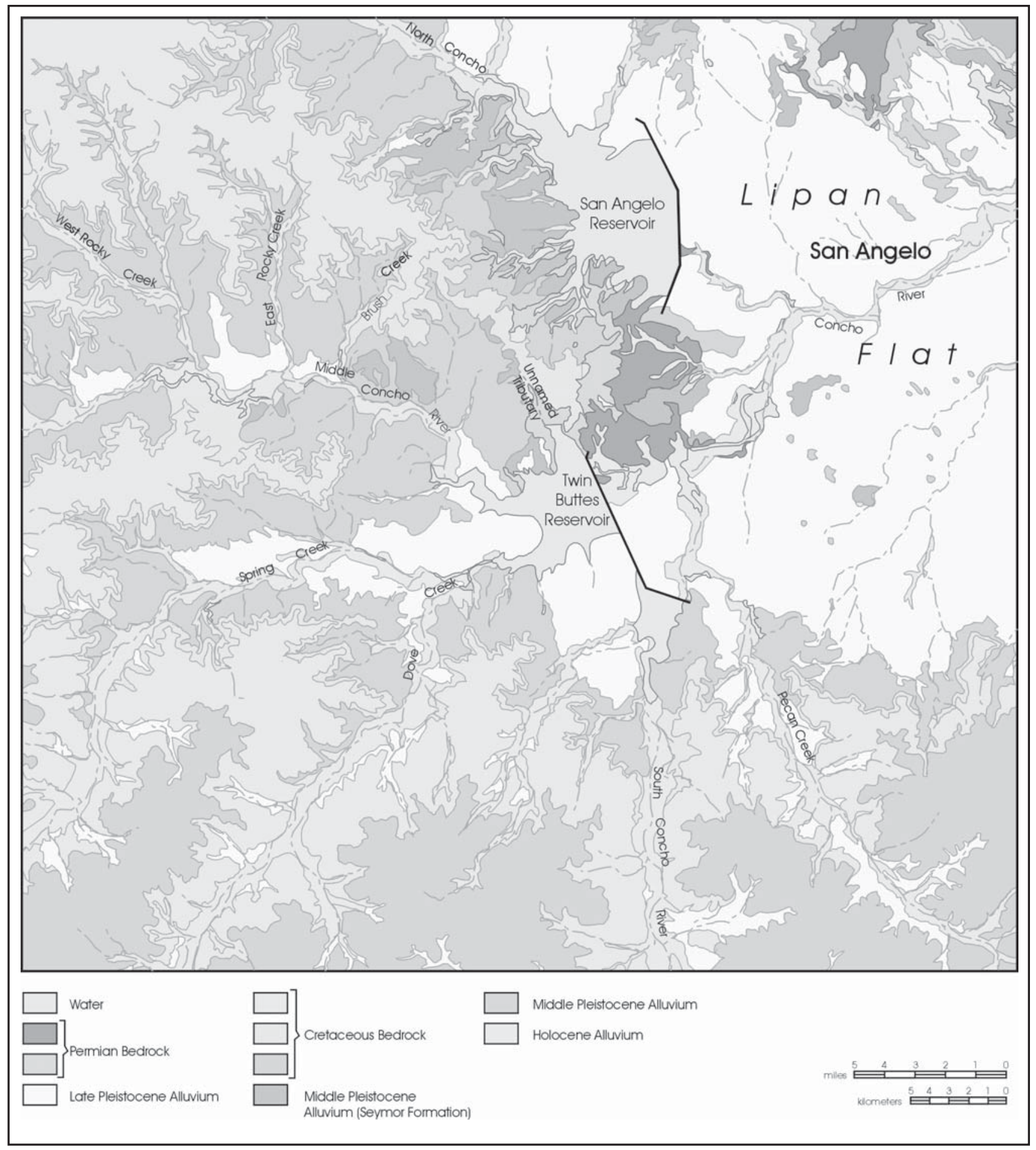

Figure 4-1. Geological formations in the vicinity of the Twin Buttes project area. Modified from Barnes (1975). 
Cretaceous bedrock (Figures 4-1, 4-2). The type section of the Seymor Formation in central Texas has been dated to approximately 620,000 BP based on the presence of Lava Creek ash (Izett and Wilcox 1982). In the project area, the highest Seymor Formation deposits can be identified by the presence of caliche gravel pits more than 50 to $60 \mathrm{~m}$ above the modern floodplains. Colluvial drapes emanating from the Seymor Formation grade to elevations as low as $30 \mathrm{~m}$ above the modern floodplains in the vicinity of the San Angelo Reservoir (Figure 4-1). Local outcrops of the Seymor are sparse, but reveal stage IV caliche layers up to several meters thick, consistent with a Middle Pleistocene age (Machette 1985). The Mereta and Kimbrough soils are typically mapped on Seymor Formation deposits. These soils classify as Petrocalcic Paleustolls with thick A-Bkm profiles (Wiedenfeld and Flores 1976).

The Middle Pleistocene alluvium also occurs within the modern stream valleys at elevations ranging between 18 and $22 \mathrm{~m}$ above the local floodplains (Figures 4-1, 4-2). The soils mapped in these areas are similar to those mapped on the Seymor Formation (Petrocalcic Paleustolls). This indicates similar ages between the two units, but based on stratigraphic position, the Middle Pleistocene alluvium must be slightly younger than the Seymor Formation. Areas in the headwaters of small streams and along the outer valley wall abutting Cretaceous and Permian bedrock, may have Late Pleistocene to Holocene colluvium and alluvium blanketing the Middle Pleistocene terrace complex. Further work is needed to resolve this issue. Based on soil mapping and limited exposures, cross-bedded channel sands and gravels occur at the base of the Middle Pleistocene terrace fill (Figures 4-2). These deposits have been largely lithified with caliche, and rest unconformably on Permian and Cretaceous bedrock.
The Late Pleistocene terrace is mapped immediately adjacent to Holocene stream valleys and eventually grade into the broad Lipan Flat surface to the east of the project area (Figures 4-1, 4-2). The Lipan Flat appears to form the constructional surface of a widespread alluvial outwash deposit. Elevations of the Late Pleistocene terrace and Lipan Flat are typically 12 to $14 \mathrm{~m}$ above adjacent channels. Most of the Late Pleistocene deposits are mapped as the Angelo series, a Torrertic Calciustoll (Wiedenfeld and Flores 1976). Numerous playas also dot the Lipan Flat surface that are mapped as the clayey Lipan series (Wiedenfeld and Flores 1976). The massive caliche channel gravels underlying the Middle Pleistocene terrace also underlie the Late Pleistocene terrace and Lipan Flat (personal observations; personal communication, Christopher Caran). This indicates that the base of the Late Pleistocene terrace and Lipan Flat deposit form a strath cut into Middle Pleistocene caliche deposits (Figure 4-2). Whereas the Middle Pleistocene terrace soils contain stage IV caliches, the Lipan Flat and associated Late Pleistocene soils contain stage II and II + carbonate morphology. Lower elevations and weaker carbonate development are consistent with a Late Pleistocene age for these deposits.

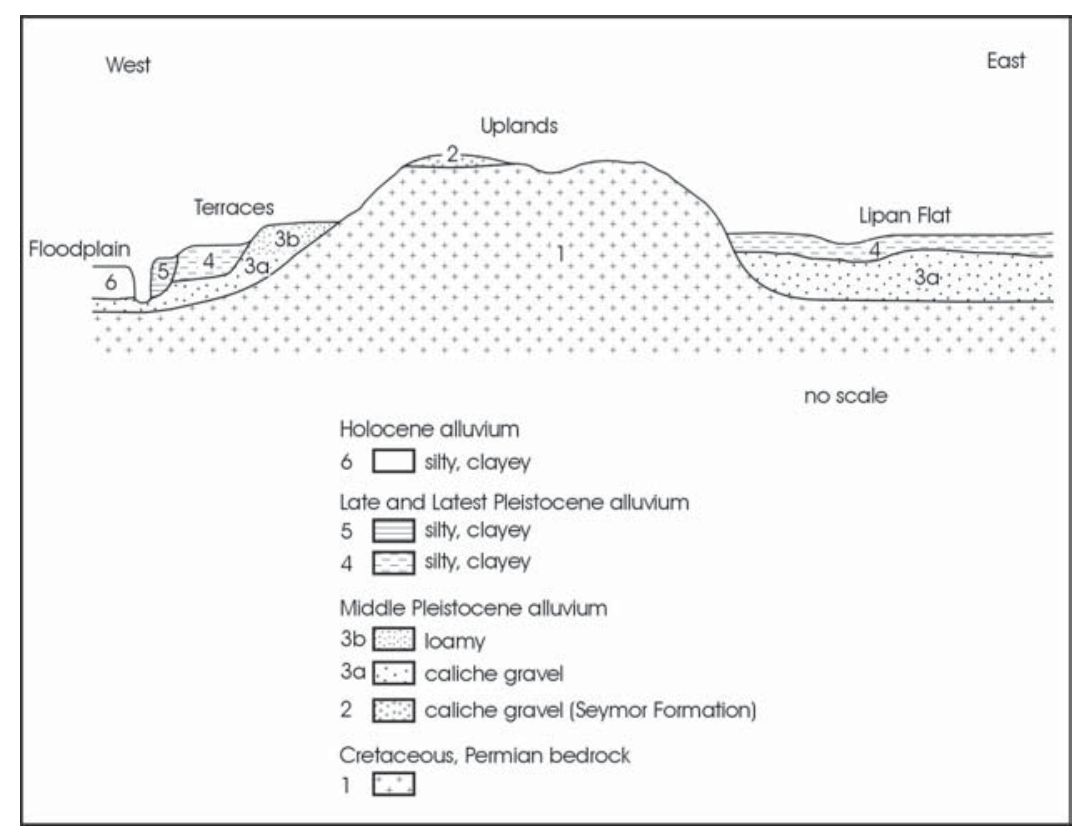

Figure 4-2. Schematic geologic cross section in the vicinity of the project area based on field observations, the geologic mapping of Barnes (1975, 1992), and personal communications with Christopher Caran (1999). 
According to recent geological work (Barnes 1992), areas formerly mapped as the Seymor Formation are now mapped as the Lingos Formation. The Lingos was extrapolated from the Rolling Plains in north-central Texas based on the work of Caran and Baumgardner (1990). The Lingos is actually part of the Paducah Group that consists of the lower Lingos dating to between $300,000+$ and 40,000 BP (fluvial and fan deposits, possibly including the Seymor Formation), the middle Lingos dating to between 40,000 and 8000 вр (fluvial and lacustrine deposits), and the upper Lingos dating to the last 8000 years (modern environments).

It is possible that both the Middle Pleistocene Seymor Formation and slightly younger Middle Pleistocene alluvium both correlate to the lower Lingos in the project area. However, there is no basis for estimating the timing of deposition of the caliche gravels underlying both the Middle and Late Pleistocene terraces other than to say that they are younger than the upland Seymor caliches. Based on relative elevation, degree of soil development, and the presence of playas, the Lipan Flat and associated Late Pleistocene stream terraces may correlate with the middle Lingos.

Narrow and discontinuous alluvial valley fills border the Middle Concho River, the South Concho River, Spring Creek, and other unnamed tributaries (Figures 4-1, 4-2). Low terraces eight to nine meters above the modern channels occur in some areas that may be Latest Pleistocene in age (Figure 4-2). These areas are mapped mainly as the Rioconcho soils (haplustolls) with A-Bw profiles along wider valley segments and along the inside of sharp meander bends (Wiedenfeld and Flores 1976). These deposits are discussed in more detail in the following sections.

\section{Middle Concho River}

The Middle Concho River enters the project area from the west, and joins with Spring Creek and the South Concho River just below the Twin Buttes Reservoir (Figure 4-1). Four late Quaternary landforms were investigated: a Late Pleistocene terrace situated 12 to $14 \mathrm{~m}$ above the channel, a Latest Pleistocene terrace situated eight to nine meters above the channel, a Holocene flood terrace located 6 to $7 \mathrm{~m}$ above the channel, and the deeply incised modern channel and floodplain. Five unconformably bound stratigraphic units were also identified: Late Pleistocene alluvium (LP1) and Latest Pleistocene alluvium (LP2) associated with the terraces, Early Holocene (EH) and Late Holocene (LH) alluvium associated with the Holocene flood terrace, and modern alluvium (MO) associated with the floodplain. Descriptions from four backhoe trenches (BHT-1 through 4) and six cutbanks (CB-1a, b, CB-2a,b,c, and CB-3), and five radiocarbon ages, were used to reconstruct the late Quaternary alluvial history of the Middle Concho River valley (Figures 4-3 through 4-7). Detailed soil-stratigraphic descriptions are given in Appendix I.

\section{Late Pleistocene}

The Late Pleistocene terrace (LP1) of the Middle Concho River was investigated with an exposure provided by BHT-2 (Figures 4-3, 4-4; Appendix I). Between a depth of 53 to $345 \mathrm{~cm}$, a thick Bk horizon was observed. This horizon consisted of clays that had been pedogenically altered to colors of yellowish brown and brown with weak prismatic structure. The Bk horizon also contained stage II carbonate morphology ranging from 10 to 35 percent nodules. A radiocarbon age of $9260 \pm 70$ BP was obtained from bulk humates at a depth of 173 to $183 \mathrm{~cm}$. This age indicates a minimum age for deposition of sediments associated with the Late Pleistocene terrace.

The upper $53 \mathrm{~cm}$ in BHT-2 consisted of brown to yellowish brown clay loams with moderate angular blocky structure. No pedogenic carbonate nodules were present, but carbonate clasts and siliceous pebbles indicate that this layer is colluvial, having formed on the edge of the Late Pleistocene terrace surface. Based on minimal soil development, the colluvium is probably Holocene in age.

The Latest Pleistocene deposit (LP2) was identified in CB2a and CB2b (Figures 4-3, 4-4, 4-5). This unit rests directly on Cretaceous bedrock at the channel bottom, having cut through the thick caliche layers underlying the Late Pleistocene terrace. This unit also extends to about six meters above the Middle Concho channel, but has been truncated by erosion from recent land use. Projecting perpendicularly away from the channel this deposit appears to relate to a terrace that is eight to nine meters above the thalweg. The 
This page has been

redacted because it

contains restricted

information. 


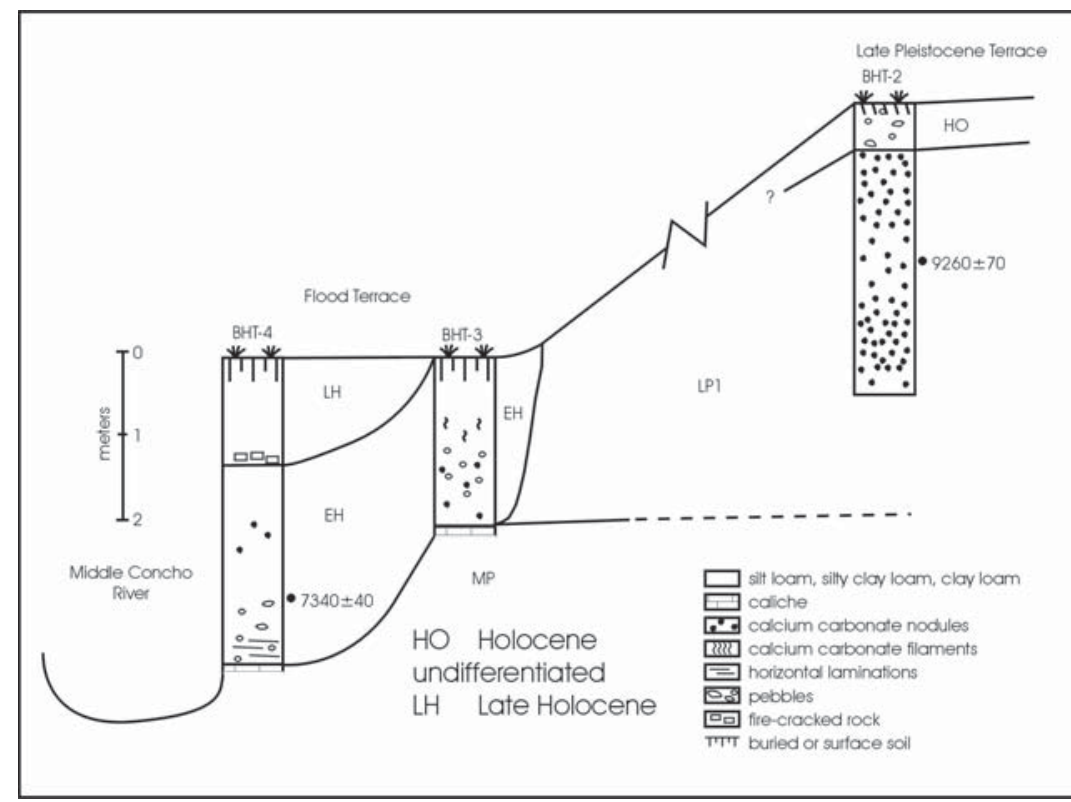

Figure 4-4. Alluvial stratigraphic cross section of the Middle Concho River based on exposures from BHT-2, BHT-3, and BHT-4.

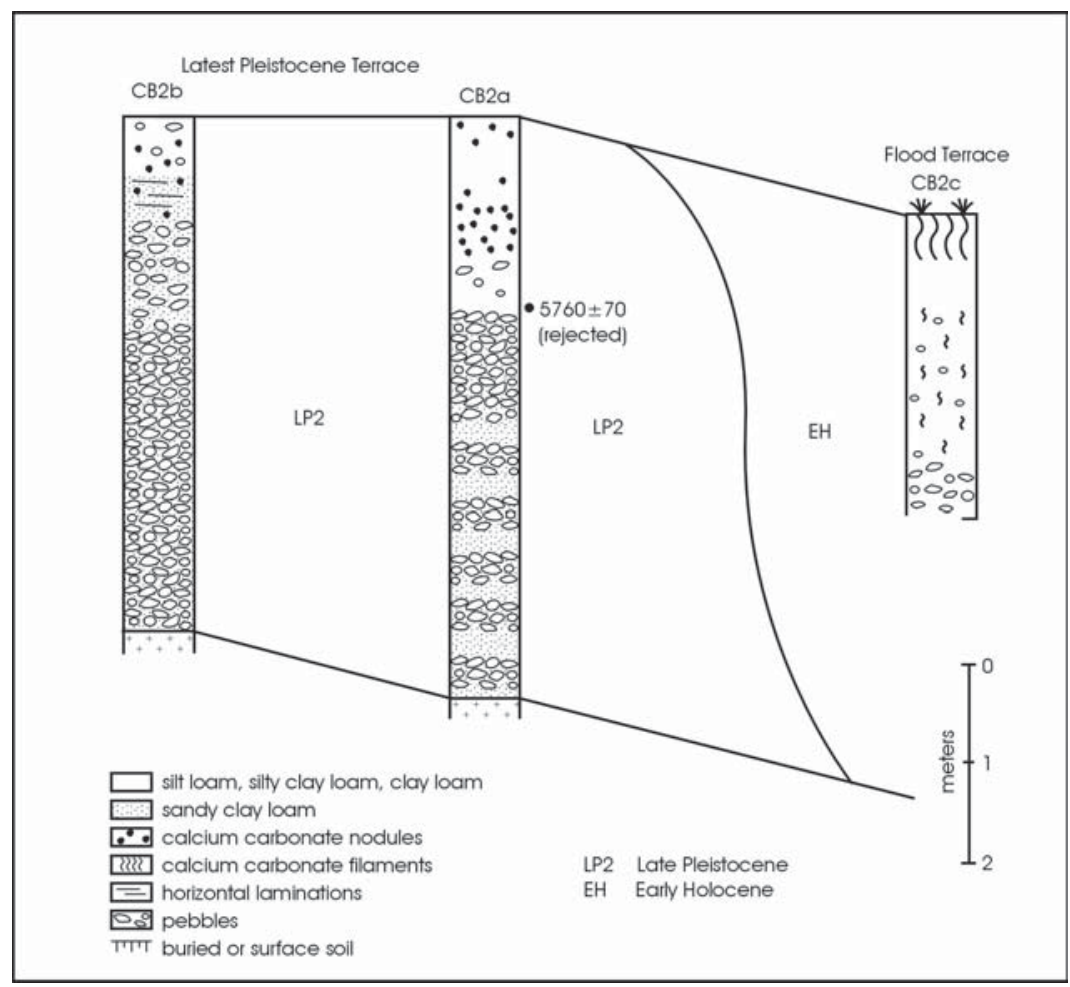

Figure 4-5. Alluvial stratigraphic cross section of the Middle Concho River based on exposures from $C B 2 a, C B 2 b$, and $C B 2 c$. deposit in CB2a and CB2b is largely of channel origin, consisting of bedded and grain supported pebbles and cobbles in a brown, loamy matrix. Brown to reddish brown pedogenically altered sediments, possibly of colluvial origin, bury the thick channel facies. This soil has moderate and strong prismatic and angular blocky structure with common carbonate nodules. This degree of carbonate development indicates a soil age consistent with the Pleistocene/Holocene boundary. A bulk humate radiocarbon age of $5760 \pm 70$ BP from the contact between the channel and overbank facies in CB2a (Figure 4-5) appears to be a poor estimate for sediment deposition given that the stratigraphic position and carbonate morphology indicate a Late to Latest Pleistocene age.

\section{Holocene}

The Holocene flood terrace of the Middle Concho River is constructed by an Early Holocene (EH) unit and a Late Holocene (LH) unit. The EH unit was identified in BHT-3 and 4 (Figures 4-3, 4-4), CB2c (Figures 4-3, 4-5), BHT-1 (Figures 4-3, 4-6), and CB3 (Figures 4$3,4-7)$. This unit consists of both channel and floodbasin facies. The channel facies was present in CB3, and consisted of grain supported and moderately well sorted pebbles interbedded with brown loams. The floodbasin facies is more common and has been pedogenically altered to a yellowish brown to reddish brown clay loam with moderate to strong angular blocky and prismatic structure (CB2c, BHT-1, 3, and 4). In BHT-3 and BHT-4 the base of the EH fill rests unconformably on caliche sand and gravel from the base of the Late Pleistocene alluvium (LP1). In BHT-1 a veneer of modern alluvium buries the EH unit. Secondary carbonate content typically ranges from a few filaments 
to a few nodules in the floodbasin facies, with thick carbonate pendents forming in the channel facies. A radiocarbon age of $7340 \pm 40$ BP was obtained from bulk humates deep in EH sediments exposed in BHT-4, indicating that deposition had begun no later than this time. In accordance with the oldest ages from the LH unit from other streams in the project area, deposition of the EH unit had terminated no later than about $3500 \mathrm{BP}$. This permits as much as 3500 to 3000 years of pedogenesis and landscape stability in the EH flood terrace position where not buried by a veneer of LH or modern alluvium.

The LH alluvial unit was observed in CB1a (Figures 4-3, 4-6) and BHT-4 (Figures 4-3, 4-4). In CB1a, a thick silt loam floodbasin fill overlies a thin loamy pale brown to gray channel fill with horizontal bedding planes. The upper part consists of a brown, prismatic structured A-Bw profile. Carbonate nodules in the lower section are probably of groundwater origin. Also in CB1a, the LH unit is buried by a veneer of modern alluvium. In BHT-4, the LH unit unconformably buries the EH unit and has similar soil properties as that exposed in CB1a. As with the EH unit, the LH channel facies in the area of BHT-4 is probably on the opposite side of the river. Deposition of the LH unit began shortly after 4000 вP based on radiocarbon ages from this unit in other drainage basins. Deposition terminated no later than $870 \pm 40$ BP according to a radiocarbon age from a hearth at the contact between the LH and modern unit in CB1a (Figures 4-6).

The modern alluvium (MO) was identified in $\mathrm{CB} 1 \mathrm{~b}$, and as a veneer covering older Holocene units in $\mathrm{CB} 1 \mathrm{a}$ and BHT-1 (Figures 4-3, 4-6). A thick channel facies was observed in $\mathrm{CB} 1 \mathrm{~b}$

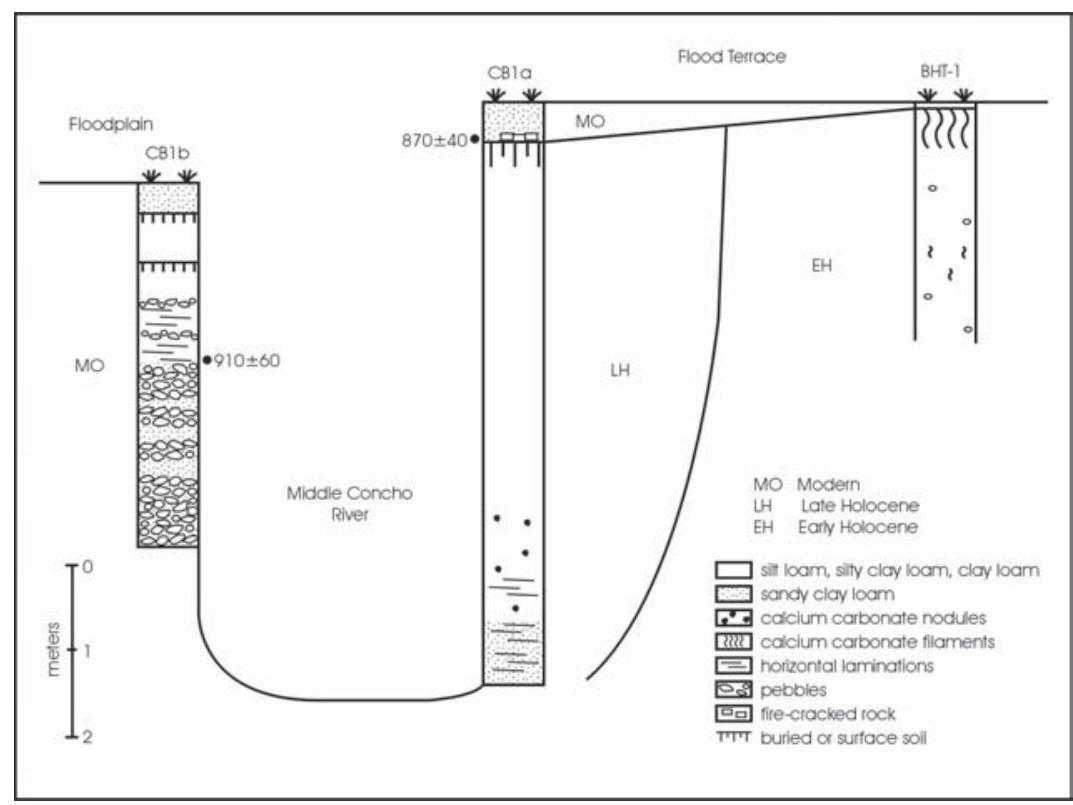

Figure 4-6. Alluvial stratigraphic cross section of the Middle Concho River based on exposures from BHT-1, CB1a, and CB1b.

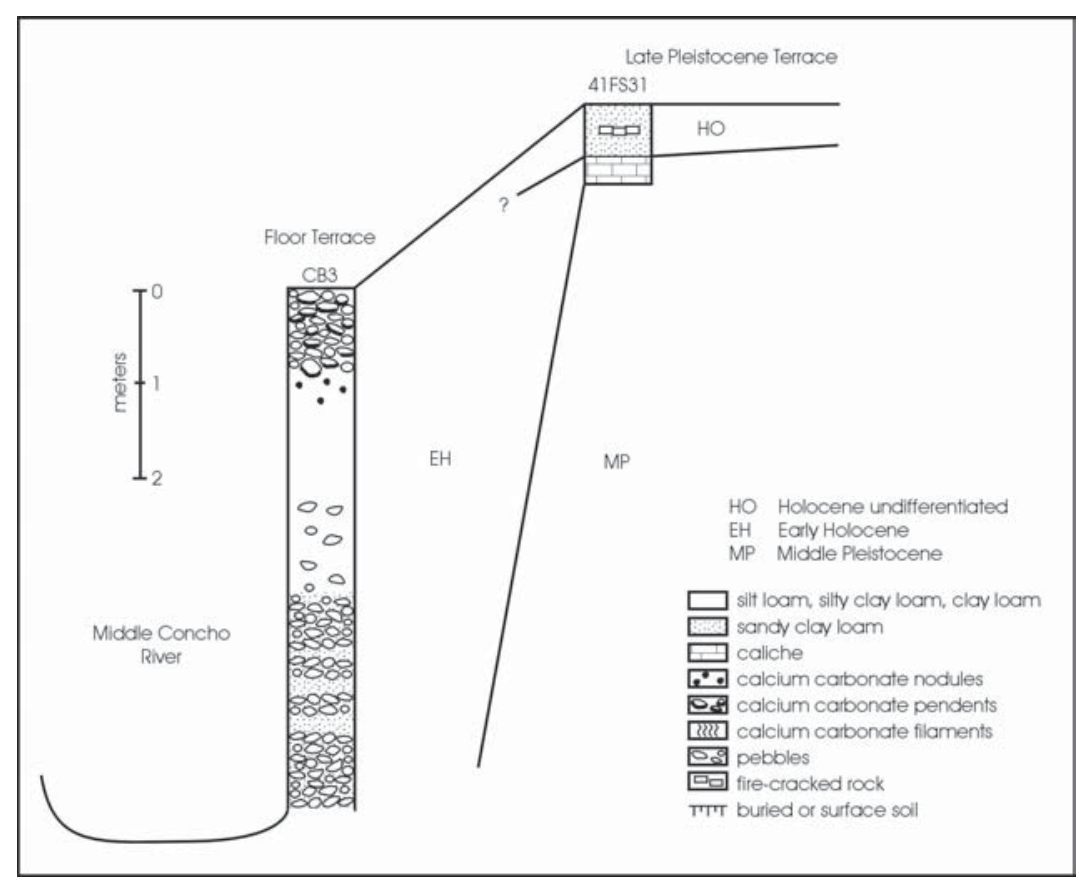

Figure 4-7. Alluvial stratigraphic cross section of the Middle Concho River based on exposures from CB3 and from TU1 at site $41 T G 389$. 
consisting of moderately well sorted and grain supported pebbles and cobbles in a loamy matrix. The upper overbank facies contained occasional gravel lenses in a dark grayish brown clay loam matrix that graded into two weakly developed paleosols with dark colors and sandy clay loam to loam textures. The uppermost sandy clay loam layer may be post-settlement alluvium. Deposition of the MO unit began by $910 \pm 60$ and 870 BP based on a radiocarbon age from CB1b (Figures 4-6), and has probably continued until today as post-settlement alluvium.

\section{South Concho River}

The South Concho River flows into a small lake south of Twin Buttes Reservoir (Figures 4-1). Below the Twin Buttes Reservoir, the South Concho joins with the other streams in the project area before forming the Concho River. This area was investigated with quarry exposures provided by CB6 and CB7 (Figures 4-8, 4-9), and by archaeological information extrapolated from nearby site 41TG91 (Figure 4-8).

As with the Middle Concho River, Early Holocene (EH), Late Holocene (LH), and modern (MO) alluvial units were identified. Alluvial landforms were not thoroughly investigated because of the limited area available for study. Soil-stratigraphic descriptions are given in Appendix I.

The EH unit was observed in both CB6 and CB7 (Figures 4-8, 4-9). In CB6, a channel facies of moderately well sorted and matrix supported pebbles was observed. Overlying the channel facies was a thick floodbasin facies that had been weathered to an A-AB-Bk-BC soil profile sequence. The surface horizon was a dark grayish brown silty clay loam that graded down into a brown to strong brown silty clay loam subsoil with few calcium carbonate filaments. A fine-grained facies of the EH unit was also identified at the base of CB7 considering color, texture, and carbonate morphology. Deposition of the EH unit had ceased no later than $3440 \pm 50$ BP based on a radiocarbon age from the LH unit in CB7.

The LH unit was exposed in CB7 as a thick channel facies grading up into a black to very dark gray silty clay loam to loam soil with an A-Bw profile sequence. The channel facies contained matrix and grain supported pebbles and a few cobbles in a dark grayish brown loamy matrix. A radiocarbon age of $3440 \pm 50$ BP was obtained from near the base of the LH unit, indicating that deposition was underway no later than this time.

At site 41TG91 fine-grained sediments with similar colors and pedogenic characteristics were excavated that contained a buried Late Archaic site dating to between 3000 and 2000 BP (Creel 1990; Figure 4-8). Deposition of the LH alluvium probably terminated shortly after $1000 \mathrm{BP}$, considering correlation to the LH alluvium of the Middle Concho River. A veneer of loamy, brown MO alluvium buried the LH unit in CB7 (Figure 4-9).

\section{Spring Creek}

Spring Creek enters Twin Buttes Reservoir between the South Concho and Middle Concho rivers (Figure 4-1). The channel currently flows on caliche-cemented sands and gravels emanating from the base of the adjacent Late Pleistocene terrace. This area was investigated with exposures provided by BHT-8, 9, and 10, and from CB5 (Figures 4-10, 4-11). A Late Pleistocene terrace and flood terrace were identified along with Late Pleistocene alluvium (LP1), Early Holocene alluvium (EH), and Late Holocene alluvium (LH). Soil-stratigraphic descriptions are given in Appendix I.

A Late Pleistocene terrace fill was observed in BHT-8 approximately eight meters above the Spring Creek channel (Figure 4-11). This unit was weathered to an A-Bw-Bk soil profile sequence. The A and Bw horizons were very dark grayish brown to brown clay loams and silty clay loams with subangular blocky structure. The Bk horizons were light brown to brown silty clay loams and clays with 15 to 35 percent carbonate masses. This degree of pedogenesis is consistent with that observed for Late Pleistocene sediments exposed in BHT-2 along the Middle Concho River.

Although truncated, BHT-10 exposed the EH unit (similar in BHT-9). Here, the upper part of the deposit was a floodbasin facies weathered to a thick 
This page has been

redacted because it

contains restricted

information. 


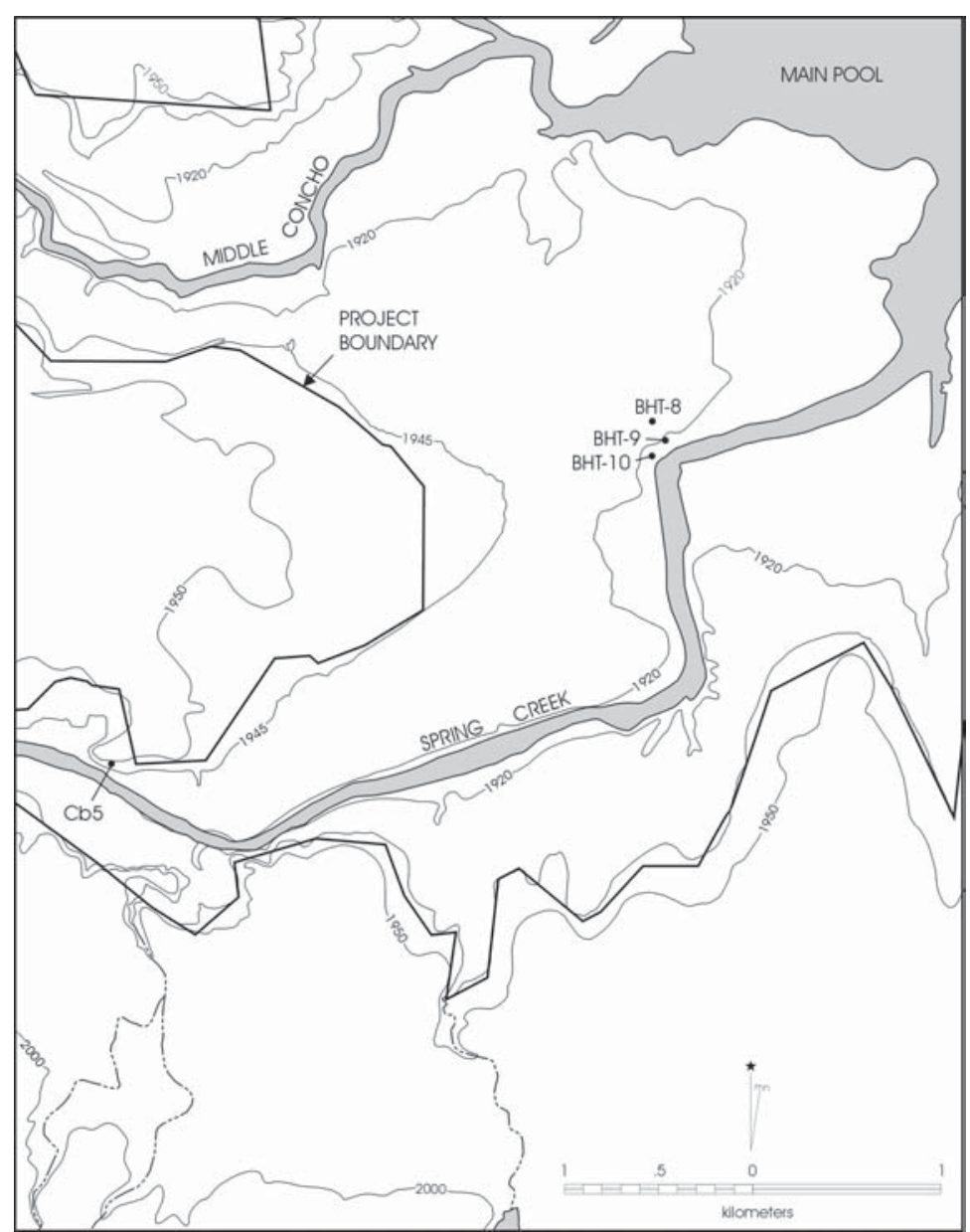

Figure 4-10. Topographic map showing backhoe trench (BHT) and cutbank (CB) localities along Spring Creek.

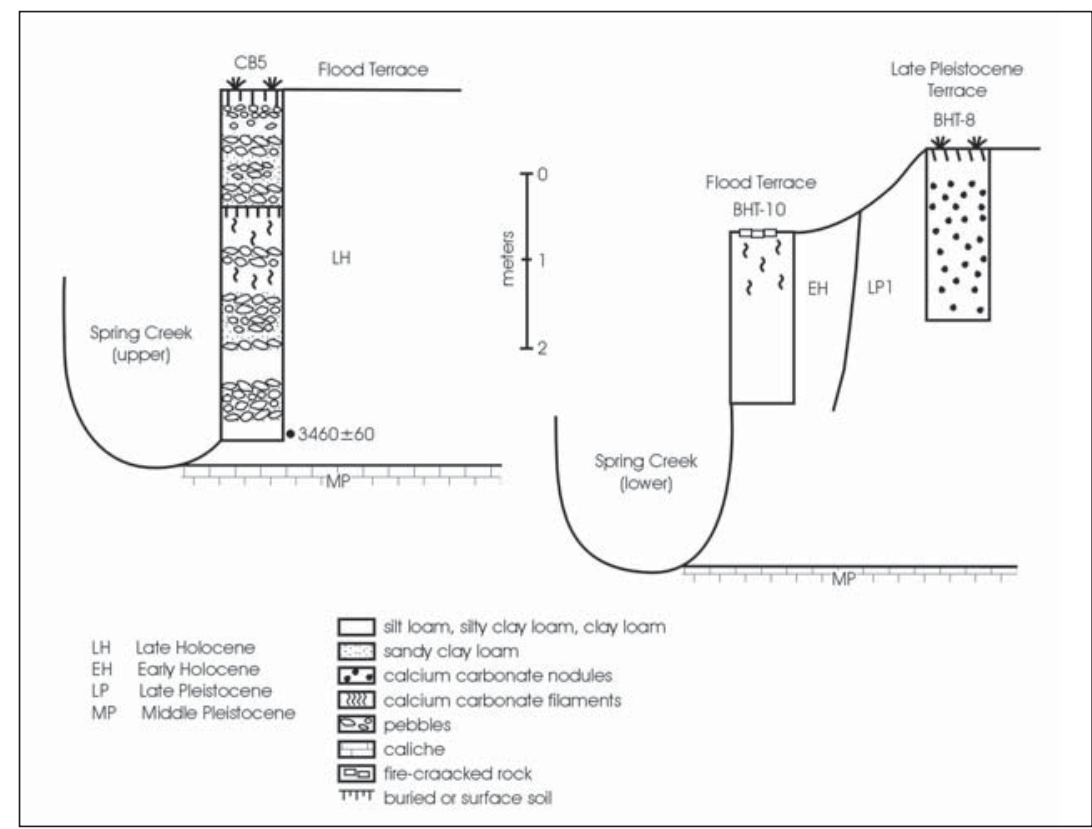

Figure 4-11. Alluvial stratigraphic cross-section of Spring Creek based on exposures from BHT-8, BHT-10, and CB5. 
Bk-Bw soil profile sequence with brown to reddish brown colors, clay loam to loam textures, and angular blocky to prismatic structure. A few filaments of calcium carbonate were present in the Bk horizon. Late Archaic artifacts and burned rock features were discovered on the deflated surface in the vicinity of BHT-10, indicating that the upper part of this deposit is at least 3000 to 2000 years old, warranting a correlation to the $\mathrm{EH}$ unit.

The LH unit was observed in CB5 as a thick channel gravel facies interbedded with gravel-free loams (Figure 4-11). The channel facies contains mainly grain supported and moderately well sorted pebbles in a grayish brown to brown loamy matrix. A brief period of depositional slowdown and soil formation was evident in the middle of the exposure. A very dark gray clay loam surface horizon forms the constructional flood terrace surface. A radiocarbon age of $3460 \pm 60$ BP was obtained from bulk humates at the base of the exposure in CB5, consistent with initiation of LH deposition recorded in the South Concho River.

\section{Unnamed Tributary}

The unnamed Tributary is a low-order stream that enters the Twin Buttes Reservoir from the north (Figure 4-1). In contrast to other streams in the project area, it drains primarily Permian bedrock. Caliche gravel and sand crop out discontinuously at, and just above, the water line in some areas of the basin. The alluvial history of the unnamed tributary was based on exposures provided by BHT-5, 6, and 7, and CB4 (Figures 4-12, 4-13). A Late Pleistocene terrace and Holocene flood terrace were identified. The flood terrace was constructed mainly by a Late Holocene unit $(\mathrm{LH})$, which buries an Early Holocene unit (EH) in some areas.

Late Pleistocene alluvium was exposed in BHT-7 (Figure 4-13). The base of this unit unconformably rested on Permian bedrock at a depth of about two meters. Basal interbedded pebbles and sands fine upwards into fine sandy loams and sandy clay loams. The upper part was pedogenically altered to an A-ABk-Bk horizon sequence. The yellowish brown sandy clay loam A horizon was probably slightly truncated. The Bk horizons were reddish yellow to strong brown sandy clay loams and fine sandy loams with up to 15 to 20 percent carbonate nodules. The dominant structure throughout was subangular blocky. The entire sequence was buried by a veneer of light gray reservoir sand. Again, the degree of carbonate development is consistent with a Late Pleistocene age similar to the Middle Concho River and Spring Creek.

BHT-6 exposed the buried EH unit on the outer half of the flood terrace within the alluvial valley (Figure 4-13). The associated paleosol consisted of a slightly truncated AB-Bk-Bw-By sequence with brown, angular blocky to prismatic structured clays throughout. The Bk and By horizons contained five percent carbonate nodules and five percent gypsum crystals, respectively. A radiocarbon age of $3360 \pm 50$ BP from the upper $\mathrm{AB}$ horizon of the paleosol represents a minimum for termination of deposition of the associated alluvial unit and a maximum for the time of burial by the overlying unit. Based on radiocarbon ages from other streams in the project area, deposition of the EH unit terminated around 4000 BP. It appears that the paleosol exposed in BHT- 6 began forming in EH alluvium around $4000 \mathrm{BP}$, before being buried by overlying LH alluvium no later than 3360 BP.

A full exposure of the LH unit was observed in BHT-5 beneath the Holocene flood terrace adjacent to the modern channel (Figure 4-13). The LH unit rested unconformably on Permian bedrock at a depth of 340 $\mathrm{cm}$. This unit contained a fining upward sequence from basal channel gravels to a thick floodbasin fill. The channel gravels were moderately to poorly sorted and supported in a yellowish brown matrix. The floodbasin facies contained an A-Bw-By profile sequence. The very dark gray surface horizons graded down into brown to strong brown clay loams with subangular to angular blocky structure. The By horizon, as in BHT-6, may be of recent groundwater origin. The LH floodbasin facies buries the EH unit in the outer half of the flood terrace as revealed in BHT-6 (also noted in CB4). Deposition of the LH unit probably began shortly after $3360 \mathrm{BP}$, consistent with the initiation of deposition in other drainage basins. Late Archaic artifacts on the surface of the Holocene flood terrace indicate that landscape stability had ensued in many areas by $1000 \mathrm{BP}$. 
This page has been

redacted because it

contains restricted

information. 


\section{Stratigraphic Summary}

The late Quaternary alluvial stratigraphy appears to correlate among the streams within the project area. As many as three episodes of alluvial deposition and terrace construction occurred in the Pleistocene: one in the Middle Pleistocene at an elevation of 18 to 22 $\mathrm{m}$ above the channels, one in the Late Pleistocene 12 to $14 \mathrm{~m}$ above the channels, and one in the Latest Pleistocene eight to nine meters above the channels.

Middle Pleistocene soils contain A-Bkm profiles with stage IV carbonate morphology. Near the confluence of the Colorado/Concho rivers downstream from the project area, Blum and Valastro (1992) observed soils on similar terrace positions that had stage III and IV carbonate morphology. These terraces were also inferred to be Early to Middle Pleistocene.

The Late Pleistocene soils in the project area typically have A-Bk profiles with stage II to II+ carbonate morphology. Caliche deposits having stage IV development occur at depths greater than three meters beneath the Late Pleistocene terrace that are probably associated with the older Middle Pleistocene alluvial unit. A radiocarbon age indicates that deposition of the Late Pleistocene unit terminated before 9200 вP. This also corresponds to a date of 14,300 BP obtained from a Late Pleistocene terrace with stage II carbonate morphology at the Concho/Colorado river confluence (Blum and Valastro 1992).

The Latest Pleistocene terrace forms a discontinuous and narrow landform adjacent to the Holocene valleys. The base of the deposit rests unconformably on bedrock near the modern channel thalweg. The associated soils have A-Bk profiles with weak stage II carbonate morphology. However, carbonate development is not as strong as on older and higher terraces.

An episode of widespread channel downcutting occurred near the Pleistocene/Holocene boundary in the project area. Deposition of the EH unit began no later than 8000-7000 BP, and terminated by around 3500 BP. During the latter stages of deposition a flood terrace was constructed that is now located outside of the modern meanderbelts. Soil formation proceeded in many areas for at least several thousand years producing A-Bk horizon sequences with stage I carbonate development. Blum and Valastro (1992) identified an Early Holocene alluvial unit at the Concho/Colorado confluence dating to between 10,000 and 5000 BP. In Runnels County north of Ballinger, Sanders (1996) mapped a severely truncated Early Holocene unit in the Elm Creek basin with radiocarbon ages between about 8000 and 5000 BP.

After a brief interval of channel erosion, deposition of the LH unit was underway by $3500 \mathrm{BP}$ and continued to as late as 1000-900 BP. This unit forms the flood terrace within the modern meanderbelts, and in places forms a veneer across the $\mathrm{EH}$ unit associated with the flood terrace outside of the modern meanderbelts. Soil development is minimal with weak A-Bw sequences. Blum and Valastro (1992) dated a Late Holocene unit to between 4000 and $1000 \mathrm{BP}$ at the Concho/Colorado confluence, with Sanders (1996) dating a Late Holocene unit to between about 4000 and 900 BP in the Elm Creek basin in Runnels County. After another period of channel erosion, deposition of the $\mathrm{MO}$ unit was underway by between 900 and 800 BP. This unit is confined to modern meanderbelts, especially within sharp meander loops. Soil profile sequences are typically A-C.

Based on limited exposures it appears that stream competency increased from the Early Holocene to the Late Holocene considering limited gravely channel facies in the EH unit and an abundance of channel gravels in the LH unit. The MO unit is similar to the LH unit in terms of paleo-hydrological properties.

Periodic channel downcutting continued throughout the late Quaternary reaching the lowest elevations within the last 1000 years. Pleistocene downcutting events were commonly several meters, with the sum of Holocene events totaling no more than one to two meters.

\section{Geoarchaeology}

The Middle and Late Pleistocene terrace surfaces within the project area may contain a full array of prehistoric sites (Figure 4-1). Contextual integrity will depend on the degree of soil bioturbation, trafficking from reservoir activity, and erosion from lake processes. However, in many cases the Pleistocene 
terraces are slightly above the high-water marks left from the fluctuating lake levels. A number of sites dating from the Early Archaic to Late Archaic were discovered on these surfaces during the pedestrian archaeological survey.

The flood terraces within the Holocene alluvial valleys became stable outside of the modern meanderbelts by shortly after $4000 \mathrm{BP}$. Accordingly, sites younger than the Early Archaic could be preserved on this surface (BHT-3, Figure 4-4; CB2c, Figure 4-5; BHT-1, Figure 4-6). In some areas, however, either Late Holocene alluvial erosion and deposition, or deposition from fluctuating reservoir levels, have buried or eroded many surface sites (BHT-4, Figure 4-4; CB7, Figure 4-9; BHT-6, Figure 4-13). Early Archaic sites occur mainly on Pleistocene terraces and in the uplands. Within the modern meanderbelts surface sites would date to no more than the last 1000 years, and possibly to no older than historic (CB1b, Figure 4-6). This is verified by the paucity of sites of any age within these areas.

A minimum radiocarbon age of 9260 BP was obtained from a $1.5 \mathrm{~m}$ depth in a Late Pleistocene fill along the Middle Concho River (BHT-2; Figure 4-4). A radiocarbon age from a similar terrace at the Concho/Colorado confluence indicates that deposition may have terminated close to $14,000 \mathrm{BP}$. If so, then there would be little potential for discovering buried sites within Late Pleistocene deposits unless pre-Clovis occupations are present. Also along the Middle Concho River, a Latest Pleistocene unit was observed that could have intact components. However, the extent of this unit is unknown, and where described, consists mainly of thick channel gravel deposits. This will reduce the likelihood of site preservation in primary contexts.

The Early Holocene alluvial unit could contain buried Early Archaic occupations (BHT-3 and 4, Figure 4-4; CB2c, Figure 4-5; BHT-1, Figure 4-6; CB3, Figure 4-7; CB6, Figure 4-9; BHT-10, Figure 4-11; BHT-6, Figure 4-13). Because of thick, fine-grained floodbasin facies many of these features could be buried in stratified, primary contexts. No features were observed buried in this unit during the investigation, perhaps because of limited exposures.
The Late Holocene alluvial unit may have buried Middle and Late Archaic components (BHT-4, Figure 4-4; CB1a, Figure 4-6; CB7, Figure 4-9; CB5, Figure 4-11; BHT-5 and 6, Figure 4-13). Contextual integrity would be best in areas where the floodbasin facies is thickest. However, many of the Late Holocene exposures were channel dominated, which would reduce the chance of site preservation in primary contexts. Late Prehistoric components would most likely occur in the uppermost part of the Late Holocene unit or within the channel dominated modern alluvium. An example of the former is a hearth that was located on top of the Late Holocene alluvial unit that dated to the Late Prehistoric (CB1a; Figure 4-6).

In sum, Paleoindian sites would be most likely encountered on the surface of the Pleistocene terraces where not eroded or buried by Holocene depositional processes, buried in Late Pleistocene alluvium, or deeply buried within the Early Holocene alluvial unit. Early Archaic sites could also occur on Pleistocene terraces, and also buried within Early Holocene alluvium. Middle and Late Archaic sites would most likely be found on the Pleistocene terraces, on the Holocene flood terrace on the outer margins of the modern meanderbelts, and deeply buried in Late Holocene alluvium. Late Prehistoric components will occur on all landforms except the modern floodplain within modern meanderbelts. In buried contexts, Late Prehistoric occupations may be found in the upper part of the Late Holocene alluvium, or deeply in modern alluvium. Preservation potentials in buried primary contexts will be best in the Early Holocene alluvium because of the presence of thick, fine-grained floodbasin facies.

\section{Site $41 \mathrm{TG} 378$}

Site 41TG378 is a Paleoindian Clovis site situated in the uplands to the east of the unnamed tributary (Figure 4-14). The landscape is denuded, probably from a combination of Holocene slope processes and shoreline erosion from the Twin Buttes Reservoir. The site is located at an elevation above the unnamed tributary floodplain that is typical of Late Pleistocene terraces in other drainage basins. The lithified caliche gravel and sand in the area may be an erosional remnant from the base of this alluvial fill. 
Sediments in TU1 revealed a truncated Bw1-Bw2-Bw3-C/B-Cr soil profile sequence (Figure 4-14; Appendix I). Angular carbonate and sandstone clasts derived from the super-adjacent hillslope occur in the Bw horizons to a depth of $38 \mathrm{~cm}$. Poorly sorted and matrix supported angular clasts in a fine-grained matrix is typical of sediments deposited by colluvial processes. Below the colluvium is partially weathered sandstone of Permian age. Colluviation may have been initiated in the Late to Latest Pleistocene when the local tributary network downcut. However, there is minimal pedogenic alteration of the colluvial sediments, indicating that the hillslope has been periodically eroding throughout the Holocene, and possibly intensified during historic times.

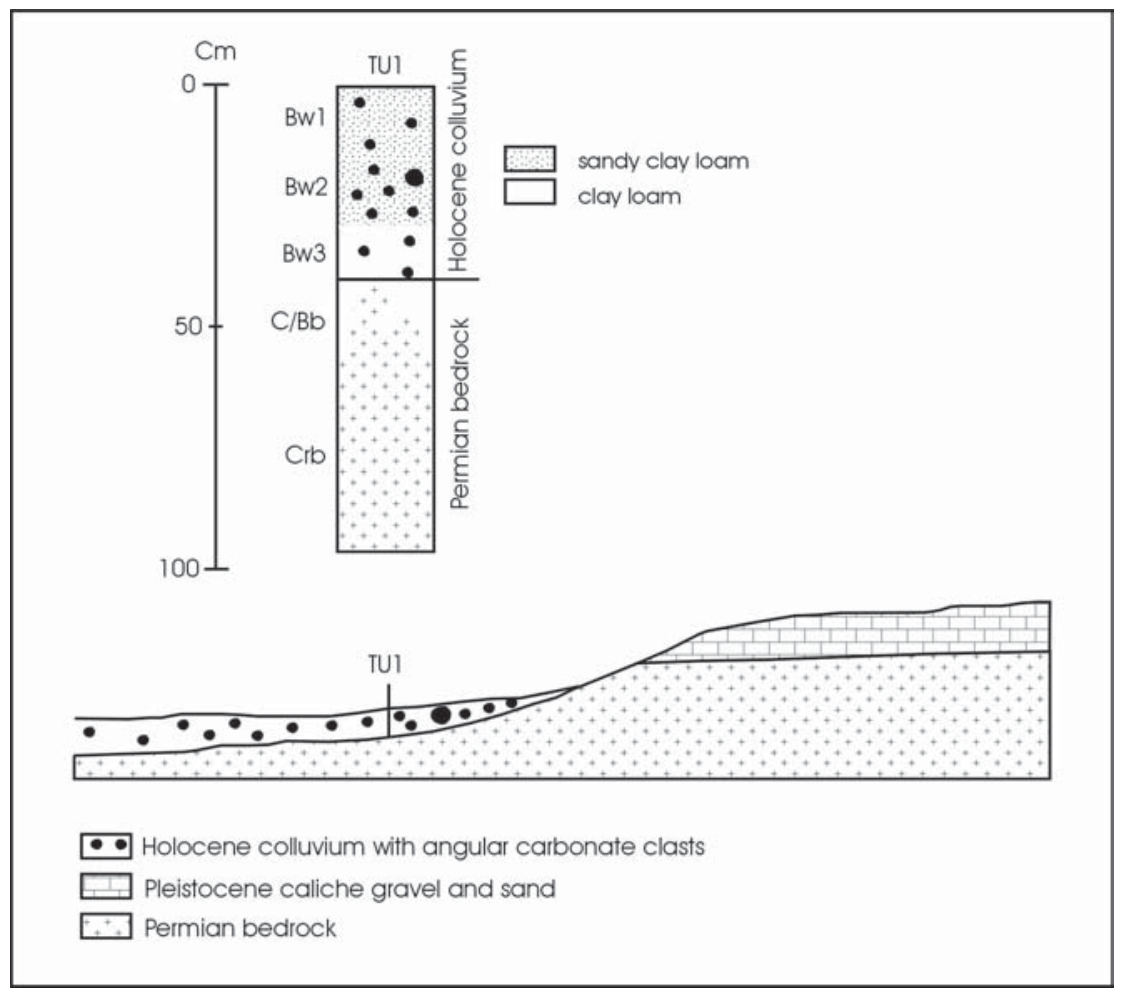

Figure 4-14. Schematic geologic cross-section in the area of site $41 T G 378$.
Paleoindian artifacts were located within and on the colluvial fill in secondary contexts. This is consistent with the interpretation that the adjacent hillslope has been actively eroding, and possibly transporting artifacts throughout the Holocene. It is also possible that the site was originally located on a veneer of alluvium and or colluvium covering the caliche on the adjacent hillslope. Further complicating site integrity is the amount of observed bioturbation as evidenced by the abundance of biological channel fills in the colluvium. In sum, it is unlikely that future artifacts will be discovered in a primary context either on the surface or buried.

\section{Site 41TG389}

Site 41 TG389 is situated on a denuded surface approximately eight to nine meters above the Middle Concho River channel (Figures 4-3, 4-7; Appendix I). Given the elevation and presence of lithified caliche gravel and sand at a depth of $59 \mathrm{~cm}$ the site appears to be located on a remnant of a Late Pleistocene terrace. The soil profile exposed in TU1 revealed an A-Bw sequence. The $\mathrm{A}$ and upper $\mathrm{Bw}$ horizons were brown fine sandy loams with subangular blocky structure. The lower Bw horizon to a depth of $59 \mathrm{~cm}$ was a brown sandy clay loam with subangular blocky structure. Degree of pedogenesis indicates a Late Holocene age for sediment deposition. The depositional process may have been eolian, based on texture and sorting. The lateral extent is unknown.

A hearth feature was excavated at the contact between the upper and lower Bw horizons, with a Transitional Archaic point discovered near the based of the deposit. The relationship between the artifact and the hearth is unclear, but the artifact substantiates a Late Holocene age for deposition. Because of bioturbation in sandy sediments individual artifacts are susceptible to vertical mixing. Large features, however, may retain some contextual integrity.

\section{Site 41 TG410}

Site 41TG410 was located on the Holocene flood terrace of the Middle Concho River to the south of Highway 67 (Figure 4-3; Appendix I). TU1 exposed sediments to a depth of $95 \mathrm{~cm}$ with an A-Bw soil profile 
sequence. The surface horizons were very dark to dark grayish brown silt loams with subangular blocky structure. The Bw horizons were brown silt loams and loams with angular blocky to prismatic structure. Because the degree and kind of soil development and stratigraphic position are similar to that in CB1a of the Middle Concho (Figure 4-6), the alluvial unit at site $41 \mathrm{TG} 410$ may be Late Holocene in age. Deposition of the Late Holocene unit had terminated by between 900 to 800 BP based on radiocarbon dating from other parts of the river. A Late Archaic point was discovered at a depth of $40 \mathrm{~cm}$ in TU1 further substantiating the Late Holocene chronology. In contrast, a dispersed charcoal age of $460 \pm 40$ BP was obtained from a shovel test unit a few meters downstream from TU1. The charcoal age seems too young unless it was sampled in an area that contained modern flood sediments or colluvium. If the Late Archaic point is in context and soil-stratigraphic correlations correct, then the deposit may in fact be associated with the Late Holocene alluvium of the Middle Concho. Site integrity for large features should again be high in these sediments, with movement of small artifacts and charcoal common.

\section{Conclusions}

The Twin Buttes project area contains a complex array of Pleistocene and Holocene alluvial, colluvial, and eolian deposits. The regional landscape is dominated by Middle to Late Pleistocene deposits, with Holocene deposits confined to narrow valleys adjacent to the modern streams. There is potential for discovering surface and buried sites of all ages. Surface sites will be more abundant on the Pleistocene terraces and in the uplands. Both surface and buried sites will occur in the Holocene alluvial valleys. Contextual integrity is problematic in many areas because of reservoir erosion, natural sheet and gully erosion, and soil bioturbation. Much more work is needed to resolve the late Quaternary alluvial stratigraphy by way of soil-stratigraphic descriptions and radiocarbon dating of more reliable materials such as charcoal and wood. 


\title{
Chapter 5: Cultural Chronology and Previous Archaeological Research
}

\author{
David Nickels, Preston McWhorter, and Kristi Miller
}

\section{Cultural Chronology}

\section{Introduction}

The location of the Twin Buttes survey area presumes cultural affinities both indigenous to the western edge of the Central Texas region as well as intrusive influences from South Texas and the Southern Great Plains. Several scholars have offered sound but differing arguments for cultural chronologies for Central and South Texas, and the Southern Great Plains extending into northern Texas, just north of the Twin Buttes area. Using the earlier works of Suhm (1960), Johnson et al. (1962) and Sorrow et al. (1967) as a springboard, Weir (1976) and Prewitt $(1981,1985)$ sorted through the archaeological data from Central Texas and established a chronology defined by phases. Although some of their data has been criticized as unreliable and their phases critiqued as actual patterns, chronological markers, and intervals (e.g., Collins 1995; Johnson 1987), they energized fellow colleagues to investigate empirical methods for inferring cultural behavior. Black (1989a, 1989b) analyzed the data of high validity available at the time and offered a synthesis of prehistoric intervals which were widely accepted. Collins (1995) reviewed the archaeological and palynological evidence for Central Texas and offered new approximate dates for human occupation from the Paleoindian through Historic periods.

Refining a cultural chronology for South Texas is much more problematic, due to the compressed nature of the archaeological record and limited excavations conducted in the region (Hester 1995:433). Hall et al. (1982:463, 1986:393-406) analyzed radiocarbon dates and artifact assemblages from Choke Canyon sites in western Live Oak and eastern McMullen counties to establish a local chronology. Black (1989c:39-62) synthesized available data from South Texas and offered a chronology similar to that of Hall and others (1982). Both chronologies were considered by Turner and Hester (1993), who offer slightly different chronological periods based on evidence found more recently in South Texas. Supported by data retrieved from Loma Sandia in Live Oak County, Black (1995:31-44) updated his South Texas chronology, again confirming that of Hall et al. (1982). Also considering Hall's scheme, Hester (1995:433) acknowledges the paucity of information that exists for South Texas, and as such offers only a general framework for prehistoric periods particular to the region. The cultural chronology, defined by complex (in lieu of the terms phase, interval, or period), of the North American High Plains has been synthesized by Hofman et al. (1989), and more recently, the Southern High Plains in Texas by Johnson and Holliday (1995) and Boyd (1995). It should be noted that the Southern Great Plains complexes are defined by shifts in climatic conditions and subsistence more so than changes in point style, which are indicators of change in Central and South Texas. The dates in the following discussion are primarily derived from Black (1995), Boyd (1995), Collins (1995), Hester (1995), Johnson and Holliday (1986, 1995), and Hofman et al. (1989), and adapted from Nickels' (2000) synthesis of the literature. A brief discussion of the Transitional Archaic as defined by Turner and Hester (1993) and Hester (1995) is also presented. All dates are approximate and given as years before present (вР).

\section{Pre-Clovis}

Although humans may have inhabited the landscape before 11,500 BP, solid evidence does not support their existence. The argument that artifacts recovered from Levi Rockshelter in Travis County are older than Paleoindian (Alexander 1983:133-145) is not supported by clustered radiocarbon dates or distinct 
artifact and extinct fauna assemblages within welldefined stratigraphy (Collins 1995:380-381). Although human behavior is inferred on stone artifacts from Friesenhahn Cave (Krieger 1964) and mammoth bones at the Waco Site (Fox et al. 1992:51-73), all are problematic for the same reasons given for Levi Rockshelter. Although several skulls of "pre-sapien ancestry with low sloping foreheads, a pronounced supra-orbital torus, and a marked postorbital construction" were found in Hitzfelder Cave in northeast Bexar County, no radiocarbon dates are available to substantiate their surmised antiquity. The Middle Archaic points found with the burials suggest the skeletons are more likely 5,000 to 6,000 years old (Givens 1968a:219). At Lewisville Lake on the Southern High Plains of north-central Texas, radiocarbon dates initially believed to be from burned charcoal in human campfires, and approximating an antiquity of 40,000 years were later disproved as dates on natural coal (Stanford 1982:208-209). As Collins (1995:380-381) offers, eroded landforms are not likely to yield solid stratigraphic proof of human occupation earlier than Late Pleistocene, and if we do find earlier occupations on stable landforms, what comprises the signature of a Pre-Clovis culture?

\section{Paleoindian}

The Paleoindian period began toward the close of the Pleistocene. This phase spans the period estimated at between ca. 11,500-8800 BP in Central Texas (Collins 1995:381-383) and between 11,200-7950 BP in South Texas (Hester 1995:433-436), although a few claims to older sites exist (Alexander 1963, 1983; Fox et al. 1992; Givens 1968a, 1968b; Krieger 1964). The Southern Great Plains were occupied by Clovis (Llano), Folsom and other complex peoples between approximately 11,500-8000 вР (Hofman 1989:29-45). During the Paleoindian interval, Hurt (1980) suggests an association with the Southern Plains and TransPecos regions. Diagnostic artifacts include Clovis and Folsom projectile points. Certainly the wide distribution of Clovis-type points across most of North America and even into Central America suggests a wide dispersal of the people who made them (Kelly 1993; Wenke 1990:201). Within Texas' political boundaries, Meltzer and Bever (1995:47-81) have documented the presence of 406 Clovis points in 128 of 254 counties. The single Clovis point found during the Twin Buttes 1998-1999 survey (this report) brings to two the total number of Clovis points documented in Tom Green County (Meltzer and Bever 1995). Other artifacts associated with the Clovis culture include bifaces and prismatic blades, engraved stones, bone and ivory points, stone bolas, ochre, and shaft straighteners.

In general the Paleoindian adaptation has been considered to be one of small bands of nomadic, big-game hunters following herds of Late Pleistocene fauna, including mammoth, mastodons, bison, camel, and horse, across North America (Black 1989a). More recently, emphasis has been placed on the wide diversity of plants and animals used for subsistence by these early Americans (Black 1989a; Hester 1983), such as turtles and tortoises, alligators, mice, badgers, and raccoons (Collins 1995:381), although they undoubtedly hunted the large animals as well (Dibble and Lorrain 1968). Known Clovis sites include killsites, quarries, caches, open campsites, ritual sites, and burials (Collins 1995:381-383; Hester 1995:433-436). A Folsom interval follows the Clovis, except perhaps in the Southern Great Plains where a transitional complex of artifacts with dart points called "Goshen" may be present (Hofman 1989:34; Irwin-Williams et al. 1973). Folsom artifacts are fairly common in Central and South Texas; however, no campsites or killsites have been found south of Pavo Real in Bexar County (Hester 1995:434-435).

Most Paleoindian finds in Central and South Texas have consisted of surface lithic scatters on upland terraces and ridges (Black 1989b:25, 1989c:48). A few Paleoindian components deeply buried in alluvium have been discovered, such as the Berclair Terrace site (Sellards 1940), the Berger Bluff site (Brown 1987), Kincaid Rockshelter (Collins et al. 1989), the Wilson-Leonard site (Collins et al. 1993), and at recent excavations of the Richard Beene site (Thoms et al. 1996). A well-documented Paleoindian Clovis site in the Southern Great Plains just northeast of the Twin Buttes Reservoir area is the McLean site in Taylor County, west of Abilene (Ray and Bryan 1938; Sellards 1952). Folsom sites in the area include the Scharbauer site in northwestern Midland County (Wendorf et al. 1955), and the Adair-Steadman site in north-central 
Nolan County (Tunnell 1977). A fourth site nearby containing a Milnesand component is Lone Wolf Creek in northeastern Mitchell County (Wormington 1957). Collins (1995:Table 2) recognizes three sites that have high-integrity Paleoindian components resting on stable landforms: Kincaid Rockshelter, Horn Shelter, and Wilson-Leonard. In addition, a late Paleoindian component with apparent high integrity has also been reported at the St. Mary's Hall site in Bexar County (Hester 1990:14-17, 1995:435).

As the warming that marks the transition from Pleistocene to Holocene climates began to take effect in Texas, prehistoric inhabitants adapted with changes in life-style. This climatic shift is also marked by the decline and extinction of mammoth, mastodon, horse, camel, and giant bison (Bison antiquus). With the possible exception of the Berclair Terrace site (Sellards 1940), archaeological evidence suggests that after $8000 \mathrm{BP}$, large gregarious game animals were either extinct or otherwise extricated from Texas. Human hunters were forced to concentrate on deer, antelope, and other medium-sized or smaller game. Changes in the subsistence base required technological shifts that mark the beginning of a new cultural period known as the Archaic.

\section{Early Archaic}

Collins (1995:383) dates the Early Archaic from 8800 to $6000 \mathrm{BP}$ in Central Texas, with three divisions based on projectile point types, while Hester (1995:436-438) identifies the Early Archaic with Early Corner Notched and Early Basal Notched dart points roughly dating between 7950 to 4450 BP. The Early Archaic on the Southern Great Plains is approximated at $8000-5000$ BP (Hofman 1989), although Johnson and Holliday (1986) offer more fine-grained dates for the Llano Estacado from the Lubbock Lake site of 8500-6400 BP. The extinction of large herds of megafauna and the changing climate at the beginning of the Holocene stimulated a behavioral change by the Prehistoric inhabitants of South Texas (McKinney 1981). While the basic hunter-gatherer adaptation probably remained intact, an economic shift away from big game hunting was necessary. In general, more intensive exploitation of local resources in Central Texas, such as deer, fish, and plant bulbs is indicated by greater densities of ground stone artifacts, fire-cracked rock cooking features, and more specialized tools such as Clear Fork gouges and Guadalupe bifaces (Turner and Hester 1993:246, 256). Weir (1976) speculates that Early Archaic groups were small and highly mobile, an inference from the fact that Early Archaic sites are thinly distributed and that diagnostic types are seen across a wide area, including most of Texas and northern Mexico. Hurt (1980) suggests that the decline in the number of bison on the plains forced the inhabitants to broaden their diets to pursue plants and animals which would produce the same amount of calories and protein with the same or slightly more effort expended. Using projectile points as temporal markers, Hurt (1980:vi) argues that the area around Twin Buttes was used more frequently in the Early Archaic than in the Middle and Late Archaic, probably due to "decline of bison and other game animals on the Southern Plains." Story, however, believes that population densities were low during this period, and that groups consisted of related individuals in small bands with "few constraints on their mobility" (Story 1985:39). Their economy was based on diffuse utilization of a wide range of resources, especially such year-round resources as prickly pear and lechugilla, as well as rodents, rabbits, and deer (Story 1985:38).

\section{Middle Archaic}

Collins (1995:383) defines this intermediate interval of the Archaic as lasting from about 6000-4000 BP in Central Texas, but Hester (1995:438-441) suggests that the period between 4450 and 2350 BP more correctly reflects the Middle Archaic in South Texas. The Southern Plains Middle Archaic complex as derived from changes in climate and subsistence is recognized generally as the period between 5000-3000 вP (Hofman 1989:45-47), and more specifically as 64004500 BP on the Llano Estacado (Johnson and Holliday 1986:46). The Middle Archaic appears to have been a time of increased population, based on the large number of sites from this period in South and Central Texas (Story 1985:40; Weir 1976:125, 128). The reasons for this increase are not known, but the amelioration of a very dry period (Altithermal) during the Early Archaic is often seen as the prime mover (Sollberger and Hester 
1972:338; Story 1985:40). A wide variation in projectile point styles at the Jonas Terrace site suggest "a time of ethnic and cultural variety, as well as group movement and immigration" (Johnson 1995:285). Hurt (1980) posits that the quantity of diversified game animals on the Southern Great Plains decreased, and thus lead to an intensified, less broad diet. On the South Texas Plains, exploitation of widely scattered, year-round resources such as prickly pear continued (Campbell and Campbell 1981:13-15), as did hunting deer and rabbit. However, a shift to concentrated, seasonal nut harvests in the riverine environments of the Balcones Escarpment seems to have occurred (Black 1989a). Weir (1976) believes that an expansion of oak on the Edwards Plateau and Balcones Escarpment led to intensive plant gathering and acorn processing. He also believes that the widely scattered bands prevalent in the Early Archaic now began to coalesce, at least during the acorn-gathering season, into larger groups who shared the intensive work of gathering and processing the acorn harvest (Weir 1976:126). Many researchers believe burned rock middens are a result of this endeavor (Creel 1986; Prewitt 1991; Weir 1976). Other investigators doubt this conclusion (Black et al. 1993; Goode 1991), but the exact processes which formed the burned rock middens are still a matter of controversy (Black 1989b:28; Black et al. 1996; Hester 1991; Leach and Bousman 1998).

The common presence of deer remains in burned rock middens encourages the view that deer processing took place at burned rock midden sites (Black and McGraw 1985:278; Nickels et al. 1998a; Weir 1976:125). Bison bone is encountered in archaeological sites in Central and South Texas, at least occasionally, during all but the earliest part of the Middle Archaic (Dillehay 1974). There has been a tendency to equate presence of burned rock middens with absence of bison (Prewitt 1981); however, examinations of several recent faunal reports show that after about 4500 вP bison and burned rock middens are contemporaneous, though not at the same sites, at least in the southern Edwards Plateau and northern South Texas Plain (Meissner 1993). Collins (1995:Table 2) recognizes only one site in Central Texas that has a high integrity Middle Archaic component resting on a stable landform: Landslide.

\section{Late Archaic}

Collins (1995:384) dates the final interval of the Archaic in Central Texas to approximately 4000-800 BP. Hester believes the Late Archaic in South Texas may better be defined as between 2350-1250 BP, while Hofman's (1989:45) synthesis of the data places the Late Archaic on the Southern Plains as 3000-2000 $\mathrm{BP}$, and possibly later. Johnson and Holliday (1986:46) specify $4500-2000$ BP as the Late Archaic period on the Llano Estacado. Some researchers believe populations increased throughout the Late Archaic (Prewitt 1985), while others feel populations remained the same or fell during this period (Black 1989b:30). Prewitt (1981:80-81) asserts that the accumulation of burned rock middens nearly ceased during the course of this period; however, excavations at the Blue Hole site in Uvalde County (Mueggenborg 1994:1-74), the Honey Creek midden at 41MS32 (Black et al. 1996), the Jonas Terrace site in Medina County (Johnson 1995), and the Mingo site in Bandera County (Houk and Lohse 1993:193-248) provide evidence that large cooking features up to $15 \mathrm{~m}$ in diameter were still very much in use (see also Black et al. 1996). Subsistence is assumed to have become less specialized and focused on acorns, in favor of a broad spectrum subsistence base (Black 1989b:30). Hurt (1980) asserts that bison began returning to the Southern Great Plains area, and we see an increase in intensive processing of bison, as well as mussel shells during the Late Archaic. However, by about $1450 \mathrm{BP}$, bison had again disappeared (Dillehay 1974).

The proliferation of distinguishable human cemeteries has been attributed to this period, with the earliest occurrences dating to the South Texas Middle Archaic (Hester 1995:439-440). At Loma Sandia, these date between ca. 2550 and 2750 BP (Taylor and Highley 1995). Story (1985:44-45) believes the presence of cemeteries at sites such as Ernest Witte (Hall 1981), Hitzfelder Cave (Givens 1968b), and Olmos Dam (Lukowski 1988) indicates that Late Archaic populations in Central and South Texas were increasing and becoming more territorial. Hurt (1980) further posits that population in the Twin Buttes area peaked during the Late Archaic with groups moving into the area from Central Texas; before that the complex of artifacts found in the region were more closely associated with those of the Trans-Pecos region. 
Although inhabitants of the South Texas Plain near Brownsville and Rockport had begun to make pottery by about $1750 \mathrm{BP}$, the northern part of the plain was still "pre-ceramic" until 1,000 years later (Story 1985:45-47). Late Archaic points tend to be much smaller than Middle Archaic points. The most common are Ensor and Frio types (Turner and Hester 1993:114,122), both of which are short, triangular points with side notches. The Frio point also has a notched base (Turner and Hester 1993:122). Collins (1995:Table 2) recognizes three sites within Central Texas with highintegrity Late Archaic components resting on stable landforms: Anthon, Loeve-Fox, and 41TG91.

\section{Transitional Archaic}

A late subperiod or interval of the Late Archaic is frequently referred to as the Terminal Archaic or Transitional Archaic. Weir (1976) defines the Terminal Archaic as $1650-1150 \mathrm{BP}$, while Turner and Hester (1993) cite data placing the Transitional Archaic as 2250-1250 BP. Although Hester may lump current data into a Late Archaic period, he cautions that more evidence will likely result in what may be termed as a "Terminal Archaic" period during the latter part of the Late Archaic in South Texas. This Terminal Archaic period is represented by diagnostics such as Ensor, Frio, and Matamoras points which appear to overlap the Late Archaic and Late Prehistoric periods (Hester 1995:442). Weir (1976) believes this marked a transition period to localized area sites, a disappearance of burned rock middens and bison, and a reappearance of highly mobile hunters and gatherers. Others (Black and McGraw 1985; Peter 1982; Skelton 1977) argue that in some locations burned rock middens did not disappear and sites were more intensely occupied during the Transitional Archaic period. During the Early Neo-Indian period on the Southern Great Plains (ca. 950-1450 BP), Hurt (1980) presents evidence for perhaps a decrease in bison processing; consistent with Dillehay's (1974) contention that there are now less bison available in the area due to climatic changes, which also lowered water tables to alkalinity levels.

\section{Late Prehistoric/Plains Woodland}

The term "Late Prehistoric" is commonly used to designate the period following the Late Archaic in Central and South Texas, while the term "Plains Woodland" or "Woodland" is commonly used on the Southern Great Plains. Collins (1995:385) recognizes that the commonly used date of $1200 \mathrm{BP}$ for the end of the Archaic and beginning of the Late Prehistoric in Central Texas is arbitrary, and Hester (1995:442) acknowledges the problematic issue of selected tools appearing at both Late Archaic and Late Prehistoric sites. A series of distinctive traits marks the shift from the Archaic to the Late Prehistoric period, including the technological shift to the bow and arrow and the introduction of pottery to Central Texas and the northern South Texas Plain (Black 1989b:32; Story 1985:45-47). Two complexes following the Late Archaic in the Southern Great Plains region are the Plains Woodland from about 2000-1150 BP, and the Plains Village from 1150-450 вр (Hofman 1989:61-90). Most researchers agree the early Late Prehistoric period was a time of population decrease (Black 1989b:32). Though small burned rock middens associated with Scallorn and Edwards points have been found (Goode 1991:71; Houk and Lohse 1993:193248), they are rare. Settlement shifts into rockshelters such as Scorpion Cave in Medina County (Highley et al. 1978) and Classen Rockshelter in northern Bexar County (Fox and Fox 1967) have been noted (Shafer 1977; Skinner 1981). Cemeteries from this period often reveal evidence of conflict (Black 1989b:32). For example, an excavation of a burial just north of San Antonio (41BX952) revealed an Edwards point between two lumbar vertebra (Meissner 1991). Sites from the Austin phase include Quinta Medina (Guderjan et al. 1992, 1993) and Panther Springs Creek (41BX228, Black and McGraw 1985). Collins (1995:Table 2) recognizes eight Central Texas sites with high integrity Late Prehistoric components resting on stable landforms: Loeve-Fox, Frisch Auf!, Smith, Rush, Mustang Branch, Rocky Branch B, Kyle, and Currie.

Beginning rather abruptly at about $650 \mathrm{BP}$, a shift in technology occurred. This phase is characterized by the introduction of blade technology, the first 
ceramics in Central Texas (bone-tempered plainwares), the appearance of Perdiz arrow points, and alternately beveled bifaces (Black 1989b:32; Huebner 1991:346). Prewitt (1985) and Black (1989b) suggest this technology encroached from north-central Texas. Patterson (1988), however, notes the Perdiz point was first seen in southeast Texas by about $1350 \mathrm{BP}$, and was introduced to the west some 600-700 years later. Hester (1995:444) recognizes this phase as the "best documented Late Prehistoric pattern" throughout South Texas, with dates ranging between ca. $650 / 700$ to $300 / 350 \mathrm{BP}$.

Steele and Assad Hunter (1986) argue for the occurrence of a distinct change in diet between the Late Archaic and the Late Prehistoric components in two sites in the Choke Canyon Reservoir area in South Texas. Analysis of the number of identified specimens (NISP) shows a marked increase in artiodactyl elements present during the late Late Prehistoric, an increase largely due to the addition of bison to the "menu" (Steele and Assad Hunter 1986:468). Huebner (1991) suggests that the sudden return of bison to South and Central Texas resulted from a more xeric climate in the plains north of Texas, and increased grass in the Cross-Timbers and Post Oak Savannah in north-central Texas, forming a "bison corridor" into the South Texas Plain along the eastern edge of the Edwards Plateau (Huebner 1991:354-355). Sites from this period frequently have associated bison (Black 1986; Black and McGraw 1985; Henderson 1978; Hulbert 1985; Prewitt 1974). However, according to Hurt (1980), the Late Neo-Indian period on the Southern Great Plains (ca. 950-450 BP) is mirrored in the archaeological record by an absence of bison and vegetal matter, most likely due to the increased alkalinity in the region's water sources. "It is interesting to note that a Neo-Indian site characterized by Perdiz points is known from the South Concho, but do not occur here (Middle Concho). This might suggest that the Middle Concho received scant visitation during this period, and insufficient use as to leave detectable archeological evidence" (Hurt 1980:107).

The only archaeological evidence that domesticated plants were ever introduced in South or Central Texas is a single corncob found in Late Prehistoric context in Timmeron Rockshelter (Harris 1985). This single cob is not enough to postulate there was ever a significant presence of maize in the area. Only the arrival of the Spanish brought significant cultivars to South and Central Texas.

\section{Historic Period}

The end of the Late Prehistoric and beginning of the Historic period in both central, south, and the Southern Plains in northern Texas should be characterized by written accounts of European contact with indigenous groups. Collins (1995:386-387) offers that the Historic period then begins ca. 260 вр in Central Texas. However in South Texas, Hester (1995:450-451) agrees with Adkins and Adkins (1982:242) when he suggests that the indigenous groups may have been affected by European influence but we are only able to observe the materials in the archaeological record because the written accounts simply are not available. He would rather label this largely unknown period "Protohistoric." Hofman (1989:91) agrees that "The Protohistoric period is encompassed by the time when there were limited European contacts with the area and brief records of these journeys, but no proper history." The cultural context for the historic groups in the area of study is largely conditioned by the presence of outside ethnic groups and regional power struggles. The numerous small groups of Jumanos and Coahuiltecans encountered by the early explorers and later Spanish intrusions are addressed in many sources (Campbell 1983; Campbell and Campbell 1985; Hester 1989; John 1975; Newcomb 1961; Swanton 1952). The various later intrusive groups, such as Tonkawa, Lipan Apache, and Comanche, are also described by numerous researchers (Ewers 1969; Hester 1989; Jones 1969; Kelley 1971; Newcomb 1961, 1993; Sjoberg 1953a, 1953b).

At the beginning of the seventeenth century, many South Texas Indian groups were being pushed northward by continual Spanish expansion. By the mid-seventeenth century, a new pressure on the Indians indigenous to the area began to come from the north: a nomadic group, the Apache adapted to a more Plains-lifeway style of bison hunting once they acquired horses from the Spaniards (Campbell and Campbell 1985:27). Later, the Apaches were to be 
displaced by another group of nomadic, bison-hunting Indians - the Comanches - from the highlands of Central Texas (Campbell 1991:111).

A combination of migration, demoralization, innergroup conflict, disease, and death due to warfare fragmented the native Indian groups, and forced continual mixing and remixing among them (Bolton 1915; Campbell 1975, 1991:345; León et al. 1961). Most of the native languages had been lost, although recent attempts at reconstruction are enlightening (e.g., Johnson 1994; Johnson and Campbell 1992). The establishment and relocation of Spanish Catholic missions along the Concho, San Saba, and San Antonio rivers in the late 1600 s and early 1700 s induced many groups to seek the relative comfort and protection offered by a sedentary, apparently well-fed, and peaceful coexistence (Campbell and Campbell 1985; Chipman 1992; de la Teja 1988; Habig 1968a, 1968b; Hard et al. 1995; Inglis 1964). Although fear of the invading Apache and Comanche pressured many of the Indians to seek the protection of the missions, they were now exposed to the exploitation of the Spanish (Campbell 1975:2, 1991:346-347).

In the autumn of 1785 , a peace treaty with the Comanche signaled the opening of a period of peaceful coexistence in which Comanches brought hides, meat, and tallow to the area to trade for goods and services not available elsewhere, such as blacksmithing and gun repair (Poyo and Hinojosa 1991:125-126). The few Comanche who entered the missions were apparently women and children who were captured during punitive raids by Spanish soldiers (Campbell and Campbell 1985:26).

Apaches continued to range over the area between San Antonio and Laredo until the early 1800 s, pushed southward by the invading Comanche who had moved into the Hill Country of Central Texas (Campbell and Campbell 1985:27). Weary of warfare with the Comanche, a few Apache were beginning to seek asylum in the missions (McGraw and Hindes 1987:367; West 1904:50). However, few landowners dared to live on their outlying lands until about 1840 , when a treaty with the Apache brought peace for a while (de la Teja 1988:167).
The newly formed government of Texas gave land grants that were large, consisting of around 5,000 acres for each property, and Spanish cattle ranching became prevalent south and southeast of San Antonio (Jackson 1986), however the vast expanse west of San Antonio toward the Twin Buttes/Concho River region was not settled until the late 1800 s. Around 1840 , settlers from Germany and Alsace-Lorraine and from other regions of the United States began to move into the Hill Country to the north, settling into communities such as Boerne, to raise sheep or cattle (Freeman 1994:5-9). Although the Fisher-Miller land grant contract with the Republic of Texas was not entirely successful, it did provide the impetus for John Muesebach to initiate a peace treaty with the Comanches occupying the region (King 1967:111-118; Tiling 1913:100). Finally, the arrival of pioneer ranchers such as Richard F. Tankersley signaled a foothold on Anglo settlement in the area around Twin Buttes (Barton 1998).

\section{Previous Archaeological Research}

In this section, the history of previous investigations in Coke, Concho, Irion, Menard, Runnels, Schleicher, Sterling, and Tom Green counties will be discussed briefly (Figure 5-1). By combining the information obtained from sites in Tom Green County with that from sites in surrounding counties we are able to see perhaps a glimpse of how the landscape and ecosystems may have been exploited through time, and only then can we begin to comprehend the prehistory of the upper reaches of Spring Creek and the Middle and South Concho rivers. In general, the small sampling of archaeological sites recorded in this micro-region of west-central Texas represents possibly thousands of other sites with evidence of human occupation over the past 11,500 years.

\section{Tom Green County}

The 178 new sites recorded during this survey project brings the total number of sites documented in Tom Green County to over 500, and together they begin to reveal how the landscape may have been exploited over the past several millennia in the Twin Buttes area. It is evident that humans have lived in the area from 

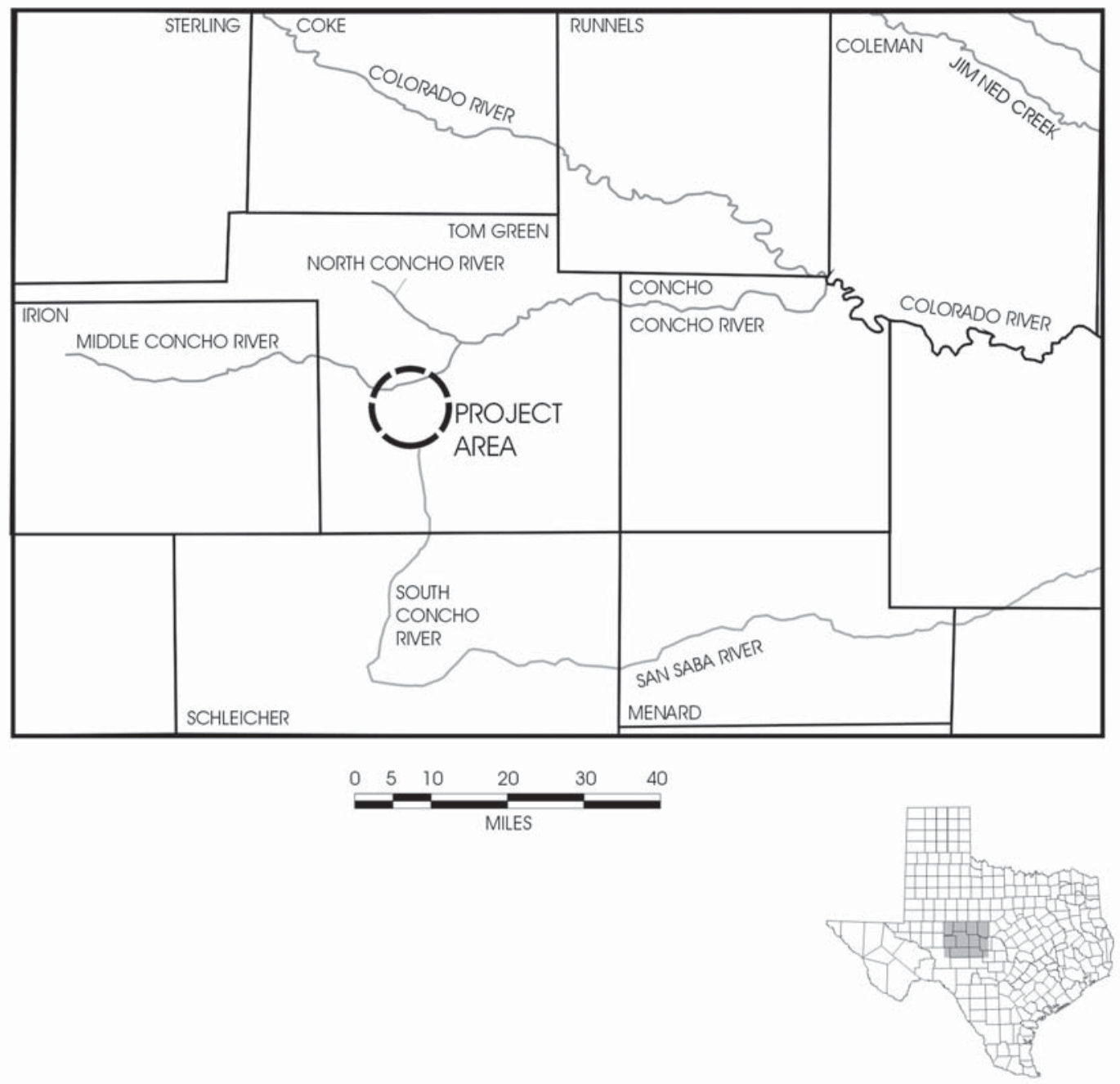

Figure 5-1. Project area with surrounding counties and major rivers identified.

the Paleoindian interval, perhaps as long ago as 11,500 years ago.

Previous archaeological investigations in the vicinity of Twin Buttes were undertaken by Kelly on the North Concho River in 1946 (Stephenson 1949). Two years later, members of the Smithsonian River Basin Survey (Stephenson 1949) recorded 13 sites which would be impacted by the construction of the San Angelo
Reservoir (later named O. C. Fisher Lake). None of the 13 were considered significant at the time and thus no further work was recommended. Willis (1958) and members of the West Texas Museum at Texas Technological College (now Texas Tech University, Lubbock) conducted a survey of the Spring Creek channel just above the proposed Twin Buttes Reservoir dam and documented five sites. One of those was 41TG109 (Figure 5-2), excavated by Green (1959). 
Little professional archaeology was conducted in the county until Southern Methodist University tested four possible prehistoric quarry sites on the Willow Creek Watershed in the northeast portion of the county in the mid-1970s (Banks and Bagot 1975). A few years later, Mayer-Oakes (1977) documented a site on O. C. Fisher Lake (San Angelo Reservoir) with a petroglyph of a human stick figure utilizing a bow and arrow carved into a boulder.

Creel conducted a survey along a portion of the South Concho River, upstream from the Twin Buttes Reservoir, and tried to correlate archaeological sites with macro environmental zones (Creel 1978). Creel documented 41TG91 (Figure 5-2), a site excavated in 1978 by the Texas State Department of Highways and Transportation (Creel 1990; Luke 1978), and located in a levee deposit of the South Concho River nearly in the center of Tom Green County. The site held a Toyah complex assemblage consisting of at least five slablined hearths, two mussel shell concentrations, and one chert debitage concentration. Human remains of perhaps two individuals were found, and probably most significant were the 447 sherds representing at least 18 vessels.

During Hurt's (1980) systematic survey in transects along the Middle Concho and its tributaries in western Tom Green and eastern Irion counties, he recorded 48 prehistoric sites, mostly open campsites. In 1985 , a survey of the potential borrow areas for the reworking of the Twin Buttes Reservoir dam was completed by Meeks Etchieson, which resulted in the discovery of 10 prehistoric sites. Of these 10 sites, seven were lithic scatters, two were burned rock accumulations/ middens, and one was a lithic procurement site (Etchieson 1985). The results of Etchieson's survey will be further discussed in the archaeology of the Twin Buttes Reservoir.

In 1990, James E. Warren headed two investigations for the City of San Angelo. One investigation was concerned with revisiting 41TG280, 41TG282, and 41TG283. The other was a survey of 1,200 acres of the San Angelo City Farm. Testing at the three sites (41TG280, 41TG282, and 41TG283) revealed that they were badly disturbed due to cultivation and therefore no additional work was warranted (Warren 1991).
The San Angelo City Farm Project survey documented 13 previously unrecorded sites. Eight of these sites were open campsites with lithic workshop areas. The remaining five were lithic procurement/testing areas, one of which included a burial (41TG291). Site 41TG289, an open campsite/lithic workshop, contained several diagnostics that included Perdiz, Martindale, Travis, Frio, Ensor, Catan, Edgewood, Darl, Kent, Pandale, Lange, Scallorn, Bulverde, and Uvalde points (Warren 1991). Other cultural material documented at these sites included Leon Plain ceramic fragments (41TG289), Olivella shell beads (41TG286), metate fragments (41TG288), and a limestone mano (41TG298).

Site 41TG351 is an open campsite dating to the Early, and perhaps Middle to Late Archaic found during a survey for the proposed Rio Vista sewer main, and later tested by McCulloch and Warren $(1995,1997)$. While surveys were in progress for the installation of a pipeline from O. H. Ivie Reservoir in 1993, two sites (41TG346 and 41TG347) were discovered along the planned pipeline route. Excavations were immediately begun to avoid interrupting pipeline installation progress. 41TG346 was characterized as being an open campsite that contained many campfire features. Twenty identifiable Late Prehistoric arrow points were recovered, including 16 Perdiz, two Harrell, one Garza (basal notched) and one Cliffton; (Quigg and Peck 1995). 41TG347 is believed to be a possible Late Prehistoric campsite with hearth clusters and a few manuports. Numerous bison bones were recovered along with one biface knife fragment.

During 1993 and 1994, a City of San Angelo Wastewater Improvement Project survey was undertaken and excavations of 41TG307 and 41TG309 were conducted (Quigg et al. 1996). 41TG307 is an open campsite, with an unknown occupation period. The site contained a possible hearth, although it was badly scattered down the slope of a cutbank. 41TG309 appeared to be an Archaic open occupation site. It contained several hearth features, a lithic scatter, a probable dart point preform, and a mano fragment.

In May 1997, the City of San Angelo, Department of Public Works requested a cultural resources investigation of a proposed pipeline route east of the city. 
This page has been

redacted because it

contains restricted

information. 
Other investigations in the area include that of a rockshelter by E. B. Sayles (1930) which contained some petroglyph panels. The rockshelter had been disturbed by looters, leaving few artifacts. Cyrus N. Ray (1948) located twenty sites near Oak Creek that contained many scrapers. Most of these sites had been picked clean of artifacts by local residents and one rockshelter had been destroyed by looters through the use of dynamite.

During 1967-1968, surveyors with the Texas Archaeological Salvage Project located over 100 sites in the Robert Lee Reservoir basin. Research revealed extensive occupation of the Colorado River Basin whose inhabitants exploited the valley and riverine resources during the Late Archaic through the Late Prehistoric periods (Sanders 1996). These sites also suggested possible interaction with the American Southwest due to the recovery of a Pecos-style clay pipe.

\section{Concho County}

During 1988 and 1989, Mariah Associates, Inc. conducted archaeological investigations for the proposed O. H. Ivie Reservoir spanning Concho, Coleman, and Runnels counties. The documented sites included three burned rock midden areas $(41 \mathrm{CC} 13,41 \mathrm{CC} 167$, and $41 \mathrm{CC} 223)$, two burned rock accumulation areas (41CC150 and 41CC222), two sites with hearth features (41CC131 and 41CC135/136), one stone ring site (41CC137), and one lithic scatter site (41CC187) with no observable features (Lintz et al. 1993a).

By 1997, 279 archaeological sites were located within Concho County. Only four investigations involving the county's archaeology occurred between 1987 and 1992, three of these were at O. H. Ivie Reservoir and the fourth involved a pipeline installation. During 1996 a survey was conducted over 105 acres of the proposed golf course for the City of Eden by American Archaeology Group. Four unrecorded sites were located as a result of this survey. One site was prehistoric (41CC280), two were historic (41CC282 and 41CC283), and the last contained both prehistoric and historic components (41CC281). A Fairland and a Perdiz point were recovered from $41 \mathrm{CC} 280$ and flake tools were found at both 41CC280 and 41CC281 (Bradle et al. 1997).

\section{Irion County}

Even though there are around 300 recorded sites in Irion County, few archaeological reports are available. One of the more systematic surveys was conducted by Hurt (1980) in eastern Irion and Tom Green counties (see Tom Green County, above). A survey of 15 acres for the Northern Gas Products Company along the Middle Concho by Espey, Huston and Associates revealed no sites (Voellinger 1981). Another survey along Spring Creek in the city of Mertzon, conducted for a water system improvement, also found no sites (SK Geo-Sciences 1991). Two historic sites consisting of a petroglyph and a limestone slab tinaja (water trap) were recorded by Guffee (1984) while surveying for a proposed electrical line route for the Concho Valley Electric Cooperative. The All American Pipeline Project survey conducted through Irion County resulted in 35 sites being recorded (Turpin et al. 1992).

\section{Menard County}

In 1979, archaeologists from the Center for Archaeological Research (CAR), The University of Texas at San Antonio (UTSA), conducted a survey for the City of Menard, Texas covering approximately 4.9 miles for a proposed natural gas pipeline. During the course of the survey, no chert of manufacturing quality was observed, and no cultural features or artifacts were found (Kelly and Valdez 1979).

\section{Runnels County}

During 1982 and 1983, survey and testing was conducted for a proposed reservoir west of Ballinger on Valley Creek. The Archaeological Research Laboratory from the Llano Estacado Museum located twelve sites - two historic and ten prehistoric. The prehistoric sites included a small lithic scatter, four quarry sites, one burned-rock midden, three campsites with small hearths, and one possible slab burial (Guffee 1989). Investigations conducted by Espey, Huston and Associates in 1980 for the proposed O. H. Ivie (Stacy) Reservoir documented 71 archaeological sites in Runnels County, four of which contained historic components only (Freeman and Freeman 1981; Godwin et al. 1981; Woolridge et al. 1981). 
In February 1992, prehistoric site 41RN129, located on a high terrace on the east side of the Colorado River 18 miles southeast of Ballinger, was tested by archaeologists from the Texas Department of Transportation, and found to contain a prehistoric cultural zone (of unknown origin) with no diagnostic artifacts, but with two possible burned rock features (Wood 1992). In April 1994, a survey was conducted at Lake Winters in preparation for the expansion of Lee Colburn Park. During the course of this survey one site, 41RN202, was identified. A lithic scatter located at 41RN202 consisted of utilized and non-utilized flakes, and one scraper. According to the investigators, the site did not appear to contain significant cultural deposits (Driver 1994).

During the Elm Creek Watershed Project, six prehistoric sites were examined (Sanders 1996). Representative samples of lithic assemblages were recovered from four of the sites (41RN61, 41RN64, 41RN65, and 41RN74). 41RN61 appears to have been a lithic procurement site due to the readily available chert; 41RN64 was a "multiple-occupation campsite" containing components from the Transitional Archaic and Late Prehistoric periods; and 41RN74 seems to have been involved in many activities including lithic tool manufacturing, plant food processing (due to the presence of manos), animal food/hide processing, and hunting (presence of projectile points).

\section{Schleicher County}

The small number of sites recorded in Schleicher County is undoubtedly a reflection of the limited number of surveys that have been conducted there. In 1981, archaeologists from CAR-UTSA conducted a survey for the Southwest Electrical Cooperative and documented seven prehistoric sites-five quarries, one campsite, and one campsite/quarry (Woerner 1981). Texas Department of Transportation archaeologist Greg Wood surveyed a proposed right-of-way for R.M. 2596 in 1980, and documented 41SL2, a site with two burned rock middens. Although few artifacts and no diagnostics were recovered from the two middens, the most common were unifacial flake tools (Luke 1981). Other small scale surveys (e.g., Espey, Huston and Associates, Inc. 1990; Luke 1981; Voellinger and
James 1984) have documented lithic scatters, burned rock middens, and campsites.

\section{Sterling County}

Although many of the sites in Sterling County have been found during pipeline or highway right-of-way surveys, Douthit (1978) recorded 62 prehistoric sites along the North Concho in 1978 for her dissertation work. Another large scale survey conducted for the Seminole Pipeline Company extension line through Sterling County in 1991 documented four sites (Turpin 1992). A cultural resources survey of the O. H. Ivie (Stacy) Reservoir to Midland pipeline route through Sterling County documented three chert procurement sites and one campsite (Treece et al. 1994). A highway right-of-way survey by Texas Department of Transportation archaeologists in 1996 along Highway 87 led to the discovery of four prehistoric, one historic, and one prehistoric/historic site. The prehistoric sites were lithic scatters with burned rocks, while the historic components consisted of a cairn burial and a stone ruin (Kenmotsu et al. 1997). In 1995, 41ST98 was located during a survey for a proposed water pipeline route to Sterling City. The site appeared as a small, disturbed campsite, containing a very small amount of burned rock and chert (Quigg 1995). Archaeologists from CAR-UTSA excavated the remains of old Camp Elizabeth west of Sterling City in 1998. The camp served as a sub-post for Buffalo Soldiers from Fort Concho (Brown et al. 1998).

\section{Previous Archaeological Investigations Within the Twin Buttes Reservoir Area}

The Twin Buttes Reservoir area, as defined for this project, encompasses the Twin Buttes, Knickerbocker, and Pecan Station quadrangle maps of the United States Geological Survey. A review of the 52 archaeological sites previously recorded within the area was conducted using the Texas Archaeological Atlas produced by the Texas Historical Commission (on the Internet at http:// pedernales.thc.state.tx.us/), as well as published material on surveys and excavations (e.g., Creel 1990; Etchieson 1985; Green 1959; Willis 1958). Site locations and 
copies of site documents were obtained from the Texas Archeological Research Laboratory.

\section{Investigations}

In 1958 the West Texas Museum completed a reconnaissance survey of the proposed Twin Buttes Reservoir (Willis 1958). A total of five sites were recorded. These sites were given site designations of TG2 (later changed to 41TG106), TG3 (41TG107), TG4 (41TG108), TG5 (41TG109), and TG6 (41TG110). Excavations conducted at TG5 (41TG109) the following year (Green 1959) produced numerous artifacts, including projectile points temporally diagnostic to the Early through Late Archaic periods (Black 1995; Collins 1995; Green 1959).

In 1985 the Bureau of Reclamation conducted a safetyof-dam study of the Twin Buttes Reservoir dam (Etchieson 1985). Pedestrian surveys of potential borrow pit areas from which fill could be excavated to repair the dam resulted in the recording of ten sites with prehistoric components only, one with both a prehistoric and a historic component, and one with a historic component only (Figure 5-2). 41TG253 has prehistoric mortar hole features as well as a historic dam (White's Dam), 41TG244 and 41TG247 are burned rock accumulations, and 41TG252 has a slablined pit. The remaining seven prehistoric component sites are categorized as either lithic procurement sites, or lithic scatters with burned rock. The other historic component documented during the project (41TG248) is also a dam (Gardner's Dam).

In 1993 Espey, Huston and Associates (Hageman 1993 ) conducted a pedestrian survey with shovel tests of a proposed $1.62-\mathrm{km}, 24.4$-meter-wide, gas pipeline right-of-way (ROW) through the northwestern edge the Twin Buttes Reservoir boundary. The project also included a geomorphological analysis of cores taken on the Middle Concho River (Hageman 1993). Three sites were located adjacent to the ROW; 41TG234, a prehistoric open campsite previously recorded by E. B. Sayles (1932), and two newly recorded sites; 41TG344, a lithic procurement site and 41TG345, a prehistoric open campsite.
Analysis

Prior to the current project there were 63 sites recorded on the Twin Buttes, Knickerbocker, and Pecan Station USGS quadrangles. This section will discuss 40 of the 63 sites; 21 were revisited during the 19981999 survey and their attributes are analyzed in Chapter 8 and are summarized in Appendix A; two of the previously recorded sites (41TG158 and 41TG285) do not have the necessary information in the Texas Archeological Sites Atlas database, and are otherwise not published. Table 5-1 presents selected attributes of the 40 sites.

Open campsites accounted for 45 percent of the sites followed by lithic procurement/quarry sites (30 percent). Close proximity to water would have been a primary consideration in establishing a campsite, and not surprisingly, all 18 campsites were located in a riverine environment. Generally, burned rock middens are located near water sources, and in this study two of the three are near a river or creek. The exception is $41 \mathrm{TG} 132$ which has two small middens located on an upland limestone shelf, with three mortar holes. The criteria for defining a campsite was that it have firecracked rock, usually with a wide variety of stone tools. Mussel shells were found at eight of the eighteen campsites, and at two of the three burned rock middens; the exception being 41TG132, the upland midden. As expected, the number of cores and tested cobbles at sites exhibiting evidence of lithic processing is inversely related to the number of bifaces and unifaces at campsites. Diagnostic projectile points were not observed at any of the 40 sites, other than fragments of arrow or dart points. This is likely a reflection of private collection activities, mentioned in some of the site reports.

Possible stone structural features were reported at 41TG128 and 41TG131, two upland lithic scatter sites. A third site (41TG126) has boulders that may be construed as structural-like, but not confirmed. The sole petroglyph site is 41TG54, located in O. C. Fisher Reservoir (discussed previously). The lone burial site (41TG107) sits on top of a small knoll in the floodplain of Dove Creek. 
Table 5-1. Site Types and Attributes in Twin Buttes, Knickerbocker, and Pecan Station Quadrangles

\begin{tabular}{|c|c|c|c|c|c|c|}
\hline & $\begin{array}{l}\text { Lithic } \\
\text { Procurement/ } \\
\text { Quarry }(n=12)\end{array}$ & $\begin{array}{l}\text { Lithic } \\
\text { Scatter } \\
(\mathrm{n}=5)\end{array}$ & $\begin{array}{l}\text { Open } \\
\text { Campsite } \\
(\mathrm{n}=18)\end{array}$ & $\begin{array}{l}\text { Burned Rock } \\
\text { Midden } \\
(\mathrm{n}=3)\end{array}$ & $\begin{array}{l}\text { Possible } \\
\text { Burial } \\
(n=1)\end{array}$ & $\begin{array}{l}\text { Petroglypgh } \\
(n=1)\end{array}$ \\
\hline Riverine & 4 & 1 & 18 & 2 & & \\
\hline Upland & 7 & 4 & & 1 & & \\
\hline Hearths & & & 13 & 2 & & \\
\hline Mortar Holes & & & & 1 & & \\
\hline Rock Structures & & 2 & & & & \\
\hline Mussel Shells & 1 & & 8 & 2 & & \\
\hline Faunal Remains & & & 2 & 1 & & \\
\hline Cores & 12 & 1 & 3 & & & \\
\hline Tested Cobbles & 4 & 1 & & & & \\
\hline Bifaces & 3 & 3 & 7 & 2 & & \\
\hline Unifaces & & 3 & 5 & 1 & & \\
\hline Flakes & 12 & 5 & 16 & 2 & & \\
\hline Scrapers & & & 3 & & & \\
\hline Burins & & & 1 & & & \\
\hline $\begin{array}{l}\text { Retouched } \\
\text { Flakes }\end{array}$ & & 1 & 2 & & & \\
\hline Ground Stone & & & & 1 & & \\
\hline $\begin{array}{l}\text { Fire-Cracked } \\
\text { Rock }\end{array}$ & 1 & & 5 & & & \\
\hline Dart Points & & & 3 & 1 & 1 & \\
\hline Arrow Points & & & 1 & & & \\
\hline
\end{tabular}




\section{Summary}

The history of professional research in the greater project area stretches back over 50 years. A variety of sites have been documented, using various typologies and cultural chronologies, and a handful of sites have been tested. Over the last few decades, a general picture of land use for much of the prehistoric sequence has begun to emerge. While a variety of interpretations of particular assemblages and sites can be advanced, the above data summary suggests that groups of varying sizes have used the region for hunting and gathering, perhaps responding to temporal fluctuations in the availability of different mixes of plants and animals, throughout the prehistoric sequence. To the degree that site typologies such as "lithic procurement/ quarries" or "open campsites" are useful indicators of adaptations, it appears that both campsites and some form of lithic procurement are common in the region, and may be geared to critical resources such as water. While the overall temporal pattern of occupation is obscured by the low number of diagnostics recovered, major uses of the region appear to have occurred in the Late Archaic (see Creel 1978; Hurt 1980:98) with some additional evidence for an earlier occupational peak sometime around the Early to Middle Archaic transition (Hurt 1980:98). Nevertheless, there is surprisingly little detailed information on adaptations for any given period. In part, this is certainly related to the low frequency of both excavation projects and large scale surveys. 



\section{Chapter 6: Methods}

\section{David Nickels}

\section{Project Description}

As noted in Chapter 1, the purpose of the project was to conduct a pedestrian survey, supplemented by archival documentation, to locate and record both historic and prehistoric cultural resources contained within the 12,790 acre Twin Buttes Reservoir. CAR's investigation included site discovery during the pedestrian survey, then revisiting and recording sites. The fieldwork was conducted by staff archaeologists under the direct supervision of the project archaeologist and periodic visits by a principal investigator and the geoarchaeological consultant. This chapter outlines the methods used during all aspects of the project.

The fieldwork consisted of surveying, limited surface collecting, surface inventories, augering, and excavating. Five hand dug units, 10 backhoe trenches, 1,106 shovel tests, and 57 auger tests were excavated. In adhering to a limited collection policy, only potentially diagnostic prehistoric and historic artifacts were collected from the surface. All cultural material recovered from shovel tests and test units was collected. Hand dug test units focused on Paleoindian, Late Archaic, and Historic components. In addition, attributes of artifacts were observed in 131 sample areas on 97 sites.

\section{Prefield Planning}

Before the project began we met with Mr. Hector Garcia from the Bureau of Reclamation to establish acceptable and required fieldwork and reporting standards for the project. Prior to initiation of actual fieldwork, more detailed archival research, soil survey, geology and topographic maps, aerial photographs, and an initial site visit to assess the geomorphological conditions were used to better understand the site potential in the project area. To insure systematic recording procedures, the principal investigator, project archaeologist, and crew chiefs met before the field work began to review artifact classifications and recording procedures.

A review was conducted of the current literature for the South, North, and Central Texas Archaeological Regions. Prehistoric sites could be defined as open campsites, lithic quarries, burned rock middens, or Native American burials. Open campsites often contain varying quantities of fire-cracked rock from possible small-hearth features and a lithic scatter, suggesting an occupational episode. Lithic quarries are those characterized by the presence of gravel exposures. Exploitation of the exposure is indicated by light to heavy scatters of chipped stone debris, including artifacts such as cores, quarry blanks, preforms, flakes, and (rarely) informal or formal tools. Burned rock middens consist of large quantities of fire-cracked rock resulting from repeated use, and normally associated with large quantities of culturally tooled lithic material. Native American burials most probably will not be marked and are often discovered in an erosional context. CAR would not disturb Native American human remains if they were encountered. Upon locating such a site, CAR personnel would avoid further impacts to that location, and would immediately notify the Bureau of Reclamation.

Farmsteads, dugouts, irrigation works, railway stations, trash dumps, isolated graves, cemeteries, early historic trading sites, and ephemeral military campsites associated with Fort Concho patrols are the types of historic sites that could be encountered during the survey. During the initial visit we observed a late nineteenth- to early twentieth-century stone structure as well as abandoned railway features.

\section{Fieldwork}

The fieldwork for the project essentially involved three phases. The first phase consisted of a pedestrian survey 
This page has been

redacted because it

contains restricted

information. 
Table 6-1. Size Definitions for Prehistoric Archaeological Occurrences

\begin{tabular}{||l|c|c||}
\hline \hline Occurrence Size & Artifact Density $/ \mathbf{2 5 m ^ { 2 }}$ & Features Present \\
\hline Site & 5 & present \\
\hline Isolate & 1 戥 4 & absent \\
\hline
\end{tabular}

as isolated finds. In all cases, isolated finds were either recorded on separate forms prepared for this project, noting location and type of artifact, or were recorded with hand held Global Positioning System receivers. The formal documentation of isolated finds were completed during the site discovery phase, and these areas were not revisited during the site-recording phase. All isolated find data are available in Appendix G. Every other day during the initial phase of the project, CAR teams reviewed locations that had sufficient artifact density to be labeled as potential sites.

If the location met the definition for a site, a datum consisting of a length of rebar was hammered into the ground at the site's center or the best vantage point. USGS 7.5' topographic maps and a Trimble Geo Explorer II Global Positioning System (GPS) were used to determine UTM coordinates. CAR surveyors took a GPS reading from the datum of the site, all features such as hearths and mortar holes, and from enough points along the perimeter to define the estimated site boundary. This data was differentially corrected by CAR Geographic Information System personnel.

A standardized form containing observations concerning site disturbance, vegetation, estimated artifact counts by category and features was completed. Examples of these forms can be found in Appendix K. Each site was assigned a temporary field number until given a trinomial site designation in the lab.

\section{Phase 2: Revisiting and Documenting Sites}

It was generally the case that a crew chief and three crew members made up the site-documenting teams. Once a potential site was relocated, crew members intensively examined the ground surface, flagged artifacts, and noted any high-density concentrations. After the location was confirmed as a site, boundaries were established according to artifact distribution. A site boundary was defined by a significant drop-off in surface artifact densities. Crew members rotated through the various tasks of properly documenting the site. The tasks included shovel testing, auger testing, surface observations, site mapping and photographing.

\section{Shovel Tests}

Shovel tests were conducted at each site to test for subsurface cultural materials and examine the geomorphology. The survey crew excavated a sufficient number of shovel tests within the site to determine the vertical extent of the archaeological deposit, the vertical extent and severity of disturbance present, and to develop a preliminary understanding of the nature of the soils and depositional history at the site. The project archaeologist or crew chief determined the number of shovel tests, taking into consideration site size, artifact frequency over the site surface, and topographical variation over the site surface.

Of the 1,106 shovel tests conducted, 1,058 were dug to evaluate the potential for buried, intact cultural deposits below cultural material exposed on the surface. Forty-eight shovel tests were dug in 30-m intervals along a north-south transect to evaluate the potential for buried cultural deposits under dense vegetation covering an interfluve between the Middle Concho River and Spring Creek. All shovel test locations were recorded using a hand held Trimble Geo Explorer II Global Positioning System (GPS). A shovel test was defined as a $30-\mathrm{cm}$ diameter unit, excavated, screened, collected, and recorded in levels no more than $10 \mathrm{~cm}$ in thickness to a standardized depth of $50 \mathrm{~cm}$ in upland areas and $70 \mathrm{~cm}$ in terraces and floodplains, unless bedrock or Pleistocene sediments were encountered. Additional levels were removed if artifacts were encountered in what would be the standard bottom 10-cm level, and the potential for subsurface cultural strata was deemed high, as in floodplain sediments or thicker loamy sediments in the uplands. All sediment was screened through $1 / 4$-inch wire mesh and the results of shovel tests recorded on a standardized form. Sediment colors were described using a Munsel 
color chart. All artifacts from shovel tests were collected, bags were labeled with their appropriate field provenience and transported to CAR for analysis and curation. Soil samples were collected from shovel tests or auger tests at selected sites. All shovel test data are presented in Appendix B, and examples of the shovel test recording forms can be found in Appendix K.

\section{Auger Tests}

Fifty-seven hand-operated bucket auger tests were placed on selected sites to evaluate not only the potential for cultural material and features below the normal maximum depth that could be reached with a shovel $(100 \mathrm{~cm})$, but also to examine the variation in the underlying sediments and geological deposits. Augering has worked well in the Sacramento Mountains and Hueco Bolson (Rocek 1991; Whalen 1986). It is a method that can be used to efficiently search a large area for buried features. The auger buckets were $20 \mathrm{~cm}$ in length and $5 \mathrm{~cm}$ in diameter. Each hole was augered to either a sterile surface, a depth of $140 \mathrm{~cm}$ (normal shaft length), or to a maximum $200 \mathrm{~cm}$ in a few cases, in $20 \mathrm{~cm}$ increments. After augering $20 \mathrm{~cm}$, the bucket contents were emptied onto $1 / 4$-inch wire mesh, and the screen moved with each bucket load so that sequential soil samples, organized by depth, were laid beside each other. Changes in soil and any cultural material was recorded on a standardized form (Appendix K), and the items were collected, bagged, and transported to the lab. Notations were made of lithics, ceramic sherds, botanical remains, osteological material, charcoal, ashy soil, or changes in soil colors and texture on a standardized form. In addition, soil samples were collected from shovel tests or auger tests at selected Twin Buttes sites in order to obtain a sample cross-section of the major drainage valleys as well as the uplands.

\section{Surface Observation Areas}

Site recording crews used one of two methods to generate quantitative data on artifact assemblages at each site. Either a 100 percent inventory of observed surface artifacts was taken, or one or more smaller-size sampling areas was inventoried. Each artifact was recorded on a standard form (see Appendix K) specifying flake types, cores, tested cobbles, bifaces, utilized and retouched pieces, and diagnostic artifacts. Attributes of over 21,000 artifacts from 97 different sites were recorded. These data are presented in Appendix D.

\section{Site Mapping and Photography}

Site maps, showing site boundaries, datum locations, shovel tests, sampled areas, collected items, features, areas of high artifact density, directions to visible landmarks, and physical features on the landscape, were recorded. Mapping was done by GPS, and by pace and compass. Landforms, roads, or streams that would be helpful in relocating the site were shown. Survey areas with site locations and boundaries were plotted on the field map and on 7.5' Series USGS quadrangles.

Archival quality 35-mm black-and-white prints, and 35-mm color slides were made of all sites and artifacts where appropriate. CAR staff took 953 photographs using primarily color print and slide film, with a limited number of black-and-white print film using Pentax cameras with zoom lenses. Photographs were recorded on standard CAR photo forms in the field. In addition to photographing general survey and excavation activities, particular attention was given to features such as hearths and mortar holes.

\section{Phase 3: Excavation and Geomorphic Documentation}

\section{Excavation Units}

A total of five hand-excavated $1-\mathrm{m}^{2}$ test units were placed in four sites; two in 41TG378, one in 41TG389, one in 41TG410, and one in 41TG473. All test units were placed on a grid system established in the four cardinal directions from the site datum. The units were placed in areas where shovel or auger tests indicated a possibly intact subsurface cultural layer. Unit datums were established in the southwest corners of each unit. Depths were recorded as "below datum" while in the field. Excavation was accomplished with trowels, picks and brushes in $10 \mathrm{~cm}$ levels, unless a significant soil change or feature was detected; then excavation levels were consistent with the changing levels of the soils or features. Feature numbers were assigned when identified. All sediments were screened through $1 / 4$-inch wire mesh, and cultural material other than special samples was placed in paper bags labeled with the field site number, provenience, date, and name 
of excavator(s). Examples of forms used during excavation are provided in Appendix K. Excavation data are presented in Appendix C.

Flotation and oxidizable carbon ratio samples were collected from Feature 1 at 41TG389. In addition, CAR drilled and collected 11 fire-cracked rock core samples from Feature 1 at 41 TG389 using an Echo E$\mathrm{Z}$ Core rock drill, model D-2801, with a 11/8-inch diamond-tipped bit. The angle and dip were recorded using a Brunton compass mounted on a goniometer. The elevation of each sample relative to the unit datum was also recorded. A plan view was drawn of the drilled rocks with the archaeomagnetic sample number assigned by the excavator. After each sample was scored and marked with a permanent marker to ensure proper alignment during the laboratory processing phase, samples were removed and placed in separate labeled bags. These data are presented in Appendix J.

\section{Backhoe Trenches}

The project geomorphologist conducted investigations using a backhoe in selected areas and profiles were recorded with standard Soil Survey Staff procedures. Ten backhoe trenches were dug between two and three meters deep, and were strategically placed in the northwest corner of the project area (see Chapter 4). Descriptive information on specific backhoe trenches are presented in Appendix I.

\section{Laboratory Methods}

A temporary CAR laboratory was established in San Angelo where artifacts and samples were accounted for daily. Upon returning to San Antonio cultural materials recovered from the survey were inventoried at the CAR-UTSA laboratory. All artifacts recovered from the survey were then identified and analyzed. Proveniences for the materials entering the CAR laboratory were verified through the use of a field sack (FS) number, which was recorded during the field investigation. FS numbers, along with Unique Item (UI) numbers, were assigned to all artifact bags in the field. Artifacts and samples were separated by artifact type and recovery context to facilitate analysis. Processing of recovered artifacts began with washing and sorting into appropriate categories. These data were entered into a spreadsheet.
At the CAR-UTSA lab all cultural material collected from the Twin Buttes project was prepared for storage in accordance with federal regulation 36 CFR part 79 , and in accordance with current guidelines of the Texas Archeological Research Laboratory (TARL). Lithic, metal, and ceramic artifacts processed in the CAR laboratory were washed, air-dried, and stored in archival-quality bags. Acid-free labels were placed in all artifact bags. Each bag was labeled with a provenience or corresponding bag number. Tools were labeled with permanent ink and covered by a clear coat of acrylic. Other artifacts were separated by class and stored in acid-free boxes. Boxes were labeled with standard labels.

\section{Soil Susceptibility and Archaeomagnetic Samples}

The 103 soil susceptibility samples, collected from sites 41TG378, 41TG389, and 41TG410, were taken to Dr. Wulf Gose at the Paleomagnetic Laboratory, Department of Geological Sciences, The University of Texas at Austin. Once there, the soils were removed from bags and placed in plastic two-centimeter cubes. The cubes were labeled alphabetically in order to provide a cross-reference with their provenience at the site. Each sample was then placed in a normal magnetometer at room temperature to measure its magnetic susceptibility (see Appendix J).

The 11 archaeomagnetic core samples drilled from fire-cracked rock in Feature 1, 41TG389, were also taken to Dr. Wulf Gose at the Paleomagnetic Laboratory. There the samples were cut down to 0.9 inches in length and labeled with pelican ink. Next they were placed in a helium-cooled cryogenic magnetometer to record their natural remanent magnetization signature. They were then subjected to thermal demagnetization to as high as $600^{\circ} \mathrm{C}$ in increments of $50^{\circ} \mathrm{C}$. After each heating event they were allowed to cool and their magnetic signature was measured in the magnetometer and recorded on a computer database before being reheated to the next higher increment (see Appendix J). 


\section{Site Forms and Mapping}

State trinomials were obtained from TARL for each site identified during the survey. The information recorded on the site recording forms in the field was transferred to TexSite software for filing with TARL. Site and artifact data used in analyses were provided in a database form compatible with Microsoft Excel. In addition to the general maps in this report, an additional sets of maps of the project area were prepared for the Bureau of Reclamation. These show the locations and site boundaries for all cultural resources in the inventory plotted on 7.5' Series USGS quadrangles.

\section{Curation}

Finally, all field notes, forms, photographs, and drawings, along with a copy of this report on acid-free paper, and computer disks pertaining to the investigations at Twin Buttes are stored in acid-free boxes at CAR. All cultural materials were retained at the CAR laboratory for permanent curation. 


\section{Chapter 7: Prehistoric Data Research Perspective, Analytical Issues, and Project Goals}

\section{Raymond Mauldin}

This chapter outlines the research perspective that guided aspects of the prehistoric data collection and analysis which are discussed in the next two chapters. Aspects of the research perspective, as well as the analytical approach, are somewhat different than commonly used in survey reports in the region. For this reason, a background to this perspective, as well as a discussion of how this perspective differs from more common schemes, is provided, along with a series of project goals that guided the prehistoric data collection and analysis.

\section{Background}

A review of several survey projects in the immediate Twin Buttes area, presented in Chapter 5, finds that the archaeological record is often conceptualized as consisting of sites that result from past decisions concerning where to locate camps, where to gather raw materials and food, where to bury the dead, and where to produce stone tools. The goal of the archaeologist is to discover those sites, describe the patterns, reconstruct the decision process at a general level, and investigate reasons for changes in the decision process through time. Critical to that perspective is the notion of site types. Surveys that actually attempt to assign sites to categories typically identify four or five types into which sites are placed, and assign temporal affiliation to these types by reference to projectile points or ceramics that have been shown elsewhere to have chronological significance. Often, these site types are simply descriptive classes, such as a burned rock midden site, lithic scatters, rock shelters, or burial sites. In more recent years, several projects have used these terms as interpretive constructs that involve behavior, such as lithic procurement sites, quarries, or habitation sites. Only within the last few years have organizational concepts been considered (e.g., foraging based residential site), and the number of attempts to actually grapple with the organizational complexities in analysis are minimal (but see Nickels et al. 1997).
The use of quasi-functional terms (e.g., campsite, lithic procurement site) is not uncommon in the state (e.g., Etchieson et al. 1979; Hurt 1980; Word 1977). A recent regional example is provided by the Justiceburg Reservoir survey conducted by Prewitt and Associates in Garza and Kent counties to the north of the current project (Boyd et al. 1989). Boyd (1989:108109 ) identifies several different site types, including lithic procurement areas, open campsites, rockshelters, lithic scatters, and lithic procurement/open campsites. While these types represent a mixture of functional (lithic procurement), geological (rockshelters), and descriptive (lithic scatters) terms, Boyd defines several of the types by reference to site functional characteristics. Open campsites are identified by the presence of burned or fire-cracked rock, late stage reduction, and finished tools. Boyd notes that "classification as a campsite assumes that food preparation (i.e., cooking) is represented" and that "these activities took place mainly at habitation sites" (Boyd 1989:108). Lithic procurement sites are located on gravel outcrops, and contain evidence of raw material testing (e.g., tested nodules) and early stage reduction (e.g., cores, primary flakes) and generally lack formal, finished tools and burned rock. The lithic procurement/open campsites contain attributes of both site types, and lithic scatters are "similar to campsites, but contain only sparse evidence of later stages of lithic reduction and occasional finished artifacts and manufacturing failures." (Boyd 1989:109). These site types are then assigned to specific temporal periods, and compared across topographic settings to investigate the use of the Justiceburg area across space and through time.

These, as well as similar studies, clearly are a logical outgrowth of the notion that the archaeological record is composed of sites that reflect prehistoric behavior. In the following chapter, we will use aspects of their approach in our analysis. However, such an analysis is problematic because the picture of the archaeological record produced by the application of 
this approach to the Twin Buttes survey data, as well as any other survey data set, is one of discrete packages of artifacts (sites) that date to a single or a few temporal periods and have a specific role in the overall settlement system operating at those time periods. For example, during the Early Archaic, we may have campsites, assumed to be habitation, and sites at which lithic procurement occurs. These sites are then contrasted to sites from other periods, essentially creating a series of synchronic models of adaptation. Differences between these synchronic models are compared, and differences in the number and distribution are explored as clues to how the adaptations differ. That is, the distribution and number of these various site types through time forms the basis of interpretations.

From this perspective, the ideal survey site is one in which only a limited range of behavior is reflected and which can be assigned to only a single temporal interval. Those survey sites that lack temporally diagnostic artifacts, have diagnostic artifacts that reflect more than one component, or have evidence of multiple behavioral themes (e.g., lithic procurement, habitation, etc.) that lack any spatial separation between the themes are necessarily less useful in interpretation. In fact, Collins (1995) has recently argued that research should focus on both finding and excavating temporally isolated, geologically sealed deposits as a way of maximizing our understanding of the archaeological record in Central Texas.

Unfortunately, reality is likely to be much more complicated than the picture of the past produced by this approach. It is likely that over the past 11,000 years, various places on the Twin Buttes landscape were used for a variety of different activities during any particular temporal period. It is likely that the activities were organized differently during different time frames. These same locations were potentially then reused for other activities at later points in time. Sometimes temporally diagnostic artifacts were deposited, and sometimes they were not. The archaeological landscape created is likely to be a complex arrangement of artifacts formed over thousands of years by both culturally organized behavior and by process of erosion, deposition, and turbation. The pristine sites searched for by Collins (1995; Collins et al. 1990) and others may simply be situations in which we are still ignorant of the processes that have shaped the record. From my perspective, the goal of archaeology is to understand all those processes that both create the archaeological record and shape our interpretations of that record. These processes include everything from culturally organized behavior through conceptual schemes used by archaeologists to interpret that record. We are competent at understanding some of these processes, and there are probably others that we have not even recognized.

\section{Current Perspective}

For a survey project such as this, the archaeological record consists of artifacts spread at varying densities across the landscape. The archaeological patterns observed and interpreted on any survey can be conceptualized as the result of the intersection of four different spheres, two of which create the record, and two of which sample and interpret the record. The baseline archaeological data are the result of a complex interaction between 1) the history of artifact deposition and feature construction at various places on the landscape and 2) the history of processes that alter those artifacts and features, as well as the landscape itself. That record is then observed by researchers using 3) a conceptual scheme, often implicit, that involves ways to sample that record (e.g., transect spacing) and group the data (site definitions). The resulting data base is then 4) interpreted to present a picture of what happened in the past.

\section{The Formation of the Archaeological Record}

The notion that the surface archaeological record is composed not of sites, but of artifacts, is not common among researchers in the state, or elsewhere. However, several researchers have convincingly argued that the survey record is in fact one of artifacts at varying densities, and that we create sites at a conceptual level (Binford 1992; Camilli 1988; Dunnell 1992; Dunnell and Dancey 1983; Ebert 1992; Larraldi 1988). We do not observe sites directly in the record. In fact, in a survey situation such as Twin Buttes, features as defined by some density of concentration of fire-cracked rock (FCR), are also a construct. Certainly, sites as 
locations of specific sets of behaviors did exist in the past. Groups of people did camp at various locations, did procure raw materials, and did produce artifacts and features. But the idea that the archaeological record is generated at an ethnographic time scale is probably not a realistic one. That is, we often conceptualize archaeological sites as reflecting a small slice of time generated by a single group conducting some finite set of activities, analogous to an ethnographic description. However, there is no necessary connection between the sites we define in the present based on arbitrary criteria and those behaviors that existed at any given point in the past. High densities of artifacts can be produced by many different processes. What we probably have in most cases are concentrations of artifacts that were deposited across a landscape at different times and at different rates.

Once deposited on the landscape, artifacts may be subject to a variety of processes minimally including bioturbation, scavenging, erosion, and deposition (e.g., Butzer 1982; Schiffer 1987; Waters 1992; Wood and Johnson 1978). In Chapter 2, we provided a series of examples of processes that impact the artifacts discovered on the Twin Buttes landscape. From a strict site behavioral position, all of these processes distort the archaeological record. From the current perspective, these processes form the record that we see, and, as such are a subject worthy of understanding. That is, the archaeological record is a current phenomena, not a fossilized or distorted picture of the past. For this survey, we view sites as arbitrarily defined locations of higher density concentrations of artifacts, including FCR. We wish to understand how they came to be in the position and configuration that we observed.

\section{Observing and Interpreting the Record}

Once formed, archaeologists observe the record using a number of conventions. The definition used on the current survey for a site, outlined in the previous chapter, is arbitrary. Had we chosen a different definition, such as that used by Boyd in the Justiceburg survey (Boyd et al. 1989) in which all isolates are given site status, there would have been over 500 sites, with a very different spatial distribution. Had we chosen a more encompassing definition, such a minimum of 10 artifacts over 100 square meters used as a standard by the United States Forest Service, we would have had many fewer sites, with different spatial and temporal distributions. All these definitions are equally arbitrary and equally justified. Changing these arbitrary definitions can change the number, distribution, size, and temporal affiliation of sites in a given project (see Mauldin 1995; Mauldin et al. 1999; O'Leary et al. 1997). The situation is analogous to the use of Minimum Number of Individuals (MNI) in faunal analysis (see Grayson 1984). That is, decisions that archaeologists make in terms of analytical units, in this case what constitutes a site and an isolate, greatly impacts not only the number of sites, but also the interpretation. Archaeologists, then, commonly structure the archaeological record simply by deciding what is, and is not, a site (O'Leary et al. 1997).

Additional considerations involve how we choose to sample the record. In survey, this is primarily determined by transect spacing. Controlled research elsewhere has shown that transect spacing can significantly impact both the number of sites observed, and the size of the sites (Mauldin 1995; Mauldin et al. 1999; O'Leary et al. 1997). The definition of what constitutes a site, and decisions about transect spacing, determine what artifacts are grouped together for analysis. In turn, it is that grouping which forms the basis of interpretation. Critically, different decisions at this level can produce radically different visions of what happened in the past.

Finally, once described, patterns must be interpreted. For cultural behavior, our own interpretive scheme comes, in part, from a theoretical background that can be most effectively classified as cultural ecology. We view cultural systems as adaptive and differentiated. By adaptive we mean that cultural systems are continually responding to changes in the natural and social realms, including changes that are a product of their own actions. Of particular concern in this regard are the strategies and tactics used to acquire food, fuel, and raw material resources from the environment. By differentiated, we mean that different activities are conducted at different times and places depending on specific circumstance. That is, the activities conducted at a location may vary considerably depending on a 
variety of specific circumstances, and the material remains left by those activities at a location will also vary. Consequently, radically different material cultural remains may be generated by individuals operating within the same cultural system.

Changes in cultural systems are, under this position, the result of changing parameters in the natural and social environments. Currently, our understanding of the mechanisms of changes in the societal realm are not as well developed as our understanding of the impact of changes in the natural realm. Especially critical in the latter arena involves strategies and tactics of energy capture, including technology, mobility, and settlement strategies used in resource acquisition. It is in this realm, where cultural systems interact with the paleoenvironment, that extant adaptive strategies are molded and constantly modified. We see changes in those strategies as a result, to a large degree, of interactions at this cultural and natural interface.

\section{Implications and Project Goals}

The implications of this overall research conception of the archaeological record are many. They range from ways that survey is conducted through analytical and interpretive decisions. In an ideal world, an archaeological survey such as this would be conducted with transect spacing that insured 100 percent of the ground surface would be observed, perhaps on the order of two to five meters in certain ground cover. All artifacts would be described and point provenienced, allowing the grouping of artifacts at a variety of different spatial scales, and subsurface testing would be systematic and at a high density, rather than concentrated on sites. We would also have a complete understanding of the geomorphology. The actual constraints of the project in terms of time and money make such a complete description of the record impossible. Consequently, we attempted to balance our overall research concerns with the needs of the United States Bureau of Reclamation (USBR) for management data.

Given these considerations, there are several fundamental data needs which, in the context of the current survey, guided the data collection and analysis. These included providing information to the USBR regarding traditional concerns such as the location of archaeological sites, providing information on of the integrity of archaeological deposits, as well as their chronological placement. In addition, we wanted to document some aspects of the technology represented both with regard to subsistence and activities at a location. In the course of accomplishing these goals, we are constantly concerned with learning not only how prehistoric populations used the Twin Buttes area, but how our conceptual schemes and analytic decisions influence the patterns that we observe.

\section{Archaeological Integrity}

The integrity of archaeological deposits is usually viewed as a critical component of any description of an archaeological record for both management and research concerns. Sites which are viewed as being mixed temporally or jumbled physically are commonly dismissed as having low integrity, and by extension, low research value. These often include surface sites as they are subjected to a variety of processes that buried, sealed deposits are not. It is this later class, the sealed, single occupation site, which is given high integrity ratings and assumed to have high research value.

As noted above, with sufficient temporal resolution, it is probably the case that all assemblages, including the sealed, "pristine" sites, are mixed by cultural and physical processes. The mere fact that a site is currently subsurface tells us little about the integrity, for all sites were, at one time, on the surface. More critically, integrity as used here is not synonymous with overall research value. We suggest that integrity is productively viewed as a continuum with respect to specific research questions. Integrity as a proxy for research value can only be considered with regard to a particular suite of questions. For some questions, sites such as those searched for by Collins (1995) are critical, but for other questions, sites that traditionally are viewed as having low integrity, are critical. For example, if our research goals are centered on reconstructing the subsistence patterns during a particular temporal period, sites which have been repeatedly occupied by a variety of different groups over thousands of years have low research potential. Conversely, single component sites, those 
traditionally viewed as having high integrity and high research potential, are of little use if our research questions center on understanding processes of reoccupation or processes of long-term change in the use characteristics of a given location.

Here, we have a tripartite distinction with regard to integrity, though it should not be considered synonymous with research value. Based on a combination of surface descriptions and site location, shovel test data, and geomorphic context, we divide sites into those with high, moderate, and low integrity. Sites with high integrity tend to have buried deposits which are consistently revealed in several shovel tests at similar depths. In contrast, sites with low integrity tend to be surface deposits with small assemblages. Of course, we have little information on the history of deposits, and so those classified as high integrity may in fact have mixed temporal and activity sets. All that is implied by our high integrity assessment is that there is some indication of additional material buried subsurface at consistent levels. It is a management tool rather than a research assessment.

\section{Temporal Patterning}

We assign site assemblages to temporal periods such as Paleoindian, Early Archaic, Middle Archaic, Late Archaic, and Late Prehistoric. When no diagnostic artifacts are discovered at a site, we place it in a temporally unknown group. Table 7-1 presents these temporal periods, dates, and the diagnostic artifacts that we use to make these prehistoric assignments. We make the assumption that artifact types such as projectile points found on a site provide a date range for the occupation of other artifacts found at that site. This assumption is certainly incorrect in an unknown number of cases. That is, assuming that the basic cross-dating is accurate for a point style, there is no necessary relationship between that point and other material in terms of chronology. However, it is standard archaeological practice to make this assertion.

\section{Lithic Technology}

The study of technology is related to questions of subsistence and settlement for many of the lithics observed at a site or component may reflect the acquisition and processing of resources. A variety of attributes are monitored using the quantitative data collected from the Surface Observation Areas (SOAs) on this project, as well as qualitative and presence/absence data for all sites. Artifact type designations included flakes, cores, tested cobbles, unifacial and bifacial retouch items, utilized and marginally retouched flakes, hammer stones, and ground stone. Variation in the frequency of these debitage and tool types may reflect differences in both reduction activities as well as site specific activities preformed at a location. Similarly, cortex percentage was monitored on all debitage from the SOAs, and qualitative and presence/absence data are available for all sites. Several studies suggest that there is a general relationship between the amount of cortex coverage and the reduction trajectory (e.g., Magne 1985). Combined with the lithic tool data, these data will be used in considering site types.

\section{Site Types}

We have two different data sets and two approaches to investigate this complex issue. The first is similar to the traditional application of site types outlined previously which relies on a definitional approach. Qualitative data, as well as presence/absence data on artifact types and features are used to assign sites to classes. These data are available for all sites and will form the basic descriptions presented in the following chapter. Essentially three types of sites are identified. Campsites are identified by the presence of features, firecracked rock, late stage reduction debris, and late stage bifaces and other tools. These are assumed to represent some form of habitation site. Lithic scatters essentially are areas without features or fire-cracked rock. These are assumed to reflect a variety of activities, including lithic procurement as well as other specialized activities. Finally, there are sites in which both types of data are present but spatially discrete. These are classified as campsite/lithic scatters. 
Table 7-1. Temporal Periods, BP Date Ranges, and Selected Diagnostic Artifact Types*.

\begin{tabular}{lll} 
Period & Time-Frame (BP) & Selected Diagnostic Types \\
PaleoIndian & $12,000-8000$ & $\begin{array}{l}\text { Golondrina, Barber, Plainview, } \\
\text { Folsom, Clovis. }\end{array}$ \\
Early Archaic & $8000-6000$ & $\begin{array}{l}\text { Martindale, Uvalde, } \\
\text { Early Split Stem/ Early } \\
\text { Triangular, Angostura, Baker, } \\
\text { Bandy, Guadalupe Tools }\end{array}$ \\
& & $\begin{array}{l}\text { Nolan, Travis, Taylor, Bell } \\
\text { Andice, Pandale. }\end{array}$ \\
Middle Archaic & $6000-4000$ & $\begin{array}{l}\text { Darl, Ensor, Frio, Fairland, } \\
\text { Marcos, Montell, Castroville, } \\
\text { Late Archaic }\end{array}$ \\
& $4000-1200$ & $\begin{array}{l}\text { Lange, Langtry, Marshall, } \\
\text { Williams, Pedernales, Kinney, } \\
\text { Bulverde, Trinity, Tortugas. }\end{array}$ \\
& & Perdiz, Scallorn, Edwards. \\
\hline
\end{tabular}

*From Collins 1995; Hester 1995; Turner and Hester 1993.

\section{Site Types, Task Variety, and Organization}

For 97 sites, we have quantitative data on artifacts collected at our Surface Observation Areas (SOAs). These data, introduced in Chapter 2, will be used in Chapter 9 to investigate site types and site type issues in more detail. Controlled, quantitative data from a variety of assemblages will be used for basic pattern recognition studies in a manner similar to that presented by Nickels and others (Nickels et al. 1997). When we use these SOA data to investigate site level patterns, we are assuming that the material from the collection area is representative of the material on the site. This assumption is incorrect in an unknown number of cases.

Our concern here is with the role that a location plays in the overall settlement and subsistence system, rather than simply the activities conducted at a location. That is, we will be concerned, at least in part, with how settlement systems are organized. It is increasingly common to draw the distinction in archaeological studies of hunters and gatherers between foraging and collecting as different strategies used to organize settlement in different environments or during different seasons within the same environment. Binford (1980; see also Kelly 1983, 1995) argues that foragers are characterized by the movement of food to people on a daily basis while collectors move food to people over a longer time frame. A foraging organization is modeled as having frequent residential moves as food resources in the immediate area are exhausted, daily inputs of resources to the residential camp from the immediate area around a residential site, generally small group size, and little or no bulk storage. In contrast, collectors are characterized by lower frequency of residential moves, larger residential group size, bulk inputs of food to the residential location by specialized task groups, and bulk storage. Binford (1980) suggests that these two types of strategies are responding to different distributions of resources, with foraging being used in settings that have ubiquitous, low density resources, and little seasonality and a collector form of organization used in settings with temporal and spatial incongruity of resources. Both strategies can be options within the same overall system, responding to seasonal or longer term changes in the distribution and character of the resource base. Both strategies can be operating in the same cultural system at the same time. 
Binford (1980) suggests that systems that are using a foraging organization generally produce two types of sites - residential sites and locations. Residential sites are likely to be characterized by low to moderate density of artifacts, structures, and features, though structures are not a necessary component of such sites. Locations are areas within the foraging radius where resources are gathered and transported back to the residential site on a daily basis. These areas should have extremely low artifact density. Collectors generate a wider variety of site types, including residential base camps, locations, field camps, stations, and caches.

Critically, Binford's descriptions of these systems is at a temporal scale analogous to an ethnographic time scale. As we argued above, this scale is not analogous to an archaeological time scale. The long-term patterning of land use produced by the operation of these strategies in a given area involves reuse of different types of sites for different purposes and changes in the organization at both short term and longer temporal scales which complicate any archaeological pattern. In a collector system, residential sites occupied for one season may be reused as special purpose locations, and then reused as residential sites at later points in the year (Binford 1982, 1983). The archaeological patterning produced by the pattern described by Binford is likely to be complex. This is also the case in systems characterized by simple foraging. This can be seen in Figure 7-1 which uses data for the //Gana of southern Africa presented by Silberbauer (1981:194-198, 246; see also Tanaka 1980). The top portion of the figure presents settlement patterns for a two year period. Residential rainy season sites are composed of larger groups and are generally created between December and July, while dry season residential sites are made up of smaller family units and, in most years, are created from August through November. The bottom portion of Figure 7-1 presents the same two-year summary with the addition of a foraging radius of $5 \mathrm{~km}$ incorporated for each site. It is in this foraging radius that locations are produced. Locations should consist of a low density of artifacts deposited across the landscape. At a two-year scale, the patterns produced are complex. Artifacts and features created and deposited at residential sites are often within the foraging radius of other residential sites, seasonal ranges overlap, and foraging radii of several different residential locations overlap to potentially form areas of artifact clustering. Recall that this is only a two-year summary of a relatively simple system with little seasonality. Repeat this pattern for several thousand years. Introduce more seasonality and the potential for seasonal switches to a collector system. Complicate the pattern further by erosion, deposition, and turbation of sediments. Given this potential complexity, any attempt to associate archaeological sites, observed and defined in the present, with past systems of settlement organization, should be undertaken with both caution and suspicion.

Methods for differentiating foraging from collecting organizations, in the face of this level of complexity, are not developed. However, we can at least begin to approach this issue by looking at two different measures, artifact variety relative to sample size, and assemblage content. We will attempt to make a distinction between special purpose locations and residential locations, and then consider assemblage content to help clarify these patterns in terms of organizational difference.

At a general level, residential sites should be distinguishable from more limited activity sites by patterns in artifact variety. That is, more varied activities are conducted at most residential sites when compared to special purpose locations. Even simple foraging residential sites (e.g., see Nicholson and Cane 1991; Yellen 1977) have a wider variety of activities relative to the locations generated by foraging groups. These differences are exacerbated when we compare a residential site in a collector based system with special purpose locations. Such differences in terms of activity variety should be observable in measures of artifact variety.

We cannot, however, simply rely on measures of artifact variety to reflect task variety, as a number of researchers have demonstrated that sample size influences measures of artifact variety (Bobrowsky and Ball 1989; Jones et al. 1983; Kintigh 1984, 1989; McCartney and Glass 1990). As the number of items within a site increases, the probability that new artifact types will be identified also increases. Measures of artifact variety, then, will be closely related to sample size. Using measures of artifact variety will 
Figure 7-1. //Gana settlement patterns.

Top: Dry and Rainy season camps. Bottom: Overlapping foraging radii (After Silberbauer 1981:246; Mauldin 1995:110-111).
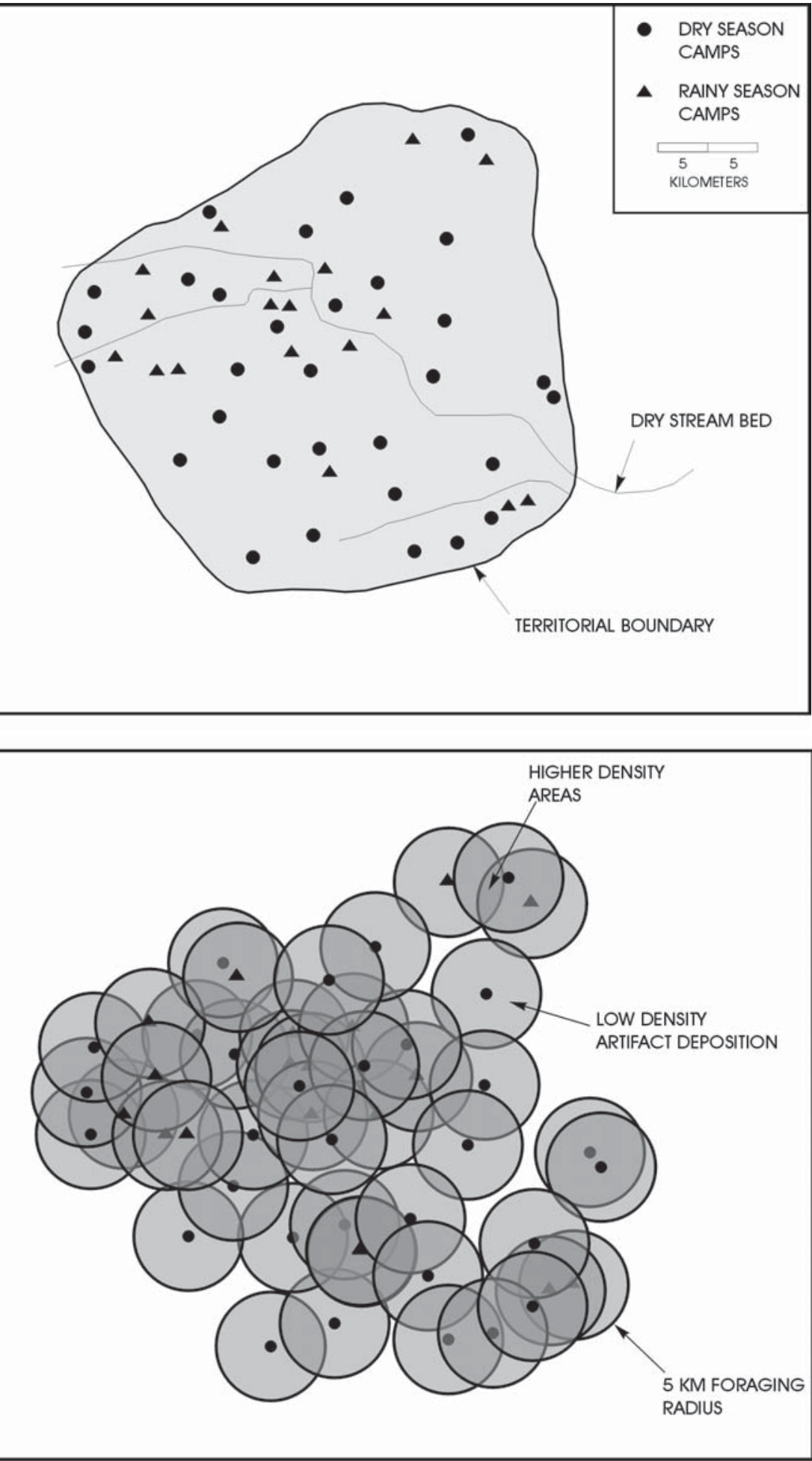
simply result in sites with larger assemblages being classified as high variety, potentially "residential" occupations, while smaller assemblages are placed in the limited variety, "special purpose" group. Here, we will use relationships between artifact variety and sample size at the site level to initially identify those sites with higher and lower variety. By comparing artifact variety, measured as the number of types present in an assemblage, relative to the sample size of the assemblage, we arrive at expectations expressed in Figure 7-2. Note that under this scenario, reoccupation of special purpose sites for the same range of activities will contribute more artifacts, increasing assemblage size, but fewer new artifact types will be introduced. Reoccupation or protracted occupation of a location for residential activities, however, will deposit new artifact types relative to sample size. That is, these two gross classes of sites should occupy different areas of Figure 7-2.

However, a number of different reoccupation or use scenarios can place a given assemblage in the high and low variety area of the figure. For example, the reoccupation of special purpose locations for different activities will create a situation of high variability relative to sample size. Low variability should be indicative of special purpose locations which are not reoccupied for different tasks, though residential sites with extremely short periods of occupation could fall into this portion of the graph as well. Sites that are eroded, forming palimpsests of artifacts from different activities on the surface will probably have higher variety measures, while assemblages that are only partially exposed may have lower variability. In addition, we have no expected patterns for what residential and special purpose site assemblages should look like, and a variety of complications, including different curational and depositional rates for different activities can be imagined. The assessment of variability, however, provides only an initial foray into an extremely complex problem. Yet, in spite of these ambiguities, the overall relationship has proven useful in other contexts (e.g., Mauldin 1996; Thomas 1983).
Additional information may come from investigating assemblage content. Within both the low variability and high variability groups, assemblages with different and redundant content can be anticipated. For example, sites used for lithic procurement should have not only a low number of artifact types, but also a specific set of artifact types. That is, locations on the landscape that were used exclusively for lithic procurement should have a low frequency of tertiary flakes, a high frequency of primary flakes, high frequencies of cores with cortex, tested cobbles, and, potentially, bifaces commonly designated as quarry blanks and preforms. Similar assemblage sets may be present for other assemblages generated at special purpose sites. It is, of course, possible that such locations could be reoccupied for different activities, and thus the lithic procurement assemblage signature, for example, would be obscured. The variability measures of such sites would, however, be high, placing then in the upper portion of Figure 7-2. That is, these composite assemblages would not initially be identified as special purpose locations.

We suggest that by using a combination of artifact variety, sample size, and assemblage content, it will be possible to at least begin to differentiate those locations that have assemblages reflecting a limited range of tasks from those locations with assemblages suggesting a wider variety of tasks. It may further be possible to suggest that some of the low variety assemblages were used as special purpose sites and some of the high variability sites were used as residential locations. Finally, it may be possible to outline some broad range of activities, such as lithic procurement, that some of these assemblages reflect. These distinctions, however, do not reflect directly on how those systems are organized. That is, they do not tell us if the systems were organized as collectors, foragers, or some combination of the two. Nevertheless, it is the case that special purpose locations should be more characteristic of collector based systems. Foraging systems should have few sites that would be identified as special purpose locations using these procedures. 
Figure 7-2. Expected relationships between number of artifacts, number

of artifact types, and task variety (after Mauldin 1996).

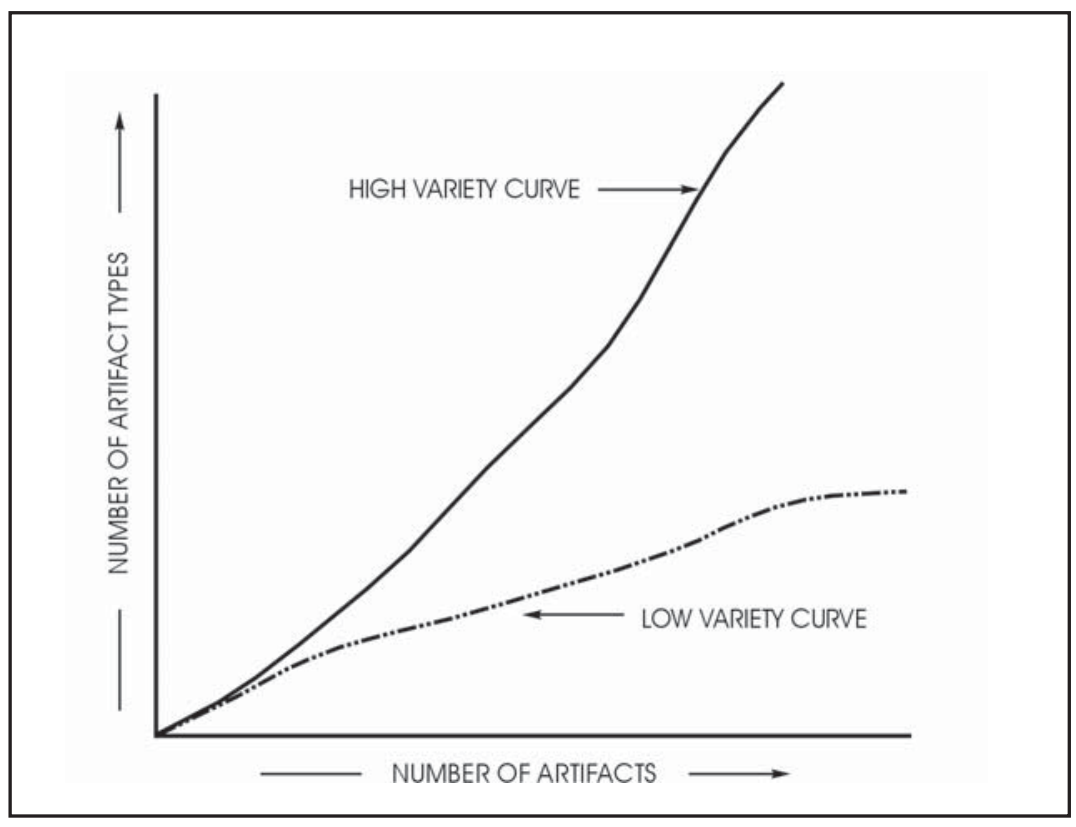

\section{Conclusion}

The archaeological record is a current phenomena, generated over thousands of years. A single location may be used for a variety of different activities during any particular temporal period. Locations were potentially reused for other activities at later points, with each set of activities organized in different ways. The archaeological landscape created is likely to be a complex arrangement of artifacts which are further structured by erosion, deposition, and turbation. We then observe the record, using sampling procedures and definitions which are often implicit. These implicit procedures include defining sites. Sites are arbitrary concepts, created by us, which have an unknown relationship to centers of prehistoric activity. The pattern of sites and isolates assigned to various temporal periods and various site types, which we create to a substantial degree by our analytical choices, does not directly reflect organizations of settlement, mobility, or subsistence in the past. Part of the potential problem we face can be seen by referring to patterns outlined in Chapter 2. For example, when Etchieson (1985) describes 41TG245 in 1985, the lack of features, fire-cracked rock, tertiary flakes, formal tools, and the dominance of primary and secondary flakes, probably identifies the site as a small lithic procurement area in most schemes. In 1999, the site is a small campsite. In a few more years with a little more erosion, it is likely to link up with 41TG246 and 41TG247 to the north and become a large campsite, certainly reflecting significant habitation. In fact, using a more generous site definition, these separate sites could easily be included as a single site at the current time. Using more closely spaced transects would probably also result in the creation of a single, large site that would certainly be classified as reflecting habitation in most schemes.

If we are to develop useful descriptions of the archaeological record, and begin to explain the patterns described, we can no longer assume that a survey records a simplistic, potentially distorted, reflection of past settlement and subsistence. I have suggested several avenues that may lead to a greater understanding of the archaeological record. Then again, they may not. The problems are complex. Nevertheless, to continue to make the assumptions that are common in survey projects in much of the state is unlikely to lead to any significant increase in our understanding of the archaeological record. 


\section{Chapter 8: Survey Results and Prehistoric Data Analysis}

\section{Raymond Mauldin}

This chapter presents descriptive data, at a general level, for prehistoric sites and isolates identified on the Twin Buttes survey. Only prehistoric material is considered here. Historic sites are discussed in Chapter 11. My goal in this chapter is simply to provide an overview of general patterns rather than a detailed discussion of each individual site and isolate found on the project. Details on individual prehistoric sites, including individual site maps, can be found in Appendix A, and information on specific isolated finds are presented in Appendix G. This chapter is divided into five sections. The first section provides an overview of the survey results, including information on several of the artifact and feature types represented on sites. The second and third sections discuss site types and temporal patterning at the site level. The fourth section presents information on isolated finds recorded on the survey. The final section of this chapter provides a brief summary.

\section{Survey Results}

As noted in Chapter 1, the Twin Buttes archaeological project involved a 100 percent pedestrian survey of 10,195 acres. We identified a total of 178 new sites, and 21 previously recorded sites were revisited. Onehundred and ninety-two of the 199 sites had prehistoric material. In addition to the survey, CAR archaeologists analyzed over 21,000 artifacts on 97 selected sites, a data base discussed in the following chapter, and conducted 1,058 shovel tests, 57 auger tests, and the excavation of five 1-x-1-meter units on sites. These data sets, provided in the Appendices B and $\mathrm{C}$, are used in both the site descriptions in Appen$\operatorname{dix} \mathrm{A}$, and in the evaluation of sites presented in the final chapter. In addition to recording data on the 199 archaeological sites, the project recorded a total of 393 isolated finds, the vast majority of which were prehistoric (see Appendix G).
Of the 192 prehistoric sites, we have consistent data gathered during the present survey for 190. The two sites with minimal information are 41TG91 (Creel 1990) and 41TG243 (Etchieson 1985). Both of these sites were relocated during the current survey. However, qualitative data comparable to the remaining 190 sites was not generated. At 41TG91, a small quantity of material was observed on the surface, but no systematic attempt to scour the area was undertaken. While we will use 41TG91 in considerations of temporal patterning, using data generated by Creel (1990), we will not use this site in our investigations of assemblage content, site size, or distance to water. Similarly, the location of 41TG243 was revisited, and a single shovel test placed at the location, but information of assemblage data was not gathered as no artifacts were seen on the current surface. We can assign this site, based on Etchieson (1985) to an unknown temporal period, but little additional information is available. In addition, for several sites (e.g., 41TG118, 41TG160) described by Creel (1978) we only have a small sample of the total site as the majority of the assemblage was located outside of our current survey boundaries.

For the remaining 190 sites, we have a variety of data sets that can be used to consider prehistoric settlement and adaptation. These data sets include presence/ absence observations on six different artifact types (i.e., debitage, cores and tested cobbles, bifaces, unifaces, utilized and/or retouched flakes, and ground stone) and on fire-cracked rock. Quantitative data on the number of features, number of mortar holes, site size, distance to water, and site elevation are also available. For most sites, we also have estimates of the number of items present on the surface. These estimates can be used as ordinal level data. Finally, we have data on the temporal placement of assemblages based on temporally diagnostic artifacts. 
Site Density, Characteristics, and Distribution

Figure 8-1 presents the distribution of the 190 sites that form the primary data base in this chapter. Including 41TG91 (not shown in figure), an overall prehistoric site density of .0187 sites per acre, or 1 site for every 53.38 acres of surveyed land, is present. Data on site density are available for three somewhat comparable projects in the rolling plains natural region, the O. H. Ivie Reservoir Project in Concho,
Coleman, and Runnels counties, the Justiceburg Reservoir Project in Garza and Kent counties, and Creel's (1978) survey of a section of the South Concho River in the immediate project area. Trierweiler et al. (1993:113-115), citing data from Woolridge et al. (1981), present site density information for the O. H. Ivie Reservoir Project, located about 50 miles to the east of Twin Buttes at the confluence of the Colorado and Concho rivers. They divide the data set into three drainage and elevation strata, the Upper Colorado River drainage, the Lower Colorado River drainage,

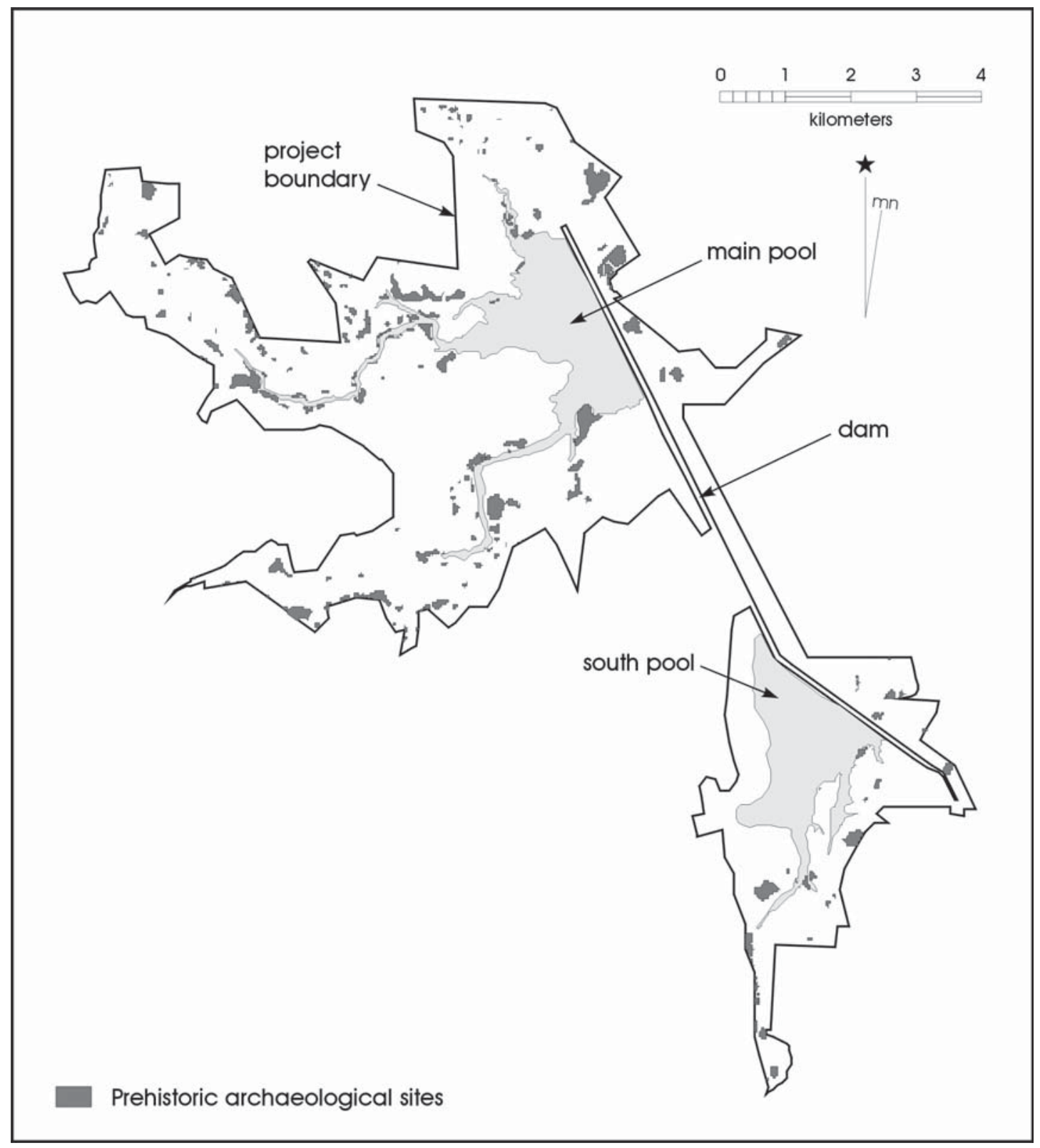

Figure 8-1. Site distribution, Twin Buttes Reservoir. 
and the Upper Concho River drainage. Site density ranges from a high of 1 site per every 59.36 acres in the Upper Colorado drainage, to a low of 1 site for every 72.74 acres in the Lower Colorado drainage strata. Boyd (1989:107), working on the Justiceburg Reservoir Project located about 110 miles to the north of Twin Buttes along the Brazos River in the Rolling Plains region, reports a much higher site density of 1 site for every 35.39 acres, while Creel (1978) recorded 49 sites in approximately 4,942 acres along the South Concho, an overall density of 1 site for every 100.86 acres. While a variety of factors, including survey procedures, exposure, and site definitions certainly impact the number of sites, the Twin Buttes density of 1 site for every 53.38 acres of surveyed land is within the range of those reported for other comparable surveys in the region.

Site density also varies relative to the three major drainages in the project area. Roughly 40.5 percent of the surveyed lands are associated with the Middle Concho, and a total of 105 prehistoric sites are present in this land area for a density of 1 site for every 39.82 acres. Spring Creek drainage, comprising about 34.3 percent of the survey, has a site frequency of 1 for every 64.82 acres, and the South Concho has the lowest overall density within the project of 1 site for every 75.48 acres of surveyed land. The higher site densities in the Middle Concho may be related to the higher overall water flow of this drainage relative to Spring Creek. While we demonstrated in Chapter 3 that, at the present time, there is little or no flow in the Middle Concho, the drainage basin and size and depth of the Middle Concho suggest that this river contained significant water flow at some point. Note also that the low densities for prehistoric sites along the South Concho, a river with significant and consistent water flow, is probably the result of the land available for survey. Recall that a significant portion of the land directly associated with the South Concho was under water at the time of survey (see Figure 8-1). As will be demonstrated below, the frequency of sites increases as the distance to water decreases, and thus site densities are probably much higher for the South Concho than the figure of 1 site for every 75.48 surveyed acres indicates.

Table 8-1 presents mean, median, upper and lower quartiles, and the minimum and maximum values for the sites with reference to distance to water $(\mathrm{km})$, elevation $(\mathrm{ft})$, and site area $\left(\mathrm{m}^{2}\right)$. Within the survey area, elevation ranges from 2,000 to 1,880 feet, though the vast majority of surveyed lands were between 1,940 and 1,900 feet, with the lower boundary being a function of water levels at the time of survey. An examination of the minimum and maximum site elevations in Table 8-1, as well as the distributional data in that table, will demonstrate that archaeological site elevations are between 1,880 and 1,985 feet, and that 50 percent of the archaeological sites are located between elevations of 1,910 and 1,945 feet. These site elevational ranges, then, seem to generally reflect the elevational ranges within the surveyed lands.

Table 8-1. Selected Characteristics of 190 Prehistoric Sites at Twin Buttes

\begin{tabular}{|c|c|c|c|}
\hline & $\begin{array}{c}\text { Distance }(\mathrm{km}) \text { to } \\
\text { Water }\end{array}$ & $\begin{array}{c}\text { Elevation } \\
(\mathrm{ft} .)\end{array}$ & Site Area $\left(\mathrm{m}^{2}\right)$ \\
\hline Mean & .541 & 1929.74 & 11275.95 \\
\hline 1st Quartile & .000 & 1910 & 1655 \\
\hline Median & .250 & 1930 & 3770 \\
\hline 3rd Quartile & .758 & 1945 & 11177.50 \\
\hline Maximum & 3.20 & 1985 & 128850 \\
\hline Minimum & .000 & 1880 & 40 \\
\hline
\end{tabular}


Comparisons of the mean, median, and quartile values for site area will demonstrate that the distribution is skewed. The majority of sites are small, with 50 percent of the cases being below 3,770 square meters. The mean value of almost 11,276 square meters is greatly influenced by a few extremely large sites, including site $41 \mathrm{TG} 385$, with a site area of 128,850 square meters, and three additional cases (41TG247, 41TG252, and 41TG424) with areas above 100,000 square meters.

An examination of Figure 8-1 and Table 8-1 will demonstrate that distance to water is also skewed. That is, a significant portion of the sites are located close to one of the three major drainages, the Middle Concho, Spring Creek, and the South Concho, that cut through the project area, and a few sites are located well away from drainages. This focus of settlement on extant drainages, while in part related both to greater exposure and higher visibility along the river channels, as well as the concentration of the survey area itself along rivers, is probably also related to the availability of resources in these settings. These resources would include a variety of plants and animals, raw material, and, of course, water itself. The latter would be especially critical in this semi-arid setting, as demonstrated in Chapter 3.

\section{Archaeological Remains on Sites}

A variety of different prehistoric archaeological remains were encountered both as sites and isolated finds during the current survey. While chipped stone debitage was by far the most common artifact type, a variety of lithic tools, including bifaces that can be characterized as projectile points and knives, unifaces and retouched items which can be characterized as scrapers and choppers, utilized flakes, and a small number of ground stone items, were also observed. Also discovered were a small number of ceramics, and a variety of different features including hearths and mortar holes. Detailed data at a site-by-site basis can be found in Appendix A.

Figure 8-2 presents examples of selected projectile points collected during the survey. Additional data on projectile points and bifaces can be found in Appendices $\mathrm{E}$ and F. As noted in Chapter 2, and as will be discussed in greater detail in the subsequent section and in the following chapter, it is likely that the Twin Buttes survey area has been heavily collected in recent years as a result of both shoreline erosion exposing deposits and the concentration of populations that use the reservoir for recreational activities. Nevertheless, the variety of different point forms represented in Figure 8-2 probably reflects the major forms present in the survey area.

Figure 8-3 presents examples of other chipped stone tools present on the survey, including bifaces, unifaces, and utilized/retouched items. Chipped stone debitage and cores (not pictured) were the most common artifact recorded on the project. Debitage was present on 189 of the 190 sites while cores were present on 161 sites. Unifaces and utilized/retouched items were less common. Utilized and retouched flakes were recorded on 99 sites, and unifaces recorded on 91 sites.

At 41TG424, a concentration of 16 ceramics, probably representing one vessel, was recorded. These items, shown in Figure 8-4, were collected from a single area of the site, and are consistent in form with those described by Creel (1990:135-143) for 41TG91. All sherds appear to have bone temper, are undecorated, and are extremely small. A single, small rim sherd was present in the collection. These ceramics appear to be consistent with those generally described as Leon Plain.

Ground stone was not common on the survey project, being observed on only 10 of the 190 prehistoric sites. In all ten cases, only a small number of ground stone items were present. Figure 8-5 presents three examples which typify the range of ground stone items, the vast majority of which were slab metate fragments. Only a few manos, all of the same form as that shown in Figure 8-5 (bottom), were observed on the project. The low frequency of ground stone in the Twin Buttes data is consistent with data reported by Creel (1990:125) for 41TG91, where only three definitive ground stone items were recovered. In contrast, Creel reports that over 10,000 chipped stone items were present from the excavations at 41TG91. This low frequency of ground stone is also consistent with data presented in Chapter 5 for the surrounding area (e.g., see Table 5-1). Within the Twin Buttes data set, those sites with ground stone tend to be located closer to extant drainages, with a 


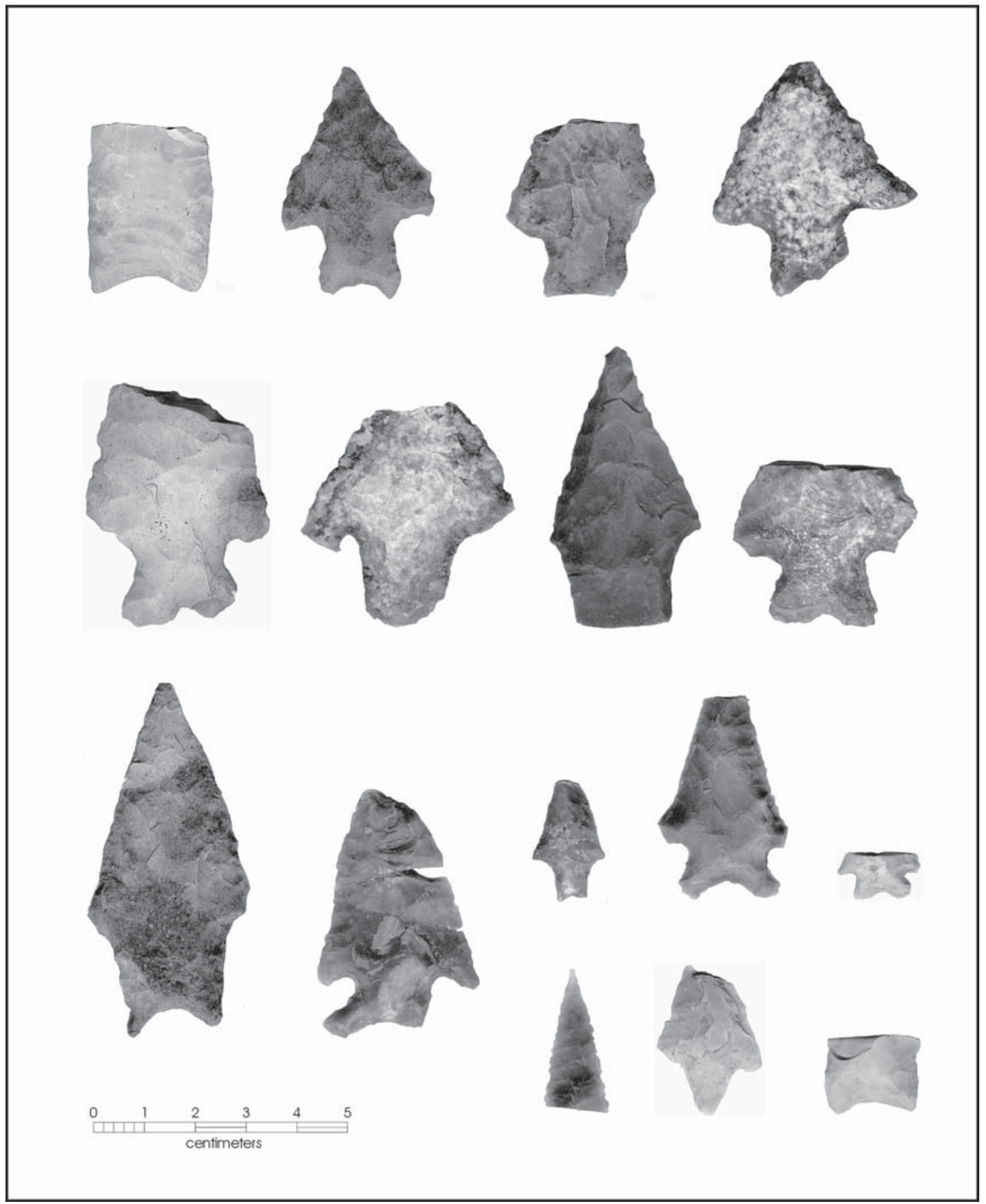

Figure 8-2. Selected projectile points from Twin Buttes.

median distance of $.007 \mathrm{~km}$, relative to those sites that lack ground stone (median $=.265 \mathrm{~km}$ ). Sites with ground stone are also larger, with a median site area of 5,590 square meters compared to 3,720 square meters for those cases without ground stone.

Just over 500 hearth features, thought to be prehistoric, were noted on the project. They primarily consisted of concentrations of burned and fire-cracked limestone such as shown in Figure 8-6 (top). In a small number of cases, features were observed in cutbanks of the major drainages (e.g., Figure 8-6, bottom). Just under 63 percent of all 190 prehistoric sites had either hearth features or FCR present that was judged to be prehistoric. Only a single burned rock midden, located on site 41TG411, was observed in the project area. 


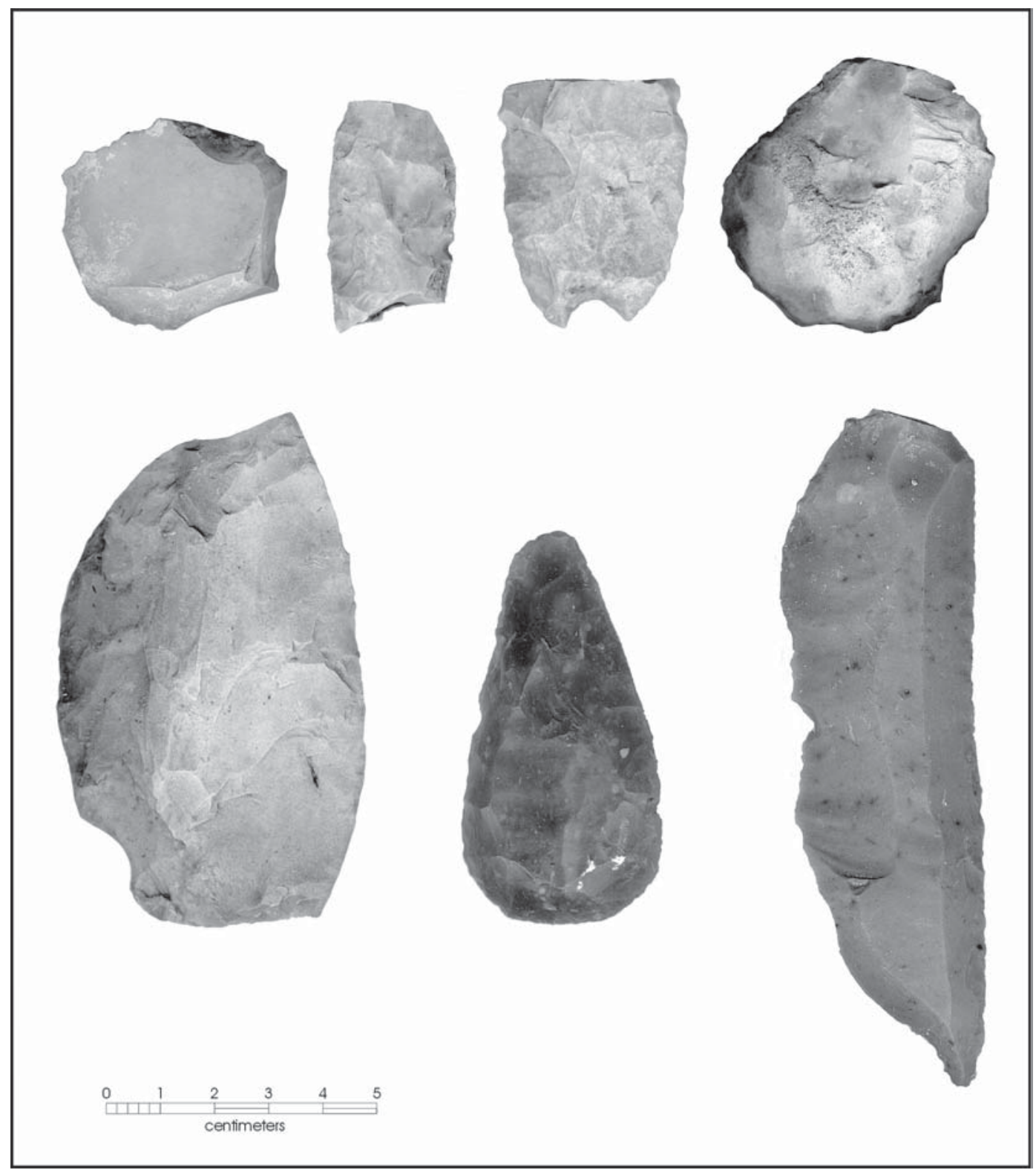

Figure 8-3. Selected chipped stone tools from Twin Buttes.

Sites with features tended to be concentrated nearer water than those without features or FCR. The median distance to water for those sites with features is $.005 \mathrm{~km}$, considerably closer than the $.50 \mathrm{~km}$ for those cases without features. In addition, sites with prehistoric hearths or FCR have a median site size of 4,575 square meters, a value almost twice that of those sites which lack hearths or FCR (2,550 square meters).

While not common on the project, a total of 68 mortar holes were recorded on eight different prehistoric sites. Figure 8-7 presents three examples of mortar holes recorded during the Twin Buttes Survey. Many of the 68 mortar holes were concentrated on two sites, 41TG409 and 41TG437. These two sites accounted for almost 65 percent of all mortar holes observed on the project, with the remaining six sites having between two and five mortar holes.

Sites with mortar holes are located close to water, with a median distance for the eight cases of $.05 \mathrm{~km}$. This figure compares to a median distance of $.275 \mathrm{~km}$ for those sites without mortar holes. In addition, sites with mortar holes are substantially larger than those without 

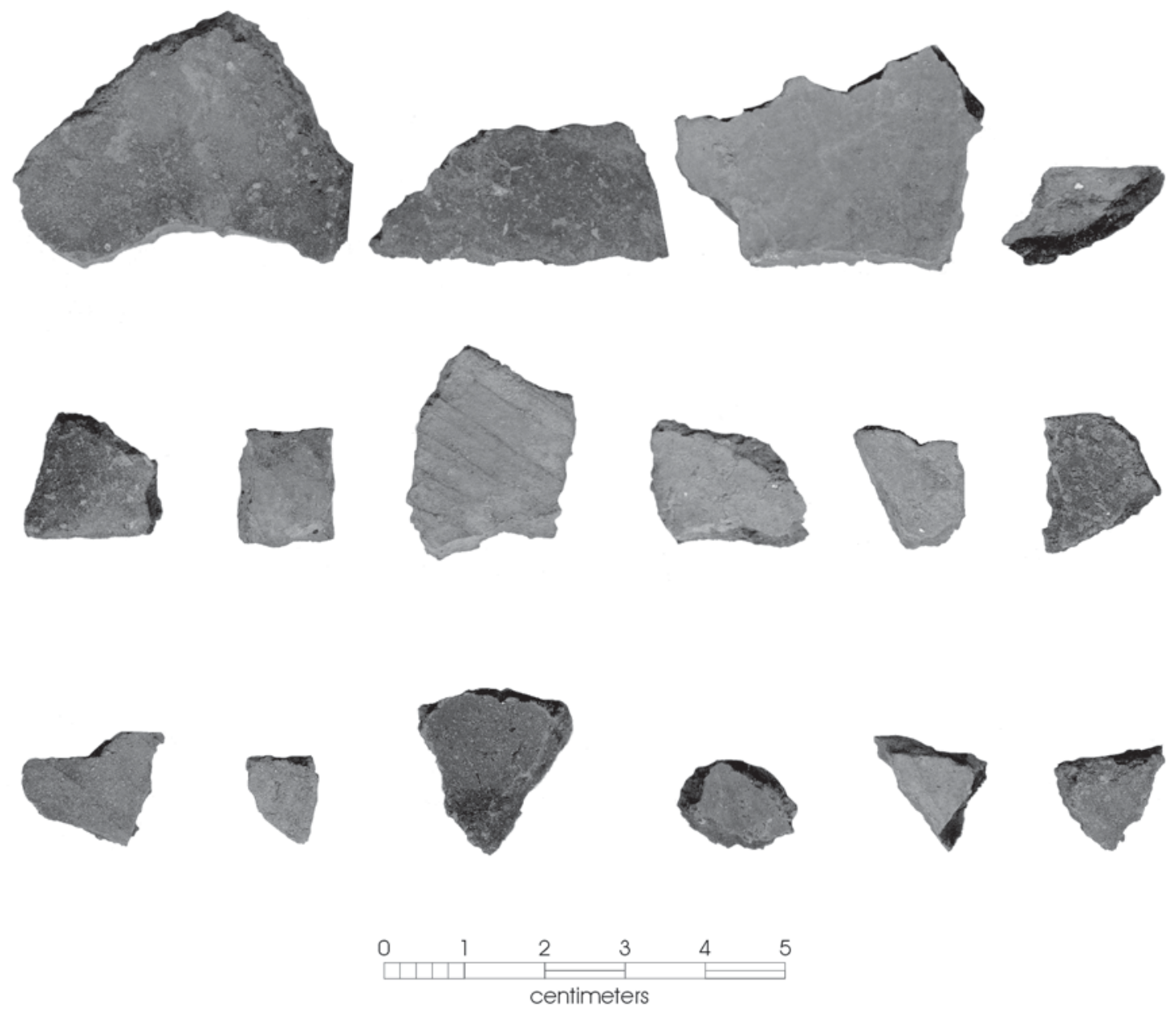

Figure 8-4. Ceramics from site 41TG424.

such features. The former has a median area of 10,710 square meters while those sites without mortar holes have an average area of 3,580 square meters.

\section{Site Types}

As noted in the previous chapter, it is common practice to assign sites to one of several broad types, such as lithic procurement, open campsites, and rockshelters. These site types are commonly assumed to reflect sets of related activities. For example, campsites are commonly thought to represent varying levels of habitation, while lithic scatters are assumed to reflect stages of lithic procurement. While aspects of this perspective will be questioned in Chapter 9, in much of this section I will make the assumption that the site types identified on this project reflect the outcome of prehistoric decisions as to where to locate broad classes of activities.

Essentially three site types were designated for the prehistoric data on this project: campsites, lithic scatters, and sites with aspects of both lithic scatters and campsites. Campsites are identified by the presence of features, fire-cracked rock, late stage reduction debris, and late stage bifaces and other tools. Lithic scatters essentially are areas without features or firecracked rock. Finally, there are sites in which both types of data are present. These are classified as campsite/lithic scatters. In addition to these general categories, a single shell midden (41TG402), and a single campsite and probable burned rock midden (41TG411) were also identified. No rockshelter or cave sites were 

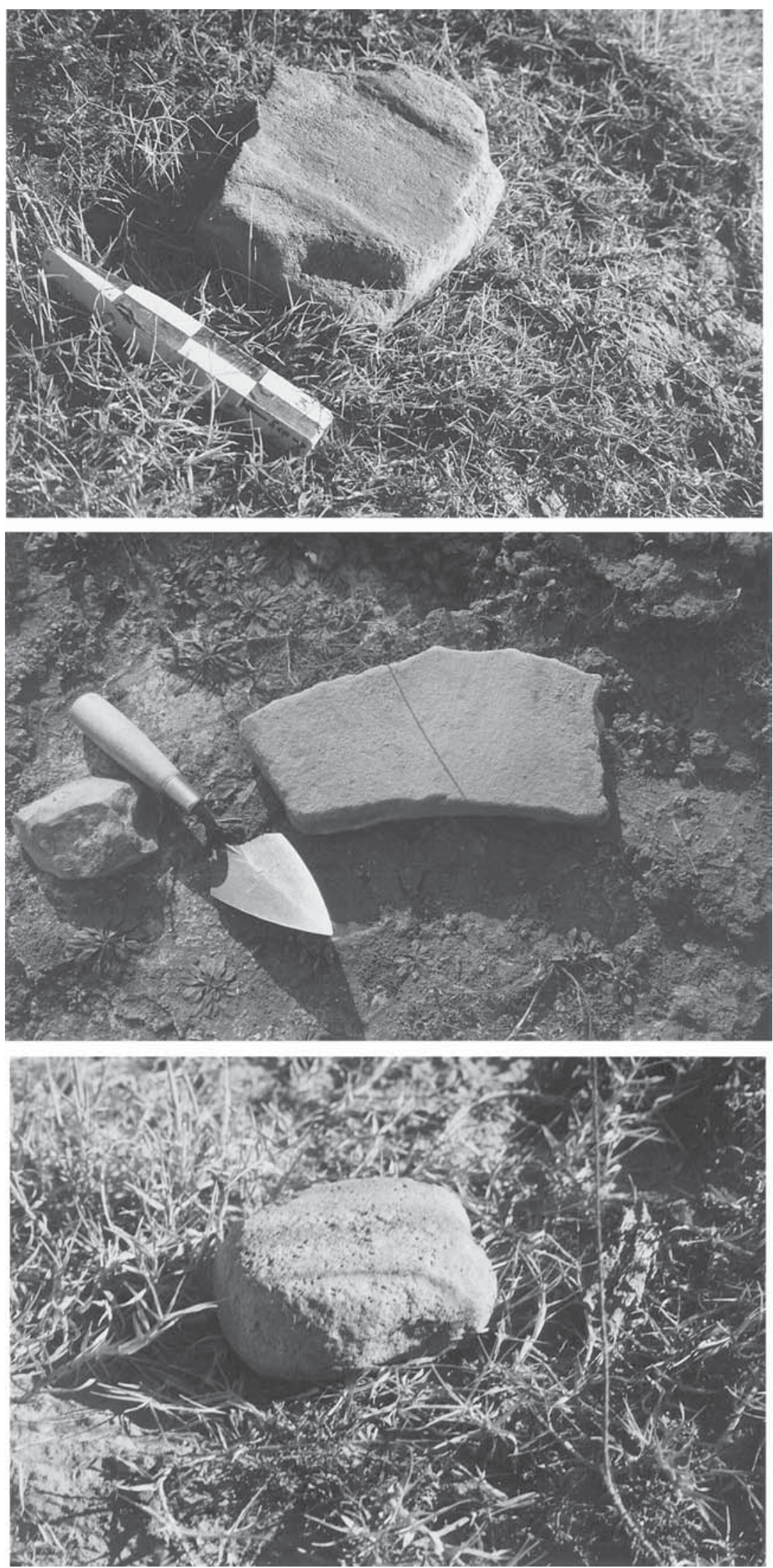

Figure 8-5. Examples of ground stone recovered from Twin Buttes. 


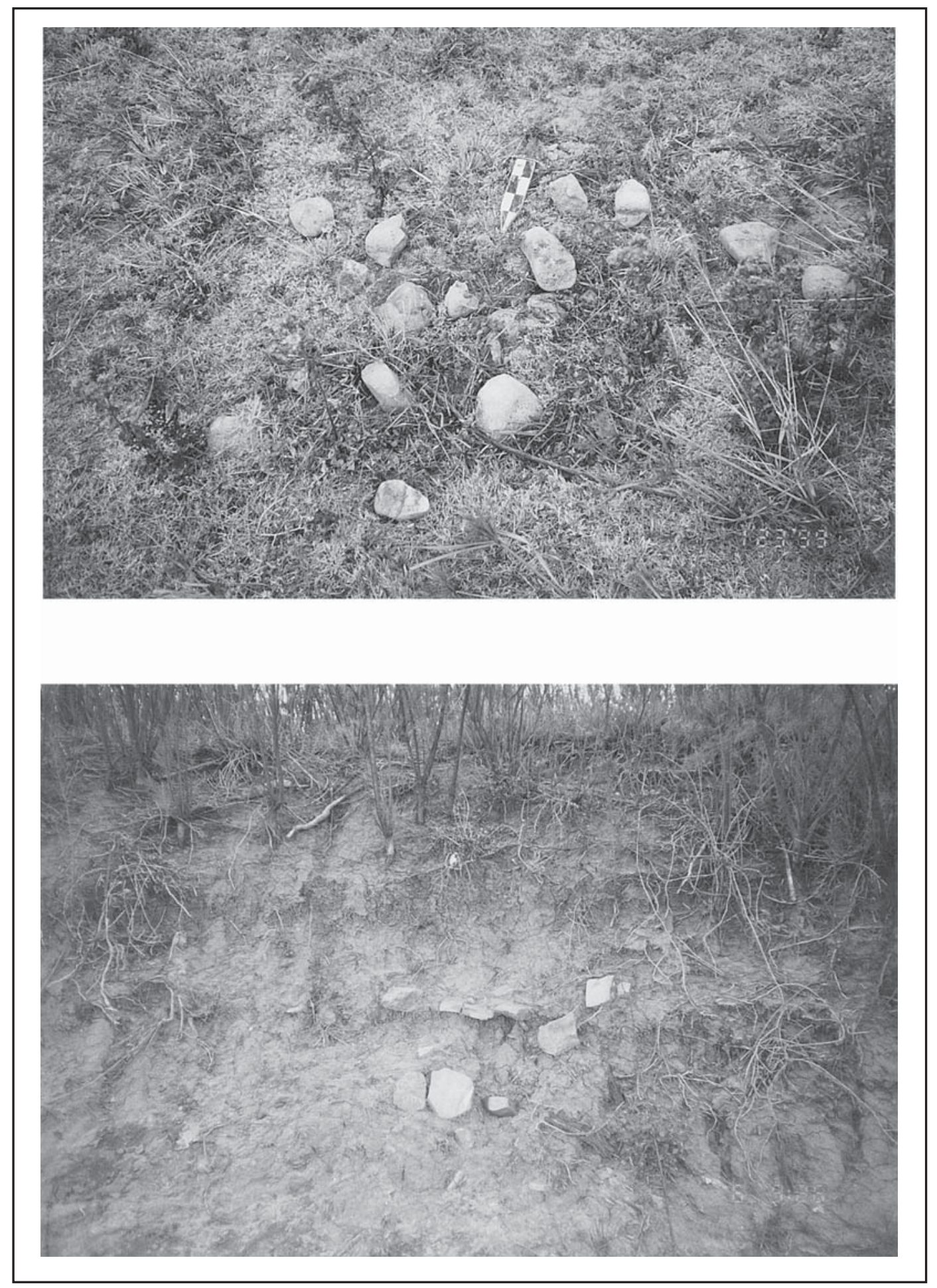

Figure 8-6. Burned and fire-cracked limestone features.

identified, and for the current chapter, we did not attempt to separate out specific aspects of lithic scatters (e.g., lithic procurement). For the purpose of this summary and the subsequent analysis, site 41TG411, the campsite/burned rock midden site, will be combined with the lithic scatter/campsite group. In addition, we will not use 41TG402, the single shell midden site, for most analysis, nor will we consistently use 41TG91. Data gathered at this site during the current project were minimal. 

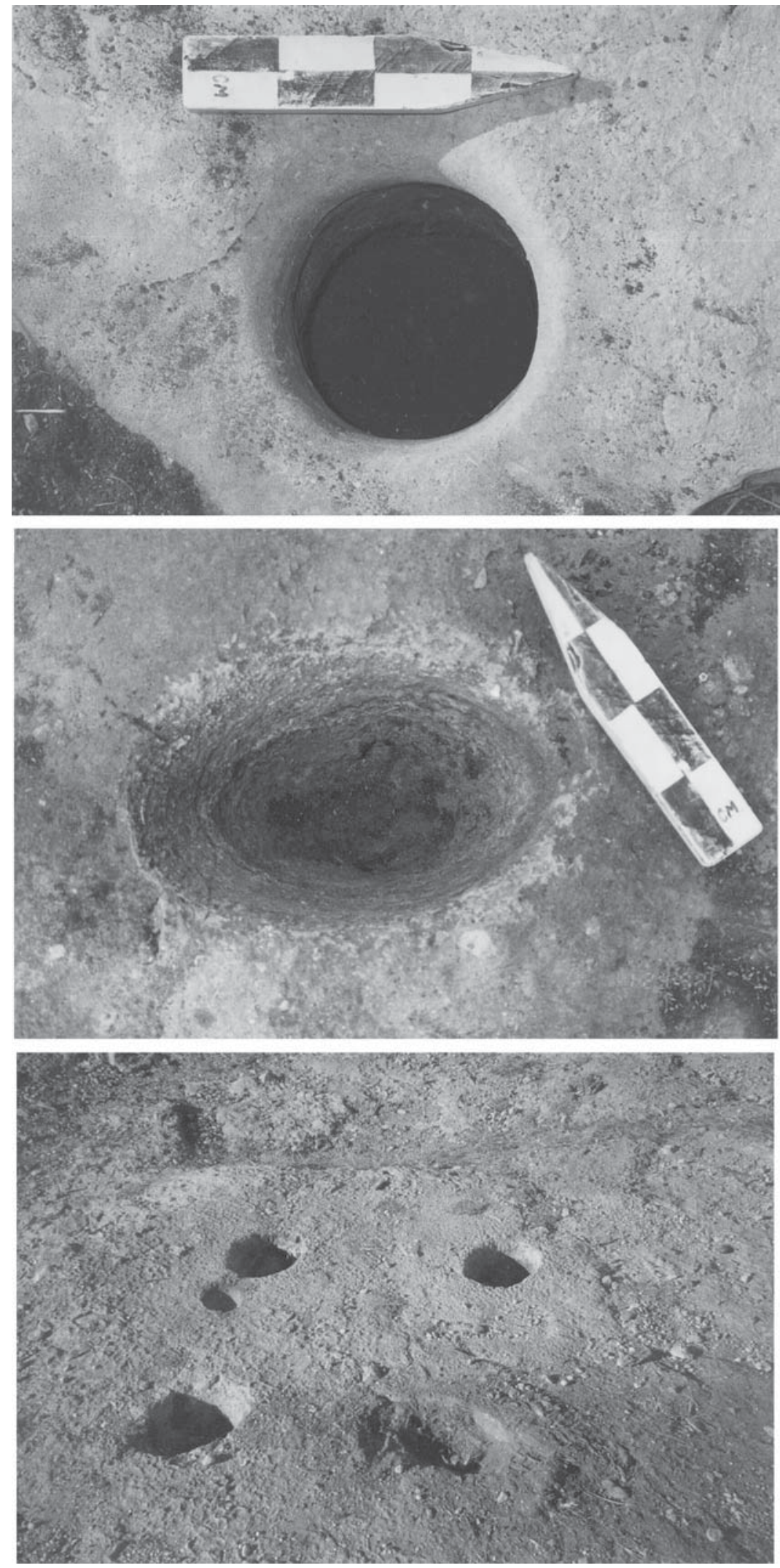

Figure 8-7. Examples of mortar holes recorded at Twin Buttes. 
Table 8-2 presents data on the number of different site types, along with their median distance to water and site size. Reference to the table will demonstrate that 43.4 percent of all sites within the Twin Buttes data set are identified as campsites. This figure is consistent with that presented in Chapter 5 (Table 5-1) where our review of extant site type data in the immediate area surrounding the Twin Buttes Survey suggested that campsites comprised about 45 percent of all sites. Sites classified as lithic scatters make up 46 percent of the Twin Buttes data base, only slightly higher than in the surrounding area where lithic scatters comprised 42 percent. The final major site type category at Twin Buttes, the combined lithic scatter/campsite group, which comprised 10.6 percent of the data set, was not used by previous surveys in the area.

Comparing the median distance to water by site types suggest that both campsites, and the combined campsite/lithic scatter group, are focused on water, whereas more than half of the 87 lithic scatter sites are located more than $.53 \mathrm{~km}$ away from rivers. These data are consistent with those from the surrounding area (Table 5-1), where all campsites with environmental data $(\mathrm{n}=18)$ are located in "riverine" settings, and 69 percent of the lithic scatters $(n=16)$ are in "upland" settings. While the distinction between riverine and upland environments was not made on the current data set, the differences in distance to water by site type seem to be consistent with such a distinction. Sites designated as campsites are, in general, closer to water than those designated as lithic scatters.

Comparative information on site size for the area surrounding the Twin Buttes project was not collected in our Chapter 5 review. However, reference to Table 8-2 suggests that for the Twin Buttes data set, campsites tend to be larger than lithic scatters, and the combined lithic scatter/ campsite group of sites are generally larger than either campsites or lithic scatters.

As noted above, we have presence/absence data on lithic types at the site level. These can provide additional information on the site type class. Essentially six different artifact classes (i.e., debitage, cores and tested cobbles, bifaces, unifaces, utilized and retouched items, ground stone) are available for consideration. We can, therefore, consider how many of these individual artifact classes are present at a site type. That is, if we have 100 campsites, then there are 600 possible cells (100 sites by 6 classes) that can have data marked as present. If only 400 of these cells have tools marked as present, then the assemblage representation is 66.7 percent $(400 / 600)$.

Using such an approach, the group of sites classified as campsites have an assemblage representation of 58.9 percent. That is, 58.9 percent of the campsite cells have data present. In contrast, those sites in the lithic scatter group have an assemblage representation of 53.6 percent. While this overall difference is not great, it is consistent with the notion that campsites, representing more general, habitation activities, should have a wider variety of artifact types present relative to more specialized lithic scatter locations. Consistent with this perspective is the relatively high figure of 78.1 percent assemblage representation of the combined lithic scatter/campsite group.

For 168 of the 192 sites, we have estimates on the number of artifacts present on the surface which can also be used to describe differences in site types. These

Table 8-2. Selected Attributes of site types identified on the Twin Buttes Project

\begin{tabular}{|c|c|c|c|}
\hline Site Type & Number & $\begin{array}{c}\text { Median distance }(\mathrm{km}) \text { to } \\
\text { water }\end{array}$ & Median site size (m2) \\
\hline Campsite & 82 & .03 & 4750 \\
\hline Lithic scatter & 87 & .530 & 2800 \\
\hline Lithic scatter/ Campsite* & 20 & .035 & 5075 \\
\hline
\end{tabular}

*Includes a single case designated as campsite/burned rock midden. 
estimates were originally collected in eight different ordinal classes (e.g., $<10$ artifacts, $10-50$ artifacts, 51100 artifacts, $101-150$ artifacts, $151-300$ artifacts, 301-500 artifacts, 501-1000 artifacts, and >1000 artifacts) using the survey forms presented in Appendix $\mathrm{K}$. The 24 sites that lack this information either had historic components which dominated the site, or we failed to record the information in the field in a consistent manner. For analysis, we re-coded these classes into three larger groups; those with less than 100 artifacts $(n=93)$, those with between 100 and 500 artifacts $(n=44)$, and those with more than 500 artifacts $(n=31)$.

Table 8-3 presents these assemblage size groups by reference to the three main site types, campsites, lithic scatters, and the combined class of campsite/lithic scatter. The table suggests that both campsites and the combined site type have substantially larger assemblages. Just over 51 percent of the 31 sites in the larger assemblage sizes ( $>500$ artifacts) are classified as campsites, 32 percent are classified as campsite/lithic scatters, and only five cases (16 percent) of large assemblages represent lithic scatters. Conversely, campsites make up 41 percent of the 92 sites with small assemblages, campsite/lithic scatters only 5 percent, and lithic scatters comprise 53 percent. A chi-square test indicates that this difference is statistically significant $\left(X^{2}=21.749\right.$; $\mathrm{df}=4$; $\mathrm{p}<.0001)$. There is a strong relationship, then, between site types and assemblage size.

\section{Exploring Site Types}

Overall, then, the data presented above suggests that as a group, campsites are large in site area, located close to water, have a variety of lithic tools represented, and have large assemblage sizes. Conversely, lithic scatters are smaller in site size, have smaller assemblages, are located farther away from water, and have a more restricted range of lithic tools represented. Campsites, by definition, also have hearths or firecracked rock (FCR) present, while lithic scatters tend to lack features and FCR. The combined campsite/ lithic scatter group has the largest sites in terms of area, have the highest assemblage variety, are located consistently close to water, and more often have larger assemblages. The site type data for the Twin Buttes survey appears to be consistent, then, with extant notions regarding the interpretations of campsites as reflecting some form of habitation and lithic scatters reflecting some form of lithic procurement.

In spite of the apparent fit between the summary data on site types, and our notion of what site types represent, the extant data are consistent with a competing scenario that relies simply on a higher frequency of reoccupation for riverine settings. That is, in a semi-arid setting such as the study area, water should be a critical variable in determining where occupation occurs. As such, it is increasingly likely that areas near water are reoccupied. Reoccupation

Table 8-3. Site types and assemblage size groups

\begin{tabular}{|c|c|c|c|c|}
\hline & \multicolumn{3}{|c|}{ Assemblage Size Groups } & \\
\cline { 2 - 5 } & $<100$ artifact & $100-500$ & $>500$ & Total \\
\hline Campsites & 38 & 19 & 16 & 73 \\
\hline Lithic Scatters & 49 & 20 & 5 & 74 \\
\hline $\begin{array}{c}\text { Lithic Scatter/ } \\
\text { Campsite }\end{array}$ & 5 & 5 & 10 & 20 \\
\hline Total & 92 & 44 & 31 & 167 \\
\hline
\end{tabular}

Note: One site classified as a shell midden was excluded from the $<100$ artifacts category. 
should result in both larger sites, larger assemblages, an associated increase in artifact variety, and, depending on the nature of activities conducted, the generation of hearths. At least some component of the three site types, types that are thought to reflect decisions regarding where to locate two broad classes of activities (habitation and lithic procurement), may be related, then, not to radically different activities conducted in different places, but rather differing levels of reoccupation. If this is the case, we should see patterning between site size and assemblage size, assemblage size and assemblage variety, assemblage size and the presence of features, and assemblage size and the number of temporal components represented. In addition, there should be relationships between assemblage size and distance to water. Each of these is considered below.

Figure 8-8, a box plot of site area by the three assemblage size groups, considers the first of these relationships. The figure clearly demonstrates a strong relationship between assemblage size and site area. Not surprisingly, as assemblage size increases, site area increases.

Table 8-4 presents data on assemblage size groups relative to measures of variety. A chi-square test

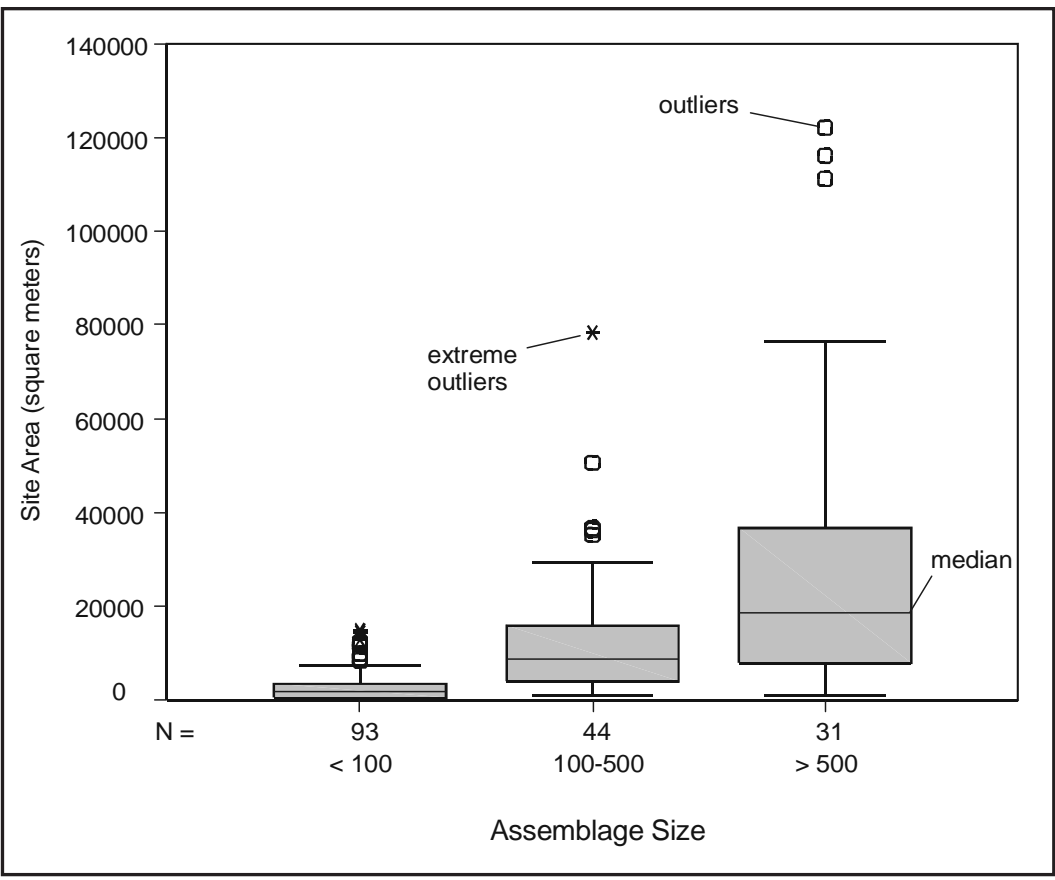

Figure 8-8. Box plot of site area by assemblage size groups.

demonstrates that the relationship is significant $\left(\mathrm{X}^{2}=53.7 \mathrm{df}=8 \mathrm{p}<.0001\right)$. Below each observed frequency are the adjusted residuals. As discussed by several authors, adjusted residuals provide information on the contribution of each individual cell to the overall significance of the table (see Everitt 1977; Haberman 1973). Adjusted residuals are thought to be analogous to $\mathrm{Z}$ scores, such that an adjusted residual value exceeding an absolute value of 1.96 suggests that the cell is significantly different at a probability beyond the level of .05 (Everitt 1977; Haberman 1973).

Table 8-4. Assemblage size and assemblage variety

\begin{tabular}{|c|c|c|c|c|c|c|}
\hline \multirow{2}{*}{$\begin{array}{l}\text { Assemblage } \\
\text { Size }\end{array}$} & \multicolumn{5}{|c|}{ Assemblage Variety } & \multirow{2}{*}{ Total } \\
\hline & 1 type & 2 types & 3 types & 4 types & $5+$ types & \\
\hline $\begin{array}{c}<100 \\
\text { Artifacts }\end{array}$ & $\begin{array}{c}11 \\
\mathbf{( 2 . 6 )}\end{array}$ & $\begin{array}{c}30 \\
\mathbf{( 4 . 3 )}\end{array}$ & $\begin{array}{c}23 \\
\mathbf{( 2 . 1 )}\end{array}$ & $\begin{array}{c}16 \\
(-.7)\end{array}$ & $\begin{array}{c}13 \\
(-6.2)\end{array}$ & 93 \\
\hline $\begin{array}{l}100-500 \\
\text { Artifacts }\end{array}$ & $\begin{array}{c}1 \\
(-1.5)\end{array}$ & $\begin{array}{c}3 \\
(-2.6)\end{array}$ & $\begin{array}{c}7 \\
(-.6)\end{array}$ & $\begin{array}{l}10 \\
(.7)\end{array}$ & $\begin{array}{c}23 \\
\mathbf{( 2 . 9 )}\end{array}$ & 44 \\
\hline $\begin{array}{c}>500 \\
\text { Artifacts }\end{array}$ & $\begin{array}{c}0 \\
(-1.7)\end{array}$ & $\begin{array}{c}1 \\
(-2.6)\end{array}$ & $\begin{array}{c}2 \\
(-2.0)\end{array}$ & $\begin{array}{c}6 \\
(0)\end{array}$ & $\begin{array}{c}22 \\
(\mathbf{4 . 7})\end{array}$ & 31 \\
\hline Total & 12 & 34 & 32 & 32 & 58 & 168 \\
\hline
\end{tabular}


Significant adjusted residual values are identified in bold in the table. An examination of the distribution of the adjusted residual values will demonstrate that as assemblage size increases, there are more artifact types represented, while sites with smaller assemblages tend to have lower assemblage variety.

Table 8-5 considers relationships between assemblage size and the presence/absence of hearths. The table demonstrates that only 10 percent of the 31 large assemblage $(n=3)$ sites lack hearths, whereas 43 percent of the 93 small assemblage sites $(n=40)$ lack hearths. A chi-square test demonstrates that the relationship is statistically significant $\left(\mathrm{X}^{2}=11.47 ; \mathrm{df}=2\right.$; $\mathrm{p}=.003$ ), and as with previous tables, significant adjusted residuals are highlighted in bold. An examination of the adjusted residual values will demonstrate that on sites with larger assemblages, hearths are increasingly likely to be present.

Figure 8-9 presents a box plot of the distance to water by assemblage size. Sites with larger assemblages (>500 artifacts) tend to be located closer to water than smaller assemblages. Note, however, that contrary to expectations, sites with small assemblages ( $<$ 100 items) are, as a group, indistinguishable from sites in the 100 to 500 artifact range with regard to distance from water. In part, this may simply be a function of exposure. A number of these cases in the less than 100 assemblage size range are represented by material exposed in cutbanks along rivers. Sometimes, these sites consist primarily of buried hearths, such as can be seen above in Figure 8-6. Such sites would, of course, have small assemblages as associated material would be primarily buried.

Finally, if the reoccupation scenario is useful, it should be the case that there is a relationship between assemblage size and the number of temporal components represented. While the following section deals with temporal components in greater detail, Table 8-6 considers the number of temporal components relative to assemblage size. The table suggests that sites with small assemblages are increasingly likely to be classified as temporally unknown. Conversely, sites with large assemblages are increasingly likely to be classified as single or multiple component. A chi-square test on the distribution demonstrates that the relationship is statistically significant $\left(X^{2}=20.41 ; d f=4 ; p<.0001\right)$. Significant adjusted residuals values demonstrate that both single and multiple components are increasingly likely to be present on sites with larger assemblages, and sites that lack temporal placement are differentially represented by sites with assemblages below 100 items.

Sites with larger assemblages, then, tend to be larger in size, have more artifact variety, and more frequently have features. These sites are more frequently located close to water, and are likely to have cases of temporal assignment. All of these are consistent with a scenario related to reoccupation. As locations are reoccupied, more artifacts, more area, and more different types of artifacts are deposited at a location. Reoccupation would increase the likelihood that features would be

Table 8-5. Assemblage size groups and presence/absence of hearths

\begin{tabular}{|c|c|c|c|c|}
\hline & \multicolumn{3}{|c|}{ Assemblage Size } & \\
\hline & $<100$ & $100-500$ & $>500$ & Total \\
\hline Hearths & 40 & 17 & 3 & 60 \\
Absent & $\mathbf{( 2 . 2 )}$ & $(.5)$ & $\mathbf{( - 3 . 4 )}$ & 108 \\
\hline Hearths & 53 & 27 & 28 & \\
Present & $\mathbf{( - 2 . 2 )}$ & $(-.5)$ & $\mathbf{( 3 . 4 )}$ & 168 \\
\hline Total & 93 & 44 & 31 & \\
\hline
\end{tabular}


present as well. The results of these combined assemblages are increasingly likely to be classified as campsites and lithic scatter/campsites, in part as a function of increased assemblage variety. Conversely, smaller sites, sites with lower variety, lower assemblage size, and lacking temporal assignment, are increasingly likely to be classified as lithic scatters in the Twin Buttes data base. In fact, these different site types may be tracking, to some degree, differences related to reoccupation rather than to distinctive activity sets.

This is not, however, to argue that all differences between the three site types identified on the current survey can be explained by positing differing intensity of occupation and reoccupation. For example, there are differences in assemblage content, at least to the degree that

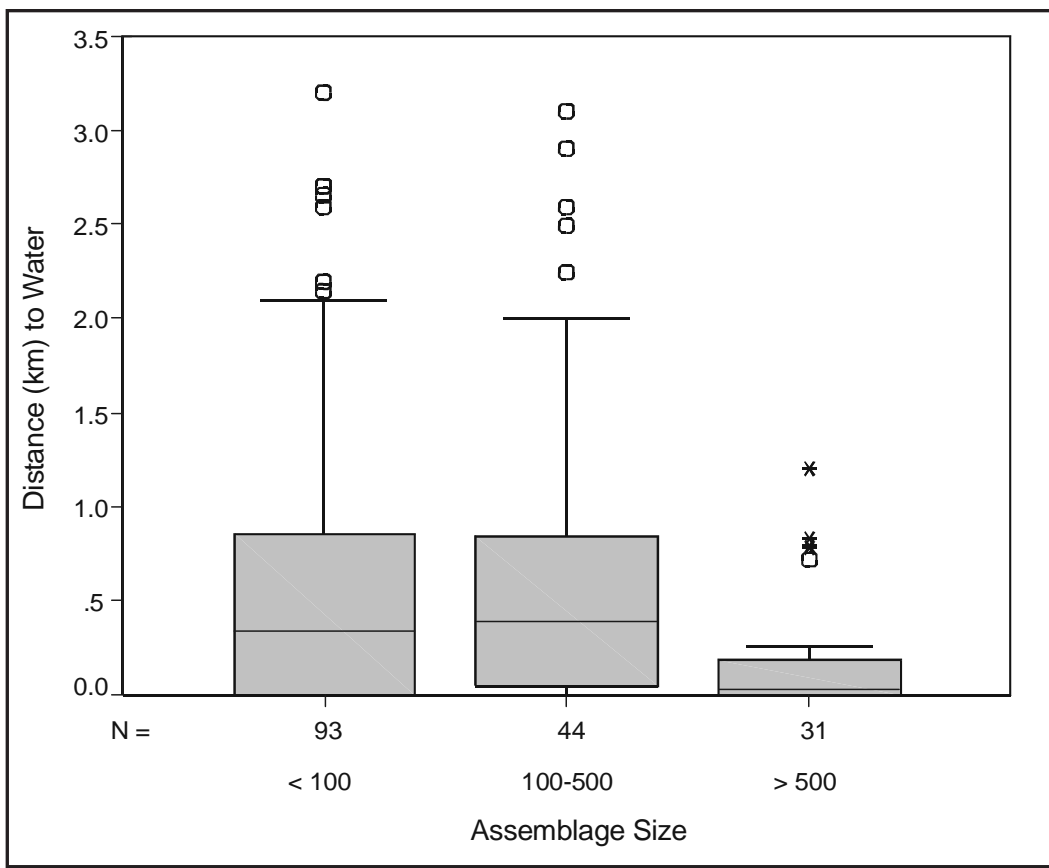

Figure 8-9. Box plot of distance to water $(\mathrm{km})$ by assemblage size groups. we can monitor these differences in terms of presence/ absence data, between the campsite group and the lithic scatter group that are not clearly related to reoccupation. For example, cores and tested cobbles occur on 92 percent of all lithic scatters ( 80 of 87 sites), but are present on only 74 percent of all campsites (61 of 82 sites). Similarly, unifaces are more commonly recorded on campsites, with 55 percent of the
82 campsites having this tool type, while only 40 percent of the sites recorded as lithic scatters have unifaces. Campsites also have higher frequencies of ground stone, bifaces, and utilized/retouched items relative to lithic scatters. The site types identified on the current project, then, probably reflect a number of different processes, including broad differences in activities and levels of reoccupation.

Table 8-6. Temporal assignments and assemblage size groups

\begin{tabular}{|c|c|c|c|c|}
\hline \multirow{2}{*}{ Assemblage Size } & \multicolumn{3}{|c|}{ Temporal Assignments } & \\
\cline { 2 - 5 } & None & Single Assignment & Multiple Assignments & Totals \\
\hline \multirow{2}{*}{100} & $\begin{array}{c}80 \\
\mathbf{( 3 . 7 )}\end{array}$ & $\begin{array}{c}10 \\
\mathbf{( - 3 . 2 )}\end{array}$ & $\begin{array}{c}3 \\
(-1.4)\end{array}$ & 93 \\
\hline $100-500$ & $\begin{array}{c}29 \\
(-1.6)\end{array}$ & $\begin{array}{c}14 \\
(\mathbf{2 . 4})\end{array}$ & 44 \\
\hline$>500$ & $\begin{array}{c}17 \\
(-3.3)\end{array}$ & $\mathbf{( 2 . 1 )}$ & $\begin{array}{c}5 \\
\mathbf{( 2 . 6}\end{array}$ & 31 \\
\hline Totals & 126 & 33 & 9 & 168 \\
\hline
\end{tabular}




\section{Temporal Assignments}

Our ability to assign sites to broad temporal periods (e.g., Late Archaic) is dependent on the presence of distinctive artifact types, usually projectile points (see Appendix F). Unfortunately, projectile points were not common on the project. While in many cases, it was possible to assign projectile points to the temporal periods outlined previously (see Table 7-1), often the collected specimens were too fragmentary to allow any temporal estimate. In a few cases, a given specimen could be assigned to either of two different categories. For example, several specimens could be placed in either the Late Archaic or the Early Archaic, but the point was too fragmentary to distinguish which of these two periods was the correct placement. In these cases, the site was assigned to both the Late Archaic and Early Archaic. Using this procedure, it was still possible to assign only 49 of the 191 prehistoric sites to any given period; 142 lack any temporal information.

Figure 8-10 presents the distribution of all 67 components on the 49 sites. These data include 41TG91 (Creel 1990). To the degree that these component assignments are accurate and to the degree that these

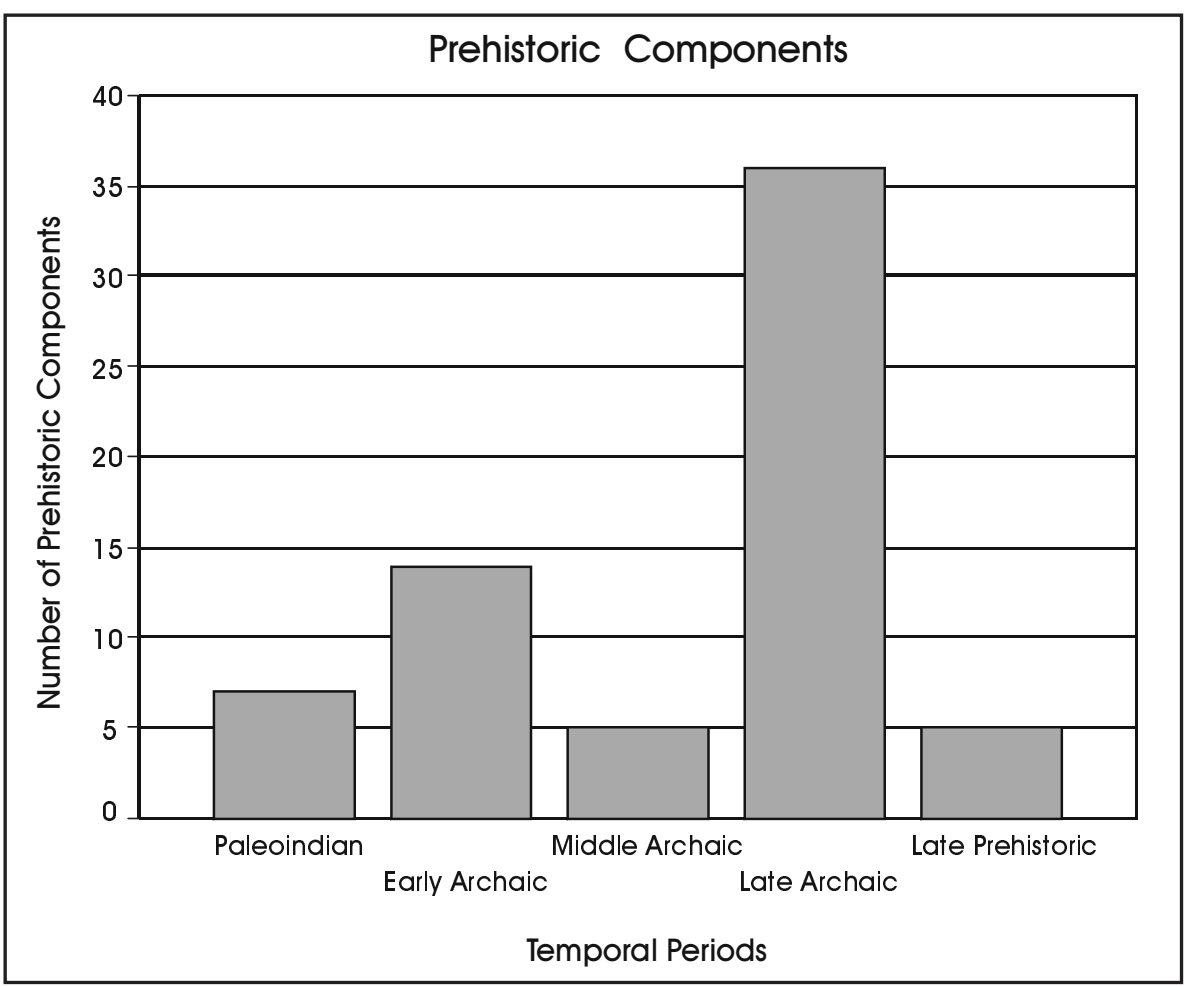

Figure 8-10. Sites with component designations. components reflect the overall pattern of prehistoric use of the region, it is clear that most occupation within the survey area occurred during the Late Archaic. Just under 54 percent of all components can be assigned to this period. Low frequencies of use are evidenced in the Late Prehistoric and in the Middle Archaic, with both periods containing 7.5 percent of the assignable components. Conversely, relatively high numbers of Early Archaic ( $\mathrm{n}=14 ; 20.9$ percent) and Paleoindian $(n=7 ; 10.4$ percent $)$ assignments are present.

While aspects of the overall temporal breakdown in Figure 8-10 may appear anomalous, a review of other surveys in the Rolling Plains area suggests considerable variability in temporal patterning. For example, Boyd (1989:111) presents temporal data from both the Justiceberg project, as well as a series of other surveys conducted in the Rolling Plains. In the case of Justiceberg, unlike Twin Buttes, the survey record is dominated by Late Prehistoric sites. In fact, 63 percent of the recorded sites are Late Prehistoric, and there are no cases of Early Archaic or Paleoindian occupations recorded. In a compilation of other Rolling Plains surveys with a total of 81 temporal assignments presented by Boyd (1989), only 18.5 percent are Late Prehistoric, 61.7 percent are Late Archaic, 9.9 percent are Middle Archaic, 6.2 percent are Early Archaic, and 3.7 percent are Paleoindian. Trierweiler et al. (1993:119), citing data from Woolridge et al. (1981) for the O. H. Ivie Reservoir survey, note 146 sites within the $\mathrm{O}$. H. Ivie project area that have temporal components. Of these, only 12 percent were Late Prehistoric, 43 percent were Late Archaic, 31 percent were Middle Archaic, 12 percent Early Archaic, and 2 percent were Paleoindian.

While these regional survey data demonstrate that Paleoindian occupations are consistently low ( 0 percent to 3.7 percent), there appears to be considerable fluctuation in the 
relative numbers of Late Prehistoric (63 percent to 12 percent), Late Archaic (61.7 percent to 43 percent), Middle Archaic ( 0 percent to 31 percent), and Early Archaic ( 0 percent to 12 percent) components in regional surveys. At this level of comparison, only the high relative frequency of Early Archaic (20.9 percent) and Paleoindian (10.4 percent) components on the Twin Buttes Survey appear anomalous.

In this regard, it is interesting to compare our results with those reported by Creel (1978) for his survey centered on the South Concho. While we lack site specific data, it is possible to consider the distribution of diagnostics for the South Concho survey as a whole, relative to Twin Buttes data. Figure 8-11 presents such a comparison. The date ranges for 64 individual named projectile points listed by Creel (1978:292) were calculated using the ranges presented in Chapter 7 (see Table 7-1) for the Twin Buttes data. Comparisons of the distribution of diagnostics in the figure clearly suggest similar patterns in both surveys for the Late Prehistoric and the Middle Archaic. In addition, both surveys are dominated by Late Archaic points. As with the regional data, only the Early Archaic and Paleoindian diagnostics are under represented in Creel's (1978) data relative to Twin Buttes. The overall temporal pattern within the Twin Buttes data, then, appear to reflect a relatively heavy use in the Early Archaic, as well as the Paleoindian period, that has not been documented in previous surveys in either the immediate area or by other surveys in the Rolling Plains.

Table 8-7 presents a variety of attributes for sites identified by diagnostics recorded during the Twin Buttes Survey. While there are dramatic differences between several of these periods in attributes such as site size, distance to water, and assemblage attributes, any interpretation of these differences is complicated by that fact that 25 percent of the 48 sites with detailed information have multiple components. That is, the table amasses data at the site level, but not all attributes of
Temporal Patterning in Diagnostics

South Concho (Creel 1978) and Twin Buttes

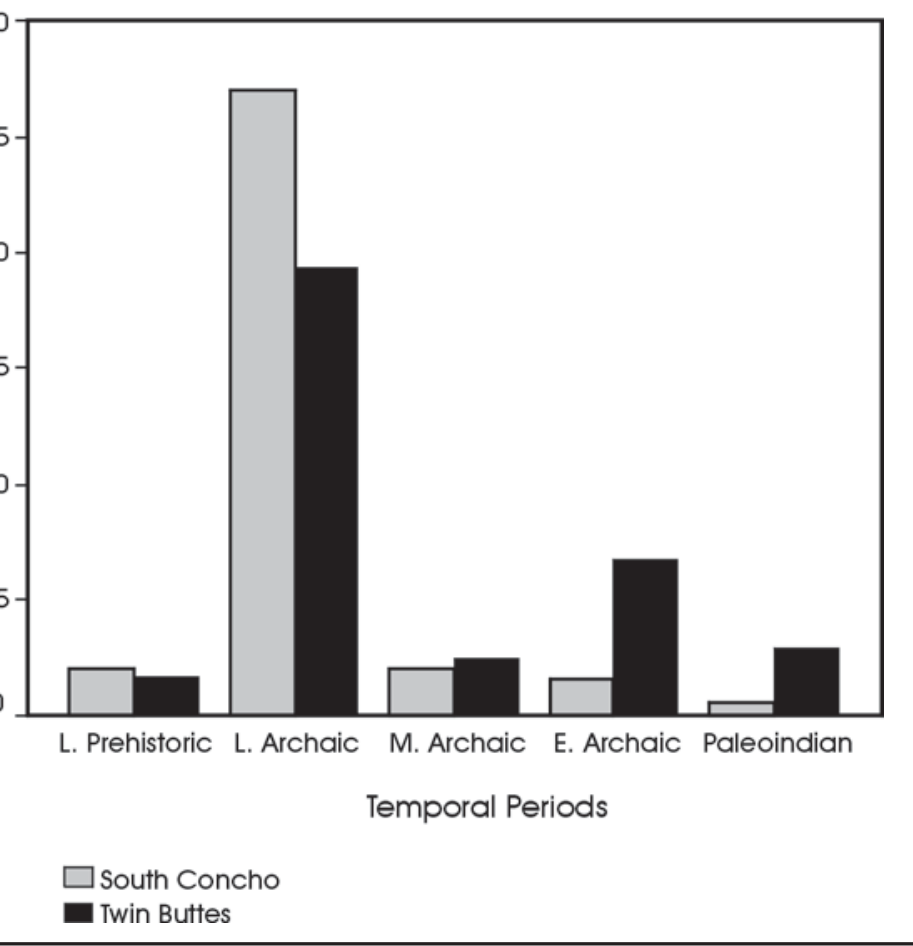

Figure 8-11. Comparisons of temporally diagnostic artifacts from Twin Buttes and Creel's (1978) South Concho survey.

a site are necessarily associated with a given diagnostic. For example, with the exception of 41TG387, a site with a number of artifacts that reflect Clovis occupation, many of the Paleoindian sites are represented by a single artifact. An example of this is site 41TG246. This campsite covers an area of over 22,700 square meters, has nine hearths, bifaces, cores, and debitage. The only diagnostic was a single, broken, late Paleoindian projectile point fragment. As this was the only diagnostic, all of the attributes of 41TG246 are identified as Paleoindian, though it is unlikely that the single point accurately dates the entire site. An additional examples come from site 41TG424, a campsite covering over 116,900 square meters with 45 hearths. A single point dating to the Late Prehistoric, a point dating to the Late Archaic, and a point dating to the Early Archaic comprise the diagnostic lithic assemblage. While the site is most probably an amalgamation of these multiple time periods, what specific features or areas go with what specific time periods cannot be ascertained given the large site size and small number of diagnostics. 
Table 8-7. Selected attributes of temporal periods*

\begin{tabular}{|c|c|c|c|c|c|}
\hline Attributes & Paleoindian & $\begin{array}{c}\text { Early } \\
\text { Archaic }\end{array}$ & $\begin{array}{c}\text { Middle } \\
\text { Archaic }\end{array}$ & $\begin{array}{c}\text { Late } \\
\text { Archaic }\end{array}$ & $\begin{array}{c}\text { Late } \\
\text { Prehistoric }\end{array}$ \\
\hline Number & 7 & 14 & 5 & 34 & 4 \\
\hline $\begin{array}{c}\text { Median Area (square } \\
\text { meters) }\end{array}$ & 22710 & 4787.5 & 4350 & 9475 & 19895 \\
\hline $\begin{array}{c}\text { Median Distance to } \\
\text { Water (km) }\end{array}$ & .49 & .10 & .39 & .105 & .075 \\
\hline $\begin{array}{c}\% \text { with hearths or } \\
\text { fire-cracked rock }\end{array}$ & 71 & 78.6 & 60 & 76.5 & 100 \\
\hline$\%$ with cores & 100 & 86 & 100 & 88 & 75 \\
\hline$\%$ with unifaces & 71 & 64 & 100 & 79.5 & 100 \\
\hline $\begin{array}{c}\% \text { with utilized or } \\
\text { retouched items }\end{array}$ & 57 & 71.4 & 100 & 73.5 & 100 \\
\hline
\end{tabular}

* 41TG91 not included as we lack comparable survey level data for this site

The temporal patterns, then, do seem to suggest a relatively higher frequency of both Paleoindian and Early Archaic occupation for the Twin Buttes area relative to previous surveys in both the immediate area and on the Rolling Plains in general. However, more detailed interpretations of the temporal patterns are hampered by a low frequency of diagnostics at a project level, a low number of diagnostics on any given site, and the fragmentary nature of temporally diagnostic artifacts.

\section{Isolated Finds}

As noted previously, the site classification was only one of two distinctions made on archaeological material on the current survey. Sites, arbitrarily defined by either the presence of features or five surface artifacts in a $25 \mathrm{~m}^{2}$ area, essentially comprise the upper end of a continuum. At the lower end of the continuum, a designation of Isolated Find (IF) was used. A total of 393 isolated finds were recorded during the current project. Table 8-8 presents summary data for these isolates at a general level, and more detailed information, including distributional data, can be found in Appendix G.
In most archaeological surveys, isolates are under reported and receive little attention beyond a mere description, if that. Cases of low density or single artifacts are seen as difficult to interpret in any behaviorally meaningful way. Comparing data between projects is difficult because of differences in definition of what is, and is not, an isolate, as well as different survey techniques and ground visibility. I argued in the previous chapter that what constitutes a site, that is, what definitions we use to identify sites, is arbitrary. That is, the definition that we used here could have easily been lower, for example three artifacts within a 5-x5-meter area. The use of a more inclusive definition would transform these "meaningless" isolates into sites, and thereby invest them with greater importance. This is, of course, not a desirable situation. Consequently, we view isolates as simply the lower end of a continuum which we have arbitrarily segmented into two groups, sites and isolated finds. Nonetheless, comparative data on isolates is difficult to acquire as most survey projects simply do not report isolated find data in any useful way (but see Nickels et al. 1997:117).

While comparisons between projects are difficult as a function of under reporting of isolate data, it is possible 
Table 8-8. Isolated finds by major artifact type for the Twin Buttes Survey

\begin{tabular}{|c|c|c|}
\hline Type & Number of Cases & Percentage \\
\hline Flakes & 251 & 63.87 \\
\hline Cores & 52 & 13.23 \\
\hline Bifaces & 27 & 6.87 \\
\hline Unifaces & 27 & 6.87 \\
\hline Retouched/ Utilized & 36 & 9.16 \\
\hline Total & 393 & 100 \\
\hline
\end{tabular}

to compare some aspects of the 393 isolated finds with those found on site within the Twin Buttes data set. In order to do this, I use the 21,769 items from 93 sites observed in our surface observation areas (SOAs). These data, introduced in Chapter 2 (see also Appendix D), are used extensively in the following chapter. Here, I use these data simply to compare the overall makeup of the isolated find data set to that of the site.

Using all SOA material, flakes make up 91.3 percent of the items observed on sites. Reference to Table 8-8 will demonstrate that within the isolated find data, flakes account for only 63.9 percent of items observed. That is, flakes appear to be more common on sites than off sites. While I will return to this discrepancy shortly, as the sample size of 19,854 flakes essentially swamps all other categories, I will eliminate flakes from both the site and isolate data base, and concentrate on the 142 isolated, or off-site tools, and the 1,915 tools on sites. Table 8-9 presents these tool categories for sites and isolates, along with their respective percentages.

Note that cores and tested cobbles, and retouched/utilized items, along with flakes (not shown) are more common on-site, while, both bifaces and unifaces are more common off-site. At a general level, there are probably several factors that interact to create these differences. Minimally, these probably include an interplay between the definitional criteria used for sites and isolates and differences in the scale at which different sets of activities are conducted.
Certain activities, such as the reduction of a core, by definition will produce a substantial number of flakes, and result in the definition of a "site." Thus, it should not be surprising that cores and flakes are relatively more common on site assemblages, for sites are defined by higher density of debris. It would be difficult to conduct even minimal reduction, and, provided that the surface of the location remained stable, not produce sufficient material to qualify a data set as a site during the current survey. By focusing on differential density in our site criteria, then, we probably influence the frequency that activities such as core reduction, characterized by both flakes and cores, are reflected in the site data base. A clear example of this is the observation that hearths are non-existent in the isolated data base. This is because we have defined hearths as a criteria for site status.

Why then are isolated flakes the most common type of artifact recovered among the 393 isolated finds? That is, even though flakes are under represented in the isolate data, comprise only 64 percent of the isolates compared to 91 percent of the site data base, flakes are still the most common item within the isolated find data (see Table 8-8). A comparison of the size of isolated flakes with those flakes observed on sites suggests one possible answer. We have the maximum length, recorded in one $\mathrm{cm}$ categories, for 250 of the 251 isolated flakes. The mean flake size for these isolates is $4.2 \mathrm{~cm}$. In contrast, the mean size of the 19,854 flakes from the site level SOA data is 2.5 $\mathrm{cm}$. Isolated flakes are significantly larger than flakes 
Table 8-9. Site and Isolated Find non-flake data by Artifact Type for Twin Buttes

\begin{tabular}{|c|c|c|c|c|}
\hline \multirow{2}{*}{ Artifact Types } & \multicolumn{2}{|c|}{ Site Level Data } & \multicolumn{2}{c|}{ Isolate Level Data } \\
\cline { 2 - 5 } & Number & Percentage & Number & Percentage \\
\hline Cores and Tested Cobbles & 905 & $\mathbf{4 7 . 3}$ & 52 & 36.6 \\
\hline $\begin{array}{c}\text { Bifaces (Includes projectile } \\
\text { points) }\end{array}$ & 241 & 12.6 & 27 & $\mathbf{1 9 . 0}$ \\
\hline Unifaces & 169 & 8.8 & 27 & $\mathbf{1 9 . 0}$ \\
\hline Retouched/ Utilized Items & 585 & $\mathbf{3 0 . 5}$ & 36 & 25.4 \\
\hline $\begin{array}{c}\text { Other (includes Ground Stone, } \\
\text { Hammer Stones) }\end{array}$ & 15 & $\mathbf{0 0 . 8}$ & 0 & 00.0 \\
\hline Totals & 1915 & 100.0 & 142 & 100.0 \\
\hline
\end{tabular}

on sites. This suggests that differential exposure and visibility may account for the higher frequency of isolated flakes. Situations in which isolated flakes are common, then, could simply be cases where additional smaller material is present, but not exposed on the surface. As I will argue in the following chapter, exposure plays a major role in determining what items are recovered by conditioning artifact size.

It is probable, then, that certain activities, such as the reduction of a core, will be more common on sites by definition. Conversely, certain activities, such as those that involve actions at a more areal scale, will result in the deposition of only a few items. These activities are more likely to be classified as isolated finds. For example, hunting of animals such as deer, depending upon the method, could be imagined to produce only isolated projectile points, lost or discarded during a hunt. Thus the differences in bifaces reflected in Table 8-9 may reflect a behavioral difference. Though the sample size is small, the observation that 37 percent of isolated bifaces were classified as projectile points, while only 7.5 percent of the 241 bifaces in the SOA site data base were given this designation, supports such a position. It seems possible, then, that prehistoric activities that take place at a larger, landscape level, will be under represented at sites. The isolate data base becomes an important part of understanding the overall adaptation, even though the use of the data set at the present time is plagued by problems of temporal placement and a lack of comparative data.

\section{Summary}

The summary of site and isolate data provided above assumes that all variability in the archaeological record is a function of human behavior in the past, and that researchers have the ability to partition that record into sites and isolates that are equivalent to that past behavior. That is, the sites that we define in the present are seen as a reflection of that past behavior. Thus, assemblages with hearths or fire-cracked rock are seen as reflecting decisions regarding where to camp, and are thought to reflect habitation activities. Assemblages lacking fire-cracked rock, but with scattered chipped stone, are thought to reflect some form of lithic procurement or some stage of reduction. Even our reoccupation scenario involves reoccupation of different portions of the landscape by prehistoric populations that create the sites and isolates that we discover. However, as noted in the previous chapter, 
we view the archaeological record as a current phenomena that results from an interaction of prehistoric behavior, as well as a variety of other factors. These other factors include geomorphic history and archaeological decisions regarding observational procedures (e.g., transect spacing) and systematics (e.g., site definition, distinction of site types, temporal assignment). In the following chapter, we will explore the impact of this perspective using quantitative data observed on a sample of locations in the Twin Buttes Reservoir. 



\section{Chapter 9: Investigating the Archaeological Record at Twin Buttes}

\section{Raymond Mauldin}

In the previous chapter, we have described the archaeological material discovered during our survey of the Twin Buttes Reservoir in somewhat traditional terms. That is, we have classified the archaeological record into sites and isolates. Sites were subdivided into site types. When possible each site was placed into a temporal period. The temporal periods were based primarily on the presence of projectile point types shown, in other contexts, to have been used during particular periods. This chapter takes a different approach to investigating the archaeological record at Twin Buttes. As noted in Chapter 7, quantitative data may be necessary in order to begin to explore some of the complexities of the archaeological record. Consequently, we designed a system that made observations on the quantity and character of assemblages from a sample of archaeological sites identified during the project. In this chapter I use these data to investigate both how the reservoir was used and identify several factors that condition the archaeological record. I suggest that exposure significantly influences the data set by conditioning artifact size. As artifact size is related to artifact type, these exposure differences condition what artifact types are present within a given sample. The impact of this size effect is mitigated by limiting the analytical sample to those items above $2.0 \mathrm{~cm}$ in length. Using regression analysis, I divide the assemblage into two groups, those with high variety and those with low variety. These groups are further investigated by considering distance to water, the presence/absence of features or fire-cracked rock (FCR), and data on lithic reduction. While a paucity of temporal data and a lack of information on specific tool types at locations precludes any detailed analysis, the two-group pattern appears to identify locations that are likely candidates for residential sites, as well as locations that may reflect a more specialized focus.

\section{The Surface Observation Data}

The goal of the surface observation effort was to generate quantitative data on artifacts during the essentially non-collection survey. A series of elements were noted on each of the surface items. The attributes had to be sufficiently general such that a variety of different individuals with different backgrounds in chipped stone analysis and different levels of training could consistently record the attributes. In addition, the process had to be done quickly, maximizing the number of items recorded and the number of areas that could be investigated. Consequently, common reduction terms such as "biface thinning flake" and "preform" were avoided as the application of a specific set of definitional criteria to several thousand flakes would have taken significant time and a substantial amount of inconsistency would certainly be introduced during the recording procedure. The attributes which were eventually selected were pared down from a more detailed list after evaluating initial tests for consistency of recording between individuals. The attributes selected included artifact types defined primarily by morphological attributes (e.g., flake, biface, uniface, retouched and/or utilized flake), maximum length and width of the artifact in $1 \mathrm{~cm}$ intervals, the percentage of cortex on chipped stone items in ordinal groups (i.e., 0 percent, $1-25$ percent, $26-50$ percent, 51-75 percent, 76-99 percent, 100 percent), and material type. Forms and definitions of specific attributes used during the surface observation are presented in Appendix K.

Sites were selected for inclusion in the sample based on both surface density and location. As our concern was generating quantitative data, those sites which were essentially defined in cutbanks or those sites noted as having few surface artifacts were generally not included in the sample. In addition, we wanted to 


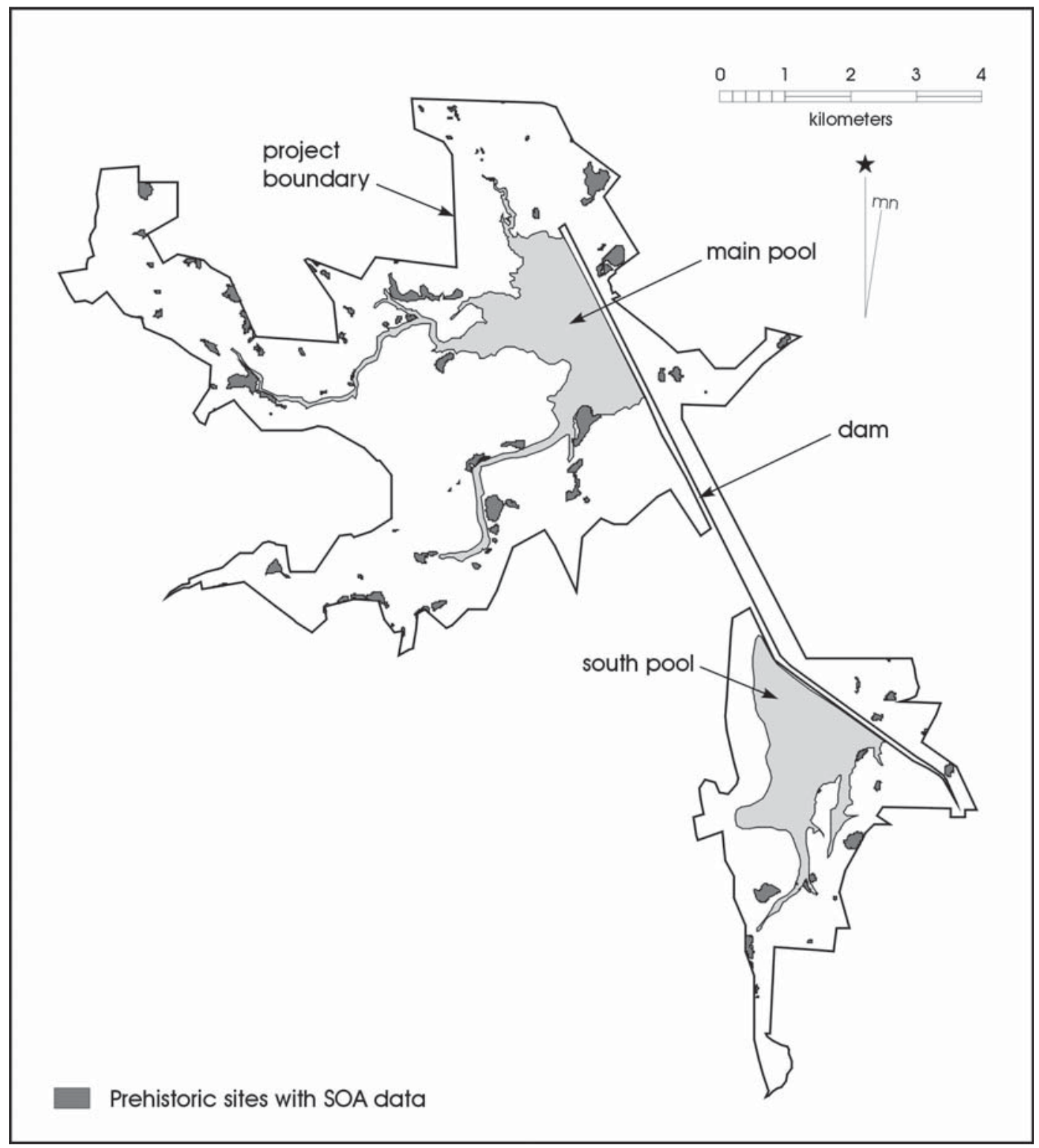

Figure 9-1. Sites with surface observation areas (SOAs).

acquire data from throughout the project area. We recorded artifacts from a total of 131 separate surface observation areas from 97 different sites, identified in Figure 9-1. Details on the procedures used to select areas within a site for inclusion in the sample, recording procedures, and specific data on each SOA by site can be found in Appendix D.

\section{Exploring Surface Data Patterns}

The database generated from the surface observations consists of attributes recorded on 21,769 items from a total area of roughly 59,865 square meters on 97 different sites from throughout the reservoir. Table 9-1 lists all 131 areas, the quantity of items observed, the associated drainage, the size of the surface observation area, resulting artifact density, and a designation of exposure. The exposure designation was made in the field by the author. A designation of 1 suggests that the surface was not exposed, being characterized either by vegetation that obscured artifacts or by what appeared to be some buildup of sediment. A designation of 2 was assigned to those areas that had both little or no vegetation and evidence of some erosion. These cases frequently were shorelines consisting of extensive gravel deposits without vegetation, exposed conglomerate with little 
Table 9-1. Surface Observation Data from Twin Buttes Reservoir

\begin{tabular}{|c|c|c|c|c|c|}
\hline 41TG__ & Quantity & Drainage & Square Meters & Density* & Exposure \\
\hline 359 & 77 & No Name & 1640 & 0.05 & 1 \\
\hline 359 & 15 & No Name & 770 & 0.019 & 1 \\
\hline 361 & 92 & No Name & 840 & 0.11 & 1 \\
\hline 361 & 59 & No Name & 570 & 0.103 & 1 \\
\hline 362 & 27 & No Name & 490 & 0.055 & 1 \\
\hline 362 & 28 & No Name & 4840 & 0.006 & 1 \\
\hline 365 & 138 & No Name & 610 & 0.226 & 2 \\
\hline 367 & 112 & No Name & 350 & 0.32 & 1 \\
\hline 368 & 104 & No Name & 740 & 0.141 & 1 \\
\hline 372 & 90 & No Name & 1270 & 0.071 & 1 \\
\hline 373 & 47 & No Name & 190 & 0.247 & 1 \\
\hline 374 & 12 & No Name & 280 & 0.043 & 1 \\
\hline 375 & 22 & No Name & 590 & 0.037 & 1 \\
\hline 378 & 36 & No Name & 1930 & 0.019 & 1 \\
\hline 378 & 123 & No Name & 2530 & 0.049 & 1 \\
\hline 385 & 71 & Middle Concho & 340 & 0.209 & 2 \\
\hline 385 & 41 & Middle Concho & 230 & 0.178 & 2 \\
\hline 385 & 35 & Middle Concho & 340 & 0.103 & 2 \\
\hline 385 & 93 & Middle Concho & 28 & 3.32 & 2 \\
\hline 386 & 30 & Middle Concho & 500 & 0.06 & 1 \\
\hline 388 & 215 & Middle Concho & 90 & 2.389 & 1 \\
\hline 388 & 134 & Middle Concho & 90 & 1.489 & 1 \\
\hline 389 & 384 & Middle Concho & 28 & 13.71 & 1 \\
\hline 389 & 170 & Middle Concho & 28 & 6.07 & 1 \\
\hline 391 & 106 & Middle Concho & 540 & 0.196 & 2 \\
\hline 392 & 115 & Middle Concho & 510 & 0.225 & 1 \\
\hline 395 & 81 & Middle Concho & 330 & 0.245 & 1 \\
\hline 397 & 128 & Middle Concho & 90 & 1.422 & 1 \\
\hline 397 & 119 & Middle Concho & 190 & 0.626 & 2 \\
\hline 400 & 168 & Middle Concho & 60 & 2.8 & 2 \\
\hline
\end{tabular}


Table 9-1. Continued...

\begin{tabular}{|c|c|c|c|c|c|}
\hline 41TG_ & Quantity & Drainage & Square Meters & Density* & Exposure \\
\hline 404 & 107 & Middle Concho & 160 & 0.7 & 1 \\
\hline 404 & 133 & Middle Concho & 50 & 2.66 & 1 \\
\hline 405 & 238 & Middle Concho & 28 & 9.75 & 2 \\
\hline 405 & 391 & Middle Concho & 28 & 13.96 & 2 \\
\hline 408 & 194 & Middle Concho & 440 & 0.441 & 1 \\
\hline 409 & 62 & Middle Concho & 0 & 0 & 2 \\
\hline 409 & 273 & Middle Concho & 28 & 9.75 & 2 \\
\hline 411 & 132 & Middle Concho & 20 & 6.6 & 2 \\
\hline 411 & 268 & Middle Concho & 30 & 8.93 & 2 \\
\hline 412 & 157 & Middle Concho & 60 & 2.617 & 1 \\
\hline 412 & 117 & Middle Concho & 120 & 0.975 & 1 \\
\hline 414 & 665 & Middle Concho & 8 & 83.12 & 2 \\
\hline 419 & 149 & Middle Concho & 220 & 0.667 & 1 \\
\hline 420 & 19 & Middle Concho & 2130 & 0.009 & 1 \\
\hline 421 & 14 & Middle Concho & 630 & 0.022 & 1 \\
\hline 423 & 112 & Middle Concho & 190 & 0.589 & 1 \\
\hline 424 & 13 & Middle Concho & 12 & 1.08 & 1 \\
\hline 424 & 118 & Middle Concho & 130 & 0.908 & 1 \\
\hline 424 & 335 & Middle Concho & 28 & 11.96 & 1 \\
\hline 424 & 189 & Middle Concho & 28 & 6.75 & 1 \\
\hline 427 & 964 & Middle Concho & 28 & 34.43 & 2 \\
\hline 430 & 223 & Middle Concho & 80 & 2.79 & 1 \\
\hline 109 & 2496 & Spring Creek & 8 & 312 & 2 \\
\hline 110 & 142 & Spring Creek & 28 & 5.07 & 1 \\
\hline 110 & 222 & Spring Creek & 28 & 7.93 & 1 \\
\hline 437 & 151 & Spring Creek & 130 & 1.16 & 2 \\
\hline 441 & 46 & Spring Creek & 390 & 0.118 & 2 \\
\hline 443 & 47 & Spring Creek & 150 & 0.313 & 1 \\
\hline 447 & 221 & Spring Creek & 50 & 4.42 & 1 \\
\hline 448 & 95 & Spring Creek & 30 & 3.17 & 1 \\
\hline
\end{tabular}


Table 9-1. Continued...

\begin{tabular}{|c|c|c|c|c|c|}
\hline 41TG_ & Quantity & Drainage & Square Meters & Density* & Exposure \\
\hline 449 & 361 & Spring Creek & 80 & 4.51 & 1 \\
\hline 253 & 345 & Spring Creek & 30 & 11.5 & 1 \\
\hline 456 & 169 & Middle Concho & 270 & 0.626 & 1 \\
\hline 456 & 116 & Middle Concho & 840 & 0.138 & 2 \\
\hline 344 & 86 & Middle Concho & 380 & 0.221 & 1 \\
\hline 247 & 52 & Spring Creek & 460 & 0.113 & 1 \\
\hline 247 & 61 & Spring Creek & 210 & 0.29 & 2 \\
\hline 247 & 1263 & Spring Creek & 28 & 45.11 & 2 \\
\hline 246 & 47 & Spring Creek & 210 & 0.224 & 1 \\
\hline 246 & 330 & Spring Creek & 40 & 8.25 & 2 \\
\hline 246 & 57 & Spring Creek & 280 & 0.204 & 1 \\
\hline 461 & 48 & Middle Concho & 450 & 0.107 & 1 \\
\hline 461 & 135 & Middle Concho & 360 & 0.375 & 2 \\
\hline 464 & 134 & Middle Concho & 70 & 1.914 & 1 \\
\hline 245 & 169 & Spring Creek & 590 & 0.286 & 1 \\
\hline 465 & 94 & Spring Creek & 4580 & 0.021 & 1 \\
\hline 466 & 115 & Spring Creek & 100 & 1.15 & 1 \\
\hline 244 & 85 & Spring Creek & 360 & 0.236 & 1 \\
\hline 244 & 23 & Spring Creek & 230 & 0.1 & 1 \\
\hline 244 & 286 & Spring Creek & 28 & 10.21 & 2 \\
\hline 467 & 167 & Spring Creek & 130 & 1.285 & 1 \\
\hline 467 & 102 & Spring Creek & 28 & 3.643 & 1 \\
\hline 468 & 361 & Spring Creek & 28 & 12.89 & 1 \\
\hline 471 & 147 & Spring Creek & 500 & 0.294 & 1 \\
\hline 472 & 103 & Spring Creek & 60 & 1.716 & 1 \\
\hline 474 & 88 & Spring Creek & 150 & 0.586 & 1 \\
\hline 478 & 88 & Spring Creek & 390 & 0.226 & 1 \\
\hline 479 & 92 & Spring Creek & 130 & 0.708 & 1 \\
\hline 482 & 94 & Spring Creek & 70 & 1.343 & 2 \\
\hline 483 & 29 & Spring Creek & 150 & 0.193 & 2 \\
\hline
\end{tabular}


Table 9-1. Continued...

\begin{tabular}{|c|c|c|c|c|c|}
\hline 41TG_ & Quantity & Drainage & Square Meters & Density* & Exposure \\
\hline 485 & 244 & Spring Creek & 40 & 6.1 & 2 \\
\hline 106 & 436 & Spring Creek & 40 & 10.9 & 2 \\
\hline 489 & 156 & Spring Creek & 90 & 1.733 & 1 \\
\hline 491 & 82 & Spring Creek & 130 & 0.631 & 1 \\
\hline 495 & 111 & Middle Concho & 110 & 1.01 & 1 \\
\hline 496 & 104 & Middle Concho & 350 & 0.297 & 1 \\
\hline 497 & 35 & Middle Concho & 170 & 0.206 & 1 \\
\hline 500 & 182 & Middle Concho & 90 & 2.02 & 1 \\
\hline 500 & 96 & Middle Concho & 28 & 3.43 & 1 \\
\hline 500 & 160 & Middle Concho & 28 & 5.71 & 1 \\
\hline 504 & 350 & South Concho & 30 & 11.67 & 2 \\
\hline 504 & 205 & South Concho & 40 & 5.13 & 2 \\
\hline 506 & 223 & South Concho & 100 & 2.23 & 1 \\
\hline 507 & 45 & South Concho & 1140 & 0.039 & 1 \\
\hline 508 & 13 & South Concho & 80 & 0.163 & 1 \\
\hline 509 & 19 & South Concho & 110 & 0.173 & 1 \\
\hline 511 & 45 & South Concho & 180 & 0.25 & 1 \\
\hline 512 & 413 & South Concho & 120 & 3.44 & 1 \\
\hline 251 & 37 & South Concho & 410 & 0.09 & 1 \\
\hline 250 & 27 & South Concho & 550 & 0.049 & 1 \\
\hline 513 & 160 & South Concho & 320 & 0.5 & 1 \\
\hline 514 & 44 & South Concho & 490 & 0.09 & 1 \\
\hline 515 & 116 & South Concho & 1120 & 0.103 & 2 \\
\hline 518 & 158 & Middle Concho & 70 & 2.26 & 2 \\
\hline 518 & 237 & Middle Concho & 28 & 8.46 & 2 \\
\hline 519 & 450 & Middle Concho & 28 & 16.07 & 2 \\
\hline 520 & 22 & Spring Creek & 850 & 0.026 & 1 \\
\hline 522 & 23 & Spring Creek & 85 & 0.271 & 1 \\
\hline 523 & 43 & Spring Creek & 290 & 0.148 & 2 \\
\hline 523 & 57 & Spring Creek & 610 & 0.009 & 2 \\
\hline
\end{tabular}


Table 9-1. Continued...

\begin{tabular}{|c|c|c|c|c|c|}
\hline 41TG_ & Quantity & Drainage & Square Meters & Density* & Exposure \\
\hline 524 & 66 & Spring Creek & 1050 & 0.63 & 1 \\
\hline 525 & 49 & South Concho & 5030 & 0.01 & 1 \\
\hline 526 & 101 & South Concho & 2740 & 0.037 & 1 \\
\hline 527 & 23 & South Concho & 440 & 0.052 & 2 \\
\hline 528 & 34 & South Concho & 1620 & 0.021 & 1 \\
\hline 530 & 86 & Middle Concho & 900 & 0.096 & 1 \\
\hline 252 & 89 & Middle Concho & 770 & 0.116 & 1 \\
\hline 252 & 56 & Middle Concho & 1280 & 0.044 & 1 \\
\hline 531 & 216 & South Concho & 150 & 1.44 & 1 \\
\hline 533 & 249 & South Concho & 230 & 1.08 & 1 \\
\hline 535 & 95 & South Concho & 400 & 0.238 & 1 \\
\hline
\end{tabular}

* Number of items per square meter.

Note: Exposure designation 1 = surface was not exposed, $2=$ little or no vegetation and evidence of some erosion.

vegetation, ridge tops with little deposition, and areas with bedrock exposed on the surface. In several cases, different levels of exposure are present within the same site, such as the case of 41TG246 discussed in Chapter 2 where artifact assemblages from the unexposed areas above and below the shoreline had significantly different patterns than those from the exposed shoreline.

This large data set can be used in a variety of different ways to consider patterns in artifacts. Figure 9-2, a histogram of the percentage of tertiary flakes for the 97 sites, is one such example. High percentages of tertiary flakes are frequently argued to reflect a focus on late stage reduction (e.g., Collins 1975). Examination of the figure suggests that a minimum of four different modes may be present in these data, potentially reflecting different reduction stages. The upper mode consists of 21 sites that have flake assemblages dominated by tertiary flakes ( $>73$ percent). A second group, consisting of 38 sites, has between
53 percent and 73 percent tertiary flakes, while a third group of sites has tertiary flake percentages between 28 percent and 53 percent. The fourth group consists of seven sites, all of which have debitage assemblages

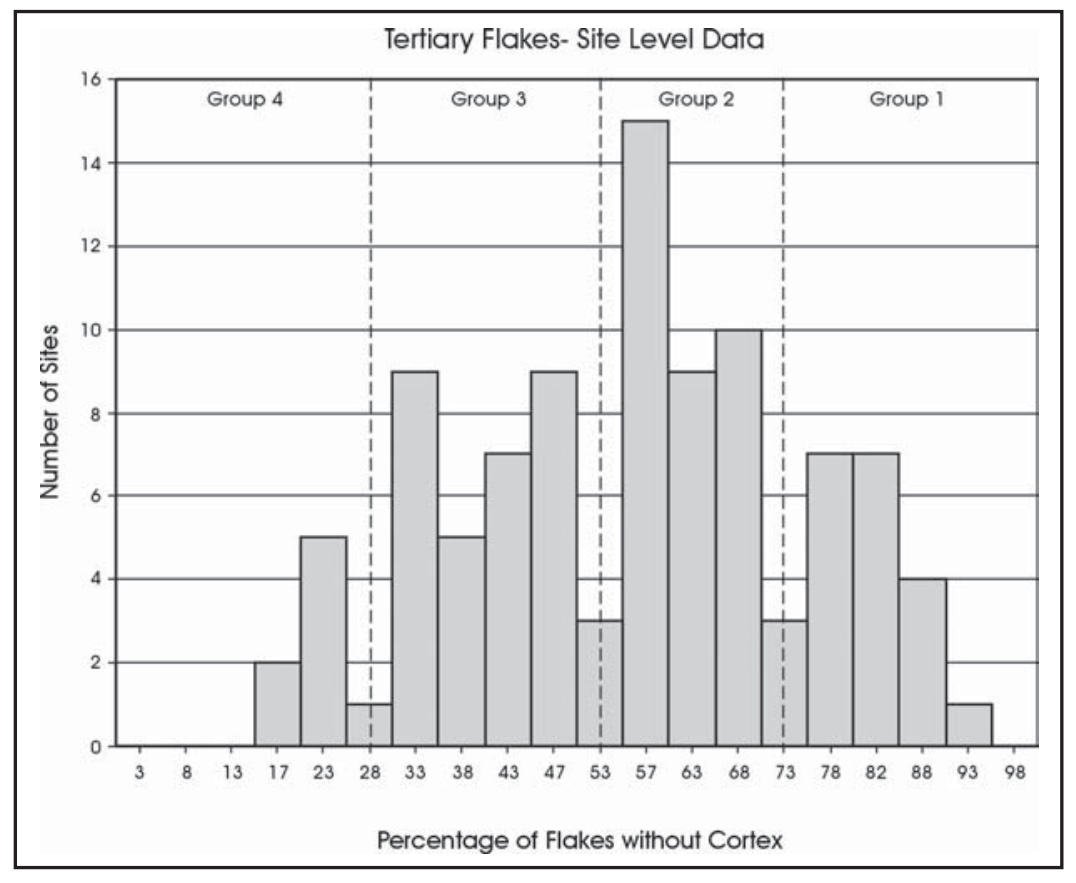

Figure 9-2. Tertiary Flake Percentages for 97 sites with SOAs. Data at the site level. 
characterized by low frequencies of tertiary flakes. Almost 97 percent of the 89 cores, tested cobbles, and bifaces on the group 4 sites have cortex present. Conversely, only 70 percent of the 243 cores, tested cobbles, and bifaces in the upper mode (group 1) have cortex present. These patterns of cores, tested cobbles, and bifaces are consistent with the suggestion that the upper mode reflects a focus on late stage reduction and that the lower mode reflects behaviors that are early in the reduction sequence.

The patterns appear to be strong. The modes are distinctive. Tertiary flake percentages within the debitage are supported by cortex patterns in cores, tested cobbles, and bifaces. The patterns fit well with a notion that distinctive reduction stages are present. These patterns could be coupled with diagnostic artifacts, distance of the sites to water, the presence/absence of features, and several other variables to create a reasonable and believable account of prehistoric use of the reservoir. It would be easy. It is tempting. However, to do so would be to assume that all variability observed in the archaeological record is directly related to variability in past human behavior. We have argued in Chapters 2 and 7 that this is unlikely to be the case. We need to understand the structure of the data sets before making the jump to prehistoric behavior. One element that significantly structures the surface patterning in the current data set is exposure.

\section{Exposure and Artifact Density}

A review of the data in Table 9-1 will demonstrate that there is considerable variability in the size of the surface observation areas, the quantity of items observed, and the overall density of material. In cases with high surface artifact densities, we selected smaller areas for the inventory as our goal was to obtain a reasonable sample size in a minimum amount of time. Conversely, in areas of low artifact density, we increased the coverage area in order to obtain a sufficient number of items in the sample. In spite of our attempt to control the sample size by changing the sampling area, significant differences remain between SOAs in terms of sample size. At the extremes, a single sample area of eight square meters from 41TG109 produced information on almost 2,500 artifacts for a density of 312 items per square meter, while only
49 artifacts were present in an area of over 5,000 square meters on 41 TG525.

Not surprisingly, these differences in artifact density are related, in part, to the exposure variable noted in Table 9-1, with those areas classified as having low exposure also having lower surface densities. The 93 SOAs identified as having low levels of exposure produced 10,679 artifacts in an area of 52,367 square meters for an overall density of roughly .204 artifacts per square meter. Conversely, the 38 SOAs classified in the field as being exposed produced observations on 11,090 artifacts from 7,498 square meters, an artifact density of almost 1.5 items per square meter. On average, exposed surfaces have over seven times as many artifacts per square meter as unexposed surfaces. This is certainly related both to lower visibility on unexposed surfaces and the potential that some of the exposed surfaces are erosional.

\section{Exposure and Artifact Types Represented}

Table 9-2 presents artifact frequencies by type and exposure. A chi-square test demonstrates that there is a significant difference in the data $\left(X^{2}=357.85\right.$; $d f=6$; $p<0.0001$ ), suggesting that the frequency of various artifact types are not randomly distributed with regard to erosion. Below each observed frequency are the adjusted residuals. As discussed in the previous chapter, adjusted residuals are thought to be analogous to $\mathrm{Z}$ scores, such that an adjusted residual value exceeding an absolute value of 1.96 suggests that the cell is significantly different at a probability beyond the level of .05 (Everitt 1977; Haberman 1973). Note that while all cells in the table have significant values, flakes are significantly over represented on exposed surfaces, while all other artifact classes are under represented.

While overall artifact density can be easily related to exposure, there is no intuitive reason to suspect that exposure should differentially impact specific artifact types. Nevertheless, as a group flakes are over represented on exposed surfaces, while all other artifact types are less common. Figure 9-3 suggests that one factor in explaining the pattern may be related to artifact size. For Figure 9-3, we have plotted the percentage of artifacts within a class that are on 
Table 9-2. Observed Frequencies of Artifact Types by Exposure

\begin{tabular}{|c|c|c|c|}
\hline Artifact Types & Not Exposed & Exposed & Total \\
\hline Flakes & $\begin{array}{c}9,361 \\
\mathbf{( - 1 8 . 1 )}\end{array}$ & $\begin{array}{c}10,493 \\
(18.1)\end{array}$ & 19,854 \\
\hline Cores & $\begin{array}{c}523 \\
(12.9)\end{array}$ & $\begin{array}{c}197 \\
(\mathbf{- 1 2 . 9})\end{array}$ & 720 \\
\hline Tested Cobbles & $\begin{array}{c}149 \\
(8.6)\end{array}$ & $\begin{array}{c}36 \\
(-\mathbf{- 8 . 6})\end{array}$ & 185 \\
\hline Bifaces & $\begin{array}{c}154 \\
(4.6)\end{array}$ & $\begin{array}{c}87 \\
(-4.6) \\
\end{array}$ & 241 \\
\hline Unifaces & $\begin{array}{c}104 \\
(3.3)\end{array}$ & $\begin{array}{c}65 \\
(\mathbf{- 3 . 3})\end{array}$ & 169 \\
\hline Utilized / Retouched & $\begin{array}{r}374 \\
(7.3) \\
\end{array}$ & $\begin{array}{c}211 \\
(-7.3) \\
\end{array}$ & 585 \\
\hline Other Items* & $\begin{array}{c}14 \\
(3.4) \\
\end{array}$ & $\begin{array}{c}1 \\
(-3.4) \\
\end{array}$ & 15 \\
\hline TOTALS & 10,679 & 11,090 & 21,769 \\
\hline
\end{tabular}

* Includes manos, metates, and hammer stones.

exposed surfaces (y axis) against the mean artifact size in $\mathrm{cm}$ for all artifacts in a class. We have subdivided the general artifact classes listed in Table 9-1 into finer distinctions based on cortex. Thus the 19,854 flakes in Table 9-1 have been subdivided into tertiary flakes $(n=13,615)$, secondary flakes $(n=4,387)$, and primary flakes $(n=1,852)$. Cores are divided into those with $(\mathrm{n}=638)$ and without cortex $(n=82)$, and similar distinctions are made for bifaces (148 with cortex; 125 without cortex), unifaces (57 with cortex; 112 without cortex), and utilized/retouched items ( $\mathrm{n}=$ 585). With the tested cobbles class and the "other tool" class, a total of 13 distinct artifact types are used in the figure. For each class, we then determined the overall mean length and the percentage of artifacts that were represented on exposed surfaces. Thus, for tertiary flakes, the mean length is 1.93 $\mathrm{cm}$ and 59.42 percent of all tertiary flakes are recovered from exposed surfaces. Conversely, for tested cobbles, the mean length is $7.59 \mathrm{~cm}$, and only 19.5 percent of the tested cobbles identified are from exposed surfaces. The linear relationship between mean artifact size of a class and the percentage of that class recovered from exposed surfaces is clearly visible in, the plot. A Spearman's rank order correlation coefficient of $-.768(p=.002)$ confirms the visual impression.

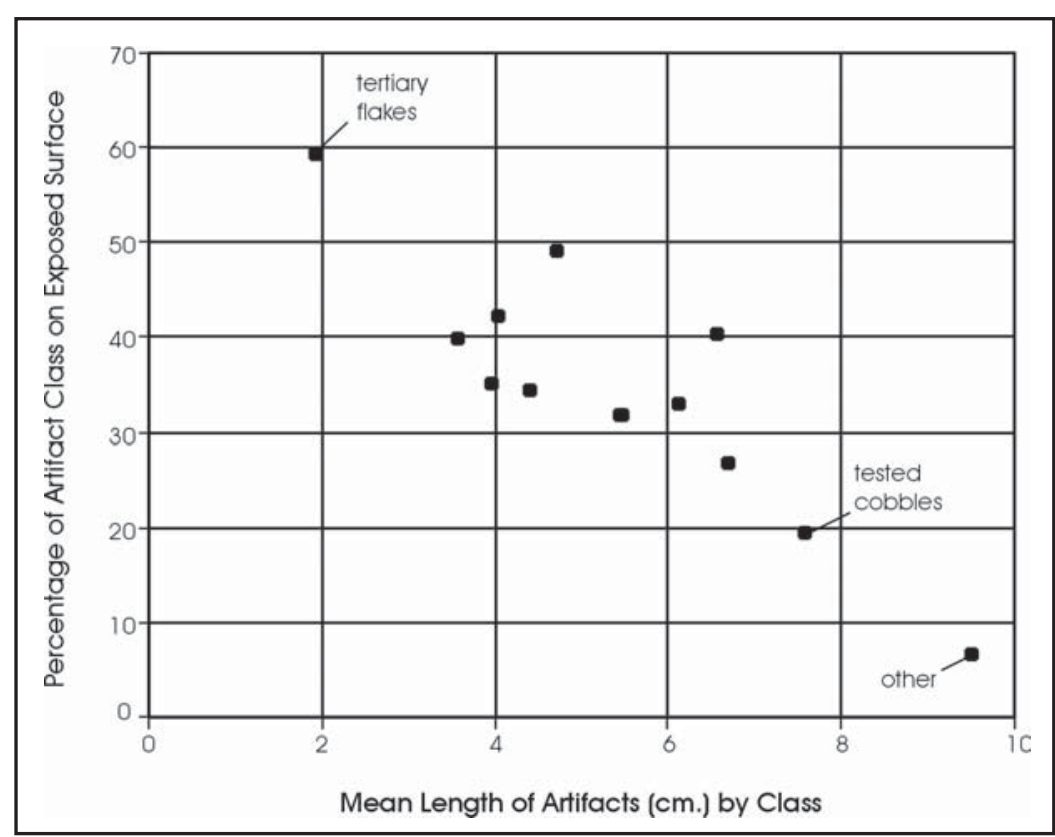

Figure 9-3. Exposure and mean artifact length by class. 
As noted previously in Chapter 2, smaller artifacts are more likely to be under represented on unexposed surfaces relative to exposed surfaces. This statement is further supported by comparing the overall size of all 11,090 artifacts found on exposed surfaces (mean=2.17 $\mathrm{cm})$ relative to the 10,679 artifacts on unexposed surfaces $(x=3.42 \mathrm{~cm})$. This difference in mean size of 1.25 $\mathrm{cm}$ is probably a function of visibility, with larger artifacts as measured by maximum length, being more visible on unexposed surfaces. Smaller artifacts, conversely, are more easily obscured. Interestingly, those artifact groups that are commonly used to measure early reduction activities (i.e., cores with cortex, primary and secondary flakes, tested cobbles, bifaces with cortex) tend to be large in size. The mean size of the 7,155 items in this early reduction group, regardless of exposure, is $4.09 \mathrm{~cm}$. Conversely, tertiary flakes, cores without cortex, and bifaces without cortex are small, with a mean size of $1.98 \mathrm{~cm}$ for the 13,845 items in this group of artifacts. As such, early reduction items should be over represented on unexposed surfaces while artifacts commonly used to measure late reduction should be over represented on exposed surfaces simply as a function of their relative size.

The impact of these size differences can be seen in Figure 9-4 which contrasts tertiary artifact lengths by $1 \mathrm{~cm}$ size groups for unexposed and exposed surfaces. While both data sets have dominate modes in the 1 to $2 \mathrm{~cm}$ size group, 71.8 percent of the 8,090 tertiary flakes on the exposed surfaces are less than $2 \mathrm{~cm}$. Conversely, only 46.2 percent of the 5,525 flakes without cortex on unexposed surfaces are less than 2 $\mathrm{cm}$. As suggested above, tertiary flakes, as a group, are over represented on exposed surfaces. This difference is especially apparent in the smaller size ranges. These flakes may certainly be present in higher numbers on surfaces classified as unexposed, but given the small overall size of these flakes they may be differentially covered by deposition or vegetation.

At least some of the strong patterns outlined earlier in Figure 9-2, where essentially four groups of sites had different modes of tertiary flake percentages, are related to exposure differences. For example, there are seven sites in the lower, "early reduction" mode in the figure. The data for these seven sites comes from nine SOAs, 89 percent of which are cases of low exposure. Low exposure settings should produce low numbers of tertiary flakes, as well as higher frequencies of cores with cortex, two data sets that were adduced in support of the early reduction pattern for the assemblages at these sites. Conversely, 13 of the 27 cases in the upper mode on Figure 9-2 are cases of high exposure. High exposure should produce higher incidences of tertiary flakes, as well as lower frequencies of larger artifacts generally indicative of early reduction. Exposure, by differentially impacting the size of items recovered, plays a significant role in determining the patterns of materials recovered.

In Figure 9-5 we have eliminated all flakes from the distribution, leaving 1,915 tools, cores, tested cobbles, and ground stone. Flakes have the smallest maximum

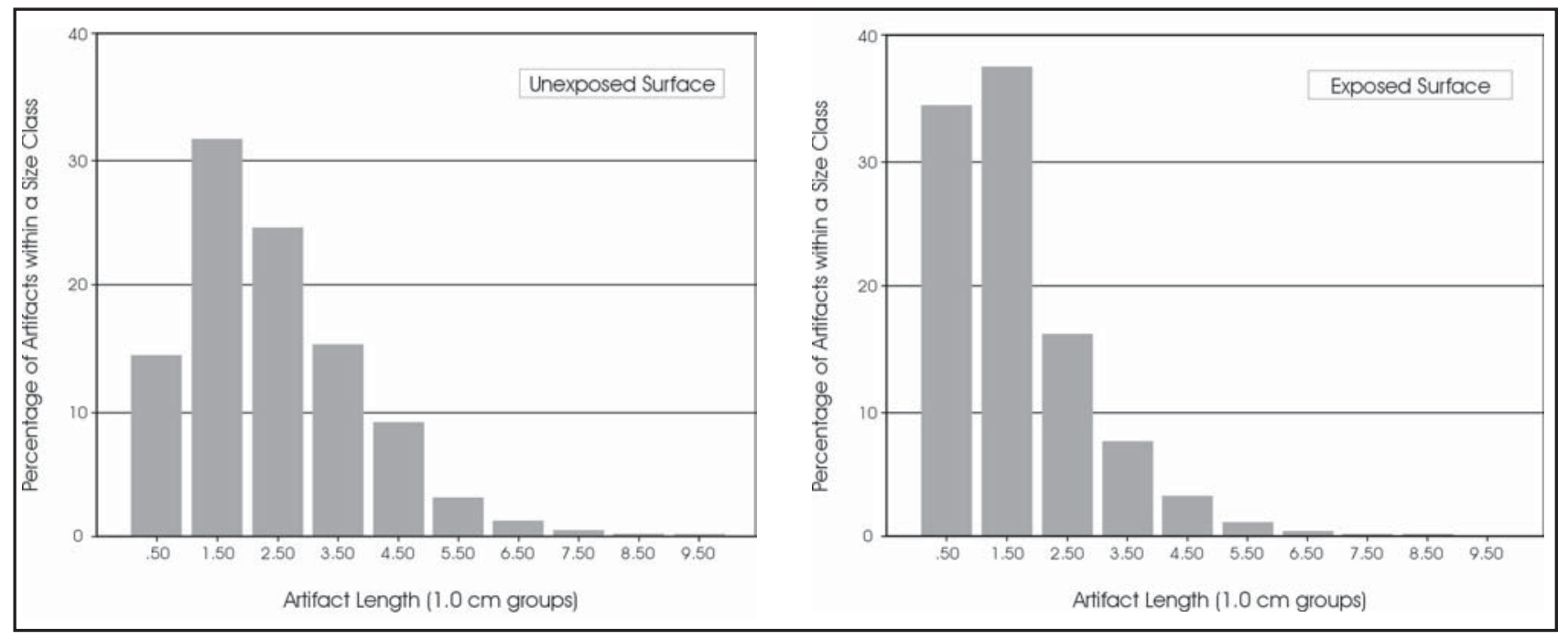

Figure 9-4. Percentage of artifacts by size groups on unexposed (left) and exposed (right) surfaces. 
length, and so should be most directly impacted by differential exposure. The unexposed and exposed bars in the figure have somewhat similar distributions, but the exposed bars are under represented in the size ranges from 6 to $12 \mathrm{~cm}$, and over represented in the areas below $6 \mathrm{~cm}$. Clearly, some of these differences may still reflect differential coverage. That is, the lower percentages of larger items on exposed surfaces may simply reflect the higher frequencies of smaller items on these same surfaces. If all aspects of the size effect could be removed, then it may be the case that the overall distributions are similar. However, not all of the differences in Figure 9-2 can be explained by differential coverage and exposure of small items. Recall that the correlation between exposure and artifact size at a class level presented in Figure 9-3, while significant, is not perfect. Other factors beyond differential coverage are certainly involved. An examination of par-

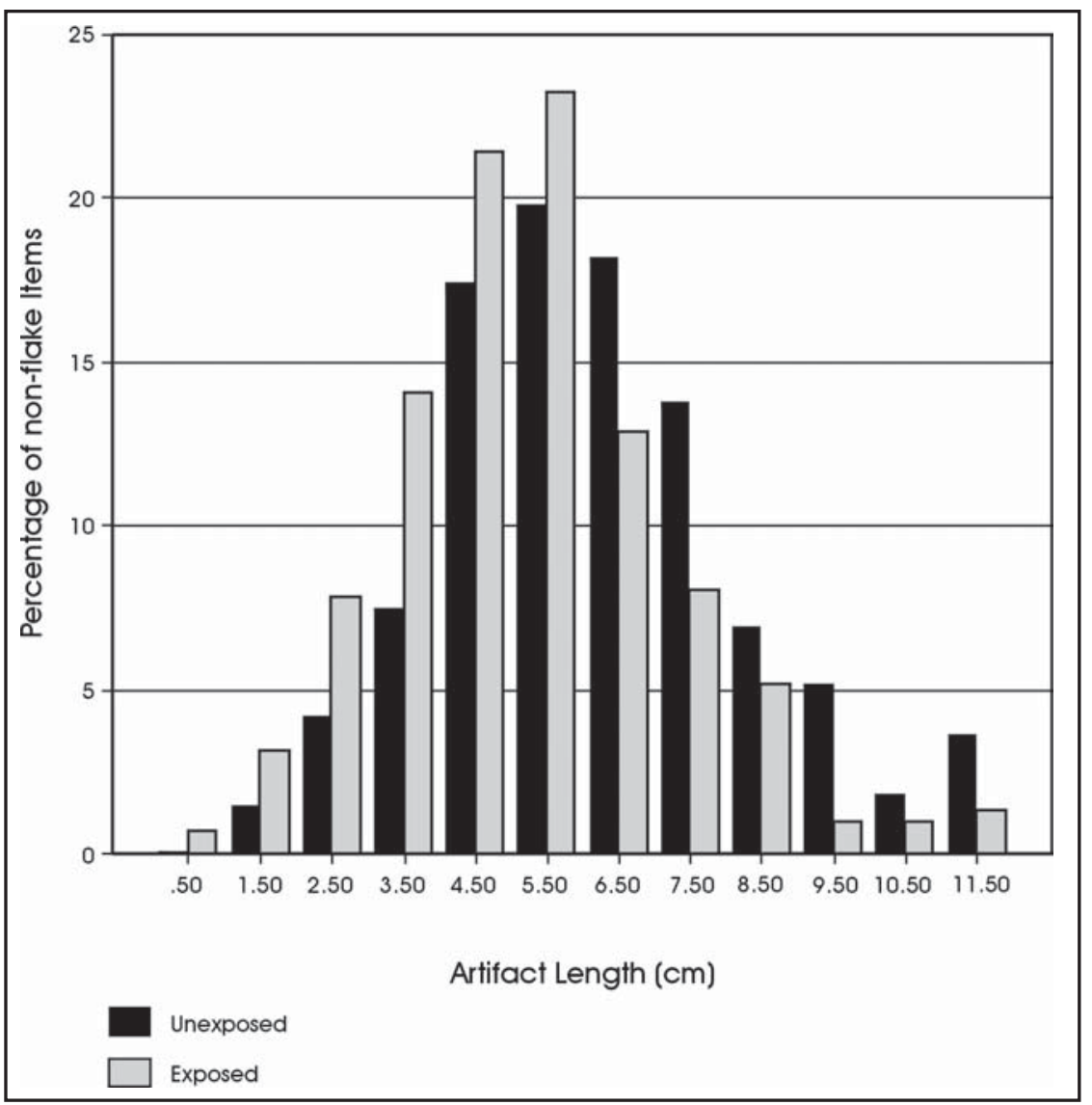

Figure 9-5. Percentage of non-flake artifacts by length for unexposed and exposed surfaces. ticular tool types suggest that at least one additional element may be differential collection of artifacts from these two types of surfaces.

\section{Collection and Exposure}

Another potential factor in producing the distribution may be related to collecting behavior. We have documented in Chapter 2 modern collecting of items, primarily bifaces, from the reservoir area, and earlier periods of scavenging of artifacts from extant sites by prehistoric populations was probably occurring as well. It is also possible that this collecting behavior was more common on exposed relative to unexposed surfaces. Assuming that there is some relationship between the size of an item and the probability of collection, and that at least some of the patterns of modern exposure can be projected back into the recent past, it is possible that collecting behavior could significantly reduce the larger sized items on exposed surfaces relative to unexposed settings.
In order to consider this possibility, we focused on bifaces as it appears that these items, especially those that have been extensively worked, have been heavily collected from the reservoir during recent years. Figure 9-6 contrasts the size distribution of all bifaces on unexposed (black bars) and exposed (grey bars) surfaces. Note that bifaces as a group tend to be larger on unexposed surfaces. The mean size is $5.26 \mathrm{~cm}$ for unexposed and $4.87 \mathrm{~cm}$ for exposed, and the modes of the two distributions are separated by about $2 \mathrm{~cm}$. While some of these differences in the mean size may be related to differential coverage of small bifaces on unexposed surfaces, the differences between modes are unlikely to change, even if a substantial number of small items are added to the unexposed sample.

Figure 9-7, like 9-6, contrasts bifaces exposed and unexposed surfaces, but here I have limited the bifaces to those without cortex. These should be impacted more heavily by collection than all bifaces. Note that the exposed distribution appears to be truncated 


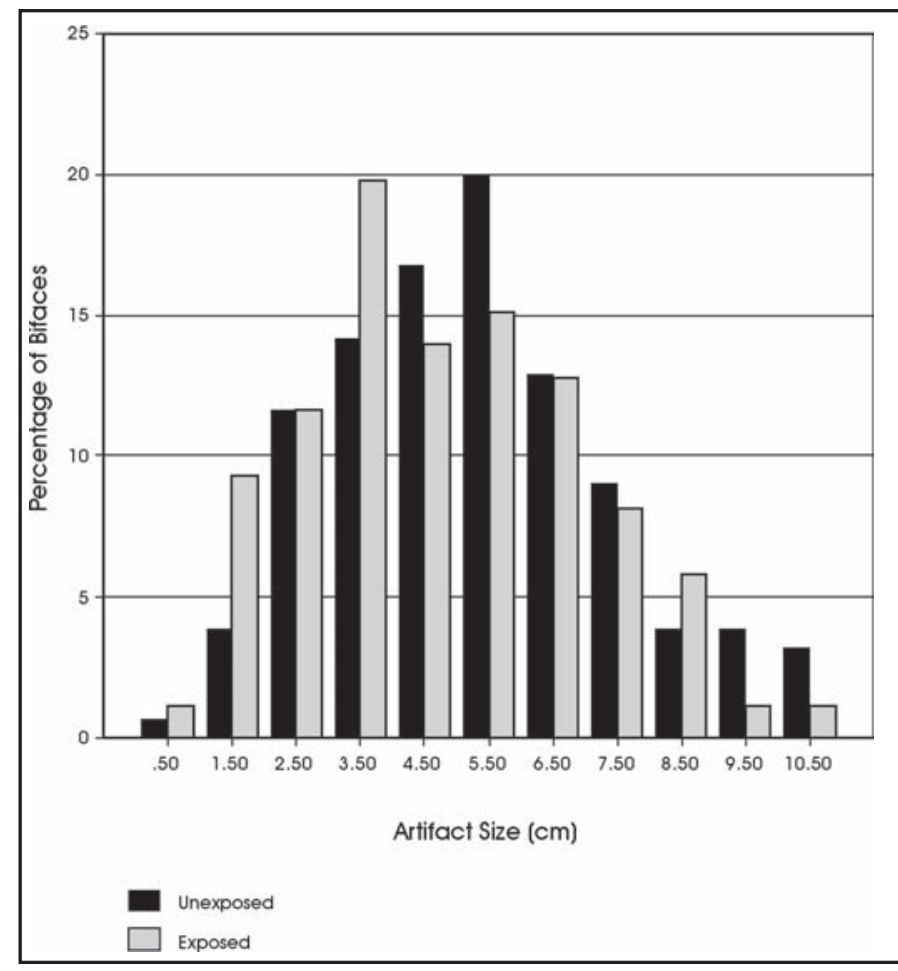

Figure 9-6. Percentage of all bifaces by length for unexposed and exposed surfaces.

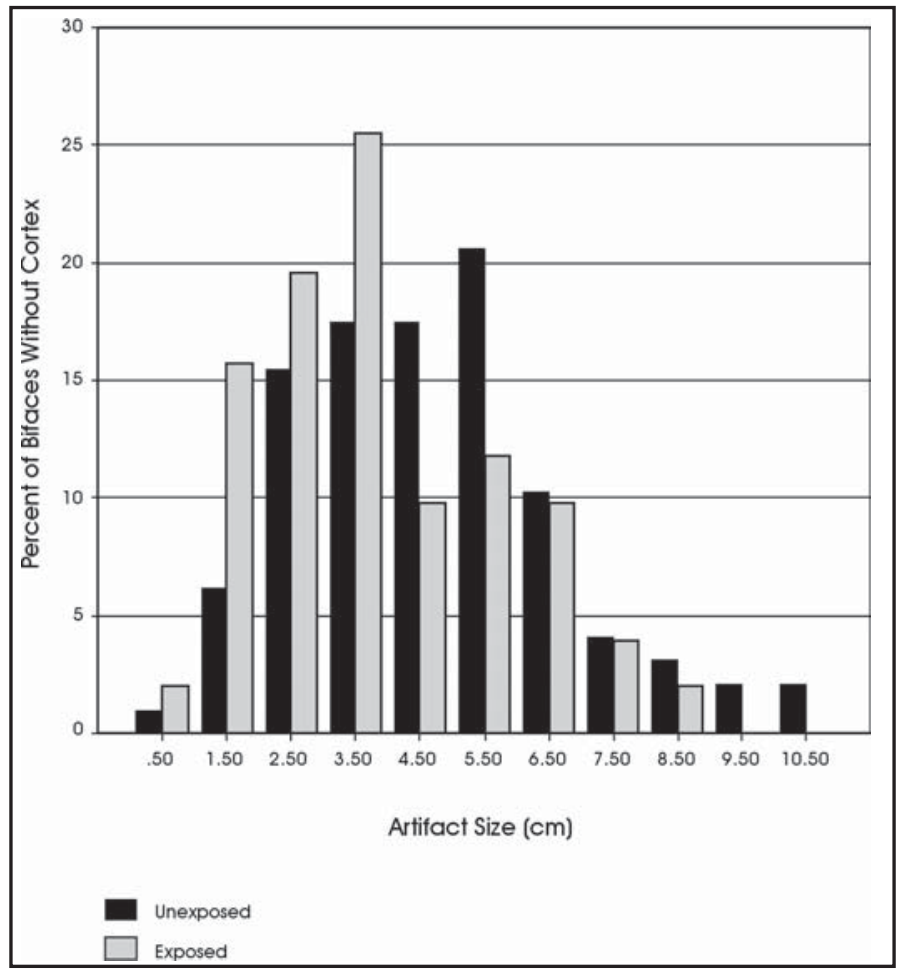

Figure 9-7. Percentage of bifaces without cortex by length for unexposed and exposed surfaces. after $4.0 \mathrm{~cm}$. Just over 25 percent of the exposed bifaces are in the 3 to $4 \mathrm{~cm}$ range, but then the percentages drop dramatically to below 10 percent for non-cortical bifaces in the 4 to $5 \mathrm{~cm}$ interval. In addition, there are no bifaces on exposed surfaces greater than $9 \mathrm{~cm}$ in length. While a variety of factors may account for the lack of a significant number of bifaces above $4 \mathrm{~cm}$, the sudden truncation of the distribution at that point, and the lack of larger non-cortical bifaces in the exposed sample, all these characteristics are consistent with the differential collection of bifaces in general, and non-cortical bifaces in particular, on surfaces classified as exposed. Such activities would, in combination with the substantial impact of differential coverage of smaller sized items, account for much of the difference between exposed and unexposed surface level patterns. While it could be argued that these biface differences are the end result of the reduction process, there is no necessary relationship between the modern observations on exposure and reduction patterns in the past.

\section{Other Considerations Regarding Exposure} Unfortunately, the factors noted above may not account for all of the differences between the two data sets. This can be seen by considering Figure 9-8, a graph that contrasts the distribution of cores with cortex, tested cobbles, and the small amount of ground stone. These items are less likely to be collected, at least by modern collectors, and thus the patterns in the exposure distribution should be similar to those for the unexposed. While the distribution of these two data sets are more similar than those shown for the bifaces, there still appear to be differences. Items on exposed surfaces are relatively smaller than those on unexposed surfaces. The mode of the exposed distribution is in the 5 to $6 \mathrm{~cm}$ bar, with the unexposed mode occurring in the 6 to $7 \mathrm{~cm}$ bar. In addition, unexposed items in the 11 to $12 \mathrm{~cm}$ interval have percentage values twice those of the exposed items. Given the overall large size of these items, and the low probability that these items are the focus of modern collectors, these differences suggest that other factors beyond simply visibility may be in operation. One such factor may be related to the differential area of the sample blocks on exposed and unexposed surfaces. 
Recall that in order to control sample size and reduce the amount of time spent on observation of any single SOA, we increased the area of surface collection on low density situations, and decreased the area observed in high density areas. This allowed us to maximize the number of SOAs investigated as well as acquire reasonable sample sizes from low density areas. However, high density areas were generally those with high exposure, while low density areas are often those classified as unexposed. While generally successful in accomplishing the surface observation efficiently, it is possible that these different sampling strategies impacted the size ranges of items on these two surfaces. That is, if we assume that, for example, cores are distributed across a site at a low density, and that within the class of tools identified as cores, larger cores are less common than those cores in the smaller size ranges, it is possible that larger cores would be over represented by larger sample areas and under represented by smaller sample areas. To the degree that the amount of area sampled on exposed surfaces is reduced, larger items may be under represented relative to their true distribution.

In order to explore this possibility, I ran a series of simulated samples. First, the two exposure groups used to create Figure 9-5 were collapsed into a single data base of 1,915 cores, tested cobbles, unifaces, bifaces, retouched and utilized flakes, ground stone items, and hammer stones. The distribution (not shown) is essentially normal, though there is a slight skewing to the right. That is, the right tail of the distribution is slightly elongated. Using this distribution as a base, we then conducted repeated random samples at sampling percentages of 10 percent and 60 percent. Five samples were conducted for each sampling interval, and the results tabulated to form Figure 9-9. Comparing the results of the 10 percent random samples with the 60 percent random samples suggests that changing the sampling fraction does have an impact, though the differences are slight. The larger sample produced slightly higher frequencies for both the $11-12 \mathrm{~cm}$ size interval, and the $0-1 \mathrm{~cm}$ size interval when compared to the results of the smaller sampling fraction. That is, smaller sampling fractions, for example 10 percent, are under representing the low

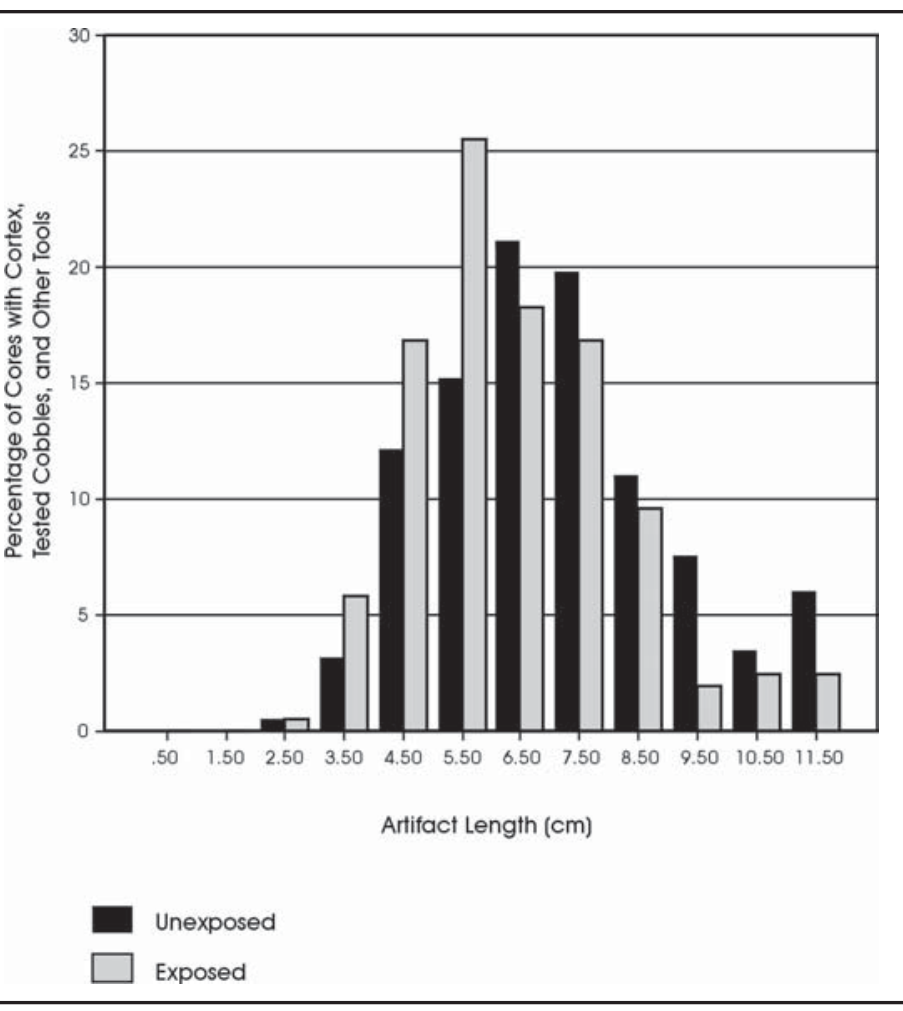

Figure 9-8. Percentage of cores with cortex, tested cobbles, and other tools.

frequency intervals of the population. Nevertheless, the differences are minimal. While differential sampling areas may contribute to the differences between exposed and unexposed artifact types by conditioning size, it is unlikely to be a major factor. However, it may account for some of the differences observed between distribution like that in Figure 9-8.

Of course, there may still be other elements causing some of the patterns observed in the exposed and unexposed data sets. Exposure may be tracking on other variables, such as distance to water, or even prehistoric activity differences. It is the case that exposed surfaces as a group are closer to water than unexposed surfaces. Consequently, elements like the apparent higher number of large cores may reflect actual differences in land use, with earlier stage reduction occurring away from streams, and later stage reduction tending to occur closer to water. Whatever these additional factors, it should be clear that differential exposure has a significant impact on assemblage content within the SOA data set. On exposed surfaces, more items, and a more complete 

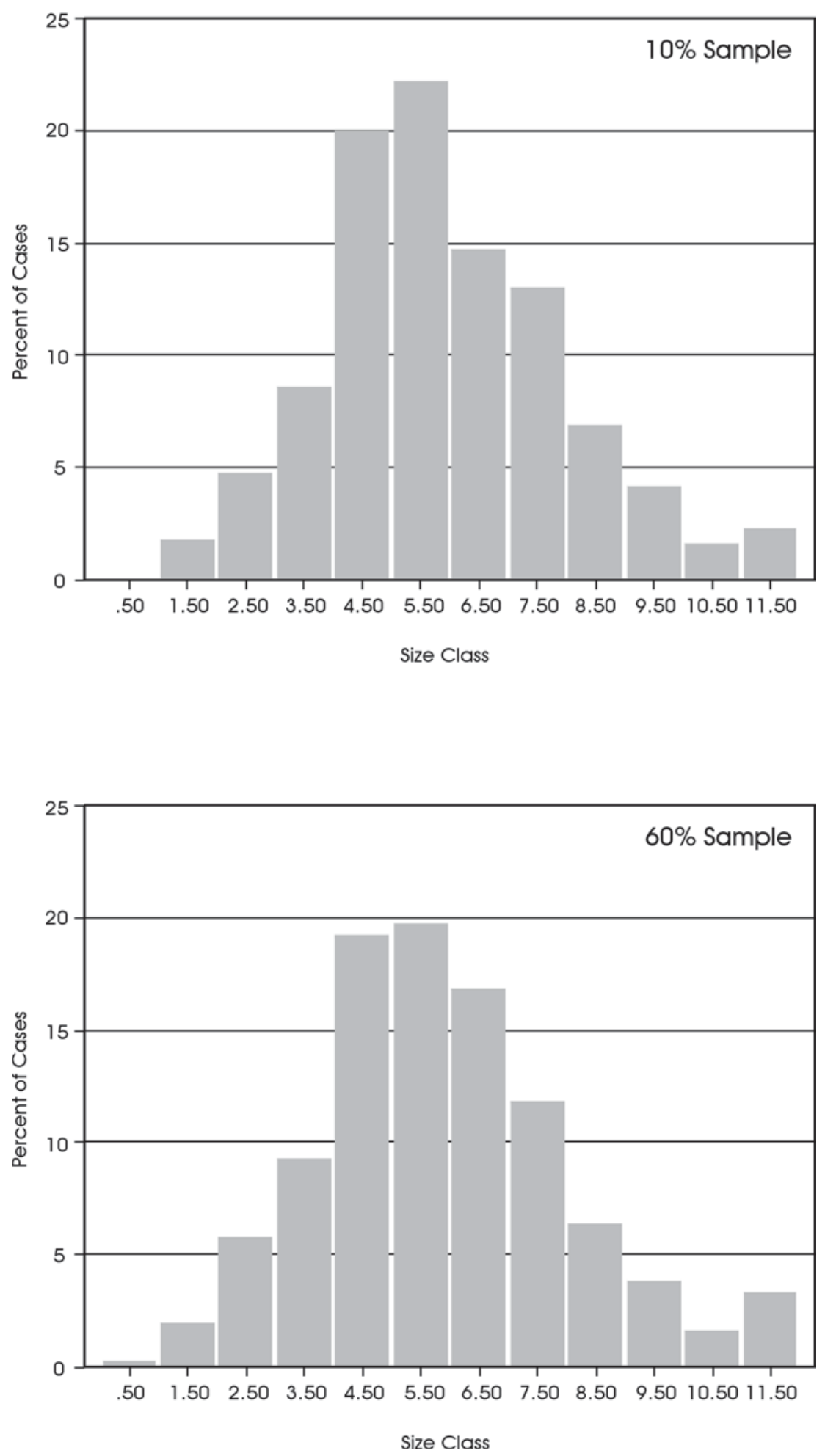

Figure 9-9. Differential sampling fractions from a single population and the resulting impact on size classes. 
size range of items, are present. Conversely, on unexposed surfaces, the SOA observations reveal a lower artifact density, and a distribution that is skewed such that smaller items are differentially covered. This translates into different frequencies of artifact types, as different artifact types have different size distributions. Exposure may provide different opportunities for collecting behavior, and the patterns may also be impacted by sampling decisions that we made in an effort to control sample size. Finally, exposure may also be tracking on other variables, such as distance to water, which may translate into different patterns of use in the past.

\section{Reducing the Impact of the Size Effect}

If we are to investigate these differential patterns of use, we need to minimize the impact of exposure. Unfortunately, little can be done to reduce the impact of several of these processes. We can not say, for example, how many non-cortical bifaces were removed from an assemblage. However, it is possible to reduce some of the major impacts of exposure in the smaller size ranges. It is, as demonstrated above, these smaller size ranges which are most directly impacted by differential exposure. After reviewing the size distribution of all data, it is apparent that those items less than $2 \mathrm{~cm}$ in length account for much of the difference in the two data sets. This can be seen in Figure 9-4 presented above. Consequently, we will simply eliminate all items less than $2 \mathrm{~cm}$ in length from any further consideration. This will differentially remove small items from exposed surfaces, as well as differentially impact some specific artifact types.

Table 9-3 presents the revised artifact totals after the removal of all items less than $2 \mathrm{~cm}$ in maximum size. Comparison of Table 9-3 with Table 9-2 will demonstrate that the removal of items less than $2 \mathrm{~cm}$ in maximum length has a significant impact on some artifact classes, such as flakes, but little or no impact on others, such as tested cobbles. This is because there are no tested cobbles in the less than $2 \mathrm{~cm}$ size range. A focus on the adjusted residuals presented in the table will show that eight of the 14 cells are still significantly different, confirming that other factors are still impacting the two data sets. This impact can be further seen by considering the overall size of the exposed and unexposed data sets. The mean artifact size

Table 9-3. Observed Frequencies of Artifact Types by Exposure for items greater than $2 \mathrm{~cm}$ in length

\begin{tabular}{|l|c|c|c|}
\hline Artifact Types & Not Exposed & Exposed & Total \\
\hline Flakes & $\begin{array}{c}6,314 \\
\mathbf{( - 7 . 3 )}\end{array}$ & $\begin{array}{c}4,141 \\
\mathbf{( 7 . 3 )}\end{array}$ & 10,455 \\
\hline Cores & $\begin{array}{c}522 \\
\mathbf{( 6 . 2}\end{array}$ & $\begin{array}{c}197 \\
\mathbf{( - 6 . 2 )}\end{array}$ & 719 \\
\hline Tested Cobbles & $\begin{array}{c}149 \\
\mathbf{( 5 . 3 )}\end{array}$ & $\begin{array}{c}36 \\
\mathbf{( - 5 . 3 )}\end{array}$ & 185 \\
\hline Bifaces & $\begin{array}{c}147 \\
(1.1)\end{array}$ & $\begin{array}{c}78 \\
(-1.1)\end{array}$ & 225 \\
\hline Unifaces & $\begin{array}{c}104 \\
(.0)\end{array}$ & $\begin{array}{c}64 \\
(0)\end{array}$ & 168 \\
\hline Utilized / Retouched & $\begin{array}{c}362 \\
(1.4)\end{array}$ & $\begin{array}{c}198 \\
(-1.4)\end{array}$ & 560 \\
\hline Other Items & $\begin{array}{c}1 \\
\mathbf{( 2 . 5 )}\end{array}$ & $\begin{array}{c}\mathbf{( - 2 . 5 )} \\
4,715\end{array}$ & 15 \\
\hline TOTALS & 7,612 & 12,327 \\
\hline
\end{tabular}


for the 7,612 artifacts from unexposed surfaces is 4.3 $\mathrm{cm}$. The 4,715 artifacts from exposed surfaces have a mean size of $3.7 \mathrm{~cm}, 0.6 \mathrm{~cm}$ smaller. However, the size difference between the two groups is reduced from the $1.25 \mathrm{~cm}$ difference reflected by the original distribution. In addition, note that the adjusted residual values, while still significant in eight cells, have been reduced from the extreme values present in Table 9-2.

\section{Artifact Variety and Assemblage Size}

In Chapter 7, we argued that residential sites may be distinguishable from more limited activity sites by patterns in artifact variety. That is, as more varied activities are commonly conducted at most residential sites when compared to special purpose locations, these locations may be distinguishable based on measures of artifact variety. We further suggested that as artifact variety is related to sample size, any measures of artifact variety must consider relative sample size. By comparing artifact variety, measured as the number of types present in an assemblage, relative to the sample size of the assemblage, a gross distinction between high variety and low variety assemblages should be possible. While a number of different scenarios can produce high and low variability, including different patterns of erosion, reoccupation, and reuse, the distinction between low variability and high variability assemblages provides an initial point for further investigation. Below, we will use the SOA data to begin this investigation of artifact variety and assemblage size.

\section{Sample and Analytical Considerations}

Essentially four decisions were made that shaped the sample used in the subsequent analysis. First, we combined SOAs from the same site whenever possible to increase sample size. However, given the importance of differential exposure demonstrated above, we only combined those SOAs that had similar exposure designations. We also avoided combining SOAs that were separated by extensive distance. For example, three SOAs were placed on 41TG500. All three had similar exposure distinctions, and, as the average distance between the three was less than 20 meters, these were combined into a single data set. Conversely, 41TG385 had four SOAs with similar exposure. However, as these were separated by an average distance of 168 meters, they were not combined. We did not combine SOAs on the same site that preliminary notes suggested may represent different activities. For example, Figure 9-10 is a map of 41TG362. Two distinct SOAs were placed at this site, one corresponding to the artifact cluster north of the road that was thought to represent lithic procurement, and one to the south of the road on the portion of the site designated as a campsite. These two SOAs were not combined. Finally, we did not combine SOAs when two distinct diagnostic artifacts suggested different periods of use. This resulted in a total of 35 different SOAs being combined from 17 different sites. After this combination, we eliminated those SOAs that had a total sample size of less than 20 items. There were seven such cases. These were SOAs 374.1, 375.1, 424.1, 421.1, 420.1, 508.1, and 509.1. The mean sample size for these seven cases was 12.7 artifacts. All of the remaining 105 cases have primary, secondary, and tertiary flakes. As our primary concern is with developing gross measures of activity levels conducted at these SOAs and sites, as all sites have these flake classes, and as these items are those most impacted by differential exposure as a function of their size range, our focus will be on comparing tool types. That is, we have eliminated these three flake categories from the regression analysis, though we will use flakes to consider reduction patterns once the initial regression analysis is complete. Table 9-4 presents the tool assemblages by SOA for the remaining 105 cases.

Finally, our initial focus is on tool types that are defined, in effect, by our morphological and reduction based typology. That is, we will use types such as unifaces without cortex, bifaces with cortex, and manos. Only manos are true tool types. The classification "unifaces with more than 50 percent cortex" may include a variety of different tool types, and subsequent analysis should focus on defining distinct tool types. As we lack data to identify such types, we will simply use the reduction types that are represented by the 1,863 tools from 105 total SOAs presented in Table 9-4. A total of 12 different tool types are used in the analysis. 


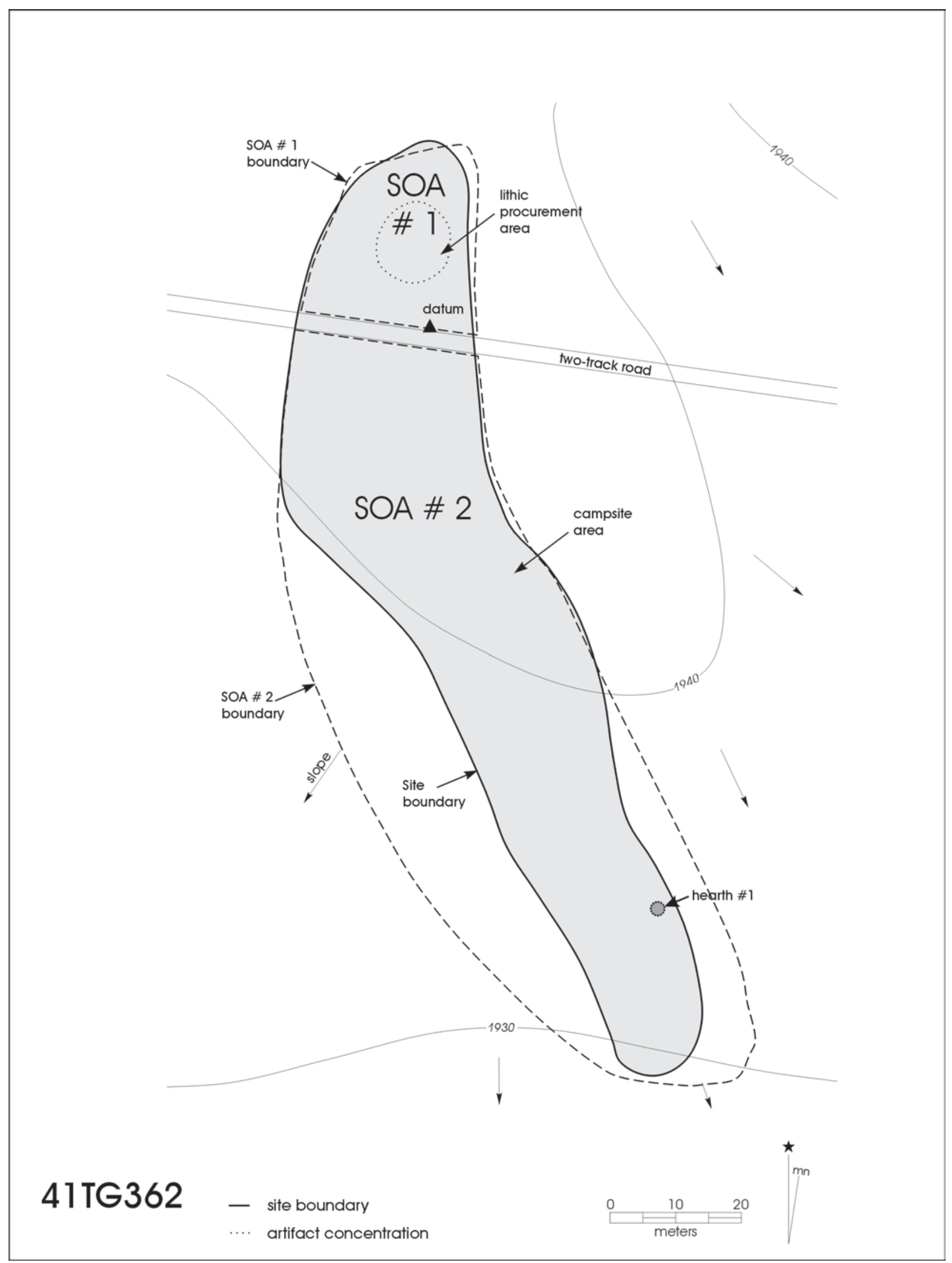

Figure 9-10. SOA boundaries on 41TG362, a site with two different activity areas noted on survey. 
Table 9-4. Tool assemblage for Surface Observation Units

\begin{tabular}{|c|c|c|c|c|c|c|c|c|c|c|c|c|}
\hline SOA & $\begin{array}{l}\text { Core } \\
1 * *\end{array}$ & $\begin{array}{l}\text { Uniface } \\
1-50 \% \\
\text { cortex } \\
\end{array}$ & $\begin{array}{c}\text { Utilized } \\
1 * *\end{array}$ & \begin{tabular}{|c|} 
Core \\
$3^{* *}$
\end{tabular} & \begin{tabular}{|c|} 
Biface \\
$1 * *$
\end{tabular} & \begin{tabular}{|c|} 
Utilized \\
$3^{* *}$
\end{tabular} & $\begin{array}{c}\text { Biface } \\
3^{* * *}\end{array}$ & \begin{tabular}{|l|}
$\begin{array}{l}\text { Uniface } \\
\text { without } \\
\text { cortex }\end{array}$ \\
\end{tabular} & \begin{tabular}{|c|} 
Uniface \\
$51-99 \%$ \\
cortex
\end{tabular} & Metate & $\mathbf{H} / \mathbf{S}^{*}$ & Mano \\
\hline 349.5 & 11 & 1 & 5 & 0 & 0 & 0 & 0 & 0 & 0 & 0 & 0 & 0 \\
\hline 361.1 & 38 & 0 & 8 & 1 & 3 & 2 & 1 & 0 & 0 & 0 & 0 & 0 \\
\hline 362.1 & 10 & 0 & 0 & 0 & 0 & 0 & 1 & 0 & 0 & 0 & 0 & 0 \\
\hline 362.2 & 4 & 0 & 1 & 1 & 1 & 0 & 0 & 0 & 0 & 0 & 0 & 0 \\
\hline 365.1 & 6 & 2 & 2 & 0 & 0 & 1 & 0 & 1 & 0 & 0 & 0 & 0 \\
\hline 367.1 & 1 & 2 & 0 & 1 & 0 & 1 & 1 & 0 & 1 & 0 & 0 & 0 \\
\hline 368.1 & 4 & 1 & 3 & 1 & 0 & 2 & 0 & 2 & 0 & 0 & 0 & 0 \\
\hline 372.1 & 5 & 2 & 3 & 0 & 0 & 5 & 1 & 1 & 0 & 0 & 0 & 0 \\
\hline 373.1 & 1 & 0 & 0 & 0 & 0 & 0 & 0 & 0 & 0 & 0 & 0 & 0 \\
\hline 378.5 & 10 & 0 & 6 & 5 & 0 & 2 & 1 & 0 & 0 & 0 & 0 & 0 \\
\hline 385.1 & 14 & 0 & 1 & 1 & 1 & 0 & 1 & 0 & 0 & 0 & 0 & 0 \\
\hline 385.2 & 3 & 0 & 0 & 0 & 0 & 0 & 1 & 0 & 0 & 0 & 0 & 0 \\
\hline 385.3 & 0 & 0 & 0 & 0 & 0 & 0 & 0 & 0 & 0 & 0 & 0 & 0 \\
\hline 385.4 & 8 & 0 & 1 & 0 & 0 & 1 & 1 & 0 & 0 & 0 & 0 & 0 \\
\hline 386.1 & 3 & 0 & 1 & 0 & 0 & 0 & 0 & 0 & 0 & 0 & 0 & 0 \\
\hline 388.5 & 25 & 4 & 12 & 4 & 2 & 9 & 3 & 1 & 0 & 0 & 0 & 0 \\
\hline 389.5 & 27 & 4 & 14 & 0 & 1 & 15 & 1 & 1 & 1 & 0 & 0 & 0 \\
\hline 391.1 & 3 & 0 & 0 & 0 & 0 & 1 & 4 & 1 & 0 & 0 & 0 & 0 \\
\hline 392.1 & 21 & 2 & 2 & 0 & 0 & 0 & 0 & 0 & 0 & 0 & 0 & 0 \\
\hline 395.1 & 3 & 1 & 1 & 1 & 1 & 1 & 2 & 3 & 1 & 0 & 0 & 0 \\
\hline 397.1 & 18 & 0 & 3 & 1 & 3 & 2 & 4 & 0 & 0 & 0 & 0 & 0 \\
\hline 397.2 & 10 & 0 & 5 & 0 & 2 & 0 & 1 & 0 & 0 & 0 & 0 & 0 \\
\hline 400.1 & 11 & 0 & 9 & 1 & 1 & 2 & 6 & 0 & 2 & 0 & 0 & 0 \\
\hline 404.1 & 12 & 0 & 1 & 0 & 2 & 1 & 1 & 0 & 0 & 0 & 0 & 0 \\
\hline 404.2 & 11 & 0 & 2 & 1 & 0 & 3 & 3 & 0 & 0 & 0 & 0 & 0 \\
\hline 405.5 & 9 & 4 & 15 & 1 & 3 & 14 & 4 & 4 & 3 & 0 & 0 & 0 \\
\hline 408.1 & 11 & 2 & 2 & 0 & 0 & 1 & 1 & 0 & 0 & 0 & 0 & 0 \\
\hline 409.2 & 0 & 0 & 0 & 0 & 0 & 0 & 0 & 0 & 0 & 0 & 0 & 0 \\
\hline 411.2 & 3 & 0 & 5 & 1 & 3 & 3 & 1 & 0 & 0 & 0 & 0 & 0 \\
\hline 412.5 & 9 & 2 & 2 & 2 & 3 & 12 & 1 & 0 & 0 & 1 & 0 & 0 \\
\hline 414.1 & 2 & 2 & 14 & 0 & 3 & 3 & 0 & 1 & 4 & 0 & 1 & 0 \\
\hline
\end{tabular}


Table 9-4. Continued...

\begin{tabular}{|c|c|c|c|c|c|c|c|c|c|c|c|c|}
\hline SOA & $\begin{array}{l}\text { Core } \\
1 * *\end{array}$ & $\begin{array}{l}\text { Uniface } \\
1-50 \% \\
\text { cortex } \\
\end{array}$ & $\begin{array}{c}\text { Utilized } \\
1 * *\end{array}$ & $\begin{array}{c}\text { Core } \\
3^{* *}\end{array}$ & $\begin{array}{c}\text { Biface } \\
1 * *\end{array}$ & $\begin{array}{c}\text { Utilized } \\
3^{* *}\end{array}$ & $\begin{array}{c}\text { Biface } \\
3 * *\end{array}$ & $\begin{array}{c}\text { Uniface } \\
\text { without } \\
\text { cortex }\end{array}$ & $\begin{array}{c}\text { Uniface } \\
\mathbf{5 1 - 9 9 \%} \\
\text { cortex } \\
\end{array}$ & Metate & $\mathbf{H} / \mathbf{S}^{*}$ & Mano \\
\hline 419.1 & 7 & 0 & 3 & 1 & 0 & 3 & 2 & 1 & 0 & 0 & 0 & 0 \\
\hline 423.1 & 9 & 0 & 4 & 0 & 3 & 2 & 1 & 0 & 0 & 0 & 0 & 0 \\
\hline 424.2 & 4 & 2 & 1 & 0 & 0 & 0 & 0 & 0 & 1 & 1 & 0 & 1 \\
\hline 424.5 & 17 & 0 & 11 & 2 & 0 & 8 & 1 & 1 & 0 & 0 & 0 & 1 \\
\hline 427.1 & 11 & 2 & 7 & 2 & 3 & 8 & 1 & 2 & 1 & 0 & 0 & 0 \\
\hline 430.1 & 13 & 0 & 5 & 0 & 2 & 4 & 2 & 0 & 1 & 0 & 0 & 0 \\
\hline 109.1 & 15 & 3 & 7 & 3 & 3 & 12 & 4 & 0 & 0 & 0 & 0 & 0 \\
\hline 110.5 & 15 & 3 & 11 & 3 & 0 & 8 & 4 & 1 & 0 & 0 & 0 & 0 \\
\hline 437.1 & 3 & 0 & 2 & 0 & 2 & 0 & 0 & 0 & 1 & 0 & 0 & 0 \\
\hline 441.1 & 3 & 0 & 0 & 0 & 0 & 0 & 3 & 0 & 0 & 0 & 0 & 0 \\
\hline 443.1 & 5 & 0 & 1 & 1 & 1 & 0 & 0 & 0 & 0 & 0 & 0 & 0 \\
\hline 447.1 & 4 & 2 & 2 & 1 & 1 & 7 & 1 & 1 & 0 & 0 & 0 & 0 \\
\hline 448.1 & 8 & 1 & 6 & 0 & 0 & 1 & 0 & 0 & 0 & 0 & 0 & 0 \\
\hline 449.1 & 0 & 0 & 6 & 0 & 2 & 0 & 5 & 1 & 0 & 0 & 0 & 0 \\
\hline 253.1 & 7 & 3 & 1 & 1 & 2 & 1 & 1 & 0 & 1 & 0 & 0 & 0 \\
\hline 456.1 & 19 & 1 & 6 & 1 & 1 & 1 & 0 & 0 & 1 & 0 & 0 & 0 \\
\hline 456.2 & 9 & 1 & 5 & 0 & 1 & 2 & 0 & 4 & 1 & 0 & 0 & 0 \\
\hline 247.1 & 21 & 1 & 1 & 4 & 1 & 6 & 2 & 4 & 0 & 0 & 0 & 0 \\
\hline 246.2 & 3 & 2 & 5 & 0 & 0 & 1 & 1 & 2 & 1 & 0 & 0 & 0 \\
\hline 246.5 & 25 & 3 & 4 & 1 & 1 & 2 & 3 & 4 & 0 & 0 & 0 & 0 \\
\hline 461.1 & 9 & 0 & 6 & 0 & 3 & 1 & 1 & 0 & 0 & 0 & 0 & 0 \\
\hline 461.2 & 6 & 2 & 5 & 2 & 1 & 7 & 1 & 0 & 0 & 0 & 0 & 0 \\
\hline 464.1 & 8 & 2 & 5 & 1 & 1 & 0 & 0 & 0 & 5 & 3 & 1 & 0 \\
\hline 245.1 & 21 & 0 & 3 & 2 & 0 & 1 & 0 & 0 & 1 & 0 & 0 & 0 \\
\hline 465.1 & 4 & 0 & 4 & 1 & 1 & 0 & 1 & 1 & 0 & 0 & 0 & 0 \\
\hline 466.1 & 11 & 1 & 1 & 0 & 0 & 0 & 0 & 0 & 0 & 0 & 0 & 0 \\
\hline 244.1 & 15 & 0 & 4 & 0 & 3 & 4 & 2 & 0 & 0 & 0 & 0 & 0 \\
\hline 244.5 & 14 & 0 & 1 & 1 & 1 & 0 & 0 & 0 & 0 & 0 & 0 & 0 \\
\hline 467.5 & 7 & 1 & 7 & 1 & 1 & 3 & 2 & 0 & 0 & 0 & 0 & 0 \\
\hline 468.1 & 11 & 3 & 10 & 0 & 1 & 6 & 2 & 0 & 0 & 2 & 2 & 0 \\
\hline 471.1 & 3 & 2 & 3 & 0 & 0 & 1 & 1 & 1 & 0 & 0 & 0 & 0 \\
\hline
\end{tabular}


Table 9-4. Continued...

\begin{tabular}{|c|c|c|c|c|c|c|c|c|c|c|c|c|}
\hline SOA & $\begin{array}{l}\text { Core } \\
1 * *\end{array}$ & $\begin{array}{l}\text { Uniface } \\
\mathbf{1 - 5 0 \%} \\
\text { cortex } \\
\end{array}$ & \begin{tabular}{|c|} 
Utilized \\
$1 * *$
\end{tabular} & \begin{tabular}{|c|} 
Core \\
$3^{* * *}$
\end{tabular} & $\begin{array}{c}\text { Biface } \\
1 * *\end{array}$ & $\begin{array}{c}\text { Utilized } \\
3 * *\end{array}$ & $\begin{array}{c}\text { Biface } \\
3^{* * *}\end{array}$ & $\begin{array}{c}\text { Uniface } \\
\text { without } \\
\text { cortex }\end{array}$ & $\begin{array}{c}\text { Uniface } \\
51-99 \% \\
\text { cortex } \\
\end{array}$ & Metate & $\mathbf{H} / \mathbf{S}^{*}$ & Mano \\
\hline 472.1 & 12 & 0 & 8 & 2 & 0 & 2 & 0 & 2 & 1 & 0 & 0 & 0 \\
\hline 474.1 & 4 & 0 & 0 & 0 & 0 & 0 & 3 & 0 & 0 & 0 & 0 & 0 \\
\hline 478.1 & 2 & 1 & 2 & 0 & 0 & 0 & 0 & 0 & 1 & 0 & 0 & 0 \\
\hline 479.1 & 6 & 1 & 1 & 0 & 0 & 0 & 0 & 0 & 0 & 0 & 0 & 0 \\
\hline 482.1 & 4 & 0 & 0 & 1 & 1 & 0 & 0 & 1 & 0 & 0 & 0 & 0 \\
\hline 483.1 & 2 & 0 & 1 & 0 & 0 & 0 & 0 & 0 & 1 & 0 & 0 & 0 \\
\hline 485.1 & 3 & 1 & 0 & 1 & 1 & 0 & 3 & 0 & 0 & 0 & 0 & 0 \\
\hline 106.1 & 14 & 0 & 3 & 4 & 2 & 3 & 0 & 2 & 0 & 0 & 0 & 0 \\
\hline 489.1 & 0 & 0 & 2 & 3 & 1 & 1 & 4 & 0 & 0 & 0 & 0 & 0 \\
\hline 491.1 & 1 & 0 & 1 & 0 & 1 & 0 & 0 & 0 & 0 & 0 & 0 & 0 \\
\hline 495.1 & 6 & 0 & 3 & 1 & 0 & 0 & 1 & 0 & 0 & 0 & 0 & 0 \\
\hline 496.1 & 8 & 0 & 2 & 0 & 2 & 0 & 1 & 0 & 0 & 0 & 0 & 0 \\
\hline 497.1 & 1 & 1 & 1 & 0 & 0 & 0 & 0 & 0 & 0 & 0 & 0 & 0 \\
\hline 500.5 & 8 & 1 & 5 & 1 & 0 & 1 & 3 & 1 & 0 & 0 & 0 & 0 \\
\hline 247.2 & 1 & 1 & 1 & 0 & 1 & 0 & 1 & 0 & 0 & 0 & 0 & 0 \\
\hline 247.3 & 5 & 0 & 0 & 0 & 1 & 0 & 1 & 1 & 0 & 0 & 0 & 0 \\
\hline 504.1 & 2 & 0 & 0 & 1 & 0 & 2 & 0 & 0 & 0 & 0 & 0 & 0 \\
\hline 506.1 & 2 & 0 & 3 & 2 & 4 & 1 & 3 & 1 & 0 & 0 & 0 & 0 \\
\hline 507.1 & 9 & 0 & 1 & 0 & 1 & 0 & 0 & 0 & 0 & 0 & 0 & 0 \\
\hline 511.1 & 3 & 0 & 0 & 0 & 1 & 0 & 2 & 0 & 0 & 0 & 0 & 0 \\
\hline 512.1 & 11 & 2 & 1 & 3 & 2 & 2 & 0 & 1 & 0 & 0 & 0 & 0 \\
\hline 251.1 & 5 & 1 & 0 & 0 & 0 & 0 & 0 & 0 & 0 & 0 & 0 & 0 \\
\hline 250.1 & 4 & 0 & 0 & 0 & 2 & 0 & 0 & 0 & 0 & 0 & 0 & 0 \\
\hline 513.1 & 1 & 0 & 0 & 1 & 0 & 0 & 5 & 0 & 0 & 0 & 0 & 0 \\
\hline 514.1 & 5 & 0 & 2 & 0 & 0 & 1 & 0 & 1 & 0 & 0 & 0 & 0 \\
\hline 515.1 & 9 & 0 & 0 & 0 & 3 & 1 & 0 & 0 & 0 & 0 & 0 & 0 \\
\hline 518.5 & 7 & 0 & 12 & 4 & 1 & 14 & 2 & 2 & 1 & 0 & 0 & 0 \\
\hline 519.1 & 0 & 0 & 2 & 0 & 0 & 3 & 1 & 1 & 1 & 0 & 0 & 0 \\
\hline 520.1 & 5 & 0 & 0 & 0 & 0 & 0 & 0 & 0 & 0 & 0 & 0 & 0 \\
\hline 522.1 & 2 & 0 & 2 & 0 & 0 & 2 & 0 & 0 & 0 & 0 & 0 & 0 \\
\hline 523.5 & 5 & 1 & 0 & 0 & 0 & 2 & 2 & 0 & 0 & 0 & 0 & 0 \\
\hline
\end{tabular}


Table 9-4. Continued...

\begin{tabular}{|c|c|c|c|c|c|c|c|c|c|c|c|c|}
\hline SOA & $\begin{array}{c}\text { Core } \\
\mathbf{1} * *\end{array}$ & $\begin{array}{c}\text { Uniface } \\
\mathbf{1 - 5 0 \%} \\
\text { cortex }\end{array}$ & $\begin{array}{c}\text { Utilized } \\
\mathbf{1}^{* *}\end{array}$ & $\begin{array}{c}\text { Core } \\
\mathbf{3}^{* *}\end{array}$ & $\begin{array}{c}\text { Biface } \\
\mathbf{1} * *\end{array}$ & $\begin{array}{c}\text { Utilized } \\
\mathbf{3}^{* *}\end{array}$ & $\begin{array}{c}\text { Biface } \\
\mathbf{3}^{* *}\end{array}$ & $\begin{array}{c}\text { Uniface } \\
\text { without } \\
\text { cortex }\end{array}$ & $\begin{array}{c}\text { Uniface } \\
\mathbf{5 1 - 9 9 \%} \\
\mathbf{c o r t e x}\end{array}$ & Metate & H/S* & Mano \\
\hline 524.1 & 14 & 0 & 6 & 0 & 0 & 1 & 1 & 1 & 1 & 0 & 0 & 0 \\
\hline 525.1 & 6 & 0 & 1 & 1 & 0 & 0 & 1 & 0 & 0 & 0 & 0 & 0 \\
\hline 526.1 & 7 & 1 & 5 & 1 & 0 & 1 & 3 & 2 & 0 & 0 & 0 & 0 \\
\hline 527.1 & 1 & 0 & 1 & 0 & 0 & 1 & 0 & 1 & 0 & 0 & 0 & 0 \\
\hline 528.1 & 3 & 0 & 2 & 0 & 0 & 1 & 1 & 1 & 0 & 0 & 0 & 0 \\
\hline 530.1 & 12 & 0 & 3 & 0 & 0 & 1 & 1 & 0 & 0 & 0 & 0 & 0 \\
\hline 252.1 & 8 & 0 & 1 & 0 & 1 & 3 & 0 & 0 & 0 & 0 & 0 & 0 \\
\hline 252.2 & 0 & 2 & 1 & 1 & 0 & 0 & 2 & 0 & 0 & 0 & 0 & 0 \\
\hline 531.1 & 8 & 1 & 3 & 1 & 3 & 2 & 5 & 0 & 0 & 0 & 0 & 0 \\
\hline 533.1 & 2 & 1 & 4 & 1 & 1 & 4 & 4 & 0 & 0 & 0 & 0 & 0 \\
\hline 106.1 & 8 & 0 & 1 & 0 & 0 & 0 & 0 & 0 & 0 & 0 & 0 & 0 \\
\hline 535.1 & 3 & 0 & 1 & 2 & 0 & 1 & 0 & 0 & 0 & 0 & 0 & 0 \\
\hline
\end{tabular}

*Hammer Stones. ** $1=$ with cortex; $3=$ without cortex.

Note: An SOA designation of .5 is given to those SOAs that have been combined.

\section{Analysis}

As noted above, the expectation for relationships between assemblage size and variety of artifacts is such that two samples will be represented in the data. Ideally, we would have two sets of known distributions, one representing limited activities and one representing a more residential focus, from which to generate expectations for comparison to the Twin Buttes data. However, clear cases of residential and special purpose sites with quantitative surface data could not be found in the literature. We therefore will use a regression approach to separate elements into two groups. Note that the approach has the disadvantage of forcing two groups to be created even though two groups may not be present.

Figure 9-11 is a plot of total number of tools and different types of tools. The pattern is non-linear. In order to transform the distribution into a linear pattern applicable to linear regression, we explored a number of different transformations. The most successful transformation was a comparison of the number of artifact types and the natural log of sample size presented in Figure 9-12. A linear regression produces an overall coefficient of determination of $.597(\mathrm{R}=.773)$. The regression formula is:

$$
\mathrm{Y}^{\wedge}=(-.81996)+\left(\mathrm{b}^{1} \cdot 2.00357\right)
$$

where $b^{1}$ is the natural log of the assemblage sample size. An examination of the Cook's D influence statistic (Cook 1977, 1979), which measures the change in the estimate produced by the deletion of any one observation, shows that all have values less than 0.01 . That is, no single point in the data set is exerting a significant influence on the estimate (Chatterjee et al. 2000:103-104). Examination of the residual plots (Figure 9-13) suggests that the transformation has removed a significant portion of the non-linearity present in the original data. 


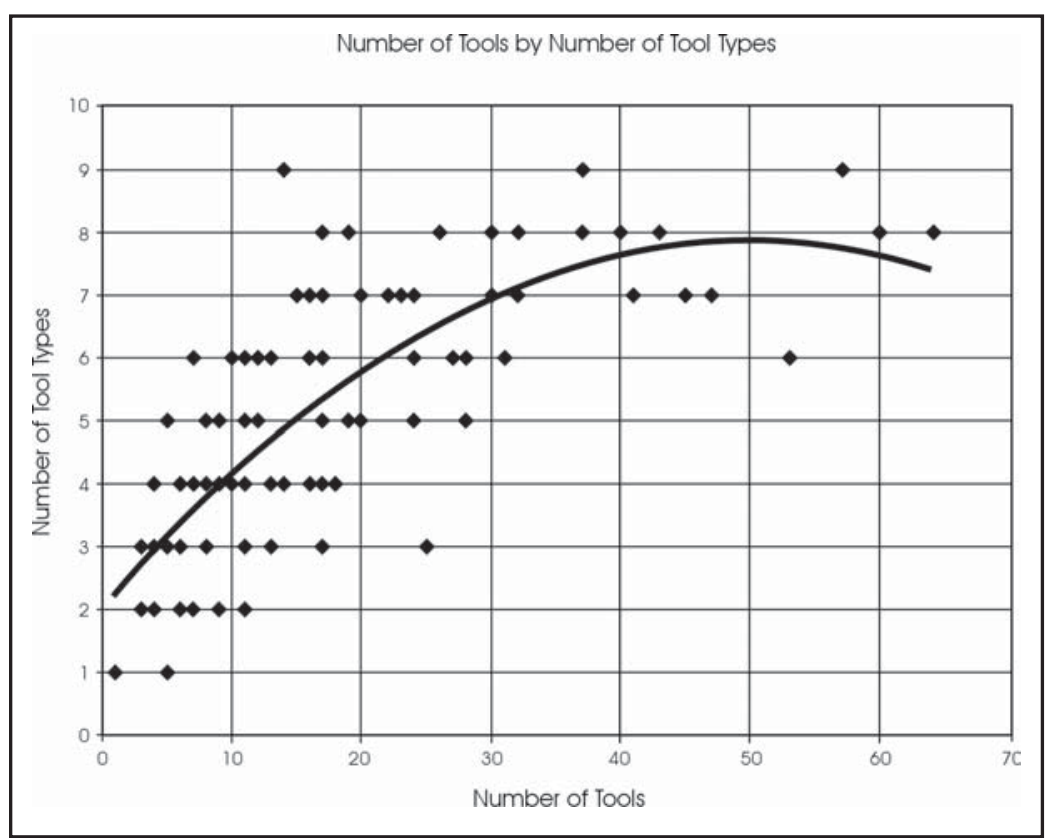

Figure 9-11. Number of tools by number of tool types.

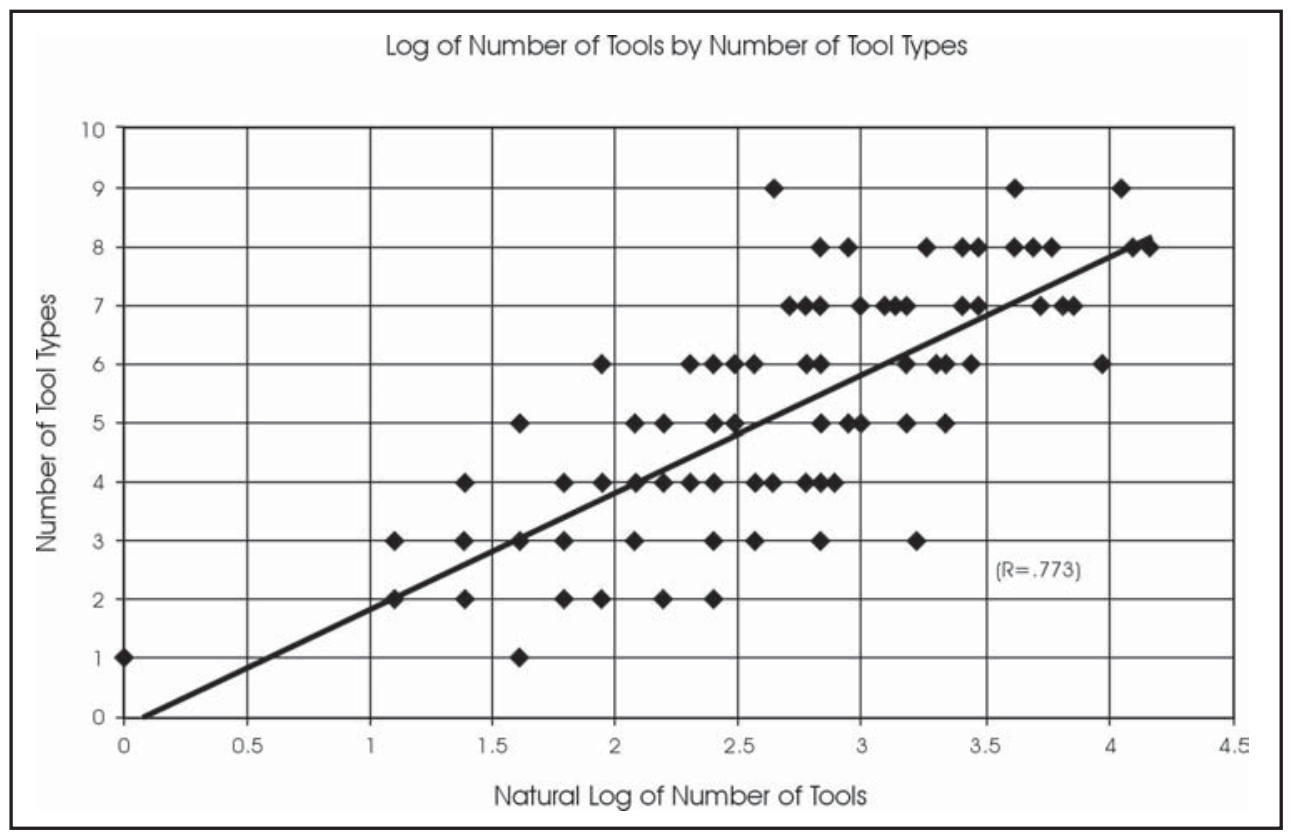

Figure 9-12. Log of number of tools by number of tool types with least squares line. 


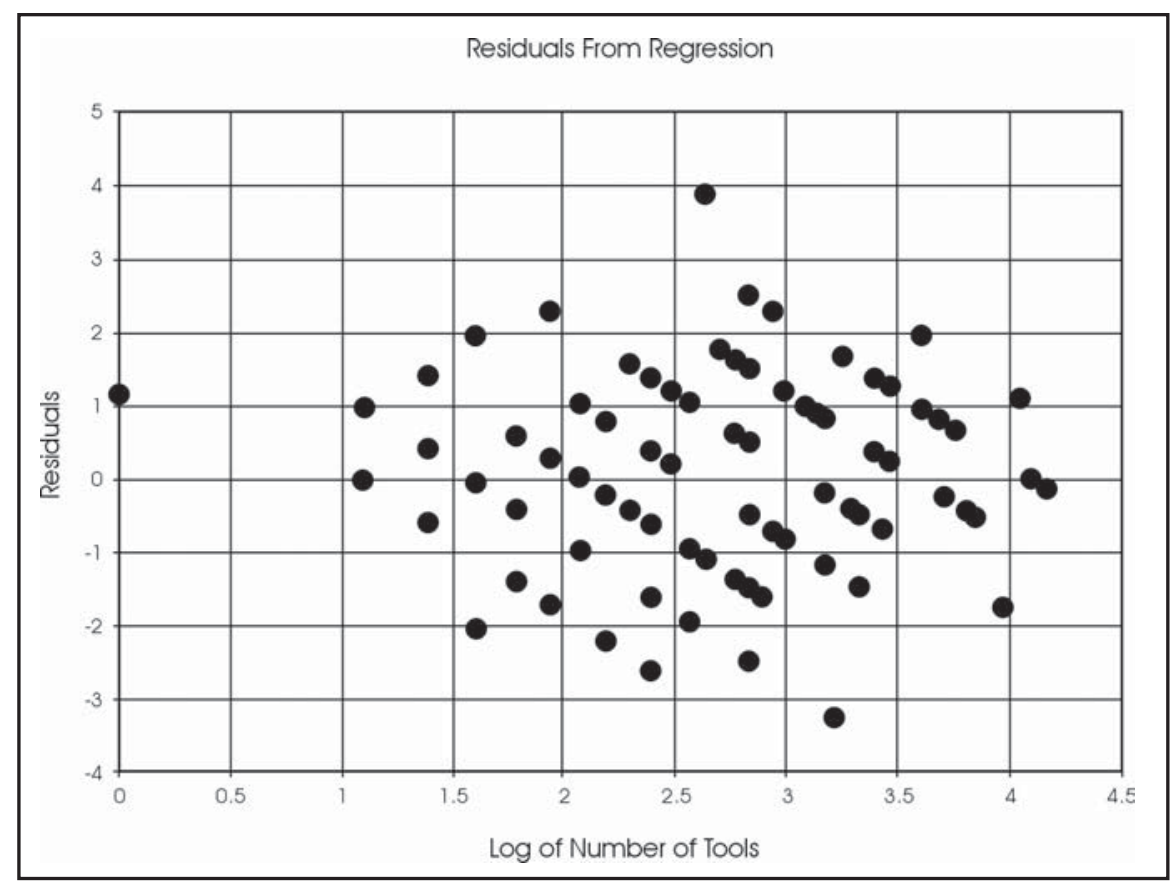

Figure 9-13. Residual plot from regression shown in Figure 9-12.

\section{Results}

Table 9-5 presents the individual SOA numbers, exposure values, number of tool types, natural $\log$ of the number of tools, predicted value from the equation presented above, residual values from the equation, studentized residuals, the presence/absence of features or FCR, and the distance to water for the SOAs. These data form the basis for the subsequent discussion. Note that two cases, both of which lack tools, have been dropped from the analysis, reducing the total number of cases to 103. Those cases that have negative residuals represent SOAs with low variety relative to sample size, while those cases above the line represent cases with higher than expected variety. There are 52 cases that fall below the line, and 51 cases above the line.

Given that exposure has a substantial impact on the assemblage structure, it is reasonable to ask if exposure has an effect on the group assignment. Even though we have attempted to limit the impact of exposure, the adjusted residuals presented previously in Table 9-3 suggest that tools may still be impacted by differential exposure. In order to consider this, a contingency table analysis was run comparing the two exposure groups and the high and low variability cases. Table 9-6 presents these data. While there are more high exposure cases reflected in the high variety cell, the chi-square test statistic is not significant $\left(X^{2}=1.86\right.$; $\mathrm{df}=1 ; \mathrm{p}=.172$ ). Exposure may still be having an impact on the group assignments, but the lack of a significant result suggests that the impact, if present, is minimal.

\section{Site Level Patterns}

A consideration of Figure 9-12 will demonstrate that we have two groups of sites, those located above the regression line and those located below the regression line. Those above the line have more tool types than expected for a given sample size, while those below the line have fewer types than expected. What do these two groups represent? Recall that in the design of the analysis, we forced the two groups to be present by splitting the distribution with a regression line. Do these two groups represent differences between residential and special purpose sites? As high variety can be generated by several different processes, 
Table 9-5. Regression results and site level data for surface observation areas

\begin{tabular}{|c|c|c|c|c|c|c|c|c|}
\hline $\begin{array}{c}\text { SOA } \\
\#\end{array}$ & Exposure & $\begin{array}{c}\begin{array}{c}\text { Number } \\
\text { of Tool } \\
\text { Types }\end{array} \\
\end{array}$ & $\begin{array}{c}\text { Log of } \\
\text { Number } \\
\text { of Tools }\end{array}$ & $\begin{array}{l}\text { Predicted } \\
\text { Value }\end{array}$ & $\begin{array}{c}\text { Residual } \\
\text { Value }\end{array}$ & $\begin{array}{c}\text { Studentized } \\
\text { Residual }\end{array}$ & $\begin{array}{c}\text { Feature or } \\
\text { FCR* }\end{array}$ & $\begin{array}{c}\text { Distance to } \\
\text { Water** }\end{array}$ \\
\hline 359.5 & 1 & 3 & 2.833 & 5.495 & -2.495 & -1.983 & 0 & 3.2 \\
\hline 361.1 & 1 & 6 & 3.970 & 7.773 & -1.773 & -1.431 & 1 & 2.9 \\
\hline 362.1 & 1 & 2 & 2.398 & 4.622 & -2.622 & -2.085 & 0 & 2.7 \\
\hline 362.2 & 1 & 4 & 1.946 & 3.717 & 0.283 & 0.226 & 1 & 2.7 \\
\hline 365.1 & 2 & 5 & 2.485 & 4.797 & 0.203 & 0.162 & 0 & 2 \\
\hline 367.1 & 1 & 6 & 1.946 & 3.717 & 2.283 & 1.822 & 1 & 2.7 \\
\hline 368.1 & 1 & 6 & 2.565 & 4.957 & 1.043 & 0.829 & 1 & 2.6 \\
\hline 372.1 & 1 & 6 & 2.833 & 5.495 & 0.505 & 0.402 & 1 & 2.2 \\
\hline 373.1 & 1 & 1 & 0.000 & -0.182 & 1.182 & 1.000 & 1 & 2.1 \\
\hline 378.5 & 1 & 5 & 3.178 & 6.185 & -1.185 & -0.945 & 1 & 0.9 \\
\hline 385.1 & 2 & 5 & 2.996 & 5.820 & -0.820 & -0.653 & 0 & 0.31 \\
\hline 385.2 & 2 & 2 & 1.386 & 2.596 & -0.596 & -0.480 & 0 & 0.31 \\
\hline 385.4 & 2 & 4 & 2.398 & 4.622 & -0.622 & -0.495 & 0 & 0.31 \\
\hline 386.1 & 1 & 2 & 1.386 & 2.596 & -0.596 & -0.480 & 0 & 0.95 \\
\hline 388.5 & 1 & 8 & 4.094 & 8.021 & -0.021 & -0.017 & 1 & 0 \\
\hline 389.5 & 1 & 8 & 4.159 & 8.151 & -0.151 & -0.122 & 1 & 0.1 \\
\hline 391.1 & 2 & 4 & 2.197 & 4.220 & -0.220 & -0.175 & 1 & 0.45 \\
\hline 392.1 & 1 & 3 & 3.219 & 6.267 & -3.267 & -2.605 & 0 & 0.57 \\
\hline 395.1 & 1 & 9 & 2.639 & 5.106 & 3.894 & 3.095 & 1 & 0.09 \\
\hline 397.1 & 1 & 6 & 3.434 & 6.698 & -0.698 & -0.558 & 0 & 0.7 \\
\hline 397.2 & 2 & 4 & 2.890 & 5.609 & -1.609 & -1.280 & 0 & 0.7 \\
\hline 400.1 & 2 & 7 & 3.466 & 6.762 & 0.238 & 0.190 & 0 & 0.28 \\
\hline 404.1 & 1 & 5 & 2.833 & 5.495 & -0.495 & -0.393 & 0 & 0.36 \\
\hline 404.2 & 1 & 5 & 2.996 & 5.820 & -0.820 & -0.653 & 0 & 0.36 \\
\hline 405.5 & 2 & 9 & 4.043 & 7.919 & 1.081 & 0.875 & 1 & 0 \\
\hline 408.1 & 1 & 5 & 2.833 & 5.495 & -0.495 & -0.393 & 1 & 0 \\
\hline 411.2 & 2 & 6 & 2.773 & 5.373 & 0.627 & 0.498 & 1 & 0 \\
\hline 412.5 & 1 & 8 & 3.466 & 6.762 & 1.238 & 0.990 & 1 & 0.02 \\
\hline 414.1 & 2 & 8 & 3.401 & 6.633 & 1.367 & 1.092 & 1 & 0 \\
\hline 419.1 & 1 & 6 & 2.833 & 5.495 & 0.505 & 0.402 & 1 & 0.03 \\
\hline 423.1 & 1 & 5 & 2.944 & 5.717 & -0.717 & -0.571 & 0 & 0.23 \\
\hline
\end{tabular}


Table 9-5. Continued...

\begin{tabular}{|c|c|c|c|c|c|c|c|c|}
\hline $\begin{array}{c}\text { SOA } \\
\#\end{array}$ & Exposure & \begin{tabular}{|c|}
$\begin{array}{c}\text { Number } \\
\text { of Tool } \\
\text { Types }\end{array}$ \\
\end{tabular} & $\begin{array}{c}\text { Log of } \\
\text { Number } \\
\text { of Tools }\end{array}$ & $\begin{array}{l}\text { Predicted } \\
\text { Value }\end{array}$ & $\begin{array}{c}\text { Residual } \\
\text { Value }\end{array}$ & $\begin{array}{c}\text { Studentized } \\
\text { Residual }\end{array}$ & $\begin{array}{c}\text { Feature or } \\
\text { FCR* }\end{array}$ & $\begin{array}{c}\text { Distance to } \\
\text { Water*** }\end{array}$ \\
\hline 424.2 & 1 & 6 & 2.303 & 4.431 & 1.569 & 1.248 & 1 & 0 \\
\hline 424.5 & 1 & 7 & 3.714 & 7.258 & -0.258 & -0.207 & 1 & 0 \\
\hline 427.1 & 2 & 9 & 3.611 & 7.053 & 1.947 & 1.561 & 1 & 0 \\
\hline 430.1 & 1 & 6 & 3.296 & 6.421 & -0.421 & -0.336 & 1 & 0.1 \\
\hline 109.1 & 2 & 7 & 3.850 & 7.532 & -0.532 & -0.428 & 1 & 0 \\
\hline 110.5 & 1 & 7 & 3.807 & 7.445 & -0.445 & -0.358 & 1 & 0 \\
\hline 437.1 & 2 & 4 & 2.079 & 3.984 & 0.016 & 0.013 & 1 & 0.18 \\
\hline 441.1 & 2 & 2 & 1.792 & 3.408 & -1.408 & -1.126 & 0 & 0.26 \\
\hline 443.1 & 1 & 4 & 2.079 & 3.984 & 0.016 & 0.013 & 0 & 0.42 \\
\hline 447.1 & 1 & 8 & 2.944 & 5.717 & 2.283 & 1.816 & 1 & 0 \\
\hline 448.1 & 1 & 4 & 2.773 & 5.373 & -1.373 & -1.092 & 1 & 0.65 \\
\hline 449.1 & 1 & 4 & 2.639 & 5.106 & -1.106 & -0.879 & 1 & 0.08 \\
\hline 253.1 & 1 & 8 & 2.833 & 5.495 & 2.505 & 1.992 & 1 & 0.08 \\
\hline 456.1 & 1 & 7 & 3.401 & 6.633 & 0.367 & 0.294 & 1 & 0.72 \\
\hline 456.2 & 2 & 7 & 3.135 & 6.100 & 0.900 & 0.717 & 1 & 0.72 \\
\hline 247.1 & 2 & 8 & 3.689 & 7.209 & 0.791 & 0.635 & 1 & 0 \\
\hline 246.2 & 2 & 7 & 2.708 & 5.244 & 1.756 & 1.396 & 1 & 0.49 \\
\hline 246.5 & 1 & 8 & 3.761 & 7.354 & 0.646 & 0.519 & 1 & 0.49 \\
\hline 461.1 & 1 & 5 & 2.996 & 5.820 & -0.820 & -0.653 & 1 & 0.05 \\
\hline 461.2 & 2 & 7 & 3.178 & 6.185 & 0.815 & 0.649 & 1 & 0.05 \\
\hline 464.1 & 1 & 8 & 3.258 & 6.346 & 1.654 & 1.319 & 1 & 0 \\
\hline 245.1 & 1 & 5 & 3.332 & 6.494 & -1.494 & -1.193 & 1 & 0.83 \\
\hline 465.1 & 1 & 6 & 2.485 & 4.797 & 1.203 & 0.957 & 1 & 0.96 \\
\hline 466.1 & 1 & 3 & 2.565 & 4.957 & -1.957 & -1.556 & 0 & 0.39 \\
\hline 244.1 & 2 & 5 & 3.332 & 6.494 & -1.494 & -1.193 & 1 & 0.08 \\
\hline 244.5 & 1 & 4 & 2.833 & 5.495 & -1.495 & -1.188 & 1 & 0.08 \\
\hline 467.5 & 1 & 7 & 3.091 & 6.011 & 0.989 & 0.787 & 1 & 0.05 \\
\hline 468.1 & 1 & 8 & 3.611 & 7.053 & 0.947 & 0.759 & 1 & 0 \\
\hline 471.1 & 1 & 6 & 2.398 & 4.622 & 1.378 & 1.095 & 1 & 0.11 \\
\hline 472.1 & 1 & 6 & 3.296 & 6.421 & -0.421 & -0.336 & 1 & 0.03 \\
\hline 474.1 & 1 & 2 & 1.946 & 3.717 & -1.717 & -1.370 & 1 & 0.23 \\
\hline
\end{tabular}


Table 9-5. Continued...

\begin{tabular}{|c|c|c|c|c|c|c|c|c|}
\hline $\begin{array}{c}\text { SOA } \\
\#\end{array}$ & Exposure & $\begin{array}{c}\text { Number } \\
\text { of Tool } \\
\text { Types }\end{array}$ & $\begin{array}{c}\text { Log of } \\
\text { Number } \\
\text { of Tools }\end{array}$ & $\begin{array}{l}\text { Predicted } \\
\text { Value }\end{array}$ & $\begin{array}{l}\text { Residual } \\
\text { Value }\end{array}$ & $\begin{array}{l}\text { Studentized } \\
\text { Residual }\end{array}$ & $\begin{array}{c}\text { Feature or } \\
\text { FCR }^{*}\end{array}$ & $\begin{array}{c}\text { Distance to } \\
\text { Water*** }\end{array}$ \\
\hline 478.1 & 1 & 4 & 1.792 & 3.408 & 0.592 & 0.473 & 1 & 0.58 \\
\hline 479.1 & 1 & 3 & 2.079 & 3.984 & -0.984 & -0.784 & 0 & 0.54 \\
\hline 482.1 & 2 & 4 & 1.946 & 3.717 & 0.283 & 0.226 & 0 & 0.78 \\
\hline 483.1 & 2 & 3 & 1.386 & 2.596 & 0.404 & 0.326 & 1 & 0.7 \\
\hline 485.1 & 2 & 5 & 2.197 & 4.220 & 0.780 & 0.621 & 1 & 0.18 \\
\hline 106.1 & 2 & 6 & 3.332 & 6.494 & -0.494 & -0.395 & 1 & 0.05 \\
\hline 489.1 & 1 & 5 & 2.398 & 4.622 & 0.378 & 0.300 & 1 & 0.26 \\
\hline 491.1 & 1 & 3 & 1.099 & 2.019 & 0.981 & 0.796 & 0 & 0.18 \\
\hline 495.1 & 1 & 4 & 2.398 & 4.622 & -0.622 & -0.495 & 0 & 1.2 \\
\hline 496.1 & 1 & 4 & 2.565 & 4.957 & -0.957 & -0.761 & 0 & 1.2 \\
\hline 497.1 & 1 & 2 & 1.099 & 2.019 & -0.019 & -0.016 & 0 & 1.1 \\
\hline 500.5 & 1 & 7 & 2.996 & 5.820 & 1.180 & 0.939 & 1 & 0.03 \\
\hline 247.2 & 1 & 5 & 1.609 & 3.043 & 1.957 & 1.570 & 1 & 0 \\
\hline 247.3 & 2 & 4 & 2.079 & 3.984 & 0.016 & 0.013 & 1 & 0 \\
\hline 504.1 & 2 & 3 & 1.609 & 3.043 & -0.043 & -0.034 & 1 & 0 \\
\hline 506.1 & 1 & 7 & 2.773 & 5.373 & 1.627 & 1.293 & 1 & 0.05 \\
\hline 507.1 & 1 & 3 & 2.398 & 4.622 & -1.622 & -1.290 & 1 & 0.87 \\
\hline 511.1 & 1 & 3 & 1.792 & 3.408 & -0.408 & -0.326 & 1 & 0.03 \\
\hline 512.1 & 1 & 7 & 3.091 & 6.011 & 0.989 & 0.787 & 1 & 0.01 \\
\hline 251.1 & 1 & 2 & 1.792 & 3.408 & -1.408 & -1.126 & 0 & 0.08 \\
\hline 250.1 & 1 & 2 & 1.792 & 3.408 & -1.408 & -1.126 & 0 & 0.98 \\
\hline 513.1 & 1 & 4 & 1.946 & 3.717 & 0.283 & 0.226 & 1 & 0.24 \\
\hline 514.1 & 1 & 4 & 2.197 & 4.220 & -0.220 & -0.175 & 0 & 1.22 \\
\hline 515.1 & 2 & 3 & 2.565 & 4.957 & -1.957 & -1.556 & 0 & 0.53 \\
\hline 518.5 & 2 & 8 & 3.761 & 7.354 & 0.646 & 0.519 & 1 & 0.11 \\
\hline 519.1 & 2 & 5 & 2.079 & 3.984 & 1.016 & 0.809 & 1 & 0 \\
\hline 520.1 & 1 & 1 & 1.609 & 3.043 & -2.043 & -1.638 & 0 & 0.55 \\
\hline 522.1 & 1 & 3 & 1.792 & 3.408 & -0.408 & -0.326 & 0 & 0.73 \\
\hline 523.5 & 2 & 4 & 2.303 & 4.431 & -0.431 & -0.343 & 0 & 0.34 \\
\hline 524.1 & 1 & 6 & 3.178 & 6.185 & -0.185 & -0.148 & 0 & 0.98 \\
\hline 525.1 & 1 & 4 & 2.197 & 4.220 & -0.220 & -0.175 & 1 & 0.03 \\
\hline
\end{tabular}


Table 9-5. Continued...

\begin{tabular}{|c|c|c|c|c|c|c|c|c|}
\hline $\begin{array}{c}\text { SOA } \\
\#\end{array}$ & Exposure & $\begin{array}{c}\text { Number } \\
\text { of Tool } \\
\text { Types }\end{array}$ & $\begin{array}{c}\text { Log of } \\
\text { Number } \\
\text { of Tools }\end{array}$ & $\begin{array}{c}\text { Predicted } \\
\text { Value }\end{array}$ & $\begin{array}{c}\text { Residual } \\
\text { Value }\end{array}$ & $\begin{array}{c}\text { Studentized } \\
\text { Residual }\end{array}$ & $\begin{array}{c}\text { Feature or } \\
\text { FCR* }\end{array}$ & $\begin{array}{c}\text { Distance to } \\
\text { Water** }\end{array}$ \\
\hline 526.1 & 1 & 7 & 2.996 & 5.820 & 1.180 & 0.939 & 0 & 0.12 \\
\hline 527.1 & 2 & 4 & 1.386 & 2.596 & 1.404 & 1.131 & 0 & 0.59 \\
\hline 528.1 & 1 & 5 & 2.079 & 3.984 & 1.016 & 0.809 & 0 & 0.36 \\
\hline 530.1 & 1 & 4 & 2.833 & 5.495 & -1.495 & -1.188 & 1 & 1.74 \\
\hline 252.1 & 1 & 4 & 2.565 & 4.957 & -0.957 & -0.761 & 1 & 0.79 \\
\hline 252.2 & 1 & 4 & 1.792 & 3.408 & 0.592 & 0.473 & 1 & 0.79 \\
\hline 531.1 & 1 & 7 & 3.135 & 6.100 & 0.900 & 0.717 & 0 & 0.03 \\
\hline 533.1 & 1 & 7 & 2.833 & 5.495 & 1.505 & 1.197 & 0 & 0.03 \\
\hline 106.1 & 1 & 2 & 2.197 & 4.220 & -2.220 & -1.768 & 0 & 0.05 \\
\hline 535.1 & 1 & 4 & 1.946 & 3.717 & 0.283 & 0.226 & 0 & 0.03 \\
\hline
\end{tabular}

* Feature and FCR data, as well as distance to water data, are based on site level attributes.

** Distance to water is in kilometers.

including greater activity range possibly associated with residential occupation and reoccupation of the same location for different special purpose activities, we must begin to consider other aspects of the assemblages. Below we will consider the characteristics of these SOAs as a group with regard to both the presence of fire-cracked rock and distance to water. If a high percentage of cases assigned to the high variety group are reflecting residential activities, then as a group, they may well be located close to permanent water and have evidence of features, in the form of hearths or scattered FCR. In contrast, if most of the cases in the limited variety class reflect special purpose activities, we expect that the group should have a lower occurrence of FCR or features. While FCR and features may certainly be present at these locations for resource processing, they should have a lower frequency of activities that involve FCR. In addition, as a group, these cases should be located in a wider variety of environmental settings, including settings away from permanent water sources.
Figures 9-14 and 9-15 are plots of the studentized regression residuals (residual/standard error of residual) for those sites without FCR (Figure 9-14) and those sites with FCR (Figure 9-15). Studentized residuals follow a " $t$ " distribution when the underlying assumptions of regression are met (Afifi and Clark 1984:100; Chatterjee et al. 2000:90). Negative residuals fall below the least squares regression line, and positive residuals are above the line. A comparison of the two figures will demonstrate that sites that lack FCR are dominated by cases with negative studentized residuals. There are 38 sites without FCR. Of these 27 (ca. 71 percent) have negative residuals. Conversely, only 25 of the 65 sites with FCR (38.5 percent) have negative residuals. Using a chi-square test, these differences are statistically significant $\left(X^{2}=10.19 ; \mathrm{df}=1 ; \mathrm{p}=.001\right)$, suggesting that those cases assigned to the high variability group on the basis of tool variety relative to sample size have a significantly higher occurrence of FCR than cases assigned to the low variability group. These patterns are consistent with regard to the overall group assignment if those sites in the high variability class reflect a significant proportion of residential activities. 
Table 9-6. Exposure and Variety Groups

Adjusted Residual Values in parenthesis

\begin{tabular}{|c|c|c|c|}
\hline & Low Variety & High Variety & Totals \\
\hline Low Exposure & $\begin{array}{c}40 \\
(1.4)\end{array}$ & $\begin{array}{c}33 \\
(-1.4)\end{array}$ & 73 \\
\hline High Exposure & $\begin{array}{c}12 \\
(1.4)\end{array}$ & $\begin{array}{c}18 \\
(1.4)\end{array}$ & 30 \\
\hline Totals & 52 & 51 & 103 \\
\hline
\end{tabular}

Figure 9-16, a box plot of distance to water for the low and high variability groups, demonstrates that high variability cases are, as a group, located closer to water than low variability cases, and have an overall smaller range than the low variability group. While both groups have a number of outliers, the 51 high variability cases are located, on average, $0.472 \mathrm{~km}$ from permanent water, and more than half of the cases are located within 0.11 kilometers of water. In contrast, the 52 low variability cases are, on average, 0.582 $\mathrm{km}$ from water, and half of the cases are within .35 $\mathrm{km}$. These patterns are, again, consistent with the expectations that the high variability group may contain a significant number of residential occupations, assuming that water is an important element in the location of residences.

Given the nature of the analysis, the fact that the regression forces two groups to be present, and the fact that a significant portion of the cases fall near the regression line, it may be useful to examine those cases which are clearly separated from the regression line. These cases are more likely to reflect significant differences in variability. We will focus on the studentized residuals in Table 9-5 (see Afifi and Clark 1984:100; Chatterjee et al. 2000:90). However, a focus on those residuals which are significantly removed from the line (e.g., \pm 1.96 ), would severely limit the sample size. As our goal is to maximize the number of cases, but eliminate those cases that are likely to cloud any subsequent analysis, we used the upper and lower quartiles of the studentized residuals as break points. This distinction translates into those cases with studentized residuals in excess of +.786 or less than .652 in Table 9-5. These 53 cases with studentized residuals that exceed these values may still include some ambiguous assignments, but the procedure represents a compromise between maximizing sample size and minimizing mis-classified cases.

As with the previous analysis using all groups, there are significant differences in the presence/absence of FCR and distance to permanent water in these extreme cases that are consistent with expectations. Eighty percent (20 of 25) of the high variety cases have FCR or features present, while only 46 percent (13 of 28) of the extreme low variety cases have FCR or features. In addition, Figure 9-17 clearly demonstrates difference in distance to water. The patterns seen previously with all groups is exacerbated by these cases with high and low studentized residuals, and while outliers are still present, the concentration of cases of high variability close to streams is unambiguous.

\section{Reduction Patterns and Variability Groups}

Both the two main groups, as well as the consideration of the extreme cases, demonstrate that the presence of features and/or FCR, and the distance to water, are consistent with expectations relative to residential and special purpose site types. Another expectation commonly associated with this distinction concerns reduction patterns. Residential sites, as a group, are commonly assumed to be the location of late stage reduction activities, activities commonly associated with tool maintenance rather than with tool production. Conversely, the most commonly suggested special 


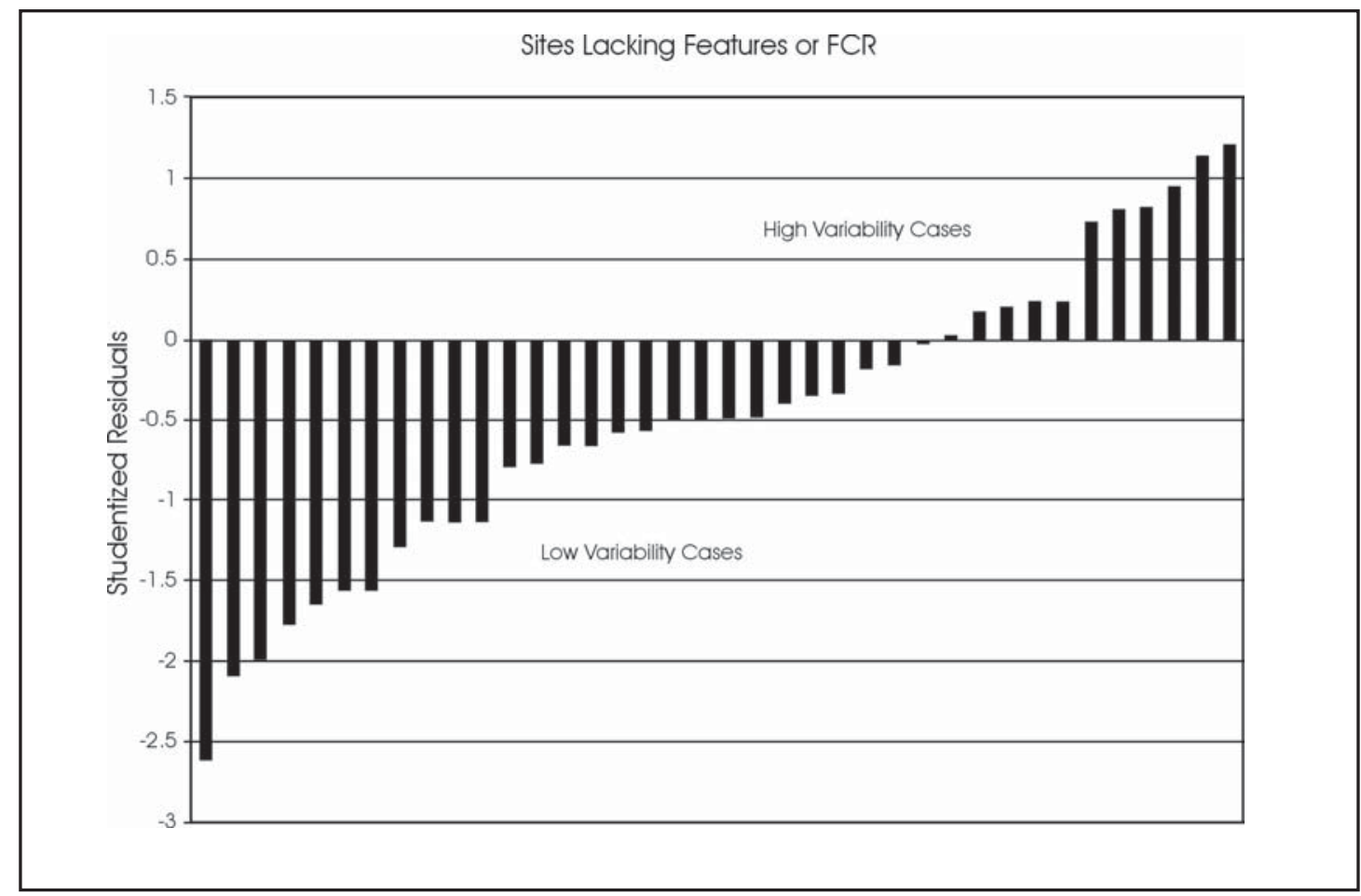

Figure 9-14. Studentized residuals for sites without features or FCR.

Sites With Features or FCR

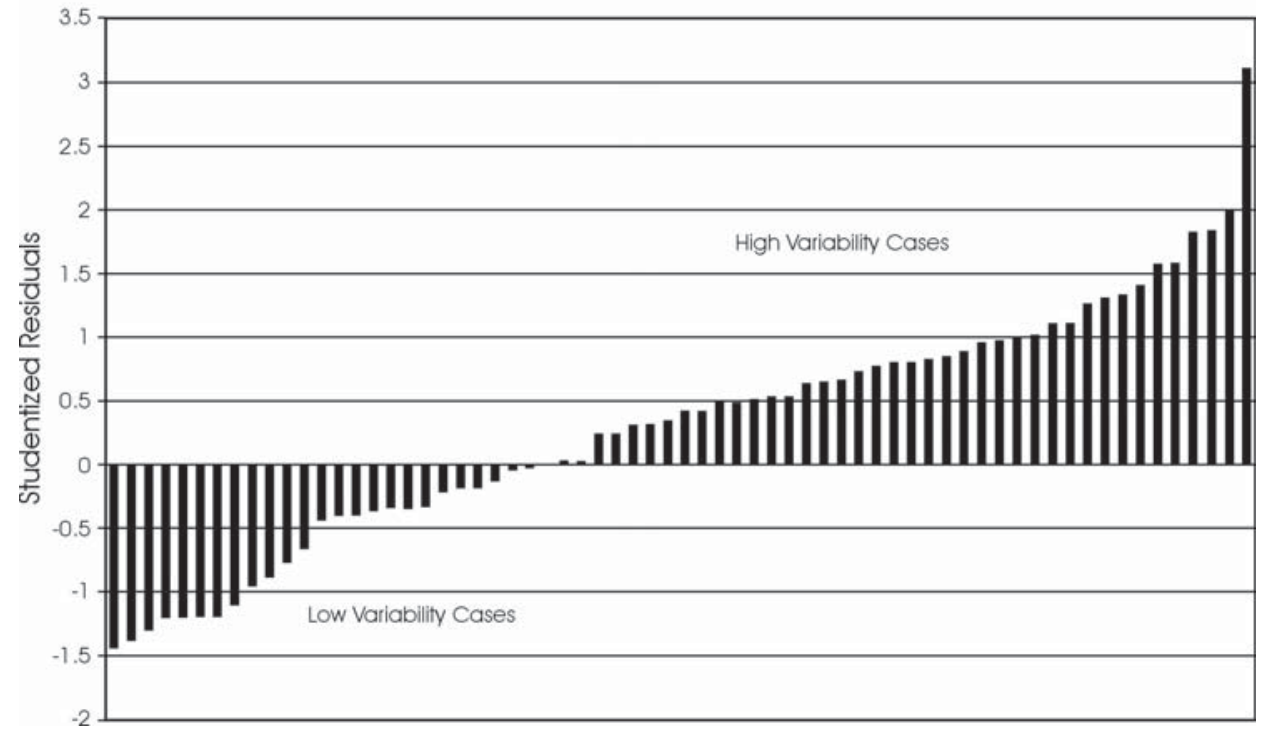

Figure 9-15. Studentized residuals for sites with features or FCR. 


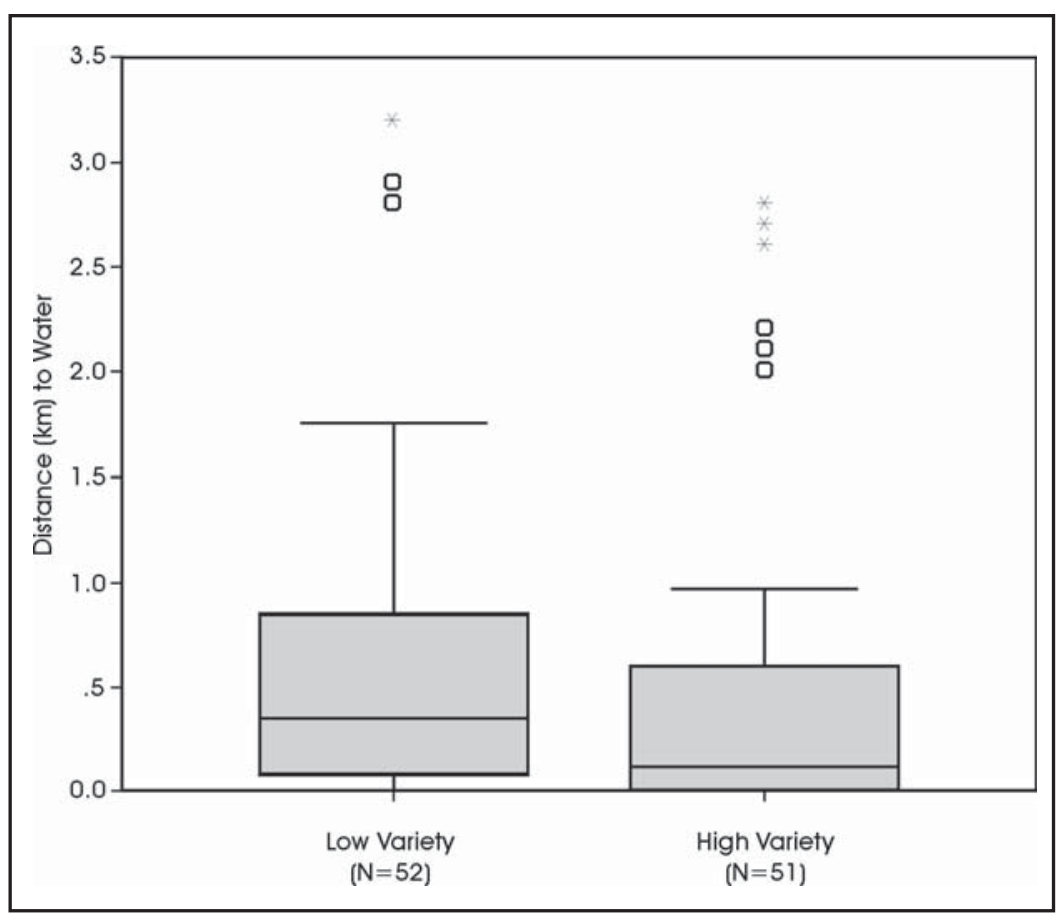

Figure 9-16. Box plot of distance to water for low and high variety groups.

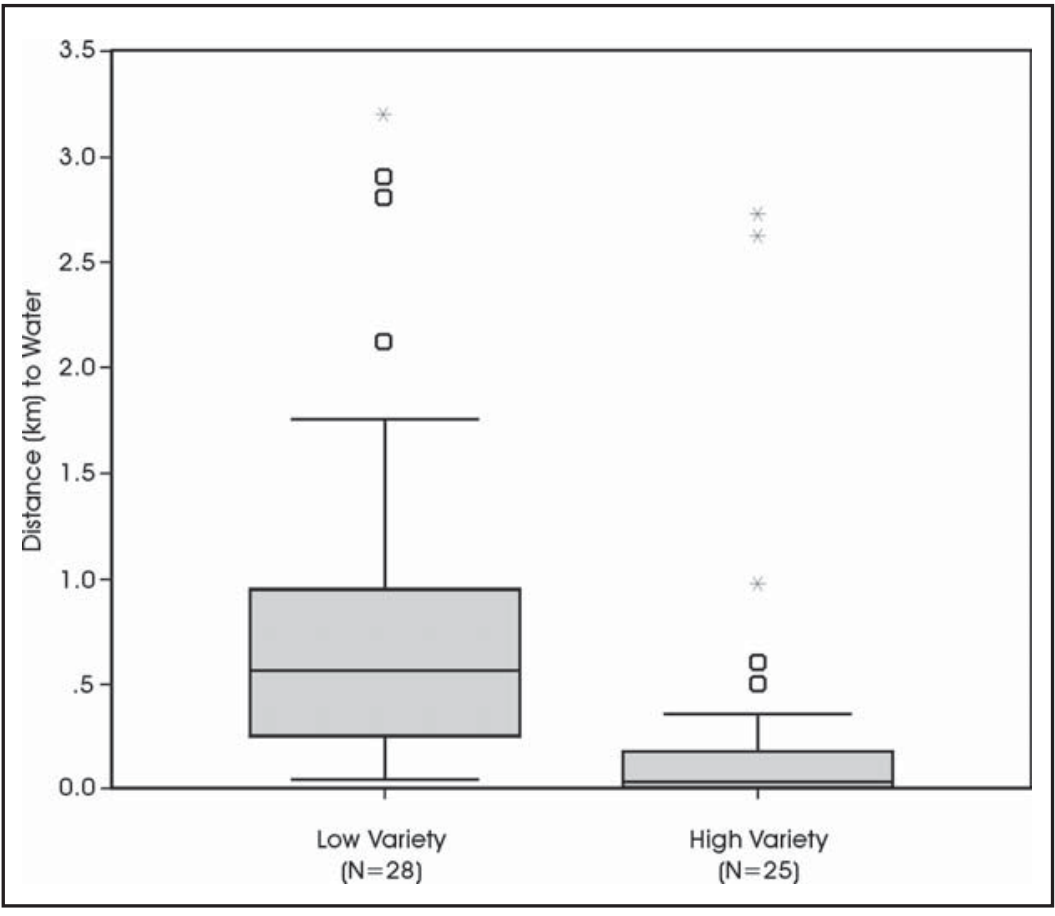

Figure 9-17. Box plot of distance to water for subset of low and high variety groups. purpose activity is associated with initial lithic procurement. While other special purpose sites may certainly be present, if the low variety group contains a high proportion of sites focused on initial lithic procurement, they should, as a group, have very different reduction patterns relative to the high variety cases.

In order to consider this, we focus on the 53 extreme cases and consider two measures of reduction. The first measure consists of the relative frequency of cores with cortex, tested cobbles, and bifaces with cortex in the total tool assemblage. Cores with cortex, tested cobbles, and bifaces with cortex should all measure early reduction. Consequently, high values on this measure should identify those cases where early reduction activities are dominant relative to all tools. Conversely, low values should identify cases where other tools (e.g., bifaces without cortex, cores without cortex, utilized flakes) are dominant, suggesting that early reduction was not a focus of activities at this location. The second measure consists of the percentage of tertiary flakes within the combined tertiary and primary flake assemblage. High values should identify those cases where late reduction is dominant. Locations used only for initial lithic procurement, for example, should have high scores on the initial measure, as they would be dominated by cortical cores, bifaces, and tested cobbles, and low scores on the second measure as the flake assemblage would be dominated by primary flakes. Conversely, locations used only for residential activities should have low scores on the first measure and high scores on the second measure. 
As a group, 70.7 percent of the 437 tools from the low variety cases are comprised of cores, tested cobbles, and bifaces with cortex. In contrast, only 32.1 percent of the 445 items from the high variety cases are comprised of cores, tested cobbles, and bifaces with cortex. These differences are statistically significant using a chi-square test on the original frequencies $\left(X^{2}=131.31\right.$; $\mathrm{df}=1 ; \mathrm{p}<.0001)$. Similarly, tertiary flakes make up 65.3 percent of the combined 1,173 tertiary and primary flakes from low variety cases, but account for 82.8 percent of the combined 2,151 tertiary and primary flakes in the high variety sample. Again, these differences are statistically significant $\left(\mathrm{X}^{2}=129.73\right.$; $\mathrm{df}=1 ; \mathrm{p}<.0001)$. As a group, then, high variety cases have indications of late reduction while low variety cases have indications of early reduction.

These differences are also apparent in the biface data presented in Appendix E. A total of 150 bifaces were present on these 53 sites. Figure 9-18 presents box plots of overall thickness (bottom) and width (top) of bifaces with complete width and thickness data $(n=133)$ for each variety group. In both cases, the bifaces from the high variety sites are smaller than those from the low variety sites. These differences are probably related to a higher incidence of finished bifaces at high variety sites. This can be seen by noting that bifaces characterized as projectile points make up 24.7 percent of all bifaces from high variety sites, but account for only 9.2 percent of bifaces on low variety sites.

In summary, there is no necessary relationship between these measures of reduction and the measures of variety that would account for this pattern. The
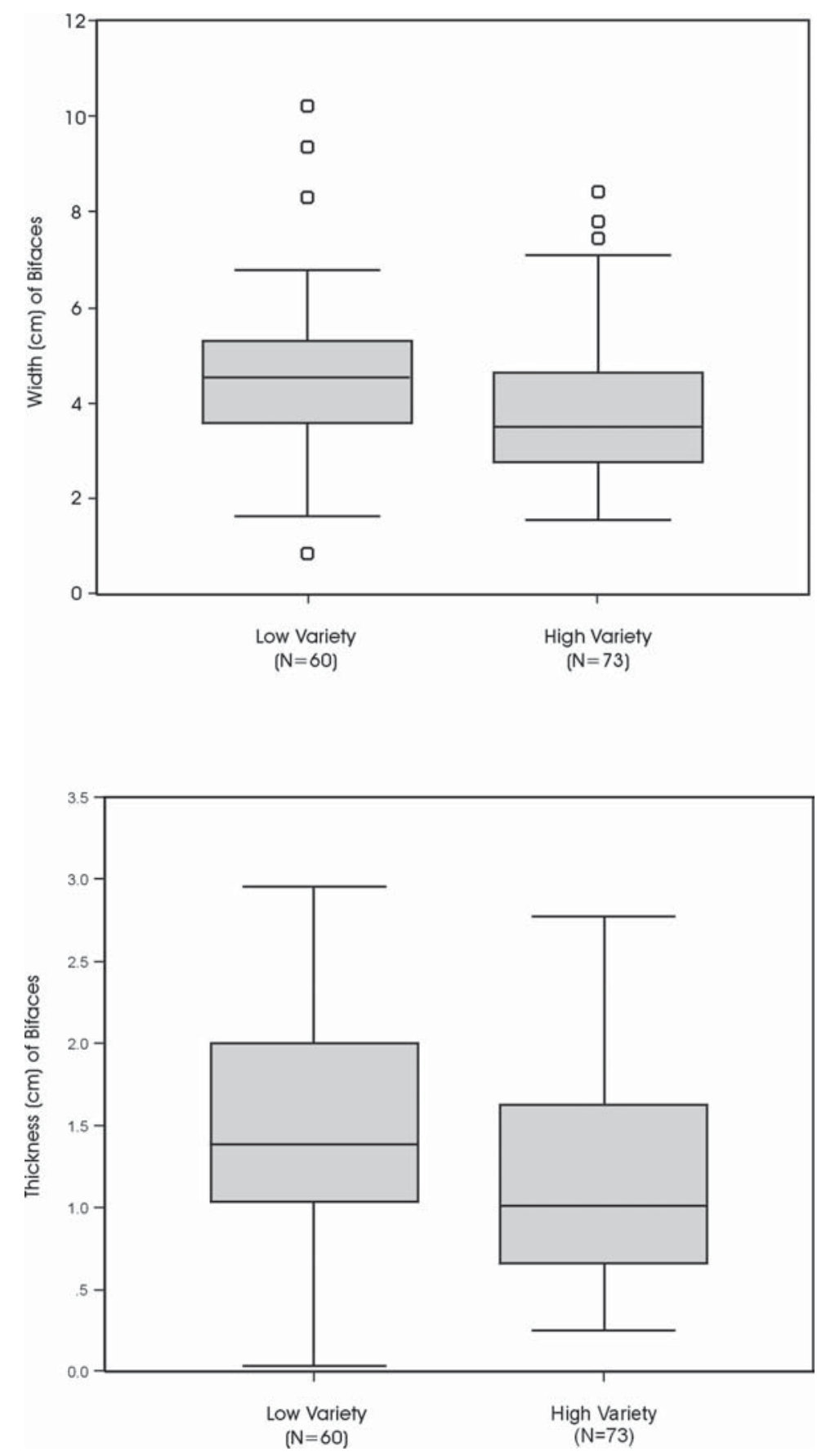

Figure 9-18. Box plots of biface width (top) and thickness (bottom) for bifaces on low and high variety groups. 
groups were defined on the basis of variety measures relative to sample size. While high variety cases, as a group, have more kinds of tool types relative to low variety cases, the tools do not necessarily have to reflect late reduction activities. Similarly, there is no underlying relationship between the metric characteristics and shape of bifaces that would account for the biface differences within the two groups. Finally, while tertiary flakes are more common on exposed settings, and while there is a tendency for high exposure sites to be classified as high variety, Table 9-6 demonstrates that the association between exposure and variety is not statistically significant. It appears, then, that at least in the 53 cases of extreme positive and negative studentized residuals, that the regression analysis has identified two groups of sites that may reflect broad differences in prehistoric activities.
It is, however, possible that only a few cases with large sample sizes are causing the differences identified at a group level. In order to consider this possibility, Figure 9-19 was constructed. This figure plots the individual scores for the sites in each group relative to these two measures. There is surprisingly little overlap in the two groups. High variety cases are clustered in the upper left corner of the graph, while low variety cases tend to fall more to the right of the graph. There are only four cases of low variety sites that fall close to the high variety cluster, and only two of these actually overlap with the high variety sites.

While the pattern of individual cases certainly supports the validity of the two group distinction, note that there is considerable spread among low variety cases, with only one case, an SOA on 41TG385, falling in the

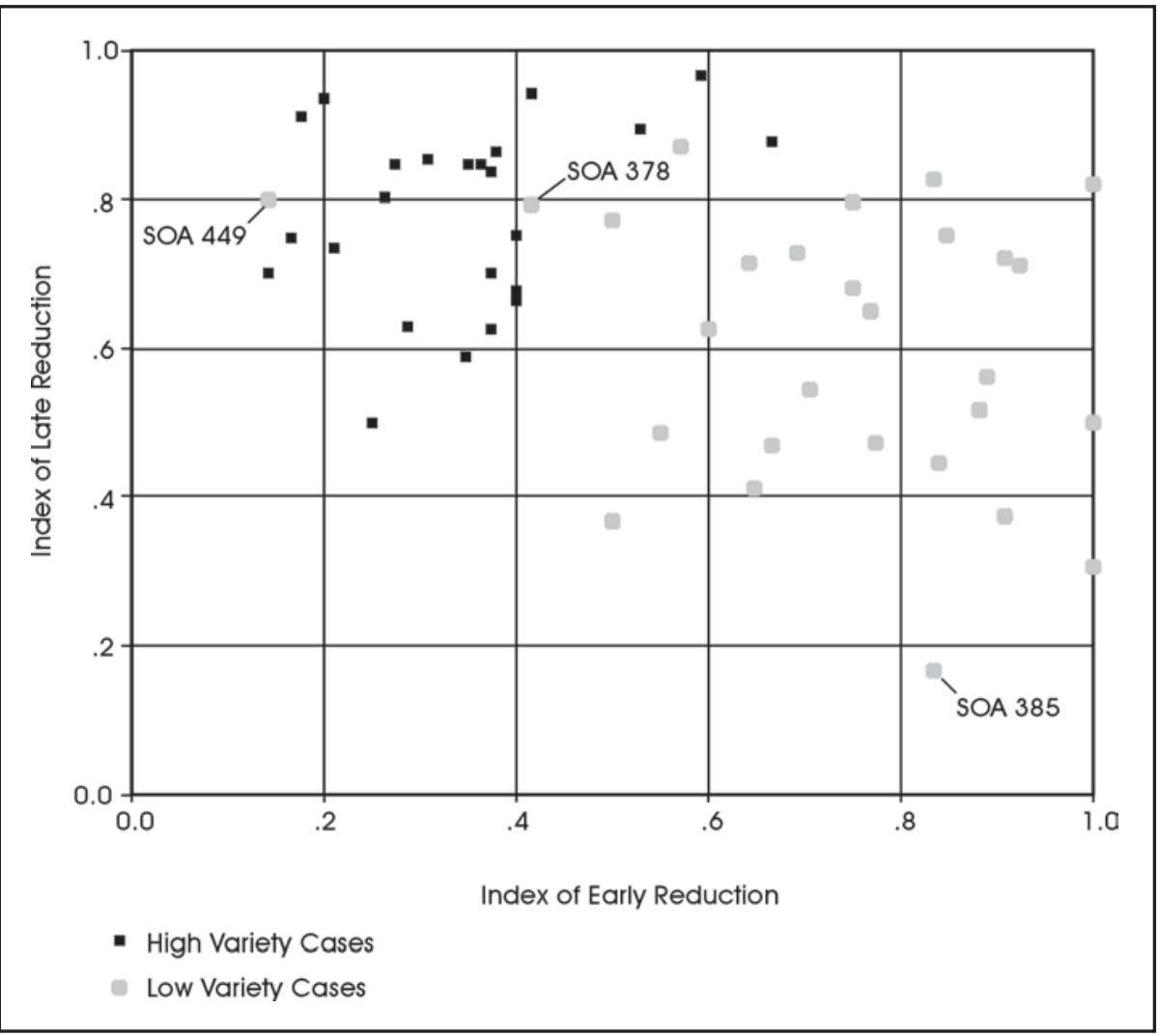

Figure 9-19. Reduction indices for subset of SOAs. 
extreme lower right corner of the graph, the area where I would expect initial lithic procurement sites to occur. The spread of cases may suggest that a variety of different activities are represented in the low variety sites, though the specific nature of these activities is not known. A detailed consideration of specific tool assemblages may produce additional information on these activities, but we lack data of this nature. We also lack temporal assignment for most of these cases. Only 18 of the 53 cases have any temporal information at the site level, precluding any significant temporal analysis. However, it is interesting that the two low variety cases that have indications of late reduction in Figure 9-19 have components which can be assigned to the Early Archaic (41TG449) and the Paleoindian (41TG378) periods. The assemblage and variety patterns reflected at these two sites are not inconsistent with a focus on specialized activities, such as may be reflected at task-specific hunting locations. Nevertheless, additional information on assemblage content, as well as better temporal resolution, is necessary before any suggestions regarding the range of activities reflected by the low variety cases can be made.

\section{Summary and Conclusions}

The approach represented by the analysis of the SOA data in this chapter is different than that commonly undertaken in archaeological survey projects. While it is intuitively pleasing to assume that all variability in the archaeological record is a direct reflection of discrete occupations that can be identified, assigned to temporal periods based on diagnostic artifacts, and placed into discrete site types, it should be clear that such an approach is at best simplistic, and at worst, self deceiving. The results of the current analysis represent an initial attempt to deal with some of the complexities which are represented by the archaeological record.

The analysis of the SOA data has provided a number of insights into processes that create the record. These include both geomorphic and visibility differences reflected in the different assemblages at exposed and unexposed locations, as well as impacts of modern collecting behavior and sampling decisions on assemblage content. Controlling for these differences to the degree possible, the regression analysis, and subsequent consideration of distance to water, presence/ absence of features and FCR at the site level, and reduction activities seem to support the notion that assemblages with high variety reflect a different range of activities relative to low variety assemblages. The content and location of high variety cases are consistent with expectations for residential sites, while the content and location of low variety cases are consistent with expectations for special purpose locations. To the degree that the spread of early and late measures of lithic reduction for the 28 low variety cases reflect different special purpose activities, we can conclude that at various points in the past, both residential and special purpose locations were present in the sites represented by the Twin Buttes data. Unfortunately, the low frequency of diagnostic artifacts at these sites precludes any detailed investigation of change through time in these site types. However, only a single case, an SOA on site 41TG385, conformed to expectations consistent with a focus on lithic procurement. This is a very different picture of the data set than that presented in the previous chapter, as well as that summarized in Chapter 5 for the surrounding counties, where lithic procurement sites are one of the most commonly identified site types. In addition, we have hints that sites such as $41 \mathrm{TG} 378$ and 41TG449 may represent special purpose sites not identified with traditional site level analysis. While further investigation is certainly necessary to assess both the validity of these suggestions, as well as the utility of the overall approach to survey level data, the analysis clearly demonstrates that to continue to partition the archaeological record using traditional site typologies limits both our understanding of the processes that create that record, and our potential to assess the observational methods that we use to investigate that record. 



\section{Chapter 10: Background and Research Design for Historic Sites}

\section{David Nickels}

\section{Introduction}

A number of research issues could be addressed for the historic period in the Twin Buttes Reservoir project area. What was the nature of the early historic occupation of the region, and what is the evidence for land use during this period? Is there evidence for Native American-European contact in the project area? What is the history of settlement of the area? What was the social and historic background of these occupants?

\section{Historical Background}

\section{Early Native American Contact}

The question of what Native American group(s) occupied the area around Twin Buttes over the past several millennia will probably never be fully answered. Though that portion of the archaeological record that remains preserved and is carefully extracted and analyzed is able to provide a great deal of insight into the lifeways of humans in prehistory, the written and oral accounts of Native American groups encountered in the area in historic times are far more certain and clear. Admittedly biased toward a Eurocentric point of view, the earliest accounts of encounters with Native American groups are those of Spanish adventurers and priests on entradas (journeys or expeditions) into previously undocumented regions of Texas. Most entradas were caused by the desire to lay claim on cities or regions with rumored wealth of immense proportions, mainly sponsored by the Spanish Crown. Some of the entradas enjoined for the purposes of gaining wealth also engaged the devout and faithful missionaries encouraged by the Catholic church to seek out new converts among the indigenous tribes and bands that inhabited this land we now call Texas.

The first European adventurer to reach the unexplored wilderness of Texas was Cabeza de Vaca, who landed on the shores of Texas on an island named Malhado (Spanish for Doom) near Galveston in 1528. Interpretations of de Vaca's Joint Report and Relation given by him after his travels in Texas suggest that he may have reached the Twin Buttes, Concho River valley area. Researchers Cleve Hallenbeck (1940) and Carl Sauer (1971) interpret de Vaca's journey through westcentral Texas as following the Colorado upstream and thence westward along the Concho before proceeding overland to the Pecos. Sauer (1971) interprets de Vaca's account of a major trading crossroads situated on a very broad river as most likely on the Concho River in close proximity of modern-day San Angelo, Texas; while Hallenbeck (1940) suggests that the crossroads was probably on the Colorado near modern-day Big Spring, Texas. Hickerson (1994:11) tends to agree with Sauer "Cabeza de Vaca was probably in contact with ancestors of the seventeenth-century Jumanos..." near San Angelo, “...because it makes it possible to identify the site as a historically important crossroads, which was the location of a Jumano base in the seventeenth century. Cabeza de Vaca's narrative suggests that the situation in the mid-sixteenth century was much the same."

Regardless of whether or not he actually traveled in the proximity of present-day Twin Buttes Reservoir, his influence and reputation as a healer and trader must have been communicated throughout Texas. More importantly, he obviously encountered a part of the large group of Native Americans known as the Jumanos. De Vaca further relates that as he traveled westward from the upper Concho toward the Pecos, the Native Americans he encountered appeared to be related to those whose villages he had recently passed through ([i.e., the Jumanos near San Angelo] Covey 1961:104).

In the 1540s, Francisco Vásquez de Coronado led a large expedition into New Mexico, Texas, Oklahoma, and Kansas (Winship 1896). With its hundreds of horses and other livestock, Coronado's expedition could have left countless numbers of strays in Texas. 
It is also likely that cattle may have strayed into Texas in the latter $1500 \mathrm{~s}$ as herds numbering in the hundreds of thousands were being tended in northern Mexico after the mid to late sixteenth century (Chipman 1992:54). Thus, the early Spanish influence in Texas includes the introduction of livestock as well as people.

\section{Early Entradas}

The Spanish Catholic influence was felt in the Concho River valley early in the first half of the seventeenth century when Jumano Indians claimed to have been visited in spirit by Venerable Sister Maria Coronel de Agreda (Lady in Blue) who taught them in the ways of Christianity, and advised them to seek further instruction from the Franciscan missionaries in New Mexico. Jumano representatives journeyed from the San Angelo region to Old Isleta, New Mexico and asked that a mission be established among them. Subsequently, Father Juan de Salas led entradas to contact the Jumano Indians in 1629 and 1632. The second entrada resulted in the first of 38 Spanish missions in Texas being established on the Concho River near San Angelo by Reverend Fray Juan de Ortega O.F.M., Fray Ortega served the Jumano Indians at the site for six months before returning to New Mexico. Noted historian Father Marion Habig refers to this mission as "San Angelo Mission" (Habig 1990:xix, 89-91, 148, 151; Chipman 1992:62).

As stated previously, the pursuit of potential riches was prevalent in the minds of Spaniards pushing north from below the El Rio del Norte (the Rio Grande). Eighteen years after Father Salas established the brief Catholic presence at the San Angelo Mission, two Spanish entrepreneurs named Hernán Martín and Diego del Castillo ventured into the Twin Buttes/San Angelo region with the intent of establishing trade relations with the Jumanos in that part of Texas, eventually evolving into extended trade with the Caddoan Hasanai in northeast Texas and beyond. While in the Concho River valley, Martin and Castillo noted the large quantities of clams in the Concho valley and even extracted some fine quality freshwater pearls from them. Their reports back to their point of origin in New Mexico aroused the interest of other entrepreneurs, including Diego de Guadalajara. Guadalajara formed an exploration party and left Santa Fe, New Mexico for the Concho valley in 1654 . Once there he and his comrades scoured the banks and bottom of the Concho looking for clams yielding illustrious freshwater pearls. By accounts, only about one in every hundred clams produced a pearl, and the effort to produce a profit was not fruitful. At some point, in these ensuing four years the name of the Concho River was thus changed from Rio de las Nueces (river of pecans) to Rio de las Conchas (river of shells). Nevertheless, the Jumano Indians were apparently still the predominant group in the region and had not as yet been displaced by invaders that would, in ensuing years, sweep into the area from the north and west (Hickerson 1994:109-114; Handbook of Texas Online 1999d).

Although limited trading continued with the Jumanos, by the 1680 s the Apaches who had infiltrated the Rio Concho area created an ominous presence for potential settlers as well as indigenous groups. In 1683 the Jumanos sent a delegation to El Paso seeking to reestablish trade relations with the Spanish. Such an alliance would also help fend off the warring Apaches. In response, Spanish military Captain Juan Dominguez de Mendoza, a squad of soldiers, and two Catholic priests set out from the El Paso area in December 1683. The two priests accompanying Mendoza were the Father Superior of New Mexico missions, Father Nicolás Lopez, and Father Juan de Zavaleta. Historian Carlos Casteñeda (1976) believed that they established Mission San Clemente (Mendoza had named the Colorado River "San Clemente") for the Jumanos (Habig 1990:152) at the confluence of the Concho and Colorado rivers. Bolton (1908:334) and Chipman (1992:70) suggest that Mendoza marched eastward from the Pecos, encountered the Middle Concho, and followed it downstream to the main Concho, and eventually the Colorado. If that's the case, then Mendoza's route took him directly across the Twin Buttes survey area. However, others believe that San Clemente was located either on the San Saba River near present-day Menard, Texas (Connor 1969; Habig 1990:121), on the Colorado River near present-day Ballinger, Texas (Bolton 1908), or on the South Llano River (Williams 1962). Regardless of the exact location, the Spanish presence at San Clemente lasted only about two months before French encroachment in East Texas drew the attention of the Spanish away from west Texas (Handbook of Texas Online 1999b). 
Although short-lived, the San Clemente Mission established in Jumano country attracted several groups from the Rio Grande and Edwards Plateau regions to the San Angelo area. A large aggregation site was established resulting in a diverse mixture of bands and tribes from several different areas of Texas. Twenty groups followed the Mendoza expedition and 37 others were expected to meet Mendoza upon arrival at San Clemente. Over 4,000 head of buffalo were killed during the approximately six weeks that Mendoza occupied San Clemente (Bolton 1908:339-341; Chipman 1992:70).

Near the end of the seventeenth century, Lipan Apaches had moved into the area from the west and north, displacing through warfare the indigenous tribes and bands (Hester 1989). However, by the end of the century the Apache were forced to ally with both the Spanish and the indigenous groups in order to defend themselves against a much fiercer enemy-the Comanches (Hester 1989; Richardson 1996). By 1705 the mounted Comanche warriors were dominating all other Indian groups in the region (Newcomb 1993:155-158).

\section{Early Settlement in Texas}

Settlement in east and south-central Texas began in earnest with the establishment of Spanish missions in those regions. However, few landowners dared to live on their outlying lands or even venture westward from San Antonio until about 1749, when a treaty with the Apaches brought a short-lived peace (de la Teja 1995:100). Apaches continued to range over the area between San Antonio and Laredo until the early 1800s, pushed southward by the invading Comanche who had moved into the Hill Country of central Texas (Campbell and Campbell 1985:27). Weary of warfare with the Comanche, a few Apache were beginning to seek asylum in the missions (McGraw and Hindes 1987:367; West 1904:50).

French encroachment into Texas caused considerable concern for the Spanish. Alliances were formed between early French traders and Native American tribes for economic reasons during the first half of the eighteenth century. In an attempt to extend their trade network from Louisiana to Santa Fe, French traders sought peaceful relations and trade agreements with
Wichita villages in Oklahoma. The Wichitas provided valuable otter, mink, beaver, and muskrat furs, as well as buffalo robes in exchange for French guns, ammunition, knives, cloth, and other hardware (Morris 1970:79-80). In 1747, the French were instrumental in helping the Wichitas form a trade alliance with the Comanches, who were encroaching on the western periphery of the Wichitas territory in modern-day western Oklahoma. The wide-ranging Comanches were able to provide more furs from territories they controlled to the west. The Wichitas acted as middlemen in the French-Comanche trade; the Wichitas accepted Comanche furs in exchange for French muskets and other goods (Morris 1970:80-81).

The French/Wichita/Comanche alliance proved costly to both the French and Spanish. In 1758, the Comanche, Wichita, and Tawakoni Indians (a Wichita group) attacked Mission San Sabá on the San Saba River, near Menard. This mission had been established at the request of the Apaches who were enemies of the Comanches. The massacre of the mission inhabitants by the Comanches and Wichitas was carried out with French muskets (Hall and Hindes 1998).

In the autumn of 1785 , after nearly a century of conflict, a peace treaty was agreed to in Santa Fe between the Don Juan Bautista de Anza representing the Spanish Crown and Cuera (Leather Jacket) representing the Comanches. The treaty signaled the opening of a period of peaceful coexistence (Fehrenbach 1978:221224; Poyo and Hinojosa 1991:125-126). However, the treaty agreement was certainly not adhered to by all Comanches, as certain groups continued to commit acts of depredations through the nineteenth century on anyone who dared challenge their range (e.g., Wilbarger 1985).

While Texas was not yet a free and independent republic, frontier naturalist Dr. Gideon Lincecum may have visited the Twin Buttes area in the Spring of 1835. While there he observed what he thought must have been 500,000 buffalo grazing on the open plains, along with plentiful deer and jackrabbits. Although he was unsure of the name of the creek he noted that the creek had a slate bottom...

"amongst which I found numerous particles of gold. To the eye of the mineralist the rocks, clay, 
the slate, all in that immediate district, bear unmistakable indications of a pretty heavy auriferous deposit. I had no means of ascertaining what the name of the creek was then, but I think it will be found by some industrious miner on one of the source branches of what is now known as the Concho River, a tributary of the Colorado of Texas. At a distance of ten or twelve miles to the north I could see two mountain peaks. I wished to climb to their summits and examine them but feared exposing myself" (Lincecum and Phillips 1994:233).

\section{Struggling for Frontier Dominance}

A struggling young Republic of Texas continued the empresario (colonization) system as a means of bringing new families to settle and develop the land. Earlier grants of huge tracts of land to empresarios such as Stephen F. Austin, Green DeWitt, Haden Edwards, Sterling Robertson, John McMullen, and others proved successful in establishing communities in south and east Texas. Around 1840 settlers from Germany and Alsace-Lorraine, and from other regions of the United States, began to flood into San Antonio. Many of the Germans moved into the Hill Country to the north, settling into communities, and raising sheep or cattle (Freeman 1994:5-9). As the sheep and cattle markets emerged in the 1880s ranchers and farmers settled farther away from San Antonio (Flanagan 1974; Lehmann 1969; Nickels et al. 1997).

Under President Sam Houston's second term in 1842, Henry Fisher, Burchard Miller, and Joseph Baker petitioned the Republic of Texas for authorization to establish 1,000 families in an area consisting of over 3 million acres of land between the Colorado and L1ano Rivers. Permission was granted to Fisher and Miller to begin recruiting 600 immigrant families who would be given 640 acres per family, provided they build a cabin and farm 15 acres of fenced land. However, settlement in the western portion of the grant, which included the Twin Buttes area, did not come easy. The objective of luring 600 families (later increased to 6,000 by the Republic) could not be accomplished for two principal reasons: 1) the northwestern portion of the tract encompassed the hunting grounds of the Comanches who were not about to relinquish their domain without a fight, and 2) the area was well west of the main San Antonio-Mexico trade routes (Biesele 1987:76-110).

Following a chain of events that led to the FisherMiller Grant being acquired by the Adelsverein (the Society for the Protection of German Immigrants in Texas), John O. Muesebach as Commissioner-General of the organization sent a survey party to the San Saba River area near Menard to investigate the possibilities of mineral wealth and tillable farmland available within the western portion of the grant. Well aware that he would be encroaching upon Comanche territory, he met with a group of Comanche chiefs for three days in March 1847 and negotiated a treaty of peaceful coexistence with them (King 1967:111-118). Speaking through an interpreter, Muesebach's treaty proposal to the Comanche chiefs (Tiling 1913:100) was as follows:

1. "My countrymen have the permission to go and travel where they please, and no harm must be done to them, but you must protect them everywhere. On the other hand, your people can come to our wigwams and cities without fear and can go wherever they please and shall be protected."

2. "You the chiefs, and your people will assist us and report to us, when bad men and redfaces of other tribes steal our horses or intend other felonies, and we shall do the same, when you are attacked."

3. "I am going to send men with the thing that steals the land (compasses), as the red men call it, and will survey the whole country of the San Saba as far as the Concho and other waters, so that we may know the boundaries where we can go and till the soil. And if you are willing after consultation with your warriors, to make this treaty, then I will give you and your squaws many presents, that we call dollars, and give you as many as one thousand and more of them."

The following May the chiefs finalized the agreement by coming into Fredericksburg to sign the treaty and collect the money promised them (King 1967:111-118). 
By the 1840 s new routes and trails were being established through the largely unsettled Twin Buttes area, due in part to the desire to reach the gold fields of California. One such group of fifteen prospectors from Austin, passed through the area in 1849 and left a written account of their adventures: They traveled to the head of Brady's Creek before heading west to the Concho River where they noted:

April 29.

Pursued our way, traveling up the creek (author's note: Brady's Creek) to its source, thence across the country to the Concho River - a due west direction, the first eight miles over a beautiful mesquite country, the rest of the way poor and rocky. Made thirteen miles today. This stream abounds in fish, in which we had the pleasure of regaling ourselves.

April 30.

Traveled this day twenty-one miles, our way through a mountainous and barren country; no water to be procured on the road. Encamped on a branch of the upper Concho. We saw pleasant looking valleys to our right and left; nothing of interest to remark on. Our camp is in a pretty valley, studded with pecan trees; plenty of good water.

May 1.

Traveled west five miles to the second Concho and encamped on the west bank. This stream has several pretty valleys of land. The face of the country on each side of the stream is mountainous. This stream is very pretty, affording good mill sites.

May 2.

Pursued our journey a due west course. We passed over the most picturesque country seen so far. Towering peaks presented themselves in front of us; two in particular, known by the name of Twin Sisters (author's note: Twin Buttes), served as landmarks to guide us on our way. We ascended the top of one of these peaks and had the most extensive view I have ever seen. On one side seven other tall peaks appeared in sight, and on the other, vision was lost in the great expanse uninterrupted by the least elevation of land or [by] any other objects. On the third
Concho we found some very good valleys of land. We traveled fifteen miles this day and pitched camp. At this place we found the skeleton of an Indian in the camp of some emigrants for California that were before us; supposed that he was killed by them.

May 3.

Left the third Concho this morning; passed through some very good land situated on this stream. Our course has been due west. Made fifteen miles and encamped on the fourth Concho. Timber scarce, but plenty of water"

(Beiber 1937:202-203).

The unknown author of the journal extract quoted above mentions emigrants traveling to California. This infers that emigrants passing through the area had already entrenched an emigrant road. By 1849 , westward expansion was foremost in the dreams of many citizens and politicians. As a result the United States Army Topographical Engineers Corps was called upon to survey various routes to El Paso and beyond. Lieutenant Francis T. Bryan was ordered to conduct a survey to determine the best route for a permanent road from the Gulf of Mexico to El Paso. Lieutenant Bryan passed through the area, describing the South Concho as a large, but gently flowing stream. As he approached the South Concho from the east the land had but a few live oaks with scattered mesquite trees, but along the banks of the river there were many large pecan trees. His party was able to cross the South Concho and Dove Creek only after clearing thick brush from the water's edge. He describes the grasses in the area between the South Concho and Dove Creek as being "only tolerable, ... old and dry." He notes that the water in Good Spring Creek was "pure and very cold." After crossing Lipan Creek his party encountered the Emigrant Road south of Green Mounds, "where the wagon road is deeply marked on the prairie." The Middle Concho afforded his men the opportunity to fish for good catfish and trout (Bryan 1849:18-19). John Russel Bartlett's expedition through the area the following year crossed the wagon trails of Lieutenant Bryan. After crossing the South Concho "...or Boiling Concho." As he called it, then Dove Creek, he camped on Good Spring Creek and could see the Twin Buttes to the north (Bartlett 1965:79). After catching a few dozen catfish and black bass in Spring Creek he and 
his fellow travelers spent the night with five Lipan Apaches, including two chiefs, who had joined them. The next day Bartlett and his group found the Emigrant Road (California Road) west of San Angelo near Green Mounds, and headed west toward El Paso (Bartlett 1965:80-83). Bartlett's narrative of the area varies little from that of Lieutenant Bryan. It is interesting to note that although Bryan's party traversed the area in the summer (June and July), and Bartlett's in the fall (October), neither of them mentioned large herds of bison that later travelers did.

\section{Early Settlement in the Twin Buttes Area}

The Twin Buttes/Concho River area was still an unsettled frontier by the $1850 \mathrm{~s}$. Remnants of the Kotsoteka and Penateka bands of Comanches still occupied the areas west and east of modern-day San Angelo respectively (Kavanaugh 1986:282-285). The Butterfield Overland Mail stage line ran through the area crossing the South Concho just west of the Twin Buttes Reservoir, and the upper Middle Concho before heading westward to El Paso, from 1857 until 1861 and the beginning of the Civil War (Bitner 1931:17). A few pioneer ranchers dared venture into the Concho Valley in the 1860s. R. F. Tankersley arrived at the head of the South Concho in 1864 aboard an ox-drawn wagon with his wife Annie, six children, 700 head of cattle, and 45 horses. The area was brimming with wildlife such as turkeys, antelope, deer, wild mustangs, coyotes, panthers, beavers, fish, and buffalo in herds "like great swarms of flies" (Barton 1998:38-39). Richard Tankersley's choice of grazing land along the South Concho was a wise one; in 1869 he herded 1,700 head to San Bernadino, California. Although he lost 700 head along the way, he received $\$ 25$ per head for the 1,000 steers that made the hot, dry trip (Barton 1998:53-54). Ben Ficklin came to the Concho valley a year after Tankersley, settling on the South Concho on 640 acres purchased from John Muesebach for $\$ 1$ per acre. He soon established the Concho Stage Station (later Ben Ficklin Station) which handled mules and coaches for the El Paso Mail Company service between El Paso and San Antonio. Passenger service on the line from San Antonio to
Ben Ficklin Station took two days and cost $\$ 25$ in gold; the trip on to El Paso took four days and cost $\$ 50$ in gold (Barton 1998:44).

Soon after the Civil War ended, the U.S. Army sought to construct and strengthen its chain of forts westward across Texas to protect immigrants and ranchers. Fort Concho (originally named Camp Hatch, also White City, later Camp Kelly) was established at the confluence of the Main and North Concho rivers in November 1867 (Barton 1998:52; Handbook of Texas Online 1999t). The army hired several masons and journeymen from Fredericksburg to help build Fort Concho, at present-day San Angelo (Zapata 1998:3). To sustain operations, the fort employed 123 civilians, including two blacksmiths and three wheelwrights in 1869 (Zapata 1998:9). During its heyday in 1879 the fort housed eight companies of soldiers and consisted of forty stone structures. As with all military posts, camps, and stations there were camp followers, traders, and civilian workers which caused the community of San Angelo (originally named Overthe-River, later Santa Angela) to spring up across the river from the fort in 1870 . Fresh vegetables were obtained from the fort's garden known as Bismarck Farm, "the first irrigated farm in West Texas," and the soldiers supplemented their army rations with buffalo and turkeys (Bitner 1931; Handbook of Texas Online $1999 t)$. At a cost of $\$ 88$ per mile telegraph lines were strung between Fort Concho and Fort Griffin. The Fort Concho telegraph office became operational on October 19, 1876. The development of Fort Concho was a significant stimuli for development and settlement of the region as a whole: "Soldiers from Fort Concho scouted and mapped large portions of West Texas; built roads and telegraph lines; escorted stagecoaches, cattle drives, and railroad survey parties; and served generally as a police force." By 1889 civilian law enforcement and a growing, stable population precluded the need for a frontier fort and it was closed (Handbook of Texas Online 1999t). Even though a flood cresting 40 feet above the river channel wiped out the then county seat of Ben Ficklin in 1882, the citizens refused to quit. Although Ben Ficklin was basically abandoned, San Angelo and the rest of the county continued to grow. 


\section{Freighting}

Even though San Angelo was rapidly developing, and Tom Green County was established in 1874 (Handbook of Texas Online 1999v) the freighting industry was essential to its continued development. San Angelo's streets were full of freight wagons of all kinds. "When there were supplies to haul, the streets were crowded with ox-driven rigs as well as horse and mule driven. This caused lots of congestion, cussing drivers, popping whips, and braying mules" (Barton 1998:63).

Texas pioneer and freighter August Santleben spoke of the Concho River region during the 1870s and 1880s as one in which "The plains and valleys that are traversed by the headwaters of the Concho River and its tributaries were then occupied by droves of buffalo whose numbers could not be computed with certainty" (Santleben 1910:176). He further alluded that although a 30-mile wide corridor extended into the area around present-day San Angelo, the southern limit of the great herds extended to about 50 miles north of Fort Concho, where the Comanches hunted freely and white settlers did not safely roam (Santleben 1910:177).

Winters were (and still are at times) severe in the region. Texas pioneer and wagon freighter August Santleben recalled he and his mules seeking shelter in the cedar-brakes at the head of the Concho River while enduring ten days of sleet and snow; the weather being so severe that the buffalo were forced to strip the tree limbs because the grass was inaccessible. The mules of many freighters were less fortunate than the native buffalo; one such case being those belonging to a Captain Edgar, a freighter out of San Antonio, whose sixty mules froze to death and whose bones marked the spot for many years (Santleben 1910:120).

Despite glowing reports of abundant protein-rich grasses from early settlers and explorers in the area, freighting ventures into the Concho valley were not accomplished without personal hardships and severe financial losses. For example, after delivering fresh corn to Fort Concho from the farmers in and around Austin, pioneer freighter August Santleben lost 40 mules from starvation while on his return trip (Santleben 1910:139).
Shipping bison hides and later bones from San Angelo by freight wagons was big business also, with an immense slaughter of bison occurring between 1874 and 1878. The local mercantile in San Angelo "...had ten thousand buffalo hides stacked ...fifteen feet high, row on row, with just enough room for men to easily walk between them" (Veck 1931). Bison hunting around San Angelo ceased during the winter of 1877 when particularly bad weather forced the bison out of the area (Bitner 1931:27-28). However, even in the waning years of hunting bison on the open plains 100,000 hides were shipped through San Angelo (Carlson 1982:103). Piles of buffalo bones stockpiled along railways were bought and sold for shipment to railheads in Kansas, to be used for everything from bonechina to bone meal to bone buttons. Texas led the world in bone production, and supplied approximately 500,000 tons of bones ranging between $\$ 3$ and $\$ 23$ per ton between 1870 and 1900 (Handbook of Texas Online 1999u).

Freighting unusual cargo through the area from Chihuahua to San Antonio was quite common in the late 1800s. Wagon freighter August Santleben tells of hauling a meteorite from Mexico through Fort Concho where the spectacle piqued the curiosity of the soldiers stationed there. It should be noted that the meteorite quite handily served as a diversion for the $\$ 200,000$ in silver stored underneath buffalo robes in the same wagon train (Santleben 1910:180-181). With the coming of the first automobile to San Angelo in 1910 , the number of freight yards and wagons began to decline (Barton 1998:72).

\section{Battle of Dove Creek}

Although minor skirmishes and depredations occurred in the area between the encroaching whites and the Native Americans throughout the nineteenth century, the Battle of Dove Creek was of large proportion and had long-lasting ill effects on the peace and stability of the region. In January 1865, Confederate and local militia forces under the command of Captain S. S. Totten and Captain N. M. Gillitine attacked a Kickapoo Indian camp on Dove Creek, which flows into Spring Creek a few kilometers south of Twin Buttes Reservoir. Although there are conflicting reports on the number of Indian casualties, the Confederate and State Militia casualty lists indicate 22 killed and 19 wounded 
(Pool 1950:382-383). At the end of the fight it was evident that the Kickapoos clearly had the advantage and soundly defeated the Confederate and militia forces. However, the battle had long-lasting effects for the area of south Texas along the Mexican border. The Kickapoos who had reportedly been peaceful and were en route to Mexico to evade the chaos caused by the Civil War in the United States, retaliated with vengeance after finally reaching Mexico. They constantly harassed and raided ranchers and settlers in south Texas until Colonel Ranald S. MacKenzie crossed the border and punished them for their depredations (Handbook of Texas Online 1999c; Pool 1950; Wallace 1993).

\section{Ranching}

Cattle ranchers in southwest Texas often watered their herds on the Middle Concho while driving them to the railhead in Amarillo which was constructed in 1877 (Holden 1986:161). The long trail drives through Tom Green County and particularly the Middle Concho valley through the Twin Buttes area began a decline when C. B. Metcalf fenced a portion of the valley in the 1880s. Much like the rest of Texas and the Great Plains, the stretching of barbed wire across previously open rangeland ired the trail drivers, but protected newly tilled farmlands (Duke 1986).

Sheep ranching took hold in the San Angelo area in the late $1800 \mathrm{~s}$. The early ranchers who introduced sheep to the area had to face the wrath of cattlemen, the savagery of wolves and coyotes, the occasional thievery by Indians from south of the Rio Grande, and the tenacity of buffalo hunters seeking the remaining herds roaming among the sheep. Early sheep ranchers in the Concho Valley were Joseph Tweedy, E. Morgan and Leslie Grinnell, and J. Barlow Reynolds, who moved sheep from the Fort Clark/Bracketville area in 1877 (Handbook of Texas Online 1999e). The first shipment of lambs from San Angelo is believed to have occurred in 1899, shipped by Sol Mayer of Fort McKavett (Carlson 1982:102-103). San Angelo became a major shipping point for markets in the east and is recognized as the Sheep and Wool Capital of the nation (Carlson 1982:213).

\section{Railroads}

As with most of the American West and Texas in the boom of the late nineteenth century, the railroad's insurgency through west Texas and Tom Green County had a significant impact on the economy and populace. The State of Texas was eager for railway expansion and granted over 38 million acres of rights-of-way to the railroads between 1853 and 1882 (Runge 1986). The first steam engine entrada into the area occurred in 1885 when the Gulf, Colorado and Santa Fe began constructing a new line from Lampasas to San Angelo (Handbook of Texas Online 19991). In 1888 the city of San Angelo raised \$50,000 to ensure the Kansas City, Mexico and Orient would bring their rails into the city, and that year the line was completed from Ballinger into San Angelo (Handbook of Texas Online 1999o, 1999q). By 1909 the Concho, San Saba and Llano Valley Railroad completed a new line from San Angelo to Sterling City (Handbook of Texas Online 1999s). The Kansas City, Mexico and Orient of Texas then pushed a new line through San Angelo from Wichita, Kansas to Alpine, Texas in the early 1900s (Handbook of Texas Online 1999n), reaching Mertzon in 1911 (Handbook of Texas Online 1999r). The Atchison, Topeka and Santa Fe (after acquiring the Kansas City, Mexico and Orient of Texas) extended a new line from San Angelo to Sonora in 1930 (Handbook of Texas Online 1999k), however the line was losing money and had to be abandoned in 1977 (Handbook of Texas Online 1999m). As costs of operations increased along with competition from the trucking and airline industries, the Gulf, Colorado and Santa Fe Railway was forced to abandon the rails between San Angelo and Sterling City in 1959 (Handbook of Texas Online 1999p). The South Orient Railroad Company, Ltd. acquired the rails from San Angelo to Presidio, Texas from the Santa Fe in 1992 (Handbook of Texas Online 1999o, 1999q), and the tracks are used occasionally to ship freight into Mexico. The South Orient is the only rail line in operation today and the only tracks being used consistently are those over which a daily freight run is made between San Angelo and Coleman (Ruben Flores, personal communication, South Orient Railroad, San Angelo, Texas 1999).

\section{Water}

When Company B of the Texas Ranger Frontier Battalion was stationed in the San Angelo area in the late 1870 s and early 1880 s, to ward off Indian attacks, one of their other missions was to provide maps of waterholes, a valuable commodity in a generally vast 
and arid land (Handbook of Texas Online 1999e, 1999f). Irrigation projects in the Concho Valley were essential to farming activities, and were began early on in the process of settlement. Briefly mentioned previously, the Bismarck Farm established by Jake Marshall in 1868 near Fort Concho was the first irrigated farm in west Texas, getting its water from the South Concho, three miles south of the fort (Handbook of Texas Online 1999t). A dam at the confluence of Antelope Creek and the South Concho diverted water into an irrigation ditch running approximately parallel to the South Concho, and eventually emptying into the Concho. The ditch system provided irrigation to over 800 acres between the ditch and the two rivers (Bitner 1931:29; Map of Bismark Ditch, undated, on file at West Texas Collection, Angelo State University, San Angelo).

Near the community of Knickerbocker the Baze brothers (Pete, Tom, and Polk) constructed the Baze irrigation ditch in 1875 to water their melon, vegetable, and hay fields. The abundant water supply from Dove Creek allowed them to produce enough to sell to the soldiers at Fort Concho. In 1878 Charley and William Lackey built a log and rock dam across Spring Creek northwest of the now-present community of Sherwood to divert water for vegetable farming. A farmers cooperative group formed to participate in the irrigation project was named the Upper Ditch Company. By 1906 the log and rock dam diverted enough water to irrigate 320 acres, and in 1912 the old dam was replaced with one of concrete construction for $\$ 570$ (Barton 1997:45-46, 63-64). A dozen years after the Baze brothers began their irrigation operation Joseph Tweedy opened a second irrigation ditch along Dove Creek in 1887 and formed the San Jose Irrigation and Power Company (Handbook of Texas 1999d). By 1904 there were two power plants operating in the area; Thomas Vinson operated one on the Baze irrigation ditch a half-mile north of Knickerbocker, and the Payne \& Jones plant, located 10 miles south of San Angelo on the Bismarck ditch was powered by waters flowing out of the South Concho (Taylor 1904:63-64).

A series of irrigation and flood control projects on the Concho Rivers have substantially increased land values as well as the capability to better manage the resources available. The Lake Nasworthy dam on the
South Concho was completed in 1930 by the West Texas Utilities Company to supply the city of San Angelo with water and to irrigate farmland in the immediate area (Handbook of Texas Online 1999g). The O. C. Fisher dam on the North Concho was completed in 1952 by the United States Corps of Engineers. The dam holds back floodwaters from San Angelo downstream and the lake water serves as a secondary source of municipal water for the city (Handbook of Texas Online 1999h). The Twin Buttes Reservoir dam was completed in 1963 by the United States Bureau of Reclamation, and retains the waters of the Middle Concho, South Concho, and Spring Creek. Besides providing a secondary source of water for the city of San Angelo, when full, the reservoir is capable of supplying irrigation water to 10,000 acres (Handbook of Texas Online 1999i). The growing demand for water has increased with the population. Since January 1995, the city of San Angelo has been able to obtain twenty-five million gallons of water a day via a pipeline from Lake O. H. Ivie on the Colorado River (Handbook of Texas Online 1999j).

\section{Archaeological Expectations}

\section{General Discussion}

There is a paucity of archaeological information available pertaining to the relationships between prehistoric and historic Indian populations. As stated in Chapter 5, the end of the Late Prehistoric and beginning of the Protohistoric/Historic period in both central and south Texas should be defined as beginning with the time that the indigenous groups may have been affected by European influence and the subsequent advent of written accounts of European contact with indigenous groups (Collins 1995:386-387; Hester 1995:450-451).

As discussed in Chapter 5, many of the archaeological sites recorded in the region thus far have contained cultural material from the Protohistoric and Historic periods. Site types include open campsites, lithic scatters and quarries, and burned rock middens. Features encountered include hearths, mortar holes, possible stone structures, and burials. Cultural material 
recorded includes chipped stone, ground stone, ceramics, mussel and snail shells, ocher, fire-cracked rock, and animal bone. Unique items include polished bone, bone beads and incised bone. Analysis of the cultural material expected to be documented during the Twin Buttes survey would have the potential to make a significant contribution toward filling some informational gaps that exist in the archaeological record of the Protohistoric/Historic period in westcentral Texas.

Open occupation sites are the predominate site type in Texas, but establishing temporal affiliations for open sites in south Texas is extremely challenging. Open campsites are most often lying on the surface and therefore subjected to erosion and intense collection by relic hunters. Diagnostic artifacts are the most recognizable and the collection of artifacts as a pastime, sport, and for some, a source of income has increased in recent years (Hester 1995:429).

\section{Protohistoric/Historic Native American Presence}

The cultural context for the historic groups in the area of study is largely conditioned by the presence of outside ethnic groups and regional power struggles. The numerous small groups of Jumanos and Coahuiltecans encountered by the early explorers and later Spanish intrusions are addressed in many sources (Campbell 1983; Campbell and Campbell 1985; Hester 1989; John 1975; Newcomb 1961; Swanton 1952). The various later intrusive groups, such as Apache, Tonkawa, Lipan Apache, and Comanche, are also described by numerous researchers (Ewers 1969; Hester 1989; Jones 1969; Kelley 1971; Newcomb 1961, 1993; Sjoberg 1953a, 1953b). Hurt (1980:107) suggests that the Historic period encompasses the period when names of Tonkawa, Apache, and Comanche groups infiltrated the area, the Tonkawa being the original (Historic) inhabitants in the Twin Buttes area. It would be extremely difficult to discern archaeologically discrete differences in the cultural material remains of the various groups, their territorial ranges, and occupational sites in the Twin Buttes area. Encampments, discrete as they might be in the archaeological record, were shared by different Native American groups, thus frustrating attempts to understand the degree of mobility and settlement of groups such as the Jumano who lived in this area of Texas during initial EuroAmerican contact, or the Kickapoos and Pottowatamies who no doubt traveled through the area before the Battle of Dove Creek. Studies of artifacts produced and used by mission Indians (Fox 1979; Schuetz 1969) provided a guide to what may be expected to be recovered at historic Indian sites. A site with bone tempered ceramics and stone tools in association with glass beads, metal knives, remnants of horse equipment, gun parts, and fragments of cast iron or copper cooking vessels could be confidently identified as the remains of a historic Indian site.

\section{European-American Settlement}

The archaeology of European-American settlement in the Twin Buttes area had not yet been fully studied. Much of the archaeological work that had been done had focused on the military presence in the area (see Chapter 5). Published accounts of early ranching and farming in the area were many (see Historic Background section, this chapter), and we expected at least ephemeral evidence of historic structures and industrial or ranching activities that occurred during the late 1800 s and early 1900 s. The presence of house foundations within the Twin Buttes Reservoir project area had been noted by Bureau of Reclamation personnel, and some structures (on the Keyes Tract) had been recently bulldozed (Hector Garcia, personal communication 1998). For the most part, houses were likely built of wood. Any wooden house which stood abandoned for a long period of time would have collapsed from decay, then gradually disappeared except for the pile of bricks or stone that represents the chimney. In addition, archaeologists working on the survey needed to be alert for scatters of nineteenthcentury ceramics and glass. Given the early presence of the military at nearby Fort Concho, and the almost certain retreat route of Confederate and State Militia forces down Spring Creek after the Battle of Dove Creek (Pool 1950), the possibility of discovering a short-term military encampment was possible. 
Specific Protohistoric/Historic Research Questions

Research Question 1: Site Function of Native American Sites An intensive effort is needed to uncover additional ethnohistorical accounts in the written record. Archaeologically, we need to confirm whether the large camps described in some written accounts were present, and if so what are their cultural signatures (see Collins 1995:386). And although short-term campsites are an integral component to Texas settlement pattern studies, their functional usage is not clearly understood (Hester 1995:431).

\section{Research Question 2:}

\section{Earliest Euro-Americans Occupation}

Evidence of early Anglo settlers in the area around the Middle Concho, South Concho and Spring Creek is most probable, therefore CAR surveyors were alerted to the possible presence of metal artifacts, decorated ceramics, and any ephemeral evidence of wooden fortifications and/or homesteads, which would suggest early nineteenth-century settlements. An on-site inspection in November 1998 revealed abandoned historic vehicular roads and railroad beds through the otherwise partially heavily wooded and brushy terrain. The presence of old roads attested to the likelihood that homestead sites existed in the area to be surveyed. Records of land ownership and deaths could be found in the West Texas Collection, Angelo State University in San Angelo. Archival research would be needed to determine the ownership of the homesteads that may exist in the area. Cattle ranching and trails through the area that dominated the economy and terrain features may also be investigated.

Research Question 3: Spatial Relationships of European American Farmsteads

Survey and limited testing are expected to reveal additional homestead foundations or site features in the area. If recovered, some of these indices were expected to clarify the intra- and inter-site spatial relationships of an early farming/livestock-raising community.
Not only would this evidence provide insight into a turn-of-the-century European-American settlement, but it would also contribute to an understanding of the economic activities dated to this particular era.

\section{Research Question 4:}

Economic Activities of European Americans

This research problem focused on classes of data that may shed light on economic status. The goals are conjoined with the first research problem in attempting to qualify specific economic activities at a EuropeanAmerican homestead, or groups of homesteads. Subtle changes in types of artifacts and construction or economic activities such as farming or cattle raising could be present in the area of study.

\section{Summary of Research Goals}

In summary, the four research goals of this project were designed to collect data relevant to the Twin Buttes area. The archaeological evidence should collaborate the archival record and provide additional details on early historic Native American as well as Euro-American adaptation in the area. In addition, the data are relevant to larger regional studies of the archaeological patterning of Native American ceramics and site function. Finally, the documentation of historic homesteads and agricultural activity sites should provide patterns of how early settlers adapted to arid environments in west-central Texas, both spatially and economically. 



\title{
Chapter 11: Historic Sites Survey Results and Analysis
}

\author{
David Nickels, Rick Robinson, and Clemente Murguia
}

\section{Introduction}

This chapter provides a general description of the historic sites and an analysis of the associated artifacts found during the survey. The analysis of the artifacts in corroboration with the documents found during our archival research provides a general synthesis of the historic development of the area. Although the written information is extremely helpful, diagnostic artifacts recovered from historic sites often provide other insightful information regarding the life-style, social and economic organization, and overall habits of the occupants. Although dated pieces such as coins or inscriptions are usually irrefutable evidence of when a site was occupied, glass, ceramics, and metal are probably the most commonly available historic artifacts that can be placed within a general temporal framework. A thorough discussion of historic artifacts that can be temporally significant is certainly beyond the scope of this report. What follows is a brief overview pertinent to the types of artifacts observed during this survey.

\section{Historic Artifact Categories}

\section{Bottle and Jar Glass}

Finding a piece of bottle or jar glass with a maker's mark on it is always helpful in determining its approximate date and place of manufacture, as well as its likely contents. The shapes of bottles are used to imply what they may have held, and by knowing their contents we can then infer their possible uses. Even though a maker's mark may not be present or legible, the manufacturing technique, labeling process, and color of the glass can provide an approximation of when it was used.

Additives caused glass colors to change through time. Other temporal affiliations can be made based on their mold-seam marks. Prior to 1900 , most bottles were formed in a hollow, bottle-shaped, two-piece, hinged container called a mold. Essentially, a glass blower would blow molten glass into the container. The molten glass would then expand against the walls of the mold, producing the desired form wanted. Then the mold would be opened and the process would begin all over again (Kendrick 1966:31-32). On average, "... in the 1880 s it took a shop of three men and three boys to produce approximately 1,500 bottles a day" (Munsey 1970:33).

Two bottle molds commonly used during the nineteenth century were open and closed molds. Open molds were used during the earlier periods of manufacture. Because the molds were impossible to keep airtight during bottle production, a seam would form on opposite sides of the bottle where the mold would open and close. The seam length serves as the basis for dating bottles. An open mold usually formed only the body of the bottle, thus leaving a seam on the shoulders, and the neck or lip would then be added by the glassblower, leaving no seam above the shoulders (Kendrick 1966:32-33). This technique was common for bottles manufactured prior to 1860. Between 1860 and 1880 , molds were enlarged to include the body and part of the neck. This newer style of mold left a seam that extended not only along the shoulders, but also partially up the neck. As with the earlier mold and technique, the upper portion of the neck and the lip were formed by the glassblower, leaving no seam (Kendrick 1966:47). It was in the 1880s that the closed mold technique became more popular in bottle production (Kendrick 1966:47).

Following the open mold technique, the closed mold was invented and used from the 1880s through about 1900. The greater encompassing closed mold formed the complete body, neck, and lip of the bottle (Kendrick 1966:33), leaving a mold seam extending from the base to the lip. However, since the lip was often smoothed by hand during that time period, the seam often stops just below the upper portion of the lip. A redesign of the bottle lip allowed it to accept a 
crown cork lid. The crown cork lid was invented in 1891 and it was with the invention of the Owens machine (Munsey 1970:105) that this lid became the standard cap for beverage bottles (Kendrick 1966:49-51).

Sometimes bottle bases with a sand-tipped pontil surface are found. The common technique throughout the nineteenth century was to mold glass with a blowpipe. A pontil is a metal rod that would be attached to the base of a bottle to hold it steady while it was still being shaped. After blowing molten glass into a mold to give it the partial shape the glassblower desired, a pontil rod was first dipped in molten glass and then sand. The sand tempered the molten glass on the end of the pontil so that it would not become welded to the base of the bottle. When the glassblower was satisfied with the final form of the bottle, he would then snap the pontil free from the bottle's base (BaugherPerlin 1982:262). When the pontil rod was removed, pebbles and bits of sand in the shape of a ring on the base called a pontil scar usually remained ingrained into the glass surface itself(Baugher-Perlin 1982:266267). The rough surface was then usually ground smooth. The use of this earlier technique may have decreased when the snap case type pontil became more popular with the glass makers in the 1870s (BaugherPerlin 1982:266-267).

Michael J. Owens patented the first automatic bottle making machine in 1903, and his Owens machine revolutionized the bottle making industry. Before 1900 as mentioned before, the bottle making industry using glassblowing molds had the capacity of producing 1,500 bottles on a given day. However, with the Owens automatic bottle-making machine the output increased to 33,000 bottles on an average day, thus reducing costs and providing greater quantities for the consumer (Munsey 1970:32-33). Thus, after 1900, the result was a bottle with two seams, one encircling the top of the mouth and the other seam around the neck. These are contact points from the plunger mechanism defining the bottle's "inner throat diameter" (Munsey 1970:41). The Owens bottle making machine also produced a distinctive off-centered ring on the base of the bottle (Kendrick 1966:83). In 1947, the Hartford I. S. machines replaced the Owens machine; the Hartford I. $\mathrm{S}$. Machines were designed so that they left no distinctive rings on the base (Kendrick 1966:47).
Aqua, amber, olive green, and brown are natural colors produced in glass manufacture. Before 1880, the predominate color of bottle glass was green. The standard, natural color of most cheap bottles produced since the beginning of glass making, until about 1900 (and even somewhat later for medicine bottles) was aqua, with "varying hues of green and blue" (Munsey 1970:37, 69). Glass is a mixture of lime, soda, and sand with traces of iron oxides. When molten, the iron oxides in the sand causes a chemical change which produces the aqua color (Kendrick 1966:53).

With the exception of "black" glass, glass color was not an important factor until around 1880 when food manufacturers began demanding clear glass containers for preserved foods. Beginning in the $1880 \mathrm{~s}$, American manufacturers added manganese to the glass as a decolorizer. After exposure to the sun's ultraviolet rays the manganese would change the color of the glass to purple (Munsey 1970:55). Manganese worked fine until the outbreak of World War I in 1914 caused another defining temporal characteristic to occur in bottles. Prior to 1914, Germany was a main supplier of manganese. When the war broke out, the supply of manganese was no longer available to bottle makers and they resorted to using selenium as a decolorizing agent (Munsey 1970:55). Selenium causes the glass to turn an amber color when exposed to light (Robinson 1971:31).

Techniques for labeling glass bottles also changed through time. Etching was common in the late nineteenth century (Munsey 1970:51), followed by Applied Color Labeling. Developed in the 1920s, Applied Color Labeling was a technique which used panels or lettering, embellished with enamel. The technique was used more commonly in the 1930s, primarily for bottles that were reused, such as soda and milk bottles, but is still in limited use today (Munsey 1970:52). After 1930, when manufacturers were finally able to produce inexpensive containers that would not change color after long exposure to the sun, clear glass that was available to the general consumer made a comeback (Kendrick 1966:24).

Many of the earlier bottles produced were distinctive, rectangular-shaped bottles containing "patented" medicines. The term patented medicines is misleading 
in the sense that in order for it to be patented, its contents must be disclosed to the United States Patent Office. Since the majority of the medicines in the nineteenth century contained alcohol or such, most medicine companies protected their secret ingredients by simply registering their brand name with the government. Thus, in the nineteenth century "patent medicines" was really a generic term for "medicines sold without a prescription" (Munsey 1970:65). Patent medicines were popular with American consumers due to their mistrust of doctors with questionable training (Young 1974:157-158). The greatest popularity of patent medicines probably occurred with the advent of traveling medicine shows between 1880 and 1900 (Munsey 1970:67; Young 1974:191). Where the railroads had not yet reached, a medicine man would be hawking his wares from an ox cart (Young 1974:106). As mentioned previously, these medicine shows became extremely popular in the latter part of the nineteenth century. Often times these shows were more like a circus whose aim was not only to provide entertainment, but to bring in a larger crowd of potential consumers (Munsey 1970:67). The arrival of the railroad was slow at first in Texas, but by 1900 about 10,000 rail lines had been built (Werner 1996:412). In San Angelo, the Santa Fe Railroad was built in 1888 , which turned the city into an important "shipping center" for that area of west Texas (Duke 1996:793). With the railroads came the mail order catalogs, with an even greater variety of patent medicines for sale. For instance, the 1897 Sears, Roebuck Catalogue listed such patented medicines as Extract Witch Hazel, promising to cure anything from sore eyes to sprains for twenty-five cents a pint-bottle. Another example is Neutralizing Cordial, which lists brandy as one of its important ingredients. Neutralizing Cordial medicine was touted to be useful in treating "dysentery, cholera morbus, and dyspepsia" at twentyeight cents for a four-ounce bottle (Israel 1968:27). By 1906, patent medicines had reached their peak with over fifty thousand different types of medicine being sold in the United States (Munsey 1970:69; Young 1974:109).
During the nineteenth century, without government interference the patent medicine industry had been able to blend whatever ingredients they wished, and then sell to American consumers at huge profits (Young 1974:244). Beginning in 1905, magazine writer Samuel Hopkins Adams began an investigation of patent medicines. His articles exposed the harmful ingredients that were used in medicines being bought over the counter by American consumers. The resulting public outcry prompted the government to pass the Pure Food and Drug Act of 1907, allowing the government to regulate patent medicines and put many companies out of business (Munsey 1970:69).

\section{Window Glass}

Dating window glass by thickness has been successfully tested in south and central Texas (Gross and Meissner 1997:240-241; Nickels and Fox 1997:11; Nickels et al. 2000) using Moir's (1988:271) regression equation of $\mathrm{I}=84.22(\mathrm{~T})+1712.7$ (in which $\mathrm{I}=$ the initial date of construction and $\mathrm{T}=$ the mean thickness in millimeters). Moir's data regression yields a regression coefficient of .93 at a 95 percent confidence level of \pm 7 years. Quite simply, the equation uses the mean thickness of window glass found at a site to provide an approximate date, \pm 7 years, that the glass was manufactured. Obviously the date of manufacture does not necessarily represent the date the glass was brought to the site, but it does offer a reasonable time frame. Often, a bimodal or even trimodal distribution in glass thicknesses will result in more than a single mean, suggesting more than one period of construction or renovation has occurred at the site. It should be noted that the regression formula is designed for window pane glass, but not special plate glass which is usually much thicker than the upper 3.3-mm parameter set for window glass (Moir 1988:264).

\section{Ceramics}

\section{Whiteware}

The presence of white-bodied wares is usually an indicator of nineteenth-century occupation. Whiteware was commonly imported to America from Britain during the $1800 \mathrm{~s}$, but the demand for this undecorated 
type increased significantly by 1860 . Whiteware became a common tableware setting for middle-class families around San Antonio after the 1860s, replacing pewter and wooden wares (Fox et al. 1989:45).

\section{Transfer Ware}

The technique of transfer-printing was developed in England in the late 1740s (Atterbury 1979:144). By the late eighteenth century, this technique was found to be a low cost way of elaborating the design on a vessel compared to painting the decoration by hand (Miller 1980:4). However, employing skilled engravers to etch the decorations on copper plating did not provide a cheaper product compared to other types of decorated wares during the late 1700s (Samford 1997:3). With the development of more reasonably priced white earthenware with an alkaline glaze in England about 1810, transfer ware became more popular (Miller 1980:4; Ramsay 1976:152). With the end of the War of 1812, transfer-printed ware became popular in American markets through the mid-nineteenth century (Miller 1980:4). A large number of these wares were exported to the coastal ports of Texas, and redistributed to major cities to meet consumer demand (Labadie 1986:111). By the mid-1850s the demand for transfer-printed wares in the United States was declining (Miller 1980:4). In Texas this trend is reflected by the increasing popularity of undecorated white granite ware between 1850 and 1870 (Blake and Freeman 1998:18; Miller 1980:4). The majority of transfer wares coming into Texas were imported from England; the naval blockades off the coast of Texas during the Civil War disrupted the market. Even in the post-Civil War years (Reconstruction), it would have been difficult to expand the market for transferprinted wares since hard cash was scarce. However, there was a short popularity in American markets for the flow-blue transfer-printed pattern from 1880 to about 1890 (Blake and Freeman 1998:18). At the end of the nineteenth century, the increased use of decals as a decorating technique for ceramics probably caused the decline of transfer-printed wares (Majewski and O'Brien 1987:147; Samford 1997:25). Transferprinted wares with a central undecorated area, usually surrounded by a floral pattern, continued to flourish (Samford 1997:25), and the 1902 Sears, Roebuck Catalogue offered it as a cheap, inexpensive table setting. This ware is still being produced today.

\section{Decalcomania}

The decalcomania decoration technique was developed in 1850 by Minton's potters in England as a way to decorate cheap tableware (Ramsay 1976:108). This type of tableware became quite popular during the midnineteenth century (Durrenberger 1965:66), and is still used today.

\section{Porcelain}

A small amount of Chinese porcelain, imported to Mexico on the Manila galleons, is present on nearly every Spanish Colonial site in Texas. It can be differentiated from European and American porcelain by careful examination of the very slightly blue-gray tint of the body, and when decoration is present, the grayish blue designs lie beneath the glaze, or delicately painted orange floral designs lie over the glaze. Porcelain is rarely present on eighteenth and early-nineteenth century sites because the fragile ware had to be transported from Europe (Ivey and Fox 1981:35), but became more prevalent after 1832, when it was commonly manufactured in the United States (Barber 1976:126-127).

\section{Stoneware}

The most common stoneware types found in central Texas include Albany Slip/Bristol glaze and Bristol Glaze. The combination of Albany Slip (brown slip) and Bristol glaze (white) appeared in the first quarter of the twentieth century and was used continuously until about 1920. Bristol glaze then became the dominant type of stoneware used after 1920, and through to about 1950 (Greer 1981:212). 


\section{Other Items}

\section{Nails}

Nails can be classified into three main categories:

1) Hand wrought;

2) Cut with hand hammered heads or cut with machine made heads; and/or

3) Wire.

Hand wrought nails were commonly used until the 1800 s, falling off in popularity with the introduction of cut nails. Cut nails with hand hammered heads were commonly used between ca. 1790 and 1825 , followed by cut nails with machine made heads which were commonly used from ca. 1825 to the present. Though they were introduced prior to the $1850 \mathrm{~s}$, wire nails did not become the dominant type until the 1890 s (Nelson 1968:1-10).

\section{Buttons}

Prior to 1850 , shell buttons had been imported to America from European markets. About 1850, the eastern part of the United States began producing its own buttons with the material source coming from Europe. However, by the 1890s button manufacturers in the United States began to commercially exploit this country's own freshwater mussels. The local industry lasted through to about 1950 (Claassen 1994:1). Shell buttons were then in even greater demand when fashion styles dictated a change from pullover type garments to buttoned front garments (Farrel-Beck and Meints 1983:4). 


\section{The Historic Components}

Fifteen historic components were newly recorded, and four previously recorded components were revisited during the current project. Table 11-1 provides data on the 19 sites with historic components and Figure 11-1 shows their locations within the Twin Buttes Reservoir survey area.
The following descriptions and summaries for each site frequently make reference to land ownership or topographic maps. The topographic map most commonly referred to is a 1923-1924 survey map. This reference and others pertaining to land ownership or structure locations can be found in Appendix L.

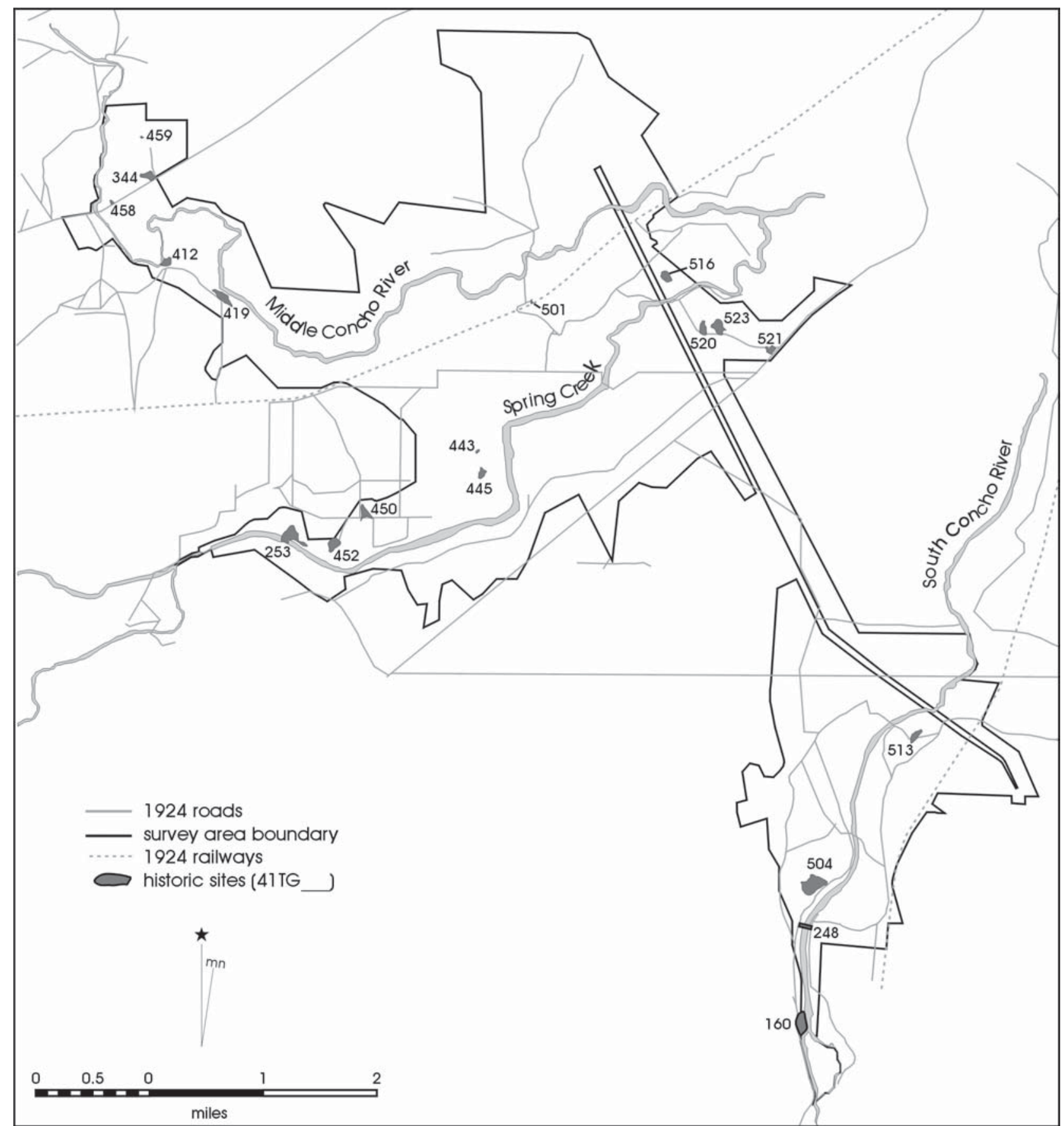

Figure 11-1. Historic site locations within the Twin Buttes Reservoir survey area. 


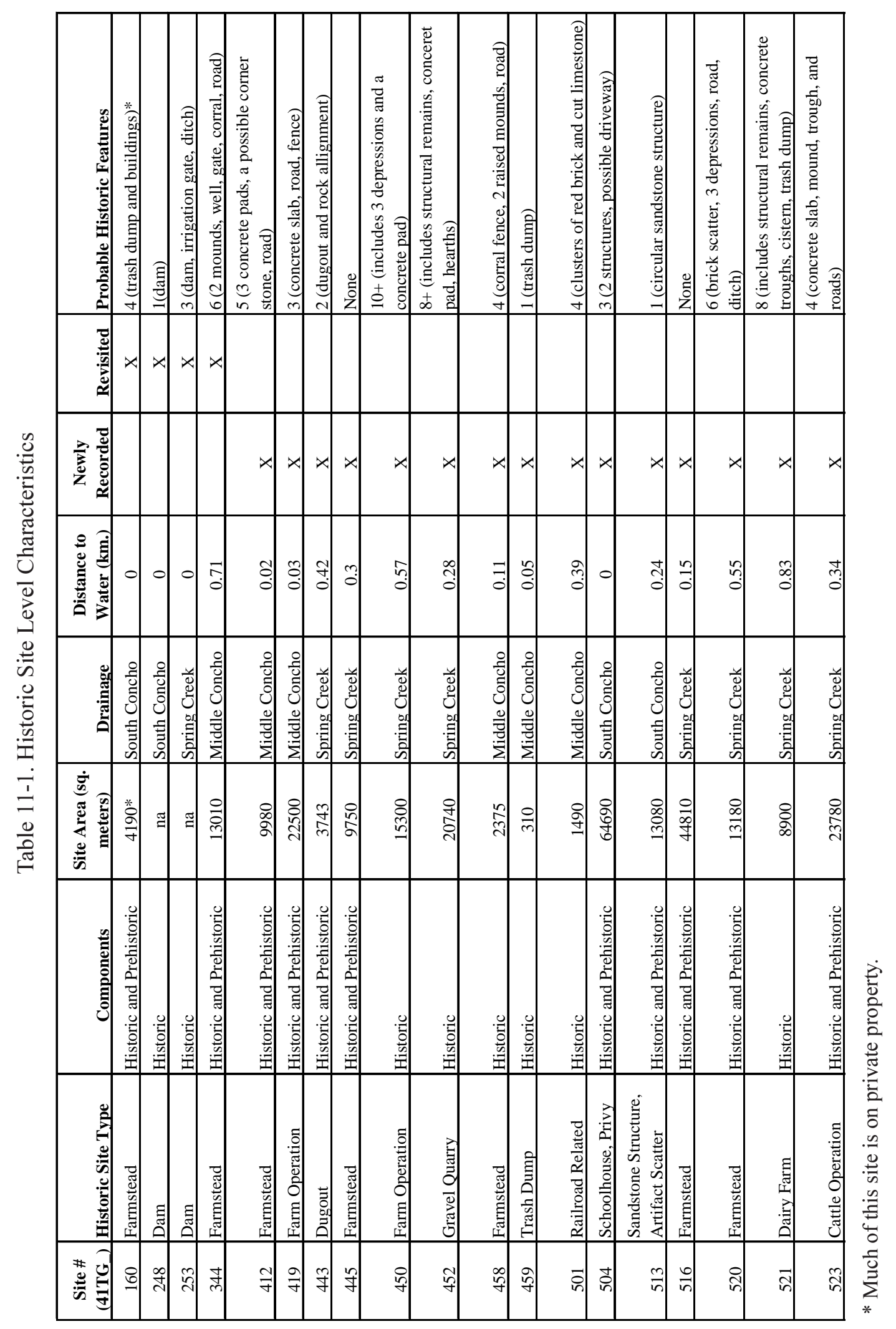




\section{$41 \mathrm{TG} 160$}

\section{Description and Discoveries}

This farmstead site sits on the edge of an upland area overlooking the South Concho River channel (Figure 11-1), and was built on the location of a prehistoric campsite (see Appendix A). The remains of a house structure and a standing barn were noted by Creel (1979) during a survey along the South Concho River, and they appeared much the same during the current survey. Both structures are now west of a new barbed wire fence that separates Bureau of Reclamation property from private property (Figure 11-2). However, a trash dump associated with the farmstead is just inside Bureau of Reclamation property. The structures are surrounded by mostly open fields with young mesquite trees and moderately dense grasses.

\section{Artifact Analysis}

Although the private property surrounding the structures was not inspected during the current survey, an array of artifacts were scattered from the trash dump northward along the fence line. Among the items observed on the surface were a rusted tricycle, undecorated and transfer ware ceramic sherds, brown glazed stoneware, pink, green, blue, aqua, and purple glass, a rusted metal washtub, and pieces of vitrified sewer pipe. Sixteen ceramic, stoneware, and porcelain sherds were collected for further examination. The porcelain sherds $(n=6)$ were hand-painted. Six sherds were ironstone, with one piece exhibiting a maker's mark resembling that made by Turner, Goddard and Company, Tunstall, Staffordshire, England between 1867 and 1874. Ironstone is a durable ware, and this specimen may have been an heirloom passed down through generations. Four pieces were earthenware, two with transfer decorations. One of these specimens was most of a serving bowl measuring $11 \frac{1 / 4}{4}$ by $63 / 4$ inches, with four legs and two handles. The decoration of vines, leaves, and flowers is brown, against the white body. The careful placement of the exquisite transfer design indicates that this piece dates before 1900, and possibly as early as the Civil War (Anne Fox, personal communication). Finally, two pieces of milk glass from a bowl or base rim were also collected.

\section{Site Summary}

The variety of artifacts strewn across the southern portion of this site suggest an occupation period of between ca. 1880 and 1950, and a 1923-1924 topographical survey map of the area indicates that this was the Russell Ranch, with a structure indicated on the map. However, a review of the available land ownership maps do not list a Russell, but rather indicate that the property surrounding the site was owned by $\mathrm{H}$. Diedrich from as early as 1894 continuing to 1962. Prior to 1894 the property was surveyed as part of McDonald's District 11 in the Fisher-Miller Land Grant, later the German Emigration Company (Appendix L). The research value of this site is considered minimal as a single entity. 


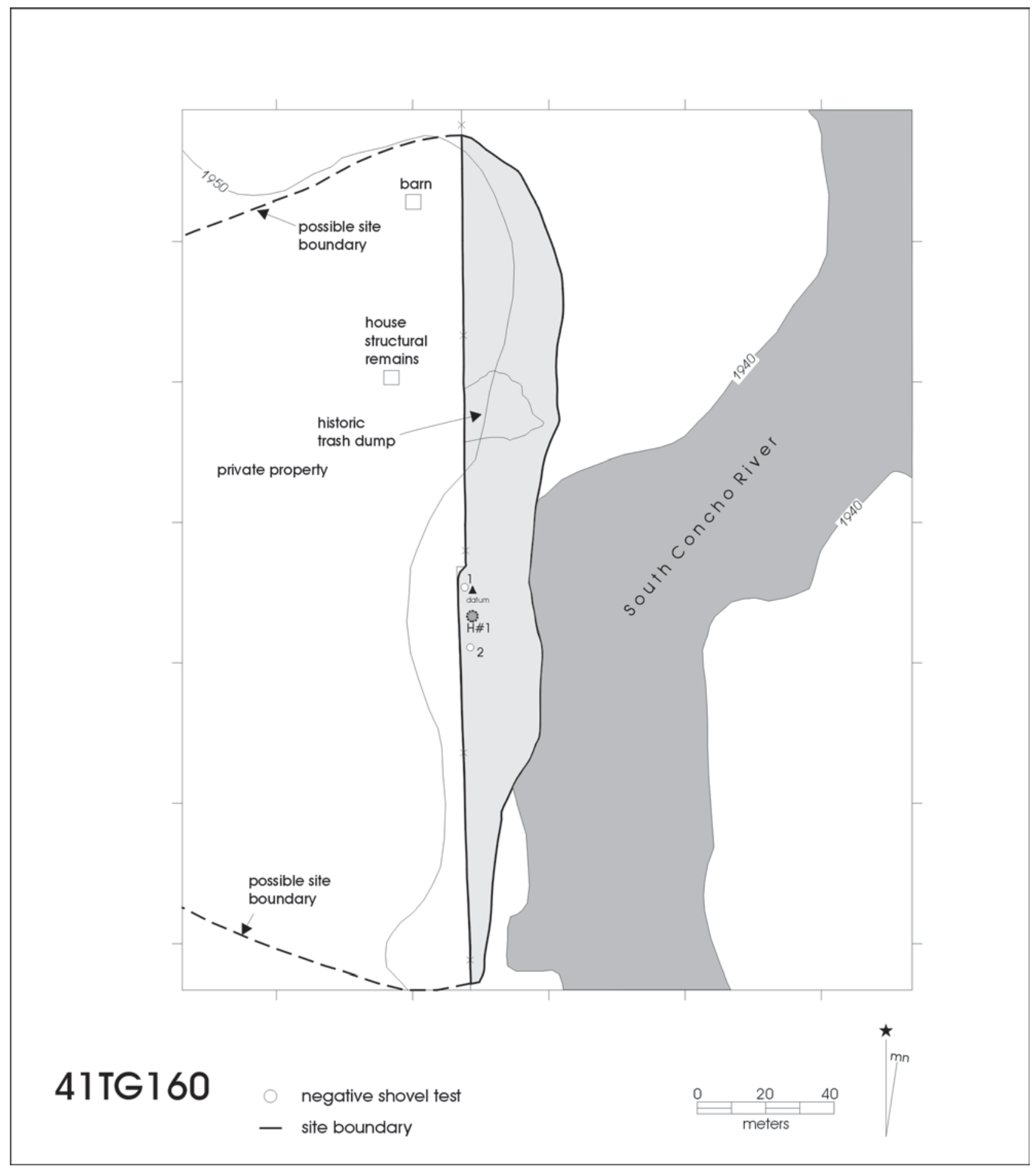

Figure 11-2. Site map of $41 T G 160$. 


\section{$41 \mathrm{TG} 248$}

\section{Description and Discoveries}

This historic irrigation diversion dam (Figures 11-1 and 11-3) across the South Concho River known as Gardner's Dam was documented by Etchieson (1985:Appendix I) during a survey of potential borrow areas in the reservoir area. His research and onsite evaluation indicates that an original dam of brush and rock was constructed in 1883 at a cost of $\$ 400$ (Taylor 1902:73). It was apparently rebuilt with concrete, possibly between 1902 and 1914. The dam diverted water into a two-mile long irrigation ditch capable of providing irrigation to 70 acres of land between the South Concho River and Spring Creek. A lower portion of the dam toward its east end acts as a spillway, and an irrigation channel runs from the west edge of the dam. For a more detailed description of the dam's construction, the reader is referred to Etchieson (1985). No artifacts or inscriptions were observed around the dam.

\section{Site Summary}

Etchieson's (1985) research suggests that the cement dam may have been constructed by C. B. Metcalf. A 1923-1924 topographic survey map of the area shows a dam and ditch located at this site. The dam is still in good condition, with minor damage along the top of it. The archival research value of this site is high in conjunction with early water resource studies carried out in west Texas. It is recommended that a more thorough research effort and documentation of the dam and channel relative to the development of the Twin Buttes/San Angelo area be conducted.

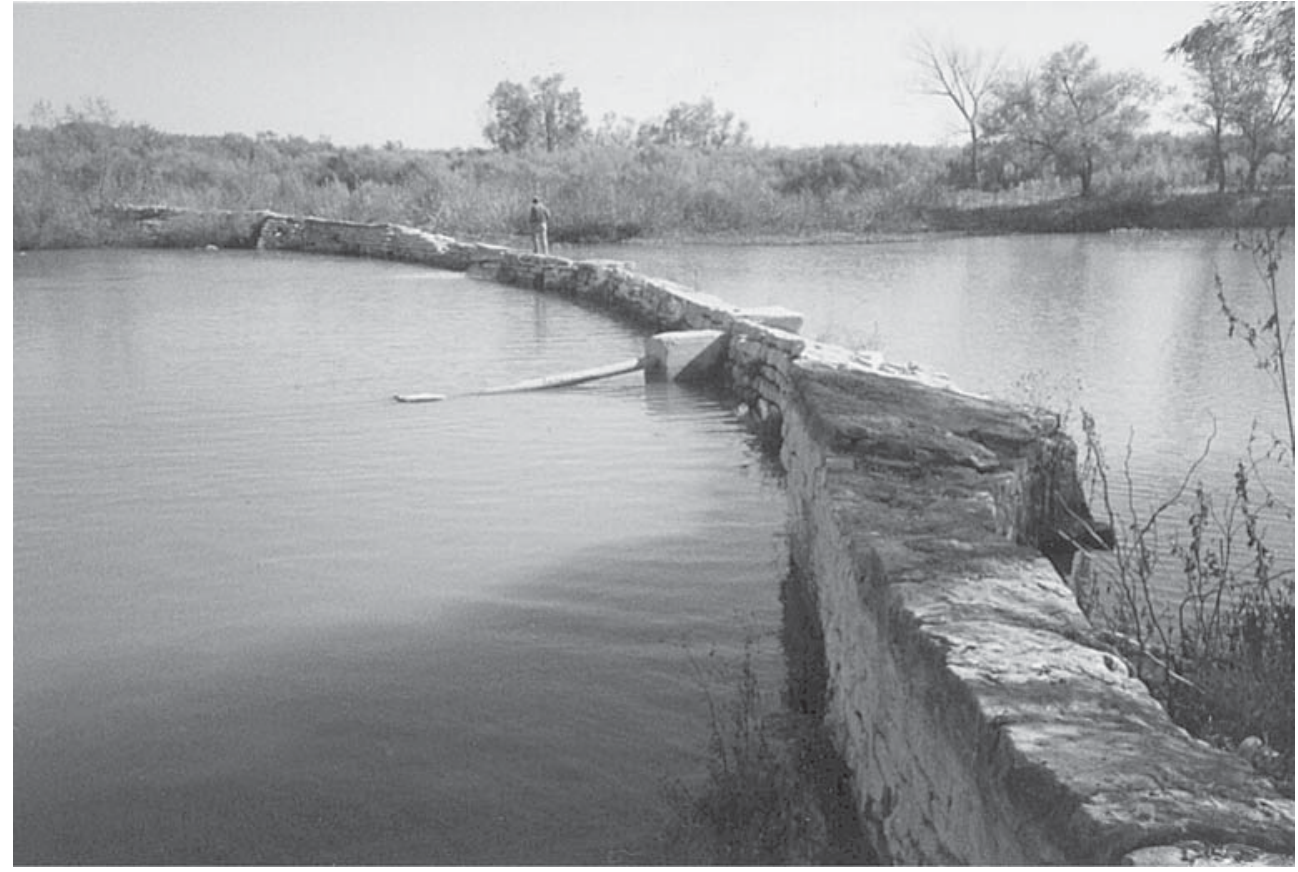

Figure 11-3. Photograph of Gardner's Dam (41TG248) across the South Concho River, facing southwest. 


\section{$41 \mathrm{TG} 253$}

\section{Description and Discoveries}

This historic irrigation diversion dam across Spring Creek (Figure 11-1 and 11-4) known as White's Dam was documented by Etchieson (1985:Appendix I) during a survey of potential borrow areas in the reservoir area. His research and on-site evaluation indicates that an original dam of wood was constructed in 1885 at a cost of $\$ 2,000$ (Taylor 1902:73). It was apparently rebuilt with concrete, possibly after a severe flood in 1906. The dam diverted water into a three-mile long irrigation ditch capable of providing irrigation to 300 acres of land between Spring Creek and the Middle Concho River. The ditch was also identified as the Twin Mountain Ditch, likely providing water to the Mott farm. The dam was built over a broadly exposed limestone conglomerate formation which contains prehistoric mortar holes, and a large prehistoric component with multiple hearth features is present on the north shore of Spring Creek adjacent to the dam (see Appendix A for a discussion of the prehistoric component). The dam itself was measured as 36 inches wide at the top and 40 inches at the bottom. The opening in the dam to provide water to the ditch was measured as 60 inches wide by 28 inches high. A piece of plywood described by Etchieson as blocking the ditch opening in the dam has now rotted away to reveal that it was actually a form for concrete poured into the opening, blocking it permanently.

\section{Artifact Analysis}

During our survey, a single purple glass bottle fragment embossed with incomplete words and part of a confederate flag were the only historic artifacts observed or collected at the site. The only clue obtained as to the antiquity of the glass fragment was its purple color, suggesting it was likely manufactured between 1880 and 1915 (Munsey 1970:55). The concrete ditch wall perpendicular to the dam is inscribed with an apparent brand or possibly initials, a date of 1908, and an impression of a hammer and a horse hoof clipper (Figure 11-5).

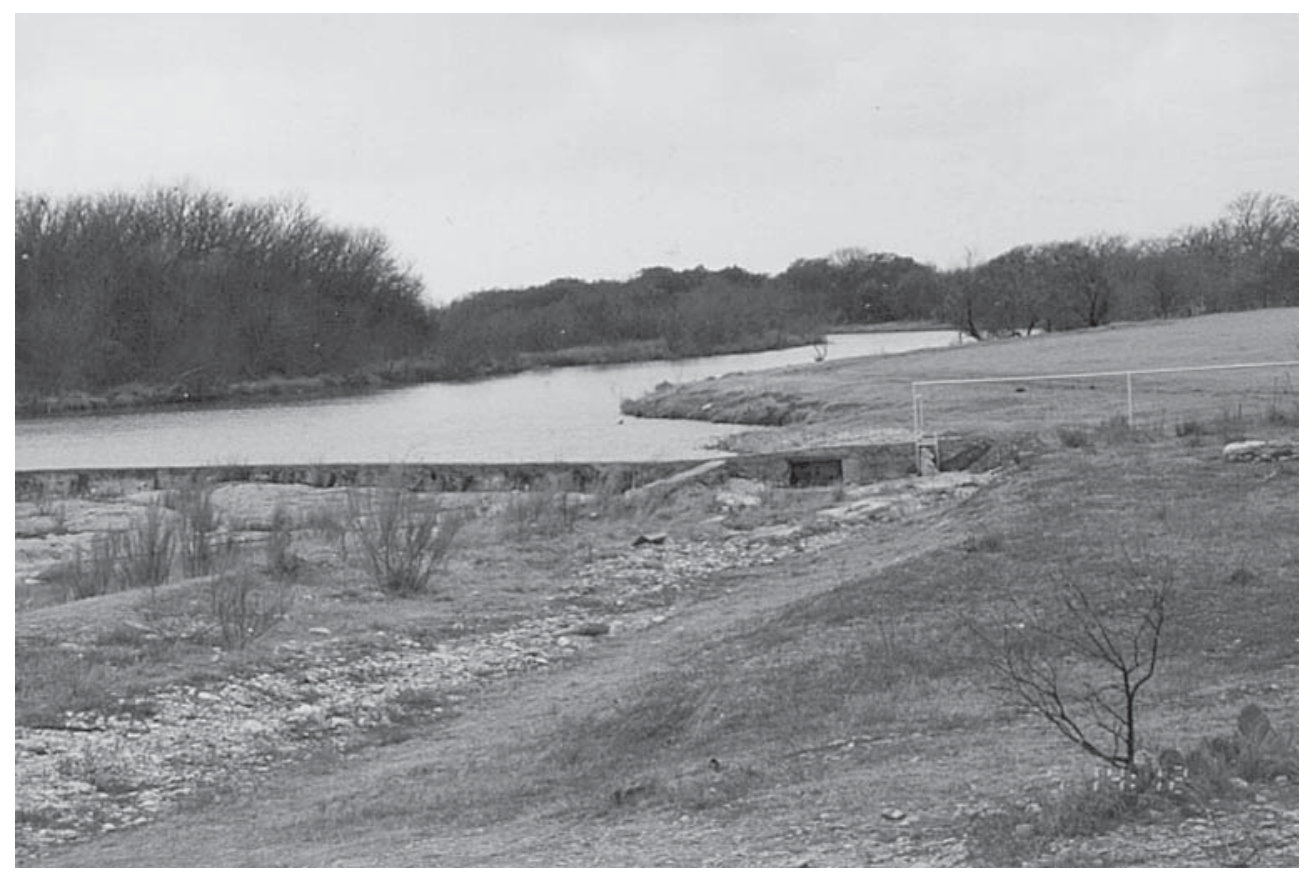

Figure 11-4. Photograph of White's Dam (41TG253) across Spring Creek, facing west, irrigation gate and ditch in foreground. 


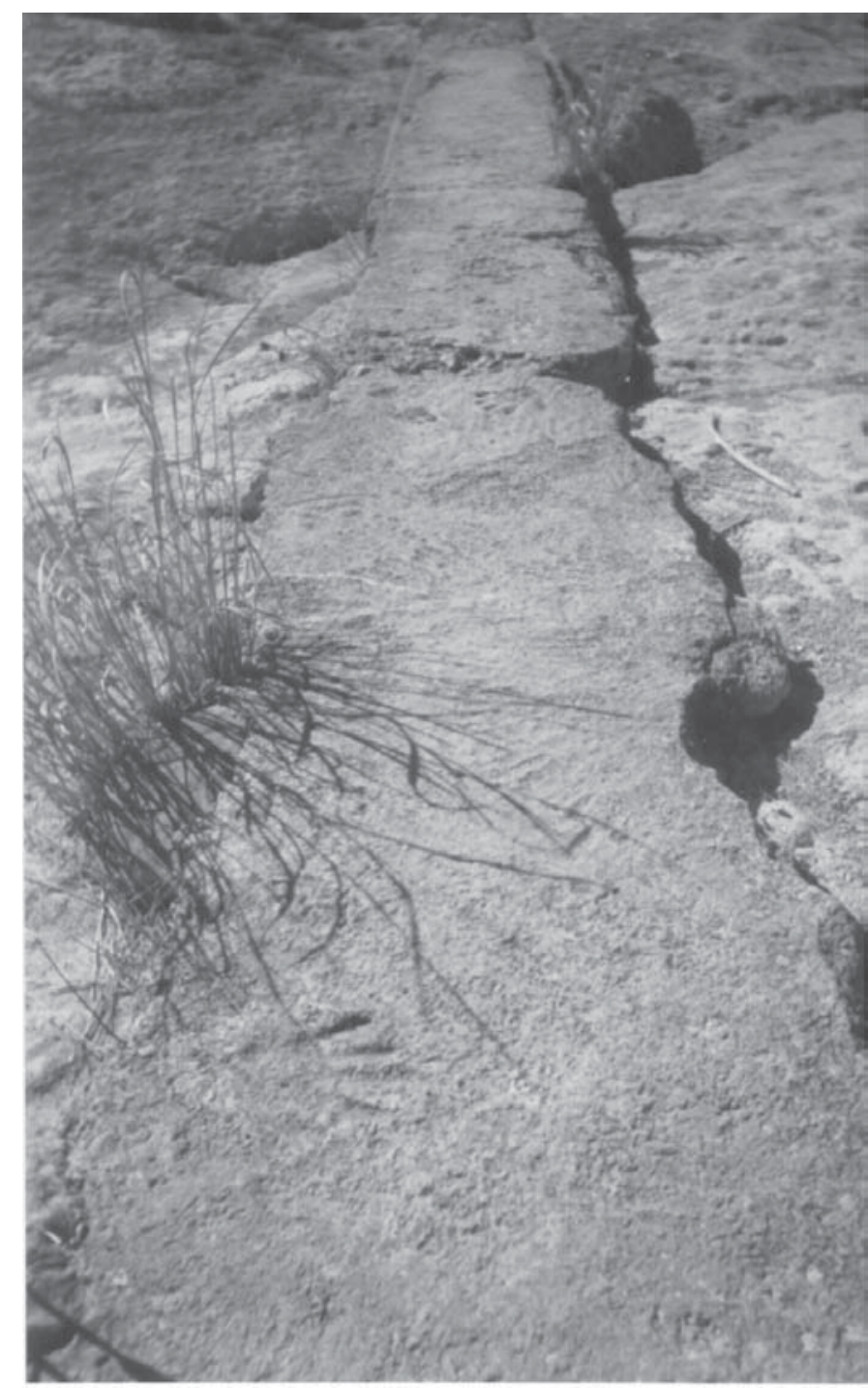

Figure 11-5. Writing and impressions on concrete ditch wall just below White's Dam.

\section{Site Summary}

A 1923-1924 topographic survey map of the area shows a dam and ditch located at this site, and available land ownership maps indicate that the property on the north side of the dam was owned at least partially by H. C. White between 1947 and 1962. The dam is still in good condition, with minor damage along the top of it. Patches of different textured concrete where repairs have been made to the top of the dam had small handprint impressions in them. The archival research value of this site is high in conjunction with early water resource studies in west Texas. It is recommended that a more thorough research effort and documentation of the dam and channel relative to the development of the Twin Buttes/San Angelo area be conducted. 


\section{TG344}

\section{Description and Discoveries}

This historic farmstead and trash dump (Figure 11-1) sits on a prehistoric lithic scatter recorded by Hageman (1993) while conducting a survey for a pipeline rightof-way in 1993 (see Appendix A). Two mounds represent the remains of two structures at the site. One is larger and rectangular-shaped, with an adjacent smaller, square mound (Figure 11-6). Traces of a twotrack road and circular driveway run by the structures, and remnants of a fenced gate are still at the end of the drive. There is also a door from a mailbox by the gate. What appears to be a stone and concrete lined, filled-in well lies northwest of the structures. Finally, a barbed wire corral is still intact south of the structural mounds.

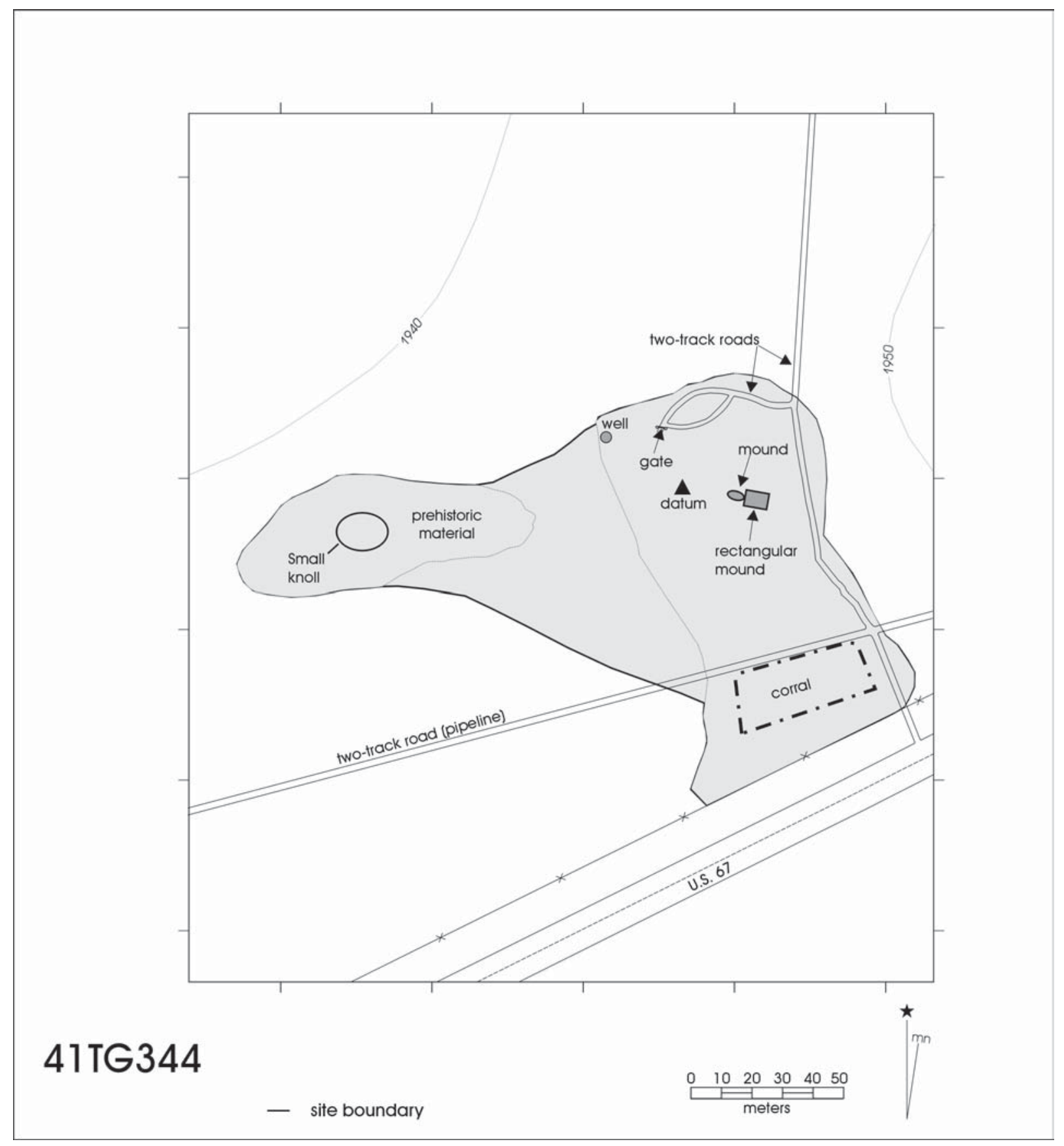

Figure 11-6. Site map of 41TG344. 


\section{Artifact Analysis}

Household trash was strewn between the two structure mounds and a small knoll with prehistoric lithic debitage to the west, but was concentrated near the knoll. Among the many items observed on the surface was a ringer from a ringer-style clothes washer, a clear glass cream server with stopper-type neck, purple, dark blue and black glass fragments, hundreds of rusted metal cans, a ceramic kerosene lamp base, pieces of sheet metal, stoneware sherds, an iron stove griddle piece, an upper ring from a steel barrel-15 inches in diameter, short sections of flat barbed wire, whiteware and yellow painted ware sherds, clear plate glass sherds, and a BF Goodrich Silverton tractor tire. Bottle fragments with maker's marks included:

1) A green Coca Cola bottle, the same as found at 41TG459, a trash dump to the northeast. This specimen was also manufactured in 1947 and distributed from San Angelo, Texas;

2) A clear glass base from a quart jar made in San Antonio. Based on its clarity, it was likely produced after 1930;

3) A clear glass base made by Owens-Illinois Glass Company in 1935;

4) A clear glass base made by Owens between 1929 and 1940;

5) A clear glass base likely produced after 1930; and

6) A Sun Crest soda bottle with blue and white labeling, and bottled by National NUGRAPE Company, Atlanta, Georgia in 1956.

\section{Site Summary}

The abundance and variety of items at the site suggest that it was both a farming operation and a residence. The fertile Tulia loam (TuB) soils surrounding the residence is equally suited for either grazing cattle or raising cotton and grain sorghum (Weidenfeld and Flores 1976:25, 28). Based on the glass colors and maker's marks on some sherds, it appears that the site was occupied ca. 1900 through the late 1950s. The site is on the western edge of the Adam Burkhardt survey and in the area which was divided into plots for the planned, early 1900s community of Bohemia. Many of the tracts were sold to newcomers, but the town never really developed as planned (San Angelo
News, March 24, 1906; Record of Survey 26DR288, page 270). A 1923-1924 topographical survey map of the area shows a structure, with a two-track road leading to it. The 1957 Twin Buttes USGS topographical map no longer shows the road, but does show a structure at the same location. The research value of the historic component at this site is considered to be minimal. 


\section{$41 \mathrm{TG} 412$}

\section{Description and Discoveries}

This farmstead sits on an upper, flat and broad terrace on an outside elbow bend of the Middle Concho River (Figure 11-1). The historic structural remains found have been built on a prehistoric component occupied about 1,200 to 2,000 years ago. Two cornerstones in the northern portion of the historic material (Figure 11-7) are the apparent remains of a pier and beam structure. The whiteware and stoneware sherds ephemerally scattered around the cornerstones suggest a possible small house, or at least a dwelling occupied temporarily. The immediate area around the cornerstones is densely overgrown with agarita and other thorny bushes, making the area almost

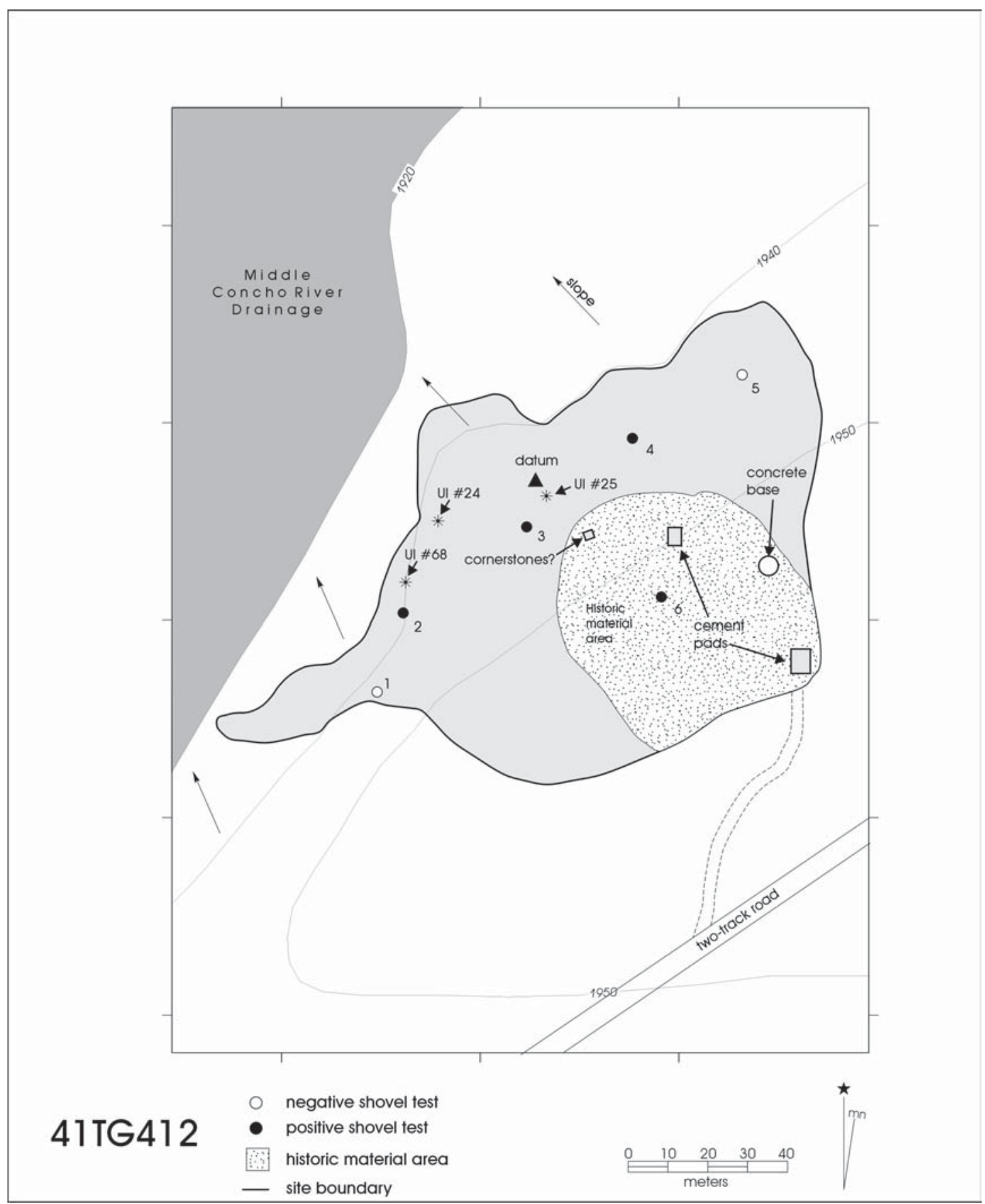

Figure 11-7. Site map of $41 T G 412$. 
impenetrable. Large, mature mesquite trees and dense grasses otherwise cover the site. A round, concrete base with raised edge, presumably for a water tank was documented east of the cornerstones. A three-inch iron pipe imbedded in the concrete floor suggests it was used as some sort of liquid holding tank base.

Two additional concrete slabs were also found. The smaller one to the north appears to be a base for a feeding trough. The larger one to the south, however, appears to be the floor of a barn. It has three different textures of concrete and a walkway along the south end, suggesting portions of the floor were laid at different times. An ephemeral trace of a driveway leading from a two-track road to the southern-most building is still visible (Figure 11-7). Historic artifacts observed around the concrete slabs consist of a glass lantern base, aqua-colored window glass sherds, a one-quart clear glass bottle with a screw top but no maker's mark, rusted, smoothed sheet metal (tin), round 16-penny nails, a round 3/8-inch washer, a spring from a spring tooth farm implement, and a leather strap.

A separate trash concentration south of the barn contains rusted metal strapping, iron stove leg pieces, a metal seal for a Mason jar, whiteware plate and cup sherds, decaled ceramic and porcelain sherds, purple, aqua, and brown bottle glass, a large metal chicken feeder, round nails, a screen door spring hinge, a rusted and broken pocketknife, and two red brick fragments. Numerous beer and whiskey bottles were scattered in the grass southeast of the barn. A large, overgrown field with immature mesquite trees southeast of the structures has been terraced and plowed. Finally, a concrete block near the driveway, southwest of the barn slab is inscribed "11-23-43 Y_."

\section{Analysis of the Artifacts}

This site has a variety of artifacts such as glass, stoneware, ceramic sherds and a metal pocket knife. The majority of the artifacts, though small fragments, retain enough attributes to provide general information on their approximate dates of manufacture. Five glass bottle necks and five bases were collected and examined at the CAR-UTSA laboratory. Three of the neck pieces are purple glass, one is clear, and the remaining one is brown.
Two of the purple neck pieces have no mold seams in the lips and thus their date(s) of manufacture can be placed between ca. 1880 and 1900. The third purple neck sherd has a vertical mold seam extending to the top of the mouth, and two horizontal seams; one encircling the top of the mouth and the other seam around the neck, indicating it was machine-made after 1900 (Kendrick 1966:47). The clear glass neck has a seam along its neck but the lip is broken, so it is not possible to tell whether the seam extended into the lip. However, the clear glass itself offers a clue that it was manufactured after 1930 (Kendrick 1967). The brown bottle neck has a lip designed for a crown cork lid, indicating that it could have been manufactured as early as 1891 . However, a seam that extends vertically into its lip indicates that it is also a machinemade bottle sherd, providing an additional clue as to its antiquity of post-1900 (Kendrick 1966:47).

Two of the broken bottle bases are clear, one brown, one purple, and one blue. The two clear bases have an off-centered ring, indicating they were made post- 1903 (Kendrick 1966:83). One of the two has an inscription of "1K009" which is probably a serial number for the manufacturers' own use (Toulouse 1971:10). However, since it is made of clear glass it is reasonably safe to assume that it was made after 1930 (Kendrick 1967:24). The second has a trademark stamp used between 1929 and 1954 by the OwensIllinois Glass Company, based in Toledo, Ohio. The word "wine" is stamped on the bottom and this is probably a bottle used by one of the many wine distillers during this period (Toulouse 1971:403). The brown base also has the machine-made, off-centered Owens ring from as early as 1903, and it has a square base similar to the brownish square snuff jars that have been sold since the early 1900s (Munsey 1970:77). Based on its color, the age of the purple base fragment could be reasonably placed between 1880 and 1915 (Munsey 1970:55). However this specimen has no distinctive off-centered ring, suggesting with greater probability that it was made between 1880 and 1900. The blue glass sherd has scalloped edges similar to those found on fancy candy bowls. The piece is too small to provide a specific time period, but the blue color was obtained by adding cobalt or copper to the glass, a common technology of the twentieth century (Munsey 1970:37). 
A single Bristol Glaze and three Albany Slip/Bristol glaze stoneware sherds were found. The combination of the Albany slip (brown slip) and Bristol glaze (white) appeared in the first quarter of the twentieth century and continued in common usage until about 1920. Around 1920, the use of Bristol glaze became prevalent through the mid-twentieth century (Greer 1981:212).

One decalcomania decorated ceramic sherd, and one porcelain sherd were also observed. The decalcomania piece is typical of tableware used for the past 150 years, and thus could date from ca. 1850 through today. The porcelain sherd is undecorated and could reasonably have been manufactured between 1800 and 1900 . The only metal artifact collected for examination is a pocketknife that measures about four inches in length. The probable wooden handles are missing and both blades are broken at the base. The frame appears to be brass and there are no markings to indicate who the manufacturer may have been.

\section{Site Summary}

The artifacts collected or observed on the surface (Table 11-2) indicate that the site could have been occupied as early as 1800; although it is highly unlikely since the area was not settled until nearly the last quarter of the nineteenth century (see Chapter 10). Although the porcelain and decalcomania sherds found could have been manufactured pre-1880, they are more likely contemporaneous with the predominance of artifacts that suggest a ca. 1880 beginning occupation. Many of the bottle sherds indicate they were left at the site after 1930, and an obvious piece of good fortune was to find the chunk of concrete on the site with the inscription "11-23-43 Y_," verifying a 1940s occupation.

A 1923-1924 topographical survey map of the area shows a structure and two-track road intersection at this location. The concrete slabs, cornerstones, and artifacts suggest that the site was a farmstead, with pier and beam living quarters on the western portion of the site overlooking the bluff, and a barn, cattle troughs, and water storage tank on the eastern portion of the site. Further to the east, the land was terraced and farmed. The Tulia loam soils surrounding the site are suitable for dryland farming, and thus should have been good for raising crops, and grazing cattle. An average yield per acre in Tulia loam should be 1,000 lbs of grain sorghum, $150 \mathrm{lbs}$ of cotton lint, or 10 bushels of wheat (Weidenfeld and Flores 1976).

Little of the historic component of this site remains. The area is designated as public recreation land and is actively being used for cattle grazing, thus there are numerous two-track roads, cattle trails, and motorcycle trails. The bluff face along the eastern edge of the site is heavily eroded due to periodic inundation and exposure to fluctuating reservoir levels. Perceived future impacts are continued erosion, vehicular and motorcycle traffic, cattle trampling, and other recreational activities. The research value of the historic component is minimal. No additional archaeological investigations are recommended, however further archival work is warranted.

Table 11-2. Artifacts inferring occupation period at $41 \mathrm{TG} 412$

\begin{tabular}{|l|l|l|l|}
\hline Artifacts & Probable Years & Artifacts & Probable Years \\
\hline Porcelain Sherd & $1800-1900$ & Brown Neck Glass & Post-1900 \\
\hline $\begin{array}{l}\text { Decalcomania Sherd } \\
\text { Blbany Slip/ } \\
\text { Bristol Glaze Sherd }\end{array}$ & Post-1850 & Brown Base Glass & Post-1903 \\
\hline $\begin{array}{l}\text { Purple Neck Glass } \\
\text { Purple Base Glass }\end{array}$ & $1880-1900$ & Bristol Glaze Sherd & Post-1920 \\
\hline \begin{tabular}{l} 
Purple Neck Glass \\
\hline
\end{tabular} & Post-1900 & Clear Neck Glass & Post-1930 \\
\hline
\end{tabular}




\section{$41 \mathrm{TG} 419$}

\section{Description and Discoveries}

The site of this farm operation on a broad, flat plain behind a ca. seven-meter-high limestone conglomerate bluff on an outside elbow bend of the Middle Concho River offers a panoramic view of the Middle Concho River valley (Figure 11-1). The vegetation today consists of mesquite trees, dense grasses, and brush, and the area has recently been burned. The historic occupation occurred amidst prehistoric fire-cracked rock hearths and a scatter of stone tools near the bluff (see Appendix A).
A rusty barbed wire fence runs across the eastern portion of the site and a 11 by 14 -foot concrete slab is on the western portion (Figure 11-8). Artifacts observed on the surface around the concrete slab area included green glass, a rusty oil filter, a rusty hatchet head, an Orange-Crush bottle, a gray brick fragment, a oneinch rotten hydraulic hose, a clear glass jar base, an aqua glass bottle sherd, and a tubeless tire. The only other construction remnants west of the concrete slab are a fence post and a cut stone, possibly structural.

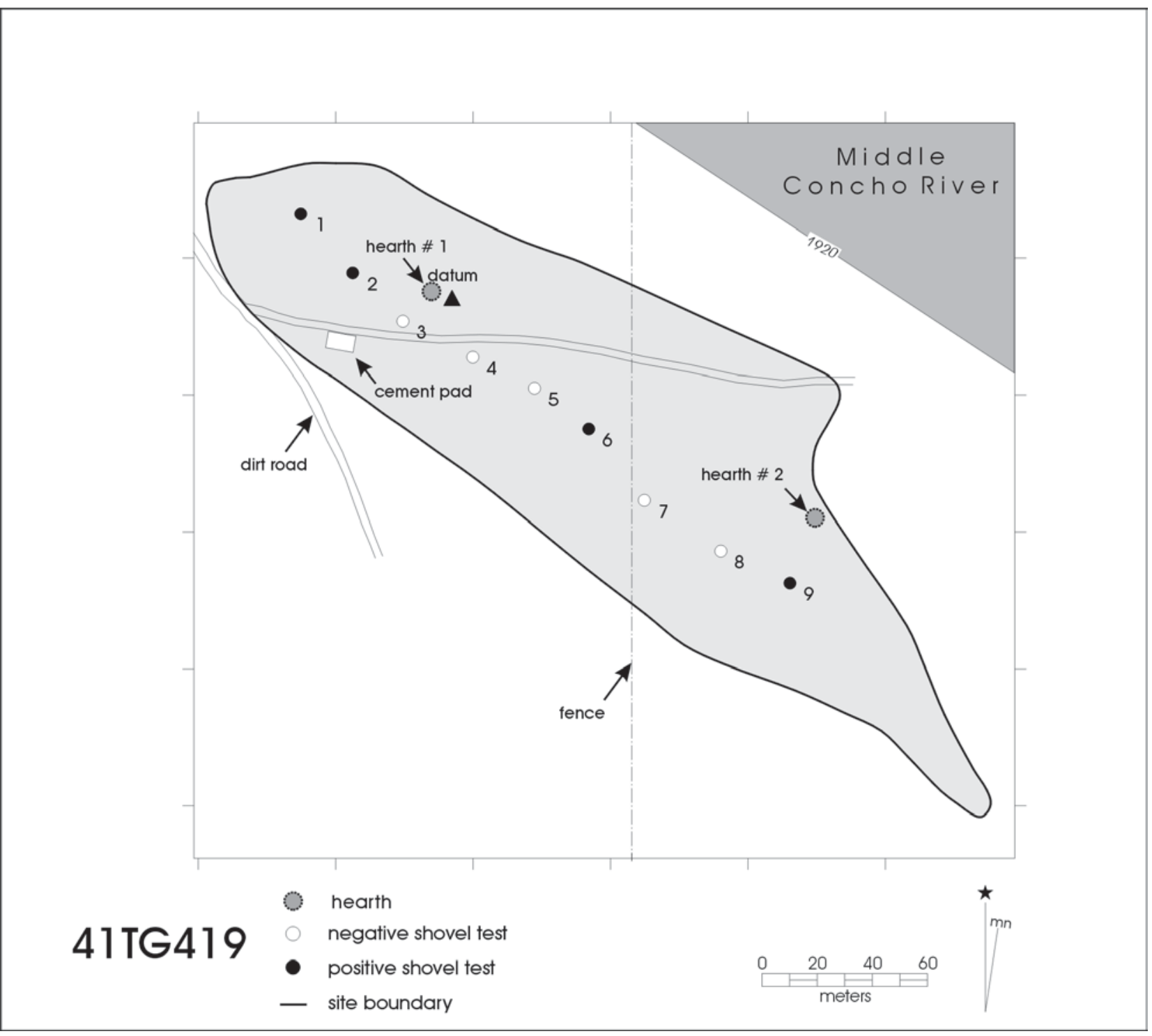

Figure 11-8. Site map of 41TG419. 


\section{Analysis of the Artifacts}

An intact glass soda bottle and the broken base of a glass container were collected from the site and examined in the CAR-UTSA laboratory. The soda bottle is dark brown with a height of 7.5 inches and a base diameter of 2 inches. The mold detail of the bottle consists of raised rings that begin at the base and extend up to the shoulder; molded diamond-shaped panels are also on opposite sides of the bottle. The diamond-shaped panels are embellished with Applied Color Labeling, suggesting that it may have been manufactured in the 1920s but most likely after 1930 . On one side of the bottle within the diamond shaped panel are the words:

\section{"Orange-Crush T.M.REG.U.S.PAT.OFF. Company Bottle,"}

whereas the opposite panel reads...

\section{“THIS BOTTLE PROTECTS THE DELICATE FRUIT FLAVOR FROM THE HARMFUL EFFECTS OF LIGHT."}

The bottle's base contains a maker's mark and the word Duraglass, which helps in identifying the container's point of origin and its age. The maker's mark is that of the Owens-Illinois Glass Company; a circle with a super-imposed diamond shape and an "I" in the center. Owens-Illinois Glass was located in Toledo, Ohio, operating under that name from 1929 to 1966 , when the company then changed its name to the present OwensIllinois Inc. Under the former name, the firm used this particular bottle mark found on the Orange-Crush bottle from 1929-1954 (Toulouse 1971:403) and the Duraglass logo from 1940 to 1963 (Toulouse 1971:170). The maker's mark has numbers to the left, right and bottom of it which provide additional information about the bottle (Toulouse 1971:403). The number "9" which appears to the left of the mark indicates it was manufactured by the Owens-Illinois, Streator plant (in Illinois) (Toulouse 1971:395). The number "2" to the right of the mark indicates the year it was made. The numeral below the bottle mark represents the mold detail of the bottle (Toulouse 1971:403). Thus, we can be reasonably assume that this particular Orange-Crush bottle was produced by the Owens-Illinois, Streator plant in Illinois in either 1942 or 1952.
The only other artifact recovered was a base fragment of a clear glass container, with the distinguishable Owens ring. It is inscribed with "P-61128 F" and a very faint "Ball" in italics. Although the ring indicates it could have been manufactured as early as 1903 , its non-colored glass indicates it wasn't manufactured until after 1930. The trademark "Ball" is one used by the Muncie, Indiana-based Ball Brothers Glass Manufacturing Company, which was formed in 1888 , and later became the Ball Brothers Company in 1919. The Ball Brothers were some of the early producers of the Mason type fruit jars after the Mason patent expired. Before the development of the 1903 Owens bottle machine, Ball had already developed their own form of semiautomatic machines for their glass making production, thus giving them an edge over their competitors. In 1910, the Ball Brothers, installed an Owens bottle-making machine and continued using it until 1947, when it was replaced by the Hartford I. S. Machine (Toulouse 1971:66-68).

The inscription "P-61128 F" located along the edge of the base fragment is not part of the trademark, but rather is a control number for the manufacturer's mold providing limited information about the age of the specimen (Toulouse 1971:10). In sum, its clear glass and absence of an Owens machine ring, indicates that this container was manufactured between 1930 and 1947 (Kendrick 1966:47).

\section{Site Summary}

The Orange-Crush bottle and Ball glass jar indicate that the site was most probably occupied after 1942, and abandoned in the 1950s. An oil filter, tubeless tire, and hydraulic hose suggest a similar occupation period. A green glass sherd observed on the surface would normally suggest an early 1900 s occupation, however it is thin, and thus within the temporal affinities of the other artifacts found on the site.

A 1923-1924 topographical survey map of the area shows no structure at this location, but a two-track road runs on the south side of the concrete slab (Figure 11-8). A 1962 Land Ownership map indicates that the cement slab is just inside the property line of $\mathrm{O}$. D. Harrison (Appendix L), and it is presumed that the barbed wire fence remnants running north-south through the site represents the property line between O. D. Harrison and G. Plahoe. 
The concrete slab, and a possible cut foundation stone indicates that at least one structure with a concrete floor measuring 11 by 14 feet was built on the site. The cut stone found on the northern portion of the site may be a remnant of a pier and beam temporary structure. The categories of artifacts found represent those generally associated with a farming operation, but the absence of general household artifacts, such as tableware, suggests that the site was not a farmstead with living quarters. Further to the east, the land is gently sloping and may have been farmed. A sixinch wellhead with a concrete base was observed along the two-track road through an open field east of the site. The Tulia loam soils surrounding the site are suitable for dryland farming, but the large pipe in the open wellhead indicates at least an attempt at irrigation. If irrigated, the soils should have been capable of yielding not only good grasses for grazing cattle, but also raising crops. An average yield per acre of selected crops in irrigated Tulia loam should be much greater than that produced around the farmstead at 41TG412; irrigation should have increased the yield per acre almost five-fold, to 5,200 lbs of grain sorghum, and $800 \mathrm{lbs}$ of cotton lint (Weidenfeld and Flores 1976).

The surrounding area is designated as public recreation land and is being actively used for cattle grazing. The bluff suffers the same periodic inundation and exposure due to fluctuating reservoir levels as do other riverside sites. Perceived future impacts are continued erosion, vehicular and pedestrian traffic, and cattle trampling. The research value of the historic component is minimal. No additional archaeological investigations are recommended, however further archival work is warranted. 


\section{$41 \mathrm{TG} 443$}

\section{Description and Discoveries}

The site of this probable dugout and possible pier and beam structure sits on the edge of a gently sloping, broad plain overlooking the terraces and channel of Spring Creek (Figure 11-1). The area has been inundated and exposed several times since the Twin Buttes Dam was constructed in the 1960 s, encouraging a dense growth of grasses and young willow bushes. Erosion has exposed an underlying limestone conglomerate shelf. Although no stone tools were found, historic artifacts were found mixed with presumably prehistoric lithic debitage.
A rock alignment on the northern portion of the site suggests that there was probably a pole and beam structure there at one time (Figure 11-9). A noticeable rectangular depression with a rock alignment on the southern portion of the site suggest a possible cellar or dugout had been excavated into the shallow sediments just off the edge of the limestone shelf. A shovel test and a 3-x-3-foot excavation unit placed within the depression revealed the remnants of either a wooden floor, or the collapsed roof of a probable dugout.

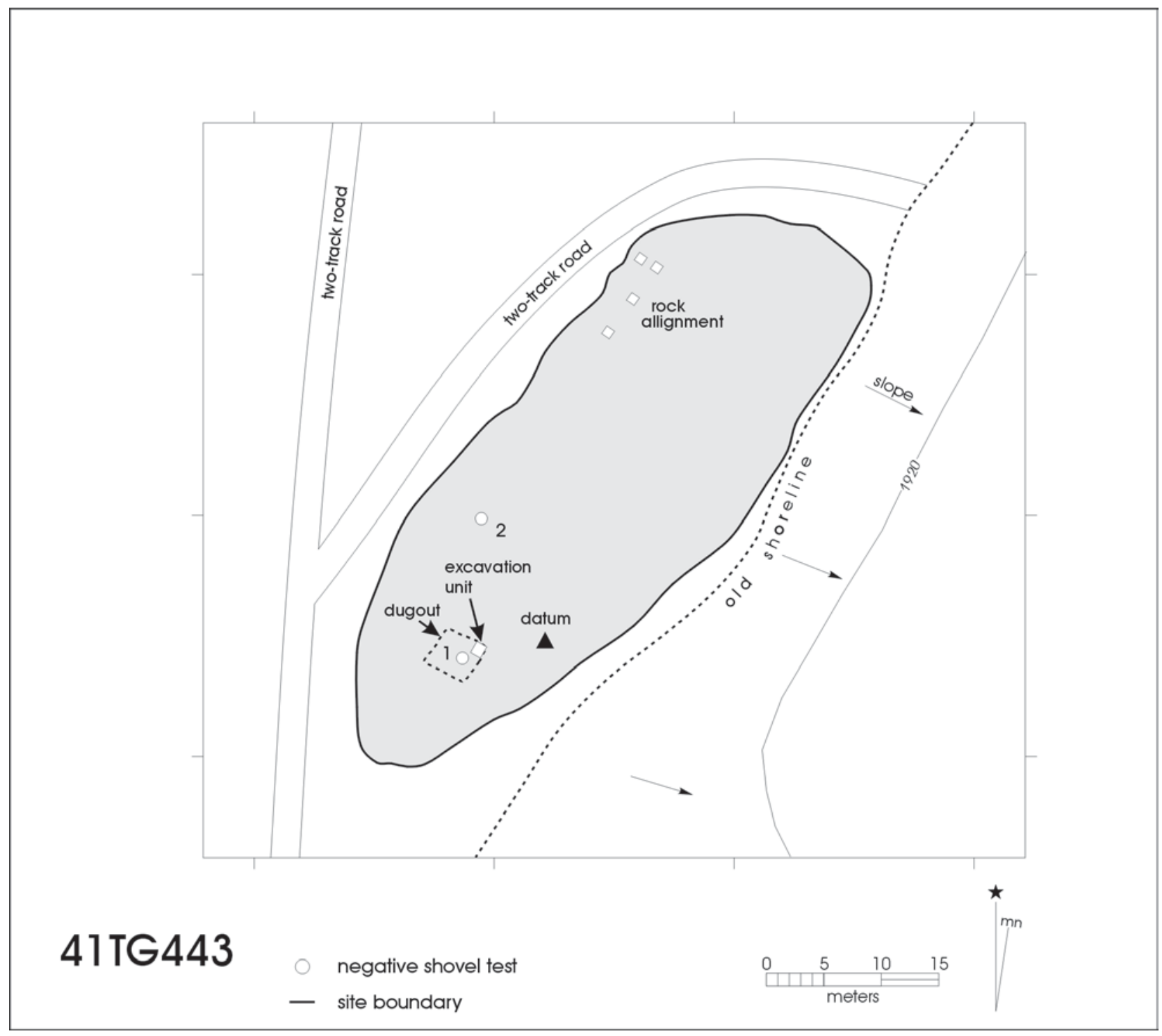

Figure 11-9. Site map of $41 T G 443$. 


\section{Analysis of the Artifacts}

Artifacts observed at the site and/or collected include glass, heavy rusted iron scrap fragments, one with a "14A" embossed on it, a rusty door latch, a metal axe head with a nail-puller notch, and a metal button-like disk. Artifacts collected from the single excavation unit include:

1) Level 1 (0-4 inches), two clear glass sherds that probably date after 1930s (Kendrick 1967:24; Munsey 1970:55);

2) Level 3 (5-6 inches), one small whiteware sherd, and a metal wire handle that may have been attached to a pail; and

3) Level 4 (6-7 inches), five heavily corroded and unidentifiable metal fragments.

Artifacts collected from the surface consist of one purple glass bottle base, two brown glass sherds, five ceramic sherds, and the metal disk. Under microscopic examination, the purple glass sherd exhibits evidence of intentional flaking to form a functional "scraper" with two working edges. One of the edges shows evidence of grinding which is typically observed on stone specimens when preparing a platform for flake removal. Its purple color suggests a date of manufacture between 1880 and 1915 (Munsey 1970:55). The two brown glass fragments are refits with the word "MARCHA" in raised lettering with three indiscernible letters below. No reference could be found which would provide a clue as to the age or source of the bottle.

Based on the thickness and paste, the five ceramic sherds appear to be whiteware from either a plate or saucer, with a transfer-printed light blue floral pattern. The whiteware attributes with flowing blue pattern date their usage to ca. 1880-1900 (Blake and Freeman 1998:18). Based on their context with other artifacts and the probable dugout at the site, but without a maker's mark or more of the pattern on the sherds, this time-frame is presumed.
A copper metal disk that measures 15.36 millimeters in diameter with a semi-square hole in the center was collected from the surface. The edge is serrated like that of a modern dime. The inscription "Pat MAR 10/ $68 \&$ MAY 6/73 is on one side while the other side is plain. This artifact "could be" the back of a three piece construction-type button commonly used by the military in the latter half of the nineteenth century (Wyckoff 1984:xix), thus the latest patent date on this specimen would presumably be 1873 .

\section{Site Summary}

A review of maps of the area dating back to 1855 shows no structure at this location, however the site may be within either Plot \#174 or \#175 allotted by the German Emigration Company in the 1840s or 1850s. The presence of whiteware, transfer ware with a flowing blue pattern, and purple and thick brown glass sherds on the site suggest it could have been occupied as early as 1860, and while the metal disk, if part of a button, indicates a probable earliest year of manufacture as 1873 . Therefore, the presence of a probable dugout does appear to be out of temporal affiliation.

The research value of this site is considered high. This site may represent one of the earliest historic occupations in the San Angelo/Twin Buttes area. The presence of a dugout that may still have an intact floor is rare. The presence of flaked glass is uncommon, but appears to be a recurring theme, with flaked glass found also at $41 \mathrm{TG} 437$ and $41 \mathrm{TG} 445$. Without further testing and the recovery of diagnostic stone tools or means of absolute dating, the possibility that the lithic assemblage at the site may be historic or Protohistoric cannot be ruled out. The site is being destroyed by continued erosion, cattle trampling, and vehicle traffic. It is recommended that additional testing focused on the dugout be initiated to determine its dimensions and possible use, and a surface collection covering 100 percent of the site be conducted. 


\section{$41 \mathrm{TG} 445$}

Description and Discoveries

This farmstead site sits on the end of a low, limestone conglomerate-based finger ridge overlooking Spring Creek valley (Figure 11-1). Shoreline erosion from the fluctuating reservoir levels has exposed the conglomerate and the presumably prehistoric stone debitage with the historic artifacts. In some portions of the site there is evidence of recent silting, and young willow bushes with sparse grasses have taken over. No evidence of a structure was found but the wide variety of household artifacts suggest that one was probably at the site. Three large cut stones with a rusted metal portion of a garden rake were observed approximately $70 \mathrm{~m}$ east of the site in what is now an

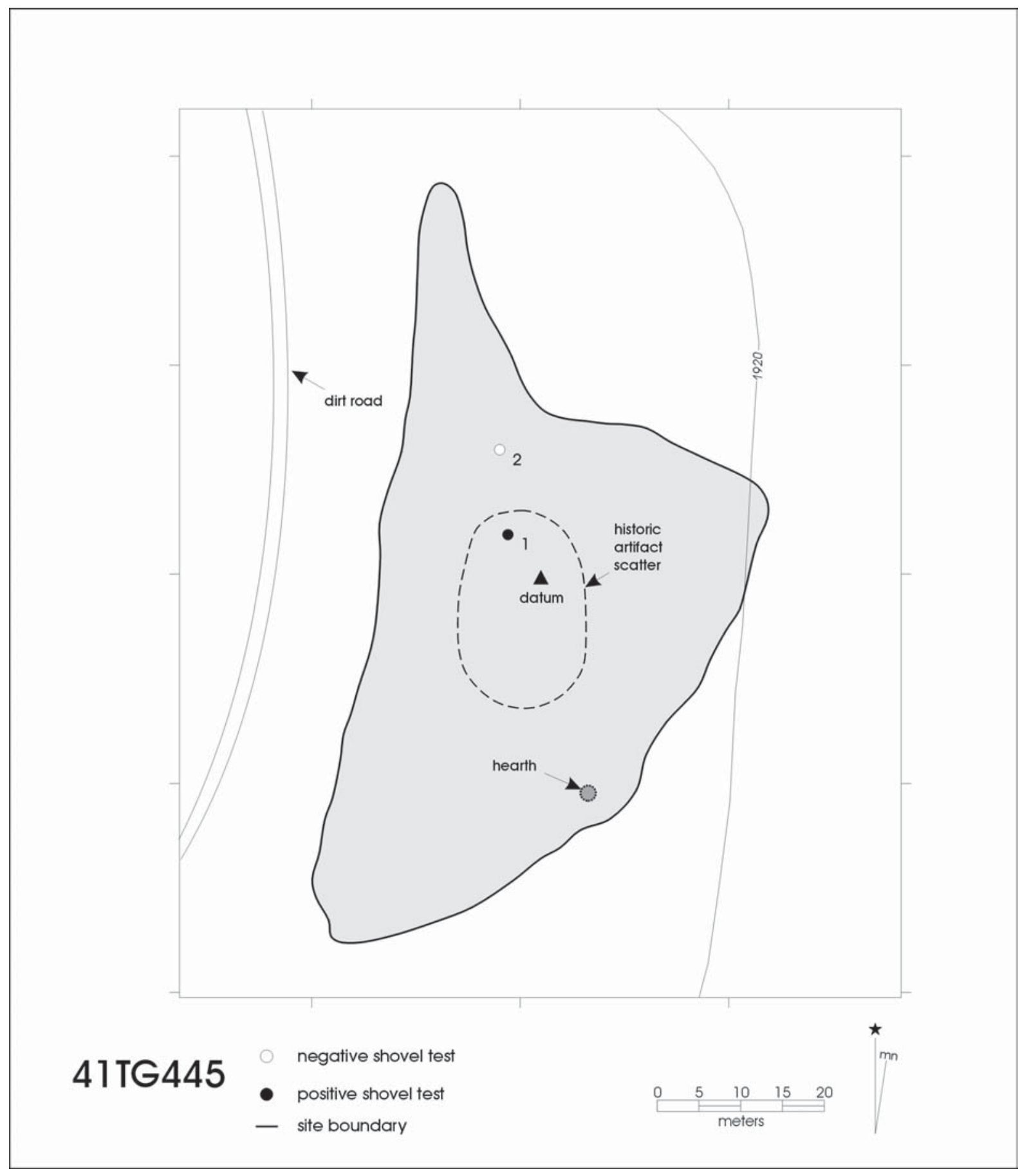

Figure 11-10. Site map of 41TG445. 
open, grassy field on a low terrace of Spring Creek, it is not known if they are related to the site. Also, a guy-wire support for an electrical or telephone pole is about $10 \mathrm{~m}$ north of the datum (Figure 11-10).

\section{Analysis of the Artifacts}

A surface collection from this site yielded a variety of artifacts such as corroded metal objects, stoneware sherds, glass container sherds, and broken window panes. The metal objects consist of the following:

1) A metal snap that is about four inches in length with the spring bolt missing and badly rusted. The same type of snap is listed as a cattle tie iron in the 1897 Sears, Roebuck Catalogue (Israel 1968:46). This item is still being made today;

2) A metal hinge with a hammered plate, a center hole and four screw holes that were apparently hand punched was recovered from the surface; and

3) A metal object that appears to be a cast-iron foot pedal from a sewing machine. Its decorative pattern is similar to one found in the 1897 edition of the Sears, Roebuck Catalogue (Israel 1968:698) and the 1895 Montgomery Ward \& Company catalogue (1969:263).

A total of 14 stoneware sherds consisting of two body fragments and twelve lid fragments from a churn were collected. They have an Albany type slip on both the exterior and interior of the vessel, a style which was popular from about 1875 to roughly 1900 (Greer 1981:197). Six glass sherds were collected and five of these showed evidence of intentional flaking. Two of the six sherds collected were aqua colored, indicating they were most likely manufactured before 1900 (Munsey 1970:37).

The aqua glass sherds consist of a partial base and a side section of a medicine bottle. The partial base does not have any seams which could date it, but it does have a blowpipe pontil scar in its center, suggesting it likely was made before 1880 (Baugher-Perlin 1982:266-267). The base fragment has intentional flaking scars on its bottom and sides. The other aqua sherd is a section of a possibly rectangular bottle that is partially embossed with "ME \& S" on one side of the sherd. This is probably a fragment of a patent medicine bottle, recognizable by its rectangular shape and aqua color (Munsey 1970:69). The construction of the railroad into San Angelo in 1888, and the accompanying increase in mail order catalog businesses being able to ship a greater variety of patent medicines into the area, suggests that this specimen was probably introduced into the site around that time, or shortly thereafter.

One bottle sherd is a small portion of a green broken bottle mouth from which no attribute is still present to objectively determine a date. However, because of its green color, it subjectively can be placed around the turn of the century, or later. There were three purple glass fragments consisting of a partial base, a fragment that has a molded raised edge with a seam through it, and a small flat fragment with embossed letters. All three have been intentionally flaked along their edges. One is a partial bottle base which has a sand-tipped pontil surface, indicating a pre-1900 date of manufacture (Baugher-Perlin 1982:266-267). a second sherd has a molded raised edge with etching on one face, a style commonly practiced in the late-nineteenth century (Munsey 1970:51). The final specimen is an embossed glass sherd which has an "S" over the letters "ORINC" but no information could be found concerning its origin or antiquity. Overall, based on their purple color, the glass sherds can generally be dated between 1880 and 1915 (Munsey 1970:55).

Ten aqua-colored window pane sherds with a mean thickness of $.26 \mathrm{~mm}$ were also recovered from the surface. Using Moir's regression formula, there is a 95 percent probability that the window was manufactured between 1924 and 1938.

Two shovel tests were dug at the site but only Shovel Test \#1 contained artifacts. A total of seven artifacts were recovered from 10-20 $\mathrm{cm}$ below the surface. Two machine-cut square nails found may have been brought to the site sometime between 1825 and 1900 (Wells 1998:83-84, 87). One of the square nails is called a brad and the other is a sprig, both of which were commonly used in the trim and flooring of buildings (Nelson 1968:6). A wire common nail that dates from the turn of the century to present was also found (Nelson 1968:7), along with a fence staple. 
Two buttons recovered from the shovel test are both machine-cut, one a two-hole shell, and the other a fourhole metal button. The shell button was most likely introduced into the assemblage at the site between 1850 and 1950 (Claassen 1994:1). The 1895 Montgomery Ward \& Company catalogue (1969:85), provides a guide which matches this particular specimen to an 18 line type, a type commonly used for men's shirts or women's dresses. Although the metal button is somewhat corroded, it can be classified as a molded type, measuring in the 28 line type; this type was used for coats or cloaks.

Other artifacts observed on the surface, but not collected, include a porcelain cup sherd, and a whiteware sherd with yellowish paste. Green, dark blue, aqua, and amber glass sherds are scattered across the surface, predominately near the center of the site.

\section{Site Summary}

A review of available maps from 1855 forward indicates no structure was ever present on the site, and our survey did not identify any structural remains. However, the artifacts and a guy-wire support suggest at least a temporary residence was occupied at the site. Window glass, wire and square nails, and particularly the sprig nail normally used in trim or floor construction, are further evidence that it is likely there was a liveable structure at one time. Further clues pointing to the existence of a household are found in the variety of colored glass bottles, buttons, and part of a sewing machine. The artifacts suggesting the possible period of occupation for site 41TG445 are shown in Table 11-3.

The research value of this site is considered minimal. No additional work is recommended for this site.

Table 11-3. Artifacts inferring occupation period at 41TG445

\begin{tabular}{|l|l|l|l|}
\hline Artifacts & Probable Years & Artifacts & Probable Years \\
\hline Square nails & $1850-1900$ & Other colored glass & ca. 1900 \\
\hline Shell button & $1850-1900$ & Wire nail & 1900-Present \\
\hline $\begin{array}{l}\text { Pontil-scarred purple } \\
\text { glass base }\end{array}$ & $1880-1915$ & Window glass & $1924-1938$ \\
\hline
\end{tabular}




\section{$41 \mathrm{TG} 450$}

\section{Description and Discoveries}

41TG450 is a farmstead operation spread over a broad upland area, sloping gently toward the south and the Spring Creek valley (Figure 11-1). The current vegetation consists of mature mesquite trees, dense grasses and prickly pear cacti. A 6 by 11 meter cement foundation and partial floor lies along an old two-track road (Figure 11-11). There is a dirt mound on the eastern end of the foundation, and an electrical box just northwest of it. Three depressions are also on the site:
Depression \#1 has concrete rubble, glass sherds, and four iron footings or pylons in it;

Depression \#2 has concrete chunks in it; and Depression \#3 appears to have nothing visible in it.

A concrete cattle watering trough lies to the southwest, and a corral made of flat barbed and woven wire is just south of the concrete foundation. Two abandoned cattle feeders made of wood are also on the property. Two mesquite trees growing inside the foundation are approximately $61 \mathrm{~cm}$ in diameter, suggesting the structure was abandoned thirty to forty years ago.

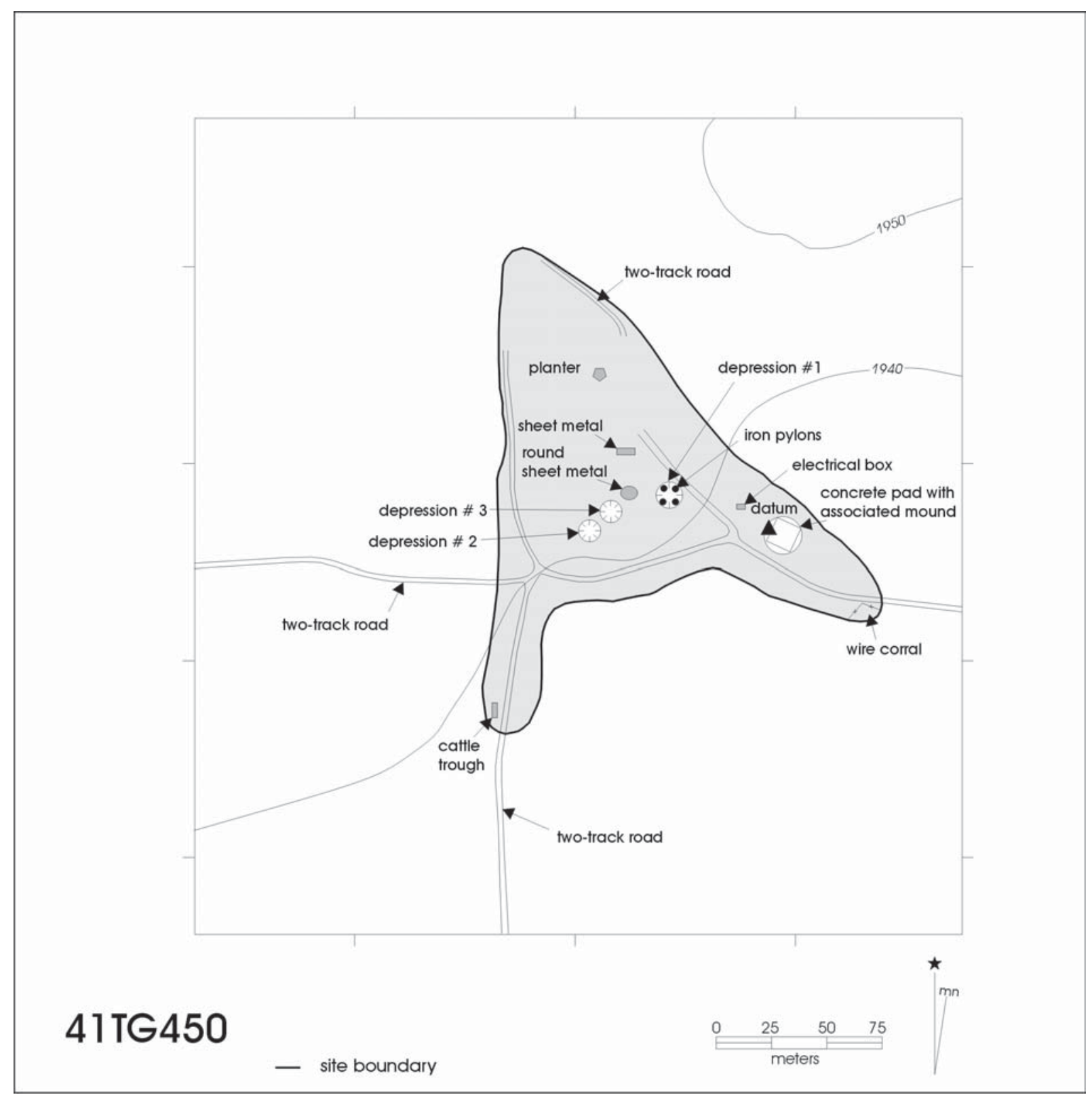

Figure 11-11. Site map of 41TG450. 


\section{Analysis of the Artifacts}

Scattered between the concrete foundation and Depression \#2 are round pieces of sheet metal, flat tin, concrete chunks, chunks of bedrock, and a few concrete block fragments. Glass fragments collected from Depression \#1 have a mean thickness of $6.65 \mathrm{~mm}$, indicating they are specialized plate glass, and not window pane sherds; thus Moir's regression formula is not applicable for dating.

\section{Site Summary}

A 1923-1924 topographic survey map of the area shows a structure located on this site, and land ownership maps indicate that the property was owned by Mr. James Davis during those years. The absence of household refuse such as broken dinnerware indicates that the structure was not likely residential, but probably a barn or storage shed. The fact that electrical lines ran to this remote location infers its significance to the overall farm operation. The research value of this abandoned farm operation is not considered significant as a single entity. No additional work at this site is recommended. 


\section{$41 \mathrm{TG} 452$}

\section{Description and Discoveries}

This gravel mining/quarry operation site is located on the edge of a gently sloping upland area overlooking the Spring Creek valley (Figure 11-1). The area is overgrown with mature mesquite trees. Some tree stumps measured over two feet in diameter and were cut several years previous. Three large quarry pits (one to three meters deep) are south of the site. A cement pad with four adjacent angle iron pylons and piers from a pier and beam building are in the northeastern portion (Figures 11-12 and 11-13). A two-track road with scattered pea gravel runs from the north, dead ending at a second set of pylons, and a third set of iron pylons are on the western portion next to an artificially created ridge. All pylons have been cut off at ground level with a cutting torch. The piers of the structure still remain except for the northwest corner, where there may have been steps, and in the middle row of the

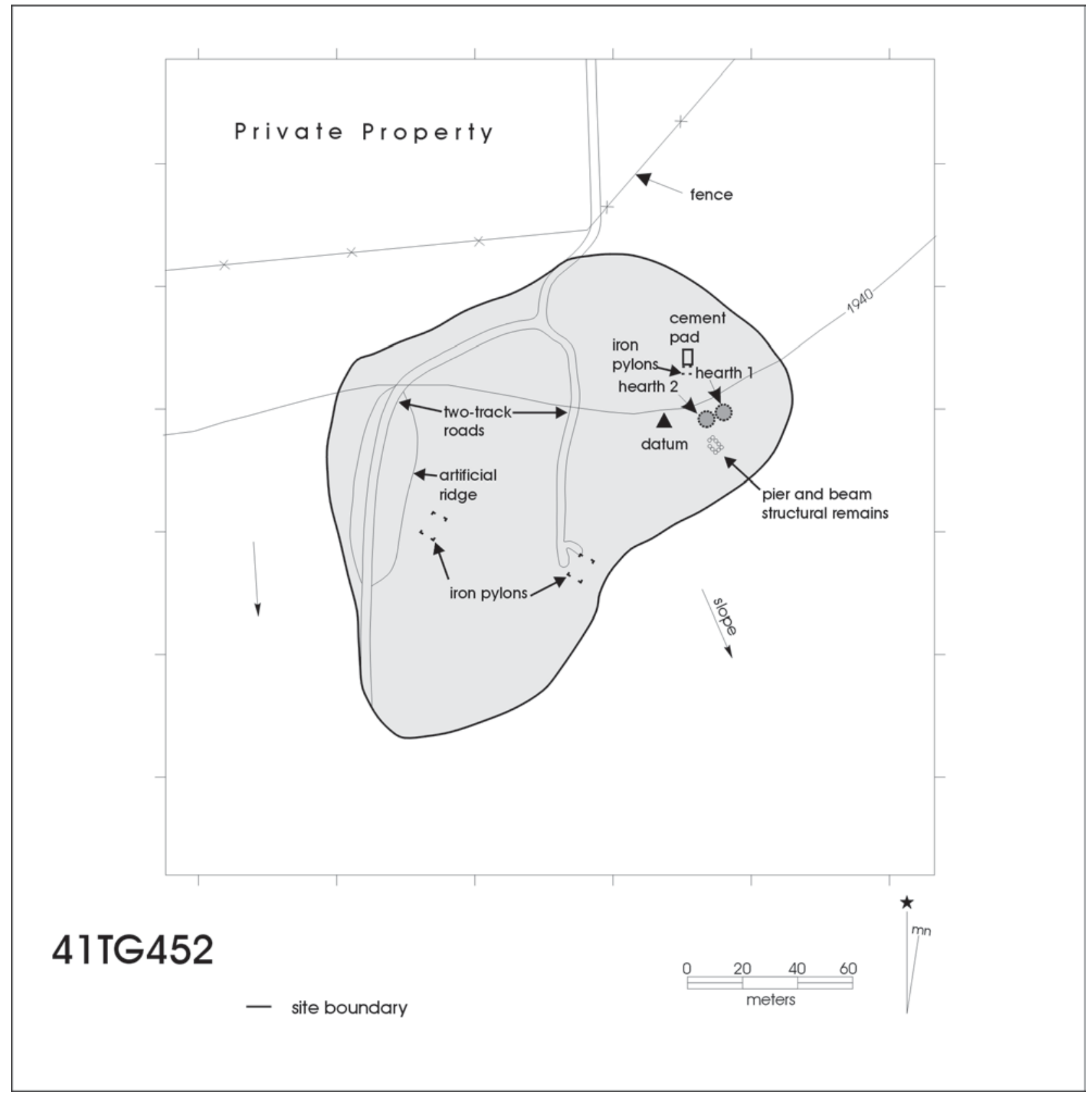

Figure 11-12. Site map of 41TG452. 


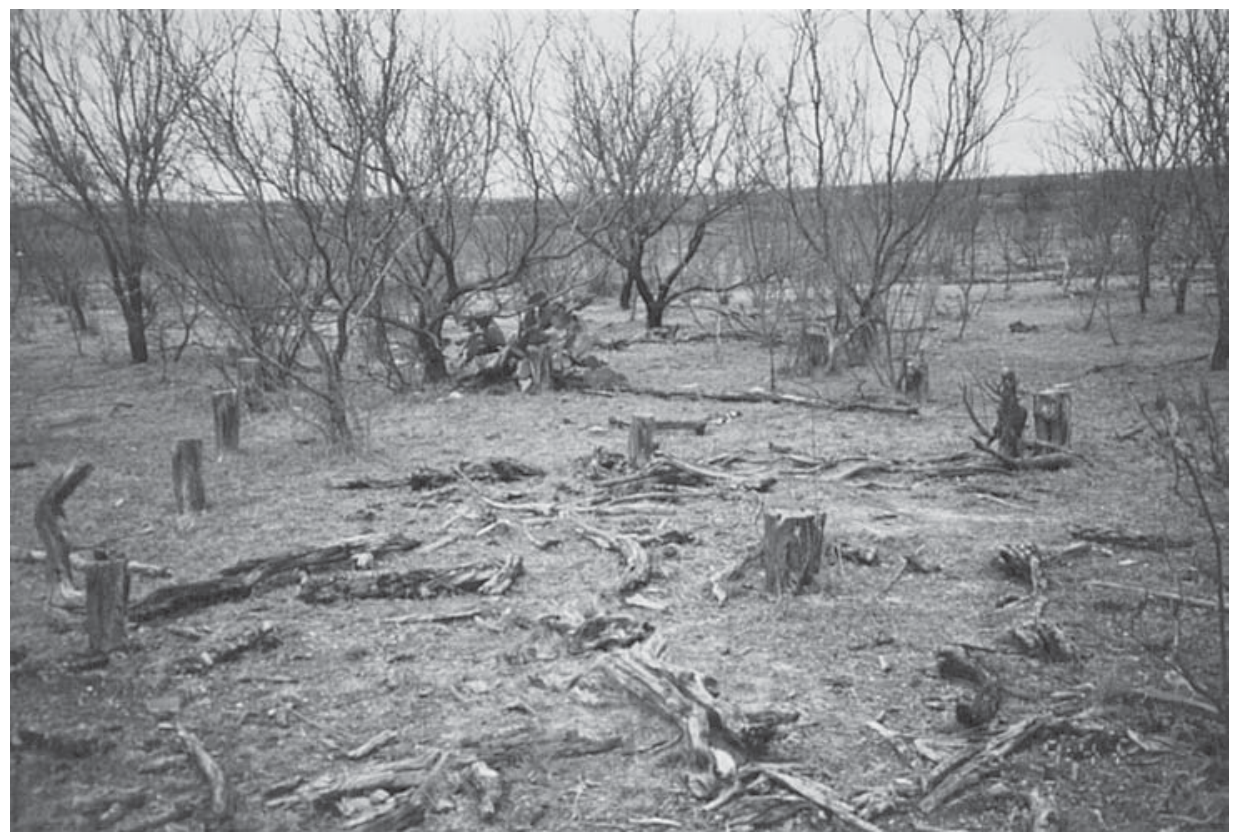

Figure 11-13. Photograph of piers from a pier and beam structure at $41 T G 452$.

southern half of the building. Each pier has a single 16-penny nail in its top. Fragments of six-inch vitrified sewer pipe and a one-inch water pipe were observed on the east and southeast sides, while window glass sherds were found on the south side. Two firecracked rock hearth features were recorded in front of the structure, and are most likely associated temporally with the use of the structure.

A piece of stovepipe, a tan brick fragment, and a oneinch piece of water pipe were observed near the cement pad. Near the ridge was a rusted water heater, a piece of 1.5-inch threaded pipe, an iron-riveted hydraulic belt, and bulldozed mounds. A two-track road runs across the top of the ridge. Near the pylons in the southern portion of the site were lengths of steel cable, angle iron, $1 / 4$-inch wire mesh, torch-cut iron sheeting, iron grates with 1.5 -inch square holes, and an eight-foot length of stovepipe.

\section{Analysis of the Artifacts}

A square, clear glass bottle with the neck missing collected from the surface has a maker's mark indicating it was produced by the Owens-Illinois Glass Company between 1929 and 1954 (Toulouse 1971:403). A clear glass sherd with remaining embossed lettering of "REUSE OF" below "ERAL LAW" was also collected. This fragment is part of a liquor bottle, and the embossing is what remains of the label "FEDERAL LAW FORBIDS SALE OR RE-USE OF THIS BOTTLE" required by the government on all liquor bottles from 1933 to 1966 (Munsey 1970:126). Finally, 28 aquacolored window pane sherds were collected. Their mean thickness is $2.56 \mathrm{~mm}$, indicating they were manufactured between 1921 and 1935 .

\section{Site Summary}

Although the structure was clearly hooked up to sewer and water lines, no evidence was found to indicate that electricity was ever hooked up to the site. It appears that power for the quarry operation and the structure(s) came from hydraulic engines and probably generators. The prolific gravel beds deposited along the upper terraces of Spring Creek made this a rich area for quarrying. A 1923-1924 topographic survey map of the area shows a structure located on this site, and land ownership maps indicate that the property was owned by Probant and Raphael during those years. The site has minimal research value remaining and no additional work is recommended. 


\section{$41 \mathrm{TG} 458$}

\section{Description and Discoveries}

This farmstead site sits on the edge of the old San Angelo to Sherwood Road near the Middle Concho 12-mile crossing (Figure 11-1) and consists of two structural mounds and associated trash. One mound is rectangular and the other is circular; both are about a foot high. The remains of a barbed wire corral are on the eastern portion of the site, and the trace of a driveway is still visible leading from the old Sherwood Road (Figure 11-14). Two small, shallow depressions are just north of the rectangular structural mound. A third structure may have been on the north side of the corral; there are more concrete blocks and tin in that area, but no mounds or depressions.

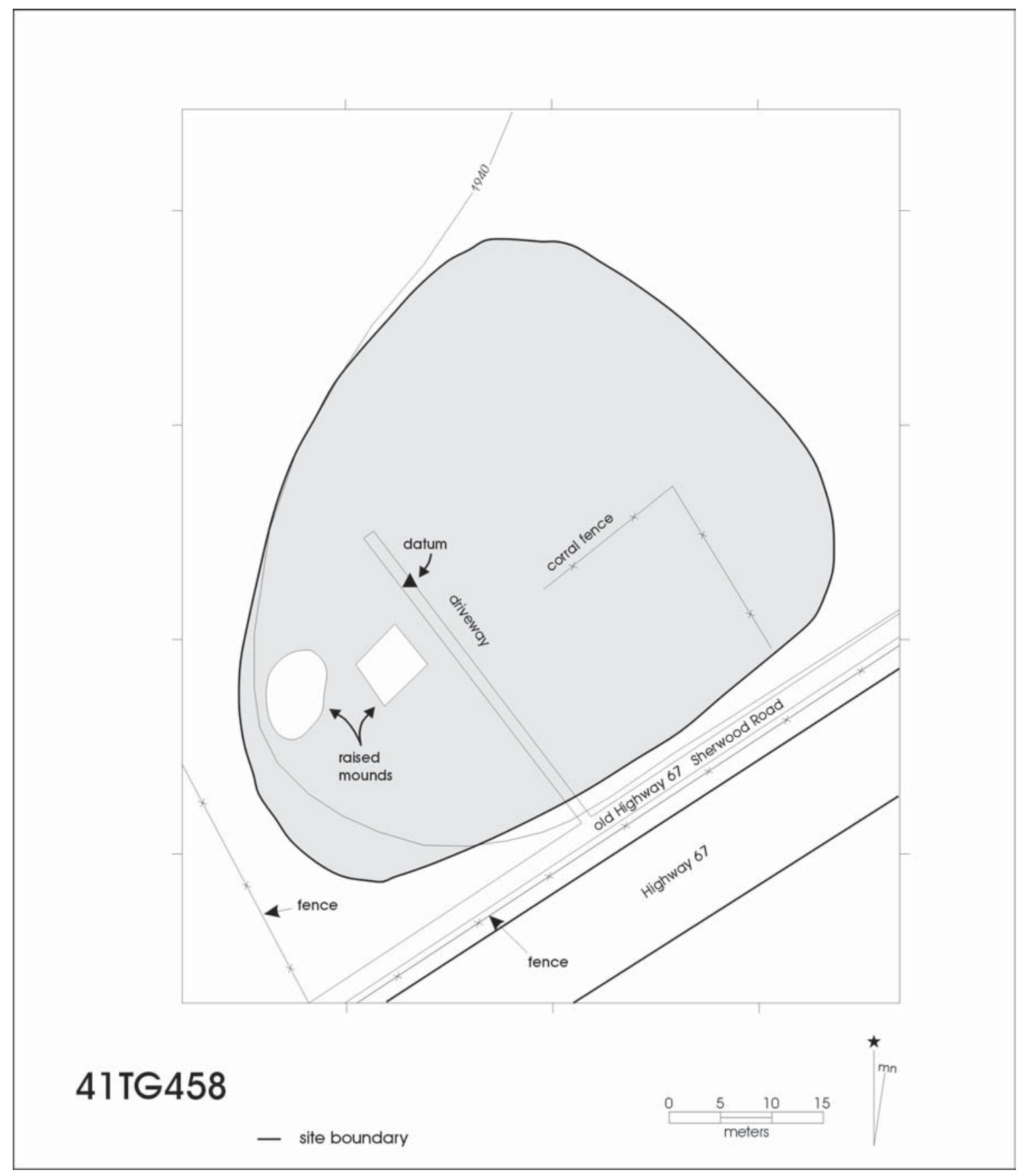

Figure 11-14. Site map of $41 T G 458$. 


\section{Artifact Analysis}

Debris observed at the site near the two mounds includes clear bottle glass, a patched inner tube, concrete block, a piece of two-inch iron pipe, pink, red, and yellow brick fragments, round nails, metal sheeting and stovepipe, round and flat barbed wire, old wooden fence posts, a five-gallon army-type "jerry" gas can, a few whiteware sherds, a full two-inch by six-inch rotted plank, a rusted gas hot water heater, an old swamp water cooler, a brass lightning rod, and a U.S. Royal nylon tubeless tire. The nylon tire carries the "Fleet Carrier" label with a 6 ply rating, thus would have been able to stand the rough roads and off-road travel in the region. The fact that it was tubeless indicates that it was made post-1950, and all of the debris observed could well have been produced around 1950 .

\section{Site Summary}

The location of this site is on the western edge of the planned community of Bohemia. Bohemia was the creation of George Hagelston who surveyed both large plots and city lots on both sides of the Sherwood Road (Highway 67) in 1906. Many of the tracts were sold to newcomers, but the town never really developed as planned (San Angelo News, March 24, 1906; Record of Survey 26DR288, page 270). The 1957 USGS Twin Buttes topographic map shows a structure at this location, but none on the available 1923-1924 survey map, indicating that the structure(s) were built sometime between 1924 and 1957. This scenario fits temporally with the artifacts and debris observed at the site. Other available land ownership maps indicate the property belonged to Rose Gandy in 1959, and then Thomas A. Childress in 1962. Although no evidence of irrigation was found, the broad, flat plain north and northeast of the structures had been artificially terraced and farmed. It has since overgrown with young mesquite trees. The Rioconcho and Spur (Rs) fertile soils surrounding the site could have yielded 2,000 bushels of grain sorghum, 275 pounds of lint cotton, or 20 bushels of wheat per acre if properly tilled (Weidenfeld and Flores 1976:28). The research value of this site is considered minimal. No additional work is recommended. 


\section{$41 \mathrm{TG} 459$}

\section{Description and Discoveries}

41TG459 is a trash dump located on the bank of a backwater flood drainage of the Middle Concho River (Figures 11-1 and 11-15). A wide variety of intact bottles, household articles, and a few vehicle parts make up the assemblage. It may be associated with 41TG344, a farmstead site across the drainage, approximately $350 \mathrm{~m}$ to the southeast.

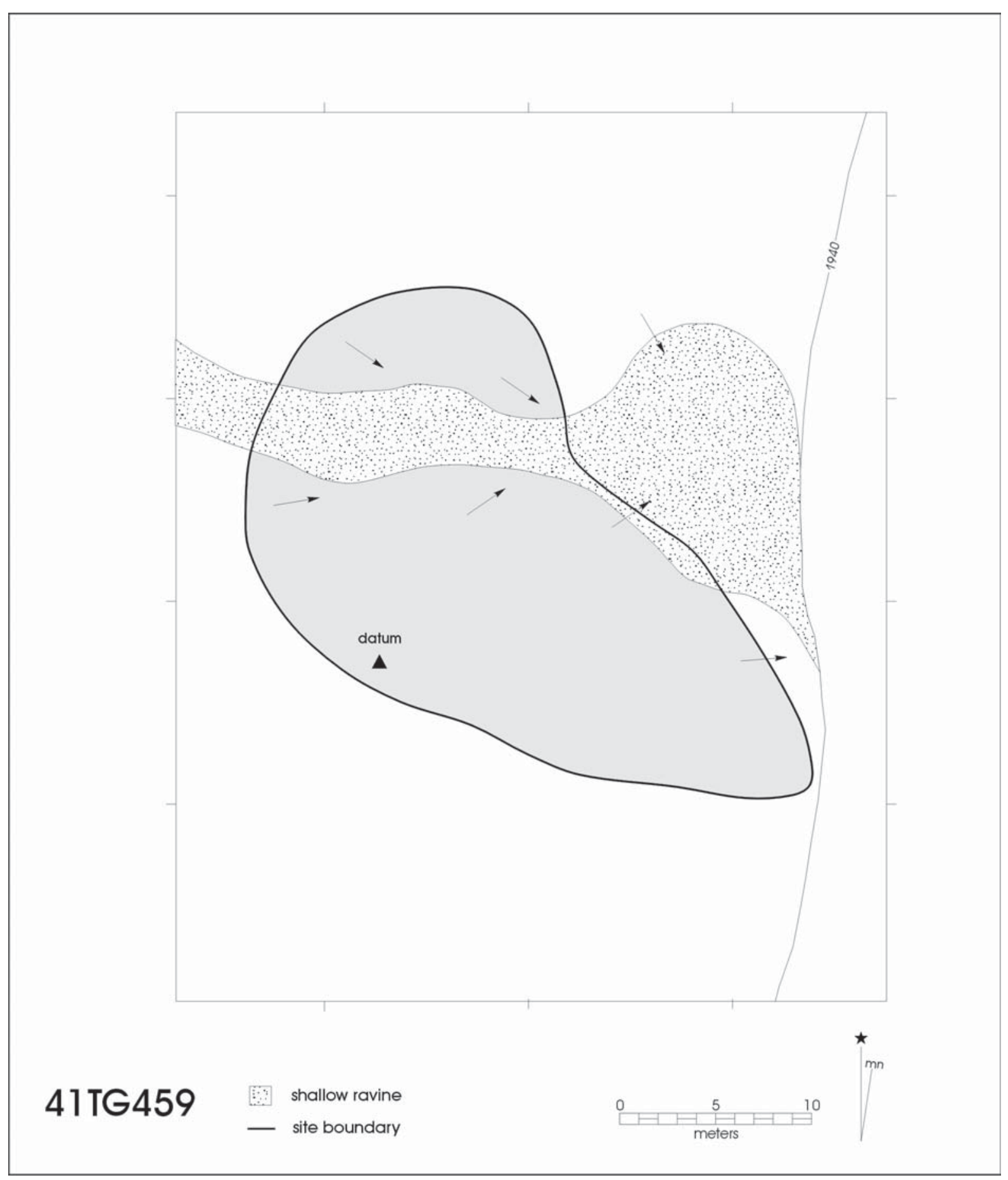

Figure 11-15. Site map of 41TG459. 


\section{Artifact Analysis}

Several intact clear glass bottles, a rubber tire (not tubeless), a green glass insulator, a green Coca Cola bottle, a section of vitrified sewer pipe, a red brick, a red tile fragment, rusted metal buckets and washtub, a metal lantern base with porcelain "slip," a porcelain toilet base, a Champion spark plug, brown and purple glass sherds, stoneware, and yellow, brown, and white ceramic kitchen ware were observed at the site. Among those documented with maker's marks were:

1) A NUGRAPE soda bottle manufactured by Laurens Glass Works, Laurens, South Carolina. Laurens has been continuously in operation since 1913;

2) A clear glass base fragment manufactured by the Hazel-Atlas Glass Company, Wheeling West Virginia. Hazel-Atlas made fruit jars from 1902 through 1964;

3) A clear catsup bottle with paper labeling and screw top. This particular specimen was manufactured by the Owens-Illinois Glass Company, Toledo, Ohio sometime between 1940 and 1966;

4) A clear glass, mustard jar with a screw top. This specimen was also manufactured by OwensIllinois within the same time period;

5) A clear glass bottle base manufactured by Whitall-Tatum and Company sometime between 1935 and 1938;
6) A whole, clear glass jar with a screw top manufactured by the Tygart Valley Glass Company, Washington, Pennsylvania sometime between 1940 and 1960;

7) A clear glass bottle fragment manufactured by Owens-Illinois sometime between 1929 and 1954; and

8) A green Coca Cola bottle manufactured in 1947 and distributed from San Angelo, Texas (Table 11-4).

\section{Site Summary}

The site is on a plat of land surveyed for McDonald's District 11 in the Fisher-Miller land grant. It was later acquired by Adam Burkhardt and surveyed into smaller plots for development of the city of Bohemia. A land ownership map indicates that the property belonged to Rose Gandy in the late 1950s before government acquisition of the land marked the terminus of cultural deposition at the site. A synthesis of those bottles with datable maker's marks and labels indicates that collectively, they could have been deposited at the site between 1902 and the present, but more likely during the 1930 s through the 1950 s. The trash dump still contains many unbroken bottles that could be inventoried before private bottle collectors and others loot the site.

Table 11-4. Years of manufacture or distribution of bottles documented at 41TG459

\begin{tabular}{|l|l|l|l|}
\hline Bottle Type & Year(s) & Bottle Type & Year(s) \\
\hline Fruit Jar & $1902-1964$ & Unknown & $1940-1960$ \\
\hline NUGRAPE Soda & 1913 -present & Catsup & $1940-1966$ \\
\hline Untypeable & $1929-1954$ & Mustard & $1940-1966$ \\
\hline & & Coca Cola & 1947 \\
\hline
\end{tabular}




\section{$41 \mathrm{TG} 501$}

\section{Description and Discoveries}

This railroad-related site sits on a limestone conglomerate-based knoll high above the broad plain between the confluence of Spring Creek and the Middle Concho
River (Figure 11-1). This site has one main cluster and three smaller clusters of cut limestone and red brick structural remains (Figure 11-16). An abandoned railroad grade runs along the southern edge, and a two-track road runs along the eastern edge of the site.

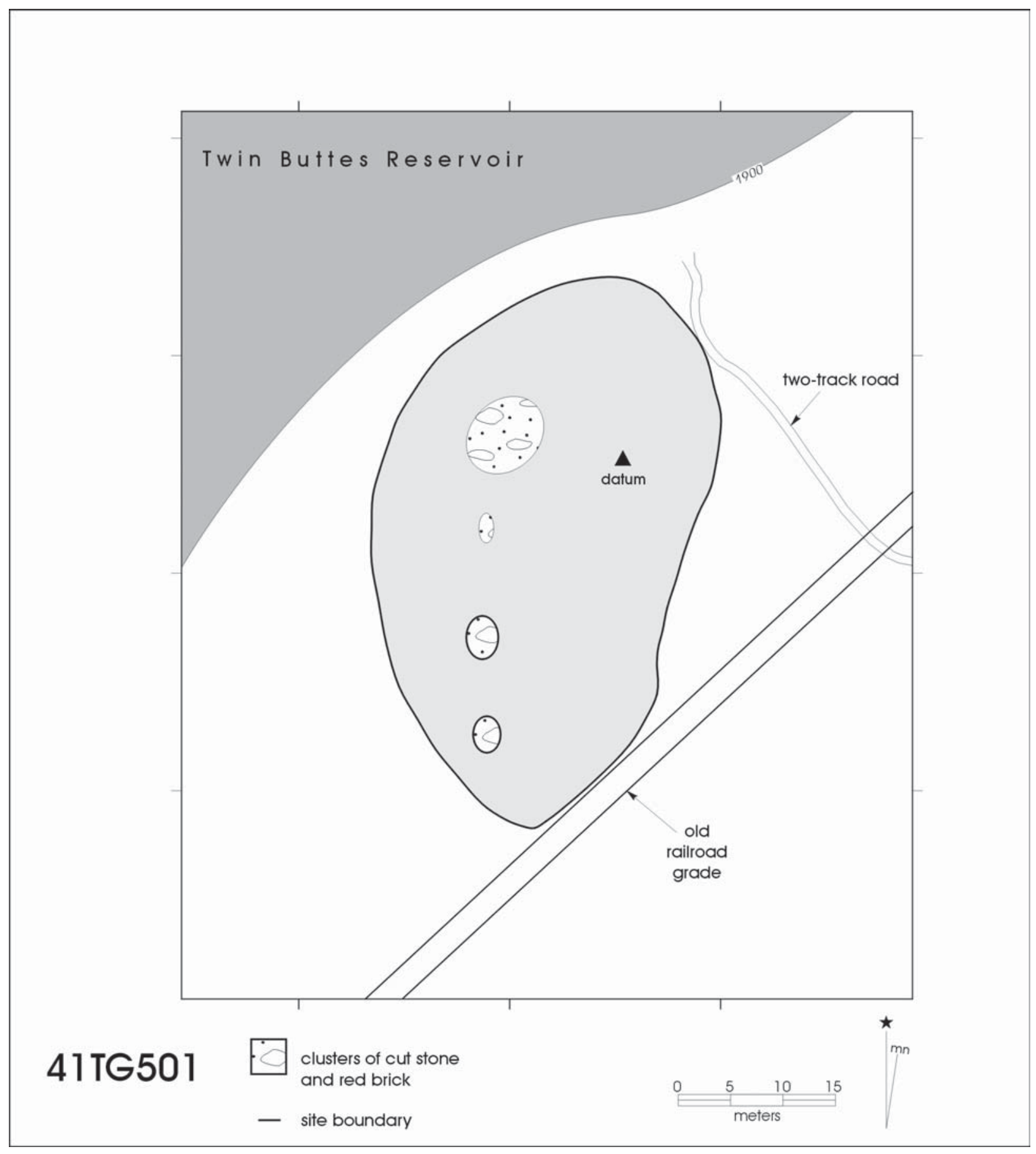

Figure 11-16. Site map of 41TG501. 


\section{Artifact Analysis}

In addition to bottle glass, two iron retaining pins and iron hardware from a wagon were observed on the surface. A few of the red bricks were labeled "THURBER." The Thurber brick plant operated from 1897 through 1930 (Maroney 1996). Three glass bottle bases were collected; one is clear, the second is aqua, and the third is brown. The first glass base has a remnant of the distinctive Owens machine ring indicating it was made after 1904, however its lack of coloring indicates it was made after the 1930s (Munsey 1970:40, 55). The aqua-colored base is rectangular and embossed with the words "ACEITO MEXICANO" across its surface. It also displays an Owens machine ring from the early part of the twentieth century. Its rectangular shape and aqua color suggest it was likely a patent medicine bottle (Munsey 1970:69). The brown glass base has a maker's mark that indicates that it was made by the Owens-Illinois Company between 1929 and 1954 (Toulouse 1971:403).

\section{Site Summary}

The structural remains and other items found at the site are probably related to the now abandoned Kansas City, Mexico and Orient Railroad bed which runs along the southern edge of the site. The Spanish translation for "Aceito Mexicano" can be either Mexican train oil, or Mexican tonic oil. The glass sherds could have been introduced into the site between 1904 and 1954, and the red brick could not have been used at the site before 1897. A structure is shown at this location on a 1923-1924 topographical survey map of the area. The research value of this site is considered minimal, though it is recommended that further archival research be conducted to evaluate the function of the site, and its connection with the economic impact of the railroad through San Angelo. 


\section{$41 \mathrm{TG} 504$}

\section{Site Description and Discoveries}

This site consists of the remnants of an early 1900s schoolhouse and privy sitting on a rise overlooking the South Concho River valley (Figure 11-1). The site has also been used as a campsite for prehistoric Native Americans perhaps as early as 9,000 years ago (see Appendix A). The immediate area around the schoolhouse is now overgrown with mature mesquite trees, prickly pear cactus, and moderately dense grasses, and range cattle were frequently seen around the site during the survey. The schoolhouse remains consist of scattered brick and cut stone, with a few pieces of wood and metal sheeting. Its estimated size is 12 by 16 feet. What is believed to be the privy lies about 20 feet northwest and is defined by a 6 -foot by 4-foot scatter of cut stones surrounding a slight depression, with an apparent doorway facing northeast. Traces of a probable driveway leading from a northsouth two-track road lead up to the south side of the schoolhouse (Figure 11-17.)

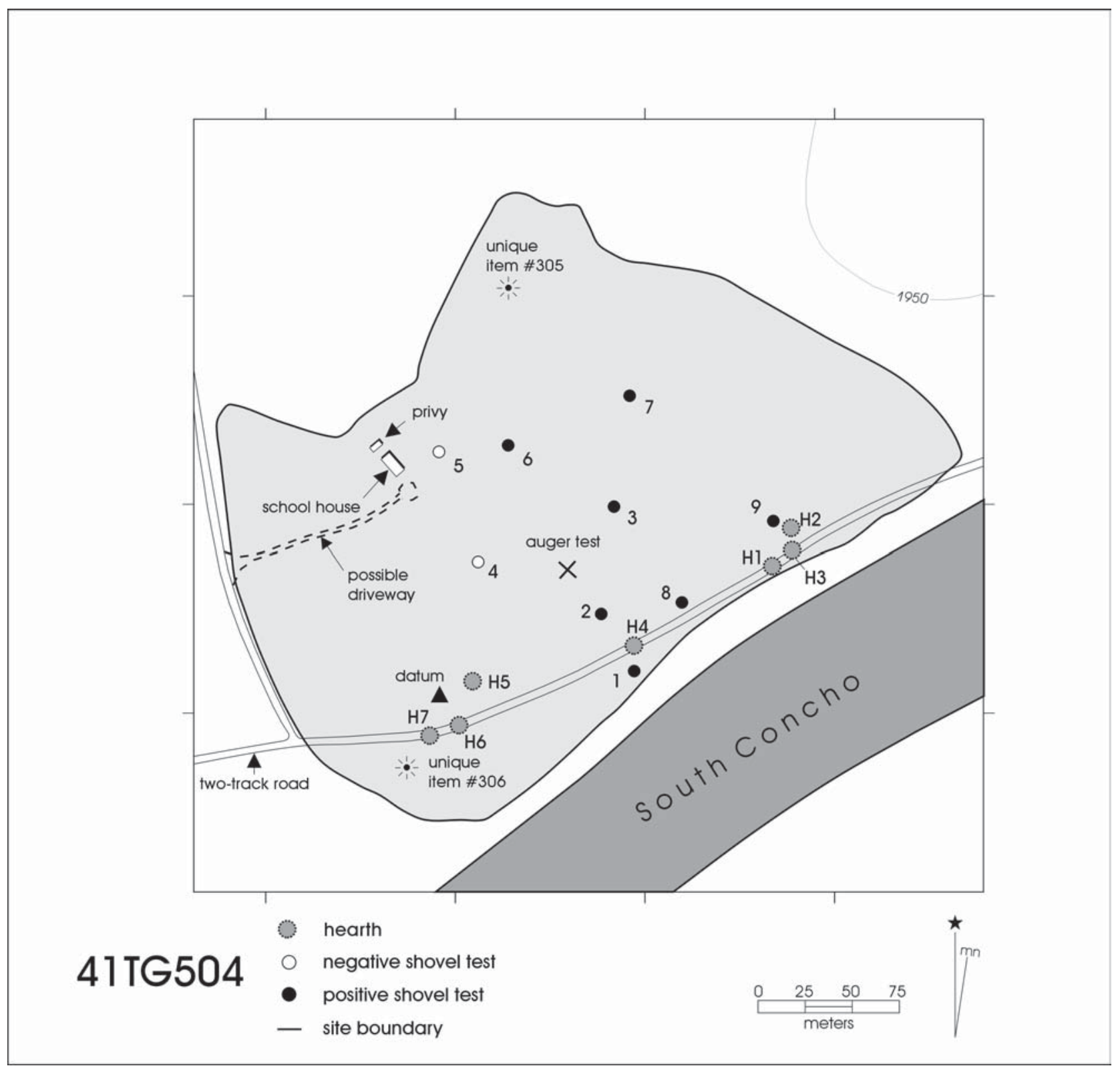

Figure 11-17. Site map of 41TG504. 
Artifact Analysis

In addition to the construction material, artifacts observed on the surface include undecorated whiteware plate and cup sherds, painted whiteware sherds, brown glazed stoneware sherds, purple and dark blue bottle glass, clear Mason jar sherds, clear bottle glass sherds, rusted tin cans, a metal wheel from a child's wagon, and a leather shoe sole. The artifacts are predominately scattered south and east, in close proximity to the schoolhouse. One of the clear glass bottles is a medicine bottle with no maker's mark, but its clarity suggests it was manufactured after 1930. A second bottle bears an Owens-Illinois Glass Company mark indicating it was manufactured between 1929 and 1966. The purple glass would likely have been brought to the site between 1880 and 1915, and the brown over white glazed stoneware is also probably of the same era. Six flat glass sherds were collected; three were thick plate glass, but the remaining three were window pane glass with a mean thickness of $2.5 \mathrm{~mm}$. Using Moir's regression formula, there is a 95 percent probability that the sherds date to between 1916 and 1930.

\section{Site Summary}

The schoolhouse appears on a 1923-1924 topographic survey map of the area, and it was probably being used before that time. The artifact assemblage suggests a period of use from about 1900 to 1930. A review of available land ownership maps indicates that the property was originally surveyed as part of McDonald's District 11 in the Fisher-Miller Land Grant, later the German Emigration Company. By 1894 Joseph Jung had acquired the 160-acre parcel and he held title until it was transferred to the Department of the Interior. The research value of the schoolhouse is considered moderate as a single entity, however its value increases when considered in context with farmsteads, economic development in the area, and related population increase. It is recommended that further archival research be conducted to determine the influences responsible for constructing a schoolhouse in this particular location. 


\section{$41 \mathrm{TG} 513$}

\section{Description and Discoveries}

This sandstone structure and artifact scatter sits on a low, gently sloping alluvial terrace near the confluence of an unnamed tributary and the South Concho River (Figure 11-1). The site has been continuously inundated and exposed due to fluctuating reservoir levels since the Twin Buttes Dam was constructed in 1962. At the time of this survey, dense marshy grasses and young willows had overgrown the site.
A circular, stacked sandstone structure with approximately 15 -inch wide walls, a 5.5 foot interior diameter, and standing approximately 18 inches high, is located on the modern shoreline at an elevation of 1,932 feet. It has an entry opening to the east, and a pile of stones adjacent (Figures 11-18 and 11-19). Its antiquity is unknown, with both prehistoric and historic artifacts in the site's assemblage. A modern twowheeled surrey which could be pulled by a medium-sized animal was located at the entry to the circular stone structure.

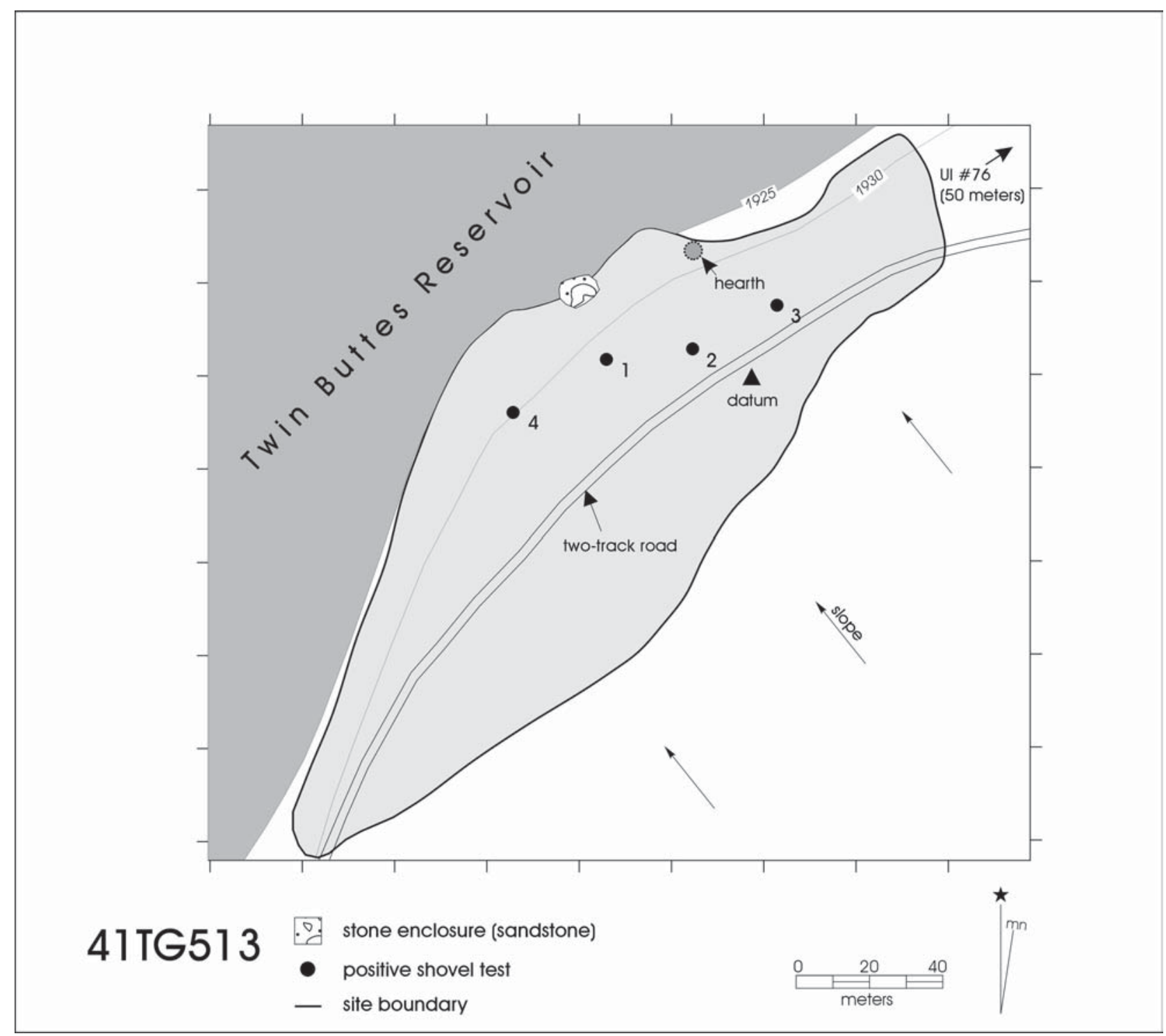

Figure 11-18. Site map of 41TG513. 


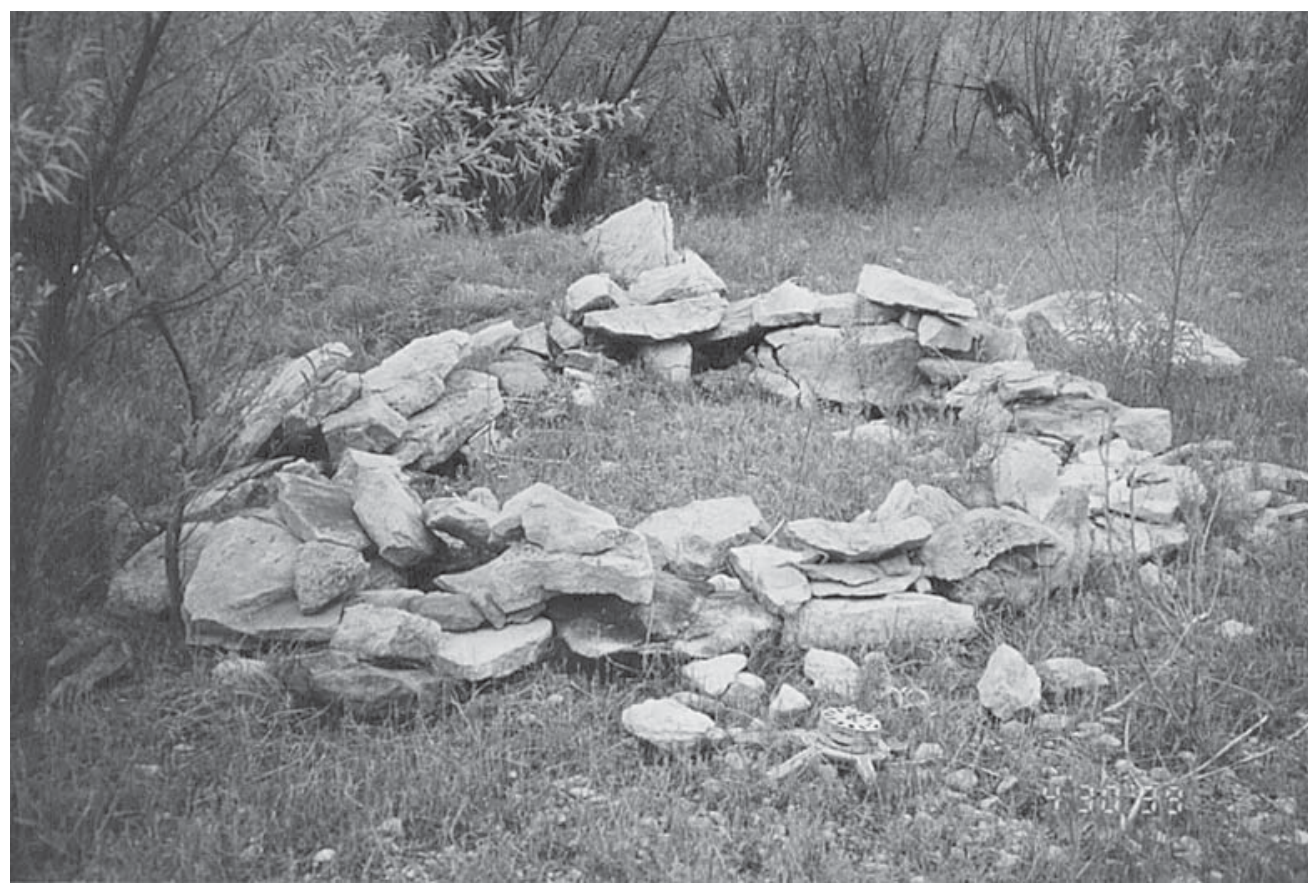

Figure 11-19. Photograph of sandstone structure of unknown age (41TG513), facing south.

\section{Artifact Analysis}

Thick glass fragments observed on the surface included green, purple, dark brown, and aqua pieces, along with whiteware sherds, brown glazed stoneware pieces, and etched purple glass. The artifacts were generally up slope and northeast of the sandstone structure. Six glass bottle fragments, two rifle cartridges, a horseshoe fragment and a copper tobacco tin case were collected for further examination. Four purple glass sherds collected were produced between 1880 and 1915 (Munsey 1970:55), with engraving on two of them. Engraving was an inexpensive practice in the late 1900s (Munsey 1970:51). An aqua colored rectangular bottle base embossed with the letter "W" followed by "U S a" was collected. Any letters in-between have been partially obliterated by a sand-tipped pontil scar commonly indicating a probable period of manufacture prior to the 1870s (Baugher-Perlin 1982:266-267). A dark amber bottle neck fragment, possibly part of a beer bottle was also collected. This particular specimen has no seam line running up the side of its lip, indicating that it was likely made before 1900 (Munsey 1970:41, 116-118).
The rifle cartridges have the marks "WRA CO 44 WCF" and "WRA CO 45-60 WCF" on the bottoms of the shell casings. The first rifle shell is a .44-40 caliber that was made by Winchester Repeating Arms for the Model 1873 Winchester rifle that was famous in the old west (Logan 1959:137). This caliber grew in popularity when the Colt single action revolver was chambered for it in 1878. This development meant that an individual had a bullet that could be used for both the rifle and pistol, which was a real advantage on the western frontier (Peterson 1962:220). The other shell casing is that of a .45-60 caliber made by Winchester Repeating Arms for their Model 1876 rifle. This rifle was developed for sportsmen who wanted a larger caliber than the .44-40 of Model 1873 (Logan 1959:141).

The copper tin hinge-type container appears to be a cigarette tobacco container, and is in two pieces; one side has an engraved building with the words "G. W. GAIL \& AX TOBACCO WORKS" below it, and the other side reads as follows: 


\section{TED BY \\ G.W. GAIL \& AX \\ BALTIMORE MD \\ SAMPLE \\ THIS PACKAGE NOT FOR SALE \\ REPACKED FROM STAMPED PACKAGE}

The age of the tin tobacco container could not be traced through its distributor, G. W. Gail and Ax. However, with the exception of five major businesses, numerous small operators produced and distributed cigarette tobacco until 1893. In that year the major producers united under the American Tobacco Company and effectively squeezed out most of the smaller concerns (Clark 1949:278-280).

The final artifact collected is a badly rusted half section of a horseshoe with a sunken groove, an indication that it is of either British or American origin (Simmons and Turley 1980:66). It is probably the type of shoe that goes on the front rather than the rear since the projection bar is not visible on the shoe (Labadie 1986:70). Because of its poor condition only a relative period of either the nineteenth or twentieth century can be assigned to it.

\section{Site Summary}

The artifacts observed at this site suggest its probable use as a residential site between ca. 1870 and 1915 (Table 11-5). Although a 1923-1924 topographic map of the area shows a road running through the site, it does not show any structure(s) at this location. It could be that any structure there at the turn of the century was destroyed before 1923. The age of the sandstone structure found at the site has not been determined. It is not large enough for a residential dwelling, and may be an outbuilding for a residential structure now under the reservoir. A review of available maps indicates that the property surrounding 41TG513 was owned by a Mr. David Lloyd from at least 1894 through 1947, and before that it was platted in McDonald's District 11 of the Fisher-Miller Land Grant, and the subsequent German Emigration Company. This site is being destroyed by shoreline erosion from periodic inundation and exposure due to fluctuating reservoir levels. It contains some of the earliest evidence of occupation within the Twin Buttes survey area and thus its research value is considered high. It is recommended that further archival research be undertaken to determine the extent of this particular occupation and what effect it may have had upon the economy and demographics during the early development of the San Angelo/Twin Buttes region. Test excavations are recommended around the sandstone structure to investigate its age and purpose.

Table 11-5. Probable antiquity of artifacts documented at 41TG513

\begin{tabular}{|l|l|l|l|}
\hline Artifact & Probable Antiquity & Artifact & Probable Antiquity \\
\hline Aqua Bottle Neck & Pre-1870 & Tobacco Tin & Pre-1893 \\
\hline $.44-40$ Rifle Cartridge & Post-1873 & Amber Bottle Neck & Pre-1900 \\
\hline $.45-60$ Rifle Cartridge & Post-1876 & Purple Glass & $1880-1915$ \\
\hline
\end{tabular}




\section{TG516}

\section{Description and Discoveries}

41TG516 is a farmstead located on a low, broad, gently sloping ridge between Spring Creek and the Middle Concho River (Figure 11-1). Historic artifacts are concentrated on the west side of a north-south paved road, a prehistoric lithic debitage scatter extends both east and south (Figure 11-20; see also Appendix A). A 19231924 topographic survey map of the area indicates there was a structure at this location, but no intact foundation was found, only some construction materials and artifacts. The area where the structure would have been located appears to have been chainedcleared, probably during construction of the Twin Buttes Dam.

\section{Artifact Analysis}

The few artifacts remaining on the surface include a rusty pair of pliers, a green Coca Cola bottle sherd, a dark brown, thick bottle glass sherd, and a screw top Mason jar. Rusted sheet metal and a piece of vitrified sewer pipe were the only items found that could have been a part of a structure. Below the surface, a printed whiteware sherd, and purple and clear glass sherds were recovered from shovel tests.

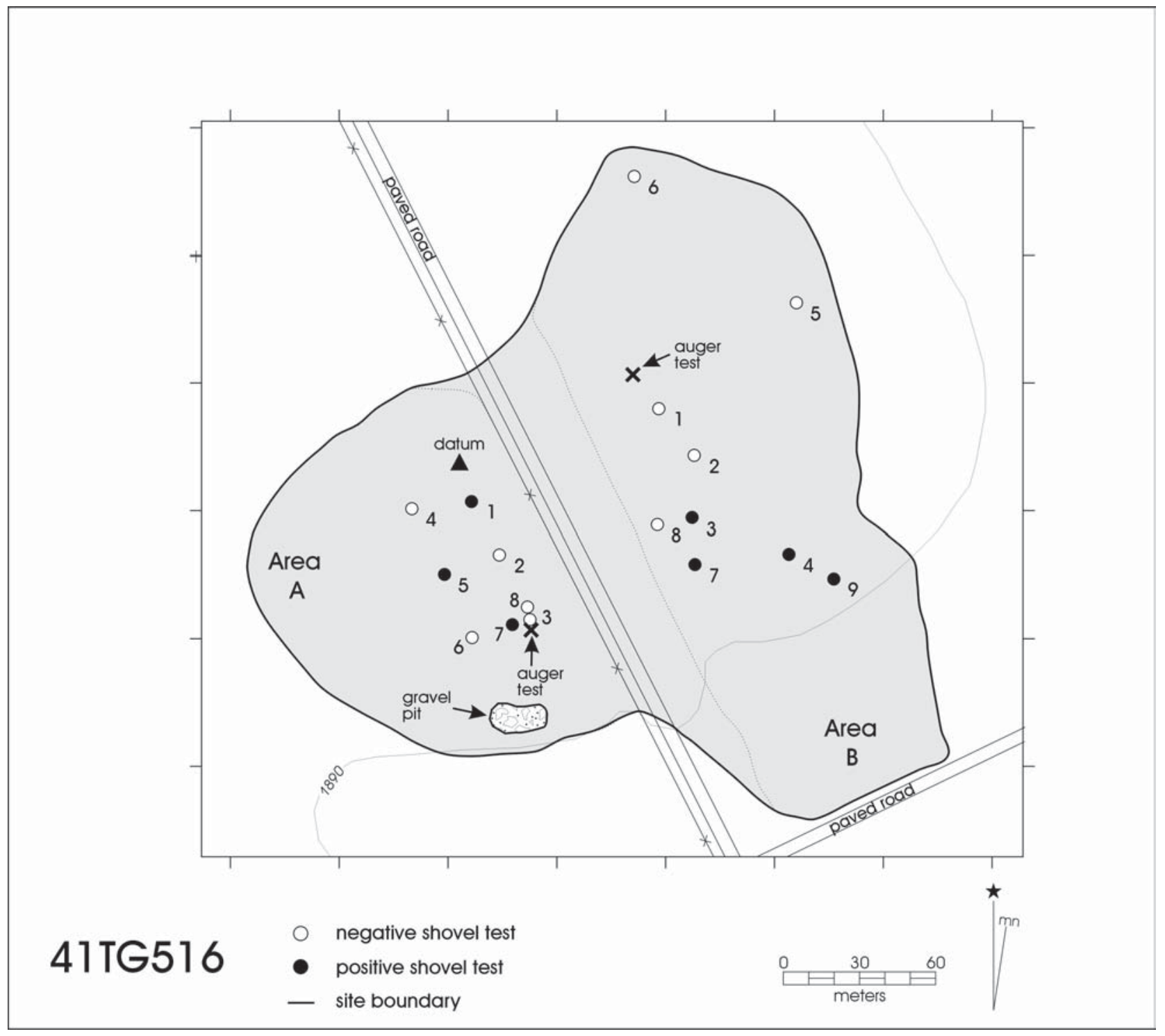

Figure 11-20. Site map of 41TG516. 


\section{Site Summary}

The area where the structure would have been is very near the Twin Buttes Dam and has been cleared of all vegetation. Although a 1923-1924 topographical survey map shows a road and structure at this location, and a few glass and whiteware sherds were found during shovel testing, it is probable that the structure may have been totally destroyed and most of its material removed from the site. The owner of the property in 1916 was Charles Mott and by 1942 title was passed to $\mathrm{H}$. Roth. It is possible that the structure may have been part of the Twin Mountains community. The research value of the historic component at 41TG516 is considered minimal as a single entity, however its value increases moderately when considered in context with other historic farmsteads in the Twin Buttes/San Angelo region. It is recommended that additional archival research be undertaken to better understand the farmstead operation and its effect upon the economic development of the Twin Buttes/San Angelo area, and in particular the Twin Mountains community. 


\section{TG520}

Description and Discoveries

This farmstead sits on the highest point on the end of a gently sloping finger ridge above an upper terrace of Spring Creek (Figure 11-1). Large, mature mesquite trees dominate the ridge growth, with thorny brush, pencil cactus, and sparse grasses encroaching across the ridge in recent years. It is apparent that the ridge was favored by prehistoric Native Americans, as evidence of a prehistoric lithic scatter is visible on the southern end of the site (see Appendix A). Although no structural foundation was obvious, a scatter of red and yellow brick at the end of a two-track road on the

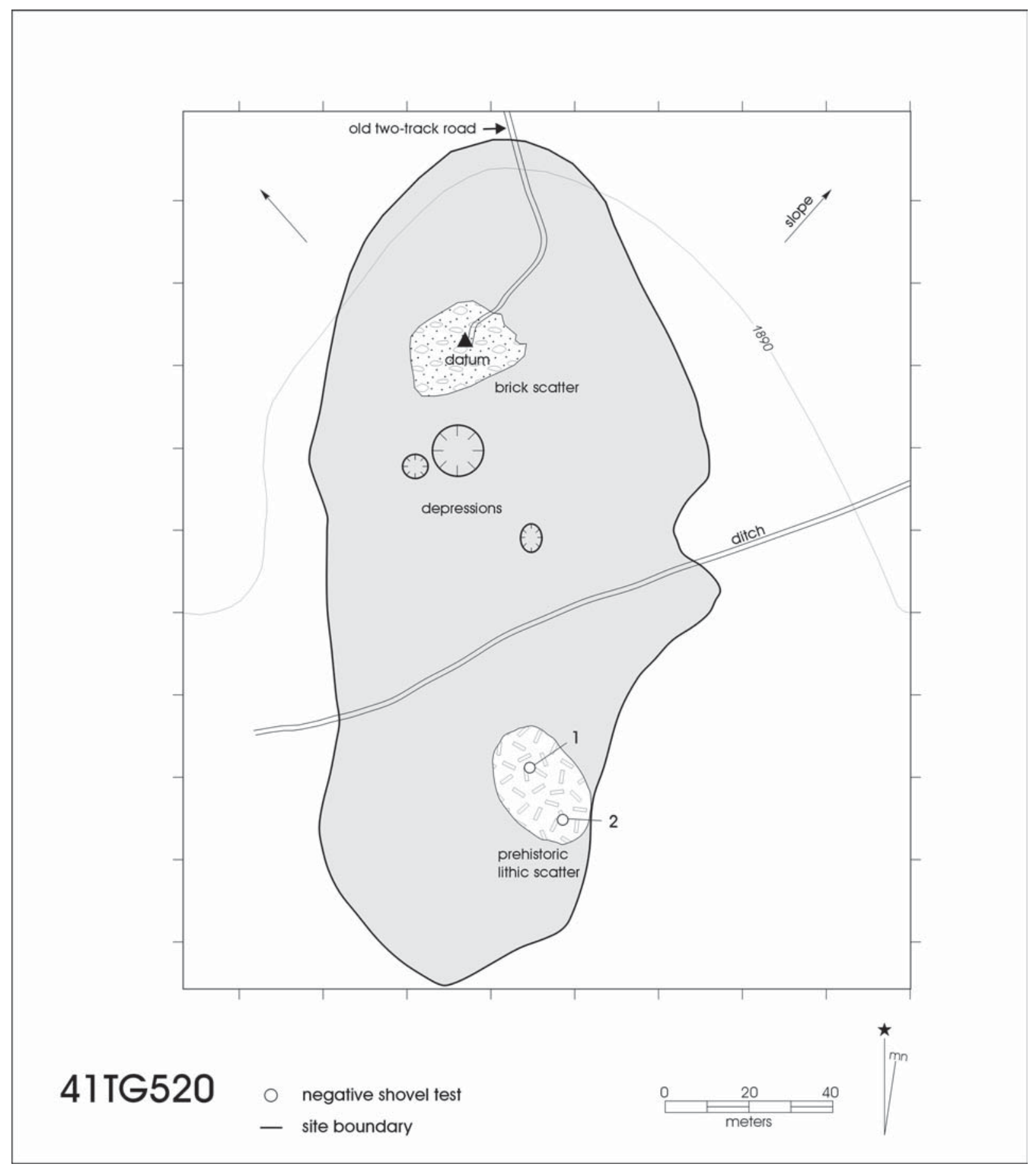

Figure 11-21. Site map of 41TG520. 
northern portion of the site appears to be the remains of a structure. Some of the bricks had remnants of mortar and some had been heavily burned after they were initially fired, suggesting they were part of a fireplace. Behind the structure are three depressions, the deepest and largest being about two feet deep, with historic artifacts scattered mainly north of an abandoned irrigation ditch that cuts through the site (Figure 11-21). An old fence line runs perpendicular to the ditch. There were no structural remains or artifacts associated with the depressions that could provide a clue as to their intended use.

\section{Artifact Analysis}

Historic artifacts observed on the surface include rusted two-gallon buckets, and a steel barrel ring. Construction items found were concrete chunks, a red brick fragment with the letters "..NE", and a few yellow bricks with mortar and the letters "..D.F; ..G; and ...UIS", and a red brick with the letters "LAOLEDE KING, ST> LOUIS." Laolede King brick was manufactured by the Laolede-Christy Clay Products Company in St. Louis, Missouri between 1904 and 1942 (Gurke 1987:83, 258-259).

Household related items were brown and white stoneware sherds, whiteware sherds, and an enamel-coated wash basin. Glass fragments at the site include a clear cork neck, a green quart jar, a Ball sauce bottle, a purple cork necked perfume bottle, and a thick lantern base. Two license plates were found with the letters and symbols as follows:

the first reads...

"Oi90 ${ }^{7} \mathbf{1}$ Texas-1928,"

and the second reads...

"Texas 193782 *FARM* 891."

\section{Site Summary}

The 1923-1924 map showing a structure at this location along with two license plates from 1928 and 1937, and the red brick made between 1904 and 1942 are all temporally associated with the assemblage of glass found at this site. Available land ownership maps indicate that the property owner during this time period was Phil Kurzenocker (Appendix L). The research value of the historic component is considered minimal as a single entity, however its value increases moderately when considered in context with other historic farmstead and industrial operations within the San Angelo/Twin Buttes area. It is recommended that additional archival investigations be undertaken to investigate the activities that occurred at the site, and to evaluate the site's impact on the economic and demographic development in the area. 


\section{$41 \mathrm{TG} 521$}

\section{Description and Discoveries}

This abandoned dairy farm operation is on a gently sloping, broad upland area above Spring Creek (Figure 11-1) with many large, mature mesquite and cedar trees. Concrete remains from the main house, an outhouse, and another outbuilding still remain, along with a cistern (Figure 11-22), concrete cattle troughs, and a trash dump (Figure 11-23). An abandoned railroad grade spur lies about 150 feet west of the structures.

\section{Artifact Analysis}

A large trash dump northwest of the structures contains hundreds of rusted metal cans, and clear and brown glass sherds. A few scraps of metal and glass sherds are also scattered across the site. All of the trash appears to represent ca. 1930s through 1950s refuse.

\section{Site Summary}

A single structure appears at this location identified as the Leedale Ranch on a 1923-1924 topographic survey map of the area, and the 1984 Knickerbocker USGS quad map shows three structures. These later structures are likely the concrete slabs found during the current survey. Mr. Hector Garcia of the Bureau of Reclamation Office in Oklahoma City has indicated that the structures had been bulldozed within the past ten years. This property, known as the Keyes Dairy, is managed by the San Angelo Nature Center, and a wetlands area has been developed nearby. A date of 1941 is inscribed on one of the concrete bases. The research value of this site is considered minimal as a single entity, however its value increases moderately when considered in context with other historic farmsteads and agricultural operations within the San Angelo/ Twin Buttes area. It is recommended that additional archival investigations be undertaken to determine the extent of the dairy operation at this site, and its impact on the economic and demographic development of the area.

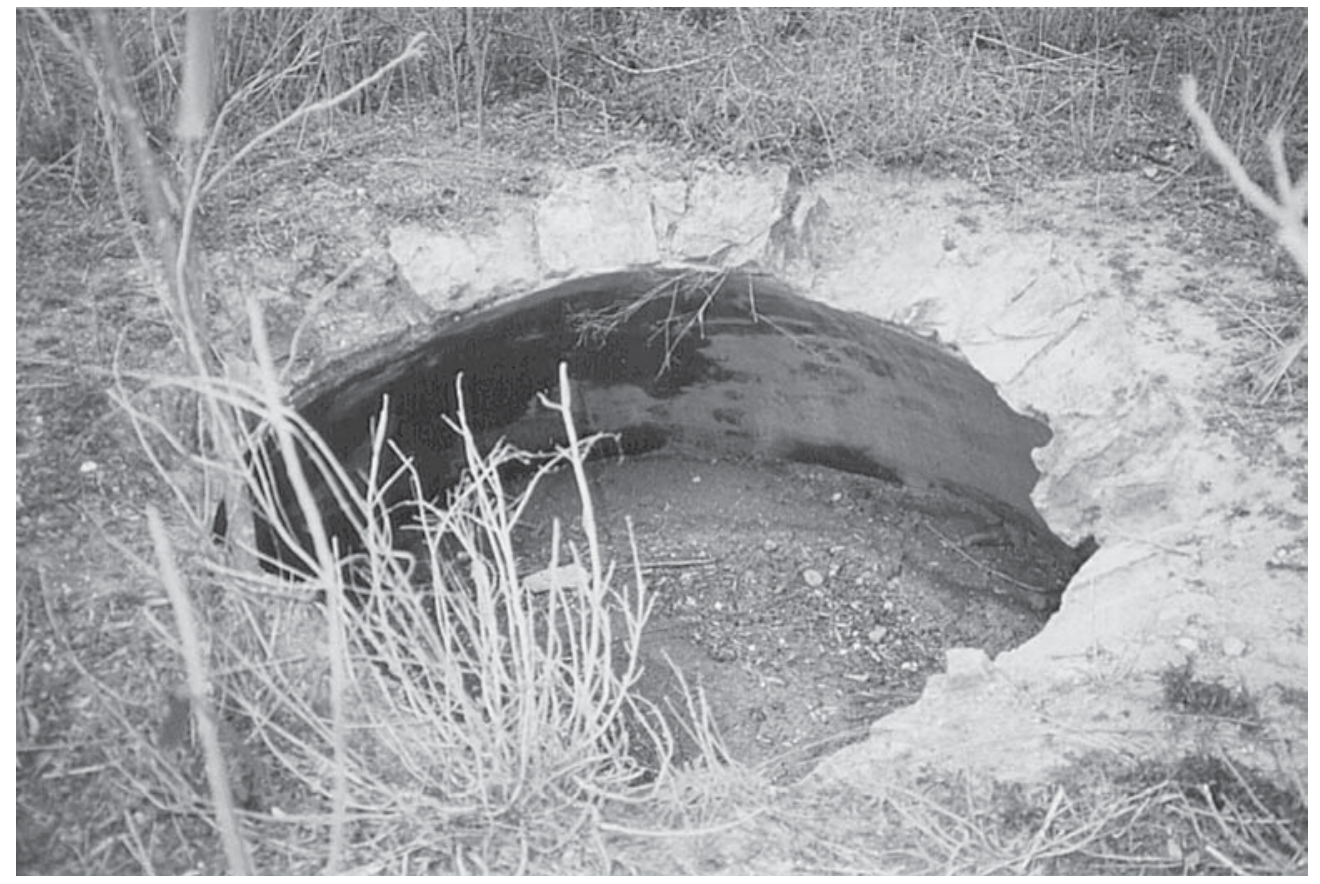

Figure 11-22. Cistern at the Keyes Dairy (41TG521). 


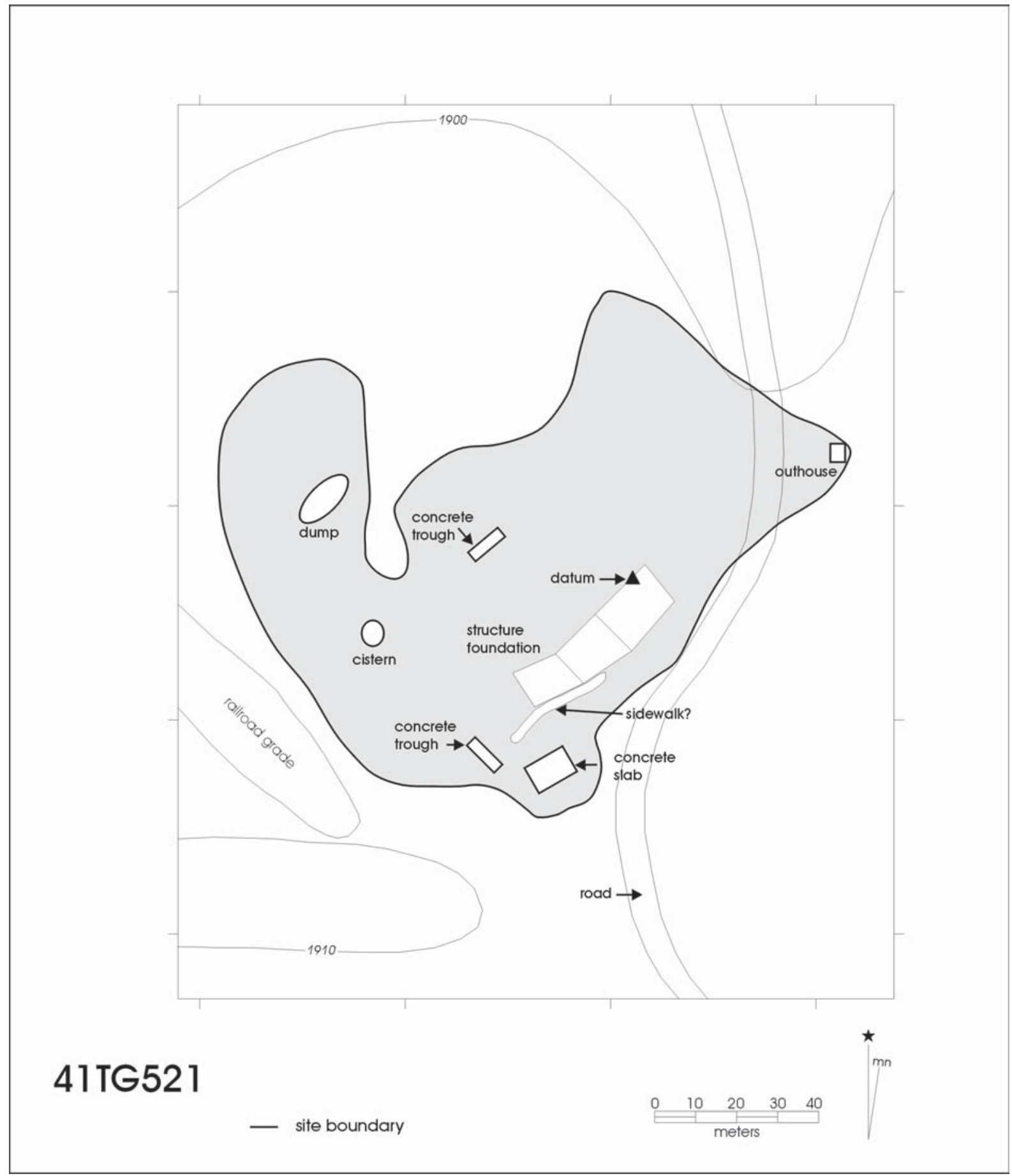

Figure 11-23. Site map of 41TG521. 


\section{TG523}

\section{Description and Discoveries}

The site of this cattle operation sits on a small, low knoll on a broad, gently sloping finger ridge overlooking an upper terrace of Spring Creek (Figure 11-1).
Some large, mature mesquite trees are surrounded by a recent understory of small cedar trees, assorted cacti, and sparse grasses. The main structural concrete slab is on the highest elevation of the site, with an earthen mound to the southwest, and below-ground concrete holding tanks farther southwest beyond the mound.

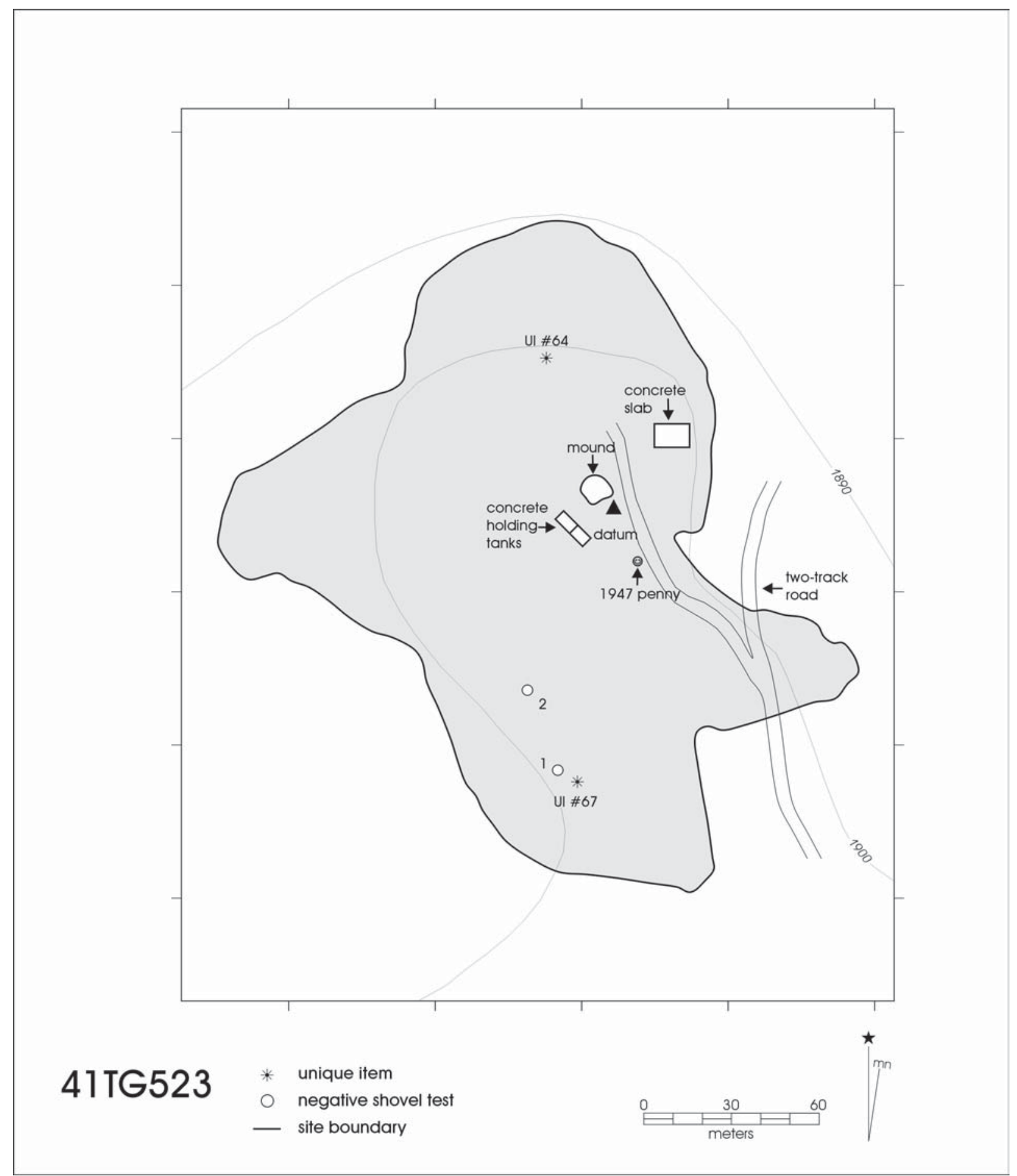

Figure 11-24. Site map of 41TG523. 
A two-track drive runs into the site (Figure 11-24). The site is also the location of a probable Late Paleoindian or Early Archaic Native American occupation (see Appendix A).

\section{Artifact Analysis}

Historic artifacts observed on the surface include a 1947 penny, found on the driveway leading to the earthen mound. Metal fragments and mostly clear glass were scattered around the larger concrete slab. The general absence of household-related artifacts suggests that the activities conducted at this site were primarily agricultural and not residential.

\section{Site Summary}

A review of the available land ownership and topographic maps for the area provides no indication that a structure existed at this location, suggesting it may have been a barn rather than a residence. Available land ownership maps indicate that the site is located on property belonging to Phil Kurzenocker in 1947. By 1959 the property had subsequently been transferred to J. F. Key. It is most likely that the activities at this site are related to the Keyes Dairy (41TG523). The research value of this site is considered minimal as a single entity, however its value increases moderately when considered in context with other farming and cattle operations in the area. It is recommended that additional archival research be undertaken to determine the scope of activities that occurred at the site, and to evaluate their impact upon the economic and demographic development of the San Angelo/ Twin Buttes area.

\section{Summary and Conclusions}

Although the archaeological and archival investigations conducted during this project were very limited, the nineteen historic sites recorded or revisited provide some insight into the settlement and development of the Twin Buttes area during the latter part of the nineteenth century, through about 1960 . As in prehistoric times, one of the major attractions of the area for new settlers were the reliable sources of water. With reliable water and the fertile soils along the drainages, early ranching and farming activities should have dominated the number and types of sites recorded.

Admittedly problematic because of limited archaeological investigations and artifact analysis, and the fact that some sites are under the reservoir and thus not part of the overall study, Table 11-6 has been created from the available information in the preceding section. A more thorough joint archival and archaeological investigation should be conducted to validate or invalidate the estimated dates shown.

A review of Table 11-6 shows the development along the three major drainages by site type. It appears that the earliest occupation in the area, possibly 1860 , may have been just above Spring Creek, with the excavation of a dugout and the construction of an adjacent pier and beam structure. The valley along Spring Creek apparently developed little until the 1880 s with a single farmstead in operation. The construction of White's dam (41TG253) across Spring Creek apparently sparked more interest in developing the area, and by 1920 there were at least two more farmsteads, a dairy farm, and a cattle operation while a gravel quarry was also operating in the valley.

Perhaps the earliest permanent occupation on the South Concho (within the survey area) took place at 41TG513 (Figure 11-1) where glass, rifle cartridges, and other artifacts were found around a sandstone structure. Even if the sandstone structure is of a later period of construction, the age and type of artifacts suggest a residence of some sort was likely in the immediate area, dating to around 1870 . The South Concho valley developed slowly, with only one farmstead recorded before 1900 . However, as with the Spring Creek valley, an irrigation dam across the South Concho (Gardner's Dam) must have sparked an 
interest in moving into the area. It is surmised that other farmstead occupants in the valley, but outside the Twin Buttes survey area, created a demand for the construction of a schoolhouse (41TG504) perhaps as early as 1900 to educate children in the surrounding area. The relative absence of either residential, agricultural, or industrial sites found on the South Concho which would initially date after 1900 suggests that the area remained predominately grazing range.
A single farmstead found along the Middle Concho suggests that this valley area was permanently occupied historically around 1880 and slowly developed, so that by 1900 a second family moved into the area. It appears that around 1920, the Panhandle and Santa Fe Railway Company built some sort of rail station (41TG501) just upstream from the present-day Twin Buttes Dam, and by 1940 two other farming and ranching families had taken up residence.

Table 11-6. Surmised development in the Twin Buttes Reservoir survey area

\begin{tabular}{|c|c|c|c|}
\hline Drainage & $\begin{array}{l}\text { Site \# } \\
(41 T G \quad)\end{array}$ & Site Type & $\begin{array}{l}\text { Earliest-Surmised } \\
\text { Occupation }\end{array}$ \\
\hline Middle Concho & 412 & Farmstead & 1880 \\
\hline Middle Concho & 344 & Farmstead & 1900 \\
\hline Middle Concho & 501 & Railroad-related & 1920 \\
\hline Middle Concho & 458 & Farmstead & 1925 \\
\hline Middle Concho & 459 & Trash Dump & 1930 \\
\hline Middle Concho & 419 & Farming Operation & 1940 \\
\hline South Concho & 513 & Sandstone Structure, Artifacts & 1870 \\
\hline South Concho & 160 & Farmstead & 1880 \\
\hline South Concho & 248 & Irrigation Diversion Dam & 1883 \\
\hline South Concho & 504 & Schoolhouse & 1900 \\
\hline Spring Creek & 443 & Dugout & 1860 \\
\hline Spring Creek & 445 & Farmstead & 1880 \\
\hline Spring Creek & 253 & Irrigation Diversion Dam & 1885 \\
\hline Spring Creek & 452 & Gravel Quarry Operation & 1920 \\
\hline Spring Creek & 516 & Farmstead & 1920 \\
\hline Spring Creek & 520 & Farmstead & 1920 \\
\hline Spring Creek & 521 & Dairy Farm & 1920 \\
\hline Spring Creek & 523 & Cattle Operation & 1920 \\
\hline Spring Creek & 450 & Farming Operation & 1930 \\
\hline
\end{tabular}





\title{
Chapter 12: Summary and Recommendations
}

\author{
Raymond Mauldin and David Nickels
}

This chapter provides a brief summary of the Twin Buttes Archaeological Project. We include recommendations, based on our assessment of the research potential, for all 199 archaeological sites. We also include a short discussion of management issues relevant to the archaeological data base at Twin Buttes Reservoir.

\section{Project Summary}

In November 1998, the Center for Archaeological Research (CAR), The University of Texas at San Antonio (UTSA) contracted with the United States Department of the Interior, Bureau of Reclamation to conduct a Class III archaeological survey of 10,195 acres (4125 ha) within Twin Buttes Reservoir in westcentral Tom Green County, Texas. The Twin Buttes survey was undertaken to meet requirements under Sections 106 and 110 of the National Historic Preservation Act (NHPA). Under Sections 106 and 110 of the NHPA, the protection of cultural resources is related to their eligibility for inclusion in the National Register of Historic Places (NRHP), which is in turn dependent on their NRHP significance as defined in 36 CFR 60.

The present survey, which was primarily a Section 110 effort, was conducted in conjunction with repair of existing seepage at Twin Buttes Dam. The repair, conducted under the Safety of Dams program, involved the construction of several borrow pits. Since the Safety of Dams repair required the Bureau of Reclamation to inventory several areas of the reservoir lands under Section 106 of the NHPA, it was decided to expand the Section 106 work, and do the entire Section 110 survey. That is, the Safety of Dams project triggered the decision to start the total inventory within Twin Buttes Reservoir.

\section{Project Results}

The survey identified a total of 199 sites, 178 of which were not previously recorded. As outlined in Chapter 6, CAR also conducted a limited surface collection strategy focused on temporally diagnostic artifacts, field analysis of over 21,000 artifacts on 97 selected sites, 1058 shovel tests and 57 auger tests on 187 sites, 48 shovel tests off-site, five 1-x-1-meter hand-excavated units on four sites, and 10 backhoe trenches. The project also recorded a total of 393 isolated finds. Volumes 2 and 3 of this report provide a series of appendices which thoroughly document the activities conducted on all prehistoric components, as well as site descriptions for all prehistoric sites (Appendix A), shovel test data (Appendix B), excavation summaries (Appendix C), site artifact observation data (Appendix D), metric data on bifaces collected and observed on the project (Appendix E), unique items collected (Appendix F), data on isolated finds (Appendix G), radiocarbon data sheets (Appendix $\mathrm{H}$ ), backhoe trench profile descriptions (Appendix I), data on paleomagnetic and soil susceptibility (Appendix J), examples of all project forms (Appendix K), and historic land ownership information (Appendix L).

\section{Recommendations and Management Considerations}

While recommendations regarding the eligibility of sites to the NRHP were not required by the survey contract, we provide an assessment of the research potential of the 199 sites recorded during the project. Though provided for information and planning purposes only, the discussion is framed by considering criterion D of 36 CFR 60 . Sites are assessed for their potential to yield information important in prehistory 
or history. The question of what information is important, a point not addressed in the NRHP, is a function of research questions. Research questions are constantly evolving as theoretical positions change and methods for investigating those theoretical positions are developed and refined. For example, the presence of burned seeds in a feature had a different relevance in 1949, prior to the development of radiocarbon dating and the widespread use of flotation techniques to assess subsistence, than in 2000.

In light of the certainty that research methods and theoretical understanding will evolve, our assessment of research potential is primarily based on the physical integrity of sites. If deposits are significantly mixed by physical processes, the potential of the assemblage to answer commonly asked questions is frequently seen as degraded. While in part this vision of the archaeological record reflects on our ability to ask questions as well as on our level of methodological sophistication, it is also an outgrowth of a position that views integrity as a dichotomy; sites either have it or they do not. We suggest that integrity, and by extension, the research potential of a location, is more productively viewed as a continuum. As argued in
Chapter 7, there is no such thing as a "pristine" site. With sufficient temporal resolution, it is probably the case that all sites or assemblages are mixed by physical processes. Different levels of integrity are relevant for addressing different research questions. Nevertheless, sites with high physical integrity are more likely to have data sets that are potentially relevant to addressing a wider variety of research questions, regardless of the theoretical position and methodological sophistication of a researcher. A consideration of Chapter 2, which outlined specific examples of impacts to the physical integrity of the Twin Buttes data base, could easily lead to the conclusion that the vast majority of sites in the reservoir lack physical integrity and therefore have limited research potential. We demonstrated in Chapters 8 and 9 that in spite of these disruptions, a great deal of information relevant to understanding the archaeological record can be gathered from surface data within the reservoir boundaries. Nevertheless, to the degree that we rely simply on physical integrity of surface data, the vast majority of sites in the reservoir do lack physical integrity. Therefore, we rely primarily on our shovel and auger test data to assess the physical integrity and, by definition, the research potential of the sites.

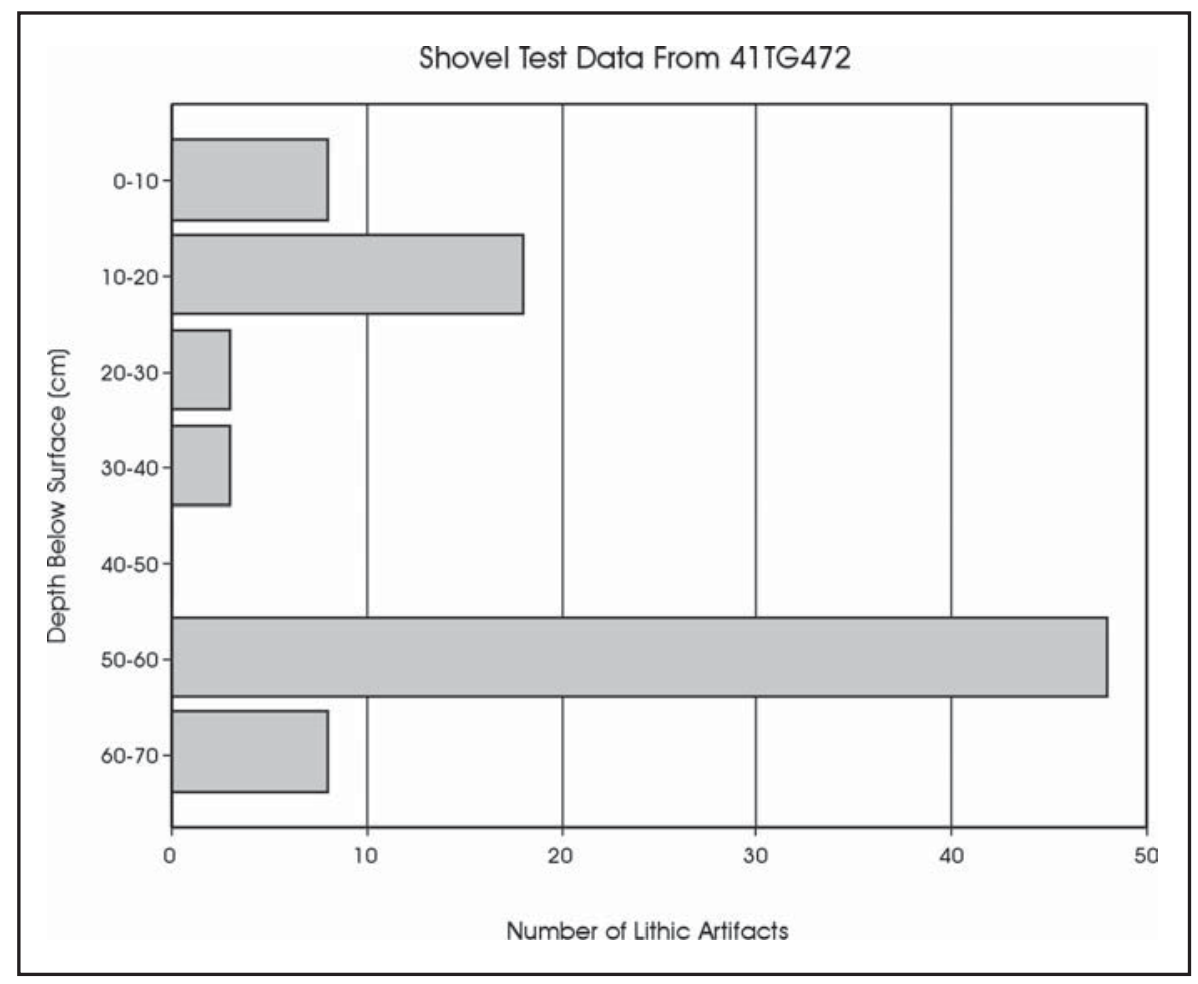

Figure 12-1. Vertical Distribution of Shovel Test Results from $41 T G 472$.
Figure 12-1 presents an example of shovel test results for site 41TG472. Clearly suggested by the graph are two components, one around $10-20 \mathrm{~cm}$ below surface, and a second component at $50-60 \mathrm{~cm}$ below surface. In this case, there is a clear separation between the components produced by a lack of material in the $40-50 \mathrm{~cm}$ level. Cases, such as this, where relatively discrete, buried occupations are present, are considered to have high research potential. Of course, simply because a deposit is buried does not mean that the deposits possess high physical integrity. All sites were, at one time, surface sites. The distributional data seen in Figure 12-1 provide 
no information on the nature or rate of burial, information on the possible exposure and reburial of the deposits, or data on other processes that may reduce the physical integrity of the occupation. Nevertheless, sites with high physical integrity are more likely to be found in buried contexts, and such sites are more likely to have artifactual and feature data that are relevant to addressing a wider variety of current research questions.

\section{Historic Sites/Components}

As discussed in Chapter 11, 19 historic components were identified on the survey. These sites primarily reflect farming, ranching, and associated activities most likely dating between 1860 and 1950. Recommendations for these components were developed in Chapter 11, and are summarized in Table 12-1. Of the 19 components, 13 have moderate or high research potential. Additional archival research should exhaust the research potential of 10 of these cases. Only in three cases, 41TG443, 41TG459, and 41TG513 is additional fieldwork suggested. The research value of the six remaining historic components has been exhausted through our recording, archival research, and shovel tests. No additional work is recommended for these cases.

\section{Prehistoric Sites/Components}

A total of 192 prehistoric archaeological sites/components are present in the Twin Buttes data base. The sites reflect occupation from the early Paleoindian period through the Late Prehistoric period. Complete descriptions of these sites are available in Appendix A, along with suggestions for site specific levels of effort necessary to investigate the research potential of those properties that we suggest have moderate or high research potential.

Table 12-2 presents 48 sites with high research potential. As noted above, our characterization of high research potential is based on the observation of some systematic patterning in the shovel and auger tests. While multiple levels and clear separation, such as evidenced in Figure 12-1, are not present in all cases, the shovel test data suggest that at least one buried component is present in these cases.

Table 12-1. Recommended Research Potential for Historic Sites/Components

\begin{tabular}{|c|c|c|c|}
\hline Site Number & Research Potential & Site Number & Research Potential \\
\hline 41TG160 & Minimal & $41 \mathrm{TG} 458$ & Minimal \\
\hline 41TG248 & Moderate & $41 \mathrm{TG} 459$ & Moderate \\
\hline $41 \mathrm{TG} 253$ & Moderate & 41TG501 & Moderate \\
\hline $41 \mathrm{TG} 344$ & Minimal & 41TG504 & Moderate \\
\hline 41TG412 & Moderate & $41 \mathrm{TG} 513$ & High \\
\hline 41TG419 & Moderate & 41TG516 & Moderate \\
\hline $41 \mathrm{TG} 443$ & High & 41TG520 & Moderate \\
\hline $41 \mathrm{TG} 445$ & Minimal & 41 TG521 & Moderate \\
\hline 41TG450 & Minimal & 41 TG523 & Moderate \\
\hline $41 \mathrm{TG} 452$ & Minimal & & \\
\hline
\end{tabular}


Table 12-3 presents 33 sites with moderate research potential. Shovel test results from these sites suggest the possibility that buried deposits are present. This potential can only be addressed with additional systematic testing, involving a combination of shovel tests and 1-x-1-meter excavation units.

Finally, Table 12-4 presents 111 sites with limited research potential. These sites either lack subsurface material, or lack any systematic pattern in the limited subsurface deposits encountered. In 51 cases, we have detailed quantitative data collected from these sites, and in all cases we have observations on features and qualitative observations on artifact types present. Given the level of surface recording and the lack of systematic patterning in subsurface features, we suggest that the data potential of these 111 sites is limited. We do not recommend any additional work on these sites.

In summary, a total of 81 prehistoric sites have high and moderate research potential, while 111 sites have limited research potential. We would recommend that the 80 prehistoric sites with high and moderate research potential be investigated to determine their eligibility status with regard to the NRHP. Specific levels of effort are suggested in Appendix A on a site-by-site basis. Of the 19 historic components, six have limited research potential, with the remaining 13 components having moderate or high research potential. In most

Table 12-2. Prehistoric Sites/Components With High Research Potential

\begin{tabular}{|c|c|c|}
\hline Site Num ber & Site Num ber & Site Num bers \\
\hline 41TG91 & 41TG409 & $41 \mathrm{TG} 485$ \\
\hline 41TG106 & 41TG410 & $41 \mathrm{TG} 487$ \\
\hline $41 \mathrm{TG} 159$ & $41 \mathrm{TG} 411$ & $41 \mathrm{TG} 489$ \\
\hline 41TG367 & 41TG412 & 41TG499 \\
\hline 41TG372 & 41TG424 & 41TG500 \\
\hline $41 \mathrm{TG} 373$ & 41TG426 & 41TG502 \\
\hline 41TG374 & 41TG427 & 41TG504 \\
\hline 41TG377 & 41TG429 & 41TG506 \\
\hline 41TG382 & $41 \mathrm{TG} 437$ & 41TG509 \\
\hline 41TG384 & 41TG438 & $41 \mathrm{TG} 513$ \\
\hline $41 \mathrm{TG} 388$ & $41 \mathrm{TG} 447$ & 41TG516 \\
\hline 41TG389 & 41TG449 & 41TG519 \\
\hline 41TG394 & 41TG454 & $41 \mathrm{TG} 523$ \\
\hline $41 \mathrm{TG} 401$ & $41 \mathrm{TG} 457$ & 41TG525 \\
\hline 41TG403 & 41TG464 & 41TG531 \\
\hline 41TG406 & $41 \mathrm{TG} 472$ & 41TG534 \\
\hline
\end{tabular}


of these 13 cases, additional archival work should exhaust the research potential of the sites. Finally, the information potential of all 393 isolated finds has been exhausted through our recording.

\section{Management Considerations}

As summarized in Chapter 2, a variety of processes impact the physical integrity of the deposits at Twin Buttes. Two of the major impacts are associated with erosional and depositional processes related to fluctuating lake levels, and collateral impacts associated with the use of the reservoir for recreational activities. Little can be done regarding fluctuating water levels in this naturally fed reservoir, and even if reservoir height could be raised and maintained, restricting the damage caused by shoreline erosion, the problem associated with off-shore erosion would render such a management strategy less than ideal. However, it may be possible to lessen the impact of recreational use through a coordinated educational effort.

While collateral damage to sites certainly occurs as a result of illegal dumping, many of the problems for the integrity of the archaeological sites revolve around

Table 12-3. Prehistoric Sites/Components With Moderate Research Potential

\begin{tabular}{|c|c|}
\hline Site Number & Site Number \\
\hline 41TG109 & $41 \mathrm{TG} 453$ \\
\hline 41TG244 & $41 \mathrm{TG} 455$ \\
\hline 41TG252 & $41 \mathrm{TG} 460$ \\
\hline $41 \mathrm{TG} 253$ & 41TG461 \\
\hline 41TG362 & 41TG462 \\
\hline $41 \mathrm{TG} 375$ & $41 \mathrm{TG} 467$ \\
\hline 41TG391 & 41TG471 \\
\hline 41TG399 & $41 \mathrm{TG} 474$ \\
\hline 41TG402 & 41TG486 \\
\hline 41TG405 & 41TG488 \\
\hline 41TG414 & 41TG491 \\
\hline $41 \mathrm{TG} 415$ & 41TG492 \\
\hline $41 \mathrm{TG} 416$ & $41 \mathrm{TG} 496$ \\
\hline 41TG433 & 41TG510 \\
\hline 41TG436 & 41TG524 \\
\hline $41 \mathrm{TG} 439$ & 41TG526 \\
\hline 41TG441 & \\
\hline
\end{tabular}


track damage associated with off-road vehicles and artifact collection. An example of the impact of offroad vehicles on archaeological sites can be seen in Figure 12-2, a series of photos of site 41TG502. The site was defined in November of 1999 and was restricted to the exposed ridge. A total of five hearths and a dense scatter of archaeological material, especially along the edges of the ridge, was present. The top photo in the figure was taken in November, shortly after the site was exposed by receding water. Note that minimal tire tracks are visible in the photo, although some damage is present in one area where, as the result of a vehicle being stuck, excavation had occurred. At the time of the photo, CAR archaeologists

Table 12-4. Archaeological Sites With Limited Research Potential

\begin{tabular}{|c|c|c|c|c|}
\hline Site Number & Site Number & Site Number & Site Number & Site Number \\
\hline 41TG105 & $41 \mathrm{TG} 371$ & $41 \mathrm{TG} 418$ & 41TG465 & 41TG505 \\
\hline 41TG110 & $41 \mathrm{TG} 376$ & $41 \mathrm{TG} 419$ & 41TG466 & 41TG507 \\
\hline 41TG117 & 41TG378 & $41 \mathrm{TG} 420$ & 41TG468 & 41TG508 \\
\hline 41TG118 & $41 \mathrm{TG} 379$ & $41 \mathrm{TG} 421$ & 41TG469 & 41TG511 \\
\hline 41TG160 & 41TG380 & $41 \mathrm{TG} 422$ & $41 \mathrm{TG} 470$ & 41TG512 \\
\hline $41 \mathrm{TG} 243$ & 41TG381 & $41 \mathrm{TG} 423$ & $41 \mathrm{TG} 473$ & 41TG514 \\
\hline $41 \mathrm{TG} 245$ & $41 \mathrm{TG} 383$ & $41 \mathrm{TG} 425$ & $41 \mathrm{TG} 475$ & 41TG515 \\
\hline $41 \mathrm{TG} 246$ & 41TG385 & 41TG428 & $41 \mathrm{TG} 476$ & 41TG517 \\
\hline $41 \mathrm{TG} 247$ & 41TG386 & $41 \mathrm{TG} 430$ & $41 \mathrm{TG} 477$ & 41TG518 \\
\hline 41TG249 & $41 \mathrm{TG} 387$ & 41TG431 & 41TG478 & 41TG520 \\
\hline $41 \mathrm{TG} 250$ & 41 TG390 & $41 \mathrm{TG} 432$ & $41 \mathrm{TG} 479$ & 41TG522 \\
\hline $41 \mathrm{TG} 251$ & 41TG392 & 41TG434 & $41 \mathrm{TG} 480$ & 41TG527 \\
\hline 41TG344 & $41 \mathrm{TG} 393$ & $41 \mathrm{TG} 435$ & $41 \mathrm{TG} 481$ & 41TG528 \\
\hline 41TG359 & 41TG395 & 41TG440 & $41 \mathrm{TG} 482$ & 41TG529 \\
\hline $41 \mathrm{TG} 360$ & 41TG396 & 41TG442 & 41TG483 & 41TG530 \\
\hline 41TG361 & 41TG397 & $41 \mathrm{TG} 443$ & 41TG484 & 41TG532 \\
\hline $41 \mathrm{TG} 363$ & 41TG398 & $41 \mathrm{TG} 444$ & $41 \mathrm{TG} 490$ & 41TG533 \\
\hline 41TG364 & 41TG400 & $41 \mathrm{TG} 445$ & $41 \mathrm{TG} 493$ & 41TG535 \\
\hline $41 \mathrm{TG} 365$ & $41 \mathrm{TG} 404$ & $41 \mathrm{TG} 446$ & $41 \mathrm{TG} 494$ & 41TG540 \\
\hline 41TG366 & 41TG407 & 41TG448 & 41TG495 & \\
\hline 41TG368 & 41TG408 & $41 \mathrm{TG} 451$ & 41TG497 & \\
\hline 41TG369 & $41 \mathrm{TG} 413$ & $41 \mathrm{TG} 456$ & 41TG498 & \\
\hline $41 \mathrm{TG} 370$ & $41 \mathrm{TG} 417$ & $41 \mathrm{TG} 463$ & 41TG503 & \\
\hline
\end{tabular}



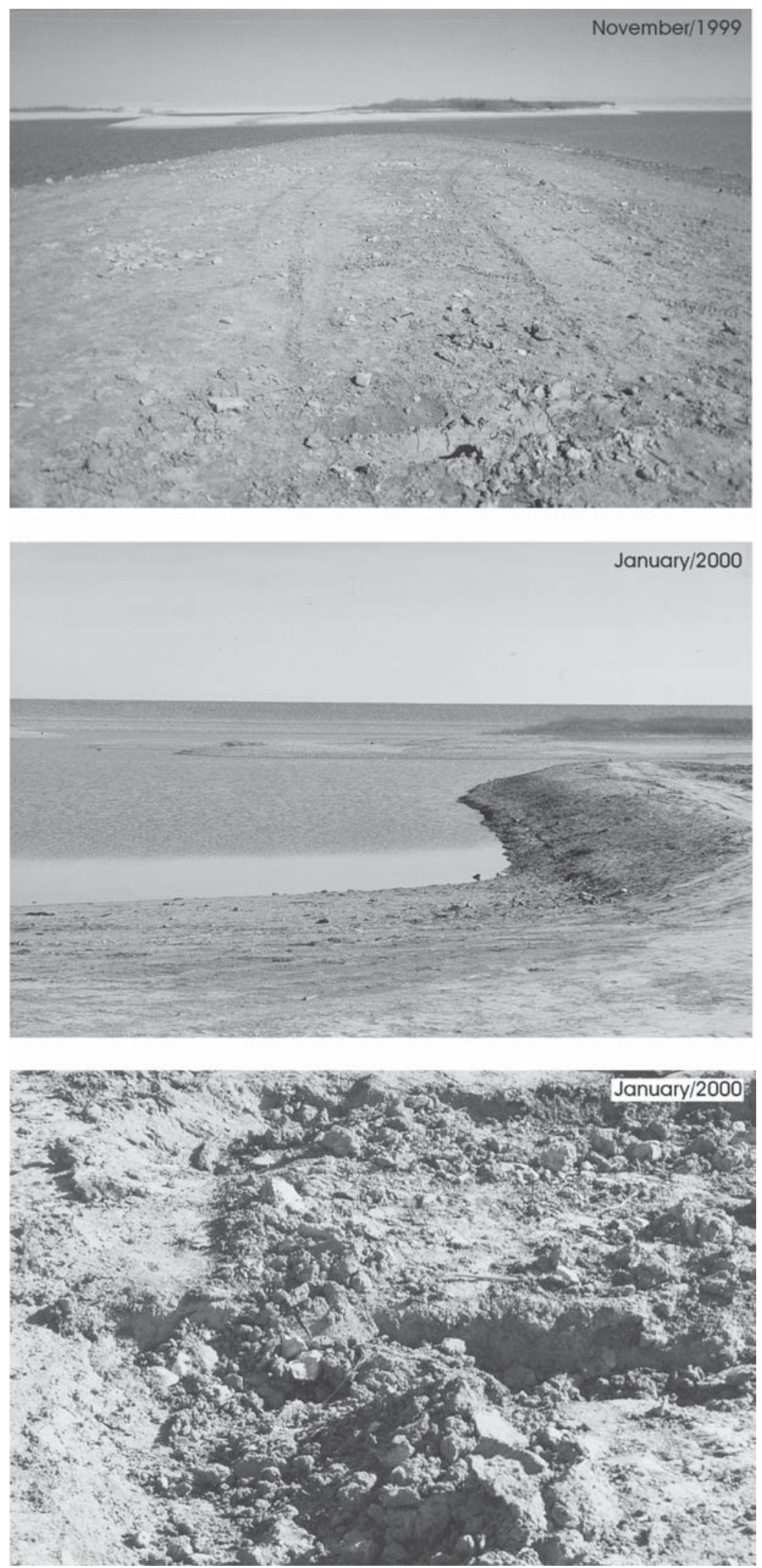

Figure 12-2. Photographs of site 41 TG502 (November, 1999; January, 2000). 
recorded five features and placed a datum in the center of the ridge. The middle and bottom photos were taken in January of 2000. Note the well-developed road surface down the center of the ridge, and the extensive damage caused to one section of the site as a result of several vehicles being mired in the mud. In January, no discrete hearth features were visible, although scattered fire-cracked rock was present. The datum, established two months earlier, was no longer present. The site surface was littered with the remains of fireworks and small, recent fires. In short, substantial damage had been inflicted on the site in a short period of time.

While recreational use will certainly continue to cause damage to archaeological sites, coordinated educational efforts to inform the general public regarding the extant resources and their protected status under federal law, may help reduce some of the impacts. Discussions conducted with individuals in the area suggest that many are unaware that the collection of artifacts from the reservoir is illegal. Minimally, we would suggest that signs, noting that the collection of artifacts from federal property is an illegal and punishable offense, be posted at all entrances. It is likely that these would have to be replaced frequently. In addition, we would suggest that a popular summary of the results of this survey be developed. This summary, modeled on one recently produced by CAR (see Nickels et al. 1998b), could be distributed to grade schools and interested individuals in the area. Such a summary could be designed to inform the public of the existence of the prehistoric and historic resources, stress the importance of maintaining the data base, and outline on-going management and research efforts. Finally, we would suggest the develop a web site for the archaeological material within the reservoir. Minimally, the web site should be cross-referenced to the popular publication, as well as to other links and literature dealing with archaeology and preservation. While this combined effort will certainly not eliminate the on-going damage to the sites, it may help reduce the level of their impacts. Ultimately, some level of testing will be required to thoroughly assess the resources at the 81 prehistoric sites, and develop mitigation procedures for those occupations with significant data. 


\section{References Cited}

Adkins, L., and R. A. Adkins

1982 A Thesaurus of British Archaeology. David and Charles, London.

Afifi, A. A., and V. Clark

1984 Computer-Aided Multivariate Analysis. Wadsworth, Toronto.

Alexander, H. L.

1963 The Levi Site: A Paleo-Indian Campsite in Central Texas. American Antiquity 28:510-528.

1983 The Pre-Clovis and Clovis Occupations at the Levi Site. In Peopling of the New World, edited by J. E. Ericson, R. E. Taylor, and R. Berger, pp. 133-145. Ballena, Los Altos, California.

Alley, W. M.

1984 The Palmer Drought Severity Index: limitations and assumptions. Journal of Climate and Applied Meteorology 23:1100-1109.

Aten, L. E.

1979 Indians of the Upper Texas Coast: Ethnohistoric and Archaeological Frameworks. Unpublished Ph.D. dissertation, Department of Anthropology, The University of Texas at Austin.

Atterbury, P. J. (editor)

1979 European Pottery and Porcelain. Mayflower Books, Inc., New York.

Banks, K., and J. T. Bagot

1975 Archeology of the Willow Creek Watershed. Archeology Research Program, Department of Anthropology, Southern Methodist University, Dallas.

Barber, E. A.

1976 The Pottery and Porcelain of the United States and Marks of American Potters. Feingold and Lewis, New York.

Barger, M. E.

1980 Cultural Resource Survey of the Proposed Fencing at Twin Buttes Project, Texas. Report on file at the Bureau of Reclamation, Southwest Region, and at the office of the Texas State Historic Preservation Officer, Austin, Texas.

Barnes, D. A.

1998 "Undercurrent Stabilizer System," Shore Stabilization/Accretion Demonstration Project. Florman Study Site: Onekema, MI. Interim Report of 1995-1997 Surveys.

<http://GEOSERV.GEOLOGY.WMICH.EDU/d...flr_report_html/flr_report_W98.htm> May 28, 1999

Barnes, V. E.

1975 Geologic Atlas of Texas, San Angelo Sheet. Scale 1:24,000. Bureau of Economic Geology, The University of Texas, Austin.

1992 Geologic Atlas of Texas. Scale 1:500,000. Bureau of Economic Geology, The University of Texas, Austin. 
Barton, B.

1998 Head 'em Up, Move 'em Out: Life of Richard F. Tankersley. Rangel Printing Company, San Angelo, Texas.

1997 Ruckus Along the Rivers. Rangel Printing Company, San Angelo, Texas.

Bascom W.

1980 Waves and Beaches. Anchor Books, Garden City, New York.

Baugher-Perlin, S.

1982 Analyzing Glass Bottles for Chronology, Function, and Trade Networks. In Archaeology of Urban America: The Search for Pattern and Process, edited by R. S. Dickens, Jr., pp. 258-289. Academic Press, New York.

Beiber, R. B. (editor)

1937 From Texas to the Gold Mines. In Southern Trails to California in 1849. Southwest Historical Series Vol. V, pp. 259-280. Arthur H. Clark Company, Glendale, California.

Biesele, R. L.

1987 The History of the German Settlements in Texas, 1831-1861. German-Texas Heritage Society, Southwest Texas State University, San Marcos.

Binford, L. R.

1980 Willow Smoke and Dogs' Tails: Hunter-gatherer Settlement Systems and Archaeological Site Formation. American Antiquity 45:4-20.

1982 The Archaeology of Place. Journal of Anthropological Archaeology 1:5-31.

1983 Long Term Land Use Patterns: Some Implications for Archaeology. In LuLu Linear Punctated: Essays in Honor of George Irving Quimby, edited by R. C. Dunnell and D. K. Grayson, pp. 27-53. Anthropological Papers No. 72. Museum of Anthropology, Ann Arbor.

1992 Seeing the Present and Interpreting the Past—and Keeping Things Straight. In Space, Time, and Archaeological Landscapes, edited by J. Rossignol and L. Wandsnider, pp. 43-59. Plenum Press, New York.

Bitner, G.

1931 The History of Tom Green County, Texas. Unpublished Master's Thesis presented to the University of Texas, Austin.

Black, S. L.

1986 The Clemente and Herminia Hinojosa Site, 41JW8: A Toyah Horizon Campsite in Southern Texas. Special Report No. 18. Center for Archaeological Research, The University of Texas at San Antonio.

1989a Central Texas Plateau Prairie. In From the Gulf Coast to the Rio Grande: Human Adaptation in Central, South and Lower Pecos Texas, by T. R. Hester, S. L. Black, D. G. Steele, B. W. Olive, A. A. Fox, K. J. Reinhard, and L. C. Bement, pp. 17-38. Research Series No. 33. Arkansas Archeological Survey, Fayetteville.

1989b Environmental Setting. In From the GulfCoast to the Rio Grande: Human Adaptation in The Central, South, and Lower Pecos Texas, by T. R. Hester, S. L. Black, D. G. Steele, B. W. Olive, A. A. Fox, K. J. Reinhard, and L. C. Bement, pp. 5-17. Research Series No. 33. Arkansas Archeological Survey, Fayetteville. 
1989c South Texas Plain. In From the Gulf Coast to the Rio Grande: Human Adaptation in the Central, South, and Lower Pecos Texas, by T. R. Hester, S. L. Black, D. G. Steele, B. W. Olive, A. A. Fox, K. J. Reinhard, and L. C. Bement, pp. 39-62. Research Series No. 33. Arkansas Archaeological Survey, Fayetteville.

1995 Archaeological and Historical Background. In Archaeological Investigations at the Loma Sandia Site (41LK28): A Prehistoric Campsite in Live Oak County, Texas. 2 Volumes. Studies in Archeology No. 20, pp 31-45. Texas Archeological Research Laboratory, The University of Texas at Austin.

Black, S. L., and A. J. McGraw

1985 The Panther Springs Creek Site: Cultural Change and Continuity in the Upper Salado Creek Drainage, South-Central Texas. Archaeological Survey Report, No. 100. Center for Archaeological Research, The University of Texas at San Antonio.

Black, S. L., L. W. Ellis, D. G. Creel, and G. T. Goode (editors)

1996 Hot Rock Cooking on the Greater Edwards Plateau: Four Burned Rock Midden Sites in West Central Texas. Studies in Archaeology, Review Draft. Texas Archaeological Research Laboratory, The University of Texas at Austin. Manuscript on file, Texas Archaeological Research Laboratory, Austin.

Black, S. L., K. Jolly, and D. R. Potter

1993 The Higgins Experiment: Field Report. Wurzbach Project Working Papers. Texas Archeological Research Laboratory, The University of Texas at Austin.

Blake, M. E., and M. D. Freeman

1998 Nineteenth-Century Transfer-Printed Ceramics from the Texas Coast: The Quintana Collection. Prewitt and Associates, Inc., Austin.

Blum, M. D., and Valastro, S.

1992 Quaternary Stratigraphy and Geoarchaeology of the Colorado and Concho Rivers, West Texas. Geoarchaeology 7:419-448.

Bobrowsky, P. T., and B. F. Ball

1989 The Theory and Mechanics of Ecological Diversity in Archaeology. In Quantifying Diversity in Archaeology, edited by R. D. Leonard and G. T. Jones, pp. 4-12. Cambridge University Press, New York.

Bolton, H. E.

1908 Spanish Exploration in the Southwest, 1542-1706. Scribner, New York.

1915 Texas in the Middle Eighteenth Century: Studies in Spanish Colonial History and Administration. Volume 3, University of California Publications in History, reprinted 1970. University of Texas Press, Austin, Texas.

Bousman, C. B.

1992 Preliminary Oxygen-Isotope Evidence for Late Pleistocene-Early Holocene Climatic Change. Current Research in the Pleistocene 9:78-80.

1994 The Central Texas Pollen Record: A Reinterpretation. Current Research in the Pleistocene 11:79-81.

1998 Paleoenvironmental Change in Central Texas: The Palynological Evidence. Plains Anthropologist (43)164:201-219. 
Boyd, D. K.

1989 Prehistoric Resources in Justiceburg Reservoir. In Phase I Cultural Resources Investigations at Justiceburg Reservoir on the Double Mountain Fork of the Brazos River, Garza and Kent Counties, Texas, by D. K. Boyd, M. D. Freeman, M. D. Blum, E. R. Prewitt, and J. M. Quigg, pp. 107-131. Reports of Investigations, Number 66. Prewitt \& Associates, Austin, Texas.

1995 The Palo Duro Complex: Redefining the Early Ceramic Period in the Caprock Canyonlands. Bulletin of the Texas Archeological Society 66:461-518.

Boyd, D. K., M. D. Freeman, M. D. Blum, E. R. Prewitt, and J. M. Quigg

1989 Phase I Cultural Resources Investigations at Justiceburg Reservoir on the Double Mountain Fork of the Brazos River, Garza and Kent Counties, Texas. Reports of Investigations, Number 66. Prewitt \& Associates, Austin, Texas.

Bradle, M. R., W. E. Moore, D. R. Cropper, W. A. Dickens, L. Nordt, and S. Carlson

1997 Archaeological Survey of the Proposed City of Eden Golf Course Project Concho County, Texas. American Archaeology Group. Report of Investigations 12.

Brown, D.

1998 Late Holocene Climates of North-Central Texas. Plains Anthropologist (43)164:157-172.

Brown, K. M.

1987 Early Occupation at Berger Bluff, Goliad County, Texas. Current Research in the Pleistocene 4:3-5.

Brown, M., J. E. Zapata, and B. K. Moses

1998 Camp Elizabeth, Sterling County, Texas: An Archaeological and Archival Investigation of a U. S. Army Subpost, and Evidence Supporting Its Use by the Military and "Buffalo Soldiers." Archaeological Survey Report, No. 267. Center for Archaeological Research, The University of Texas at San Antonio.

Brune, G.

1975 Major and Historic Springs of Texas. Report No. 189. Texas Water Development Board, Austin.

Bryan, F. T.

1849 Report of a Reconnaissance of a Route from San Antonio, via Fredericksburg, to El Paso, to Obtain Information in Reference to a Permanent Military Road from the Gulf of Mexico to El Paso. In Reports of the Secretary of War, $31^{\text {st }}$ Congress, $1^{\text {st }}$ Session, Executive Document No. 64, pp. 14-25.

Bryant, V. M., Jr., and R. G. Holloway

1985 Late-Quaternary Paleoenvironmental Record of Texas: An Overview of the Pollen Evidence. Pollen Records of Late-Quaternary North American Sediments, edited by V. T. Bryant, Jr., and R. G. Holloway, pp. 39-70. American Association of Stratigraphic Palynologists Foundation, Dallas.

Bryant, V. M., Jr., and H. J. Shafer

1977 The Late Quaternary Paleoenvironment of Texas: A Model for the Archeologist. Bulletin of the Texas Archeological Society 48:1-25.

Butzer, K. W.

1982 Archaeology as Human Ecology: Method and Theory for a Contextual Approach. Cambridge University Press, Cambridge, England. 
Camilli, E. L.

1988 Interpreting Long-Term Land-Use Patterns from Archaeological Landscapes. American Archaeology 7:57-66.

Campbell, T. N.

1975 The Payaya Indians of Southern Texas. Special Publications No. 1. Southern Texas Archaeological Association, San Antonio.

1983 Coahuiltecans and Their Neighbors. In Handbook of North American Indians Volume 10: Southwest, edited by A. Ortiz, pp. 343-358. Smithsonian Institution, Washington, D.C.

1991 Coahuiltecans and Their Neighbors. In Ethnology of the Texas Indians, edited by T. R. Hester. Spanish Borderlands Sourcebooks 7. Garland, New York.

Campbell, T. N., and T. J. Campbell

1981 Historic Indians of the Choke Canyon Reservoir and Surrounding Area, Southern Texas. Choke Canyon Series, No. 1. Center for Archaeological Research, The University of Texas at San Antonio.

1985 Indian Groups Associated with Spanish Missions of the San Antonio Missions National Historical Park. Special Report, No. 16. Center for Archaeological Research, The University of Texas at San Antonio.

Camper, H. A.

1991 Pollen Analysis of Patschke Bog. Unpublished MS thesis, Department of Botany, Texas A\&M University, Bryant, Texas. Data archived at the World Data Center-A for Paleoclimatology Data. NOAA/ NGDC Paleoclimatology Program, Boulder, Colorado.

Caran, S. C.

1998 Quaternary Paleoenvironmental and Paleoclimatic Reconstruction: A Discussion and Critique, with Examples from the Southern High Plains. Plains Anthropologist (43)164:111-124.

Caran, S. C., and Baumgardner, R. W.

1990 Quaternary Stratigraphy and Paleoenvironments of the Texas Rolling Plains. Geological Society of America Bulletin 102:768-785.

Carlson, P. H.

1982 Texas Woollybacks: The Range Sheep and Goat Industry. Texas A\&M University Press, College Station.

Casteñeda, C. E.

1976 Our Catholic Heritage in Texas, Vol. 1. Arno Publishing, New York.

Chatterjee, S., A. S. Hadi, and B. Price

2000 Regression Analysis by Example. Third edition, John Wiley and Sons, New York.

Chipman, D. E.

1992 Spanish Texas, 1519-1821. University of Texas Press, Austin.

Claassen, $\mathrm{C}$.

1994 Washboards, Pig Toes, and Muskets: Historic Musseling in the Mississippi Watershed. Historical Archaeology 28(2):1-145. 
Clark, J. S.

1949 History of Manufacturers in the United States, Volume III, 1893-1928. A reprint of the Carnegie Institution of Washington's 1929 edition. Peter Smith Publishing, New York.

Collins, M. B.

1975 Lithic Technology as a Means of Processual Inference. In Lithic Technology, Making and Using Stone Tools, edited by E. Swanson, pp. 17-34. Mouton Publishers, Paris.

1995 Forty Years of Archeology in Texas. Bulletin of the Texas Archeological Society 66:361-400.

Collins, M. B., C. B. Bousman, P. Goldberg, P. R. Takac, J. C. Guy, J. L. Lanata, T. W. Stafford, and V. T.

Holliday

1993 The Paleoindian Sequence at the Wilson-Leonard Site, Texas. Current Research in the Pleistocene 10:10-12.

Collins, M. B., B. Ellis, and C. Dodt-Ellis

1990 Excavations at the Camp Pearl Wheat Site (41KR243), An Early Archaic Campsite on Town Creek, Kerr County, Texas. Studies in Archeology 6. Texas Archeological Research Laboratory, The University of Texas at Austin.

Collins, M. B., G. L. Evans, T. N. Campbell, M. C. Winans, and C. E. Mears

1989 Clovis Occupation at Kincaid Rockshelter. Current Research in the Pleistocene 6:3-5.

Conley, D. C., and D. L. Inman

1992 Field observations of the fluid-granular boundary layer under near-breaking waves. Journal of Geophysical Research 97:9631-9643.

Connor, S. V.

1969 The Mendoza-Lopez Expedition and Location of San Clemente. In West Texas Historical Association Yearbook 45. San Angelo, Texas.

Cook, R. D.

1977 Detection of Influential Observations in Linear Regression. Technometrics 19:15-18.

1979 Influential Observations in Linear Regression. Journal of the American Statistical Association 74:169174.

Covey, C. (editor)

1961 Cabeza de Vaca's Adventures in the Unknown Interior of America. Collier Books, New York.

Creel, D.

1978 An Archeological Survey in the South Concho River Area, West Central Texas. Bulletin of the Texas Archeological Society 49:241-307.

1979 Survey Field notes and site reports on file with the Texas Archeological Research Laboratory, The University of Texas at Austin.

1986 A Study of Prehistoric Burned Rock Middens in West Central Texas. Unpublished Ph.D. dissertation, The University of Arizona, Tucson.

1990 Excavations at 41TG91, Tom Green County, Texas, 1978. Texas State Department of Highways and Public Transportation, Publications in Archeology No. 38. Austin, Texas. 
Creel, D., R. F. Scott IV, and M. B. Collins

1990 A Faunal Record From West Central Texas and its Bearing on Late Holocene Bison Population Changes in the Southern Plains. Plains Anthropologist 35:55-69.

de la Teja, J. F.

1988 Land and Society in 18th Century San Antonio de Bexar, A Community on New Spain's Northern Frontier. UMI, Ann Arbor.

1995 San Antonio de Bexár: A Community on New Spain's Northern Frontier. University of New Mexico Press, Albuquerque.

Dibble, D. S., and D. Lorrain

1968 Bonfire Shelter: A Stratified Bison Kill Site, Val Verde County, Texas. Miscellaneous Papers 1. Texas Memorial Museum, Austin.

Dillehay, T.

1974 Late Quaternary Bison Population Changes on the Southern Plains. Plains Anthropologist 19:180196.

Douthit, M. L.

1978 An Archeological Survey of the North Concho River Valley, Sterling County, Texas. Unpublished Ph.D. dissertation, The University of Texas at Austin.

Driver, W. D.

1994 The Lee Colburn Park Expansion Project. Archaeological Research, Inc. El Paso, Texas.

Duke, E. F.

1986 A Population Study of Tom Green County, 1880. In Historical Montage of Tom Green County, pp. 2236. Anchor Publishing, San Angelo, Texas.

1996 San Angelo, Texas. In New Handbook of Texas, Vol. 5, pp. 793-794. Texas State Historical Association, Austin.

Dunnell, R. C.

1992 The Notion of Site. In Space, Time, and Archaeological Landscapes, edited by J. Rossignol and L. Wandsnider, pp. 21-41. Plenum Press, New York.

Dunnell, R. C., and W. C. Dancey

1983 The Siteless Survey: A Regional Scale Data Collection Strategy. In Advances in Archaeological Method and Theory, vol. 6, edited by M. B. Schiffer, pp. 267-287. Academic Press, New York.

Durrenberger, E. P.

1965 Anderson's Mill (41TV130): A Historical Site in Travis County, Texas. Bulletin of the Texas Archeological Society 36:1-70.

Ebert, J. I.

1992 Distributional Archaeology. University of New Mexico Press, Albuquerque. 
Eckhardt, R. F.

1975 Vascular Flora of Tom Green County, Texas. Unpublished MS thesis, Department of Botany, Angelo State University, San Angelo, Texas.

Espey, Huston \& Associates, Inc.

1990 Cultural Resources Survey of Five Eleven-Acre Tracts for the U. S. Air Force Ground Emergency Network System, Christoval Site, Schleicher County, Texas. Espey, Huston \& Associates, Inc., Austin.

Etchieson, G. M.

1985 An Archeological Survey of Potential Borrow Areas at Twin Buttes Reservoir, Tom Green County, Texas. U.S. Bureau of Reclamation, Southwest Region. Amarillo, Texas.

Etchieson, G. M., R. D. Speer, and J. T. Huges

1979 Archaeological Investigations in the Crowell Reservoir Area, Cottle, Foard, King and Knox Counties, Texas. Archaeological Research Laboratory, Killgore Research Center, West Texas State University, Canyon, Texas.

Everitt, B. S.

1977 The Analysis of Contingency Tables. Chapman and Hall, London.

Ewers, J. C. (editor)

1969 The Indians of Texas in 1830. Publication Series 4745. Smithsonian Institution Press, Washington, D.C.

Farrel-Beck, J. A., and R. H. Meints

1983 The Role of Technology in the Fresh-water Pearl Button Industry of Muscatine, Iowa, 1891-1910. Annals of Iowa 47:3-18.

Fehrenbach, T. R.

1978 The San Antonio Story. Continental Heritage, Tulsa, Oklahoma.

Fenneman, N.

1931 Physiography of the Western United States. McGraw Hill, New York.

Flanagan, S.

1974 Trailing the Longhorns: A Century Later. Madrona, Austin.

Folk, R. L.

1980 Petrology of Sedimentary Rocks. Hemphill Publishing Company, Austin.

Fox, A. A., I. W. Cox, L. Highley, and D. Hafernik

1989 Archaeological and Historical Investigations at the Site of the New Bexar County Justice Center in Downtown San Antonio, Texas. Archaeological Survey Report, No. 184. Center for Archaeological Research, The University of Texas at San Antonio.

Fox, A. A., and D. E. Fox

1967 The Classen Rockshelter, 41BX23. Manuscript on file. Center for Archaeological Research, The University of Texas at San Antonio. 
Fox, D. E.

1979 The Lithic Artifacts of Indians at the Spanish Colonial Missions, San Antonio, Texas. Special Report 8. Center for Archaeological Research, The University of Texas at San Antonio.

Fox, J., C. B. Smith, and D. O. Lintz

1992 Herd Bunching at the Waco Mammoth Site: Preliminary Investigations, 1978-1987. In Proboscidean and Paleoindian Interactions, edited by J. W. Fox, C. B. Smith, and K. T. Wilkins, pp. 51-73. Baylor University Press, Waco.

Frederick, C. D.

1998 Late Quaternary Clay Dune Sedimentation on the Llano Estacado. Plains Anthropologist (43)164:137156.

Fredlund, G.

1994 The Phytolith Record at the Wilson-Leonard Site. Program and Abstracts, 52nd Plains Conference, 65th Annual Meeting of the Texas Archaeological Society. Lubbock.

Fredlund, G. G., C. B. Bousman, and D. K. Boyd

1998 The Holocene Phytolith Record from Morgan Playa in the Rolling Plains of Texas. Plains Anthropologist (43)164:187-200.

Freeman, M. D.

1994 Agriculture in Texas: Ranching and Stock Farming on the Eastern Edwards Plateau, 1845-1941. Komatsu/Rangel, Fort Worth.

Freeman, M. D., and J. C. Freeman

1981 A Cultural Resource Inventory and Assessment of the Proposed Stacey Reservoir, Concho, Coleman, and Runnels Counties, Volume II: Historical Resources. Espey, Huston \& Associates, Inc., Austin.

George, R., R. E. Flick, and R. T. Guza

1994 Observations of turbulence in the surf zone. Journal of Geophysical Research 99: 801-810.

Givens, R. D.

1968a On the Peopling of America. Current Anthropology 9:219.

1968b A Preliminary Report on Excavations at Hitzfelder Cave. Bulletin of the Texas Archeological Society 38:47-50.

Godwin, M., M. Davis, P. Denney, and R. Stephenson

1981 A Cultural Resource Inventory and Assessment of the Proposed Stacey Reservoir, Concho, Coleman, and Runnels Counties, Volume III: Appendices. Espey, Huston \& Associates, Inc., Austin.

Goode, G. T.

1991 Late Prehistoric Burned Rock Middens in Central Texas. In The Burned Rock Middens of Texas: An Archaeological Symposium, edited by T. R. Hester, pp. 71-93. Studies in Archeology 13. Texas Archeological Research Laboratory, The University of Texas at Austin.

Grayson, D. K.

1984 Quantitative Zooarchaeology. Academic Press, New York. 
Green, F. E.

1959 Archeological Salvage in the Twin Buttes Area, San Angelo, Texas. Bulletin of the Texas Archeological Society 30:183-197.

Greer, G. H.

1981 American Stonewares, The Art and Craft of Utilitarian Potters. Schiffer Publishing, Exton, Pennsylvania.

Gross, K. J., and F. Meissner

1997 Architectural Materials. In Archaeology at the Alamodome: Investigations of a San Antonio Neighborhood in Transition, Volume III, edited by A. A. Fox, M. Renner, and R. J. Hard, pp. 229-241. Archaeological Survey Report, No. 238. Center for Archaeological Research, The University of Texas at San Antonio.

Guderjan, T. H., B. Baker, B. Bousman, C. K. Chandler, A. Fox, and B. Meissner

1992 Prehistoric Settlement in the Medina Valley and the 1991 STAA-ITC Field School. La Tierra 19(2):1428.

Guderjan, T. H., B. Meissner, B. Baker, C. K. Chandler, S. Kennedy, D. McReynolds, H. R. Smith, F. Ward, J. Watts, and J. Zapata

1993 The Medina Valley Project and the 1992 STAA-ITC Field School. La Tierra 20(1):12-26.

Guffee, E. J.

1984 Concho Valley Electric Cooperative, Inc., Proposed Electrical Line Construction. Plainview, Texas. 1989 An Archeological Investigation on Valley Creek, Runnels County, Texas. Archeological Research Laboratory, Llano Estacado Museum, Plainview, Texas.

Gunn, J., and R. Mahula

1977 Hop Hill: Culture and Climatic Change in Central Texas. Special Report, No. 5. Center for Archaeological Research, The University of Texas at San Antonio.

Gurke, K.

1987 Bricks and Brickmaking. A Handbook for Historical Archaeology. University of Idaho Press, Moscow, Idaho.

Haberman, S. J.

1973 The Analysis of Residuals in Cross-classified Tables. Biometrics 29:205-220.

Habig, M.A.

1968a San Antonio's Mission San José, State and National Historic Site, 1720-1968. Naylor, San Antonio.

1968b The Alamo Chain of Missions, A History of San Antonio's Five Old Missions. Franciscan Herald, Chicago.

1990 Spanish Texas Pilgrimage: The Old Franciscan Missions and Other Spanish Settlements of Texas, 1632-1821. Franciscan Herald Press, Chicago.

Hageman, J. B.

1993 Summary Report: Results of a Cultural Resources Survey of a Segment of the Proposed San Angelo Pipeline, Tom Green County, Texas. Espey, Huston \& Associates, Inc., Austin. 
Hall, G. D.

1981 Allens Creek: A Study in the Cultural Prehistory of the Brazos River Valley, Texas. Research Report 61. Texas Archeological Survey, The University of Texas at Austin.

Hall, G. D., S. L. Black, and C. Graves

1982 Archaeological Investigations at Choke Canyon Reservoir, South Texas: The Phase I Findings. Choke Canyon Series, No. 5. Center for Archaeological Research, The University of Texas at San Antonio.

Hall, G. D., T. R. Hester, and S. L. Black (editors)

1986 The Prehistoric Sites at Choke Canyon Reservoir, Southern Texas: Results of the Phase II Archaeological Investigations. Choke Canyon Series, No. 10. Center for Archaeological Research, The University of Texas at San Antonio.

Hall, G. D., and K. Hindes

1998 The Rediscovery of Santa Cruz de San Sabá, A Mission for the Apache in Spanish Texas. San Saba Regional Survey Report 1. Archaeology Laboratory, Texas Tech University, published jointly by the Texas Historical Foundation and Texas Tech University.

Hall, S. A., and S. Valatro, Jr.

1995 Grassland Vegetation in the Southern Great Plains during the Last Glacial Maximum. Quaternary Research 44:237-245.

Hallenbeck, C.

1940 Alvar Nuñez Cabeza de Vaca: The Journey and Route of the First European to Cross the Continent of North America, 1534-1536. Arthur C. Clark Publishing, Glendale, California.

Handbook of Texas Online

1999a Twin Buttes.

$<$ http://www.tsha.utexas.edu/handbook/online/articles/view/Ssuqs10.html $>$ June 10.

1999b San Clemente Mission.

$<$ http://www.tsha.utexas.edu/handbook/online/articles/view/Ssuqs10.html $>$ June 2.

1999c Dove Creek, Battle of.

$<$ http://www.tsha.utexas.edu/handbook/online/articles/view/Ssuqs10.html $>$ June 2.

1999d Concho River.

$<$ http://www.tsha.utexas.edu/handbook/online/articles/view/Ssuqs10.html $>$ June 2.

1999e Knickerbocker, Texas.

$<$ http://www.tsha.utexas.edu/handbook/online/articles/view/Ssuqs10.html $>$ June 2.

1999f Peak, Junius W.

$<$ http://www.tsha.utexas.edu/handbook/online/articles/view/Ssuqs10.html $>$ June 7.

$1999 \mathrm{~g}$ Lake Nasworthy.

$<$ http://www.tsha.utexas.edu/handbook/online/articles/view/Ssuqs10.html $>$ June 7.

1999h O. C. Fisher Lake.

$<$ http://www.tsha.utexas.edu/handbook/online/articles/view/Ssuqs10.html $>$ June 7.

1999i Twin Buttes Reservoir.

$<$ http://www.tsha.utexas.edu/handbook/online/articles/view/Ssuqs10.html $>$ June 7.

1999j Colorado River Municipal Water District.

$<$ http://www.tsha.utexas.edu/handbook/online/articles/view/Ssuqs10.html $>$ June 7. 
1999k Panhandle and Santa Fe Railway.

$<\mathrm{http} / /$ www.tsha.utexas.edu/handbook/online/articles/view/Ssuqs10.html $>$ June 7.

19991 Lometa, Texas.

$<$ http://www.tsha.utexas.edu/handbook/online/articles/view/Ssuqs10.html $>$ June 7.

1999m Sutton County.

$<$ http://www.tsha.utexas.edu/handbook/online/articles/view/Ssuqs10.html $>$ June 7.

1999n Stilwell, Arthur Edward (1859-1928).

$<$ http://www.tsha.utexas.edu/handbook/online/articles/view/Ssuqs10.html $>$ June 7.

1999o Ballinger, Texas.

$<$ http://www.tsha.utexas.edu/handbook/online/articles/view/Ssuqs10.html $>$ June 7.

1999 p Gulf, Colorado and Santa Fe Railway.

$<$ http://www.tsha.utexas.edu/handbook/online/articles/view/Ssuqs10.html $>$ June 7.

1999q Kansas City, Mexico and Orient Railway.

$<$ http://www.tsha.utexas.edu/handbook/online/articles/view/Ssuqs10.html $>$ June 7.

1999r Mertzon, Texas.

$<$ http://www.tsha.utexas.edu/handbook/online/articles/view/Ssuqs10.html $>$ June 7.

1999s Concho, San Saba and Llano Valley Railroad.

$<$ http://www.tsha.utexas.edu/handbook/online/articles/view/Ssuqs10.html $>$ June 7.

1999 t Fort Concho.

$<$ http://www.tsha.utexas.edu/handbook/online/articles/view/Ssuqs10.html $>$ June 8.

1999u Bone Business.

$<$ http://www.tsha.utexas.edu/handbook/online/articles/view/Ssuqs10.html $>$ June 8.

1999v Tom Green County.

$<$ http://www.tsha.utexas.edu/handbook/online/articles/view/Ssuqs10.html $>$ June 8.

Hard, R. J., A. A. Fox, I. W. Cox, K. J. Gross, B. A. Meissner, G. I. Méndez, C. L. Tennis, and J. E. Zapata

1995 Excavations at Mission San José y San Miguel de Aguayo, San Antonio, Texas. Archaeological Survey Report, No. 218. Center for Archaeological Research, The University of Texas at San Antonio.

Harris, E. S.

1985 An Archaeological Study of the Timmeron Rockshelter (41HY95), Hays County, South Central Texas. Special Publication 4. Southern Texas Archaeological Association, San Antonio.

Henderson, J.

1978 Faunal Analysis of Site 41BX36, with Data Presented for 41BX377 and 41BX428. In The Fort Sam Houston Project: An Archaeological and Historical Assessment, edited by A. Gerstle, T. C. Kelly, and C. Assad, pp. 229-252. Archaeological Survey Report, No. 40. Center for Archaeological Research, The University of Texas at San Antonio.

Hester, T. R.

1983 Late Paleo-Indian Occupations at Baker Cave, Southwestern Texas. Bulletin of the Texas Archeological Society 53:101-119.

1989 Historic Native American Populations. In From the Gulf to the Rio Grande: Human Adaptation in Central, South, and Lower Pecos Texas, edited by T. R. Hester, S. L. Black, D. G. Steele, B. W. Olive, A. A. Fox, K. J. Reinhard, and L. C. Bement, pp. 77-84. Research Series No. 33. Arkansas Archeological Survey, Fayetteville.

1990 Plainview Artifacts at the St. Mary's Hall Site, South Central Texas. Current Research in the Pleistocene $7: 14-17$.

1995 The Prehistory of South Texas. Bulletin of the Texas Archeological Society 66:427-459. 
Hester, T. R. (editor)

1991 The Burned Rock Middens of Texas: An Archeological Symposium. Studies in Archeology 13, Texas Archeological Research Laboratory, The University of Texas at Austin.

Hickerson, N. P.

1994 The Jumanos: Hunters and Traders of the South Plains. University of Texas Press, Austin.

Highley, L., C. Graves, and G. Judson

1978 Archeological Investigations at Scorpion Cave (41ME7), Medina County, Texas. Bulletin of the Texas Archeological Society 49:139-194.

Hofman, J. L.

1989 Prehistoric Culture History-Hunters and Gatherers in the Southern Great Plain. In From Clovis to Comanchero: Archeological Overview of the Southern Great Plains, by J. L. Hofman, R. L. Brooks, J. S. Hays, D. W. Owsley, R. L. Jantz, M. K. Marks, and M. H. Manhein, pp. 25-60. Research Series No. 35. Arkansas Archeological Survey, Fayetteville.

Hofman, J. L., R. L. Brooks, J. S. Hays, D. W. Owsley, R. L. Jantz, M. K. Marks, and M. H. Manhein 1989 From Clovis to Comanchero: Archeological Overview of the Southern Great Plains. Research Series No. 35. Arkansas Archeological Survey, Fayettville.

Holden, W. C.

1928 West Texas Droughts. The Southwestern Historical Quarterly 32(9):103-123.

1986 Rollie Burns or An Account of the Ranching Industry on the South Plains. Texas A\&M University Press, College Station.

Holliday, V. T.

1985 Holocene Soil-Geomorphological Relations in a Semi-Arid Environment: The Southern High Plains of Texas. In Soils and Quaternary Landscape Evolution, edited by J. Boardman, pp. 325-357. John Wiley \& Sons, Inc., New York.

Holman, R. A., and A. J. Bowen

1982 Bars, bumps and holes: Models for the generation of complex beach topography. Journal of Geophysical Research 87:457-468

Houk, B. A., and J. C. Lohse

1993 Archaeological Investigations at the Mingo Site, Bandera County, Texas. Bulletin of the Texas Archeological Society 61:193-247.

Hulbert, R. C., Jr.

1985 Vertebrate Faunal Remains. In The Panther Springs Creek Site: Cultural Change and Continuity within the Upper Salado Creek Watershed, South-Central Texas, edited by S. L. Black and A. J. McGraw, pp. 209-215. Archaeological Survey Report, No. 100. Center for Archaeological Research, The University of Texas at San Antonio.

Humphrey, J. D., and C. R. Ferring

1994 Stable Isotopic Evidence for Latest Pleistocene and Holocene Climatic Change in North-Central Texas. Quaternary Research 41:200-213. 
Hurt, R. D.

1980 Archeological Investigations of Portions of the Middle Concho Valley. Unpublished Masters Thesis, Texas Tech University, Lubbock.

Inglis, J. M.

1964 A History of Vegetation on the Rio Grande Plain. Bulletin 45. Texas Parks and Wildlife Department, Austin.

Irwin-Williams, C., H. Irwin, G. Agogino, and C. V. Haynes, Jr.

1973 Hell Gap:Paleo-Indian Occupation on the High Plains. Plains Anthropologist 18:40-53.

Israel, F. L.

19681897 Sears, Roebuck Catalogue (facsimile). Chelsea House Publishers, New York.

Ivey, J. E., and A. A. Fox

1981 Archaeological Survey and Testing at Ranchos de las Cabras, Wilson County, Texas. Archaeological Survey Report, No. 104. Center for Archaeological Research, The University of Texas at San Antonio.

Izett, G. A., and Wilcox, R. E.

1982 Map showing localities and inferred distributions of the Huckleberry Ridge, Mesa Falls, and Lava Creek ash beds (Pearlette family of beds) of Pliocene and Pleistocene age in the western United States and southern Canada: U.S. Department of the Interior, U.S. Geological Survey Miscellaneous Investigations Series Map I-1325. Scale 1:4,000,000. Washington, D.C.

Jackson, J.

1986 Los Mesteños. Texas A\&M University Press, College Station.

John, E. A. H.

1975 Storms Brewed in Other Men's Worlds: Confrontations of Indians, Spanish and French in the Southwest, 1540-1795. Texas A\&M University Press, College Station.

Johnson, L., Jr.

1987 A Plague of Phases. Bulletin of the Texas Archeological Society 57:1-26.

1994 The Reconstructed Crow Terminology of the Titkanwatits, or Tonkawas, with Inferred Social Correlates. Plains Anthropologist (39)150:377-413.

1995 Past Cultures and Climates at Jonas Terrace, 41ME29, Medina County, Texas. Office of the State Archeologist, Report 40. Texas Department of Transportation and Texas Historical Commission, Austin.

Johnson, L., and T. N. Campbell

1992 Sanan: Traces of a Previously Unknown Aboriginal Language in Colonial Coahuila and Texas. Plains Anthropologist 37(140):185-212.

Johnson, L., and G. T. Goode

1994 A New Try at Dating and Characterizing Holocene Climates, as well as Archaeological Periods, on the Eastern Edwards Plateau. Bulletin of the Texas Archeological Society 65:1-51. 
Johnson, E., and V. T. Holliday

1986 The Archaic Record at Lubbock Lake. In Current Trends in Southern Plains Archaeology, edited by T. G. Baugh. Plains Anthropologist Memoir 22:7-54.

1995 Archeology and Late Quaternary Environments of the Southern High Plains. Bulletin of the Texas Archeological Society 66:519-540.

Johnson, L., Jr., D. A. Suhm, and C. D. Tunnell

1962 Salvage Archaeology of Canyon Reservoir: The Wunderlich, Footbridge, and Oblate Sites. Bulletin No. 5. Texas Memorial Museum, The University of Texas at Austin.

Jones, G. T., D. K. Grayson, and C. Beck

1983 Artifact Class Richness and Sample Size in Archaeological Surface Assemblages. In LuLu Linear Punctated: Essays in Honor of George Irving Quimby, edited by R. C. Dunnell and D. K. Grayson, pp. 53-73. Anthropological Papers 72. Museum of Anthropology, University of Michigan, Ann Arbor.

Jones, W. K.

1969 Notes on the History and Material Culture of the Tonkawa Indians. Smithsonian Contributions to Anthropology 2(5). Smithsonian Institution, Washington, D.C.

Karl, T. R.

1983 Some Spatial Characteristics of Drought Durations in the United States. Journal of Climate and Applied Meteorology 22:1356-1366.

Kavanaugh, T. W.

1986 Political Power and Political Organization: Comanche Politics, 1786-1876. Unpublished Ph.D. dissertation, Department of Anthropology, University of New Mexico, Albuquerque.

Kelley, D.

1971 Indian Tribes of Texas, edited by D. H. Winfrey. Texian, Waco.

Kelly, R. L.

1983 Hunter-Gatherer Mobility Strategies. Journal of Anthropological Research 39:277-306.

1995 The Foraging Spectrum: Diversity in Hunter-Gatherer Lifeways. Smithsonian Institution Press, Washington D.C.

Kelly, T. C.

1993 Preceramic Projectile-Point Typology in Belize. Ancient Mesoamerica 4:205-227.

Kelly, T. C., and F. Valdez, Jr.

1979 Natural Gas Pipeline Survey, Northwest Menard County, Texas. Archaeological Survey Report, No. 78. Center for Archaeological Research, The University of Texas at San Antonio.

Kendrick, G.

1966 The Antique Bottle Collector. Edwards Brothers, Inc., Ann Arbor, MI.

1967 Bottle Fragments Betray Age of Historic Sites. El Palacio 74(2):19-24. 
Kenmotsu, N. A., J. W. Clark, Jr., and D. Crawford

1997 Archeological Assessment of Historic and Prehistoric Sites Along U.S. 87 Sterling County, Texas. Texas Department of Transportation, Archeological Studies Program, Austin.

Kibler, K. W.

1998 Late Holocene Environmental Effects on Sandstone Rockshelter Formation and Sedimentation on the Southern Plains. Plains Anthropologist (43)64:173-186.

King, I. M.

1967 John O. Meusebach, German Colonizer in Texas. University of Texas Press, Austin.

Kintigh, K. W.

1984 Measuring Archeological Diversity by Comparison with Simulated Assemblages. American Antiquity 49:44-54.

1989 Sample Size, Significance, and Measures of Diversity. In Quantifying Diversity in Archaeology, edited by R. D. Leonard, and G. T. Jones, pp. 25-36. Cambridge University Press, New York.

Krieger, A. D.

1964 Early Man in the New World. In Prehistoric Man in the New World, edited by J. D. Jennings and E. Norbeck, pp. 23-81. University of Chicago Press, Chicago.

Labadie, J. H. (assembler)

1986 La Villita Earthworks (41BX677): San Antonio, Texas. A Preliminary Report of Investigations of Mexican Siege Works at the Battle of the Alamo. Archaeological Survey Report, No. 159. Center for Archaeological Research, The University of Texas at San Antonio.

Larraldi, S.

1988 The Timeless Survey: Problems in Defining Component Assemblages. American Archaeology 7:8-12.

Leach, J. D., and C. B. Bousman

1998 Cultural and Secondary Formation Processes: On the Dynamic Accumulation of Burned Rock Middens. In Test Excavations at the Culebra Creek Site, 41BX126, Bexar County, Texas, by D. L. Nickels, C. B. Bousman, J. D. Leach, and D. A. Cargill, pp. 119-145. Archaeological Survey Report, No. 265, Center for Archaeological Research, The University of Texas at San Antonio; Archeology Studies Program, Report 3, Environmental Affairs Division, Texas Department of Transportation,

Lehmann, V. W.

1969 Forgotten Legions. Texas Western, The University of Texas at El Paso.

León, A., J. B. Chapa, and F. S. de Zamora

1961 Historia de Luevo León, con Noticias sobre Coahuila, Tamaulipas, Texas y Nueva México. Estudio Preliminar y Notas de Israel Cavzos Garza. Centrio de Estudios Humanistico, Universidad de Nuevo León, Monterrey.

Lincecum, J. B., and E. H. Phillips (editors)

1994 Adventures of a Frontier Naturalist: The Life and Times of Dr. Gideon Lincecum. Texas A\&M University Press, College Station. 
Lintz, C., A. C. Treece, F. M. Oglesby, K. Kibler, P. L. O’Neill, W. N. Trierweiler, C. Frederick, J. M. Quigg, and A. J. Taylor

1993a Cultural Resource Investigations in the O. H. Ivie Reservoir, Concho, Coleman, and Runnels Counties, Texas. Report No. 346-II. Mariah Associates, Inc., Austin.

Lintz, C., W. N. Trierweiler, and J. J. Kuhl

1993b Introduction. In Cultural Resource Investigations in the O. H. Ivie Reservoir, Concho, Coleman, and Runnels Counties, Texas, pp. 1-44. Report No. 346-I. Mariah Associates, Inc., Austin

Luke, C. J.

1978 Initial Testing Report for 41TG91. Texas State Department of Highways and Public Transportation. Report on file at the Texas Historical Commission, Austin.

1981 The Excavations at Three Burned Rock Midden Sites in Sutton and Schleicher Counties, Texas. Report No. 19. Texas State Department of Highways and Public Transportation, Austin.

Lukowski, P. D.

1988 Archaeological Investigations at 41BX1, Bexar County, Texas. Archaeological Survey Report, No. 135. Center for Archaeological Research, The University of Texas at San Antonio.

McCartney, P. H., and M. F. Glass

1990 Simulation Models and the Interpretation of Archaeological Diversity. American Antiquity 55:521536.

McCulloch, S. D., and J. E. Warren

1995 A Report on the Cultural Resources Survey of the Proposed 36" Rio Vista Sewer Main, San Angelo, Tom Green County, Texas. Department of Public Works, Report No. 433.

1997 A Report on the Limited National Register Testing of Site 41TG351 San Angelo, Tom Green County, Texas. Department of Public Works, Report No. 442.

1998 A Report on the Cultural Resources Survey of the Proposed 48-inch Wastewater Pressure Line San Angelo, Tom Green County, Texas. Department of Public Works, Report No. 473.

McGraw, A. J., and K. Hindes

1987 Chipped Stone and Adobe: A Cultural Resources Assessment of the Proposed Applewhite Reservoir, Bexar County, Texas. Archaeological Survey Report, No. 163. Center for Archaeological Research, The University of Texas at San Antonio.

Machette, M. N.

1985 Calcic Soils of the Southwestern United States. In Soils and Quaternary Geology of the Southwestern United States, edited by D. L. Weide, pp. 1-21. Soc. Am Spec. Pap. 203, Boulder, Colorado.

McKinney, W. W.

1981 Early Holocene Adaptations in Central and Southern Texas: The Problem of the Paleo-Indian-Archaic Transition. Bulletin of the Texas Archeological Society 52:91-120.

Magne, M. P. R.

1985 Lithics and Livelihood: Stone Tool Technologies of Central and Southern Interior British Columbia. Mercury Series No. 133. National Museum of Man, Ottawa, Canada. 
Majewski, T., and M. J. O'Brien

1987 The Use and Misuse of Nineteenth-Century English and American Ceramics in Archaeological Analysis. In Advances in Archaeological Method and Theory, vol. 11, edited by M. B. Schiffer, pp. 97-207. Serial Publication Series. Academic Press, New York.

Maroney, J. C.

1996 Thurber, Texas. In New Handbook of Texas, Vol. 6, edited by R. Tyler, pp. 488-489. Texas State Historical Association, Austin.

Maxwell, T. C.

1979 Avifauna of the Concho Valley of West-Central Texas with Special Reference to Historical Change. Unpublished Doctoral Dissertation, Wildlife and Fisheries Sciences, Texas A\&M University, College Station.

Mauldin, R. P.

1995 Groping for the Past: Investigating Archaeological Patterns Across Space and Time in the Southern Southwestern United States. Unpublished Ph.D. dissertation, University of New Mexico, Albuquerque.

1996 Exploring Patterns in Late Archaic and Early Ceramic Residential Occupation in the Northern Chihuahuan Desert. In Early Formative Adaptations in the Southern Southwest, edited by B. Roth, pp. 85-97. Prehistory Press, Madison, Wisconsin.

Mauldin, R. P., B. L. O'Leary, and T. Kludt

1999 Site Criteria and Implications for Interpreting the Past: An Example From the Jornada Lowlands, New Mexico. In Archaeology of the Jornada Mogollon: Proceedings from the 10th Jornada Mogollon Conference, compiled by M. Stowe and M. Slaughter, pp. 125-149. Geo-Marine Inc., Engineering and Environmental Services, Plano, Texas.

Mayer-Oakes, W. J.

1977 Preliminary Archeological Reconnaissance of Two Sites at O.C. Fisher Lake, Texas. Cultural Resources Institute, Department of Anthropology, Texas Tech University, Lubbock.

Meissner, B. A.

1991 Notes on the Excavation of 41BX952. Manuscript on file. Center for Archaeological Research, The University of Texas at San Antonio.

1993 Where the Buffalo Roam: Archaeological Evidence of Bison Populations in South and Central Texas. Manuscript on file. Center for Archaeological Research, The University of Texas at San Antonio.

Meltzer, D. J., and M. R. Bever

1995 Paleoindians of Texas: An Update on the Texas Clovis Fluted Point Survey. Bulletin of the Texas Archeological Society 66:47-81.

Miller, G.

1980 Classification and Economic Scaling of 19th Century Ceramics. Historical Archaeology 14:1-19.

Moir, R. W.

1988 Windows and Window Glass. In Historic Farming on the Hogwallow Prairies, Ethnoarchaeological Investigations of the Mountain Creek Area, North Central Texas. Joe Pool Lake Archaeological Project, Volume 2. Archaeological Research Program, Institute for the Study of Earth and Man, Southern Methodist University, Dallas. 
Montgomery Ward \& Company

1969 Montgomery Ward \& Company Catalogue No. 57 (reprint). Dover Publications Inc., New York.

Morris, W.

1970 The Wichita Exchange; Trade on Oklahoma's Fur Frontier, 1719-1812. Great Plains Journal (9)2:7984. Great Plains Historical Association, Lawton, Oklahoma.

Mueggenborg, H. E.

1994 Excavations at the Blue Hole Site, Uvalde County, Texas, 1990. Bulletin of the Texas Archeological Society 62:1-74.

Munsey, C.

1970 The Illustrated Guide to Collecting Bottles. Hawthorn Books, New York.

National Weather Service

1999 Normals, Means, and Extremes for San Angelo, Texas. Data on file at the National Weather Service Office, San Angelo Texas.

NCDC (National Climatic Data Center)

1999a Rainfall Data. <http://www.ncdc.noaa.gov/ghen/temp/17449.txt> June 11, 1999.

1999b Temperature Data. <http://www5.ncdc.noaa.gov/ol/climvis/temp/fsod_29046.txt> June 11, 1999.

1999c Drought Data. <http://www5.ncdc.noaa.gov/ol/climvis/drought/main.html > June 11, 1999.

Nelson, L. H.

1968 Nail Chronology as an Aid to Dating Old Buildings. American Association for State and Local History, Technical Leaflet No. 48. Nashville, TN.

Newcomb, W. W., Jr.

1961 The Indians of Texas: From Prehistoric to Modern Times. University of Texas Press, Austin.

1993 Historic Indians of Central Texas. Bulletin of the Texas Archeological Society 64:1-63.

Nicholson, A., and S. Cane

1991 Desert Camps: Analysis of Australian Aboriginal Proto-Historic Campsites. In Ethnoarchaeological Approaches to Mobile Campsites, edited by C. S. Gamble and W. A. Boismier, pp. 263-354. International Monographs in Prehistory, Ann Arbor.

Nickels, D. L.

2000 The Biesenbach Site (41WN88), Wilson County, Texas: A Study of Toyah Diet-breadth. Unpublished Master's Thesis, The University of Texas at San Antonio.

Nickels, D. L., C. B. Bousman, J. D. Leach, and D. A. Cargill

1998a Test Excavations at the Culebra Creek Site, 41BX126, Bexar County, Texas. Archaeological Survey Report No. 265, Center for Archaeological Research, The University of Texas at San Antonio; Archeology Studies Program, Report 3, Environmental Affairs Division, Texas Department of Transportation, Austin. 
Nickels, D. L., A. A. Fox, and W. W. McKinney

1998b 9,000 Years of Human Occupation at Lackland Air Force Base. Special Report No. 22. Center for Archaeological Research, University of Texas at San Antonio.

Nickels, D. L., and A. A. Fox

1997 Archaeological Investigations Within the Church Sacristy at Mission San Jose (41BX3), San Antonio, Bexar County, Texas. Archaeological Survey Report, No. 242. Center for Archaeological Research, The University of Texas at San Antonio.

Nickels, D. L., A. A. Fox, R. A. Mathews, C. A. Murguia, and P. Camfield

2000 Archaeological Investigations at the Fassel-Roeder Wheelwright Shop on the Grounds of the Gillespie County Pioneer Museum, Fredericksburg, Texas: Interim Report Number 1. Manuscript on file, Southern Texas Archaeological Association.

Nickels, D. L., D. W. Pease, and C. B. Bousman

1997 Archaeological Survey of Lackland Air Force Base, Bexar County, Texas. Archaeological Survey Report, No. 248. Center for Archaeological Research, The University of Texas at San Antonio.

Nordt, L. C., T. W. Boutton, J. S. Jacob, and R. Mandel

1994 Late Quaternary Climates of Central Texas Based on the Stable Isotopic Composition of Organic Carbon. Program and Abstracts, 52nd Plains Conference, 65th Annual Meeting of the Texas Archeological Society, Lubbock.

O’Leary, B. L. , T. Kludt, T. Church, and R. Mauldin

1997 The McGregor Guided Missile Range Survey Project, New Mexico: Volume I: The Archaeology of Landscape-General Survey. Archaeological Technical Report Number 14. Anthropology Research Center, The University of Texas at El Paso.

Palmer, W. C.

1965 Meteorological Drought. United States Weather Bureau Research Paper No. 45, U.S. Department of Commerce Weather Bureau, Washington, D.C.

Patterson, L. W.

1988 Intergroup Conflict in Prehistoric Texas. Houston Archeological Society Journal 90:8-10.

Peregrine, D. H.

1983 Breaking waves on beaches. Annual Review of Fluid Mechanics 15:149-178.

Peter, D. E.

1982 Alternative Perspectives on Burned Rock Middens. In Archaeological Investigations at the San Gabriel Reservoir Districts, Central Texas, Vol. 2, compiled and edited by T. R. Hays, pp. 20.1-20.15. Archaeology Program, Institute of Applied Sciences, North Texas State University, Denton.

Pool, W. C.

1950 The Battle of Dove Creek. Southwestern Historical Quarterly 59:367-385. 
Potzger, J. E., and B. C. Tharp

1943 Pollen records of Canadian Spruce and Fir from a Texas Bog. Science 98:584.

1947 Pollen Profile from a Texas Bog. Ecology 28:274-280.

Poyo, G. E., and G. M. Hinojosa (editors)

1991 Tejano Origins in Eighteenth-Century San Antonio. University of Texas Press, Austin.

Prewitt, E. R.

1974 Archeological Investigations at the Loeve-Fox Site, Williams County, Texas. Research Report 49. Texas Archeological Survey, The University of Texas at Austin.

1981 Culture Chronology in Central Texas. Bulletin of the Texas Archeological Society 52:65-89.

1985 From Circleville to Toyah: Comments on Central Texas Chronology. Bulletin of the Texas Archeological Society 54:201-238.

1991 Burned Rock Middens: A Summary of Previous Investigations and Interpretations. In The Burned Rock Middens of Texas: An Archeological Symposium, edited T. R. Hester, pp. 25-32. Studies in Archeology 13. Texas Archeological Research Laboratory, The University of Texas at Austin.

Quigg, J. M.

1995 Sterling City Water Pipeline Development: An Archaeological Inventory and Assessment, Sterling County, Texas. TRC Mariah Associates, Inc., Austin.

Quigg, J. M., and J. Peck

1995 The Rush Site (41TG346) A Stratified Late Prehistoric Locale in Tom Green County, Texas. Report No. 816C. Mariah Associates, Inc., Austin.

Quigg, J. M., J. Peck, C. Lintz, A. C. Treece, C. D. Federick, R. Clem, G. L. Ellis, P. Schuchert, and J. T.

Abbott

1996 Early Archaic Use of the Concho River Terraces: Cultural Resource Investigations at $41 T G 307$ and 41TG309, Tom Green County, San Angelo, Texas. TRC Mariah Associates, Inc., Austin.

Ramsay, J.

1976 American Potters and Pottery. Ars Ceramica, Ann Arbor.

Ray, C. N.

1948 Survey of Twenty Coke County Sites. Bulletin of the Texas Archeological and Paleontological Society 19:36-56.

Ray, C. N., and K. Bryan

1938 Folsomoid Point Found in Alluvium Beside H. Mammoth’s Bones. Science, New Series 88(2281):257258.

Richardson, R. N.

1996 The Comanche Barrier to South Plains Settlement. Eakin Press, Austin.

Ricklis, R. A., and K. A. Cox

1998 Holocene Climatic and Environmental Change in the Texas Coastal Zone: Some Geoarchaeological and Ecofactual Indicators. Plains Anthropologist (43)164:125-136. 
Robinson, D. P.

1971 Antique Bottle Identification Made Easy. ATR Enterprizes, Prescott, Arizona.

Robinson, R. L.

1979 Biosilica and Climatic Change at 41GD21 and 41GD21A. In Archaeological Investigations of Two Prehistoric Sites on the Colette Creek Drainage, Goliad County, Texas, edited by D. E. Fox, pp. 102113. Archaeological Survey Report, No. 69. Center for Archaeological Research, The University of Texas at San Antonio.

1982 Biosilica Analysis of Three Prehistoric Archaeological Sites in the Choke Canyon Reservoir, Live Oak County, Texas: Preliminary Summary of Climatic Implications. In Archaeological Investigations at Choke Canyon Reservoir, South Texas: The Phase I Findings, edited by G. D. Hall, S. L. Black, and C. Graves, pp. 597-610. Choke Canyon Series, No. 5. Center for Archaeological Research, The University of Texas at San Antonio.

Rocek, T. R.

1991 Research at LA51344, The Dunlap-Salazar Pithouse Site, Near Lincoln, New Mexico. In Mogollon V, edited by P. Beckett, pp. 106-118. COAS Publishing, Las Cruces.

Runge, C.

1986 Sidelights of Texas Land Titles. In Historical Montage of Tom Green County, pp. 1-6. Anchor Publishing, San Angelo, Texas.

Samford, P. M.

1997 Response to a Market: Dating English Underglaze Transfer-Printed Wares. Historical Archaeology 31(2):1-30.

Sanders, C. B.

1996 Archaeological Investigations in the Elm Creek (1250) Watershed, Runnels County, Texas: Sites 41RN61, $41 R N 64,41 R N 65$, 41RN72, 41RN74, 41RN76. Reports of Investigations No. 4. Center for Environmental Archaeology, Texas A\&M University, College Station.

Santleben, A.

1910 A Texas Pioneer. Edited by J. D. Affleck. The Neale Publishing Company, New York and Washington.

Sauer, C. O.

1971 Sixteenth-Century North America: The Land and the People as Seen by the Europeans. University of California Press, Berkeley.

Sayles, E. B.

1930 A Rock Shelter in Coke County. Bulletin of the Texas Archeological and Paleontological Society 2:33-40.

1932 Site Form for 41TG234. On file with the Texas Archeological Research Laboratory, The University of Texas at Austin.

Schiffer, M. B.

1987 Formation Processes of the Archaeological Record. University of New Mexico Press, Albuquerque. 
Schuetz, M. K.

1969 The History and Archeology of Mission San Juan Capistrano, San Antonio, Texas (Vol. 2). Description of the Artifacts and Ethnohistory of the Coahuiltecan Indians. Archeology Program Report 11. State Building Commission, Austin.

Sellards, E. H.

1940 Pleistocene Artifacts and Associated Fossils from Bee County, Texas. Bulletin of the Geological Society of America 51:1627-1658.

1952 Early Man in America. University of Texas Press, Austin.

Shafer, H. J.

1977 Art and Territoriality in the Lower Pecos Region. Plains Anthropologist 22:13-22.

Silberbauer, G.

1981 Hunter and Habitat in the Central Kalahari Desert. Cambridge University Press, New York.

Simmons, M., and F. Turley

1980 Southwestern Colonial Ironwork. Museum of New Mexico Press, Santa Fe.

Sjoberg, A. F.

1953a The Culture of the Tonkawa, A Texas Indian Tribe. Texas Journal of Science 5(3):280-304.

1953b Lipan Apache Culture in Historical Perspective. Southwestern Journal of Anthropology 9(1):76-98.

Skelton, D. W.

1977 Archeological Investigations at the Fayette Power Project, Fayette County, Texas. Research Report 60. Texas Archeological Survey, The University of Texas at Austin.

SK Geo-Sciences

1991 Archaeological Assessment and Mitigation Recommendations for Water System Improvements Along Spring Creek, City of Mertzon, Irion County, Texas. SK Geo-Sciences, San Angelo, Texas.

Skinner, S. A.

1981 Aboriginal Demographic Changes in Central Texas. Plains Anthropologist 26(92):111-118.

Soil Survey Division Staff.

1993 Soil Survey Manual. U.S. Department of Agriculture Handbook No. 18. Washington, D.C.

Sollberger, J. B., and T. R. Hester

1972 The Strohacker Site: A Review of Pre-Archaic Manifestations in Texas. Plains Anthropologist 17(58):326-344.

Sorrow, W. M., H. J. Shafer, and R. E. Ross

1967 Excavations at Stillhouse Hollow Reservoir. Papers of the Texas Archeological Salvage Project, No. 11. 
Stahle, D. W., and M. K. Cleaveland

1995 Texas Paleoclimatic Data from Daily to Millennial Time Scales. In The Changing Climate of Texas: Predictability and Implications for the Future, edited by J. Norwine, J. R. Giardino, G. R. North, and J. B. Valdes, pp. 49-69. GeoBooks, Texas A\&M University, College Station.

Stanford, D. J.

1982 A Critical Review of Archaeological Evidence Relating to the Antiquity of Human Occupation of the New World. In Plains Indian Studies: A Collection of Essays in Honor of John C. Ewers and Waldo R. Wedel, edited by D. H. Ubelaker and H. J. Viola, pp. 202-218. Smithsonian Contributions to Anthropology 30. Washington, D.C.

Steele, D. G., and C. Assad Hunter

1986 Analysis of Vertebrate Faunal Remains from 41MC222 and 41MC296, McMullen County, Texas. In The Prehistoric Sites at Choke Canyon Reservoir, Southern Texas: Results of Phase II Archaeological Investigations, edited by G. D. Hall, T. R. Hester, and S. L. Black. Choke Canyon Series, No. 10. Center for Archaeological Research, The University of Texas at San Antonio.

Stephenson, R. L.

1949 Archeological Survey of San Angelo Reservoir, Tom Green County, Texas. River Basin Surveys, Smithsonian Institution.

Story, D. A.

1985 Adaptive Strategies of Archaic Cultures of the West Gulf Coastal Plain. In Prehistoric Food Production in North America, edited by R. I. Ford, pp. 19-56. Anthropological Papers No. 75. Museum of Anthropology, University of Michigan, Ann Arbor.

Suhm, D. A.

1960 A Review of Central Texas Archaeology. Bulletin of the Texas Archeological Society 28:63-108.

Svendsen, I. A., H. A. Schaffer, and J. B. Hansen

1987 The interaction between the undertow and the boundary layer flow on a beach. Journal of Geophysical Research 92:11,845-11,846.

Swanton, J. R.

1952 The Indian Tribes of North America. Bulletin 145. Bureau of American Ethnology, Washington, D.C.

Tanaka, J.

1980 The San Hunter-Gatherers of the Kalahari. Translated by D. W. Huges. University of Tokyo Press, Tokyo.

Taylor, A. J., and C. L. Highley

1995 Archaeological Investigations at the Loma Sandia Site (41LK28): A Prehistoric Campsite in Live Oak County, Texas, 2 volumes. Studies in Archeology No. 20. Texas Archeological Research Laboratory, The University of Texas at Austin.

Taylor, T. U.

1904 The Water Powers of Texas. Water Supply and Irrigation Paper No. 105, Series N, Water Power 7. United States Geological Survey, Department of the Interior, Washington. 
Texas Historical Commission

1999 Texas Archeological Atlas. <http://pedernales.thc.state.tx.us/>

TGLO (Texas General Land Office)

1999 Shoreline Erosion Rates.

$<$ http://www.glo.state.tx.us/coastal/erosion/erosionrates.html> December 16, 1999.

Thomas, D. H.

1983 The Archaeology of Monitor Valley I: Epistemology. Anthropological Papers of the American Museum of Natural History 58(1). American Museum of Natural History, New York

Thoms, A. V., D. D. Kuehn, B. W. Olive, J. E. Dockall, P. A. Clabaugh, and R. D. Mandel

1996 Early and Middle Holocene Occupations at the Richard Beene Site: The 1995 Southern Texas Archaeological Association Field School Project. La Tierra (23)4:1-36.

Tiling, M.

1913 History of the German Element in Texas from 1820-1850. Published by the author, Houston.

Toomey, R. S., M. D. Blum, and S. Valastro, Jr.

1993 Late Quaternary Climates and Environments of the Edwards Plateau, Texas. Global and Planetary Change 7:299-320.

Toomey, R. S., and T. W. Stafford, Jr.

1994 Paleoenvironmental and Radiocarbon Study of the Deposits from Hall's Cave, Kerr County, Texas. Program and Abstracts, 52nd Plains Conference, 65th Annual Meeting of the Texas Archeological Society. Lubbock.

Toulouse, J. H.

1971 Bottle Makers. Thomas Nelson, Inc., New York.

Treece, A. C., F. M. Oglesby, C. Lintz, and W. Doering

1994 A Cultural Resources Survey of the O. H. Ivie Reservoir to Midland Pipeline, Concho, Tom Green, Sterling, Glasscock, and Midland Counties, Texas. Mariah Associates, Inc., Austin.

Trierweiler, W. N., A. C. Earls, P. L. O’Neill, F. M. Oglesby, and C. Lintz.

1993 Methods of Investigation. In Cultural Resource Investigations in the O. H. Ivie Reservoir, Concho, Coleman, and Runnels Counties, Texas, by C. Lintz, W. N. Trierweiler, A. C. Earls, F. M. Oglesby, M. Blum, P. L. O’Neill, J. Kuhl, R. Holloway, L. Scott-Cummings, and D. Scurlock, pp. 111-260. Report No. 346-I. Mariah Associates, Inc., Austin.

Tunnell, C.

1977 Fluted Point Production as Revealed by Lithic Specimens from the Adair-Steadman Site in Northwest Texas. The Museum Journal 17:140-168.

1978 The Gibson Lithic Cache from West Texas. Texas Historical Commission, Austin.

Turner, E. S., and T. R. Hester

1993 A Field Guide to Stone Artifacts of Texas Indians. Gulf Publishing Co. Houston. 
Turpin, J.

1992 Targeted Archeological Survey Along the Seminole Pipeline Company Extension, Gaines to Austin Counties, Texas. Technical Series 27. Texas Archeological Research Laboratory, University of Texas at Austin.

Turpin, S. A., L. C. Bement, and D. G. Robinson

1992 All American Pipeline Project: Final Status Report. Texas Archeological Research Laboratory, University of Texas, Austin.

USBR (United States Bureau of Reclamation)

1999 Reservoir Data for Twin Buttes, Texas.

$<$ http://WWW.GP.USBR.GOV/www/tx/trgt> December 14.

USGS (United States Geological Survey)

1999a Water Data for Twin Buttes Reservoir (Station 08131200).

$<$ http://tx.usgs.gov/nwis-bin/nwismap?site_id=08131200> June 11.

1999b Twin Buttes Reservoir Near San Angelo, Tx. (Station 08131200).

$<$ http://tx.usgs.gov/cgi-bin/nwisman?station=08131200 $>$ January 16.

1999c South Concho River.

$<\mathrm{http}: / /$ waterdata.usgs.gov/nwis-w/TX/?statnum==08128000> June 17.

1999d Spring Creek.

$<$ http://waterdata.usgs.gov/nwis-w/TX/?statnum==08129300> June 17.

1999e Dove Creek.

$<$ http://waterdata.usgs.gov/nwis-w/TX/?statnum==08130500 $>$ June 17.

1999f Middle Concho River.

$<\mathrm{http}: / /$ waterdata.usgs.gov/nwis-w/TX/?statnum==08128500 $>$ June 17.

Veck, W. S.

1931 The Hide Trade at Ft. Concho. Oral interview with Mrs. W. S. Veck, recorded by J. Evetts Haley, September 12, 1931. J. Evetts Haley Collection, Nita Stewart Haley Memorial Library, Midland, Texas.

Voellinger, L.

1981 Archaeological Survey of the Northern Gas Products Co., Middle Concho Plant. Espey, Huston \& Associates, Inc., Austin.

Voellinger, L., and S. James

1984 Summary Report: Cultural Resources Survey of the Southwest Pave Paws Facility Site, Utility Corridors and Perimeter Fence. Espey, Huston \& Associates, Inc., Austin.

Wallace, E.

1993 Ranald S. MacKenzie on the Texas Frontier. Texas A\&M University Press, College Station.

Warren, J. E.

1991 Cultural Resources Survey and Testing in the San Angelo Wastewater Improvement Project, Tom Green County, Texas. Report No. 231.

Waters, M. R.

1992 Principles of Geoarchaeology. University of Arizona Press, Tucson. 
Weidenfeld, C. C., and P. H. Flores

1976 Soil Survey of Tom Green County, Texas. United States Department of Agriculture, Soil Conservation Service, in cooperation with the Texas Agricultural Experiment Station.

Weir, F. A.

1976 The Central Texas Archaic. Unpublished Ph.D. dissertation. Anthropology Department, Washington State University.

Wendorf, F., A. D. Krieger, C. C. Albritton, and T. D. Stewart

1955 The Midland Discovery. University of Texas Press, Austin.

Wenke, R. J.

1990 Patterns in Prehistory: Humankind's First Three Million Years. 3rd Edition. Oxford University Press, Oxford, England.

Werner, G. C.

1996 Railroads. In New Handbook of Texas, Vol. 5, edited by R. Tyler, pp. 411-489. Texas State Historical Association, Austin.

West, E. H. (translator)

1904 A Brief Compendium of the Events Which Have Occurred in the Province of Texas from its Conquest, or Reduction to the Present Day, Written by Antonio Bonilla in 1772. Quarterly of the Texas State Historical Association VIII(1):1-78.

Whalen, M. E.

1986 Excavations of Early Pithouses in the Hueco Bolson: The 1984 Season. In Mogollon Variability, edited by C. Benson and S. Upham, pp. 285-295. New Mexico State University, The University Museum, Las Cruces.

Wilbarger, J. W.

1985 Indian Depredations in Texas: Original Narratives of Texas History and Adventure, 1885. Reprinted by Eakin Press. Austin.

Williams, J. W.

1962 New Conclusions on the Route of Mendoza, 1683-1684. West Texas Historical Association Yearbook 38. San Angelo, Texas.

Willis, L. E.

1958 Archaeological Survey of Twin Buttes Reservoir, Tom Green County, Texas. Unpublished manuscript. Copy on file. Center for Archaeological Research, The University of Texas at San Antonio.

Winship, G. P.

1896 The Coronado Expedition, 1540-1542. In Fourteenth Annual Report of the Bureau of American Ethnology 1892-1893, Part I, pp. 339-637. Government Printing Office, Washington, D. C. 
Woerner, M. C.

1981 An Archaeological Survey for the Southwest Texas Electric Cooperative in Schleicher and Crockett Counties, Texas. Archaeological Survey Report, No. 109. Center for Archaeological Research, The University of Texas at San Antonio.

Wood, G. P.

1992 Archaeological Testing of 41RN129 Runnels County, Texas. Department of Transportation Highway Design Division, Austin.

Wood, W. R., and D. L. Johnson

1978 A Survey of Disturbance Processes in Archaeological Site Formation. In Advances in Archaeological Method and Theory, vol. 1, edited by M. B. Schiffer, pp. 315-381. Academic Press, New York.

Woolridge, H. G., A. Adams, M. Davis, P. Denny, P. Nichols, B. Stewart, R. Stephenson, and G. Woodall

1981 A Cultural Resources Inventory and Assessment of the Proposed Stacey Reservoir, Concho, Coleman, and Runnels Counties, Texas, Volume I: Prehistoric Cultural Resources. Espey, Huston \& Associates, Inc., Austin.

Word, J. H.

1977 Site Locations and Functions of the Eastern Central Llano Estacado and Adjacent Rolling Plains. Bulletin of the South Plains Archaeological Society 3:25-36.

Wormington, H. M.

1957 Ancient Man in North America. The Denver Museum of Natural History, Popular Series 4, Denver.

Wyckoff, M. A.

1984 United States Military Buttons of the Land Service, 1787-1902. A Guide and Classification System. McLean County Historical Society, Bloomington, Illinois.

Yellen, J.

1977 Archaeological Approaches to the Present. Academic Press, New York.

Young, J. H.

1974 The Toadstool Millionaires: A Social History of Patent Medicines in America before Federal Regulation. Princeton University Press, New Jersey.

Zapata, J. E.

1998 Soldiers and Civilians at Fort Concho. Unpublished list, on file at Center for Archaeological Research, The University of Texas at San Antonio. 